\title{
Petroleum geology and geochemistry of oils and possible source rocks of the southern East Coast Basin, New Zealand
}

Nils Erik Elgar

Submitted in fulfilment of the requirements

for the degree of Doctor of Philosophy in Geology

Victoria University of Wellington

1997 


\section{Abstract}

The East Coast Basin of New Zealand contains up to $10,000 \mathrm{~m}$ of predominantly finegrained marine sediments of Early Cretaceous to Pleistocene age, and widespread oil and gas seepages testify to its status as a petroleum province. A suite of oils and possible source rocks from the southern East Coast Basin have been analysed by a variety of geochemical techniques to determine the hydrocarbon potential and establish oil-oil and oil-source rock correlations.

Results of TOC and Rock-Eval pyrolysis indicate that the latest Cretaceous Whangai Formation and Paleocene Waipawa Black Shale represent the only good potential source rock sequences within the basin. The middle to Late Cretaceous Glenburn and Te Mai formations, previously considered good potential source rocks, are organic-rich (TOC contents up to $1.30 \%$ and $1.52 \%$ respectively), but comprise predominantly Types III and IV (structured terrestrial and semi-opaque) kerogen and, therefore, have little hydrocarbon generative potential (HI values <50). Early Cretaceous and Neogene formations are shown to have low TOC contents and have little source rock potential.

The Waipawa Black Shale is a widespread, thin $(<50 \mathrm{~m})$, dark brown, non-calcareous siltstone. It contains up to $1.9 \%$ sulphur and elevated quantities of trace metals. Although immature to marginally mature for hydrocarbon generation in outcrop, it is organic-rich (TOC content up to 5.69\%) and contains oil and gas-prone Types II and III kerogen. The extracted bitumen comprises predominantly marine algal and terrestrial higher plant material and indicates that deposition occurred under conditions of reduced oxygen with significant anoxic episodes.

The Whangai Formation is a thick $(300-500 \mathrm{~m})$, non-calcareous to calcareous siliceous mudstone. Although immature to marginally mature in outcrop, the Upper Calcareous and Rakauroa members have a TOC content up to $1.37 \%$ and comprise oil and gasprone Types II and III (structured aqueous and structured terrestrial) kerogen. Bitumen extracts comprise predominantly marine organic matter with a moderate terrestrial higher plant component and indicate that deposition occurred under mildly reducing conditions, with periodic anoxic episodes indicated for the Upper Calcareous Member.

Two families of oils are recognised in the southern East Coast Basin. The Kerosene

Rock, Westcott, Tiraumea and Okau Stream oils comprise both algal marine and terrestrial higher plant material and were deposited under periodically anoxic conditions. 
They are characterised by high relative abundances of unusual $\mathrm{C}_{30}$ steranes $\left(\mathrm{C}_{30}\right.$ indices of 0.24-0.40) and 28,30-bisnorhopane, low proportions of $\mathrm{C}_{28}$ steranes and isotopically heavy $\delta^{13} \mathrm{C}$ values ( -20.9 to $-23.0 \%$ ). The Waipatiki and Tunakore oils from southern Hawke's Bay and the Kora-1 oil from the northern Taranaki Basin have similar geochemical characteristics and are also included in this family of oils. These same characteristics are also diagnostic of the Waipawa Black Shale and an oil-source rock correlation is made on this basis.

The Knights Stream and Isolation Creek oils are derived from predominantly marine organic matter with a moderate terrestrial angiosperm contribution, and characterised by low relative abundances of $\mathrm{C}_{30}$ steranes $\left(\mathrm{C}_{30}\right.$ indices of 0.06-0.12) and 28,30 -bisnorhopane, high proportions of $\mathrm{C}_{28}$ steranes and isotopically light $\delta^{13} \mathrm{C}$ values $(-26.8$ to $-28.9 \%$ ) . Also included in this family of oils, with a slightly greater marine influence, are the major seep oils of the northern East Coast Basin (Waitangi, Totangi and Rotokautuku). A tentative oil-source rock correlation with the Upper Calcareous and Rakauroa members of the Whangai Formation is based on their similar geochemical characteristics. 


\section{Acknowledgements}

I would like to thank my supervisors Associate Professors John Collen and Jim Johnston for their help during this project. Special gratitude to John for initially putting this project together, for tirelessly editing this thesis in its final stages, and for concern over my general well-being over the past five years. I'm sorry for the despair I must have caused through my frequent trips away into the hills.

I gratefully acknowledge the sponsorship of Petrocorp Exploration Ltd, (the former) Southern Petroleum NL and the Ministry of Commerce, without whom this project would not have been possible.

Victoria University of Wellington Internal Grants Committee are also acknowledged for their financial support.

I am indebted to the following people and organisations who helped in various ways:

The technicians of the Chemistry and Geology Departments, and the Analytical Facility, especially Michael France (GC-MS), Isabella Pomer and Rhys Batchelor (GC), Elizabeth Kundycki (GC analyses), Ken Palmer (TOC and XRF), John Patterson (XRF), Cliff Snell (hydrous pyrolysis experiments), Salli Rowe (graphics) and Andrew Sutton for keeping my computer going.

Dr Jane Newman from Coal Research Ltd, University of Canterbury, for taking time out of her busy schedule to show and discuss aspects of vitrinite reflectance and vitrinite reflectance and fluorescence (VRF).

Dr Mike Hannah for the visual kerogen analyses.

Mike Judd and Mark Ogilvy of the Petroleum Information Unit, Ministry of Commerce for their assistance regarding Petroleum Reports.

Anjali Pande for her help during fieldwork in Marlborough.

A very big thanks to Karyne Rogers, initially my work partner and later my friend. Thanks for your help in the lab when I was finding my feet, the discussion of ideas and 
kick-starting me into action. I really enjoyed our wide-ranging discussions and needed your encouragement.

Thanks to my father John Elgar for help in the latter stages of thesis production, in particular for the geological map and the construction of Appendix 9, a job which I really didn't want to do!

To all those who kept me busy with some excellent adventures both here and overseas - I hold you personally responsible for my long stay here at varsity...

Finally, I would like to thank my parents for their ongoing support of me throughout my time here at Victoria University; your patience and generosity are greatly appreciated. 


\section{Contents}

Abstract $\quad$ i

Acknowledgements $\quad$ iii

Contents $v$

List of figures $\quad$ ix

List of tables $\quad x i$

List of plates xii

List of abbreviations xiii

Chapter 1 Introduction $\quad 1$

1.1 General introduction 1

1.2 Formation of petroleum 2

1.2.1 Introduction 2

1.2.2 Production, accumulation and preservation of organic matter 2

1.2.3 Maturation of organic matter 3

$\begin{array}{ll}1.3 \text { Contribution of organic geochemistry to the exploration for petroleum } & 7\end{array}$

1.4 Petroleum exploration history in the southern East Coast Basin 9

1.4.1 Introduction 9

$\begin{array}{ll}\text { 1.4.2 Early petroleum exploration } & 10\end{array}$

$\begin{array}{ll}\text { 1.4.3 Recent petroleum exploration } & 12\end{array}$

$\begin{array}{ll}\text { 1.4.4 Exploration history in Marlborough } & 13\end{array}$

1.5 Previous studies of petroleum geochemistry in the southern East Coast Basin 14

$\begin{array}{lr}1.6 \text { Thesis objectives } & 19\end{array}$

Chapter 2 Geology of the southern East Coast Basin 21

2.1 General geology of the southern East Coast Basin 21

$\begin{array}{ll}2.1 .1 \text { Introduction } & 21\end{array}$

2.1.2 Tectonic setting $\quad 21$

2.1.3 Structure of the East Coast Basin 22

$\begin{array}{ll}2.1 .4 \text { Stratigraphy } & 23\end{array}$

2.2 Petroleum geology of the southern East Coast Basin 36

$\begin{array}{ll}2.2 .1 \text { Petroleum geology } & 36\end{array}$

$\begin{array}{ll}2.2 .2 \text { Occurrences of oil } & 38\end{array}$

Chapter 3 Analytical procedures $\quad 41$

$\begin{array}{ll}3.1 \text { Sampling } & 41\end{array}$

3.1.1 Sampling strategy $\quad 41$

3.1.2 Sample collection $\quad 41$

3.1.3 Sample preparation $\quad 42$

3.2 Laboratory procedure 43

3.2.1 Introduction 43

3.2.2 Solvent extraction $\quad 43$

3.2.3 Separation of organic constituents 44 
Chapter 4 Total organic carbon and Rock-Eval pyrolysis $\quad 46$

4.1 Total organic carbon (TOC) 46

4.1.1 Introduction $\quad 46$

$\begin{array}{ll}4.1 .2 \text { Methods } & 47\end{array}$

4.1.3 Results 47

4.1.4 Discussion $\quad 48$

$\begin{array}{ll}4.2 \text { Rock-Eval pyrolysis } & 49\end{array}$

4.2.1 Introduction and methods 49

4.2.2 Geochemical parameters derived from Rock-Eval pyrolysis $\quad 50$

4.2.3 Results $\quad 52$

4.2.4 Discussion $\quad 54$

$\begin{array}{ll}4.2 .5 \text { Conclusions } & 57\end{array}$

Chapter 5 Biomarker studies using gas chromatography (GC) 59

$\begin{array}{ll}5.1 \text { Introduction } & 59\end{array}$

$\begin{array}{ll}5.1 .1 \text { Biomarkers } & 59\end{array}$

5.1.2 Gas chromatography (GC) $\quad 59$

$5.2 \mathrm{~N}$-alkane and isoprenoid biomarker parameters 61

$\begin{array}{ll}5.2 .1 \text { Introduction } & 61\end{array}$

5.2.2 Carbon preference index (CPI) 61

5.2.3 $\mathrm{N}$-alkane distribution and $\mathrm{C}_{\max } \quad 62$

5.2.4 $\mathrm{C}_{21}+\mathrm{C}_{22} / \mathrm{C}_{28}+\mathrm{C}_{29} \quad 62$

5.2.5 Pristane/phytane ratio 63

5.2.6 Pr/n- $\mathrm{C}_{17}$ and $\mathrm{Ph} / n-\mathrm{C}_{18} \quad 63$

$\begin{array}{ll}5.3 \text { Methods } & 64\end{array}$

$\begin{array}{ll}5.4 \text { Results } & 65\end{array}$

5.4.1 Introduction $\quad 65$

5.4.2 N-alkane and isoprenoid geochemistry of the oils 66

5.4.3 $\mathrm{N}$-alkane and isoprenoid geochemistry of possible source rocks 67

$\begin{array}{ll}5.5 \text { Summary of results and discussion } & 74\end{array}$

$\begin{array}{ll}\text { 5.5.1 Oils and oil-oil correlation } & 74\end{array}$

$\begin{array}{ll}\text { 5.5.2 Possible source rocks } & 75\end{array}$

$\begin{array}{ll}\text { 5.5.3 Oil-source rock correlation } & 77\end{array}$

$\begin{array}{ll}5.6 \text { Conclusions } & 79\end{array}$

Chapter 6 Biomarker investigations using gas chromatography-mass $\begin{array}{ll}\text { spectrometry (GC-MS) } & 81\end{array}$

6.1 Application of GC-MS to the investigation of biomarkers 81

$\begin{array}{ll}6.1 .1 \text { Introduction } & 81\end{array}$

$\begin{array}{ll}\text { 6.1.2 Principles of GC-MS } & 81\end{array}$

6.2 Sterane and triterpane biomarkers $\quad 83$

$\begin{array}{ll}6.2 .1 \text { Introduction } & 83\end{array}$

6.2.2 Sterane $(\mathrm{m} / \mathrm{z} 217) \quad 83$

6.2.3 Triterpanes $(\mathrm{m} / \mathrm{z} 191) \quad 85$ 
6.3 Source, maturity and biodegradation: What the biomarker parameters can tell us

6.3.1 Source-specific biomarkers $\quad 87$

6.3.2 Maturity biomarker parameters 90

6.3.3 Biodegradation biomarker parameters 94

6.3.4 Oil-oil and oil-source rock correlation 95

$\begin{array}{ll}6.4 \text { Methods } & 96\end{array}$

6.5 Results - biomarker geochemistry of the oils 97

6.5.1 Introduction 97

6.5.2 Biomarker geochemistry of the oils 98

6.5.3 Source-specific biomarkers 100

$\begin{array}{ll}\text { 6.5.4 Maturity biomarker parameters } & 102\end{array}$

$\begin{array}{ll}\text { 6.5.5 Biodegradation biomarker parameters } & 104\end{array}$

$\begin{array}{ll}\text { 6.5.6 Oil-oil correlations } & 104\end{array}$

6.6 Results - biomarker geochemistry of the possible source rocks 105

6.6.1 North Island possible source rocks 105

6.6.2 South Island possible source rocks 113

$\begin{array}{ll}\text { 6.6.3 Source-specific biomarkers } & 118\end{array}$

$\begin{array}{ll}\text { 6.6.4 Maturity biomarker parameters } & 121\end{array}$

6.6.5 Biodegradation biomarker parameters $\quad 122$

6.6.6 Oil-source rock correlations 122

$\begin{array}{ll}6.7 \text { Summary of results and discussion } & 124\end{array}$

6.7.1 Source/depositional environment 124

$\begin{array}{ll}\text { 6.7.2 Maturity } & 125\end{array}$

6.7.3 Oil-oil and oil-source rock correlations $\quad 126$

$\begin{array}{lr}6.8 \text { Conclusions } & 129\end{array}$

$\begin{array}{ll}\text { Chapter } 7 \text { Other analytical techniques } & 131\end{array}$

$\begin{array}{ll}7.1 \text { Stable carbon isotopes } & 131\end{array}$

$\begin{array}{ll}7.1 .1 \text { Introduction } & 131\end{array}$

$\begin{array}{ll}\text { 7.1.2 Uses of stable carbon isotopes } & 131\end{array}$

$\begin{array}{ll}7.1 .3 \text { Methods } & 133\end{array}$

$\begin{array}{ll}7.1 .4 \text { Results } & 133\end{array}$

$\begin{array}{ll}7.1 .5 \text { Discussion } & 135\end{array}$

$\begin{array}{ll}\text { 7.1.6 Conclusions } & 137\end{array}$

$\begin{array}{lr}7.2 \text { Visual kerogen analysis (VKA) } & 139\end{array}$

$\begin{array}{ll}7.2 .1 \text { Introduction } & 139\end{array}$

$\begin{array}{ll}7.2 .2 \text { Methods } & 141\end{array}$

$\begin{array}{ll}7.2 .3 \text { Results } & 141\end{array}$

$\begin{array}{ll}7.2 .4 \text { Discussion } & 143\end{array}$

$\begin{array}{ll}\text { 7.2.5 Conclusions } & 145\end{array}$

$\begin{array}{ll}7.3 \text { Vitrinite reflectance }\left(R_{\mathrm{o}}\right) & 146\end{array}$

$\begin{array}{ll}7.3 .1 \text { Introduction } & 146\end{array}$

$\begin{array}{ll}\text { 7.3.2 Methods and results } & 147\end{array}$

$\begin{array}{ll}\text { 7.3.3 Discussion } & 148\end{array}$

$\begin{array}{ll}\text { 7.3.4 Conclusions } & 149\end{array}$ 
$\begin{array}{lr}7.4 \text { X-ray fluorescence (XRF) spectroscopy } & 150\end{array}$

$\begin{array}{ll}7.4 .1 \text { Introduction } & 150\end{array}$

$\begin{array}{ll}\text { 7.4.2 Geochemical indices } & 150\end{array}$

$\begin{array}{ll}\text { 7.4.3 Methods } & 153\end{array}$

$\begin{array}{ll}\text { 7.4.4 Results } & 154\end{array}$

$\begin{array}{ll}\text { 7.4.5 Discussion } & 158\end{array}$

$\begin{array}{ll}\text { 7.4.6 Conclusions } & 161\end{array}$

$\begin{array}{lr}\text { Chapter } 8 \text { Discussion and summary } & 163\end{array}$

$\begin{array}{ll}8.1 \text { Geochemistry of the oils } & 163\end{array}$

8.1.1 Geochemical characterisation of the oils 163

$\begin{array}{ll}8.1 .2 \text { Oil-oil correlations } & 164\end{array}$

8.2 Geochemistry of the possible source rocks 166

8.2.1 Geochemical characterisation of the possible source rocks $\quad 166$

8.2.2 Potential source rocks in the southern East Coast Basin 175

8.2.3 Oil-source rock correlations 175

$\begin{array}{ll}\text { 8.3 Hydrocarbon generation in the East Coast Basin } & 177\end{array}$

$\begin{array}{ll}\text { 8.4 Southern East Coast Basin prospectivity } & 179\end{array}$

8.4.1 Distribution and thickness of potential source rocks 179

$\begin{array}{ll}\text { 8.4.2 Burial and maturation of potential source rocks } & 179\end{array}$

8.4.3 Southern East Coast Basin prospectivity 180

$\begin{array}{ll}8.5 \text { Summary } & 182\end{array}$

$\begin{array}{ll}\text { References } & 185\end{array}$

\section{Appendices}

Appendix 1 Sample locality data $\quad$ A1

Appendix 2 Total organic carbon (TOC) and carbonate analyses $\quad$ A2

Appendix 3 Rock-Eval pyrolysis data $\quad$ A3

Appendix 4 Gas chromatography (GC) data $\quad$ A4

Appendix 5 Gas chromatography-mass spectrometry (GC-MS) data A5

Appendix 6 Stable carbon isotope data $\quad$ A6

$\begin{array}{ll}\text { Appendix } 7 \text { Visual kerogen analysis (VKA) data } & \text { A7 }\end{array}$

Appendix 8 X-ray fluorescence (XRF) spectroscopy data $\quad$ A8

Appendix 9 GC-MS data: $\mathrm{m} / \mathrm{z} 191$ and 217 mass chromatograms A9 


\section{List of figures}

[N.B. F=facing page]

Figure 1.1 The three stages of maturation of organic matter

Figure 1.2 Stages of oil generation correlated to approximate vitrinite reflectance values

Figure 1.3 Locations of exploration wells in the southern East Coast Basin

Figure 2.1 Geological map of the East Coast Basin

Figure 2.2 Location map showing New Zealand's position relative to the plate boundary

Figure 2.3 Diagrammatic cross-section of the central East Coast Basin

Figure 2.4 Structural divisions of eastern North Island

Figure 2.5

Figure 2.6

Figure 4.1

Figure 4.2

Figure 4.3

Figure 5.1

Generalised stratigraphy of the southern East Coast Basin

The East Coast Basin petroleum system

Comparison of van Krevelen's diagram with HI vs OI cross-plot

HI vs OI cross-plot

$\mathrm{S}_{2}$ vs TOC cross-plot for the Waipawa Black Shale

Diagram of gas chromatograph

Figure 5.2

Gas chromatograms of the oils

Figure 5.3

Figure 5.4

Gas chromatograms of possible source rocks from eastern North Island

Figure 5.5

Gas chromatograms of possible source rocks from eastern North Island

Figure 5.6

Figure 5.7

Figure 6.1

Figure 6.2

Figure 6.3

Gas chromatograms of possible source rocks from eastern North Island

Gas chromatograms of possible source rocks from Marlborough

Gas chromatograms of possible source rocks from Marlborough

A gas chromatograph-mass spectrometer showing its six essential functions

(F) 21

(F) 22

(F) 22

(F) 23

(F) 24

36

50

53

56

60

(F) 66

(F) 68

(F) 69

(F) 71

(F) 72

(F) 73

Fragmentation pattern of steranes and triterpanes

Structure of the four common regular steranes

Figure 6.4 The precursor sterol and the biological and geological configurations of the sterane biomarker molecules and the equilibrium pathways between the different configurations

Figure 6.5 Pentacyclic triterpane with additional side chain

Figure 6.6 The biological and geological configurations of the hopane biomarkers and the equilibrium pathways between the different configurations

Figure 6.7 Relationship between sterol compositions in organisms and the environment in which they exist

Figure $6.8 \quad 20 \mathrm{~S} /(20 \mathrm{~S}+20 \mathrm{R})$ sterane isomerization

Figure 6.10 Equilibrium between -22R (biological epimer) and -22S (geological epimer) for the $\mathrm{C}_{31}$ to $\mathrm{C}_{35}$ homohopanes

Figure 6.11 Structural forms of $17 \alpha(\mathrm{H})-22,29,30$-trisnorhopane $(\mathrm{Tm})$ and $18 \alpha(\mathrm{H})-22,29,30$-trisnorneohopane (Ts)

Figure 6.12 Approximate correlation of selected maturity parameters plotted against the hydrocarbon generation curve and corresponding vitrinite reflectance values

Figure 6.13 GC-MS m/z 191 and 217 mass chromatograms of the oils

Figure 6.14 Ternary diagrams showing the composition of oils. A. $\mathrm{C}_{27}-\mathrm{C}_{28}-\mathrm{C}_{29}$ steranes. B. $\mathrm{C}_{27}-\mathrm{C}_{29}-\mathrm{C}_{30}$ steranes

Figure 6.15 Diagrammatic representation of the relative proportion of steranes in each of the oil samples

Figure 6.16 GC-MS m/z 191 and 217 mass chromatograms of possible source rocks (N.I.)

Figure 6.17 GC-MS m/z 191 and 217 mass chromatograms of possible source rocks (N.I.)

Figure 6.18 GC-MS m/z 191 and 217 mass chromatograms of possible source rocks (N.I.)

(F) 106

Figure 6.19 GC-MS m/z 191 and 217 mass chromatograms of possible source rocks (N.I.)

(F) 107

(F) 109

Figure 6.20 GC-MS m/z 191 and 217 mass chromatograms of possible source rocks (N.I.)

(F) 110

Figure 6.21 GC-MS m/z 191 and 217 mass chromatograms of possible source rocks (N.I.)

(F) 112

Figure 6.22 GC-MS m/z 191 and 217 mass chromatograms of possible source rocks (S.I.)

(F) 114 
Figure 6.23 GC-MS m/z 191 and 217 mass chromatograms of possible source rocks (S.I.)

(F) 115

Figure 6.24 GC-MS m/z 191 and 217 mass chromatograms of possible source rocks (S.I.)

(F) 117

Figure 6.25 Ternary diagrams showing the sterane compositions of selected formations

(F) 118

and the six oils. A. $\mathrm{C}_{27}-\mathrm{C}_{28}-\mathrm{C}_{29}$ steranes. B. $\mathrm{C}_{27}-\mathrm{C}_{29}-\mathrm{C}_{30}$ steranes

Figure 7.1 Saturate vs aromatic cross-plot of $\delta^{13} \mathrm{C}(\%)$ values of oils and possible

Figure 7.2 Sulphur vs organic carbon plot, showing three different depositional environments

Figure 7.3 Stratigraphic plot of selected trace element concentrations from eastern

North Island

(F) 154

Figure 7.4 Sulphur vs organic carbon plot

Figure 7.5 Correlation between the amount of organically-bound sulphur in kerogen and the onset of oil generation for known source rocks

Figure 8.1 Known distribution of the Waipawa Black Shale

(F) 179

Figure 8.2 Thickness maps of: a. Waipawa Black Shale and b. Whangai Formation

(F) 179 


\section{List of tables}

[N.B. F=facing page]

Table 1.1 Methods of geochemical analysis and the information that each can provide

Table 2.1 Promising reservoir units of eastern North Island

Table 2.2 List of oil samples, their locations and geology

(F) 37

Table 4.1 Source rock quality as determined by TOC analyses

Table 4.2 Summary of selected TOC data

Table 4.3

Comparison with TOC results of previous studies

(F) 47

Table 4.4

Parameters describing types of hydrocarbons generated

Table 4.5

Parameters describing source rock generative potential

Table 4.6

Parameters describing level of thermal maturation

Table 4.7

Summary of selected Rock-Eval pyrolysis data

Table 4.8

Summary of Rock-Eval pyrolysis data from previous studies

(F) 52

Table 5.1

Summary of the $n$-alkane and isoprenoid biomarker parameters of the oils

(F) 54

Table 5.2 Comparison of the $n$-alkane and isoprenoid biomarker parameters of oils from the northern East Coast Basin with those from the southern region

Table 5.3 Summary of the $n$-alkane and isoprenoid biomarker parameters of eastern North Island formations

(F) 76

Table 5.4 Summary of the $n$-alkane and isoprenoid biomarker parameters of Marlborough formations

Table 6.1 Ten point scale ranking the extent of biodegradation (from Peters and Moldowan, 1993), with comparison to the biodegradation scale of Volkman et al. (1983)

Table 6.2 Biomarker identification of triterpanes and steranes

Table 6.3

Summary of selected source-specific biomarker parameters of the oils

Maturity parameters from triterpane and sterane biomarker ratios

Table 6.4

Summary of selected source-specific biomarker parameters of possible source rocks

Table 6.5

Table 7.1

Stable carbon isotope analyses from Waikato University

(F) 119

(F) 132

Table 7.2

Comparison with stable carbon isotope data from previous studies

(F) 137

Correlation of TAI with vitrinite reflectance maturation parameters

Table 7.4 Visual kerogen analyses (VKA) data

(F) 141

Selected visual kerogen analysis (VKA) data of Rogers (1995)

(F) 144

146

148

151

153

Table 7.9 Correlation of paleo-oxygenation indices

Table 7.10 Summary of paleo-oxygenation indices for southern East Coast Basin formations

Table 8.1 Summary of the source/depositional environment characteristics

Table 8.2 Summary of maturity parameters from triterpane and sterane biomarker ratios

Table 8.3 Summary of hydrocarbon generative potential of the possible source rocks from eastern North Island and correlation with the oils

Table 8.4 Summary of hydrocarbon generative potential of the possible source rocks from Marlborough and correlation with the oils

(F) 176

Table A2-1 Comparison of total carbon, TOC and carbonate carbon values of MAG-1 standard by different authors 


\section{List of plates}

[N.B. F=facing page]

Plate 2.1 Indurated Springhill Formation, White Rock Road (S28/153706)

(F) 25

Plate 2.2 Alternating carbonaceous sandstone and mudstone of the Te Mai Formation, near Akitio (U25/995634)

(F) 26

Plate 2.3 Creamy-weathered Waipawa Black Shale and glauconitic sandstone. Rotohiwi Road quarry (U23/992098)

(F) 28

Plate 2.4 Alternating sandstone and mudstone of the Whakataki Formation, near Whakataki (U26/817323)

Plate 2.5 Alternating carbonaceous sandstone and mudstone of the Wharfe Sandstone Member, Split Rock Formation. Swale Stream, Coverham (P30/823170)

(F) 29

Plate 2.6 Massive sulphur-stained Conway Siltstone. Railway cutting, Claverley Road

Plate 2.6 Massive sulphur-stained Conway Siltstone. Railway cutting, Claverley Road Mata Series. S.H. 1, opposite Kaikoura Racecourse (031/654660)

(F) 32

(F) 33

(F) 34

Plate 2.8 Cretaceous/Tertiary boundary within the Amuri Limestone. Woodside Creek (P30/998190)

Plate 2.9 Oil-stained sandstone 'Westcott oil' within Miocene siltstone. Adjacent to Mangapuku Stream at Westcott (U24/888902)

(F) 34

Plate 2.10 Oil-stained glauconitic sandstone. 'Okau Stream oil' enclosed within Waipawa Black Shale. Okau Stream (U26/817364)

(F) 39

(F) 40 


\section{List of abbreviations}

\begin{tabular}{|c|c|}
\hline$\AA$ & Ångström unit $\left(10^{-10} \mathrm{~m}\right)$ \\
\hline$A_{r}$ & Atomic weight \\
\hline aro & Aromatic fraction \\
\hline $\mathrm{BNH}$ & 28,30-Bisnorhopane (see Table 6.2) \\
\hline${ }^{\circ} \mathrm{C}$ & Degrees Celsius \\
\hline$c$. & Circa \\
\hline CGQ & Centre Géoscientifique de Québec \\
\hline $\mathrm{cm}$ & Centimetre \\
\hline CPI & Carbon preference index \\
\hline CSIA & Compound specific isotope analysis \\
\hline $\mathrm{CV}$ & Canonical Variable \\
\hline $\mathrm{dm}$ & Decimetre \\
\hline DOP & Degree of pyritisation \\
\hline E. & Early \\
\hline FID & Flame ionisation detector \\
\hline $\mathrm{Fm}$ & Formation \\
\hline $\mathrm{g}$ & Gram \\
\hline GC & Gas chromatography \\
\hline GC-MS & Gas chromatography-mass spectrometry \\
\hline GC-MS/MS & Gas chromatography-mass spectrometry/mass spectrometry \\
\hline GERM & Geological resource map \\
\hline $\mathrm{HC}$ & Hydrocarbon \\
\hline $\mathrm{HCl}$ & Hydrochloric acid \\
\hline $\mathrm{HF}$ & Hydrofluoric acid \\
\hline HI & Hydrogen index \\
\hline I.D. & Inner diameter \\
\hline IGNS & Institute of Geological and Nuclear Sciences Ltd \\
\hline IR & Infrared \\
\hline $\mathrm{kg}$ & Kilogram \\
\hline $\mathrm{km}$ & Kilometre \\
\hline $\mathrm{kPa}$ & Kilopascals \\
\hline 1 & Litre \\
\hline L. & Late \\
\hline Ist & Limestone \\
\hline $\mathrm{m}$ & Metre \\
\hline $\mathrm{Ma}$ & Million years \\
\hline $\mathrm{mD}$ & Millidarcey \\
\hline Mem. & Member \\
\hline $\mathrm{mg}$ & Milligram \\
\hline $\min$. & Minute \\
\hline $\mathrm{ml}$ & Millilitre \\
\hline $\mathrm{mm}$ & Millimetre \\
\hline $\mathrm{M}_{\mathrm{r}}$ & Molecular weight \\
\hline (MRM) GC-MS & Metastable reaction monitoring GC-MS \\
\hline mst & Mudstone \\
\hline $\mathrm{m} / \mathrm{z}$ & Mass/charge ratio \\
\hline N.I. & North Island \\
\hline $\mathrm{nm}$ & Nanometre \\
\hline NSO & Nitrogen, Sulphur, Oxygen compounds (resins) \\
\hline OI & Oxygen index \\
\hline PDB & Peedee Belemnite \\
\hline $\mathrm{Ph}$ & Phytane \\
\hline PI & Production index \\
\hline
\end{tabular}




\begin{tabular}{|c|c|}
\hline ppm & Parts per million \\
\hline $\operatorname{Pr}$ & Pristane \\
\hline $\mathrm{R}_{\mathrm{o}}$ & Vitrinite reflectance \\
\hline rpm & Revolutions per minute \\
\hline$s$ & Second \\
\hline sat & Saturate fraction \\
\hline S.D. & Standard deviation \\
\hline S.G. & Specific gravity \\
\hline S.I. & South Island \\
\hline SIM & Selected ion monitoring \\
\hline sst & Sandstone \\
\hline Stm & Stream \\
\hline TAI & Thermal alteration index \\
\hline TCD & Thermal conductivity detector \\
\hline $\operatorname{Tm}$ & Trisnorhopane (see Table 6.2) \\
\hline TNH & $17 \beta(H)-22,29,30$-Trisnorhopane (see Table 6.2) \\
\hline TOC & Total organic carbon \\
\hline Ts & Trisnorneohopane (see Table 6.2) \\
\hline TSE & Total soluble extract \\
\hline TWT & Two-way time \\
\hline$\mu l$ & Microlitre \\
\hline USGS & United States Geological Survey \\
\hline VKA & Visual kerogen analysis \\
\hline VRF & Vitrinite reflectance and fluorescence \\
\hline WBS & Waipawa Black Shale \\
\hline wt. & Weight \\
\hline XRF & $\mathrm{X}$-ray fluorescence \\
\hline $\mathrm{yr}$ & Year \\
\hline
\end{tabular}




\section{Chapter 1}

\section{Introduction}

\subsection{General introduction}

The presence of hydrocarbons on the East Coast was recorded as early as 1865 , from the Poverty Bay District near Gisborne (McLernon, 1992). Today it is known that oil and gas seepages are widespread throughout the East Coast Basin (Field et al., 1995; Francis, 1995a). Some 50 wells have been drilled as a direct result of this but to date there have been no commercial discoveries.

Until recently, one of the major problems encountered by the petroleum exploration industry during East Coast Basin exploration has been a general lack of information regarding the possible source rocks for these seeps. Of the data available much are contradictory or of limited value due to restricted data sets, regionality of studies or the use of widely differing analytical methods.

This study forms part of a larger geochemical survey of the entire East Coast Basin by the petroleum research group at Victoria University of Wellington, supported by New Zealand Ministry of Commerce, Petrocorp Exploration Ltd and Southern Petroleum NL. Its central aim is to determine the likely source $\operatorname{rock}(s)$ for the oil seeps and impregnations present throughout the East Coast Basin. In this part of the survey some 150 outcrop and six oil samples have been obtained from throughout the southern East Coast Basin for source rock evaluation and oil-oil and oil-source rock correlation. In addition, the geochemical characteristics of the oils and possible source rocks (including source, maturity and biodegradation) have also been investigated.

Geochemical analyses used in this study include total organic carbon (TOC), Rock-Eval pyrolysis, gas chromatography (GC), gas chromatography-mass spectrometry (GC-MS), stable carbon isotopes, visual kerogen analysis (VKA), vitrinite reflectance and X-ray fluorescence spectroscopy (XRF). The intention of the present study is to provide an overview of the petroleum geology and geochemistry in the southern East Coast Basin and this is best achieved through the use of a wide range of analytical techniques, but necessarily limits the detail in which each technique is utilised. 


\subsection{Formation of petroleum}

\subsubsection{Introduction}

Certain conditions are necessary for the formation of petroleum. These include the accumulation and preservation of organic matter, followed by thermal maturation through burial (Tissot and Welte, 1978). In general, these conditions are limited to those that exist in sedimentary basins.

Sedimentary organic matter includes both the products (such as faecal material) and remains of living organisms. Terrestrial organic matter includes predominantly higher plants whereas aquatic organic matter comprises mainly phytoplankton (such as diatoms, dinoflagellates and cyanobacteria), zooplankton (such as foraminifera) and bacteria (Tissot and Welte, 1978).

\subsubsection{Production, accumulation and preservation of organic matter}

Organic-rich sediments occur sporadically throughout the sedimentary record and it seems that special conditions are required for the production, accumulation and preservation of organic matter (Killops and Killops, 1993). At present the primary productivity of organic matter in aquatic environments is approximately the same as that in terrestrial environments (Tissot and Welte, 1978). Preservation of organic matter in the terrestrial environment, however, is minimal, with bacterial activity causing degradation during exposure to air and moisture (Tissot and Welte, 1978).

Photosynthesis is the basis for the mass production of organic matter (Tissot and Welte, 1978). Primary production is influenced by light, water (important in terrestrial settings), temperature and water chemistry and these are complexly interrelated to basin morphology, ocean currents and convergence/divergence zones (Tissot and Welte, 1978). Regions of high primary production include surface waters near land masses with nutrient supply from either terrestrial runoff or coastal upwelling, and include continental margins, upwelling zones, algal beds and reefs, estuaries, swamps and marshes, and lakes (Killops and Killops, 1993).

Only a small fraction of the organic matter produced in the photic zone reaches the sediment surface (Tissot and Welte, 1978; Perrodon, 1988; Killops and Killops, 1993; Wakeham and Lee, 1993), the amount depending on the depth of the water column and the amount of primary production in the photic zone (Killops and Killops, 1993). The 
deeper the water column the longer the travel time and hence exposure to scavenging and bacterial degradation. Browsing is less efficient in areas of high productivity and, therefore, proportionally more organic matter reaches the sediment than in low productivity areas (Killops and Killops, 1993).

Dissolved organic matter is adsorbed onto the surface of clays and carbonate particles, proportionally more on fine-grained sediments than coarse-grained ones and hence finegrained (usually distal) sediments tend to be organic-rich (Killops and Killops, 1993). Lagoons, estuaries, inland or silled seas or lakes with calm, confined and often stratified conditions provide favourable environments for organic matter to accumulate without being carried away by currents (Killops and Killops, 1993).

Preservation of deposited organic matter depends on the sedimentation rate and amount of oxygen present at the sediment surface and in pore spaces (Tissot and Welte, 1978; Killops and Killops, 1993). Rapid sedimentation transports organic matter quickly to greater depths and higher temperatures, thereby limiting bacterial degradation (Perrodon, 1988). Balancing this, however, is the dilution of organic matter by clastic input. Slow sedimentation favours concentration of organic matter but anoxic conditions are also required (Tissot and Welte, 1978; Perrodon, 1988). Oxic conditions at the watersediment interface, aided by burrowing organisms, encourage scavenging by benthic organisms or decomposition by bacteria. Grain size dictates the porosity of the sediment which in turn governs the diffusion of oxygen. Fine-grained sediments restrict diffusion, creating anoxic conditions which limit bioturbation and the further browsing and decomposition of organic matter. Decomposition can continue under anoxic conditions by anaerobic bacteria but this occurs at a much lower rate (Killops and Killops, 1993). The preservation rate of primary organic production is usually less than $0.1 \%$ but under favourable conditions may be up to $4 \%$ (Tissot and Welte, 1978).

\subsubsection{Maturation of organic matter}

Thermal maturation is achieved through burial of organic matter by sedimentation and subsequent basin subsidence. Maturation of organic matter is considered to take place in three stages: diagenesis, catagenesis and metagenesis (Tissot and Welte, 1978) (Figure 1.1). 


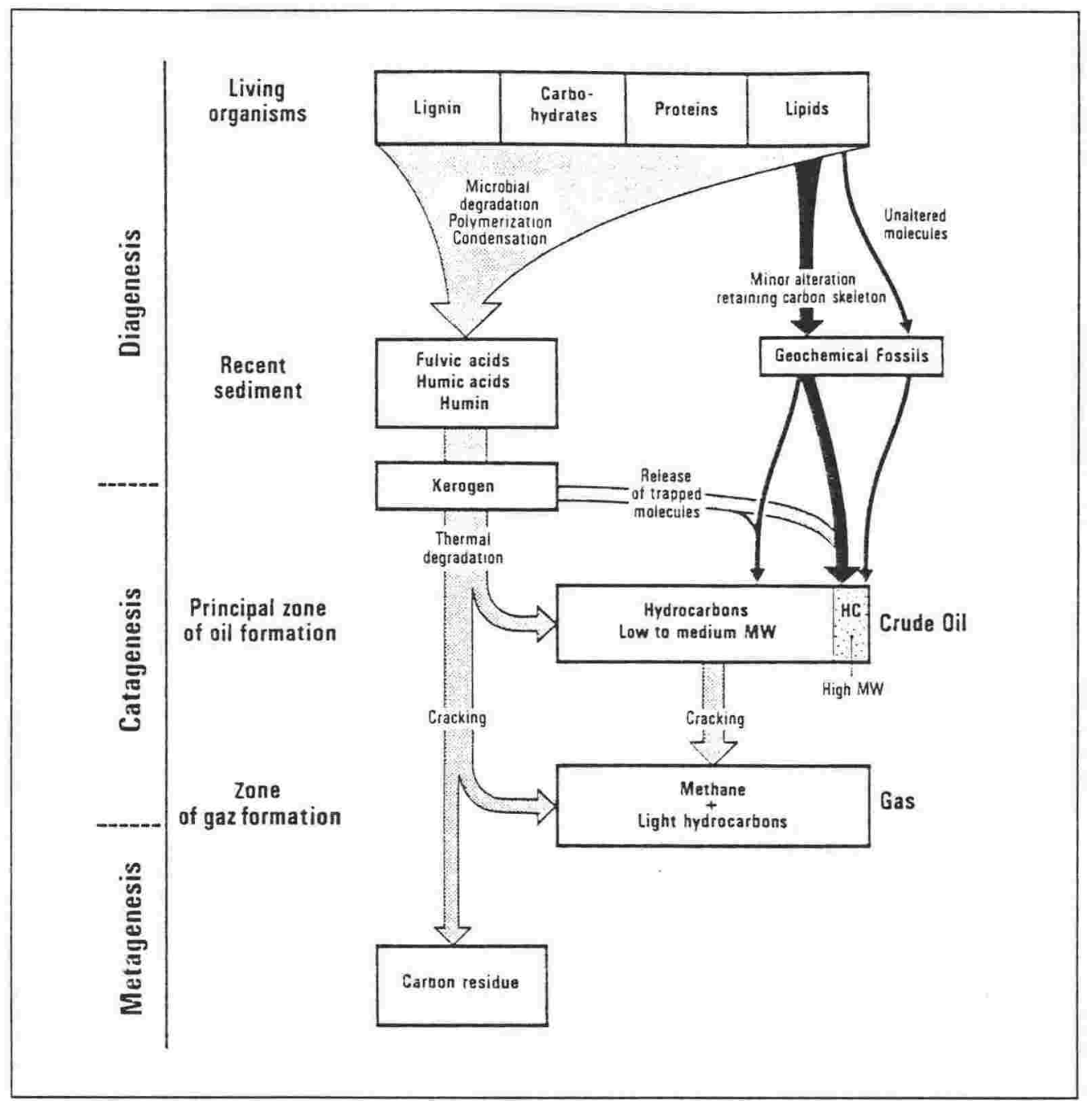

Figure 1.1 The three stages of maturation of organic matter (from Tissot and Welte, 1978).

\section{Diagenesis}

Diagenesis of organic matter occurs both prior to deposition and during the stages of early burial (to depths of several hundred metres), and hence under conditions of low temperature and pressure (Tissot and Welte, 1978; Killops and Killops, 1993). Microbial activity is the main cause of change during early diagenesis (Tissot and Welte, 1978) although chemical transformations are also possible (Killops and Killops, 1993). 'Biopolymers' (such as proteins, carbohydrates, lipids, and lignin) are destroyed by microbial activity during the initial stages of burial but these later recombine through polycondensation and insolubilization to form 'geopolymers' that precurse kerogen (Tissot and Welte, 1978). Carbon dioxide, water and methane are released during diagenesis, which is essentially complete on the formation of kerogen at a vitrinite reflectance value of $0.5 \%$ (Horsfield and Rullkötter, 1994). 


\section{Catagenesis}

Progressive burial and basin subsidence lead to organic matter reaching depths of several kilometres with temperatures of 50 to $150^{\circ} \mathrm{C}$ and pressures of 300 to 1500 bars, conditions under which catagenesis, the main phase of hydrocarbon formation, occurs (Tissot and Welte, 1978). Unlike diagenesis, catagenesis involves thermodynamic rather than biogenic changes (North, 1990) and is characterised by the thermal degradation of kerogen by progressive cleaving of aliphatic and aromatic side chains. Oil and later 'wet gas' and condensate are produced accompanied by significant amounts of methane, the quantity and composition of which depends on the original composition of the organic matter (Killops and Killops, 1993). The main phase of oil generation occurs between vitrinite reflectance values of 0.65 and $1.3 \%$ and the end of catagenesis is reached when all aliphatic side chains are cleaved and an ordering of basic kerogen units begins (vitrinite reflectance of about 2\%) (Tissot and Welte, 1978).

\section{Metagenesis}

Metagenesis is only reached at great depth where temperature and pressure are high. Organic matter here comprises only methane and carbon residue, where some crystalline ordering of kerogen units begins to develop (Tissot and Welte, 1978). Metagenesis continues up to the onset of greenschist metamorphism at a vitrinite reflectance of $4 \%$ (Tissot and Welte, 1978; Horsfield and Rullkötter, 1994).

\section{Organic maturation}

Discussion of organic maturation and level of organic maturity is made complex because it has been found that kerogen 'matures' and generates hydrocarbons at different levels of thermal stress according to its chemical composition. Hydrogen-rich kerogen has been found to mature at a slower rate than oxygen-rich kerogen (Price and Barker, 1985), and similarly, sulphur-rich kerogen has been found to generate hydrocarbons at a very early stage of catagenesis compared with sulphur-poor kerogen (Rullkötter, 1993). Hence a detailed discussion of the various geochemical maturity parameter values, as indicators of different stages of hydrocarbon generation, is usually of limited use unless kerogen type is also discussed. However, it is often more practical to discuss organic maturity according to these generalised stages of hydrocarbon generation, especially when using multiple geochemical maturity parameters. While recognising that kerogen types differ among formations of the southern East Coast Basin (see Section 7.3), it was felt appropriate that, for ease of description and comparison, the stages of hydrocarbon generation be 'standardised'. Figure 1.2 shows the different stages of thermal maturation and oil generation, ranging from diagenesis through to the end of catagenesis, correlated with vitrinite reflectance $\left(\mathrm{R}_{\mathrm{o}}\right)$ values. 


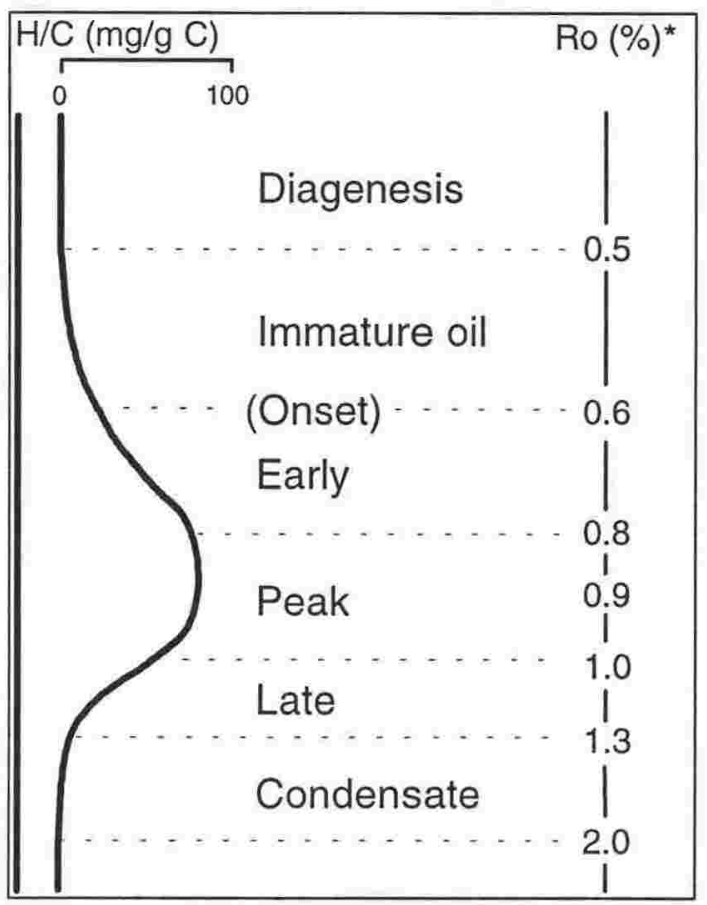

*Values change with different kerogen types.

Figure 1.2 Stages of oil generation correlated to approximate vitrinite reflectance values (after Tissot and Welte, 1978; and Peters and Moldowan, 1993).

Unfortunately these common descriptions of stages of thermal maturation have allowed some confusing terminology to arise in the literature whereby, for example, it is possible to have an 'immature' oil with maturity below the onset of oil generation (less than $0.6 \% \mathrm{R}_{\mathrm{o}}$ ). 


\subsection{Contribution of organic geochemistry to the exploration for petroleum}

Subsurface features that can trap hydrocarbons are located mainly by seismic reflection techniques. At present however, other than by drilling the structure, there is generally no sure method of determining whether it actually contains hydrocarbons (Barker, 1979). Additional, cost-effective exploration tools are required to improve exploration success by determining whether hydrocarbons are likely to be present. Organic geochemistry is one such tool and is useful in petroleum studies for:

- Screening possible source rocks (for quantity and type of organic matter);

- Characterising oils and potential source rocks (source/depositional environment, maturity, migration and post-source alteration (especially biodegradation); and

- Oil-oil and oil-source rock correlations.

\section{Source rock geochemistry}

Evaluating the source rock potential within a prospective basin is fundamental to any petroleum exploration programme. A number of criteria regarding source rock potential must be met before further, more expensive, work is carried out. Four questions must be answered when assessing the hydrocarbon potential of possible source rocks: (1) Is sufficient organic matter present in the rock?; (2) Is the organic matter of suitable type?; (3) Is the organic matter sufficiently thermally mature to produce hydrocarbons?; and (4) Have hydrocarbons been expelled? (Barker, 1979; Anders, 1991). If the answers to these questions are favourable the prospectivity of the basin is greatly enhanced and further investigation may be warranted.

\section{Oil geochemistry}

It is generally accepted that oil originates from sedimentary organic matter (Anders, 1991). When hydrocarbons are produced in sedimentary rocks only a small percentage is released, hence both the migrated oil and the resident bitumen contain similar organic compounds. Investigation at the molecular level can identify these similarities and this forms the basis for oil-oil and oil-source rock correlations.

\section{Analytical tools used in organic geochemistry}

Through advances in technology and the field of organic geochemistry a host of routine analytical tools and geochemical parameters have been developed that provide information regarding the origin and nature of organic matter in both oils and their possible source rocks. These techniques are well proven and used extensively by the oil 
industry in their exploration programmes. Table 1.1 lists the analytical tools used in this study and the derived geochemical parameters and briefly outlines the information that can be obtained from them.

\begin{tabular}{|c|c|c|}
\hline Analytical tool & Geochemical parameters & Information \\
\hline Total organic carbon & TOC & $\begin{array}{l}\text { Quantity of organic matter } \\
\text { Quantity of carbonate carbon }\end{array}$ \\
\hline Rock-Eval pyrolysis & $\mathrm{S}_{1} ; \mathrm{S}_{2} ; \mathrm{S}_{3} ; \mathrm{HI} ; \mathrm{OI} ; \mathrm{T}_{\max } ; \mathrm{PI}$ & $\begin{array}{l}\text { Quantity of extractable organic } \\
\text { matter } \\
\text { Quantity of kerogen } \\
\text { Type of organic matter } \\
\text { Maturity }\end{array}$ \\
\hline Gas chromatography (GC) & $\begin{array}{l}\mathrm{Pr} / \mathrm{Ph} ; \mathrm{CPI} ; \mathrm{Pr} / n-\mathrm{C}_{17} ; \\
\mathrm{Ph} / n-\mathrm{C}_{18} ; \mathrm{C}_{21}+\mathrm{C}_{22} / \mathrm{C}_{28}+\mathrm{C}_{29}\end{array}$ & $\begin{array}{l}\text { Environment of deposition } \\
\text { Maturity }\end{array}$ \\
\hline $\begin{array}{l}\text { Gas chromatography-mass } \\
\text { spectrometry (GC-MS) }\end{array}$ & $\begin{array}{l}\text { Identification of numerous } \\
\text { individual biomarker } \\
\text { compounds and ratios, e.g. } \\
\mathrm{C}_{30} \text { index; oleanane; } \\
28,30 \text {-bisnorhopane etc }\end{array}$ & $\begin{array}{l}\text { Source } \\
\text { Maturity } \\
\text { Migration } \\
\text { Biodegradation } \\
\text { Oil-oil and oil-source rock } \\
\text { correlation }\end{array}$ \\
\hline Stable carbon isotopes & Sofer Value & $\begin{array}{l}\text { Oil-oil and oil-source rock } \\
\text { correlation } \\
\text { ?Environment of deposition }\end{array}$ \\
\hline Visual kerogen analysis (VKA) & TAI & $\begin{array}{l}\text { Type of organic matter } \\
\text { Environment of deposition } \\
\text { Maturity }\end{array}$ \\
\hline Vitrinite reflectance $\left(\mathrm{R}_{0}\right)$ & & Maturity \\
\hline $\begin{array}{l}\text { X-ray fluorescence } \\
\text { spectroscopy (XRF) }\end{array}$ & $\mathrm{S} / \mathrm{C} ; \mathrm{V} / \mathrm{Cr} ; \mathrm{Ni} / \mathrm{V} ; \mathrm{U} / \mathrm{Th}$ & $\begin{array}{l}\text { Bottom-water oxygenation } \\
\text { Source rock provenance }\end{array}$ \\
\hline
\end{tabular}

Table 1.1 Methods of geochemical analysis and the information that each can provide.

Total organic carbon and Rock-Eval pyrolysis typically provide a quick way of screening a large number of samples to determine whether they have any hydrocarbon source potential. Those samples with $>0.5 \%$ TOC and adequate $S_{1}$ and $S_{2}$ values are usually submitted for further analyses such as VKA, GC, GC-MS, vitrinite reflectance and stable carbon isotopes. These analyses are designed to provide more detailed information to help characterise the organic matter in both oils and their possible source rocks to aid oiloil and oil-source rock correlations. Clearly there are many interpretive constraints when considering the results of individual geochemical parameters. Their value becomes apparent however when a suite of different geochemical parameters are used. 


\subsection{Petroleum exploration history in the southern East Coast Basin}

\subsubsection{Introduction}

The presence of hydrocarbons in the East Coast Basin was recorded in 1865 from the Gisborne region, although their existence were known to Maori many generations earlier (McLernon, 1992). In the following years three main oil seeps were discovered in the northern East Coast Basin at Waitangi, Totangi and Rotokautuku. Exploration began in 1874 with the drilling of Waitangi Hill-1 and -2, shallow, timber-lined, hand-dug shafts, completed by boring with rods (Francis, 1993a). Geological assessments were not considered important and wells were often sited adjacent to oil or gas seeps (Brooks and Remus, 1985). The period following 1921, however, saw the entry of larger companies using modern petroleum exploration methods (Francis, 1993a). Most exploration took place in the northern part of the basin near the three main oil seeps, but several wells were drilled in southern Hawke's Bay (Figure 1.3).

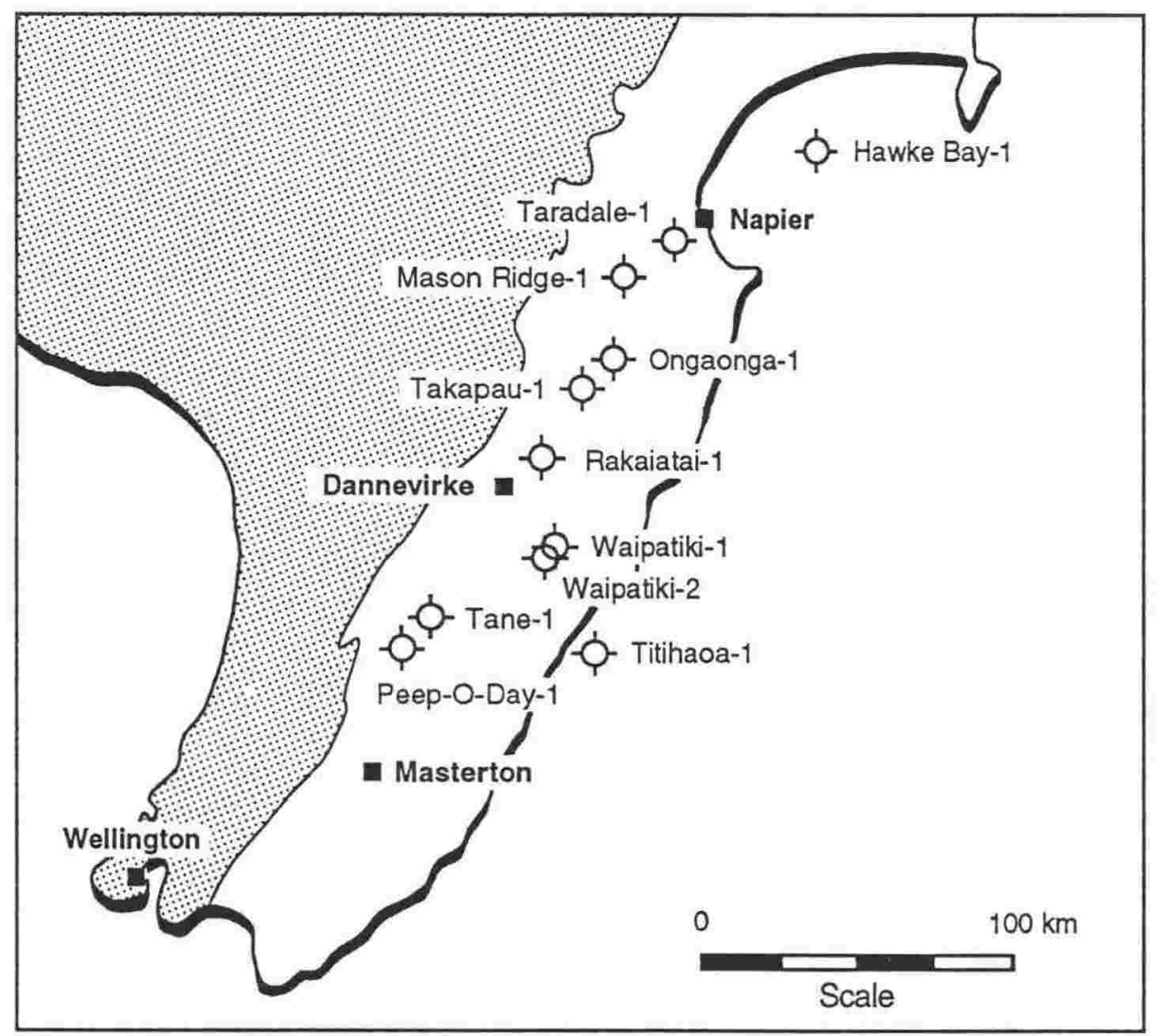

Figure 1.3 Locations of exploration wells in the southern East Coast Basin.

The history of petroleum exploration in the East Coast Basin has been summarised by McLernon (1992) and Francis (1993a; 1994; 1995b). The petroleum exploration history of the Dannevirke, Gisborne and East Coast areas has been discussed by Laing (1961), 
Brooks and Remus (1985) and Simpson and Jarvis (1993) respectively in unpublished petroleum reports.

\subsubsection{Early petroleum exploration}

Kotuku Oilfields Syndicate, a Royal Dutch Shell subsidiary, drilled three unsuccessful wells on the West Coast of the South Island before venturing into the East Coast Basin (Laing, 1961). Prospects in the southern part of the basin were viewed more favourably than those in the north (Francis, 1993a) and between 1912 and 1913 two wells, Waipatiki-1 and -2, were drilled south-east of Dannevirke. The first was sited near a gas seep and drilled Paleocene and Upper Cretaceous rocks; the second, $1800 \mathrm{~m}$ to the south-west, spudded in Upper Cretaceous and remained in rocks of this age (Francis, 1993a). Both wells encountered oil and gas shows and gas from Waipatiki-1 was piped to local residents' houses for many years (Laing, 1961; Francis, 1993a). Waipatiki-2 was subsequently deepened by a local syndicate in 1926 .

During 1912-14 Mangaone Oilfields Ltd drilled Tane-1, $13 \mathrm{~km}$ east of Eketahuna. The well spudded in Lower Pliocene rocks and finished in the Upper Miocene. In 1927 the same company also drilled Peep-O-Day-1, $9 \mathrm{~km}$ east of Eketahuna which only reached a depth of $30 \mathrm{~m}$ (Francis, 1993a). During the 1920s the Taranaki Oil Company mapped the Dannevirke area without drilling, and in the middle to late 1930s New Zealand Oil Exploration Ltd mapped much of northern Wairarapa and central and southern Hawke's Bay. Work comprised mainly reconnaissance geological mapping and no wells were drilled. In the early 1940s the Superior Oil Company mapped the Dannevirke Basin and samples were analysed using modern geochemical techniques. Prospects were considered poor and no further work was done.

In 1957 BP Shell and Todd Petroleum Development Consortium acquired petroleum prospecting licences covering almost the entire onshore East Coast Basin of the North Island (Brooks and Remus, 1985; Francis, 1995b). Several farm-in agreements were reached, firstly with New Zealand Aquitaine Petroleum and then International Pacific Exploration. In 1969 BP Shell Aquitaine and Todd Petroleum Development Limited drilled Taradale-1 and Rakaiatai-1 in southern Hawke's Bay to test the Te Aute Limestone, identified in outcrop as an excellent reservoir with high porosity and permeability (Darley, 1969a; 1969b). Taradale-1 was sited on a structure identified by an earlier (1959) seismic reflection survey. The well was abandoned as a dry hole in strata of Paleocene age. No reservoir beds were encountered and no hydrocarbons detected in an almost entirely mudstone sequence (Darley, 1969a). Rakaiatai-1 was sited solely by 
surface mapping of an anticline. It encountered greywacke below rocks of probable Nukumaruan age (2.4-1.2 Ma) at shallow depth, and was subsequently abandoned as a dry hole. Reservoir rocks were never encountered and no hydrocarbons were detected (Darley, 1969b). After drilling some unsuccessful wells in the northern part of the basin, the consortium relinquished all its onshore East Coast licences.

In 1971 a three well programme was concluded by Beaver Exploration New Zealand Limited and Longreach Oil Limited in a farm-out agreement with BP Shell Aquitaine and Todd Petroleum Development Limited. Ongaonga-1, Takapau-1 and Mason Ridge-1, all situated in southern Hawke's Bay, were drilled to test the hydrocarbon potential of the Te Aute Limestone (Leslie, 1971a; 1971b; 1971c). Ongaonga-1, located on a closed subsurface seismic high, penetrated greywacke after drilling through $1460 \mathrm{~m}$ of PlioPleistocene sediments. The Tertiary rocks comprised a marine sequence of silty, fossiliferous mudstone with interbedded coquina limestone. At $1290 \mathrm{~m}$ a $105 \mathrm{~m}$ thick limestone was encountered with excellent porosity and permeability but containing fresh water. No significant hydrocarbons were encountered and the well was abandoned as a dry hole (Leslie, 1971a).

Takapau-1 was sited on the crest of a seismically-defined subsurface faulted anticline. The well terminated in greywacke after drilling $1000 \mathrm{~m}$ of Plio-Pleistocene sediments. A $100 \mathrm{~m}$ thick reservoir was encountered at $835 \mathrm{~m}$ with excellent porosity and permeability but was water filled. No significant shows of hydrocarbons were detected and the well was abandoned as a dry hole (Leslie, 1971b).

Mason Ridge-1 was located on a north-plunging nose of a surface high which had poor subsurface seismic expression. The well drilled $1640 \mathrm{~m}$ of Plio-Pleistocene silty, fossiliferous mudstone interbedded with silty sandstone and coquina limestone. A major unconformity or fault was encountered, below which were $230 \mathrm{~m}$ of steeply dipping Miocene siltstone and mudstone. Strong gas indications were present in the Pliocene(?) shale but the Te Aute Limestone was missing. The well was abandoned as a dry hole at a depth of $1870 \mathrm{~m}$ (Leslie, 1971c) and the licence subsequently expired in 1972.

BP Shell Aquitaine and Todd Petroleum Development Ltd continued exploration offshore and conducted a number of seismic reflection surveys off eastern New Zealand in the middle to late 1960s. One prospect, a large anticlinal feature, was identified in Hawke Bay, $45 \mathrm{~km}$ north-east of Napier in $57 \mathrm{~m}$ of water. Hawke Bay-1, the first offshore well in the East Coast Basin, was drilled in 1976. The primary targets were porous sandstones and limestones of Pliocene age (equivalent to Te Aute Limestone of 
southern Hawke's Bay) with Upper Miocene sandstone units providing a secondary target. Drilling revealed a poorly developed limestone. Porosity was $25 \%$ but there was no closure at that level and it was water bearing. The Upper Miocene sandstones did not occur and were replaced by a silty clay, partly turbiditic facies. A major unconformity was encountered at $2255 \mathrm{~m}$ underlying Middle Miocene sediments. Sediments below this gave a gas kick which was determined to be methane only. The well was terminated after the bottom hole assembly stuck in clays of Whaingaroan age (Heffer et al., 1976) and the partnership subsequently relinquished the licence.

Katz (1981) identified a series of anomalous reflections on seismic records from offshore, eastern North Island and concluded they were probably gas hydrate accumulations. If correctly interpreted, the extent of these features suggests huge amounts of gas hydrate have accumulated along the continental margin below waters 1000-2500 m deep.

\subsubsection{Recent petroleum exploration}

No further exploration licences were sought until the 1988 licensing round. In 1986, however, BP conducted a proprietary geochemical SNIFFER survey over 758 line kilometres in the Cook Strait region. Five areas were identified which had hydrocarbon levels elevated above background. Two comprised only methane, which were thought to be indicative of a biogenic origin and were, therefore, omitted from further analyses. The remaining three anomalous regions contained quantities of ethane and higher molecular weight hydrocarbons, but these were not of thermogenic character and hence were also considered to be of biogenic origin (Sigalove, 1986).

The 1988 licensing round resulted in licences being awarded in central and southern Hawke's Bay, northern Wairarapa and much of the offshore area of southern East Coast Basin. Croft Exploration Ltd, operating in southern Hawke's Bay, reprocessed existing seismic, acquired new seismic and subsequently identified a prospect (Croft Staff, 1992). Unfortunately no partners could be found and the licence was relinquished without drilling in 1994 (Francis, 1995b). NZ CQX Ltd (Conquest Exploration Co.) conducted a programme involving seismic, gravity, magnetic and bathometric surveys with additional seafloor sampling. Detailed geological mapping was conducted on coastal sections adjacent to the licence areas (see Francis 1993b; 1993c; 1993d). Their licences were, however, relinquished prior to identification of any suitable structures. 
Following exploration of northern Wairarapa in the early 1960s by BP, Shell and Todd Petroleum Development Ltd (see Laing, 1961) a consortium, with Lakes Oil Limited as operator, identified a number of target structures from field work. Reservoir studies were conducted and three stratigraphic holes were drilled to test the presence of adequate reservoir beds and establish the extent of beds known to contain oil and gas. Greensands of the Eocene Wanstead Formation and the Miocene Westcott Formation proved to be the most oil-stained units (Laing, 1991). No further work was done and the licence was surrendered.

Amoco New Zealand Exploration Co. Ltd was awarded PPL 38318 (offshore from Castlepoint) in mid 1988. Onshore geological mapping and associated geochemistry (Hutson, 1989; Lipke, 1989; Zumberge, 1990; Biros et al., 1994), reprocessing of existing seismic, magnetic and gravity data, a marine geochemical programme and new seismic led to the drilling of the East Coast Basin's second offshore well, Titihaoa-1. A farm-in group of Mobil Exploration and Production New Zealand Inc., Taranaki Offshore Petroleum Company Ltd and Todd Petroleum Mining Co. Ltd drilled the Titihaoa Prospect in 1994/95. The well was subsequently plugged and abandoned as a dry hole. Amoco withdrew from the partnership and the licence was relinquished in 1996, without further exploration.

\subsubsection{Exploration history in Marlborough}

Compared to eastern North Island, the exploration history in Marlborough is brief. In the late 1950s BP Shell and Todd Petroleum Development Ltd acquired three licences in the north-eastern part of the South Island and several independent operators held adjacent licences. Geological mapping was conducted and two oil seeps located at London Hill and Isolation Creek. No seismic reflection surveys were shot and no wells were drilled. Striker Petroleum was awarded acreage in north-eastern Marlborough in 1988 but no work was undertaken and the licence was surrendered shortly after. 


\subsection{Previous studies of petroleum geochemistry in the southern East Coast Basin}

Studies of petroleum geochemistry in New Zealand have generally concentrated on the Taranaki Basin, New Zealand's only commercial petroleum province (e.g. Cook, 1987; Collier, 1989). Until recently, relatively few such studies have been conducted in the East Coast Basin.

'Modern' methods of petroleum geochemistry were first applied on the East Coast Basin in the 1930s by the Vacuum Oil Company, who included a chemist in their exploration team. Although using a different methodology from conventional present day TOC analyses, organic carbon analyses of Waipawa Black Shale were obtained which averaged $8.2 \%$ with samples of Whangai Formation averaging a modest $1.5 \%$ (Francis, 1994), values similar to those recorded recently (e.g. Moore et al., 1987).

Lowe and O'Reilly (1980) analysed a number of outcrop samples, well cuttings (from Mangaone-1 and Taradale-1) and oil from the Waitangi seep in the Gisborne area. Results from vitrinite reflectance, visual kerogen analysis, stable carbon isotope and soluble extract studies indicated that the only sediments with significant hydrocarbon potential were Paleocene and Middle Eocene in age. The stable carbon isotope ratios of the Waitangi oil suggested a marginal marine origin. Isotopic ratios for Waipawa Black Shale and Middle Eocene sediments indicated a highly marine origin for the kerogen and suggested these were unlikely to have sourced the Waitangi oil seep; however no source for the Waitangi seep could be identified. Vitrinite reflectance studies suggested most samples were immature for hydrocarbon generation. Visual kerogen studies identified Waipawa Black Shale as having considerable oil source potential and this was supported by pyrolysis studies.

Gibbons (1980) reviewed studies of maturity and source rock potential in the Gisborne region and concluded that "...the only potentially significant source in the Gisborne region and adjacent areas is the Paleocene Waipawa Black Shale". He noted that its thickness $(c .10 \mathrm{~m})$ was a limiting factor but suggested it should thicken eastwards. All other formations analysed had little or no potential to source oil and gas, regardless of maturity level. From this he suggested that the prospects of finding commercial quantities of oil or even gas, in the Gisborne region, were poor.

Fry (1982) presented the results of geochemical analyses of 17 outcrop samples of Early Cretaceous to Paleogene age from throughout the East Coast Basin. The samples were 
examined for maturity by vitrinite reflectance and visual kerogen analysis and were found to be immature for oil generation. The samples were then screened by Rock-Eval pyrolysis and, where suitable, analysed by pyrolysis GC. Those found to have good source potential were submitted for further analyses including GC-MS and stable carbon isotope studies. Waipawa Black Shale samples were found to be dominated by amorphous kerogen of marine algal origin and demonstrated both oil and gas potential, although all were immature for hydrocarbon generation. They were found to be isotopically heavy and contain novel $\mathrm{C}_{30}$ sterane biomarkers. An oil stain (Tunakore Stream) was shown to be mature and very biodegraded, containing predominantly isoprenoids with little $n$-alkane material. It also exhibited novel $\mathrm{C}_{30}$ steranes and isotopically heavy $\delta^{13} \mathrm{C}$ values. Despite observed similarities between the Tunakore Stream oil stain and the Waipawa Black Shale samples no correlation was described as it was concluded that the source had not yet been found.

Jackson (1982) presented the results of a geochemical study of 30 outcrop samples of Cretaceous to Miocene age from throughout the East Coast Basin in a companion study to that of Fry (1982). Again, most samples were found to be immature with respect to hydrocarbon generation. Only three samples were considered to have moderate to good hydrocarbon potential and these were from the Waipawa Black Shale, Whangai and Karekare formations and were both oil and gas-prone. A number of samples were thought to contain migrated hydrocarbons. Extracted hydrocarbons gave two signatures, one indicating a marine source and the other more terrigenous. None of the outcrop samples examined appeared to source the oil-like extracts and no correlation was made between the oil-like extracts or possible source rocks and the Waitangi oil seep. A sample of oil from sandstones near Westcott Station was shown to be biodegraded.

Moore et al. (1987) carried out Rock-Eval pyrolysis on 30 samples in a source rock investigation as part of a wider study of the uppermost Cretaceous to Paleocene sequence in eastern North Island. Whangai Formation samples (0.06-1.46\% TOC) were found to have little source potential. By comparison, the Waipawa Black Shale, with 1.8 to $12.3 \%$ TOC, was found to have very high generative potential. Kerogen in the two formations was determined to consist primarily of mixed Types II (marine) and III (terrestrial). The Upper Calcareous Member of the Whangai Formation was found to contain dominantly marine organic matter whereas the Rakauroa Member had a higher proportion of terrestrially-derived organic matter.

Adams and Ballance (1988) investigated the petroleum potential of the Cretaceous sequence of southern Hawke's Bay. Results showed the sequence to have moderate TOC 
values, low hydrogen/carbon ratios and low vitrinite reflectance values indicating "...at best, marginal oil source beds."

Weston et al. (1988) conducted a biomarker correlation study of the three main seep oils in the northern East Coast Basin (Waitangi, Totangi and Rotokautuku) (Figure 2.1) and a number of rock bitumens. The three oils were found to exhibit similar characteristics: They were all mature and only slightly degraded. A neritic depositional environment was indicated with a significant input of terrigenous organic matter. The oils were presumed to have been derived from Cretaceous shales although biomarker correlation with the rock bitumens was not possible. Two rock bitumens from southern East Cast Basin were included in the study: One was a "Paleocene chocolate shale" from Waipawa and; the other an "Upper Cretaceous black shale" from near Castlepoint. The grid reference for the latter, however, appears to suggest this too was Waipawa Black Shale. These samples were uniquely characterised by a relatively low saturate fraction, and high aromatic, polar and asphaltene fractions, compared with the northern oils and were shown not to be the source for these oils.

Hirner and Lyon (1989) and Hirner and Robinson (1989) used carbon and sulphur stable isotopes to correlate between different oils and between oils and possible source rocks throughout New Zealand. East Coast Basin samples included the three main oil seeps in the northern East Coast Basin, two oils from the Marlborough region and a Waipawa Black Shale sample from Castlepoint. The East Coast Basin oils were shown to form a distinct family, differing from the Taranaki and West Coast oils in that they exhibited greater marine influence. It was also contended that the Waipawa Black Shale did not source any of the East Coast Basin oils sampled.

During 1988 and 1989 extensive proprietary research was conducted by Amoco New Zealand Exploration Co. Ltd relating to their licences offshore of northern Wairarapa (PPL 38318) and southern Hawke's Bay (PPL 38323). However, results of their research, which include detailed organic geochemistry of oil and gas seeps and possible source rocks from the adjacent onshore region, were not made publicly available until late 1994/1995. Several geochemical evaluations of oil and gas seeps, bitumen-stained sandstones and outcrop samples were conducted (e.g. Lipke, 1989; Zumberge, 1990), based on fieldwork and sampling mainly from southern Hawke's Bay and northern Wairarapa. Geochemical analyses included Rock-Eval pyrolysis, GC, GC-MS, VKA, elemental analysis, stable carbon isotope and gas analysis. 
Overall the best potential source rock sampled was the Waipawa Black Shale with TOC content up to $9.2 \%$ while, with somewhat less source potential, the Whangai Formation was found to have up to $2 \%$ TOC. In outcrop, both the Waipawa Black Shale and Whangai Formation were found to be of low maturity with maximum values of early peak oil generation. The Waipawa Black Shale was shown to be highly variable in oilproneness and this was considered to be due either to differential weathering or to a change in organofacies. The Oligocene and younger sequences (Figure 2.5) sampled generally had low TOC contents and were considered to have no source potential. Wanstead Formation samples, however, had an average TOC content of $1.1 \%$, with gasprone and immature kerogen. Older Cretaceous units (Figure 2.5) were not adequately sampled and their source potential was unknown, although it was thought to be much less than that of the Waipawa Black Shale. Glenburn Formation samples, however, averaged $2.1 \%$ TOC but the organic matter was determined to be of such poor quality that, even when mature, gas generation would be minimal.

Two general types of oils were recognised in the East Coast Basin: Predominantly marine-sourced oils such as the Waitangi, Totangi and Rotokautuku seep oils, and mixed Type II/III oils from impregnated sandstones to the south (e.g. Okau Stream, Kerosene Rock and Waipatiki oils and an oil-stained Wanstead Formation sample). Based on biomarker and stable carbon isotope ratios, these oils are typically more mature than the northern marine-sourced oils, biodegraded (with $n$-alkanes and isoprenoid hydrocarbons absent), isotopically heavy, often contain the unusual biomarker bisnorhopane, and appear to be derived from mature Waipawa Black Shale. The gas seeps analysed proved to be mainly wet gases indicating a possible petroleum source.

Johnston et al. (1992), in a preliminary biomarker study of oil seeps, impregnations and source rock bitumens from throughout the East Coast Basin, showed the oil seeps and impregnations to have similar characteristics suggesting a possible common source. The oils were shown to be dominantly mature marine oils with a minor and less mature terrestrial component. It was suggested that such a source could be a Lower Cretaceous marine formation, with a minor terrestrial component, or a Lower Miocene formation buried to sufficient depth for oil generation.

Leckie et al. (1992) presented the results of a petroleum source rock study involving 190 TOC and Rock-Eval analyses of Late Cretaceous to Paleogene strata throughout the East Coast Basin. The Whangai Formation, with the exception of the Upper Calcareous Member, was found to have low TOC values and hydrogen indices (HI). The Waipawa Black Shale, described as a $50 \mathrm{~m}$ thick, "...marine condensed section...", was found to 
have TOC contents up to $5.3 \%$ with Type II organic matter and HI to 550. In outcrop the Waipawa Black Shale lies just above the oil window but in the subsurface was thought to be in the oil window or to have just passed through it. 


\subsection{Thesis objectives}

The following represents a brief summary of the key points of the exploration history and petroleum geochemistry of the southern East Coast Basin that was publicly available prior to the commencement of the present study:

- Numerous oil seepages and impregnations and gas seeps are present throughout the East Coast Basin;

- Some 50 wells have been drilled in the East Coast Basin, 11 from the southern region, but to date there have been no commercial discoveries;

- No oil-source rock correlations have been established;

- The seep oils from the northern East Coast Basin (Waitangi, Totangi and Rotokautuku oils) appear to have similar geochemical characteristics and, unlike the oils from the Taranaki and West Coast basins, have a predominantly marine signature;

- Oils with different geochemical characteristics to the northern seep oils are also present in the basin;

- The Paleocene Waipawa Black Shale represents the best potential source rock with high TOC and HI values although, in outcrop, is immature for hydrocarbon generation. The uppermost Cretaceous Whangai Formation, the Upper Calcareous Member in particular, also represents a good potential source rock;

- Although poorly investigated the older Cretaceous and younger Neogene sequence appear to have little hydrocarbon potential; and

- The Waipawa Black Shale is not the source for the northern seep oils.

\section{Thesis objectives}

The presence of oil and gas seepages prove that effective source rocks exist in the East Coast Basin, and early oil exploration efforts appear to have concentrated on identifying hydrocarbon traps rather than establishing the source for the petroleum. Serious efforts to determine the source rock potential of the basin did not begin until the early 1980s, but these often involved small numbers of samples and were often restricted in nature. 
No real systematic approach was used with the outcome that no conclusive oil-source rock correlations were determined and the source rock potential of the basin was not fully established. The present study was originally conceived with the broad aims of resolving these two major problems. To achieve this, however, a systematic approach to the petroleum geochemistry and geology of the southern East Coast Basin was required and the aims of the present study include the following:

- Geochemically characterise the southern East Coast Basin oils and hence determine their source, maturity and biodegradation characteristics;

- Geochemically characterise all possible source rock formations and determine the source of the organic matter and its level of thermal maturity;

- Assess the hydrocarbon generative potential of each of the possible source rock formations and from these identify potential source rocks; and

- Establish oil-oil and oil-source rock correlations.

The geochemical survey covers the entire onshore East Coast Basin with Rogers (1995) providing an appraisal of the northern East Coast Basin. The present study is concerned with the southern part of the basin which extends from Napier, in central Hawke's Bay, south to Marlborough and approximately Cheviot which borders the North Canterbury Basin. 


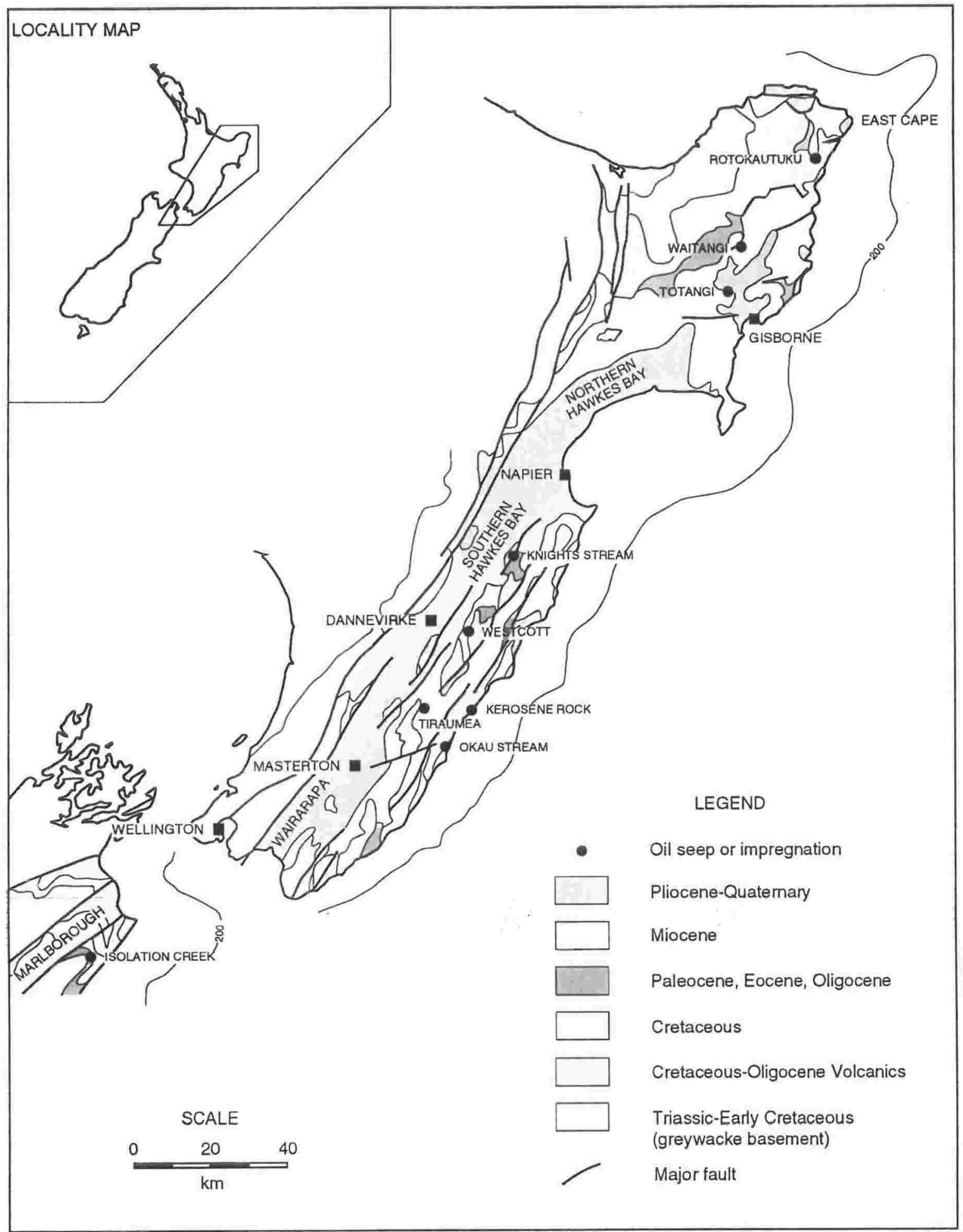

Figure 2.1 Geology of the East Coast Basin (after Ministry of Commerce, 1993). 


\section{Geology of the southern East Coast Basin}

\subsection{General geology of the southern East Coast Basin}

\subsubsection{Introduction}

The East Coast Basin (Figure 2.1) extends along the eastern margin of New Zealand from East Cape in the north-east to Marlborough in the south-west and from the axial ranges seaward to the Hikurangi Trough. It occupies an area of some $70,000 \mathrm{~km}^{2}$ of which approximately half is offshore (Ministry of Commerce, 1993) and has been in existence since the Early Cretaceous. Up to $10,000 \mathrm{~m}$ of mainly fine-grained marine sediments may be present in parts of the basin (Ministry of Commerce, 1993).

Eastern North Island and north-eastern South Island have variously been referred to as the East Coast Fold Belt (Katz, 1976), Axial Tectonic Belt (Walcott, 1978), East Coast Deformed Belt (Spörli, 1980), Eastern Structural Belt (Moore, 1988a) and East Coast Region (Laird, 1992). Many of these terms describe the same tectonic province and have been the subject of debate (see Katz, 1983; Pettinga, 1983 and Spörli, 1983). The term 'East Coast Basin' has found favour with those in the petroleum industry (e.g. Francis, 1995a), best describing the region as a petroleum province and as such will be used in this thesis. First used by Leslie and Hollingsworth (1972), the East Coast Basin was defined as the "full length of the eastern side of the North Island from Wellington to East Cape. It is bounded to the west by the Tararua-Ruahine-Raukumara Ranges and extends offshore to the east". This has since been enlarged to include Marlborough and extended eastwards to the Hikurangi Trough (Ministry of Commerce, 1993).

\subsubsection{Tectonic Setting}

New Zealand is located at the southern end of the Tonga-Kermadec-Hikurangi subduction zone (Lewis and Pettinga, 1993) (Figure 2.2). Within this, the East Coast Basin lies on the Hikurangi Subduction Margin (Cutten, 1992) occupying a forearc position (Figure 2.3). Here the forearc is defined as the region lying between the trenchslope break and the arc or frontal-arc high (Ballance, 1993b). 
Figure 2.2 Location map showing New Zealand's position relative to the plate boundary (from Lewis and Pettinga, 1993). Stippled area indicates New Zealand continent. Numbered arrows show rates of relative convergence in $\mathrm{mm} / \mathrm{y}$. Cross-hatching represents thickened oceanic crust of the subducting Hikurangi Plateau.

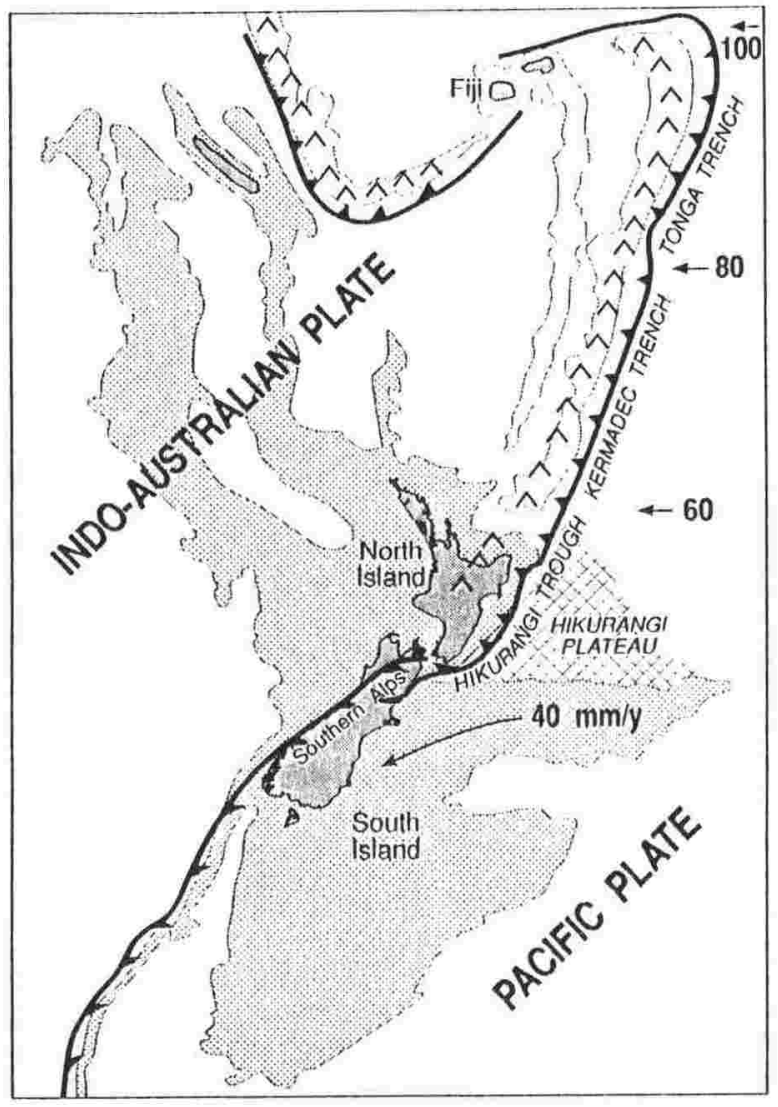

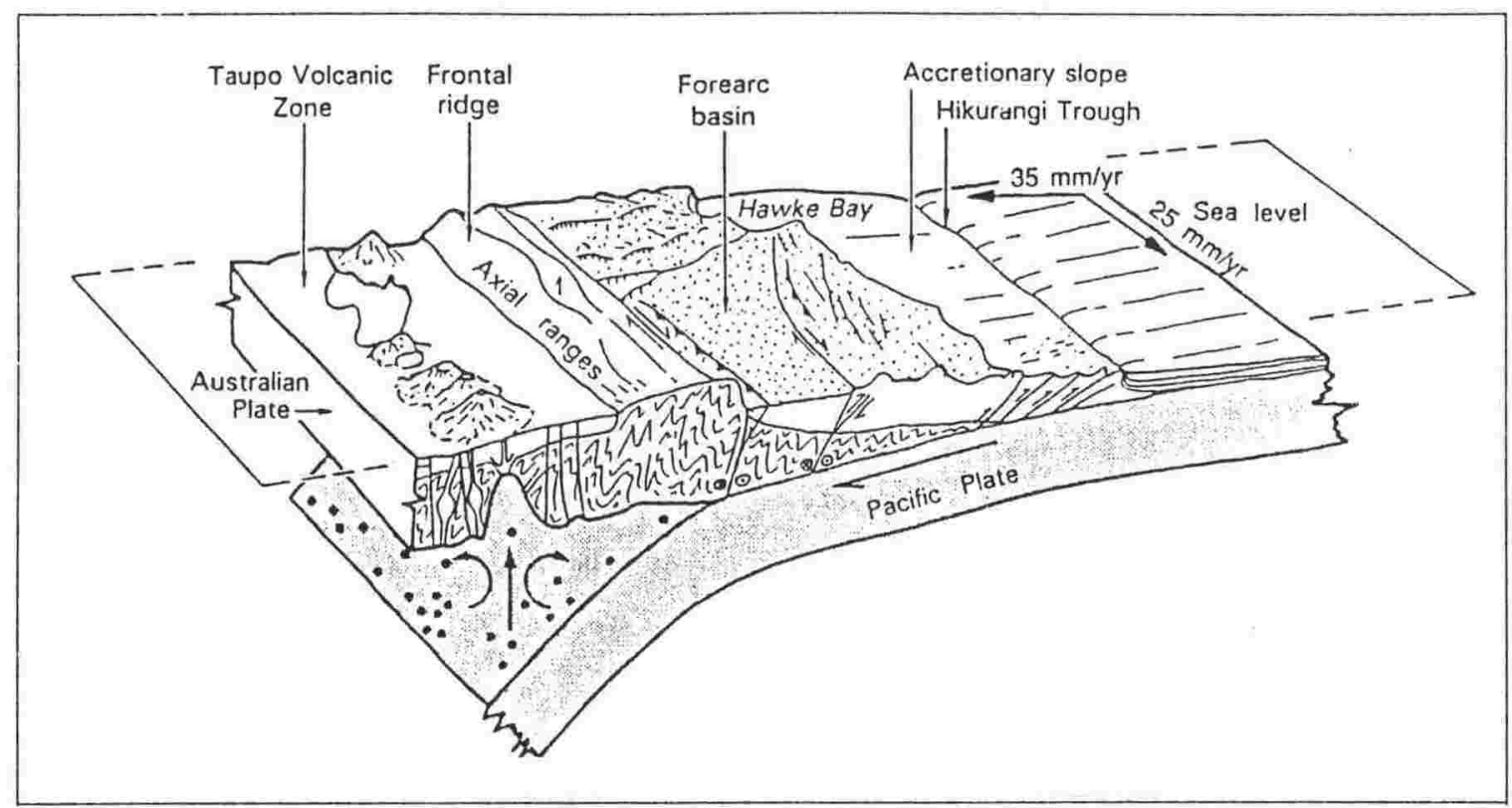

Figure 2.3 Diagrammatic cross-section of the central East Coast Basin showing the position of the axial ranges and forearc basin with respect to the subducting Pacific Plate (from Cutten, 1992). 
To the north the East Coast Basin forms an "imbricate-thrusted, seaward-thinning wedge-shaped sedimentary basin complex" compressed against indurated Mesozoic greywacke forming the axial ranges (Wright et al., 1992). This is associated with oblique westward subduction of the Pacific Plate beneath the Indo-Australian Plate which began $25 \mathrm{Ma}$ ago (Ballance, 1993b; Lewis and Pettinga, 1993). The rate of relative plate motion over the last three million years in the Hawke's Bay area has been calculated at $43.5 \mathrm{~mm} / \mathrm{yr}$, and this resolves into convergent and transcurrent components of 35 and $25 \mathrm{~mm} / \mathrm{yr}$ respectively (Cutten, 1992). Plate convergence becomes progressively more oblique to the south, to the point that in the Cook Strait area the motion consists almost entirely of strike-slip movement (Kamp, 1992).

\subsubsection{Structure of the East Coast Basin}

Deformation of the basin occurs at the subduction complex where some of the relative plate motion is transferred across the plate boundary into the overlying Australian Plate, and is mainly caused by the drag associated with oblique subduction (Lewis and Pettinga, 1993). Perpendicular motion is taken up by thrusting on the trench slope while transcurrent movement is accommodated along major strike-slip faults present along the western side of the basin, adjacent to the axial ranges. Total Neogene displacement along these faults is estimated at $150-200 \mathrm{~km}$ with late Quaternary movement rates of 1-4 mm/yr (Cutten, 1992). Partitioning of the oblique convergence into orthogonal and transcurrent movement is a characteristic feature of the Hikurangi Subduction Margin (Erdman and Kelsey, 1992).

Moore (1988a) proposed the division of eastern North Island into seven structural blocks and two sub-belts based on differences in stratigraphy and structure of the CretaceousPaleogene sequence (Figure 2.4). The following are brief descriptions of the five structural blocks in the southern part of the basin (from Moore, 1988a) which have been adopted in the present study.

Woodville Block is bounded by the Tararua and Ruahine ranges to the west and the Wairarapa-Makuri-Oruawharo faults to the east. Surface outcrop and oil exploration wells indicate that the Torlesse Supergroup is directly overlain by Miocene or younger sediments. The northern boundary is unknown but lies to the north of Mason Ridge-1 south-west of Napier.

Pongaroa Block contains a relatively complete, generally open folded, Cretaceous to Paleogene 'cover' sequence, overlying the more deformed Lower Cretaceous Pahaoa 


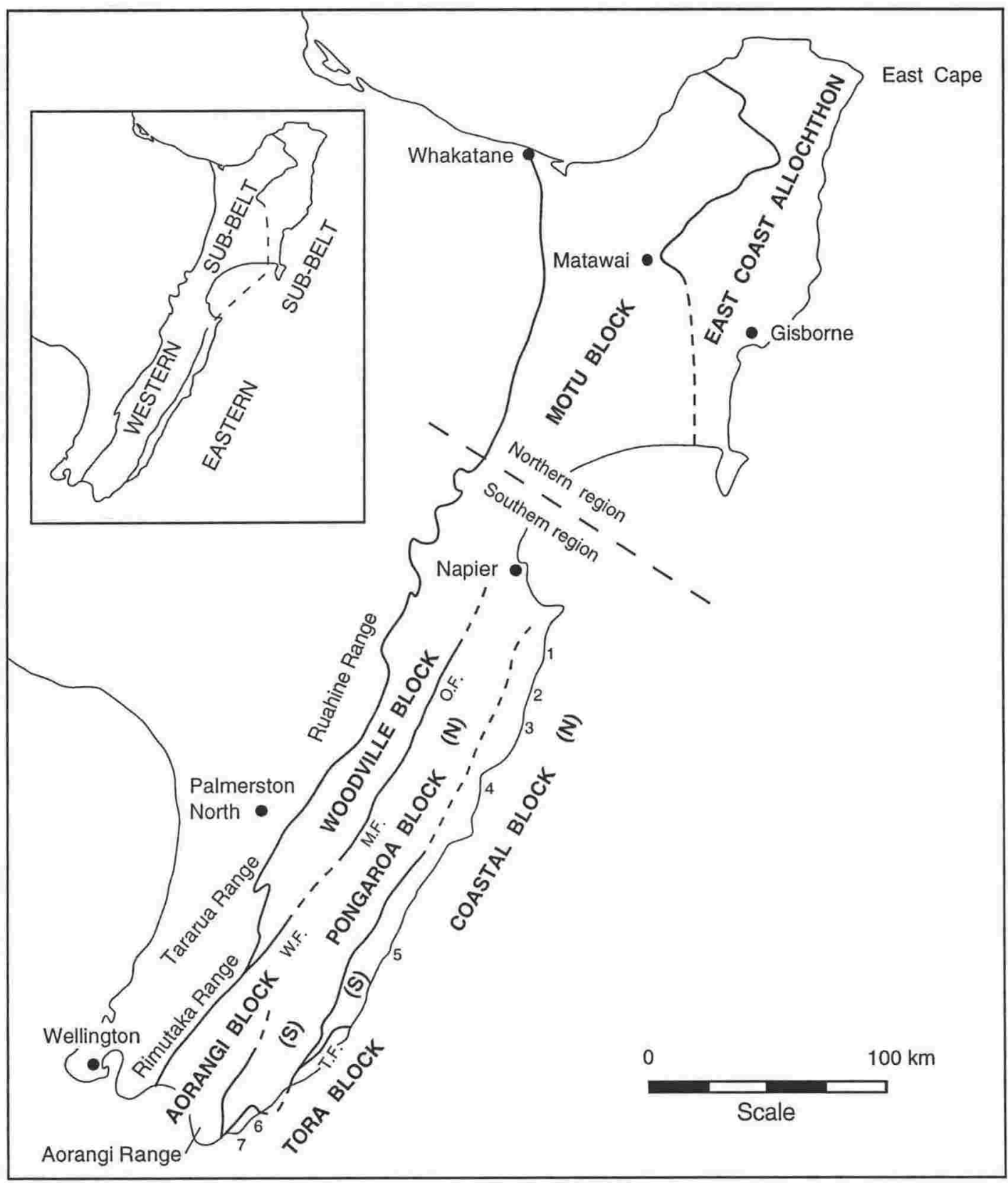

1. Waimarama Beach; 2. Mangakuri Beach; 3. Paoanui Point; 4. Porangahau Beach; 5. Castlepoint; 6. Tora; 7. Te Kaukau Point/White Rock; W.F.=Wairarapa Fault; M.F.=Makuri Fault; O.F.=Oruawharo Fault; T.F.=Tutu Fault.

Figure 2.4 Structural divisions of eastern North Island (after Moore et al., 1986; Moore, 1988a). 
Group sediments. A northern and southern segment have been distinguished, with Upper Cretaceous and Paleogene strata generally absent in the south.

Coastal Block comprises most of the coastal ranges and in south-eastern Wairarapa is bounded to the east by the Tutu Fault. Its extent offshore is unknown. This block is also divided into northern and southern segments, based largely on facies changes within the Whangai Formation.

Tora Block stratigraphy more closely resembles that present in Marlborough. Paleogene strata are faulted against Early Cretaceous rocks (Pahaoa Group). Eastern and southern limits of the block are unknown.

In the Aorangi Block Tertiary strata are largely absent, with the oldest rocks overlying basement being of Late Miocene age. The Cretaceous sequence in the Aorangi Ranges includes at least two major units: the Whatarangi Formation and the Moikau Formation. It is unknown whether these are correlatives of the Mangapokia and Springhill formations of the southern Pongaroa Block.

\section{Western and Eastern Sub-belts}

In addition to distinguishing seven major structural blocks, Moore (1988a) divided the geology of eastern North Island into two sub-belts: The Western Sub-belt is structurally more simple and comprises a mudstone-dominated Cretaceous sequence and minor igneous rocks; the Eastern Sub-belt is characterised by much stronger deformation, a Cretaceous flysch facies, and relatively common igneous rocks. The Western Sub-belt includes the Motu, Woodville, Pongaroa, and Aorangi blocks. The Eastern Sub-belt consists of the East Coast Allochthon, Coastal Block and Tora Block. Moore's work was limited to the North Island and, therefore, excludes the basin's southern extension into Marlborough.

\subsubsection{Stratigraphy}

A considerable amount has been written on East Coast Basin stratigraphy with early reviews by Kingma and Speden (1978), Lensen (1978a; b) and Suggate (1978). Moore and Speden (1984) investigated the Early Cretaceous rocks of eastern Wairarapa and Moore (1988b, 1989) studied the Late Cretaceous to Paleocene sequence of eastern North Island. More recently, Lewis and Pettinga (1993) and Ballance (1993b) investigated the stratigraphy and structure of Neogene subduction related sediments and 


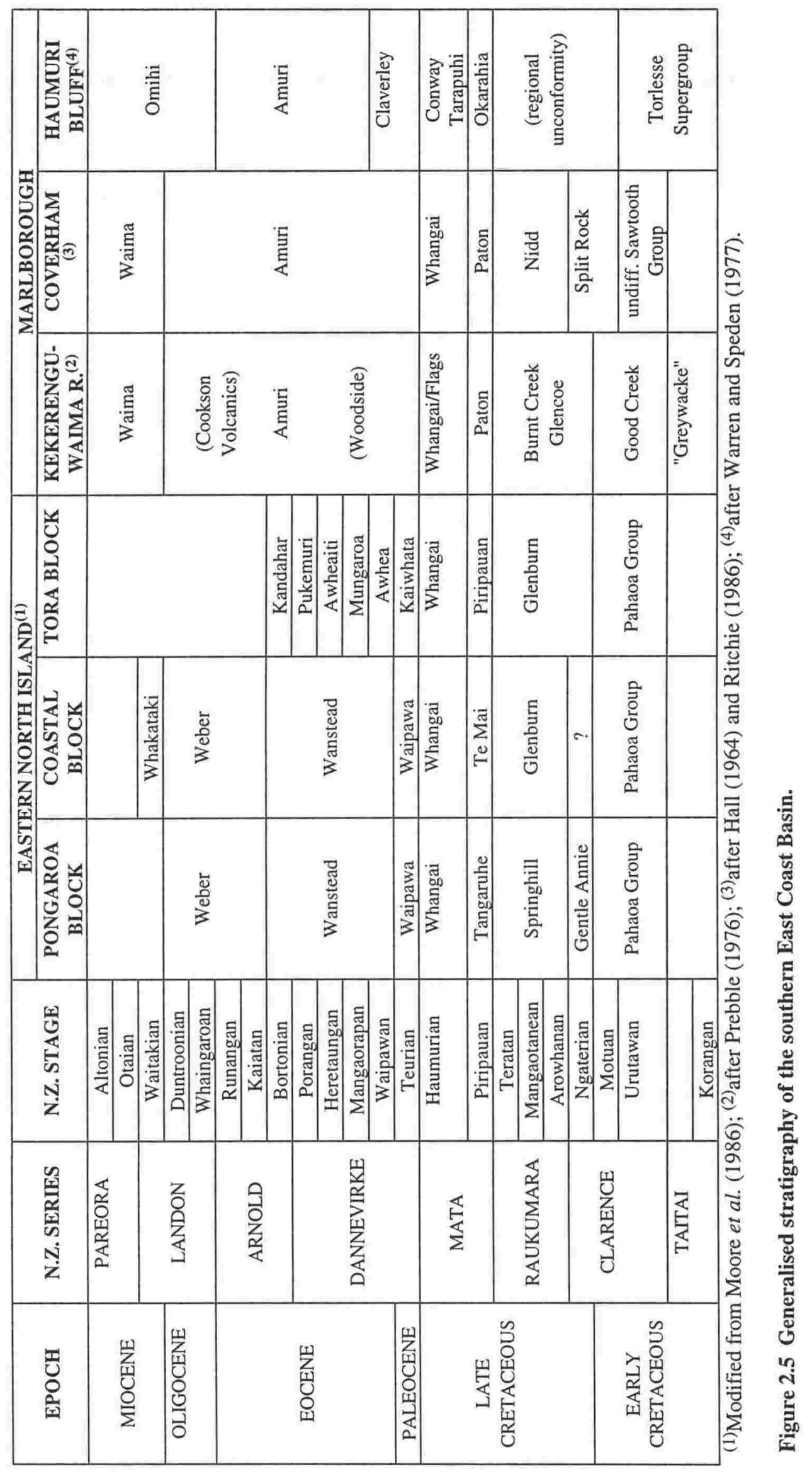


Ballance (1993a) reviewed the Upper Cretaceous and Paleogene passive margin sequence.

The stratigraphy of the East Coast Basin can be divided into three sequences (Francis, 1992b; Lewis and Pettinga, 1993; Ministry of Commerce, 1993):

- Lower Mesozoic basement

- Upper Cretaceous and Paleogene passive margin sediments

- Subduction related Neogene sediments

East Coast Basin stratigraphy is reviewed below with the eastern North Island ('North Island') considered first, followed by a section on Marlborough ('South Island'). Emphasis is on fine-grained units with possible hydrocarbon source potential. The generalised stratigraphy of the southern East Coast Basin is shown in Figure 2.5.

\section{North Island stratigraphy}

Torlesse Supergroup (after Speden, 1976)

'Basement' rocks of eastern North Island comprise greywacke (Torlesse Supergroup and Pahaoa Group) of middle Permian to Early Cretaceous age. Middle Permian to Jurassic age rocks, collectively called Torlesse Supergroup (Speden, 1976), are present in the Rimutaka, Tararua and western Aorangi ranges. Torlesse Supergroup comprises structurally complex, well indurated, quartz-veined, quartzofeldspathic sandstone and argillite with minor conglomerate, spilitic lava and associated volcanogenic sediments (Moore and Speden, 1984).

Pahaoa Group (after Moore and Speden, 1979)

Early Cretacous Pahaoa Group rocks are exposed forming coastal hills extending from the Whangai Range east of Dannevirke, to White Rock south-east of Martinborough. Pahaoa Group is composed of several units. Mangapokia Formation comprises complexly deformed, moderately indurated, alternating sandstone and siltstone. Enclosed within this formation are the Stronvar Member, a matrix-supported breccia-conglomerate and the Taipo Formation, a poorly-sorted sandstone (Moore and Speden, 1984).

Mangapokia Formation (after Moore and Speden, 1979)

Mangapokia Formation comprises complexly deformed, moderately indurated, thin to thick-bedded, carbonaceous, alternating sandstone and siltstone with minor spilitic igneous rocks with associated volcanogenic sediments and chert (Moore and Speden, 1984). Plant remains are carbonised and coal fragments are common (Moore and 


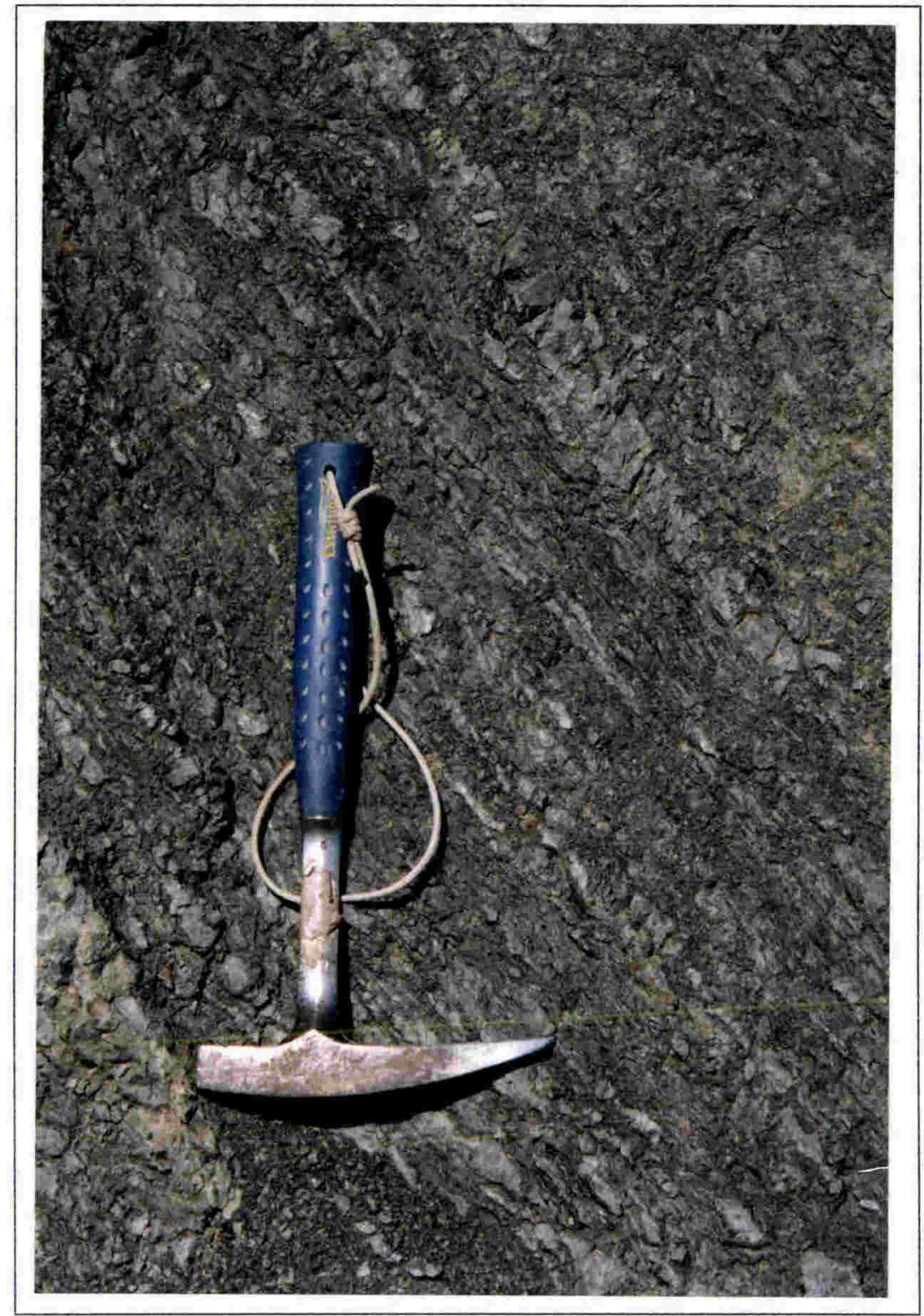

Plate 2.1 Indurated Springhill Formation, White Rock Road (S28/153706). 
Speden, 1979). Thickness is uncertain due to complex folding and faulting but is at least $1500 \mathrm{~m}$ (Moore and Speden, 1984). The basal contact is not exposed but the Gentle Annie Formation unconformably overlies Pahaoa Group. Fossil identifications give a Motuan and possibly Urutawan age (Moore and Speden, 1984). The depositional environment is thought to be a submarine fan-delta where the Mangapokia Formation represents a middle to outer fan deposit (Moore and Speden, 1979; 1984).

Gentle Annie Formation (after Moore and Speden, 1979)

Gentle Annie Formation comprises slightly to moderately indurated, relatively undeformed breccia-conglomerate (Moore and Speden, 1984). Clasts include sedimentary and igneous pebbles and concretions in a matrix of soft sandy siltstone or muddy sandstone (Moore and Speden, 1984). The formation is up to $600 \mathrm{~m}$ thick, rests unconformably on Pahaoa Group sediments and conformably underlies the Springhill Formation (Johnston, 1975; 1980). Fossil identifications indicate a Motuan age (Moore and Speden, 1984). Deposition is considered to be from a mass-flow resulting from tectonic and/or gravity induced slumping (Moore and Speden, 1984).

Springhill Formation (after Moore and Speden, 1979)

Springhill Formation comprises moderately indurated, blue-grey siltstone, with interbedded thin to medium-bedded alternating sandstone and siltstone (Moore and Speden, 1984) (Plate 2.1). It is pyritic and contains large barite concretions, abundant Inoceramus fossils and carbonised plant remains (Moore and Speden, 1984; Adams and Ballance, 1988). Parallel and cross-lamination is common as are ripple and sole markings (Moore and Speden, 1984). Formation thickness is uncertain due to folding and faulting but Johnston $(1975 ; 1980)$ estimated it to be up to $1800 \mathrm{~m}$ while Adams and Ballance (1988) determined a thickness of about $350 \mathrm{~m}$. The Springhill Formation conformably overlies the Gentle Annie Formation and is overlain conformably or unconformably by either the Te Mai or Tangaruhe formations (Adams and Ballance, 1988) and is of Motuan to Piripauan age (Moore and Speden, 1984). Sedimentary features indicate that "traction currents in a shelf environment played a major role in deposition" (Moore and Speden, 1979).

Glenburn Formation (after Moore et al., 1986)

Glenburn Formation comprises thick-bedded, parallel and cross-laminated carbonaceous sandstone, conglomerate and breccia-conglomerate, thin-bedded sandstone, and dark grey siltstone with intraformational slump zones, cyclic sequences and thin coal seams (Moore, 1980). Dolerite sills and thin dikes of basalt and dolerite intrude the sequence (Moore, 1980). Sedimentary features include scouring at the top and base of individual 


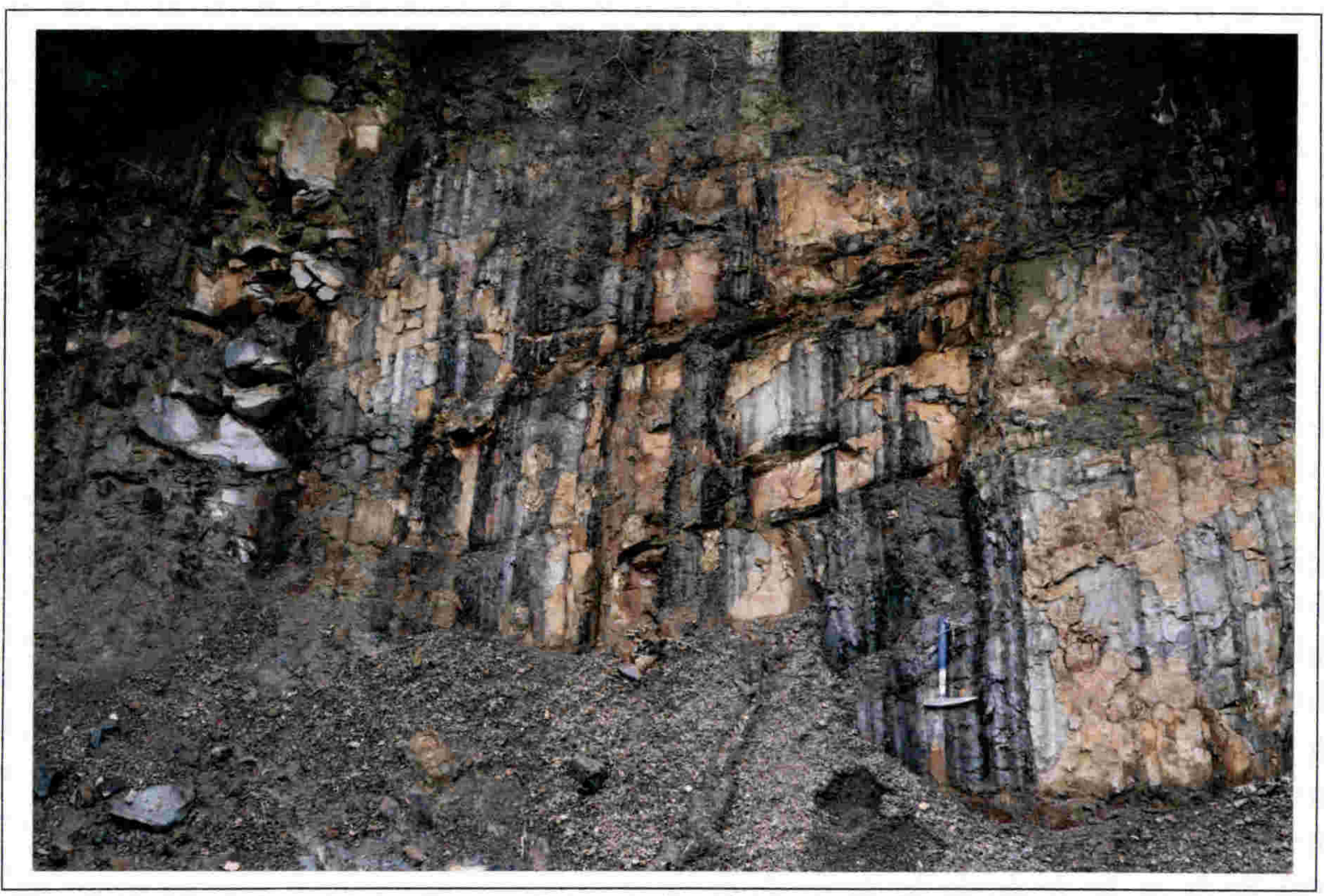

Plate 2.2 Alternating carbonaceous sandstone and mudstone of the Te Mai Formation, near Akitio (U25/995634). 
beds and fluid escape structures (Murray, 1992). The Glenburn Formation is up to $1800 \mathrm{~m}$ thick (Adams and Ballance, 1988), is unconformably overlain by the Te Mai Formation (Johnston, 1980), and is of Ngaterian to Piripauan age (Moore et al., 1986). Poorly sorted conglomerates with no clear imbrication suggest emplacement by marine mass-flow (Moore, 1980; Murray, 1992).

Te Mai Formation (after Johnston, 1980)

Te Mai Formation comprises cross-bedded, alternating sandstone and siltstone with interbedded thick grit and conglomerate beds (Plate 2.2). Glauconite is present, greensand beds exist and many beds contain carbonaceous material. Thickness is uncertain but is probably about $1500 \mathrm{~m}$ (Johnston, 1975). The lower contact is conformable with the Glenburn and possibly the Springhill formations while the upper contact is conformable with the Whangai Formation. The age is considered to be largely Piripauan, possibly extending down to middle Teratan Stage (Neef, 1991; 1992). Johnston (1980) interpreted the presence of cross-bedding in eastern sections to indicate deposition in a shallow current-swept environment. Current directions based on crossbedding indicate opposing currents, suggesting the Te Mai Formation was deposited in a narrow tidal strait. Abundant burrowing and numerous fossils, including planktonic foraminifera, also suggest a shelf environment (Johnston, 1980). In contrast, Neef (1992) described the formation in the Pongaroa district as having thickly-bedded alternating sandstone-mudstone units with sharp bases and rare flute casts, and interpreted this as deposition from turbidity currents in a bathyal environment.

\section{Tangaruhe Formation (after Moore et al., 1986)}

Tangaruhe Formation comprises alternating, medium blue-grey, micaceous, slightly glauconitic sandstone and blue-grey, micaceous, slightly glauconitic siltstone (Moore et al., 1986). Sandstone units are graded with sharp bases and sharp to gradational tops. Sole markings, flame structures, flaser-bedding and load casts are present. Above the alternating sequence is $20 \mathrm{~m}$ of medium, dark grey, weathering light brownish-grey, massive, glauconitic and micaceous, slightly sandy mudstone. The Tangaruhe Formation is at least $160 \mathrm{~m}$ thick, has a gradational but irregular upper contact with the Whangai Formation and is of early Piripauan to early Haumurian age (Moore et al., 1986).

\section{Whangai Formation (after Moore, 1988b)}

Moore (1988b) identified the Whangai Formation as comprising three main members: Rakauroa, Upper Calcareous, and Porangahau, and two local members: Te Uri and Kirks Breccia (not present in the study area). In addition two regionally-extensive facies were distinguished: a Western Facies composed mainly of poorly-bedded, non-calcareous to 
slightly calcareous mudstone, and an Eastern Facies of mostly well-bedded, noncalcareous to highly calcareous mudstone.

Rakauroa Member comprises hard, poorly bedded, rusty weathering, bioturbated, medium grey, non-calcareous, micaceous mudstone with thin glauconitic sandstone beds, calcareous concretions, pyrite nodules and calcareous beds (Moore, 1988b). Apart from fish scales and sparse foraminifera, fossils are rare (Moore, 1988b). Thickness ranges from 40 to $400 \mathrm{~m}$ but is generally about 200-300 m (Moore, 1988b).

Upper Calcareous Member consists of hard, poorly bedded, light to bluish-grey weathering, medium grey, slightly to moderately calcareous, bioturbated, laminated micaceous mudstone with minor calcareous concretions, pyrite nodules and glauconitic sandstone beds (Moore, 1988b). Carbonate content generally increases upward. With the exception of Terebellina tubes and fish scales, macrofossils are scarce (Moore, 1988b). Thickness ranges from 50 to $200 \mathrm{~m}$ (Moore, 1988b).

Porangahau Member comprises hard, well-bedded, grey-white weathering, grey to green-grey, slightly to highly calcareous mudstone with common glauconitic sandstone beds (Moore, 1988b). Red-brown and green mudstone, and ripple-laminated sandstone, as well as alternating light and dark grey mudstone 'zebra beds' are also present. Mudstone beds are usually moderately to highly bioturbated but, other than foraminifera and trace fossils such as Zoophycos, fossils are rare (Moore, 1988b). Thickness ranges from 20 to $300 \mathrm{~m}$ (Moore, 1988b; Leckie et al., 1992).

Te Uri Member consists of hard, light grey, glauconitic, slightly calcareous, laminated siltstone with interbedded glauconitic sandstone (Moore, 1988b). Thickness ranges from 20 to $40 \mathrm{~m}$. Te Uri Member appears to be a lateral equivalent of the Waipawa Black Shale (Moore, 1988b).

The Western Facies conformably overlies the Tangaruhe, Glenburn or Te Mai formations whereas the Eastern Facies generally overlies the Glenburn Formation (Moore, 1988b). In most cases both the Eastern and Western facies are overlain by the Waipawa Black Shale (the exceptions being in the Whangai Range where there was non-deposition or later erosion and in the Tora Block, which has a stratigraphy similar to that in Marlborough). The Whangai Formation is Haumurian to Teurian in age based on foraminifera and dinoflagellates (Moore, 1988b; Ballance, 1993a). 


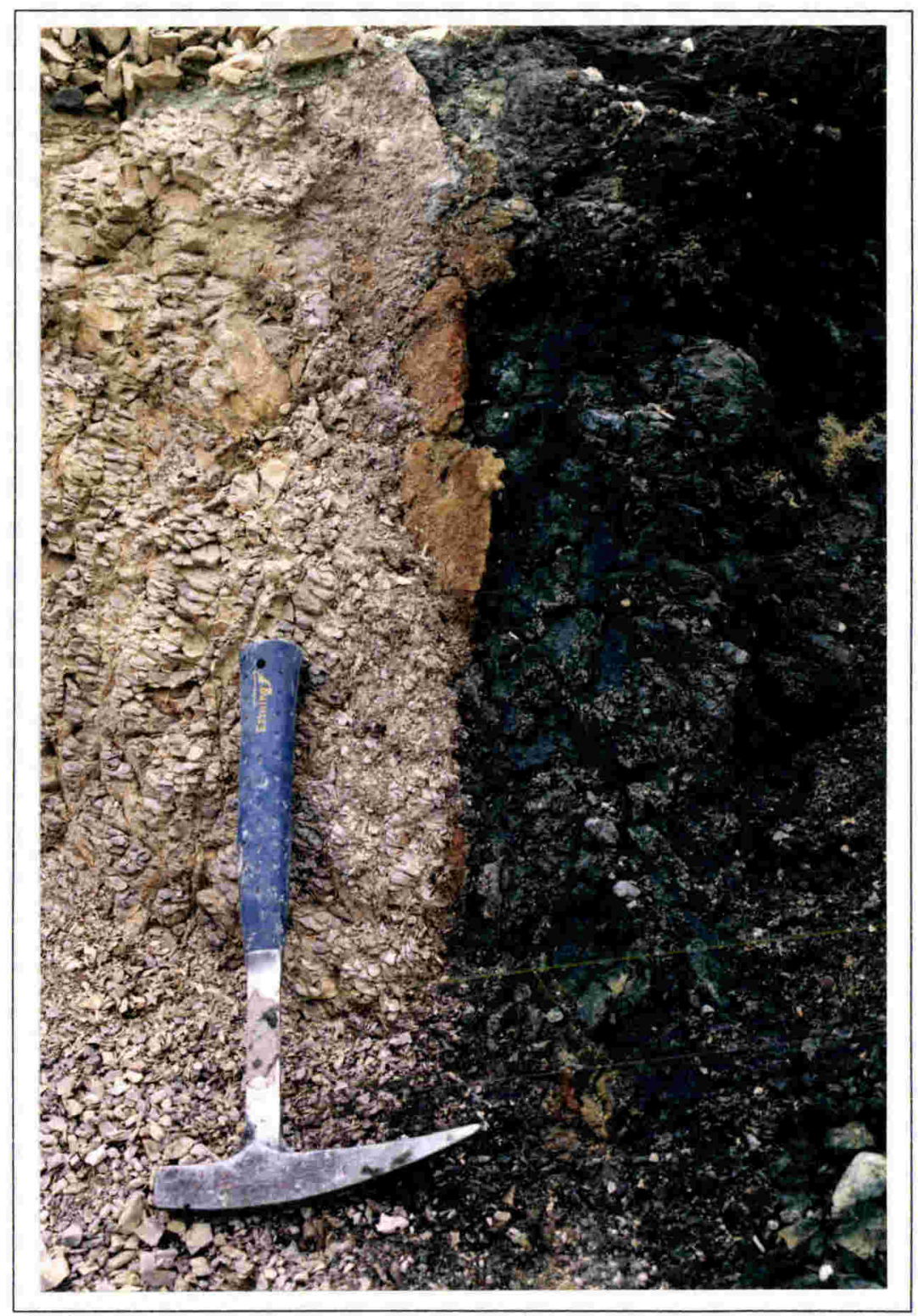

Plate 2.3 Creamy-weathered Waipawa Black Shale and glauconitic sandstone. Rotohiwi Road quarry (U23/992098). 
The Whangai Formation is known to extend south into Marlborough (Wellman, 1955; Hall, 1964; Prebble, 1976). Lateral equivalents from the Marlborough-North Canterbury region include the Conway Siltstone, Woolshed Shale, Herring and Mirza formations (Moore, 1988b). The Whangai Formation is recognised in the Northland Allochthon where it is known as Ngatuturi Claystone and also known from the Great South Basin and New Caledonia (Ballance, 1993a). Deposition is thought to have occurred during a marine transgression in a slowly subsiding basin or basins (Moore, 1988b). The high silica content (averaging 83\%) is attributed to diagenesis of diatom and radiolarian tests and the restricted fauna considered to indicate deposition in a shelf environment, possibly under conditions of reduced oxygen levels and subnormal salinity (Moore, 1988b).

\section{Waipawa Black Shale (after Hornibrook, 1959)}

Waipawa Black Shale comprises very poorly-bedded, hard to moderately soft, dark brown-grey to brownish-black, bioturbated, micaceous mudstone and fine sandstone with common glauconitic sandstone or greensand and intervals of Whangai-like calcareous mudstone (Moore, 1989) (Plate 2.3). Few macrofossils other than locally common Terebellina tubes and small bivalves are present (Moore, 1980). Foraminifera are sparse with agglutinated species dominating whilst dinoflagellates and some radiolaria have also been identified (Moore, 1989). Chemical analyses indicate the Waipawa Black Shale has a high silica content (averaging 75\%). Organic matter is predominantly of marine origin with TOC content ranging from 1.8 to $12.3 \%$, averaging $6 \%$ (Moore et al., 1987). Thickness ranges from a few metres to more than $50 \mathrm{~m}$ (Moore, 1989). It conformably overlies the Whangai Formation with a gradational contact, and is conformably overlain by the Wanstead Formation (Moore, 1989). Dinoflagellates and foraminifera indicate a middle to late Teurian age (Moore, 1988b).

Moore (1988b) interpreted the Waipawa Black Shale to have been deposited in a shallow marine environment, possibly under conditions of reduced oxygen levels, abnormal salinity and elevated water temperature. Recent interpretations, however, place deposition at a water depth equivalent to the upper slope or shelf break (Killops et al., 1996). Leckie et al. (1992) interpreted the formation to represent a condensed section deposited at the peak of a marine transgression, and the high proportion of terrestrial plant debris to result from the flooding of nonmarine areas and increased supply of land plant organic matter. The lack of planktonic foraminifera, may indicate deposition under anoxic conditions (Leckie et al., 1992). The geographic extent of the Waipawa Black Shale and its lateral equivalents has been extended to include northern Taranaki, Northland, Canterbury, Great South and possibly southern Westland basins (Killops et al., 1996) (see Figure 8.1). Both this and a deep-water depositional environment for the 


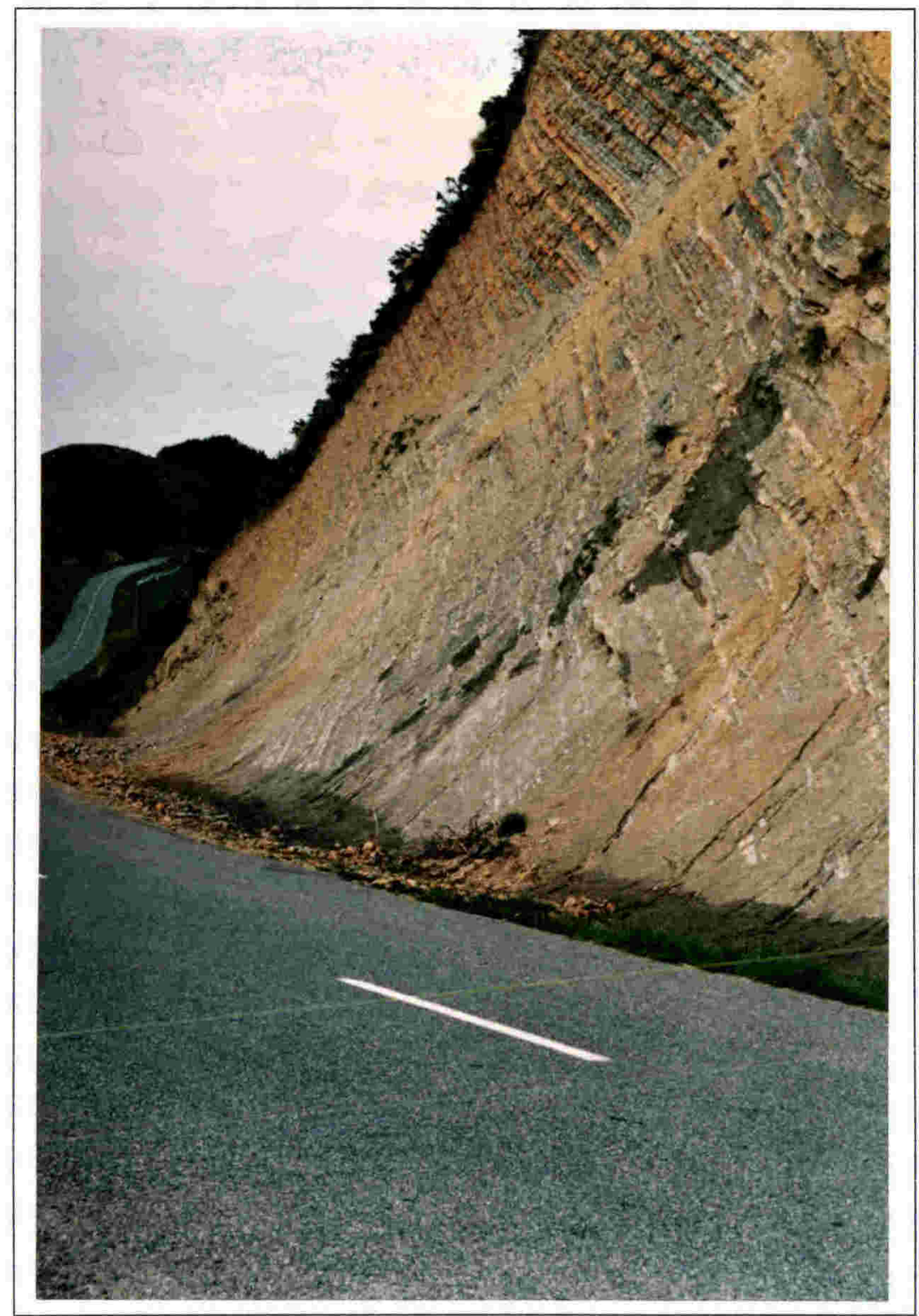

Plate 2.4 Alternating sandstone and mudstone of the Whakataki Formation, near Whakataki (U26/817323). 
underlying and overlying units provide support for the outer shelf/upper slope depositional environment proposed by Killops et al. (1996).

\section{Wanstead Formation (after Moore et al., 1986)}

Wanstead Formation comprises very poorly-bedded, moderately hard, light grey weathering, grey to greenish-grey, highly bioturbated, calcareous, mudstone with sparse, thin glauconitic sandstone beds (Moore and Morgans, 1987). Scattered nodules and veins of pyrite are common in places (Leckie et al., 1992). Macrofossils are absent but foraminifera, dominantly benthic, are abundant (Johnston, 1980). The Wanstead Formation is up to $490 \mathrm{~m}$ thick, conformably overlies the Waipawa Black Shale and in turn is overlain conformably by the Weber Formation, and ranges from middle Teurian to Runangan in age (Moore and Morgans, 1987). Fine-grained sediments, the lack of macrofossils and the abundant foraminifera imply deposition in moderately deep water, distant from land (Johnston, 1980). Foraminiferal studies indicate middle to upper bathyal depths with short periods of outer shelf conditions and possibly a trend towards increased oceanicity, productivity and paleodepths throughout the Paleogene (Moore and Morgans, 1987).

\section{Weber Formation (after Johnston, 1975)}

Weber Formation comprises dark to light grey, almost white, calcareous mudstone and siltstone with scattered grit, conglomerate, and hard pure limestone beds (Johnston, 1980). Carbonate content ranges from 23-70\%, averaging 40-50\% (Leckie et al., 1992) and is of foraminiferal origin (Morgans, 1977). Thickness is uncertain but is about $730 \mathrm{~m}$ in the Tinui-Castlepoint area (Johnston, 1975). The Weber Formation conformably overlies the Wanstead Formation in southern Hawkes Bay and is conformably overlain by the Whakataki Formation (Johnston, 1980) and is ?Kaiatan-Runangan to early Waitakian in age (Leckie et al., 1992). The abundance of fine-grained calcareous sediments and planktonic foraminifera indicates deposition under quiet conditions distant from shore (Johnston, 1980) in water depths of about 400-500 m (Morgans, 1977).

\section{Whakataki Formation (after Johnston, 1975)}

Whakataki Formation comprises graded, carbonaceous, grit-mudstone beds with minor lenses of algal limestone, conglomerate and breccia (Moore, 1980) (Plate 2.4). The lower part of each bed is laminated and the upper part, commonly convolutely-bedded (Johnston, 1975). Flame structures and flute casts are present (Johnston, 1975; Neef, 1992). The Whakataki Formation is at least $3000 \mathrm{~m}$ thick in the Castlepoint coastal area (Johnston, 1980). It conformably overlies the Weber Formation and is overlain by the Maunsell Formation (Johnston, 1975). Foraminiferal studies indicate an Otaian to 
Clifdenian age at Whakataki Beach (Turnbull, 1988) and a Waitakian to Otaian age at Akitio (Neef, 1992). The formation was deposited in inner trench slope conditions from turbidity currents and coarse-grained sediment gravity flows (Turnbull, 1988). Additional processes related to fan sedimentation were slumping and down-slope sediment creep with feeder channels supplying the basin.

\section{Early Tertiary Tora Block stratigraphy}

Early Tertiary stratigraphy in the Tora Block is considerably different from that in other structural blocks of eastern North Island and closely resembles that found in Marlborough. The stratigraphy was resolved by Waterhouse and Bradley (1957) and, although slightly modified by Alexander (1990), remains in use today.

\section{Manurewa Formation (after Waterhouse and Bradley, 1957)}

Manurewa Formation comprises centimetre to decimetre-bedded, alternating fine to medium, calcareous, glauconitic sandstone and siltstone with common massive greensand and graded-bedded greensand interbedded with porcellaneous limestone (Alexander, 1990). Total thickness is estimated to be $315 \mathrm{~m}$ (Alexander, 1990). The Manurewa Formation disconformably overlies the Whangai Formation with a sharp and possibly channelled contact and is overlain by the Awhea Formation with a sharp and non-planar contact, probably as a result of slumping (Alexander, 1990). Fossil identifications give a Teurian age (Waterhouse and Bradley, 1957).

\section{Awhea Formation (after Alexander, 1990)}

Awhea Formation comprises thin-bedded blue-grey, calcareous sandstone and black, micaceous mudstone (Waterhouse and Bradley, 1957). In some outcrops it includes heterogeneous blocks (1-15 $\mathrm{m}$ in size) of greensand, limestone and calcareous siltstone in a sheared siltstone matrix, resembling an olistostrome deposit (Alexander, 1990). The Awhea Formation is up to $590 \mathrm{~m}$ thick (Alexander, 1990) and is of Teurian age.

Mungaroa Member of Awhea Formation comprises light grey to white, indurated, thin-bedded, slightly sandy limestone (Alexander, 1990). It is well developed at Te Kaukau Point, reaching $100 \mathrm{~m}$ in thickness, but rapidly thins northwards such that, in the Tora area, it reaches a maximum thickness of $5 \mathrm{~m}$ and is often absent from the stratigraphy (Alexander, 1990).

\section{Kandahar Formation (after Alexander, 1990)}

Kandahar Formation comprises creamy, thin-bedded, soft marl with occasional interbeds of fine sandstone and red and green pelagic mudstone and common bentonite towards 
the top of the formation (Alexander, 1990). Waterhouse and Bradley (1957) distinguished the Kandahar Formation from underlying chocolate-coloured shales of the Pukemuri Siltstone, but Alexander (1990) found that, in the Tora area, the 'chocolate' shales interfingered with the Kandahar Formation and therefore did not differentiate them. The Kandahar Formation is $860 \mathrm{~m}$ thick, has a gradational, conformable contact with the underlying Awhea Formation (Alexander, 1990) and is Waipawan to Bortonian in age (Waterhouse and Bradley, 1957).

\section{Marlborough stratigraphy}

\section{Sawtooth Group (Torlesse Supergroup)}

Greywacke of the Torlesse Supergroup forms the basement rocks in the Marlborough region (Ritchie, 1986). It comprises dominantly complexly deformed and indurated sandstone and mudstone, but includes conglomerate, rare chert, volcanics and limestone (Laird, 1992). Due to complexity in structure, the total thickness is unknown. Torlesse rocks are separated from younger strata by a major regional angular unconformity. The unconformity, however, represents only about $5 \mathrm{Ma}$ as undeformed Motuan rocks overlie Torlesse greywacke (Laird, 1992). In the Marlborough region Torlesse greywacke is latest Jurassic to Early Cretaceous (Motuan) in age (Prebble, 1976; Laird, 1992).

Prebble (1976) recognised the Good Creek Formation, a $3600 \mathrm{~m}$ thick sequence of alternating pale grey sandstone and dark grey to black argillite, massive sandstone and conglomerate in the Kekerengu area. The formation appeared to be less indurated than basement greywacke and was characterised by abundant conglomerate, grit and massive sandstone. An Urutawan to ?Ngaterian age is indicated based on Inoceramus species (Prebble, 1976). The dominance of angular sand-size clasts and the abundance of thick conglomerates and massive sandstones indicated rapid deposition near a tectonically active terrain and Prebble (1976) interpreted the formation to be a redeposited flyschtype sediment. Ritchie (1986) did not differentiate between Torlesse greywacke and the Good Creek Formation and mapped all Torlesse Supergroup-like rocks in the Kekerengu-Coverham area as 'Undifferentiated Sawtooth Group' and concluded that "structural/deformation characteristics cannot be used as criteria for separating the Torlesse from non-Torlesse rocks".

Split Rock Formation (after Ritchie, 1986)

Champagne Member comprises basal conglomerate overlain by moderately indurated, dark blue-grey to grey-black siltstone and graded-bedded sandstone and siltstone (Hall, 1964). The conglomerate consists of well rounded, indurated pebbles of greywacke, 


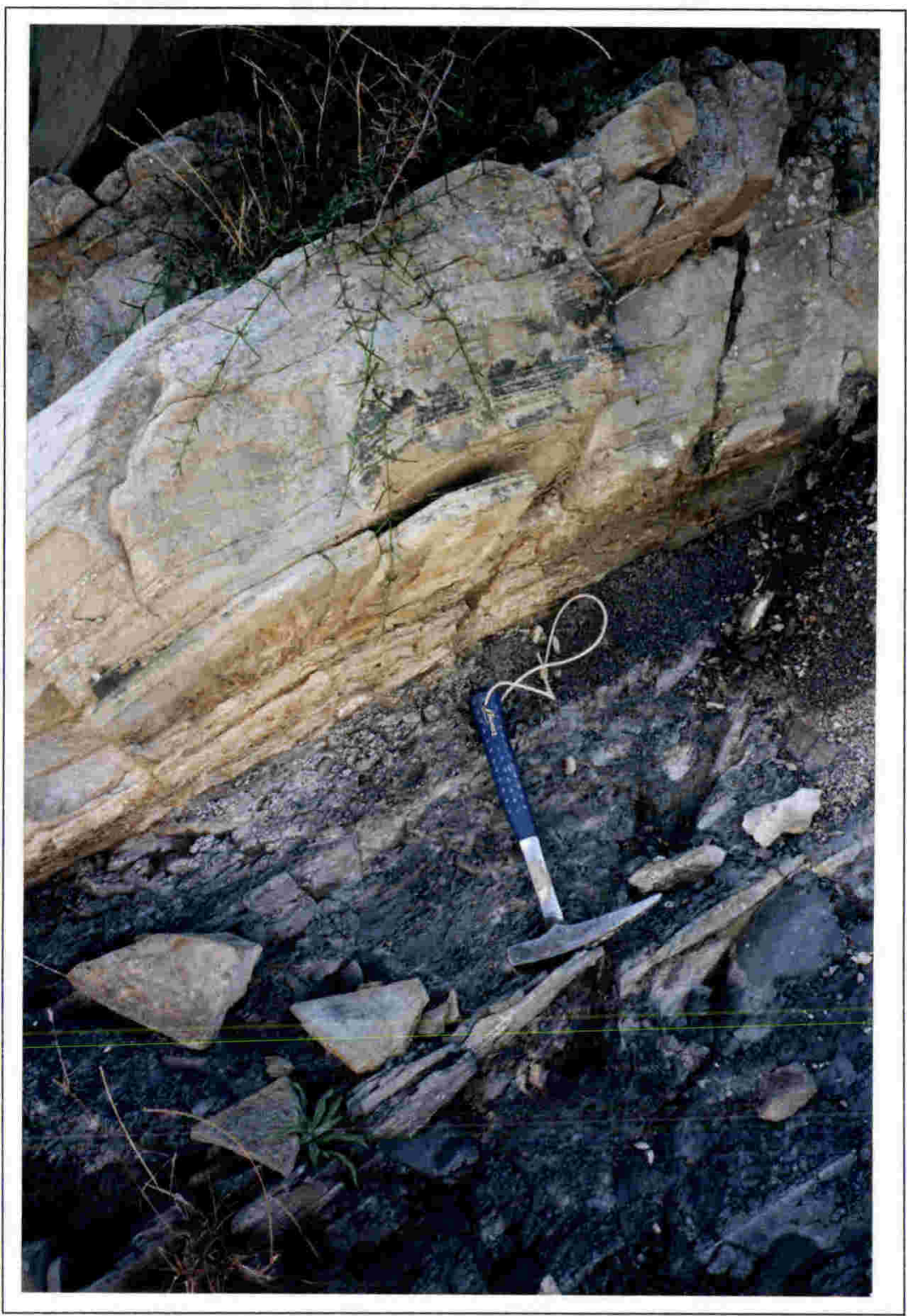

Plate 2.5 Alternating carbonaceous sandstone and mudstone of the Wharfe Sandstone Member, Split Rock Formation. Swale Stream, Coverham (P30/823170). 
argillite, quartz, jaspillite and granite up to $15 \mathrm{~cm}$ across set in a matrix of indurated sandstone (Hall, 1964). The Champagne Member is generally about 500-650 m thick but in the Ouse-Wharfe area is replaced by the Ouse and Wharfe members. The basal conglomerate of the Champagne Member overlies Torlesse greywacke with an angular unconformity and there is considerable difference in metamorphic rank across the contact (Hall, 1964). Fossil identifications give a Motuan age.

Ouse Member comprises brittle, crushed argillite beds at the base, and elsewhere a moderately soft, dark blue-grey siltstone. Graded-bedded sandstone and siltstone in the upper part of the member is sheared and contorted. The Ouse Member is $250 \mathrm{~m}$ thick, disconformably overlies the Champagne Member with no angular discordance, and is of Motuan age (Hall, 1964).

Wharfe Sandstone Member comprises alternating, moderately hard, medium to light grey, finely laminated sandstone and moderately hard, dark blue-grey to black, weathering light grey, siltstone (Hall, 1964) (Plate 2.5). Small slump structures are apparent and plant fragments and scour casts are common on the base of the sandstone beds. The Wharfe Sandstone Member is $120 \mathrm{~m}$ thick, lies conformably on the Ouse Member with the boundary arbitrarily placed where sandstone beds dominate siltstone and is of Motuan age (Hall, 1964).

Swale Siltstone Member comprises massive, dark mudstone with abundant large, spherical, calcareous concretions (Hall, 1964). The upper part of the member comprises graded-bedded sandstone and siltstone. Plant fragments and scour casts occur at the base of the sandstone bands. The Swale Siltstone Member is $500 \mathrm{~m}$ thick, conformably overlies the Wharfe Sandstone Member and is of Ngaterian age (Hall, 1964).

The Split Rock Formation was deposited on deformed Sawtooth Group sediments as slope basin (fan delta) sediments (Ritchie, 1986). The presence of echinoids and calcareous foraminifera suggest moderate depths (Ritchie, 1986). The basal conglomerate of the Champagne Member is likely to have been emplaced by debris flows and to have been sourced from erosion of Sawtooth or Sawtooth-like rocks. Reay (1980) considered the Split Rock Formation to have been deposited by traction currents in a distributary channel of a shallow marine fan-delta on a fault controlled coast.

\section{Burnt Creek Formation (after Hall, 1964)}

Burnt Creek Formation comprises blue-grey siltstone, graded sandstone and siltstone beds with interbedded conglomerate and a $10 \mathrm{~m}$ basal conglomerate (Prebble, 1976). It is 


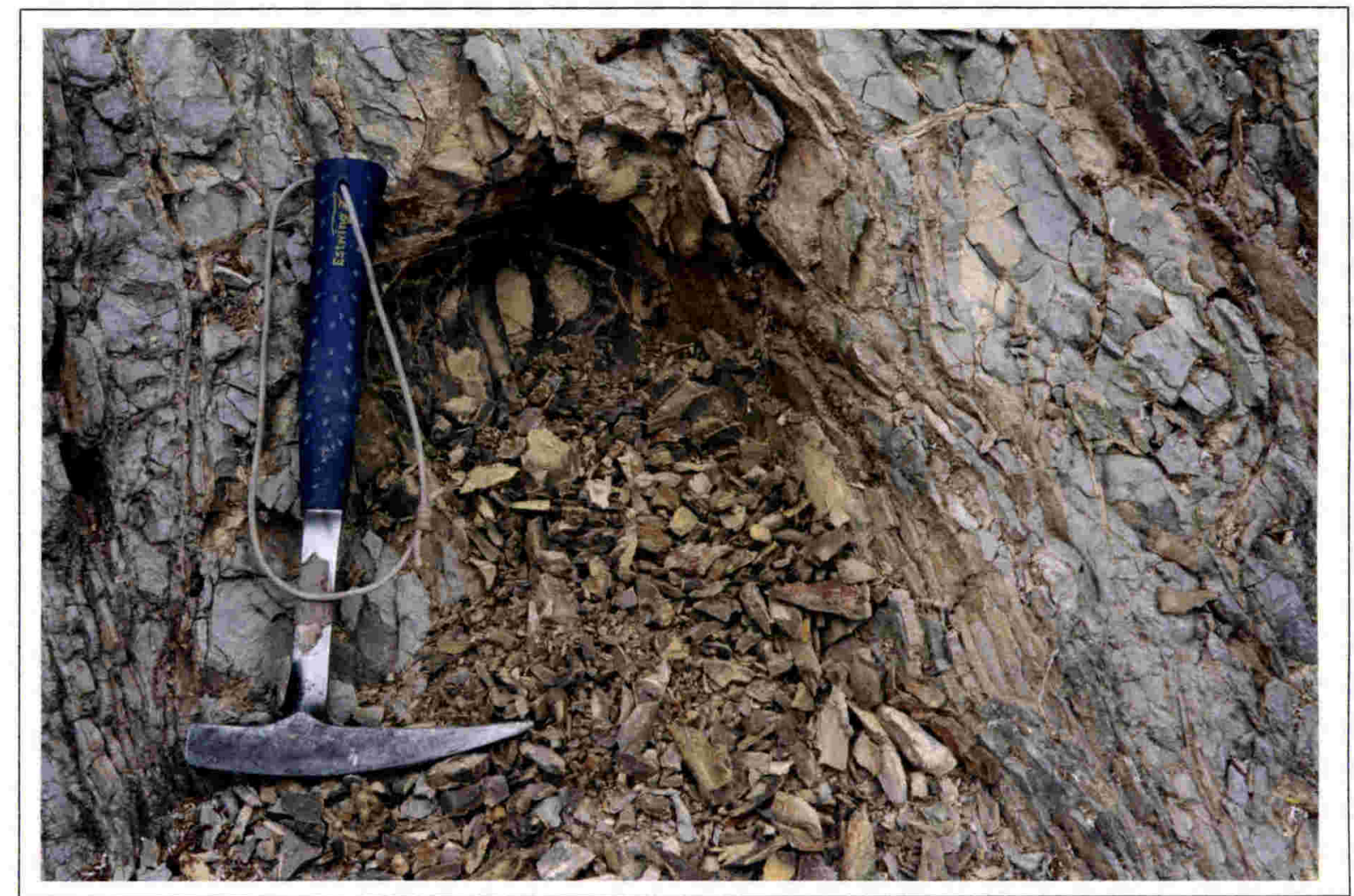

Plate 2.6 Massive, sulphur-stained Conway Siltstone. Railway cutting, Claverley Road (O32/474442). 
$400 \mathrm{~m}$ thick, rests unconformably on the Good Creek Formation and based on Inoceramus species is Teratan in age (Prebble, 1976).

Conway Siltstone (after Warren and Speden, 1977)

Conway Siltstone comprises massive, medium to dark grey, bioturbated siltstone with minor glauconite and hard, spherical, calcareous concretions, often containing reptilian bones (Warren and Speden, 1977) (Plate 2.6). It is $240 \mathrm{~m}$ thick, conformably overlies the Tarapuhi Grit and is conformably overlain by the Claverley Sandstone, and is of Haumurian age (Warren and Speden, 1977). The Conway Siltstone was deposited in a marine, probably near-shore environment with restricted bottom circulation, possibly a barred submarine depression (Warren and Speden, 1977). The high sulphur content is thought to be caused by bacterial activity in an organic-rich, low-oxygen environment and the extensive burrowing was due to molluscs tolerant of low oxygen levels (Warren and Speden, 1977). The Conway Siltstone is lithologically similar to the 'Sulphur Sands' of the middle Waipara area and is recognised throughout North Canterbury. It is also a lateral equivalent of the Whangai Formation but is less siliceous and more massive (Warren and Speden, 1977).

\section{Claverley Sandstone (after Warren and Speden, 1977)}

Claverley Sandstone comprises massive yellow-grey, poorly-sorted, glauconitic sandstone with lenses of grey, very hard, calcareous silty sandstone. The sandstone is extensively reworked by burrowing organisms. The formation is $43 \mathrm{~m}$ thick at Claverley, and conformably overlies the Conway Siltstone, is conformable overlain by the Amuri Limestone and is Haumurian to Waipawan in age (although there is no evidence of Teurian rocks (Warren and Speden, 1977). The Claverley Sandstone is considered to have been deposited very slowly in a shallow marine environment, receiving wind-blown sand, with intermittent deposition of carbonate mud of local biogenic origin (Warren and Speden, 1977).

\section{Flags Formation (after Prebble, 1976)}

Flags Formation comprises pale brown, convolute and truncate-laminated, quartz sandstone, graded beds of quartz sandstone and dark nodular siltstone and mudstone with minor glauconitic grit and glauconitic pebble conglomerate (Prebble, 1976). The quartz sandstone often displays sole markings and scour and fill features and frequently occurs in thick bands interfingering with the Whangai Formation (Prebble, 1976). The Flags Formation is $200 \mathrm{~m}$ thick. No contacts with underlying or overlying strata were found but it grades laterally into the Whangai Formation from east to west (Prebble, 1976). Foraminifera indicate an Haumurian age (Prebble, 1976). Graded bedding and 


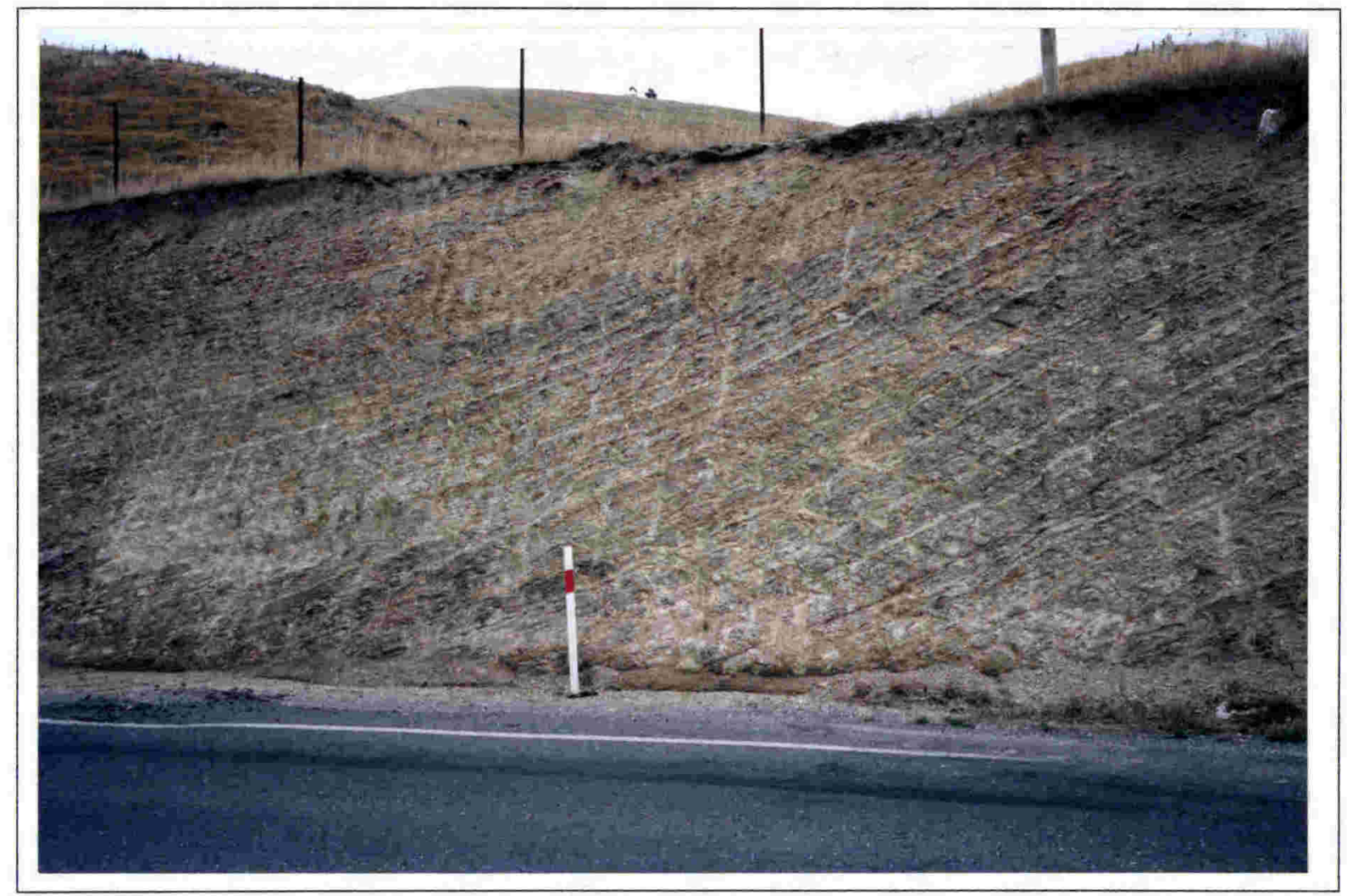

Plate 2.7 Mata Series. S.H. 1, opposite Kaikoura Racecourse (O31/654660).

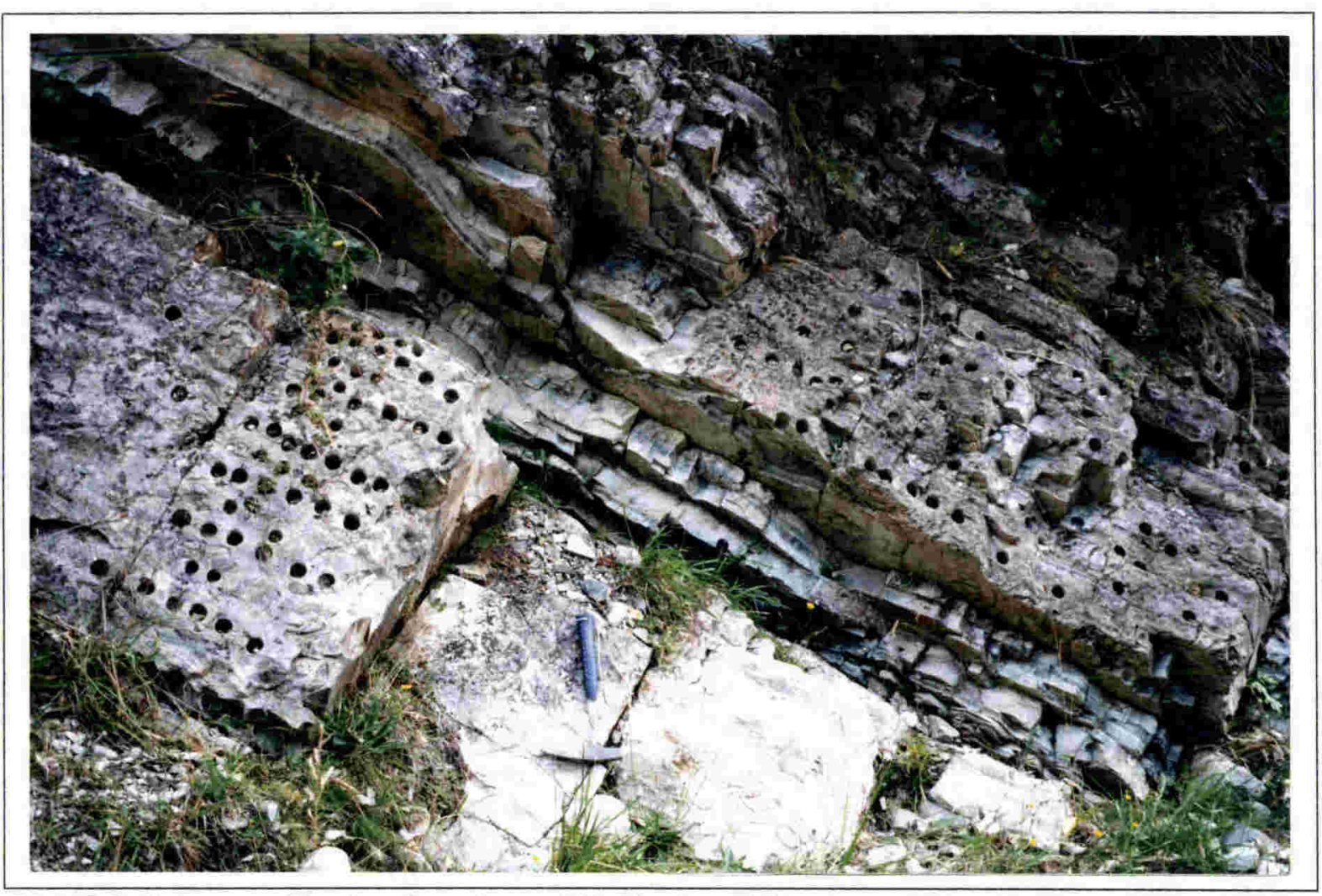

Plate 2.8 Cretaceous/Tertiary boundary within the Amuri Limestone. Woodside Creek (P30/988190). 
associated sedimentary features indicate the formation represents a turbidite sequence, a redeposited facies equivalent of the Whangai Formation and Sulphur Sands (transitional and shallow water deposits respectively) (Prebble, 1976).

\section{Undifferentiated Mata Series (after Lensen, 1962)}

Mata Series sediments (Plate 2.7) comprise lateral equivalents of the Whangai Formation that have slightly different sedimentological characteristics. East of Ward Mata Series sediments comprise argillaceous siltstone interbedded with lensoidal argillaceous limestone (Lensen, 1962) and are similar in appearance to the Amuri Limestone. South of Kaikoura, Mata Series sediments grade laterally into glauconitic and sulphur-stained sandstone and become similar in appearance to the Claverley Sandstone and Conway Siltstone.

\section{Whangai Formation (after Wellman, 1955)}

Whangai Formation comprises poorly-bedded, dark grey or grey-brown, micaceous, siliceous siltstone with a sulphurous efflorescence, a well developed cleavage with splintery fracture and abundant large concretions near the top of the formation (Prebble, 1976). Moore's (1988b) subdivision of the Whangai Formation did not include the Marlborough region and it is, therefore, discussed here as a single unit. The formation is up to $500 \mathrm{~m}$ thick in the Kekerengu area, rests conformably on the Paton Sandstone and is conformably overlain by the Flint Beds of the Amuri Limestone (Prebble, 1976). Fossil identifications indicate an Haumurian age (Prebble, 1976).

Amuri Limestone (after Hall, 1964)

Amuri Limestone (Plate 2.8) comprises seven members which are, from top to bottom:

$\begin{array}{lll}\text { Whales Back Limestone } & 60-110 \mathrm{~m} & \text { Whaingaroan-Waitakian } \\ \text { Fells Greensand } & 25 \mathrm{~m} & \text { Runangan-Whaingaroan } \\ \text { Upper Bentonite } & 90-180 \mathrm{~m} & \text { Porangan-Runangan } \\ \text { Middle Limestone } & 180 \mathrm{~m} & \text { Heretaungan-Bortonian } \\ \text { Lower Bentonite } & 90 \mathrm{~m} & \text { Mangaorapan-Heretaungan } \\ \text { Lower Limestone } & 120 \mathrm{~m} & \text { Teurian-Mangaorapan } \\ \text { Flint Beds } & 315 \mathrm{~m} & \text { Haumurian-Teurian }\end{array}$

The limestone members are generally hard, well-bedded white to cream-coloured, porcellaneous limestone (Prebble, 1976). The Bentonite members comprise alternating beds of white limestone and greenish-white calcareous bentonitic mudstone (Prebble, 1976). The Fells Greensand Member is a green or greenish-brown, medium to coarse- 
grained, finely laminated, calcareous, highly glauconitic sandstone (Prebble, 1976). The Flint Beds comprise dark grey to black, hard, lenticular chert. The upper Flint Beds alternate with thin beds of hard, white siliceous limestone (Prebble, 1976). Formation thickness is about $1000 \mathrm{~m}$ over much of the Kekerengu-Waima region and thins rapidly to the east (Prebble, 1976). The Flint Beds lie abruptly but conformably over the Whangai Formation and the Upper Bentonite Member is conformably overlain by the Woodside Formation (Prebble, 1976).

The Amuri Limestone is characterised by having minimal clastic input. The fine grain size and lack of fossils suggest that the limestone members and the Flint Beds were chemically deposited (Prebble, 1976). Clastic deposition is restricted to the graded beds of the Upper and Lower bentonites, interpreted as being the extreme distal end of turbidites, and to the Fells Greensand, considered to be a more proximal turbidite deposit (Prebble, 1976). Clastic input is dominated by clay, quartz and glauconite and indicates slow deposition from a land of low, subdued relief (Prebble, 1976).

\section{Woodside Formation (after Prebble, 1976)}

Woodside Formation comprises graded beds of moderately soft, pale grey, slightly glauconitic sandstone and moderately soft, dark grey or brownish-grey, mudstone with occasional bands of slightly harder, massive, pale grey, glauconitic sandstone (Prebble, 1976). The formation is at least $170 \mathrm{~m}$ thick and conformably overlies the Upper Bentonite Member of the Amuri Limestone (Prebble, 1976). The upper contact has not been found. Foraminifera indicate a Waipawan to Heretaungan age (Prebble, 1976). The well developed graded-bedding suggests that the Woodside Formation is a turbidite sequence and marks the onset of clastic deposition in the east at a much earlier time than the rest of the Kekerengu-Waima River-Coverham area (Prebble, 1976).

\section{Waima Siltstone (after Hall, 1964)}

Waima Siltstone comprises moderately soft, medium blue-grey, slightly micaceous and glauconitic, calcareous siltstone with rare macrofossils (Hall, 1964; Prebble, 1976). The lower half of the siltstone is muddy while the upper half is sandier and contains silty sandstone beds and scattered pebbles. Graded beds of fine sandstone and siltstone occur near the top of the formation (Prebble, 1976). The Waima Siltstone is 200-300 m thick and conformably overlies the Whales Back Limestone Member of the Amuri Limestone and is conformably overlain by the Great Marlborough Conglomerate (Hall, 1964). Foraminifera indicate the formation is Waitakian to Otaian, and possibly Altonian, in age (Prebble, 1976). The Waima Siltstone is a moderately deep water (slope or bathyal) deposit and marks the end of calcareous deposition in the region (Hall, 1964). 


\subsection{Petroleum geology of the southern East Coast Basin}

\subsubsection{Petroleum geology}

With more than 400 oil and gas seeps and impregnations recorded, the East Coast Basin has proven hydrocarbon generation (Francis, 1992b; Field et al., 1995). This shows that effective source rocks (a combination of potential source rocks and sufficient thermal maturity) are present within the basin. The accumulation of hydrocarbons, however, depends on the factors such as reservoir, seal, structure and trap, collectively known as the 'petroleum system' (Magoon and Dow, 1994). The East Coast Basin petroleum system has been discussed by Field et al. (1995) (Figure 2.6) and is summarised below.

\begin{tabular}{|c|c|c|c|}
\hline CRETACEOUS & PALEOGENE & \multicolumn{2}{|c|}{ NEOGENE } \\
\hline 100 & \multicolumn{2}{|l|}{50} & $\mathrm{Ma}$ \\
\hline ACTIVE & "PASSIVE" & ACTIVE & Tectonism \\
\hline \multirow[t]{5}{*}{ ? } & & & Source Rock \\
\hline & & & $\begin{array}{l}\text { Reservoir Rock } \\
\text { Seal Rock }\end{array}$ \\
\hline & & & Overburden Rock \\
\hline & & & Trap Formation \\
\hline & & & Generation - Migration \\
\hline \multicolumn{3}{|c|}{ patchy } & Preservation \\
\hline & & & Critical "Period" \\
\hline
\end{tabular}

Figure 2.6 The East Coast Basin petroleum system (from Field et al., 1995). Paler shading indicates lesser certainty or significance.

\section{Source rocks}

Numerous possible source rocks have been described from the southern East Coast Basin. The middle to Late Cretaceous Glenburn and Te Mai formations, comprising alternating beds of carbonaceous mudstone and sandstone with abundant terrestrial organic material, provide significant source potential although probably are predominantly gas-prone (Ministry of Commerce, 1993; Francis and Johansen, 1996). The latest Cretaceous Whangai Formation, particularly the Upper Calcareous and Rakauroa members, have shown moderate to high TOC and HI values (Moore, 1988b; Leckie et al., 1992) indicating oil and mixed oil and gas-prone kerogen. The Paleocene Waipawa Black Shale has been considered the best potential source formation in the East 


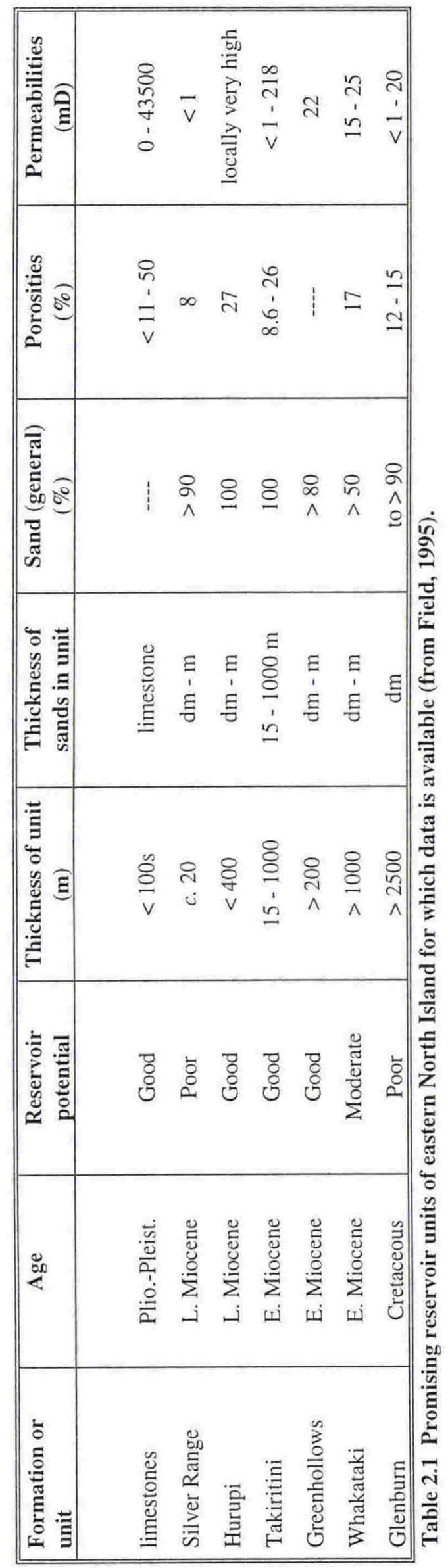


Coast Basin (Ministry of Commerce, 1993; Field et al., 1995) with TOC and HI values up to $12.3 \%$ and 428 respectively (Moore, 1989). Waipawa Black Shale outcrops often smell strongly of hydrocarbons, and have given rise to names such as Kerosene Bluff. The Eocene Wanstead Formation, however, only provides a limited source prospect (Amoco Staff, 1990) and Miocene flysch sediments (such as the Whakataki Formation), despite moderate levels of organic matter, appear to be thermally immature.

\section{Maturation}

The presence of oil and gas seeps provide obvious evidence that sufficient maturation for hydrocarbon generation has occurred. Basin thickness is estimated to be up to $7-8 \mathrm{~km}$ in Hawke Bay (Field et al., 1995). The Upper Cretaceous to Paleogene possible source rock sequence have undergone rapid burial since the Miocene with up to 3-4 $\mathrm{km}$ of Neogene sediments deposited in the southern part of the basin (Field et al., 1995).

\section{Reservoir rocks}

Numerous reservoir rocks are present in the stratigraphic sequence (Table 2.1) although they are predominantly Miocene or younger in age (Field et al., 1995). The Glenburn Formation provides, in general, a poor reservoir, but its great thickness increases its significance. Fracture porosity is a possibility in the Whangai Formation in regions of intense structure (Francis, 1995a). Paleocene to Oligocene greensands in southern Hawke's Bay and Wairarapa are proven reservoirs, often containing migrated hydrocarbons. Miocene flysch sediments and paralic or shelfal sands contain good porosity and permeability values and are regional in extent (Francis, 1992b). The Pliocene and Quaternary Te Aute limestones were early recognised as excellent reservoir units and were the primary drilling target for a number of exploration wells (Francis, 1992b; Ministry of Commerce, 1993).

\section{Seal}

Seal rocks are not considered a problem in the East Coast Basin due to a predominance of fine-grained marine sediments. Only for shallow exploration targets (such as the Te Aute Limestone) could the seal be insufficient where Lower Quaternary marine cover is thin or sandy (Ministry of Commerce, 1993). Seal quality, however, is reduced by the large number of faults present in the basin. Widespread oil and gas seepages attest to numerous migration pathways and many of these have been associated with faulting.

\section{Structure}

The Woodville Block has been shown to comprise only thin Miocene and Pliocene cover on basement. The Pongaroa Block, however, comprises a much more complete 
Cretaceous, Paleogene and Neogene sequence (Francis, 1992b). Within the Pongaroa Block many structures are too intense (disjointed) for significant hydrocarbon accumulation but there are a number of gentle structures present, especially within the Akitio Syncline (Francis, 1992b). The Aorangi Block, like the Woodville Block, also has Miocene resting on basement with the possible source rock sequence absent and therefore is also relatively unprospective.

\subsubsection{Occurrences of oil}

Unlike the well known and visually spectacular Waitangi, Totangi and Rotokautuku seep oils of the northern East Coast Basin, oil occurrences in the southern part of the basin manifest themselves in a somewhat less obvious manner, typically as oil impregnations. A large number of oil seeps and impregnations have been described in the literature (e.g. McLernon, 1978), but subsequent fieldwork established that a high proportion of these are no longer active. At the conclusion of fieldwork six oil samples had been obtained (Table 2.2). Grid-references for their locations are provided in Appendix 1.

\begin{tabular}{||l|l|l|l||}
\hline \hline Sample No. & Location & Phenomenon & Geology \\
\hline NE27OIL & 'Knights Stream', Otane & oil impregnation & \\
NEICOIL & 'Isolation Creek' & oil film & Whangai Fm, Rak. Mem. \\
NE110OIL & 'Kerosene Rock', Owahanga & oil impregnation & Amuri Limestone \\
NE115OIL & 'Westcott' Station & oil impregnation & glauconitic sandstone \\
NE120OIL & 'Tiraumea' Valley Rd & oil impregnation & Miocene sandstone \\
NE130OIL & 'Okau Stream' & oil impregnation & greensand within WBS \\
\hline
\end{tabular}

Informal names are given in apostrophes. WBS=Waipawa Black Shale.

Table 2.2 List of oil samples, their locations and geology.

The following is a brief description of each of the oil occurrences.

\section{Knights Stream oil}

This was collected from an outcrop of Whangai Formation (Rakauroa Member) adjacent to Knights Stream, near Otane in southern Hawke's Bay. The outcrop smelt strongly of hydrocarbons. The oil appears not to be in situ but to have migrated to its current location, as biomarker studies (Section 6.5.2) of nearby outcrops of the Whangai Formation and Waipawa Black Shale indicate they are immature for hydrocarbon generation. 


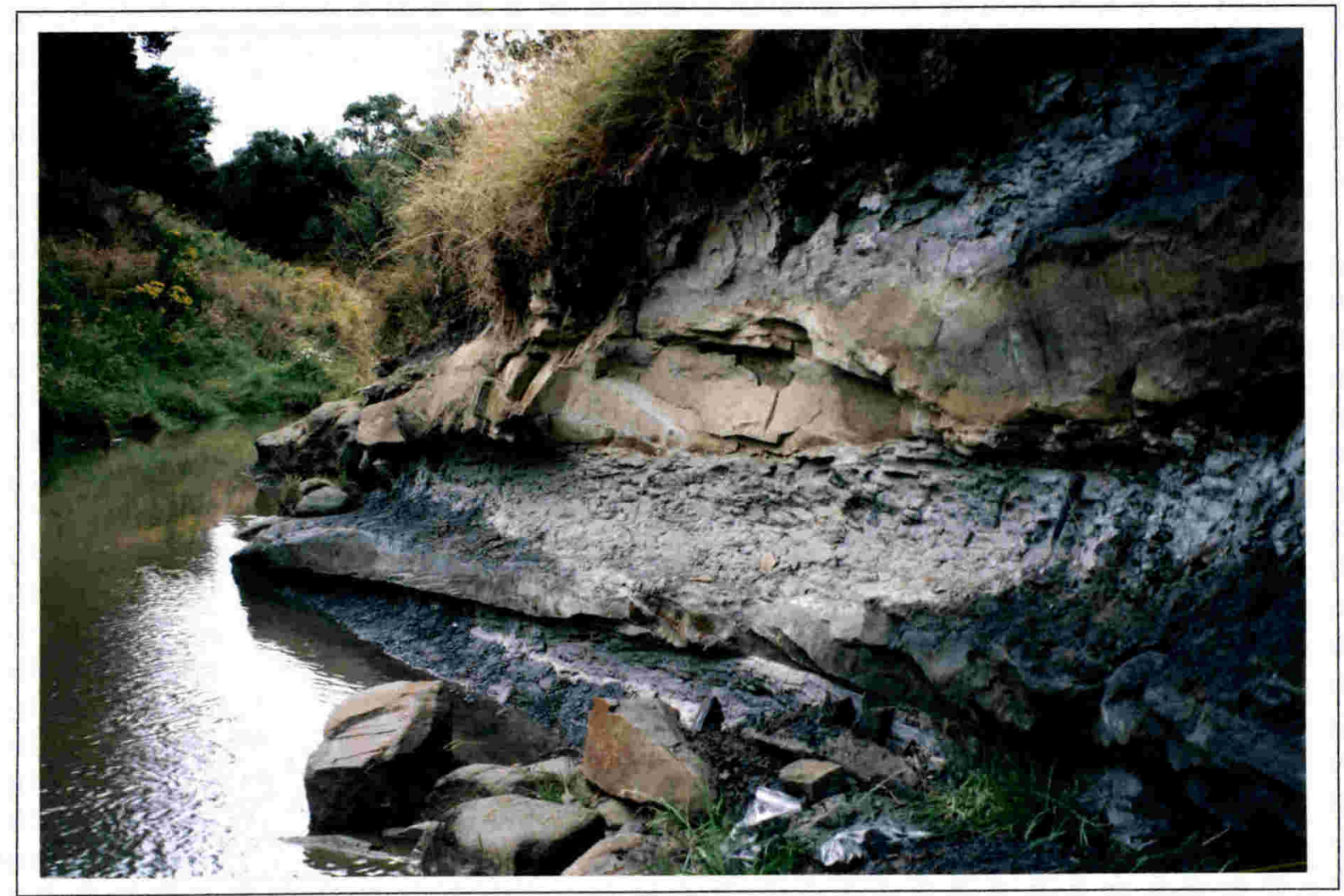

Plate 2.9 Oil-stained sandstone 'Westcott oil' within Miocene siltstone. Adjacent to Mangapuku Stream at Westcott (U24/888902). 


\section{Isolation Creek oil}

This was collected from Isolation Creek in north-eastern Marlborough. The Isolation Creek oil seep is well known, being shown on the geological map of Lensen (1962). The seep appears to be somewhat sporadic in nature, being more active at certain times and even appearing in slightly different locations indicating multiple migration pathways. The sample was collected from a thin film of oil coating a small pool adjacent to the true right hand tributary, a short distance upstream from the hut (refer to NMZS 260 map sheet P29/Q29). A sulphurous-smelling ooze was also found seeping from a bedding plane in the host rock (Amuri Limestone).

\section{Kerosene Rock oil}

This was collected from Kerosene Rock at Owahanga, on coastal north-eastern Wairarapa. Kerosene Rock is an oil-stained glauconitic sandstone of early Oligocene age (Hutson, 1989), set in a jumble of Upper Cretaceous to Eocene strata resulting from Neogene diapirism (Neef, 1992). This glauconitic sandstone has been accorded 'member' status and is referred to as the Akitio Sandstone Member of the Weber Formation (Amoco Staff, 1990). A strong hydrocarbon smell emanated from freshly broken rock.

\section{Westcott oil}

This was obtained from what was formerly Westcott Station (status at the time of fieldwork was unclear) and is commonly referred to as the Westcott oil seep. The sample was collected from a sandstone bed within a marine siltstone of Early Miocene age (Plate 2.9) (see Hutson, 1989).

\section{Tiraumea oil}

This was discovered while investigating a coal outcrop on Tiraumea Valley Road. The host rock appeared to be a marine siltstone or sandstone of ?Miocene age.

\section{Okau Stream oil}

This was obtained from a tributary of Okau Stream, north of Castlepoint. It was collected from a $c .1 .5 \mathrm{~m}$ thick bed of greensand enclosed within the Waipawa Black Shale (Plate 2.10). The location has been previously noted by Moore (1989) and described more recently by Francis (1992a). The enclosing formation did not appear to be oil-stained and biomarker studies indicate it is not the immediate source for the oil.

Occurrences of oil referred to as 'Maunga Structure', 'Cook's Tooth' and 'Kerosene Bluff' (see McLernon, 1978) were also visited but there was no sign of any activity. A number of the Waipawa Black Shale outcrops, notably those from Taurekaitai and Otoro streams 


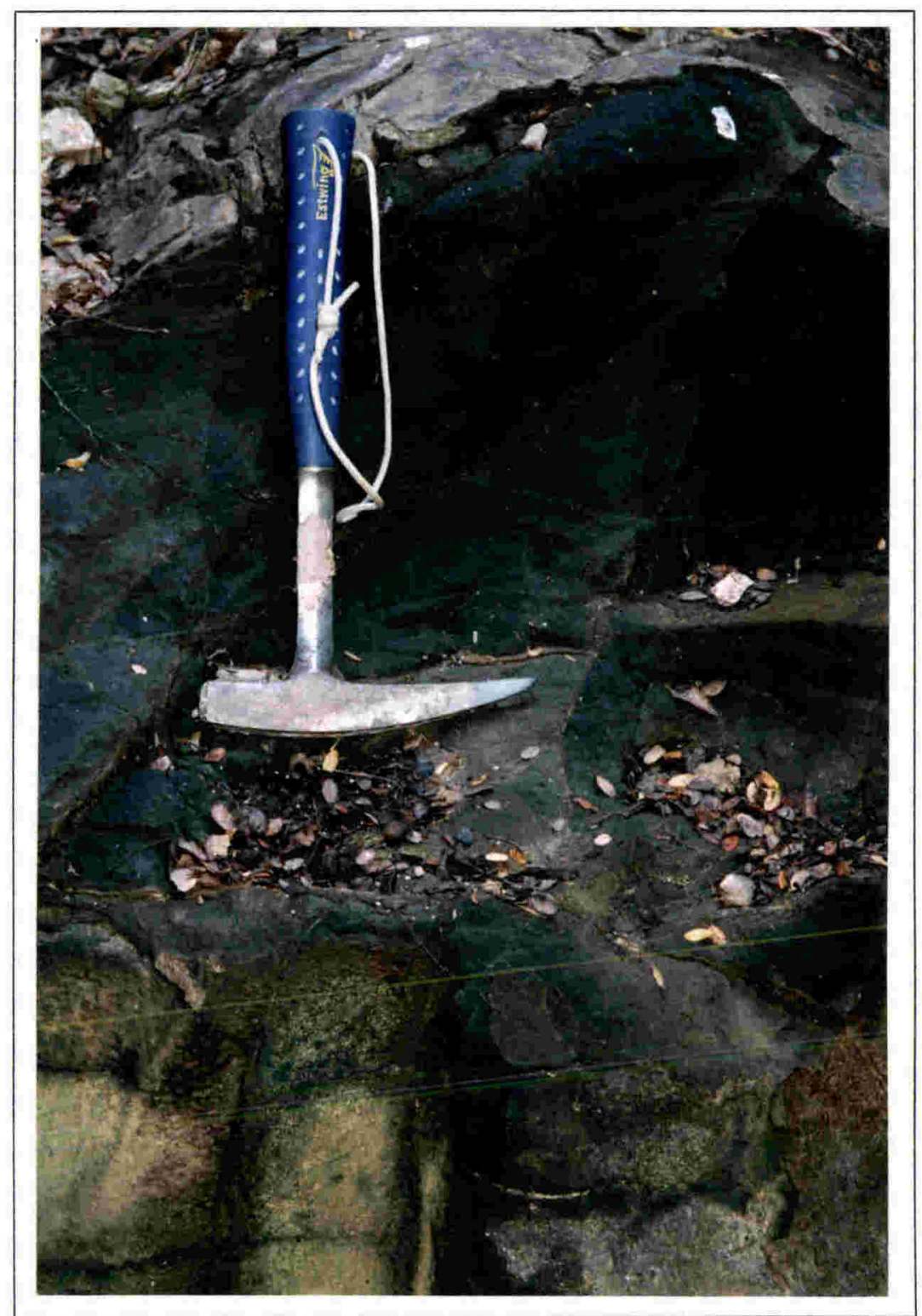

Plate 2.10 Oil-stained glauconitic sandstone 'Okau Stream oil' enclosed within Waipawa Black Shale. Okau Stream (U26/817364). 
(samples NE31 and NE33 respectively), smelt strongly of hydrocarbons, but biomarker results (Section 6.5.2) indicate they are not mature oils and hence they may be the product of early generation. Gas seeps and mud volcanoes were also encountered during fieldwork.

Only the Isolation Creek oil was obtained from the Marlborough region; London Hill, the other known oil seep [also shown on the geological map of Lensen (1962)], was inactive when visited. The landowner commented that his livestock waterhole adjacent to the seep is often covered by an oily film. It appears that late summer, when much of the fieldwork was conducted, is not a good time to look for oil seeps as the water table at this time recedes underground. 


\section{Chapter 3}

\section{Analytical procedures}

\subsection{Sampling}

\subsubsection{Sampling strategy}

The initial aim of the present study was to sample all possible source formations, both geographically and stratigraphically. Unfortunately poor exposures meant that the exact stratigraphic location of samples often proved indeterminable.

Time constraints and the nature of this study precluded detailed geological mapping. Instead the location and identification of samples were obtained through a literature survey. Primary sources of information included university theses (mainly from Victoria University of Wellington but also Canterbury University in regard to Marlborough stratigraphy), various journals (notably New Zealand Journal of Geology and Geophysics), unpublished open-file Petroleum Reports lodged at Resource Information, Energy and Resource Division of the Ministry of Commerce, and in-house publications from the Institute of Geological and Nuclear Sciences Limited (IGNS). References to oil sample localities were obtained from both McLernon (1978) and the Geological Resource Map (GERM) data base.

\subsubsection{Sample collection}

Meaningful geochemical analyses require minimal alteration or contamination of samples, and every attempt was made to collect fresh material. This sometimes involved considerable excavation of the exposure and weathering rinds where present. Soil, vegetation (particularly lichen and roots) and insects were all carefully removed. Despite this, some outcrops were in rather poor condition and these were noted. Typically, two to three kilograms of each sample were collected.

The only seep oil collected was that at Isolation Creek in Marlborough. Here the seep was situated adjacent to a stream and was most easily collected by skimming a thin oil film from the surface of the water. 
Unlike the northern East Coast Basin, the southern portion has had relatively few exploration wells drilled, and these often penetrated sequences that lacked prospective source formations. Therefore, after consideration, no well cuttings were taken for analyses and the present study is based on approximately 150 outcrop and six oil samples.

\subsubsection{Sample preparation}

Prior to crushing and powdering, damp samples were air-dried at room temperature (to retain any volatile hydrocarbons present). Any remaining extraneous matter was removed. The samples were initially broken up in an hydraulic press and then crushed to a maximum size of -2 to -3 phi $(4-8 \mathrm{~mm})$. They were then powdered in a TEMA (tungsten carbide) swing mill to $200 \mu \mathrm{m}$. Approximately $100 \mathrm{~g}$ of powdered sample was obtained.

Due to the different requirements of each analytical method, whole rock, crushed and powdered fractions were prepared for each sample. Whole rock samples were used in vitrinite reflectance and VKA. Powdered samples were used in TOC, Rock-Eval pyrolysis and XRF analyses. Gas chromatography, GC-MS and stable carbon isotope analyses were also obtained from organic matter extracted from powdered samples. 


\subsection{Laboratory procedure}

\subsubsection{Introduction}

Total organic carbon, Rock-Eval pyrolysis, GC, GC-MS, stable carbon isotope, VKA, vitrinite reflectance, and XRF spectroscopy analyses were conducted as part of the present study. Methodologies of these analytical techniques are not included here but are discussed within their relevant chapter or section following their introduction.

Gas chromatography (GC), GC-MS and stable carbon isotope analyses of oils and possible source rocks require the extraction of soluble organic matter (bitumen) and its

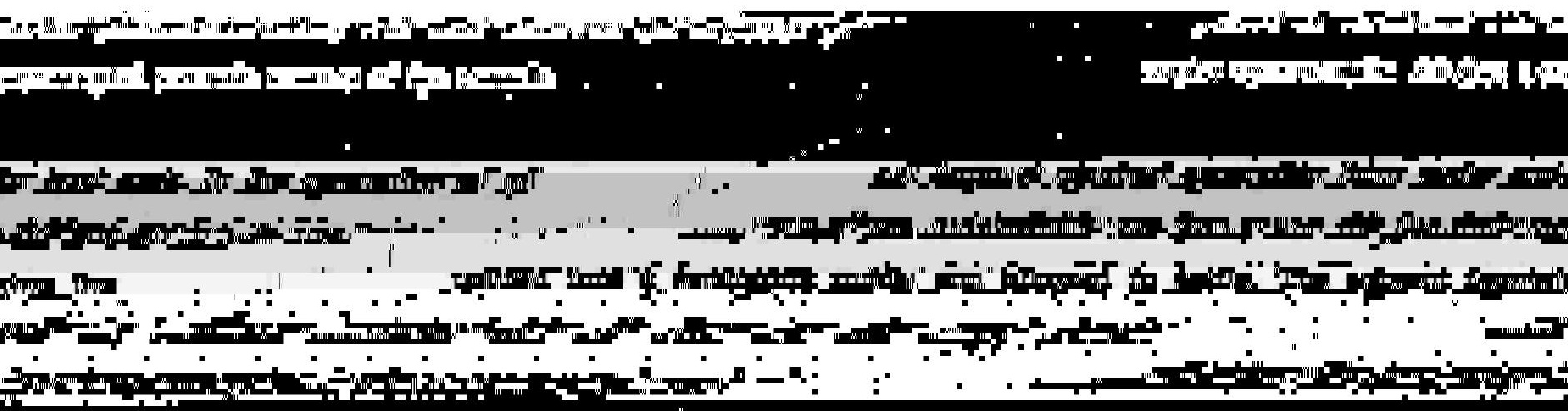




\subsubsection{Separation of organic constituents}

Bitumen and oil samples comprise hundreds of complex organic compounds of which only a few specific compound types are required in GC and GC-MS analysis. The remaining fraction may interfere in the analysis by coeluting with the compounds of interest. Therefore, prior to analysis, bitumen and oil samples were separated into their various components and interfering fractions, such as asphaltenes, aromatics and $n$-alkanes, are isolated and then removed, as described in the following.

\section{Precipitation of asphaltenes}

Asphaltenes comprise NSO compounds which, if not removed from the GC extract, would interfere with separation of components during gas chromatography (Muirhead, 1983). Asphaltenes were removed by precipitation in a non-polar solvent ( $n$-pentane), followed by filtration (Muirhead, 1983). No analyses were done on this fraction.

\section{Separation of aromatic from saturate fractions}

Muirhead (1983) described two methods of liquid-solid chromatography for the separation of petroleum, one of which was suitable for small samples (c. $100 \mathrm{mg}$ ), typical in oil-oil and oil-source rock correlation studies. This was the method used in the present study.

The aromatic fraction was separated from the saturate fraction in a process of elution chromatography using a dual silica gel-alumina column. The silica splits the saturates from the aromatics, while the alumina causes a subseparation of the aromatics (Muirhead, 1983). A $30 \mathrm{~cm} \times 12 \mathrm{~mm}$ I.D. glass column was fitted with an Interflon stopcock and a coarse glass sinter above it (Muirhead, 1983). The adsorbents were silica gel and alumina, conditioned at $150^{\circ} \mathrm{C}$ and $400^{\circ} \mathrm{C}$ respectively. The column was initially halffilled with $n$-pentane to which $5 \mathrm{~g}$ of alumina and $3 \mathrm{~g}$ of silica were added. The organic extract, diluted slightly in $n$-pentane, was then added to the column. The saturate fraction was washed through with $100 \mathrm{ml}$ of $n$-pentane eluant and then concentrated by rotary evaporation. The aromatic fraction was eluted with $100 \mathrm{ml}$ of trichloromethane and also concentrated by rotary evaporation. This fraction was later investigated by stable carbon isotope analysis. The saturate fraction was split into two. One-half was ready to be analysed by $\mathrm{GC}$, the other half required further processing prior to analysis by GC-MS.

\section{Removal of $n$-alkanes by molecular sieve adsorption}

$\mathrm{N}$-alkanes interfere with the analysis of biomarkers (they give significant peaks for ions of low relative abundances, such as $\mathrm{m} / \mathrm{z} 191$ and 217) because they are considerably more 
abundant than steranes and triterpanes (Collier, 1989). Therefore before the saturate fraction is analysed by GC-MS the $n$-alkanes need to be separated from the branched and cyclic saturates. This was done by refluxing the saturate fraction in 2,2,4-trimethylpentane (isooctane) with a molecular sieve for 12 hours. The Union Carbide SP 115 molecular sieve $(6 \AA)$ preferentially adsorbs the straight-chained saturates, effectively separating them from the desired fraction which can be decanted and then concentrated by rotary evaporation.

All samples were stored in small $(2 \mathrm{ml})$ glass vials at reduced temperature $\left(-7^{\circ} \mathrm{C}\right)$, to restrict biodegradation, prior to GC, GC-MS or stable carbon isotope analyses. Although the samples degrade with time, if they are analysed within two months of storage, there is no noticeable affect. The entire extraction and separation process takes approximately five days and sufficient equipment was available to process nine samples at a time. 


\section{Total organic carbon and Rock-Eval pyrolysis}

\subsection{Total organic carbon (TOC)}

\subsubsection{Introduction}

An essential requirement for a prospective source rock is the presence of sufficient organic matter of suitable type (Tissot and Welte, 1978). Total organic carbon (TOC) analysis, expressed as weight percent of rock, is a quick method of screening large numbers of samples to determine whether they warrant further, more detailed analyses. Quantity of organic carbon, as determined from TOC analyses, is a common classification of source rock quality (Table 4.1).

\begin{tabular}{||l|c|c||}
\hline Classification & $\begin{array}{c}\text { TOC in clastics } \\
(\mathbf{w t} \text { \% })\end{array}$ & $\begin{array}{c}\text { TOC in carbonates } \\
\text { (wt. \%) }\end{array}$ \\
\hline Poor & $0.00-0.50$ & $0.00-0.20$ \\
Fair & $0.50-1.00$ & $0.20-0.50$ \\
Good & $1.00-2.00$ & $0.50-1.00$ \\
Very good & $2.00-5.00$ & $1.00-2.00$ \\
Excellent & $>5.00$ & $>2.00$ \\
\hline
\end{tabular}

Table 4.1 Source rock quality as determined by TOC analyses (from Jarvie, 1991).

Certain minimum values of TOC are required before expulsion of hydrocarbons from a source rock is possible and these are considered to be $0.3 \%$ for carbonates and $0.5 \%$ for shales (Tissot and Welte, 1978), carbonates having a higher concentration of hydrocarbons per unit TOC than shales (Gehman, 1962).

There are two common methods of determining TOC from rock samples, both of which are comprehensively reviewed by Jarvie (1991) and Peters and Moldowan (1993). The first method requires acid treatment of samples to remove carbonate carbon followed by combustion in an induction furnace at $1200^{\circ} \mathrm{C}$ under an oxygen atmosphere (Tissot and Welte, 1978; Jarvie, 1991; Peters and Moldowan, 1993). Evolved $\mathrm{CO}_{2}$ is measured by a thermal conductivity detector (TCD). A second, increasingly common, way to measure TOC is by the Rock-Eval/TOC method which combines Rock-Eval pyrolysis with an 


\begin{tabular}{|c|c|c|}
\hline Formation & $\begin{array}{l}\text { TOC average } \\
(\%)\end{array}$ & $\begin{array}{c}\text { TOC range } \\
(\%)\end{array}$ \\
\hline \multicolumn{3}{|l|}{ North Island stratigraphy } \\
\hline Whakataki Formation (2) & 0.52 & $0.44-0.60$ \\
\hline Weber Formation (2) & 0.22 & $0.15-0.29$ \\
\hline Wanstead Formation (5) & 0.17 & $0.03-0.24$ \\
\hline Waipawa Black Shale (17) & 2.67 & $0.28-5.69$ \\
\hline \multicolumn{3}{|l|}{ Whangai Formation: } \\
\hline Te Uri Member (2) & 0.31 & $0.28-0.33$ \\
\hline Porangahau Member (4) & 0.17 & $0.03-0.32$ \\
\hline Upper Calcareous Member (7) & 0.62 & $0.36-1.19$ \\
\hline Rakauroa Member (6) ${ }^{1}$ & 0.62 & $0.09-1.37$ \\
\hline Undiff. [N.I.] (11) & 0.872 & $0.19-3.50$ \\
\hline Tangaruhe Formation (2) & 0.36 & $0.32-0.40$ \\
\hline Te Mai Formation (5) & 0.85 & $0.19-1.52$ \\
\hline Glenburn Formation (7) & 0.72 & $0.09-1.30$ \\
\hline Springhill Formation (2) & 0.26 & $0.24-0.27$ \\
\hline Pahaoa Group (12) & $0.30^{3}$ & $0.05-1.54$ \\
\hline Torlesse Supergroup (1) & 0.19 & \\
\hline \multicolumn{3}{|l|}{ South Island stratigraphy } \\
\hline Waima Siltstone (1) & 0.41 & \\
\hline Woodside Formation (1) & 0.06 & \\
\hline Amuri Limestone (10) & 0.09 & $0.03-0.15$ \\
\hline Whangai Formation, undiff. (4) & 0.49 & $0.46-0.51$ \\
\hline Mata Series (8) & 0.31 & $0.03-0.96$ \\
\hline Flags Formation (1) & 0.52 & \\
\hline Claverley Sandstone (1) & 0.39 & \\
\hline Conway Siltstone (1) & 0.55 & \\
\hline Burnt Creek Formation (2) & 0.33 & $0.25-0.41$ \\
\hline Split Rock Formation (5) & 0.36 & $0.29-0.41$ \\
\hline Torlesse Supergroup 4 (6) & 0.35 & $0.26-0.45$ \\
\hline
\end{tabular}

IIncludes an oil-stained sample. ${ }^{2}$ Average would be $0.61 \%$ if sample with $3.50 \%$ TOC was removed from data set. ${ }^{3}$ Average would be $0.19 \%$ if sample with $1.54 \%$ TOC was removed from data set. ${ }_{4}^{4}$ Includes Good Creek Formation. Number in brackets () denotes number of samples in data set.

Table 4.2 Summary of selected TOC data obtained from LECO RC-412 Multiphase Carbon Determinator. 
oxidation cycle (Jarvie, 1991). Here the organic carbon in the pyrolysate $\left(S_{1}+S_{2}\right)$ is added to that obtained by oxidising the residual organic matter in a second oven at $600^{\circ} \mathrm{C}$ (Jarvie, 1991; Peters and Moldowan, 1993). The advantages of this method are that acid treatment is unnecessary and both Rock-Eval pyrolysis and TOC data are available from one analysis.

\subsubsection{Methods}

Total organic carbon data were obtained from two sources during this study. The first data set includes results from screening all possible source rocks using a LECO carbon determinator. The second set includes results from samples analysed by Rock-Eval pyrolysis which measured TOC using the Rock-Eval/TOC method. These results provided a check against those determined earlier.

Total organic carbon analyses using the LECO method were conducted on a LECO RC-412 Multiphase Carbon Determinator in the Analytical Facility at Victoria University of Wellington. Sample preparation was discussed in Section 3.1.3 and a detailed description of the method used in the LECO analyses is given in Appendix 2. Total organic carbon analyses using the TOC/Rock-Eval method were conducted at Lanzhou Institute of Geology, P. R. China.

\subsubsection{Results}

A summary of TOC data from the LECO analyses appears in Table 4.2. Full TOC results from both LECO and Rock-Eval/TOC analyses are presented in Appendix 2 with carbonate content data for carbonate-rich samples.

Relatively few formations in the southern East Coast Basin are organic-rich (Table 4.2). Only the Waipawa Black Shale demonstrates 'very good' source potential, with the Whakataki Formation, Upper Calcareous and Rakauroa members of the Whangai Formation, Te Mai, Glenburn and Flags formations, and Conway Siltstone showing 'fair' source potential. The Weber, Wanstead, Tangaruhe and Springhill formations, Pahaoa Group, Waima Siltstone, Woodside Formation, Amuri Limestone, Claverley Sandstone, Burnt Creek and Split Rock formations, and the Torlesse Supergroup all demonstrate 'poor' source potential based on average TOC content. A Miocene coal sample (NE109) recorded $4.70 \%$ TOC but is very localised in extent and is not considered a possible source rock for the oils in southern East Coast Basin. 


\subsubsection{Discussion}

The middle Cretaceous to Paleocene sequence comprising the Glenburn, Te Mai and Whangai formations and Waipawa Black Shale has the only significant organic-rich rocks in the southern East Coast Basin, with both Lower Cretaceous and Neogene strata appearing to have little source rock potential. Emphasis on sampling was directed at the Upper Cretaceous to Paleocene sequence and the limited number of analyses from other formations may not be sufficient to fully assess their hydrocarbon potential; the results obtained, however, indicate limited hydrocarbon potential. Overall, the results of the present study are more conservative than those of Moore et al. (1987), Zumberge (1990), Leckie et al. (1992) and Rogers (1995) (Table 4.3) and this may partially be a function of different sampling methodologies of different authors (see Section 4.2.4).

\begin{tabular}{|l|c|c|c|c|c||}
\hline Formation & $\begin{array}{c}\text { TOC (\%) } \\
\text { Moore } \text { et al. } 1\end{array}$ & $\begin{array}{c}\text { TOC (\%) } \\
\text { Zumberge }^{2}\end{array}$ & $\begin{array}{c}\text { TOC (\%) } \\
\text { Leckie } \text { et al. }^{3}\end{array}$ & $\begin{array}{c}\text { TOC (\%) } \\
\text { Rogers }^{4}\end{array}$ & $\begin{array}{c}\text { TOC (\%) } \\
\text { This study5 }\end{array}$ \\
\hline & & & & & \\
Weber & & & 0.41 & $0.08(2)$ & $0.22(2)$ \\
Wanstead & & & & $0.33(6)$ & $0.17(5)$ \\
Waipawa Black Shale & $5.61(10)$ & $3.67(33)$ & 3.09 & $3.66(20)$ & $2.67(17)$ \\
Whangai: & & & & & \\
Te Uri Mem. & & & 0.39 & & $0.31(2)$ \\
Upper Calc. Mem. & $0.32(5)$ & & 0.58 & $0.66(8)$ & $0.62(7)$ \\
Rakauroa Mem. & $0.66(11)$ & & 0.61 & $0.90(11)$ & $0.62(6)$ \\
\hline
\end{tabular}

Number in brackets () denotes number of samples in data set. ${ }^{1}$ Moore et al. (1987); ${ }^{2}$ Zumberge (1990); ${ }^{3}$ Leckie et al. (1992); ${ }^{4}$ Rogers (1995).

Table 4.3 Comparison with TOC results of previous studies.

Results of a source rock geochemistry study arising from the recent drilling of Titihaoa-1 included 25 Whakataki Formation samples which averaged 0.33\% TOC (Biros et al., 1994), somewhat less than that determined from the present study ( $0.52 \%$ TOC). 


\subsection{Rock-Eval pyrolysis}

\subsubsection{Introduction and methods}

Total organic carbon analyses determine quantity but not type of organic matter present in a sample. Optical and chemical methods of determining organic matter type involve considerable work, requiring kerogen isolation, and are therefore unsuitable for screening large numbers of samples (Tissot and Welte, 1978; Peters, 1986).

Rock-Eval pyrolysis, a technique developed at the Institut Français du Pétrole, is a rapid way of determining the quantity and type of source kerogen, and its degree of maturation (Tissot and Welte, 1978; Peters, 1986; Philp and Galvez-Sinibaldi, 1991). It involves the selective detection of both hydrocarbon and oxygenated compounds by pyrolysis of ground rock samples in an inert atmosphere (North, 1990). The pyrolysis is conducted under a specific temperature programme so as to capture $\mathrm{CO}_{2}$ from the organic matter but not mineral (especially carbonate) matter (North, 1990). Powdered samples weighing approximately $100 \mathrm{mg}$ are pyrolysed at $300^{\circ} \mathrm{C}$ for $3-4 \mathrm{~min}$. followed by heating at $25^{\circ} \mathrm{C} / \mathrm{min}$. to $550^{\circ} \mathrm{C}$ (Peters, 1986). The analysis is completely automated and, including oven cooling time, takes about $20 \mathrm{~min}$. per sample. Rock-Eval pyrolysis is typically performed on samples with TOC content greater than $0.5 \%$.

Three peaks are recorded in the analysis:

- The first peak $\left(S_{1}\right)$, represents hydrocarbons that have already been generated and are therefore volatilised at $300^{\circ} \mathrm{C}$ (Peters, 1986). $\mathrm{S}_{1}$ is measured in milligrams of hydrocarbons per gram of rock (mg $\mathrm{HC} / \mathrm{g}$ rock) and is indicative of both in situ and migrated hydrocarbons.

- The second peak $\left(\mathrm{S}_{2}\right)$, represents hydrocarbons produced by thermal degradation of kerogen during pyrolysis to $550^{\circ} \mathrm{C}$ and is a measure of the residual petroleum potential of the sample (Peters, 1986). It is also measured in $\mathrm{mg} \mathrm{HC/g}$ rock.

- The third peak $\left(\mathrm{S}_{3}\right)$ represents $\mathrm{CO}_{2}$ generated from the organic matter during heating to $390^{\circ} \mathrm{C}$ (Peters, 1986). It is measured in milligrams of carbon dioxide per gram of rock ( $\mathrm{mg} \mathrm{CO} / 2$ rock). 


\subsubsection{Geochemical parameters derived from Rock-Eval pyrolysis}

Geochemical parameters determining quantity, type and maturation of organic matter can be derived by Rock-Eval pyrolysis. Despite the relative simplicity of the data there are a number of considerations to be made when making interpretations and these have been discussed by Espitalié et al. (1980), Katz (1983), Peters (1986) and Langford and BlancValleron (1990).

\section{Type of organic matter}

One of the most common methods of characterising organic matter is the van Krevelen diagram (Figure 4.1a). Here a plot of atomic H/C vs O/C defines four different types of organic matter based on differences in elemental composition: Type I very oil-prone; Type II oil-prone; Type III gas-prone; and Type IV inert (Peters, 1986). Maturation is along the pathways shown with the most mature samples in the bottom left hand corner with low $\mathrm{H} / \mathrm{C}$ and $\mathrm{O} / \mathrm{C}$ ratios.

Determination of $\mathrm{H} / \mathrm{C}$ and $\mathrm{O} / \mathrm{C}$ ratios require elemental analyses, which are both time consuming and expensive (Peters, 1986; Philp and Galvez-Sinibaldi, 1991). The development of Rock-Eval pyrolysis provided information that has allowed two new parameters to be derived. The hydrogen index $(\mathrm{HI})$, defined as $\left(\mathrm{S}_{2} / \mathrm{TOC}\right) \times 100$ correlates directly with the $\mathrm{H} / \mathrm{C}$ atomic ratio. The oxygen index (OI), defined as $\left(\mathrm{S}_{3} / \mathrm{TOC}\right) \times 100$ correlates with the O/C ratio. A plot of HI vs OI (Figure $4.1 \mathrm{~b}$ ) describes type of organic matter, similar to the van Krevelen diagram (Peters, 1986).

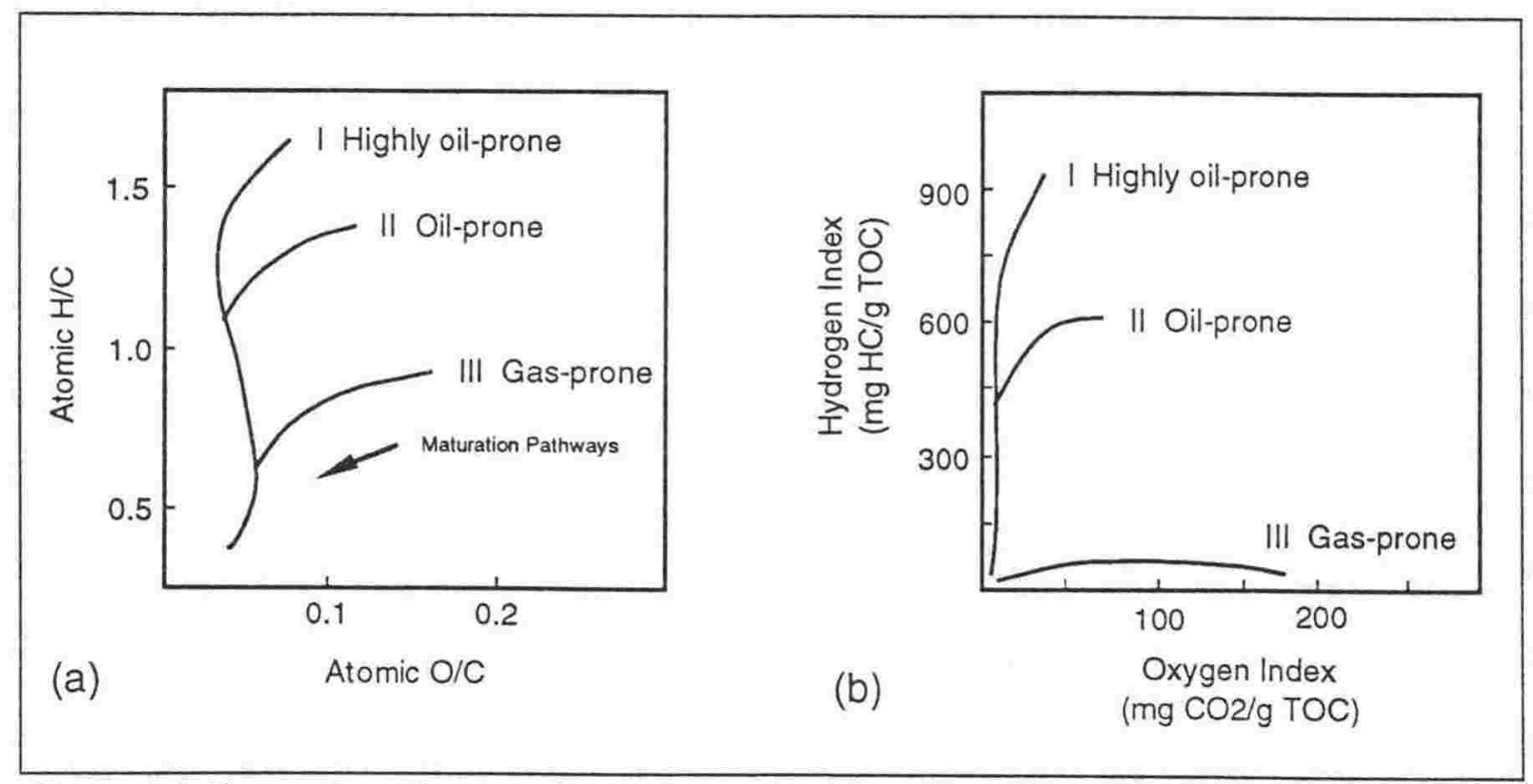

Figure 4.1 Comparison of maturation pathways between (a) van Krevelen's diagram, $\mathrm{H} / \mathrm{C}$ vs $\mathrm{O} / \mathrm{C}$, with (b) HI vs OI cross-plot (after Peters, 1986). 
Related to the HI vs OI cross-plot is the $S_{2} / S_{3}$ ratio, which also gives a measure of the oil-proneness of the sample. $\mathrm{HI}$ and $\mathrm{S}_{2} / \mathrm{S}_{3}$ values can be used to show the types of hydrocarbons generated when organic matter reaches maturity (Table 4.4).

\begin{tabular}{||l|c|c||}
\hline \hline Type & $\begin{array}{c}\text { HI } \\
(\mathbf{m g ~ H C} / \mathbf{g} \text { TOC })\end{array}$ & $\mathbf{S}_{2} / \mathbf{S}_{\mathbf{3}}$ \\
\hline Inert & $<50$ & $<1$ \\
Gas & $50-150$ & $1-3$ \\
Gas and oil & $150-300$ & $3-5$ \\
Oil & $>300$ & $>5$ \\
\hline
\end{tabular}

Table 4.4 Parameters describing types of hydrocarbons generated (after Peters, 1986; Peters and Cassa, 1994).

\section{Quantity of organic matter}

The quantity of organic matter in a sample can be determined by the amount of $S_{1}$ and $S_{2}$ recorded in the pyrolysis (Table 4.5$)$. $\left(S_{1}+S_{2}\right)$ represents total hydrocarbons present and is a measure of the potential yield of the sample. It is expressed as $\mathrm{mg} \mathrm{HC/g}$ of rock.

\begin{tabular}{||l|c|c||}
\hline \hline Source rock quality & $\begin{array}{c}\mathbf{S}_{1} \\
(\mathbf{m g ~ H C} / \mathrm{g} \text { rock })\end{array}$ & $\begin{array}{c}\mathbf{S}_{2} \\
(\mathbf{m g ~ H C} / \mathrm{g} \text { rock })\end{array}$ \\
\hline & & \\
Poor & $0.0-0.5$ & $0.0-2.5$ \\
Fair & $0.5-1.0$ & $2.5-5.0$ \\
Good & $1.0-2.0$ & $5.0-10.0$ \\
Very good & $>2.0$ & $>10.0$ \\
\hline
\end{tabular}

Table 4.5 Parameters describing source rock generative potential (from Peters, 1986).

\section{Maturity of organic matter}

The production index (PI), defined as the ratio $S_{1} /\left(S_{1}+S_{2}\right)$, represents the amount of petroleum generated relative to the amount of hydrocarbons present. With increasing thermal maturity $S_{1}$ will increase and $S_{2}$ will decrease as petroleum is generated from the organic matter (Philp and Galvez-Sinibaldi, 1991). The production index can therefore be used as a measure of maturity of the sample (Table 4.6). $\mathrm{T}_{\max }$, the temperature (in ${ }^{\circ} \mathrm{C}$ ) at which the $S_{2}$ peak reaches its maximum, has been shown to increase as the maturity of the sample increases (Philp and Galvez-Sinibaldi, 1991), and therefore can also be used as a maturity indicator (Table 4.6). Both parameters are, at best, only crude indicators of maturity with many influencing factors and are best used in conjunction with other maturity indicators (Peters, 1986) such as vitrinite reflectance and biomarker ratios. 


\begin{tabular}{|c|c|c|c|c|c|c|c|}
\hline $\begin{array}{r}0 \\
0 \\
0 \\
0 \\
0 \\
0 \\
0 \\
0 \\
\text { o. } \\
0\end{array}$ & 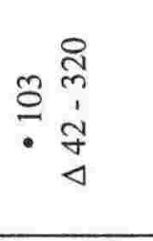 & 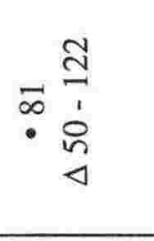 & 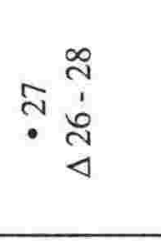 & 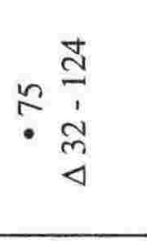 & $\begin{array}{l}\frac{8}{0} \\
\div \frac{8}{7} \\
\frac{1}{4}\end{array}$ & 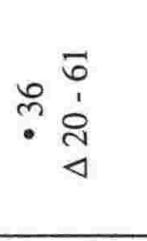 & \multirow{10}{*}{ 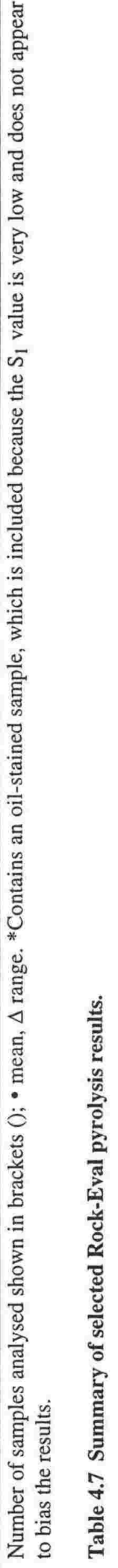 } \\
\hline 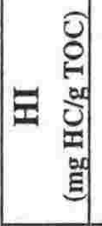 & 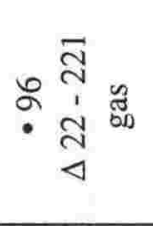 & 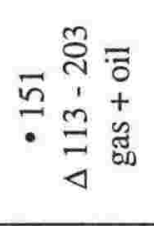 & 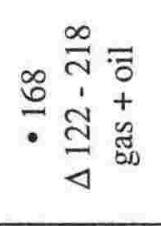 & 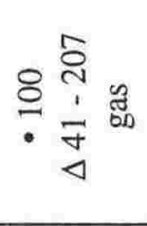 & 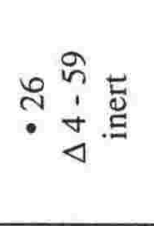 & 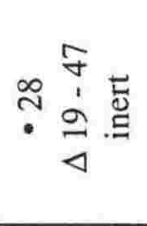 & \\
\hline$\frac{\mathscr{n}}{\tilde{N}^{2}}$ & 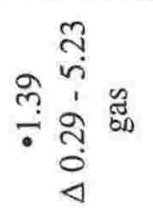 & 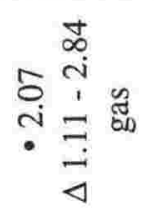 & 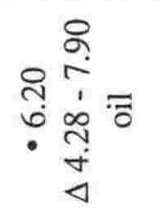 & 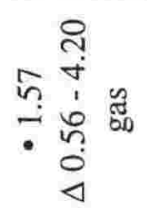 & 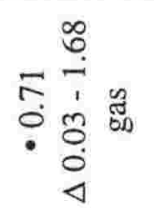 & 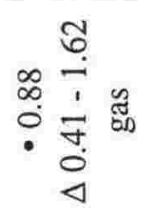 & \\
\hline 窇。 & 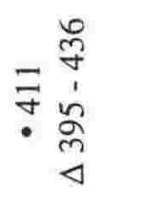 & ヘָ & 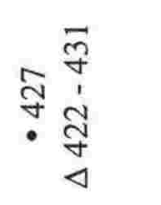 & 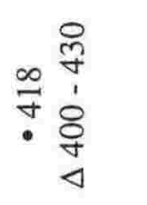 & 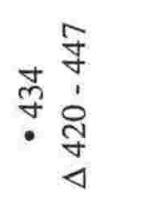 & 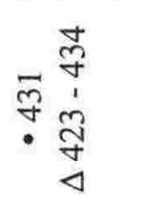 & \\
\hline 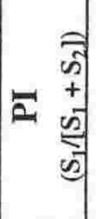 & 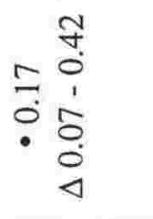 & 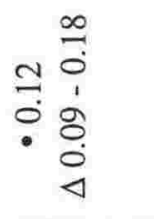 & $\begin{array}{l}\text { I } \\
0 \\
0 \\
0 \\
0 \\
0 \\
0 \\
0 \\
0 \\
0 \\
4\end{array}$ & $\begin{array}{l}\text { त } \\
+0 \\
\pm \\
0 \\
0 \\
0 \\
0 \\
0 \\
0 \\
4\end{array}$ & 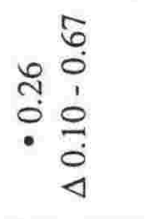 & 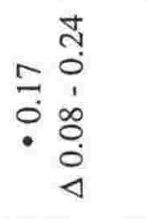 & \\
\hline क 产 & 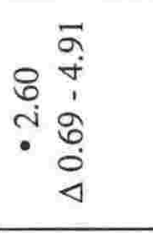 & $\begin{array}{ll} & 0 \\
0 & = \\
0 & 1 \\
0 & 1 \\
0 & 0 \\
0 & 0 \\
0 & 4\end{array}$ & 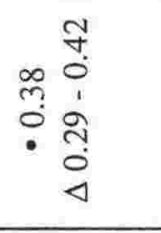 & $\begin{array}{ll} & n \\
0 & \\
\infty & 0 \\
0 & 1 \\
0 & 0 \\
0 \\
0 \\
4\end{array}$ & 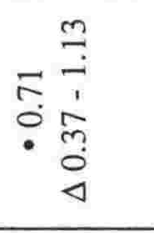 & $\begin{array}{ll} & 0 \\
n & 0 \\
\infty & 0 \\
n & 1 \\
0 & 0 \\
0 & 0 \\
0 \\
\ddots\end{array}$ & \\
\hline क 현 & 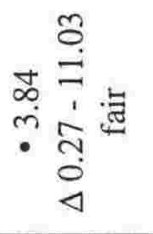 & 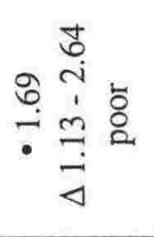 & 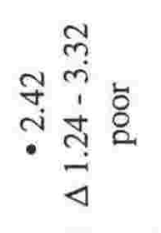 & 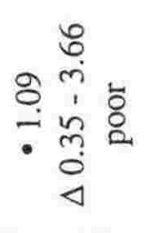 & 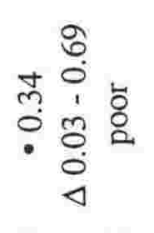 & 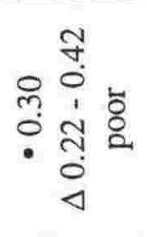 & \\
\hline क 战 & 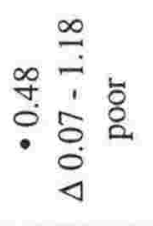 & 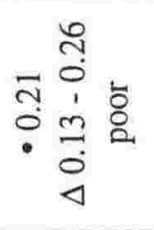 & 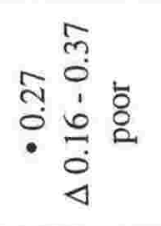 & 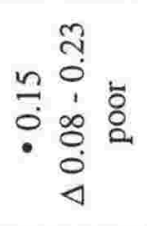 & 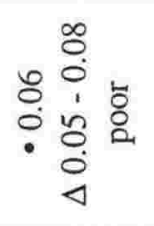 & 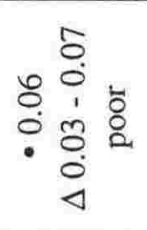 & \\
\hline$\left[\begin{array}{cc}0 & 0 \\
0 & 5\end{array}\right]$ & 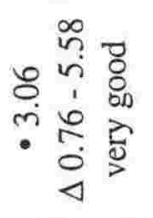 & 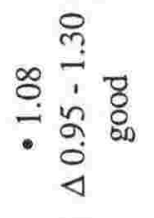 & 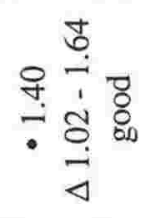 & 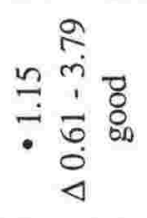 & 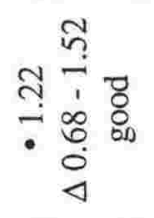 & 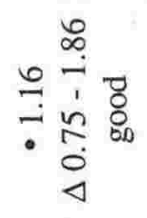 & \\
\hline 㺼 & $\begin{array}{l}\sqrt{2} \\
\infty \\
\infty \\
3\end{array}$ & 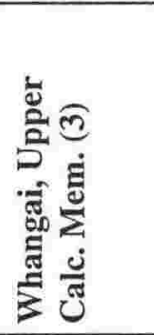 & 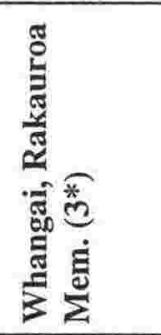 & 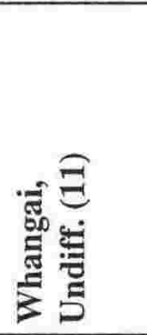 & 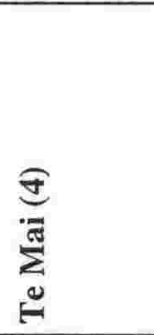 & 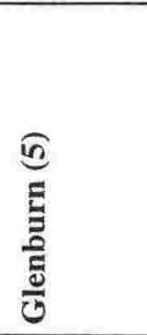 & \\
\hline
\end{tabular}




\begin{tabular}{||l|c|c|c||}
\hline Maturity & $\begin{array}{c}\mathbf{R}_{\mathbf{0}} \\
(\%)\end{array}$ & $\begin{array}{c}\mathbf{P I} \\
\left(\mathbf{S}_{1} /\left[\mathbf{S}_{1}+\mathbf{S}_{2}\right]\right)\end{array}$ & $\begin{array}{c}\mathbf{T}_{\max } * \\
\left({ }^{\circ} \mathbf{C}\right)\end{array}$ \\
\hline Immature & $<0.6$ & $<0.1$ & $<435$ \\
Onset of oil generation & 0.6 & $\sim 0.1$ & $\sim 435-445$ \\
Peak oil generation & 0.9 & $\sim 0.25$ & $\sim 445-450$ \\
End of oil generation & 1.3 & $\sim 0.4$ & $\sim 470$ \\
Postmature & $>1.3$ & $>0.4$ & $>470$ \\
\hline \hline
\end{tabular}

(*depends on type of organic matter)

Table 4.6 Parameters describing level of thermal maturation, and correlation with vitrinite reflectance values (from Peters and Moldowan, 1993).

\subsubsection{Results}

Forty six samples exceeding $0.5 \%$ TOC were forwarded to Lanzhou Institute of Geology, P. R. China, for Rock-Eval pyrolysis and a summary of results appears in Table 4.7. Full results, with the exception of the original Rock-Eval pyrograms, are presented in Appendix 3.

\section{Quantity of organic matter}

'Good' to 'very good' TOC values were recorded for the samples, but these are obviously not representative of their respective formations due to the nature of the selection criteria (see above). With the exception of the Waipawa Black Shale, 'poor' average $\mathrm{S}_{1}$ and $\mathrm{S}_{2}$ values were recorded for all the possible source rocks. The Te Mai and Glenburn formations, in particular, demonstrate little or no source potential despite their encouraging TOC values. Individual samples of both the Waipawa Black Shale and Whangai Formation, however, demonstrate 'fair' to 'very good' source potential.

\section{Type of organic matter}

The type of organic matter present in the samples can be characterised by an HI vs OI cross-plot (Figure 4.2). Waipawa Black Shale samples are widely scattered over this plot but have a dominant mixture of Types II and III kerogen. Rakauroa Member samples plot close to the Type II kerogen line, while samples of the Upper Calcareous Member plot as a mixture of Types II and III kerogen. The Whakataki Formation, Flags Formation and the majority of undifferentiated Whangai Formation samples plot between the Type III and Type IV kerogen lines, while the Te Mai, Glenburn and Mangapokia formations and Conway Siltstone samples all plot below the Type IV kerogen line. 


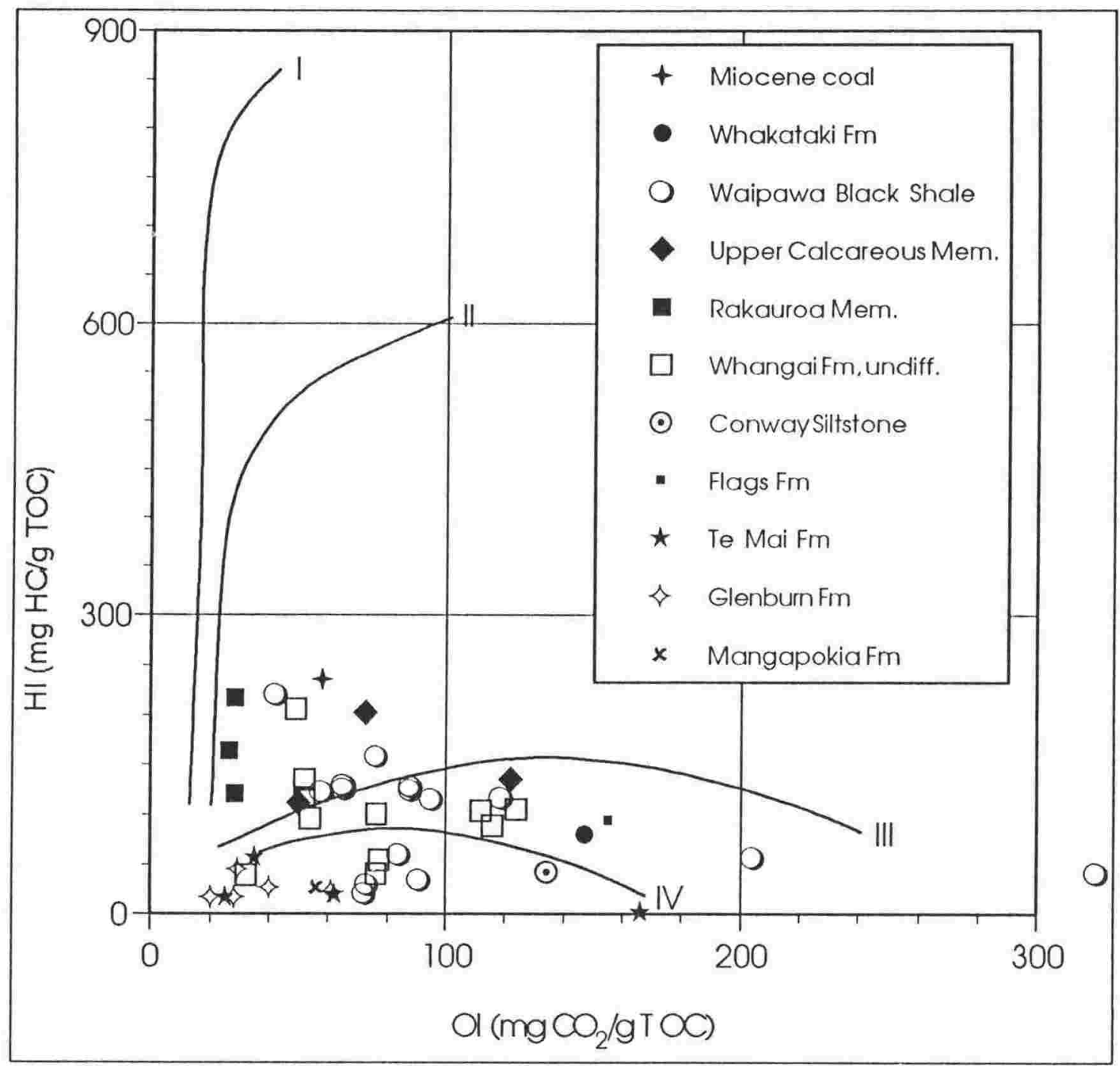

Figure 4.2 HI vs OI cross-plot showing kerogen types present in the samples. I-IV represent the four kerogen types and the lines represent their maturation pathways, increasing toward the origin.

$\mathrm{HI}$ and $\mathrm{S}_{2} / \mathrm{S}_{3}$ values (Table 4.7) indicate that the kerogen in samples of Upper Calcareous and Rakauroa members are oil and gas-prone. The Whakataki Formation, Waipawa Black Shale, Flags Formation and undifferentiated Whangai Formation samples are gas-prone, while the Te Mai, Glenburn and Mangapokia formations and Conway Siltstone samples are either poorly gas-prone or inert. Hydrogen indices are shown to vary considerably in the Waipawa Black Shale (22-221) with some samples inert and others oil-prone.

\section{Maturity}

$\mathrm{T}_{\max }$ and PI values (Table 4.7) do not correlate well, and it appears that $\mathrm{T}_{\max }$ is the more reliable parameter as the results of the present study are very similar to those obtained in previous studies. For example, the average $T_{\max }$ for outcrop samples of the Waipawa Black Shale determined in the present study is $411^{\circ} \mathrm{C}$, compared with averages of $414^{\circ} \mathrm{C}$ 


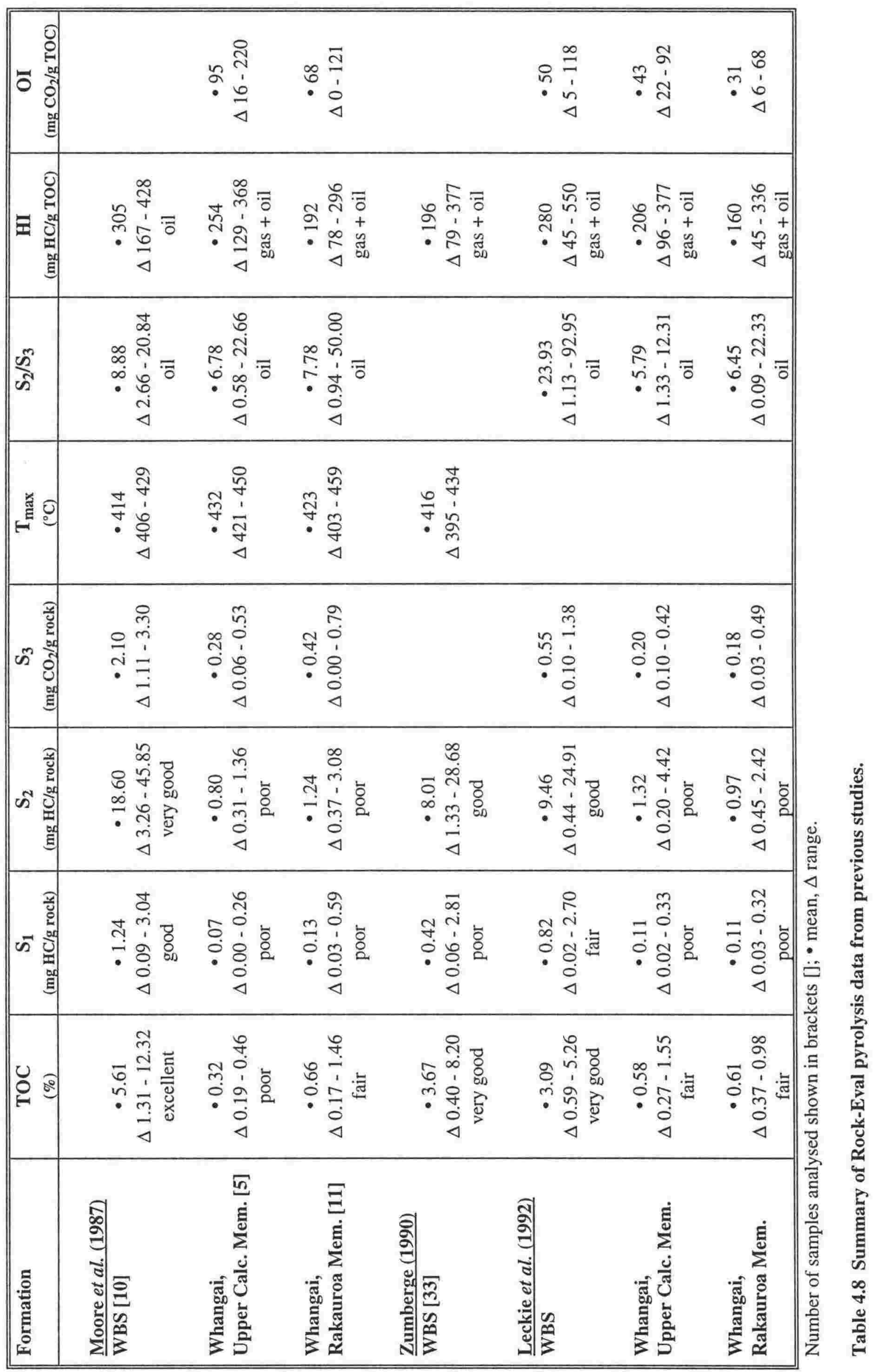


and $416^{\circ} \mathrm{C}$ determined by Moore et al. (1987) and Zumberge (1990) respectively. Production indices determined in the present study, however, reach 0.42 for the Waipawa Black Shale and average 0.17, which is well above the onset of oil generation (at $\sim 0.1$ ). Although not shown, the corresponding PI values determined by Zumberge (1990) average about 0.05 which better correlates with $\mathrm{T}_{\max }$. It may be possible that degradation of the organic matter, resulting in the loss of both $S_{1}$ and $S_{2}$, may be the cause for unreliable PI in the present study, while $\mathrm{T}_{\max }$ is not greatly affected.

Results show that the Waipawa Black Shale samples are immature to marginally mature in outcrop ( $T_{\max }$ of $395-436^{\circ} \mathrm{C}$ ), with only a few reaching the onset of oil generation $\left(\mathrm{T}_{\max } \sim 435^{\circ} \mathrm{C}\right.$ or $0.6 \% \mathrm{R}_{\mathrm{o}}$ ). Whangai Formation samples are also generally immature $\left(\mathrm{T}_{\max }\right.$ of $\left.400-431^{\circ} \mathrm{C}\right)$ and have not quite reached the onset of oil generation. Samples of the Te Mai and Glenburn formations are slightly more mature $\left(\mathrm{T}_{\max }\right.$ of $\left.420-447^{\circ} \mathrm{C}\right)$, with a number of samples reaching a maturity equivalent to the onset of oil generation, and several samples of the Te Mai Formation (NE51 and NE59) reaching a maturity equivalent to peak oil generation $\left(\mathrm{T}_{\max } 445-450^{\circ} \mathrm{C}\right.$ or $0.9 \% \mathrm{R}_{\mathrm{o}}$ ). Upper Cretaceous samples from Marlborough have not reached the maturity of the onset of oil generation.

$\mathrm{T}_{\max }$ values indicate that the majority of middle Cretaceous or younger formations, in outcrop, have a maturity below the onset of oil generation $\left(\mathrm{T}_{\max } \sim 435^{\circ} \mathrm{C}\right)$, which indicates the assessment of the hydrocarbon generative potential of possible source rock formations has not been affected by maturity [loss of hydrocarbons $\left(\mathrm{S}_{2}\right)$ with increasing maturity].

\subsubsection{Discussion}

Lower $S_{2}$ and higher $S_{3}$ values recorded in the present study differ from those of Moore et al. (1987), Zumberge (1990) and Leckie et al. (1992) (Table 4.8). Parameters derived from $S_{2}$ and $S_{3}$, such as $S_{2} / S_{3}$, $\mathrm{HI}$ and OI are, therefore, also affected. The results of the present study appear to down-grade the hydrocarbon source potential of the uppermost Cretaceous to Paleocene sequence compared with these other authors and there are a number of possible reasons to explain this.

\section{Effect of weathering}

The average HI value for Waipawa Black Shale samples determined in the present study is only $96 \mathrm{mg} \mathrm{HC} / \mathrm{g}$ TOC, compared with averages of 305, 196 and 280 determined by Moore et al. (1987), Zumberge (1990) and Leckie et al. (1992) respectively. Some outcrops sampled during fieldwork had been subjected to severe weathering and this has 
the effect of lowering $S_{1}$ and $S_{2}$ and raising $S_{3}$ (Peters, 1986), effectively decreasing $H I$ and increasing OI. NE26 is a highly weathered sample collected from a slip-face near Paoanui Point, and resulting $\mathrm{HI}$ and $\mathrm{OI}$ values (42 mg HC/g TOC and $320 \mathrm{mg} \mathrm{CO} 2 / \mathrm{g}$ TOC respectively) (see Figure 4.2) clearly support this observation. However, not all samples were weathered and the highest HI value obtained (221 mg HC/g TOC) was still considerably lower than those reported by others. Data from Zumberge (1990) comprised two sample suites with contrasting results. The second suite of Waipawa Black Shale samples were found to be significantly more oil-prone than the first, which was thought to be caused either by differential weathering or a change in organofacies (Zumberge, 1990). Another possible explanation for the low HI values is oxidation resulting from the powdering of samples prior to Rock-Eval pyrolysis (Peters and Cassa, 1994).

\section{Rock-matrix adsorption and the Hydrogen Index}

Determination of $\mathrm{S}_{2}$ is complicated by retention of some of the generated hydrocarbons by the rock matrix (Espitalié et al., 1980; Katz, 1983); hence the HI will not give a true ratio unless corrections are made (Langford and Blanc-Valleron, 1990). By plotting $\mathrm{S}_{2}$ vs TOC, a regression equation for the data can be determined which can then be used to obtain the true average HI value and measure the adsorption of hydrocarbons by the rock matrix (Langford and Blanc-Valleron, 1990).

Rock-matrix adsorption is caused mainly by clay minerals and indicates the quantity of organic matter that must be present before hydrocarbons are released from the rock by pyrolysis (Langford and Blanc-Valleron, 1990). The matrix effect is indicated by a positive intercept on the $\mathrm{X}$-axis, with the amount of adsorption given by the value of the intercept (Langford and Blanc-Valleron, 1990). The Y-intercept gives the adsorptive capacity of the matrix, i.e. the maximum capacity of the rock matrix to hold hydrocarbons.

The regression equation for an $\mathrm{S}_{2}$ vs TOC cross-plot of Waipawa Black Shale samples (Figure 4.3) gives an average HI value of $187 \mathrm{mg} \mathrm{HC} / \mathrm{g}$ TOC. Although almost the same as the value obtained by Zumberge (1990), it is still considerably lower than those of Moore et al. (1987) and Leckie et al. (1992). More importantly, though, it does indicate that Waipawa Black Shale is both oil and gas-prone. Accurate regression equations for $\mathrm{S}_{2}$ vs TOC cross-plots of the remaining formations were not possible, but rock-matrix adsorption is expected to have considerable affect on the predominantly fine-grained Upper Cretaceous to Oligocene strata. 


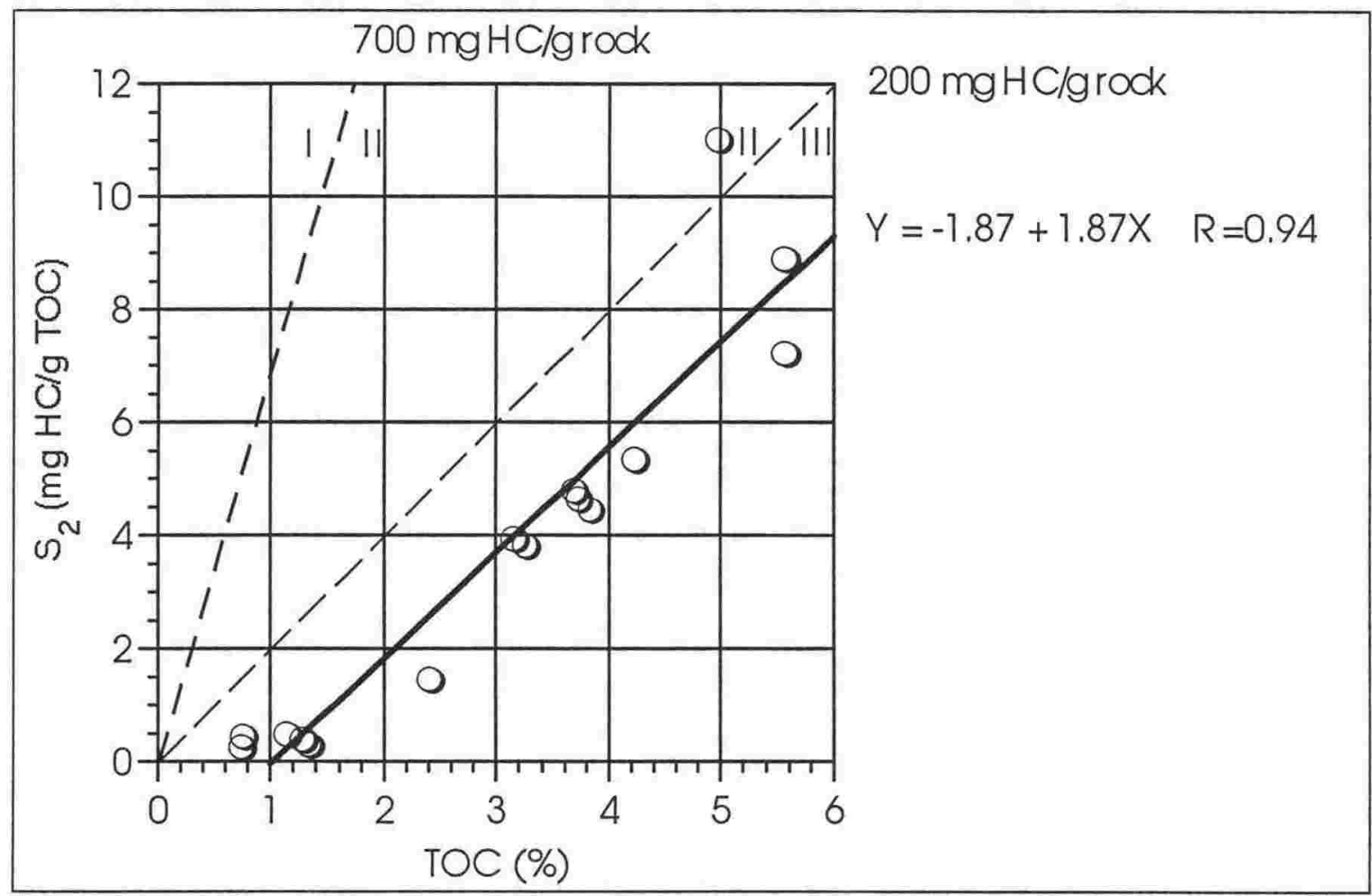

Figure $4.3 \mathrm{~S}_{2}$ vs TOC cross-plot for the Waipawa Black Shale. HI is determined by multiplying the slope of the line by $100(\mathrm{HI}=187)$. The $\mathrm{X}$-intercept gives the matrix adsorption $(1.00 \mathrm{mg}$ $\mathrm{HC} / \mathrm{g}$ rock) and the $\mathrm{Y}$-intercept gives the adsorptive capacity ( $1.87 \mathrm{mg} \mathrm{HC} / \mathrm{g}$ rock). The dashed lines indicate the boundary (slopes) between kerogen Types I \& II and II \& III (from Langford and Blanc-Valleron, 1990).

\section{Type and maturity of organic matter}

A suite of samples with the same type of organic matter and at the same maturity should have a constant HI value (Langford and Blanc-Valleron, 1990). The $\mathrm{S}_{2}$ vs TOC crossplot shows that despite appearing to differ widely in their Rock-Eval parameters, Waipawa Black Shale samples appear to comprise relatively homogeneous organic matter. In a recent study, Leckie et al. (1996) have shown that while HI values of Waipawa Black Shale fall in a narrow band within certain regions, considerable variation in HI values exists between regions. They suggested that changes in kerogen composition within each region are less significant than the degree of dilution by inorganic matter experienced by different regions. However, both marine and nonmarine organic matter are common in marine depositional environments and while parameters derived from Rock-Eval pyrolysis would vary according to the relative contributions of marine and terrestrial organic matter, heterogeneity is largely concealed by bulk chemical analyses and more diagnostic analyses such as VKA are better at determining the actual kerogen composition of samples.

Samples of the Te Mai and Glenburn formations contain predominantly Type IV kerogen (Figure 4.2), indicative of either postmature or highly oxidised organic matter. $\mathrm{T}_{\max }$ 
values indicate that the kerogen is not postmature and so it is probably highly oxidised through severe weathering. Once again, the bulk chemical analyses cannot differentiate between indigenous and recycled kerogen, and it remains highly likely that both the Te Mai and Glenburn formations contain a component of recycled kerogen. A single Glenburn Formation sample analysed by Zumberge (1990) comprised predominantly vitrinite and had a very low HI value (22) and, therefore, was considered to have very little hydrocarbon potential.

\section{Sampling}

Both the TOC and Rock-Eval pyrolysis analytical techniques require only $100 \mathrm{mg}$ of powdered sample for analysis and representative sampling becomes very important when such small quantities are involved. If only a few grams are selectively obtained from an organic-rich seam then TOC, $S_{1}, S_{2}$ and $H I$ values may be inflated and not truly representative of the formation under investigation. While the sampling methodologies of other authors are unknown, the one used in the present study (described in Section 3.1) tries to avoid such biases and may partially explain the conservative results compared to other studies.

\subsubsection{Conclusions}

- Most formations in the southern East Coast Basin are organic-poor; only the Whakataki Formation, Waipawa Black Shale, Upper Calcareous and Rakauroa members of the Whangai Formation, Te Mai and Glenburn formations, from eastern North Island, and the Whangai Formation and lateral equivalents (Mata Series sediments, Flags Formation and Conway Siltstone), from Marlborough, are shown to have 'fair' (>0.5\%) TOC levels or better;

- Of the formations with $>0.5 \%$ TOC, however, only the Waipawa Black Shale and the Whangai Formation have samples that show 'fair' to 'good' hydrocarbon generative potential $\left(S_{1}\right.$ and $\left.S_{2}\right)$. The Waipawa Black Shale and Whangai Formation are both oil and gas-prone $(\mathrm{HI}>150)$ and comprise predominantly Types II and III kerogen;

- The Whakataki and Flags Formation comprise gas-prone $(\mathrm{HI}<150)$, Types III and IV kerogen and have 'poor' hydrocarbon generative potential $\left(\mathrm{S}_{1}\right.$ and $\left.\mathrm{S}_{2}\right)$;

- The Te Mai, Glenburn and Mangapokia formations, from eastern North Island, and Conway Siltstone, from Marlborough, contain Type IV kerogen and, therefore, have 
'poor' hydrocarbon generative potential $\left(\mathrm{S}_{1}\right.$ and $\left.\mathrm{S}_{2}\right)$ and are inert $(\mathrm{HI}<50)$ with respect to hydrocarbon generation. These formations are not considered potential source rocks; and

- $\mathrm{T}_{\max }$ values indicate that the majority of middle Cretaceous or younger formations, in outcrop, have a maturity below the onset of oil generation $\left(\mathrm{T}_{\max } \sim 435^{\circ} \mathrm{C}\right.$ or $0.6 \% \mathrm{R}_{\mathrm{o}}$ ). 


\section{Chapter 5}

\section{Biomarker studies using gas chromatography (GC)}

\subsection{Introduction}

\subsubsection{Biomarkers}

Biological markers or biomarkers, also known as geochemical, chemical or molecular fossils are complex organic compounds derived from once-living organisms (Tissot and Welte, 1978; Philp, 1985a; 1985b; Peters and Moldowan, 1993). Biomarkers are largely derived from lipids and include compounds such as steroids, terpenoids, porphyrins and acyclic isoprenoids (such as pristane and phytane) which are resistant to degradation and retain their basic structure as they are incorporated into the sedimentary record (Tissot and Welte, 1978) (see Figure 1.1). Consequently biomarker distributions can provide detailed information regarding source, maturity, migration and biodegradation characteristics of hydrocarbons (Seifert and Moldowan, 1986).

The development of biomarker technology has greatly improved our knowledge of petroleum geochemistry. Total organic carbon, Rock-Eval pyrolysis, VKA and vitrinite reflectance analyses are useful only in source rock investigations while biomarker studies permit direct comparison between oils and source rocks, and hence oil-oil and oil-source rock correlation.

\subsubsection{Gas chromatography (GC)}

Chromatography is based on the differential migration of sample components in a mobile phase over the surface of a stationary phase with varying affinity for different compound types (Pecsok et al., 1976). This differential migration results in the effective separation of these individual components, which can then be detected and recorded.

In gas chromatography the sample is injected as a solution into the head of the column where it vaporises in the injector. Once in the column the higher molecular weight compounds condense again in a process of 'cold trapping' (Peters and Moldowan, 1993). The column is held inside a computer-controlled oven and the temperature is programmed to increase at a predetermined rate between an initial and final value. With increasing temperature the various compounds are progressively vaporised according to 
their boiling points and an inert carrier gas (the mobile phase), typically hydrogen or helium, then moves these compounds through the column where they interact with the stationary phase which coats the inner surface of the column and has varying affinity for different compounds in the sample. Retention times vary for each of the compounds resulting in their elution at different times (Figure 5.1). Eventually all the compounds are flushed through the column where they are detected by a flame ionisation detector (FID) and recorded. A plot of the detector response versus time shows a series of peaks, representing either single or multiple components and is called a chromatogram (Peters and Cassa, 1994). Due to their relative abundance, $n$-alkanes and acyclic isoprenoids dominate the chromatograms, with minor cyclic compounds adding to the background 'noise'.

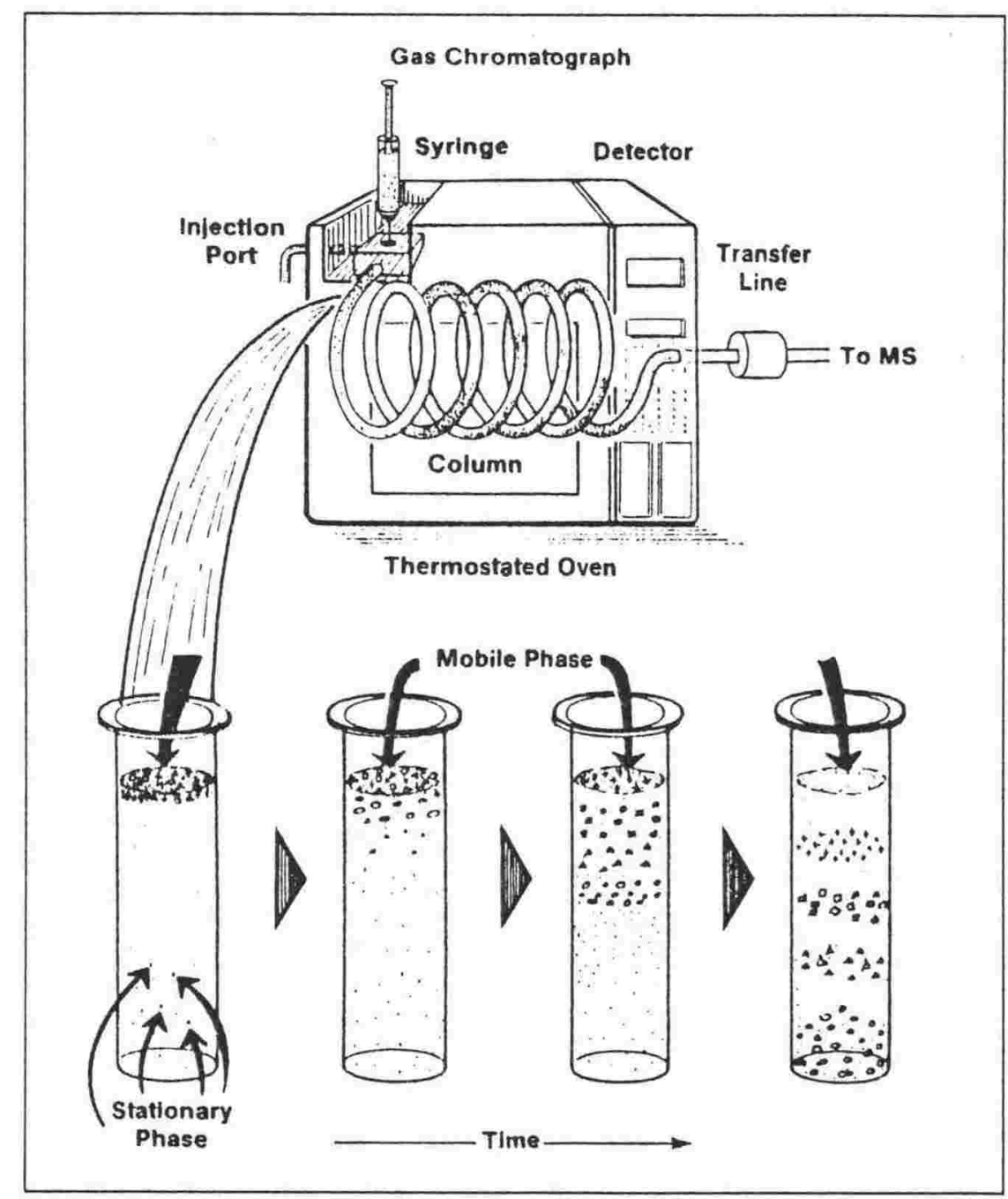

Figure 5.1 Diagram of gas chromatograph. The enlargement (bottom) shows the separation of compounds during movement through the column as they interact with the stationary phase (from Peters and Moldowan, 1993). 


\section{$5.2 \mathrm{~N}$-alkane and isoprenoid biomarker parameters}

\subsubsection{Introduction}

Gas chromatography (GC) is used in the oil exploration industry to investigate the acyclic saturate fraction of oils and source rocks. Despite their simple structures, normal $(n-)$ alkanes and acyclic isoprenoids (especially pristane and phytane) have been used as biomarkers for several decades due to their abundance and ease of detection (Philp, 1985b). $\mathrm{N}$-alkanes have been used primarily in source and maturity studies but are also affected by migration and biodegradation and are consequently useful for study of these (Philp, 1985a; Seifert and Moldowan, 1986). Their simple structures, however, mean that they are not as specific as the structurally-complex polycyclic biomarkers analysed by GC-MS, and their distribution or occurrence is not easily attributable to source, maturity, migration or biodegradation alone. Six biomarker parameters, determined by gas chromatography, were used in the present study and are examined in the following sections with a discussion of the information they yield and also their limitations.

\subsubsection{Carbon preference index (CPI)}

Lipids derived from plants show a strong predominance of odd-carbon-numbered $n$-alkanes (Tissot and Welte, 1978), but thermal maturation converts high molecular weight $n$-alkanes into low molecular weight homologues without odd-carbon predominance. The carbon preference index (CPI) is a measure of the odd-to-even $n$-alkane predominance and provides an estimate of the thermal maturity for both oils and source rocks (Peters and Moldowan, 1993). Numerous CPI equations have been used in the literature (e.g. Tissot and Welte, 1978; Barker, 1979; Moldowan et al., 1985; Philp, 1985a) as they can be adjusted to include any range of carbon numbers. The following CPI equation, used by Rogers (1995), has been retained in the present study for compatibility reasons:

$$
\mathrm{CPI}=\frac{\left[\left(\mathrm{C}_{15}+\mathrm{C}_{17}+\ldots \mathrm{C}_{29}\right)+\left(\mathrm{C}_{17}+\mathrm{C}_{19}+\ldots \mathrm{C}_{31}\right)\right]}{2\left(\mathrm{C}_{16}+\mathrm{C}_{18}+\ldots \mathrm{C}_{30}\right)}
$$

The CPI, however, is also dependent on the original source material. Planktonic algae and bacteria also produce high molecular weight $n$-alkanes, but these are generally (but not always) without odd-over-even predominance and therefore the CPI of these samples is approximately one, regardless of maturity (Tissot and Welte, 1978). The use of the $\mathrm{CPI}$ for maturity studies is, therefore, limited to those samples containing organic matter of terrigenous higher plant origin. 
Guidelines for CPI interpretation were recently given by Peters and Moldowan (1993):

- A CPI value significantly above or below 1.0 indicates the oil or bitumen is thermally immature; and

- Values of 1.0 suggest, but do not prove, an oil or bitumen is thermally mature.

Moldowan et al. (1985) used the CPI to distinguish nonmarine oils from marine carbonate oils. Marine shale-derived oils were found to overlap the domains of the other two and therefore could not be conclusively identified. A CPI $>1$ indicates a nonmarine oil (particularly in the high molecular weight $n$-alkanes) while a value $<1$ indicates a marine carbonate-sourced oil (Moldowan et al., 1985).

\subsection{3 $\mathrm{N}$-alkane distribution and $\mathrm{C}_{\max }$}

The $n$-alkane distribution provides information primarily on source, but is also influenced by maturity, migration and biodegradation. High molecular weight $n$-alkanes (predominantly $\mathrm{C}_{27}, \mathrm{C}_{29}$ and $\mathrm{C}_{31}$ ) are usually derived from terrestrial higher plant waxes, although certain algae are also known to contain high molecular weight $n$-alkanes. Low molecular weight $n$-alkanes (predominantly $\mathrm{C}_{15}, \mathrm{C}_{17}$ and $\mathrm{C}_{19}$ ) are generally derived from marine or lacustrine algae (Tissot and Welte, 1978). The positions of the $n$-alkane maxima $\left(\mathrm{C}_{\max }\right)$ can be used as source indicators but care must be taken to recognise migration and/or biodegradation interference (Philp, 1985a). Expulsion and primary migration has been shown to favour short chain hydrocarbons (e.g. Leythaeuser et al., 1984), and low molecular weight $n$-alkanes have been shown to move more rapidly than high molecular weight homologues during secondary migration (Philp, 1985b). Biodegradation causes the progressive removal of the low molecular weight $n$-alkanes and water-washing can have a similar effect (Philp, 1985b). Thermal maturation causes the cracking of high molecular weight $n$-alkanes (usually with an initial odd-over-even predominance), thereby producing short-chained hydrocarbons (without an odd-overeven predominance).

\subsection{4 $\mathrm{C}_{21}+\mathrm{C}_{22} / \mathrm{C}_{28}+\mathrm{C}_{29}$}

The $\mathrm{C}_{21}+\mathrm{C}_{22} / \mathrm{C}_{28}+\mathrm{C}_{29}$ ratio is another measure of the $n$-alkane distribution and provides information regarding source material. A sample dominated by $n-\mathrm{C}_{28}$ and $n-\mathrm{C}_{29}$ will have a low ratio and is likely to be of terrestrial origin, while samples richer in $n-\mathrm{C}_{21}$ and $n-\mathrm{C}_{22}$ are more likely to be marine dominated. $A \mathrm{C}_{21}+\mathrm{C}_{22} / \mathrm{C}_{28}+\mathrm{C}_{29}$ ratio $>1.5$ suggests 
aquatically-sourced material while a ratio $<1.2$ indicates terrestrially-sourced organic matter and these values increase with increasing maturity (Geotech, 1992).

\subsubsection{Pristane/phytane ratio}

Pristane and phytane (and other isoprenoids below $\mathrm{C}_{20}$ ) are thought to be formed during diagenesis from phytol, derived from the side chain of chlorophyll (Tissot and Welte, 1978). Under oxidising conditions phytol is transformed to pristane by oxidation to phytanic acid, followed by decarboxylation and hydrogenation. Under reducing conditions phytane is produced by dehydration and hydrogenation of phytol (Powell and McKirdy, 1973; Tissot and Welte, 1978). Hence, determination of the pristane to phytane $(\mathrm{Pr} / \mathrm{Ph})$ ratio may indicate the depositional environment of source rocks.

Powell and McKirdy (1973) first used the $\mathrm{Pr} / \mathrm{Ph}$ ratio as an indicator of depositional environment, differentiating between marine and nonmarine environments. More recent studies (Alexander et al., 1981; Moldowan et al., 1985; Volkman and Maxwell, 1986; ten Haven et al., 1987), however, have shown that the $\mathrm{Pr} / \mathrm{Ph}$ ratio is not a definitive indicator and requires corroborating data. Peters and Moldowan (1993) provided the following guidelines for interpreting $\mathrm{Pr} / \mathrm{Ph}$ ratios, which are used in the present study:

- For samples of low maturity, $\mathrm{Pr} / \mathrm{Ph}$ ratios are not recommended as indicators of depositional environment; and

- For samples within the oil window:

- $\mathrm{Pr} / \mathrm{Ph}$ ratios $>3.0$ indicate terrestrial organic matter input under oxic conditions;

- $\mathrm{Pr} / \mathrm{Ph}$ ratios < 0.6 typify anoxic, commonly hypersaline, conditions; and

- $\mathrm{Pr} / \mathrm{Ph}$ ratios between 0.8-2.5 are not conclusive paleoenvironmental indicators and need corroborating data.

\subsection{6 $\mathrm{Pr} / n-\mathrm{C}_{17}$ and $\mathrm{Ph} / n-\mathrm{C}_{18}$}

$\mathrm{Pr} / n-\mathrm{C}_{17}$ and $\mathrm{Ph} / n-\mathrm{C}_{18}$ ratios have been used for oil-source rock correlations (e.g. Alexander et al., 1981) but have been found to be influenced not only by the type of source kerogen, but also the extent of generation and biodegradation (ten Haven et al., 1987). Peters and Moldowan (1993) expressed reservations over the use of $\operatorname{Pr} / n-C_{17}$ and $\mathrm{Ph} / n-\mathrm{C}_{18}$ as biomarker parameters and also commented that biodegradation preferentially affects $n$-alkanes before isoprenoids, resulting in high ratios. However, they did note that marine-sourced organic matter tends to have a $\mathrm{Pr} / n-\mathrm{C}_{17}$ ratio $<0.5$ while terrestrial organic matter tends to have a $\mathrm{Pr} / n-\mathrm{C}_{17}$ ratio $>0.6$. 


\subsection{Methods}

The saturate fractions of the oils and rock bitumens were prepared for gas chromatography analysis by standard methods of organic extraction and separation as described in Chapter 3. Samples were analysed on a Hewlett Packard 5890 Series II Gas Chromatograph housed in the Chemistry Department, Victoria University of Wellington. A J\&W DB1 (30 m, 0.25 mm I.D., $0.25 \mu \mathrm{m}$ film thickness) fused silica capillary column was used for gas chromatographic separation of the saturate fraction of each sample. The following temperature programme was used:

\begin{tabular}{|ll|}
\hline Initial temperature & $130^{\circ} \mathrm{C}$ (held for $\left.3 \mathrm{~min}.\right)$ \\
Rate & $6^{\circ} \mathrm{C} / \mathrm{min}$. \\
Final temperature & $300^{\circ} \mathrm{C}$ (held for $\left.9 \mathrm{~min}.\right)$ \\
Total time & $40.33 \mathrm{~min}$. \\
\hline
\end{tabular}

The samples were dissolved in $n$-pentane and approximately 4-5 $\mu \mathrm{l}$ of the solution was injected. Helium, the carrier gas, was used at a pressure of $80 \mathrm{kPa}$ and a flow rate of $20.0 \mathrm{ml} / \mathrm{min}$.

The gas chromatograph was coupled to a Shimadzu C-R3A Chromatopac (data processor) which plotted a chromatogram, listed peak retention times and integrated peak areas. the equipment was not equipped with a disc drive and therefore only the original hard copies are available. Individual peaks were identified and biomarker ratios, based on integrated peak areas, were calculated manually.

In addition, approximately 15 samples were analysed on a similar model GC at the Centre Géoscientifique de Québec (CGQ) in Canada. Peak areas were not integrated, however, and biomarker ratios were determined by calculating peak heights instead. 


\subsection{Results}

\subsubsection{Introduction}

Sections 5.4.2 and 5.4.3 include somewhat tedious descriptions of the gas chromatograms of the oils and possible source rocks for those interested in the characteristics of individual formations. Section 5.5 summarises the meaningful results and discusses them with reference to other geochemical data and previous studies.

A list of samples and their biomarker parameter values appears in Appendix 4. Missing data are due to uncertainty in peak identification. The interpretation of $n$-alkane and isoprenoid biomarker parameter values, in isolation, is necessarily tentative as more than one explanation for a given distribution is possible, and it is likely that there are several contributing factors. For example, because the data set comprises only outcrop samples it is very likely that the $n$-alkane distributions have all been affected to some degree by loss of the lower molecular weight component due to weathering. As a result the $\operatorname{Pr} / n-\mathrm{C}_{17}$ and $\mathrm{Ph} / n-\mathrm{C}_{18}$ and possibly the $\mathrm{C}_{\max }$ parameters may have been affected.

Many samples (e.g. NE18, Figure 5.3d) record high relative abundances of two unknown compounds, one eluting between $n-\mathrm{C}_{20}$ and $n-\mathrm{C}_{21}$ and the other coeluting with the $\mathrm{C}_{25} n$-alkane; both appear randomly throughout the sample gas chromatograms. The first compound is easily recognised and does not affect the $n$-alkane and isoprenoid biomarker parameter values. It is also present in the gas chromatograms of southern East Coast Basin samples analysed by Lipke (1989), and determined by GC-MS to be an alkyl cycloalkane, possibly derived from Recent algal or bacterial fatty acids (Zumberge, 1990). The second compound coelutes with the $C_{25} n$-alkane and unless recognised would inflate the CPI values and, therefore, the maturity indicated for these samples. Although this compound is of unknown origin, Simoneit (1977) observed a large peak in the region of the $\mathrm{C}_{25} n$-alkane which he attributed to a $\mathrm{C}_{8}$ phthalate. Phthalates have been reported to leach from plastic containers and rubber-lined caps during storage of oils (Peters and Moldowan, 1993). Coelution of this compound is easily recognised, and where it has resulted in the $\mathrm{C}_{25} n$-alkane becoming the dominant peak, Appendix 4 shows an asterisk '*' denoted against what is assumed to be the correct $n$-alkane maximum. In such cases the corresponding CPI value (if any) will be unreliable.

This particular study is qualitative in nature with common reference to the 'relative abundance' of certain compounds. In this case it is meant relative only to the overall saturate fraction(s) under discussion. 


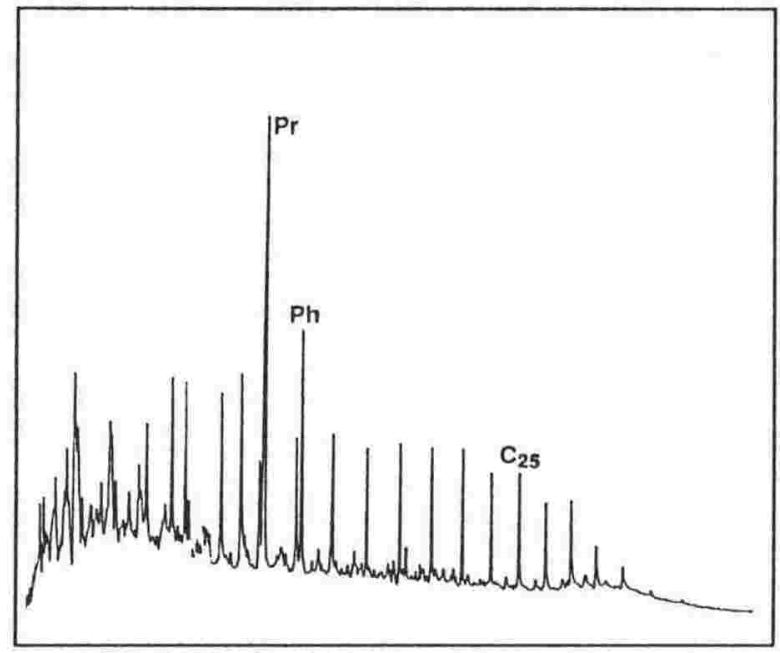

a. NE27OIL - Knights Stream oil

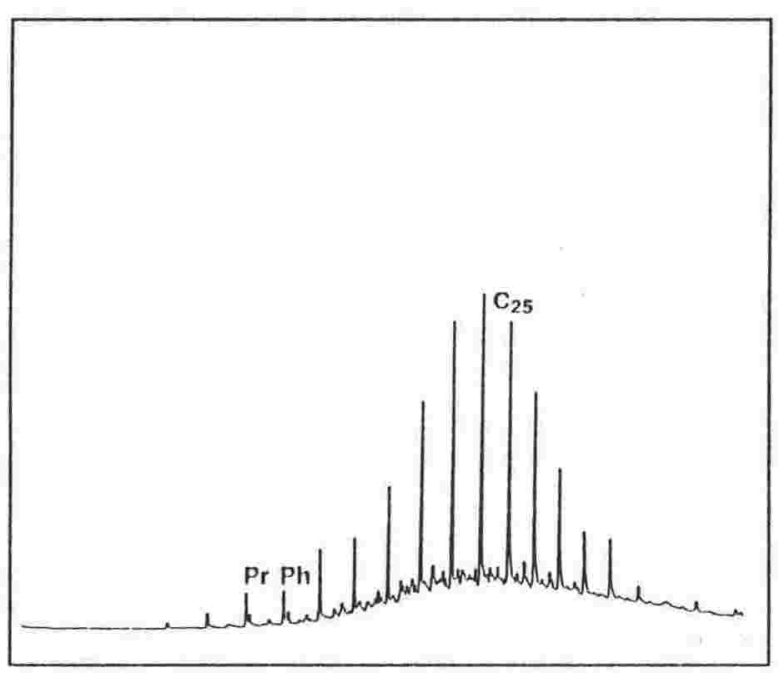

b. NEICOIL - Isolation Creek oil

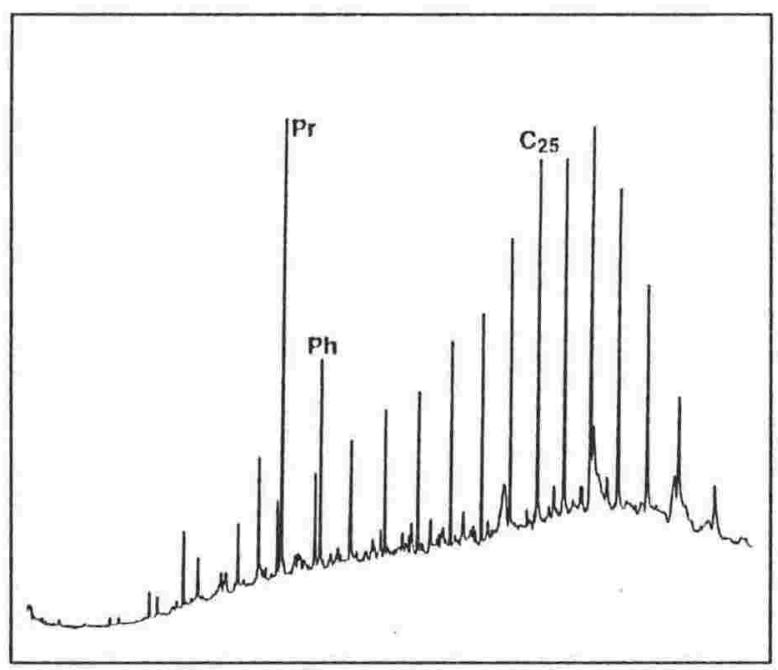

c. NE110OIL - Kerosene Rock oil

\section{b. NEICOIL - Isolation Creek oil}

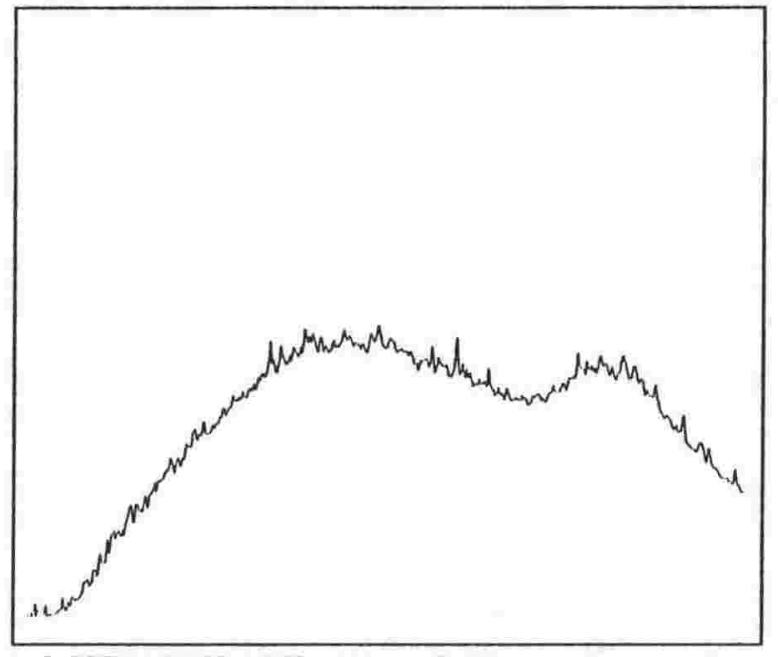

d. NE115OIL - Westcott oil

Figure 5.2 Gas chromatograms showing the saturate fractions of the oils. 


\subsection{2 $\mathrm{N}$-alkane and isoprenoid geochemistry of the oils}

Gas chromatograms of the Knights Stream, Isolation Creek and Kerosene Rock oils (Figure 5.2a-c) show the oils to be either nonbiodegraded or only mildly biodegraded, and a summary of their biomarker parameters appears in Table 5.1. The Westcott, Tiraumea and Okau Stream oils, however, are at least moderately biodegraded with only trace $n$-alkanes and isoprenoids remaining (e.g. Figure 5.2d), and derivation of source and maturity biomarker parameters from these oils is not possible.

\begin{tabular}{||l|c|c|c|c|c|c||}
\hline \hline Oil samples & $\operatorname{Pr} / \mathbf{P h}$ & $\operatorname{Pr} / n-\mathbf{C}_{17}$ & $\mathbf{P h} / n-\mathbf{C}_{18}$ & CPI & $\begin{array}{c}n \text {-alkane } \\
\max \end{array}$ & $\frac{\mathbf{C}_{\mathbf{2 1}}+\mathbf{C}_{\mathbf{2 2}}}{\mathbf{C}_{\mathbf{2 8}}+\mathbf{C}_{\mathbf{2 9}}}$ \\
\hline Knights Stream & 2.57 & 3.66 & 1.57 & 1.02 & 16 & 2.73 \\
Isolation Creek & 0.99 & 0.38 & 0.42 & 1.05 & 24 & 2.14 \\
Kerosene Rock & 2.17 & 6.12 & 2.11 & 0.97 & 27 & 0.38 \\
Westcott* & - & - & - & - & - & - \\
Tiraumea* & - & - & - & - & - & - \\
Okau Stream* & - & - & - & - & - & - \\
\hline \hline
\end{tabular}

$\mathrm{Pr}=$ Pristane; $\mathrm{Ph}=$ Phytane. *biodegraded oils.

Table 5.1 Summary of the $n$-alkane and isoprenoid biomarker parameters of oils from the southern East Coast Basin.

Knights Stream oil: The chromatogram (Figure 5.2a) is characterised by a unimodal $n$-alkane distribution with a maximum at $\mathrm{C}_{16}$ and a high $\mathrm{C}_{21}+\mathrm{C}_{22} / \mathrm{C}_{28}+\mathrm{C}_{29}$ ratio (2.73), indicative of a predominantly marine, possibly algal source. However, $n$-alkanes extending to $\mathrm{C}_{31}$ with a slight odd-over-even predominance between $\mathrm{C}_{18}$ and $\mathrm{C}_{28}$ suggest a minor terrestrial contribution. A moderately high $\mathrm{Pr} / \mathrm{Ph}$ ratio (2.57) may indicate deposition in an oxic environment. High relative abundances of pristane and phytane resulting in high $\mathrm{Pr} / n-\mathrm{C}_{17}$ and $\mathrm{Ph} / n-\mathrm{C}_{18}$ ratios may be the result of a relatively low maturity, but weathering and/or minor biodegradation of the lower molecular weight $n$-alkanes is considered more likely. The latter is supported by the presence of a small unresolved hump in the region of low molecular weight $n$-alkanes $\left(<\mathrm{C}_{13}\right)$.

Isolation Creek oil: The saturate fraction (Figure 5.2b) is very unusual and is likely to be the result of degradation; the following interpretations are therefore only tentative. The saturate fraction is characterised by a unimodal $n$-alkane distribution with a maximum at $\mathrm{C}_{24}$ and a high $\mathrm{C}_{21}+\mathrm{C}_{22} / \mathrm{C}_{28}+\mathrm{C}_{29}$ ratio (2.14) that indicates a predominance of marine organic matter. Low relative abundances of pristane and phytane and an $n$-alkane distribution that is unusually tightly constrained between $\mathrm{C}_{19}$ and $\mathrm{C}_{29}$ may be 
caused by loss due to weathering, migration and/or biodegradation of the lower molecular weight component. The oil is considered to have migrated as it was found seeping from the Amuri Limestone, which was shown by TOC and Rock-Eval pyrolysis to have no hydrocarbon generative potential. Contamination is considered unlikely as the sample locality is in a scenic reserve, distant from the likely use of machinery, and has been observed for many years.

Kerosene Rock oil: The saturate fraction (Figure 5.2c) is characterised by a unimodal $n$-alkane distribution with a maximum at $\mathrm{C}_{27}$ and a low $\mathrm{C}_{21}+\mathrm{C}_{22} / \mathrm{C}_{28}+\mathrm{C}_{29}$ ratio (0.38), indicative of a predominantly terrestrial source. This is supported by a high $\mathrm{Pr} / n-\mathrm{C}_{17}$ ratio. The moderately high $\mathrm{Pr} / \mathrm{Ph}$ ratio (2.17), although not conclusive according to the interpretive guidelines of Peters and Moldowan (1993), suggests deposition under oxic conditions. The CPI of 0.97 indicates a mature oil, although a slight odd-over-even predominance is present in the high molecular weight $n$-alkanes. The predominance of high molecular weight $n$-alkanes is likely to be caused by mild degradation of the lower molecular weight $n$-alkanes, which may have the effect of masking a minor algal contribution. The loss of lower molecular weight $n$-alkanes also affects the interpretation of a dominant terrestrial component but this is not considered significant.

Westcott, Tiraumea and Okau Stream oils: The saturate fractions of these oils (e.g. Figure 5.2d), show an unresolved 'hump' in the baseline with only trace $n$-alkane and isoprenoids remaining, characteristic of (at least) moderate biodegradation according to the guidelines of Peters and Moldowan (1993) (see Table 6.1).

\subsection{3 $\mathrm{N}$-alkane and isoprenoid geochemistry of possible source rocks}

Sterane and triterpane biomarkers have shown Neogene samples to be immature for hydrocarbon generation (see Sections 6.6.1 and 6.6.2) and, therefore, the $\mathrm{Pr} / \mathrm{Ph}$, $\mathrm{Pr} / n-\mathrm{C}_{17}$ and $\mathrm{Ph} / n-\mathrm{C}_{18}$ ratios are considered unreliable parameters (ten Haven et al, 1987). Where $n$-alkanes have either not yet been generated or have been removed through biodegradation, high $\mathrm{Pr} / n-\mathrm{C}_{17}$ and $\mathrm{Ph} / n-\mathrm{C}_{18}$ ratios are probably more indicative of low thermal maturity or biodegradation than source. In particular, the $\mathrm{Pr} / n-\mathrm{C}_{17}$ ratio in almost every sample is $>0.6$ which indicates a predominance of terrestrial organic matter despite other evidence clearly indicating a marine origin for the organic matter.

\section{North Island possible source rocks}

Miocene coal: The saturate fraction (NE109, Figure 5.3a) is characterised by a unimodal $n$-alkane distribution with a maximum at $\mathrm{C}_{29}$, an odd-over-even predominance between 


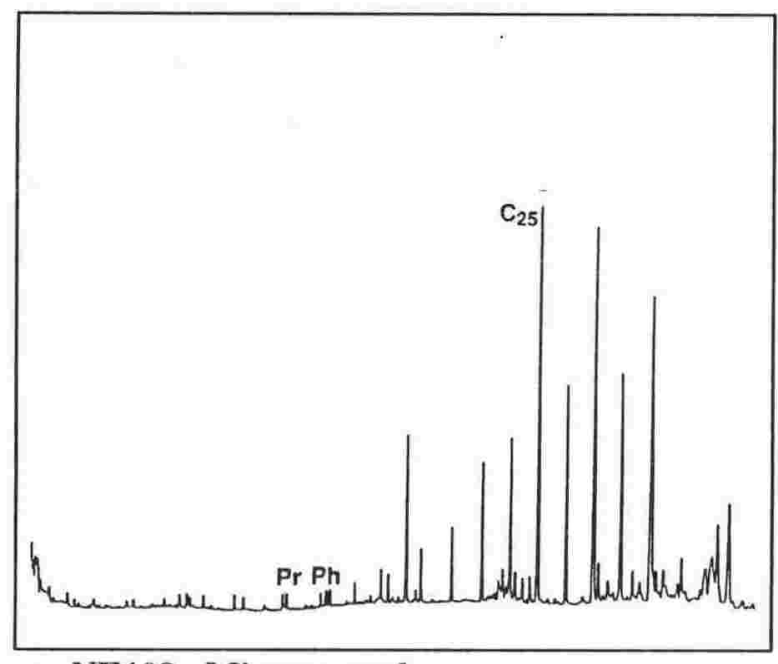

a. NE109 - Miocene coal

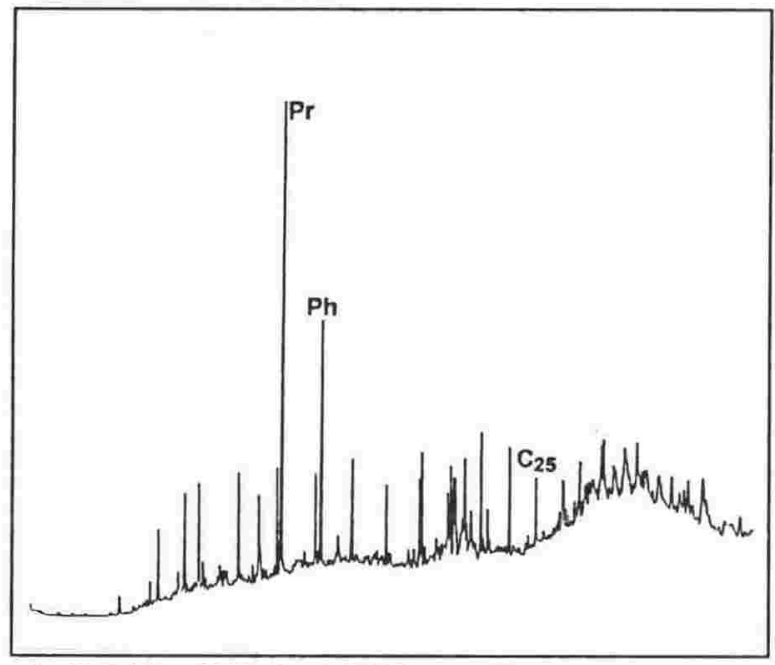

b. NE112 - Whakataki Formation

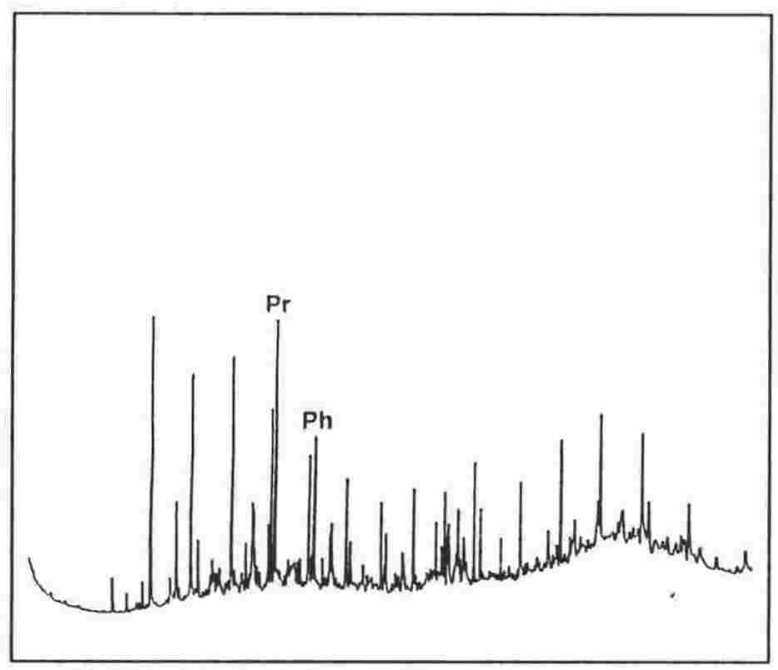

c. NE61 - Weber Formation

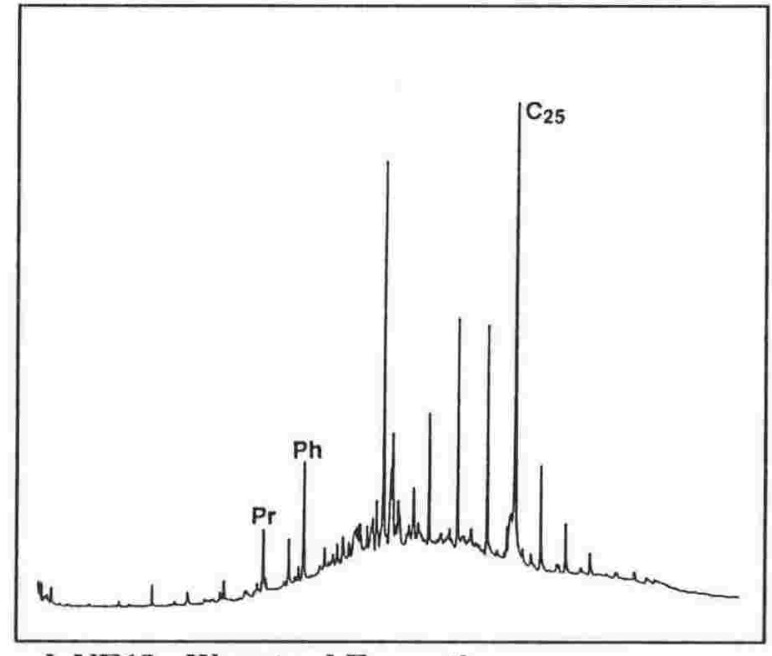

d. NE18 - Wanstead Formation

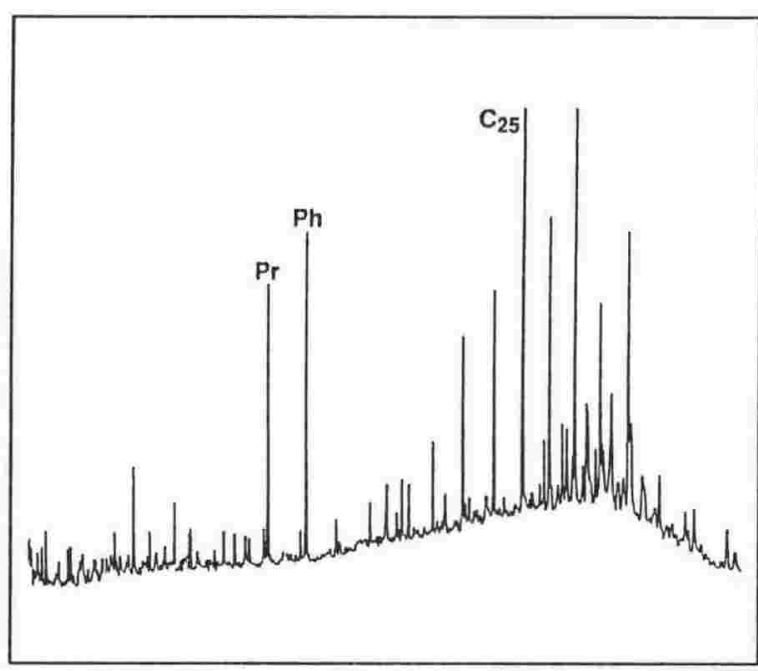

e. NE45 - Waipawa Black Shale

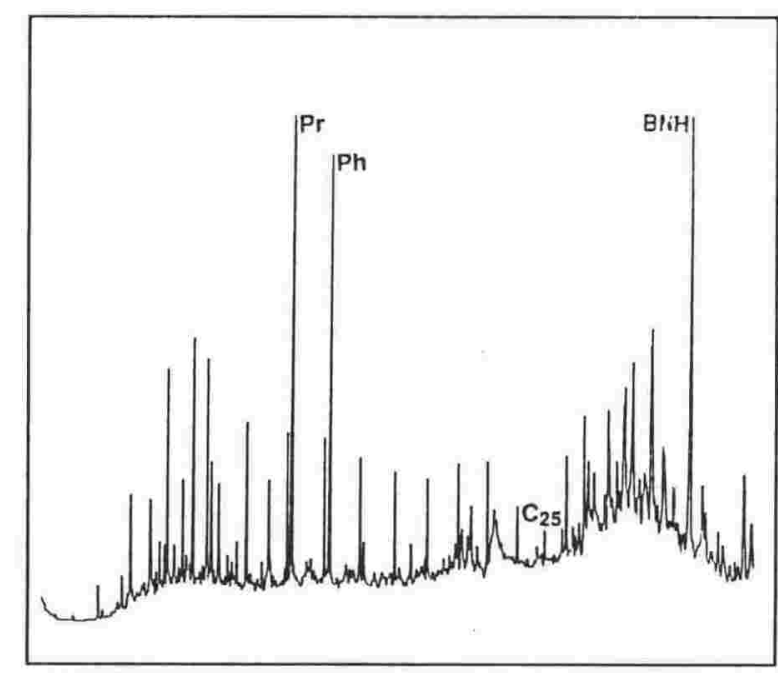

f. NE54 - Waipawa Black Shale

Figure 5.3 Gas chromatograms showing the saturate fractions of the possible source rocks from eastern North Island. 
$\mathrm{C}_{23}$ and $\mathrm{C}_{29}$ and a low $\mathrm{C}_{21}+\mathrm{C}_{22} / \mathrm{C}_{28}+\mathrm{C}_{29}$ ratio (0.18), all clearly indicative of a terrestrial higher plant source for the organic matter. Lower molecular weight $n$-alkanes (below $\mathrm{C}_{22}$ ), pristane and phytane are present in low relative abundances. A low maturity is indicated by the odd-over-even predominance and the low relative abundance of low molecular weight $n$-alkanes.

Whakataki Formation: The saturate fraction (NE112, Figure 5.3b) shows a unimodal (flat-topped) $n$-alkane distribution. The higher molecular weight component $\left(>C_{26}\right)$ is unidentifiable within an unresolved hump, and this may indicate deposition of predominantly marine organic matter, although an odd-over-even predominance from $\mathrm{C}_{17}-\mathrm{C}_{24}$ may suggest a terrestrial contribution. High relative abundances of pristane and phytane are present, resulting in high $\mathrm{Pr} / n-\mathrm{C}_{17}$ and $\mathrm{Ph} / n-\mathrm{C}_{18}$ ratios, and this may be due to low maturity. Moderate relative abundances of low molecular weight isoprenoids are present and may indicate the presence of marine organic matter.

Weber Formation: Two contrasting gas chromatograms were recorded. NE61 (Figure 5.3c) has a unimodal $n$-alkane distribution with a maximum at $\mathrm{C}_{14}$, and an unresolvable higher molecular weight component $\left(>C_{24}\right)$. This is indicative of marine organic matter. Pristane, phytane and higher molecular weight isoprenoids are present in moderate relative abundances. NE19 (not shown) is characterised by a unimodal $n$-alkane distribution with a maximum at $\mathrm{C}_{25}$ and a low $\mathrm{C}_{21}+\mathrm{C}_{22} / \mathrm{C}_{28}+\mathrm{C}_{29}$ ratio (0.33), indicating the presence of terrestrial organic matter. These chromatograms, therefore, show variable contributions of marine and terrestrial organic matter to the Weber Formation.

Wanstead Formation: The saturate fractions are characterised by unimodal $n$-alkane distributions with maxima at $\mathrm{C}_{15 / 16}$ or $\mathrm{C}_{23 / 24}$. Half the samples show a unimodal $n$-alkane distribution with a maximum at $\mathrm{C}_{23}$ or $\mathrm{C}_{24}$ and low relative abundances of the higher molecular weight component $\left(>\mathrm{C}_{26}\right)$. Moderate relative abundances of pristane and phytane are present, and low $\mathrm{Pr} / \mathrm{Ph}$ ratios may indicate deposition in an anoxic environment. NE18 (Figure 5.3d) has a high $\mathrm{C}_{21}+\mathrm{C}_{22} / \mathrm{C}_{28}+\mathrm{C}_{29}$ ratio (3.35) which suggests dominantly marine organic matter. The general absence of low molecular weight $n$-alkanes may result from loss due to weathering and the background hump may support this. The remaining samples have abundant $n$-alkanes and isoprenoids between $n$ - $\mathrm{C}_{14}$ and $n$ - $\mathrm{C}_{19}$ with $n$-alkane maxima at $\mathrm{C}_{15}$ or $\mathrm{C}_{16}$, characteristic of a marine, possibly algal, contribution. Unresolved peaks occur in the region of the high molecular weight component. The $n$-alkane distributions of all the samples indicate a minimal terrestrial contribution. 


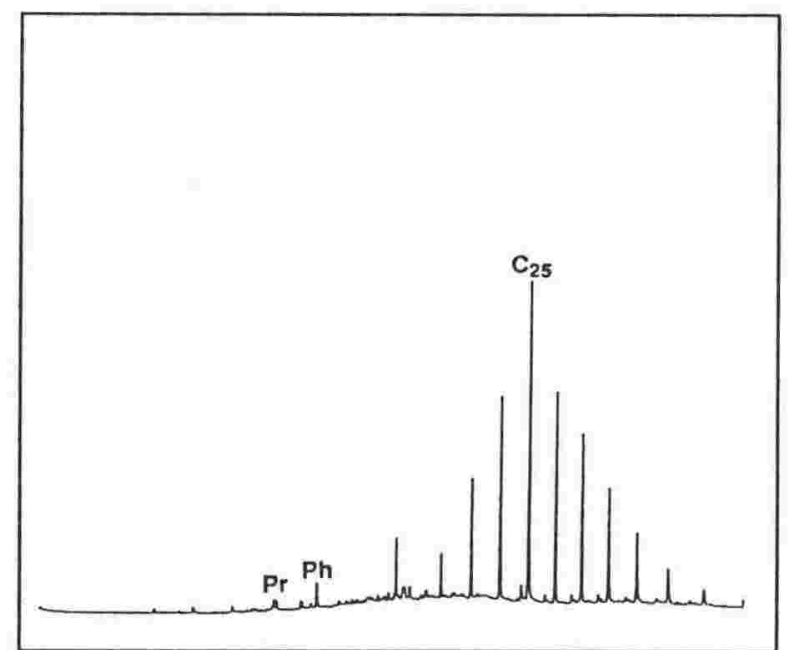

a. NE11 - Whangai Formation, Te Uri

Member

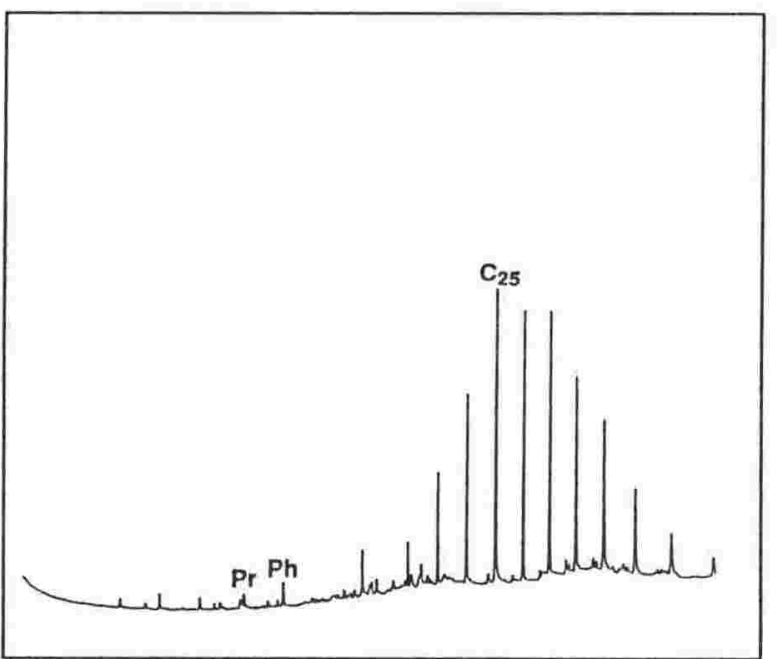

b. NE17 - Whangai Formation, Porangahau Member

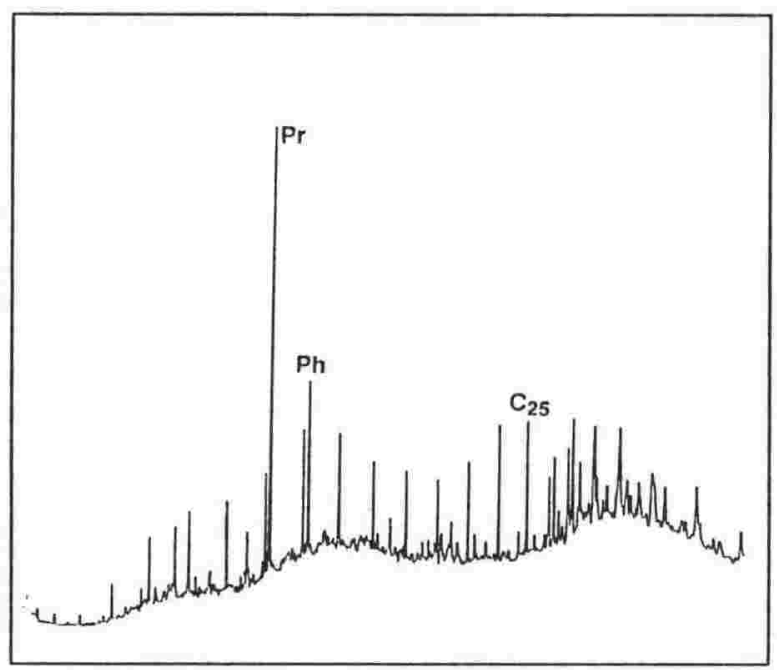

c. NE113 - Whangai Formation, Upper Calcareous Member

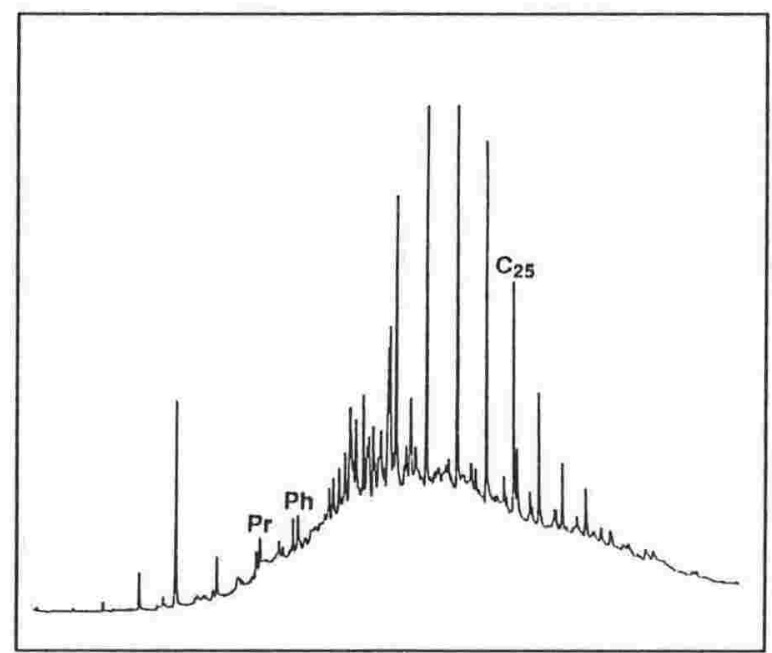

d. NE3 - Whangai Formation, Rakauroa Member

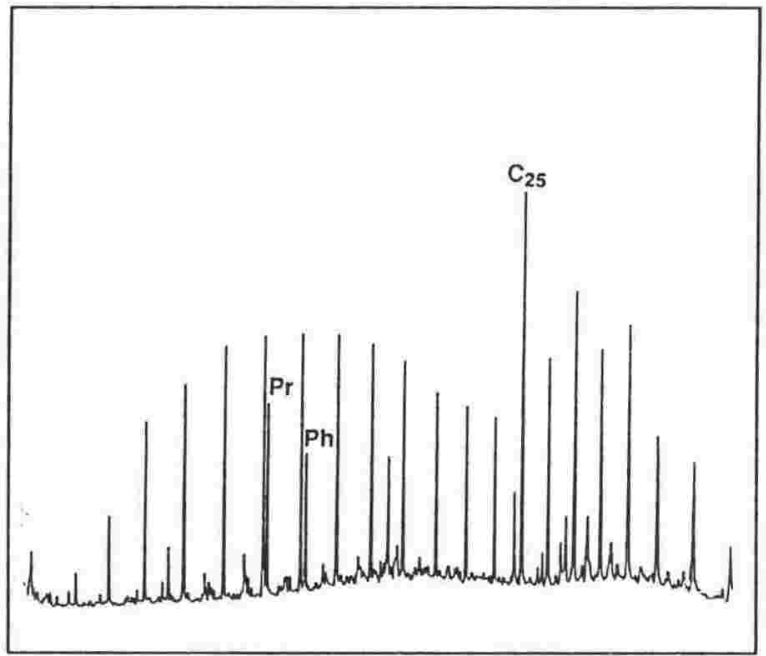

e. NE53 - Whangai Formation, undifferentiated (N.I.)

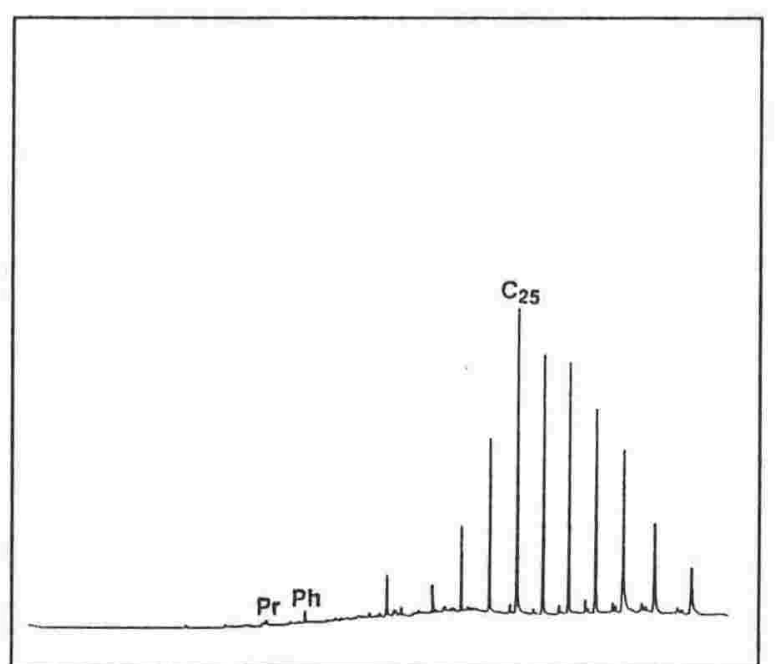

f. NE9 - Tangaruhe Formation

Figure 5.4 Gas chromatograms showing the saturate fractions of the possible source rocks from eastern North Island. 
Waipawa Black Shale: Two general types of $n$-alkane distributions are present in Waipawa Black Shale samples. The first type is unimodal with $n$-alkane maxima between $\mathrm{C}_{23}$ and $\mathrm{C}_{25}$. These samples usually have high $\mathrm{C}_{21}+\mathrm{C}_{22} / \mathrm{C}_{28}+\mathrm{C}_{29}$ ratios, indicative of a dominantly marine contribution, and often have low $\mathrm{Pr} / \mathrm{Ph}$ ratios which may indicate deposition under anoxic conditions. The second type of $n$-alkane distribution is bimodal with first maxima at $\mathrm{C}_{14}$ or $\mathrm{C}_{15}$ and second maxima (usually the dominant one) at $\mathrm{C}_{27}$ or $\mathrm{C}_{29}$ (e.g. NE54, Figure 5.3f). This indicates a minor algal marine and predominant terrestrial contribution of organic matter. They generally have low $\mathrm{C}_{21}+\mathrm{C}_{22} / \mathrm{C}_{28}+\mathrm{C}_{29}$ ratios which are indicative of terrestrial organic matter. An odd-over-even predominance in the higher molecular weight $n$-alkanes is common. High $\mathrm{Pr} / n-\mathrm{C}_{17}$ and $\mathrm{Ph} / n-\mathrm{C}_{18}$ ratios occur in many samples and this may be due to the loss of $n$-alkanes through biodegradation or weathering. A compound coeluting between $n-\mathrm{C}_{29}$ and $n-\mathrm{C}_{30}$ in a few samples (e.g. NE54, Figure 5.3f) has been tentatively identified as 28,30-bisnorhopane, based on retention time and comparison with the GC-MS m/z 191 chromatogram (see Appendix 9). This biomarker is indicative of deposition in an anoxic environment (see Section 6.3.1).

\section{Whangai Formation}

Te Uri Member: The saturate fractions (e.g. NE11, Figure 5.4a) are characterised by unimodal $n$-alkane distributions with maxima at $\mathrm{C}_{24}$ or $\mathrm{C}_{25}$. Variable $\mathrm{C}_{21}+\mathrm{C}_{22} / \mathrm{C}_{28}+\mathrm{C}_{29}$ ratios indicate contributions of both marine and terrestrial organic matter. Low $\mathrm{Pr} / \mathrm{Ph}$ ratios (0.31-0.54) suggest deposition may have occurred under anoxic conditions. NE11 shows low relative abundances of low molecular weight $n$-alkanes, pristane and phytane and this may result from loss due to weathering.

Porangahau Member: The chromatograms of this member show unimodal $n$-alkane distributions. Half the samples (e.g. NE17, Figure 5.4b) have low $\mathrm{C}_{21}+\mathrm{C}_{22} / \mathrm{C}_{28}+\mathrm{C}_{29}$ ratios and $n$-alkane maxima at $\mathrm{C}_{26}$ or $\mathrm{C}_{27}$, indicative of predominantly terrestrial organic matter, while the other half have high $\mathrm{C}_{21}+\mathrm{C}_{22} / \mathrm{C}_{28}+\mathrm{C}_{29}$ ratios, $n$-alkane maxima at $\mathrm{C}_{23}$, and low relative abundances of high molecular weight $n$-alkanes $\left(>\mathrm{C}_{25}\right)$ indicating a marine source of organic matter. Low relative abundances of pristane and phytane and lower molecular weight $n$-alkanes may be the result of loss due to weathering. Low $\mathrm{Pr} / \mathrm{Ph}$ ratios suggests deposition under anoxic conditions.

Upper Calcareous Member: This member (e.g. NE113, Figure 5.4c) is characterised by unimodal $n$-alkane distributions with maxima at $\mathrm{C}_{23}$ or $\mathrm{C}_{24}$ and high $\mathrm{C}_{21}+\mathrm{C}_{22} / \mathrm{C}_{28}+\mathrm{C}_{29}$ ratios (0.51-6.11), which indicate a predominantly marine contribution of organic matter. The high relative abundance of $n-\mathrm{C}_{15}$ in some samples may indicate an algal input. NE46 
is bimodal with high relative abundances of both lower molecular weight $n$-alkanes and pristane and phytane. Low $\mathrm{Pr} / \mathrm{Ph}$ ratios in some samples may indicate deposition under anoxic conditions. NE46 (not shown) shows a dominant peak in the region of high molecular weight $n$-alkanes which has been tentatively identified as 28,30-bisnorhopane, based on retention time and comparison with GC-MS m/z 191 chromatogram (see Appendix 9). This provides further evidence for a reduced oxygen depositional environment. NE113 also has abundant lower molecular weight $n$-alkanes and moderate concentrations of isoprenoids.

Rakauroa Member: The saturate fraction is characterised by $n$-alkane distributions with high $\mathrm{C}_{21}+\mathrm{C}_{22} / \mathrm{C}_{28}+\mathrm{C}_{29}$ ratios (2.21-9.03) and maxima at $\mathrm{C}_{22}$ or $\mathrm{C}_{23}$, which indicate a strong marine influence. High relative abundances of $n-\mathrm{C}_{15}$ are present in some samples (e.g. NE3, Figure 5.4d) which, like samples from the Upper Calcareous Member, may be due to an algal contribution. Pristane, phytane and low molecular weight $n$-alkanes are present in low relative abundances and this may be due to loss through weathering. Occasionally low $\mathrm{Pr} / \mathrm{Ph}$ ratios may indicate deposition under conditions of reduced oxygen. Two samples have different characteristics with $n$-alkane maxima at $\mathrm{C}_{25}$ or $\mathrm{C}_{26}$, more indicative of terrestrial organic matter. They also have high relative abundances of pristane and phytane and high $\mathrm{Pr} / \mathrm{Ph}$ ratios which may indicate deposition in an oxic environment.

Undifferentiated: Both unimodal and bimodal $n$-alkane distributions are present in undifferentiated Whangai Formation samples. A number of samples show $n$-alkane distributions with maxima at $\mathrm{C}_{29}$ and a high odd-over-even predominance in the higher molecular weight component, indicative of predominantly terrestrial organic matter. Moderate to high relative abundances of $\mathrm{C}_{14}-\mathrm{C}_{17} n$-alkanes, with maxima at about $\mathrm{C}_{16}$, and low relative abundances of high molecular weight $n$-alkanes are characteristic of other samples. NE53 (Figure 5.4e) shows a bimodal distribution with no observable oddover-even preference between $\mathrm{C}_{12}$ and $\mathrm{C}_{24}$ and then an odd-over even preference between $\mathrm{C}_{25}$ and $\mathrm{C}_{32}$ demonstrating contributions of both marine and terrestrial organic matter.

Tangaruhe Formation: The saturate fractions are characterised by unimodal $n$-alkane distributions with maxima at $\mathrm{C}_{25}$ or $\mathrm{C}_{26}$ (e.g. NE9, Figure 5.4f). The distributions are skewed towards the higher molecular weight components, resulting in low $\mathrm{C}_{21}+\mathrm{C}_{22} / \mathrm{C}_{28}+\mathrm{C}_{29}$ ratios and appear to be related to degradation through weathering. Low $\mathrm{Pr} / \mathrm{Ph}$ ratios may indicate deposition under anoxic conditions, but these too are considered likely to be affected by degradation. 


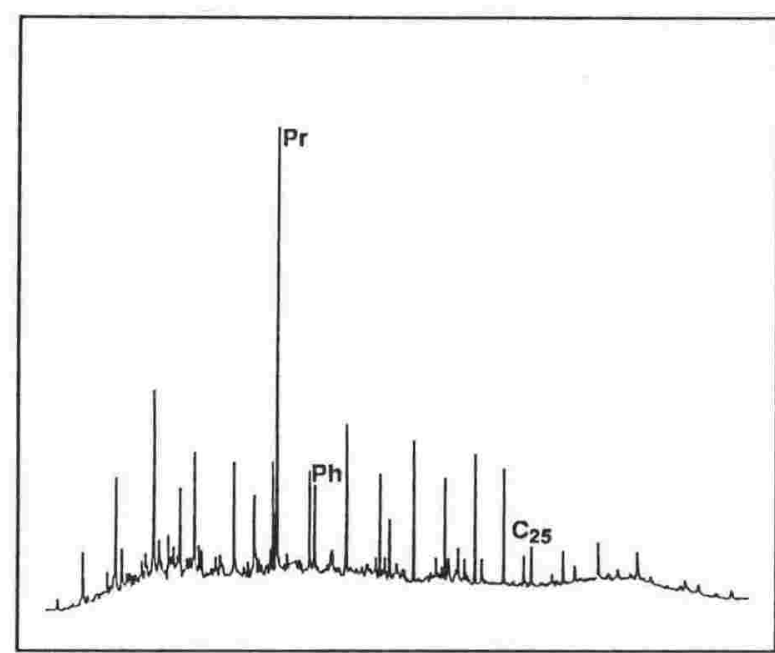

a. NE59 - Te Mai Formation

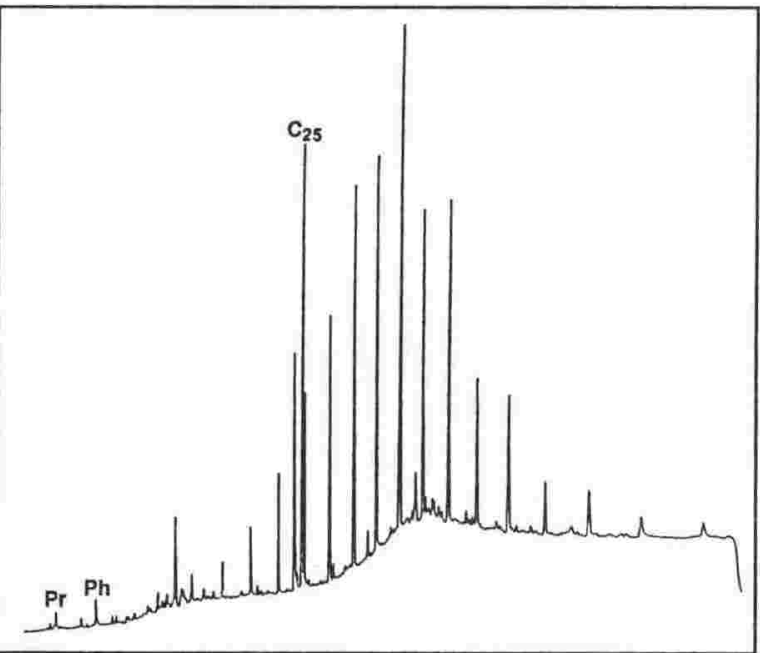

b. NE118 - Glenburn Formation

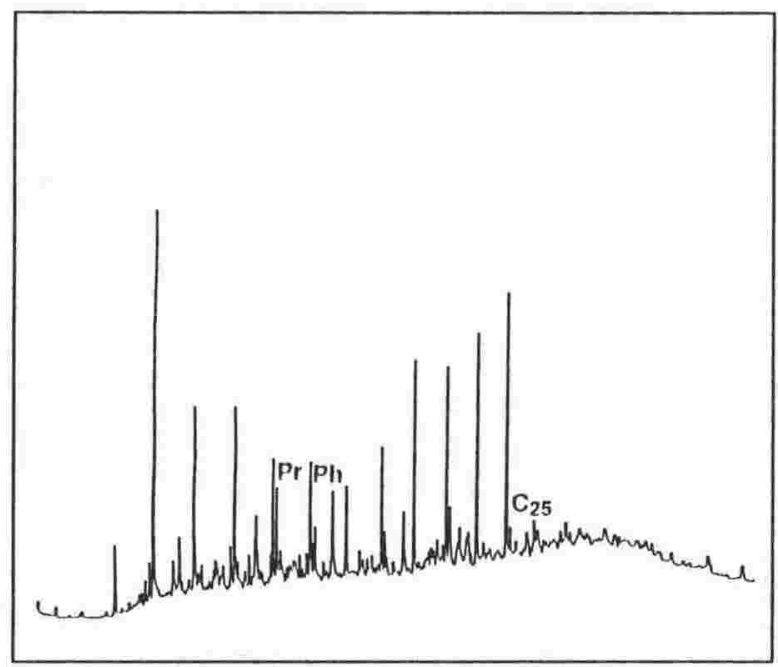

c. NE66 - Mangapokia Formation

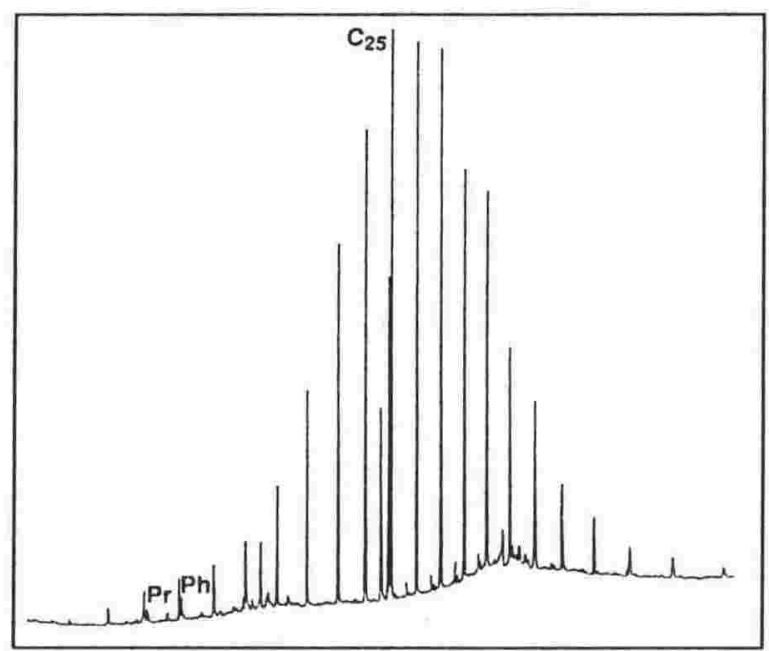

d. NE114 - Torlesse Supergroup

Figure 5.5 Gas chromatograms showing the saturate fractions of the possible source rocks from eastern North Island. 
Te Mai Formation: The chromatograms are characterised by bimodal $n$-alkane distributions. Both marine and terrestrial contributions of organic matter are indicated. NE59 (Figure 5.5a) shows a high relative abundance of $\mathrm{C}_{14}-\mathrm{C}_{18} n$-alkanes with an oddover-even predominance between $\mathrm{C}_{15}$ and $\mathrm{C}_{24}$, indicative of a marine contribution. High $\mathrm{Pr} / \mathrm{Ph}$ ratios indicate deposition in an oxic environment. Other samples show $n$-alkane distributions with a maxima at $\mathrm{C}_{27}$, an odd-over-even predominance between $\mathrm{C}_{27}$ and $\mathrm{C}_{31}$ and low $\mathrm{C}_{21}+\mathrm{C}_{22} / \mathrm{C}_{28}+\mathrm{C}_{29}$ ratios, all indicative of a terrestrial higher plant contribution.

Glenburn Formation: The saturate fractions (e.g. NE118, Figure 5.5b) are characterised by unimodal $n$-alkane distributions with high maxima $\left(\mathrm{C}_{25}\right.$ or $\left.\mathrm{C}_{29}\right)$ and are often skewed towards the higher molecular weight components. An odd-over-even predominance is commonly present between $\mathrm{C}_{27}$ and $\mathrm{C}_{33}$, and almost all samples have low $\mathrm{C}_{21}+\mathrm{C}_{22} / \mathrm{C}_{28}+\mathrm{C}_{29}$ ratios, both indicative of a predominant terrestrial contribution. Low relative abundances of pristane, phytane and low molecular weight $n$-alkanes are considered to be the result of loss due to weathering (such as NE118, Figure 5.5b).

Mangapokia Formation: The saturate fractions are either unimodal or bimodal with $n$-alkane maxima ranging from $\mathrm{C}_{14}-\mathrm{C}_{19}$ or $\mathrm{C}_{27}$, suggesting both marine and terrestrial contributions. An odd-over-even predominance between $\mathrm{C}_{17}$ and $\mathrm{C}_{24}$, and low relative abundances of higher molecular weight $n$-alkanes may indicate an algal source in some samples (e.g. NE66, Figure 5.5c). $\mathrm{C}_{21}+\mathrm{C}_{22} / \mathrm{C}_{28}+\mathrm{C}_{29}$ ratios, where available, are low and indicate a contribution of terrestrial higher plant organic matter. This is supported by an odd-over-even predominance in $n$-alkanes between $\mathrm{C}_{25}$ and $\mathrm{C}_{30}$. High $\mathrm{Pr} / \mathrm{Ph}$ ratios are indicative of deposition under oxic conditions.

Torlesse Supergroup: The saturate fraction (NE114, Figure 5.5d) is characterised by a unimodal $n$-alkane distribution with maximum at $\mathrm{C}_{26}$ and a low $\mathrm{C}_{21}+\mathrm{C}_{22} / \mathrm{C}_{28}+\mathrm{C}_{29}$ ratio (0.43) indicative of terrestrial organic matter. Low relative abundances of pristane, phytane and low molecular weight $n$-alkanes may result from loss due to weathering. A low $\mathrm{Pr} / n-\mathrm{C}_{17}$ ratio (0.44) indicates a component of marine organic matter.

\section{South Island possible source rocks}

Waima Siltstone: The chromatogram (NE85, Figure 5.6a) is characterised by a unimodal $n$-alkane distribution with a maximum at $\mathrm{C}_{22}$, but high relative abundances of the high molecular weight component and a low $\mathrm{C}_{21}+\mathrm{C}_{22} / \mathrm{C}_{28}+\mathrm{C}_{29}$ ratio. This indicates a predominance of terrestrial organic matter, but also a minor marine contribution. High relative abundances of pristane and phytane and other isoprenoids compared with lower 


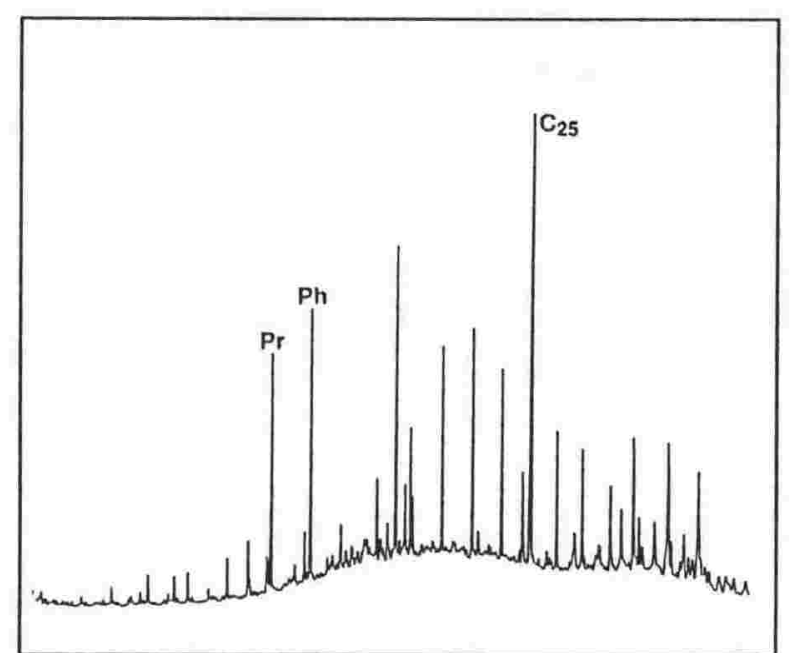

a. NE85 - Waima Siltstone

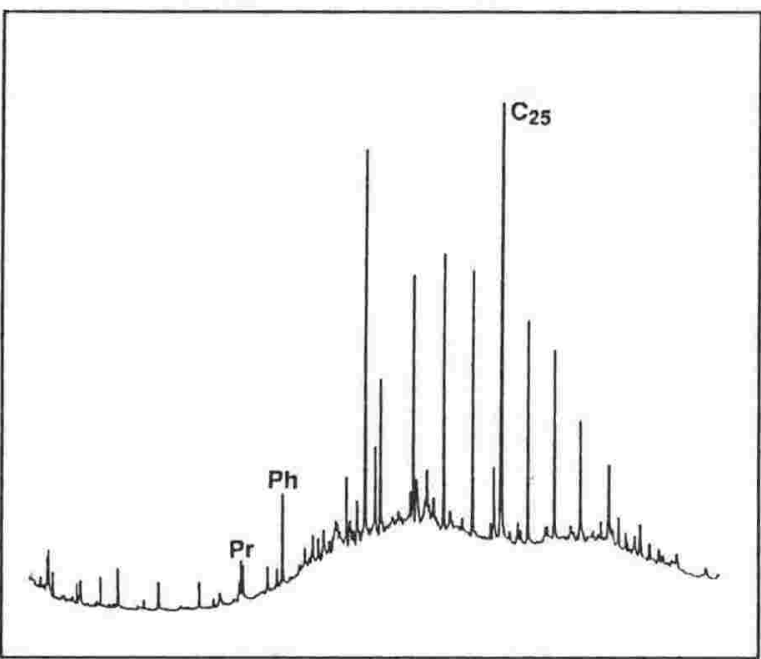

b. NE100 - Amuri Limestone

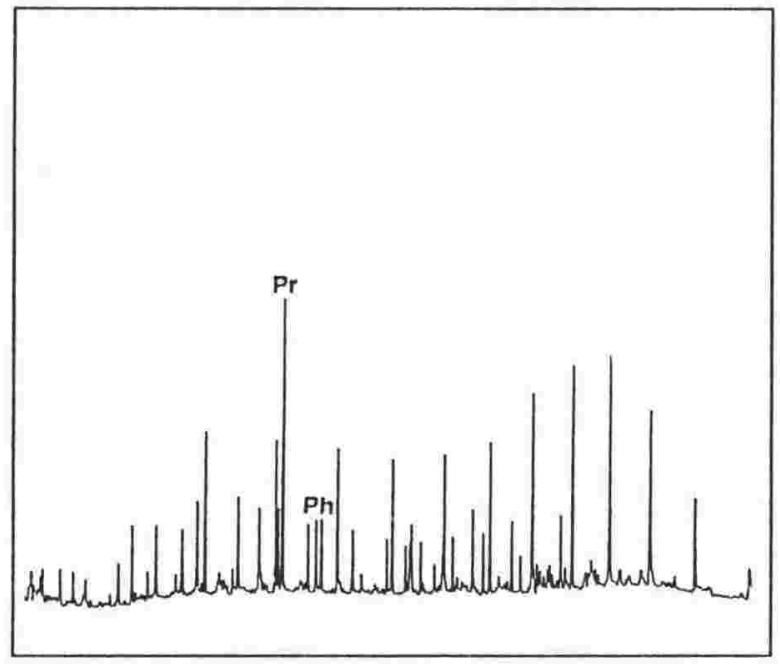

c. NE86 - Whangai Formation, undifferentiated (S.I.)

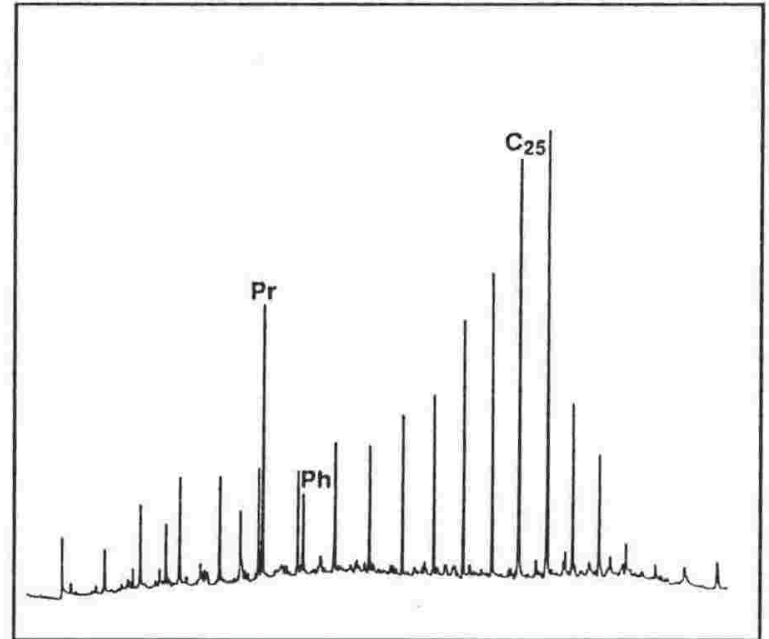

d. NE78 - Mata Series

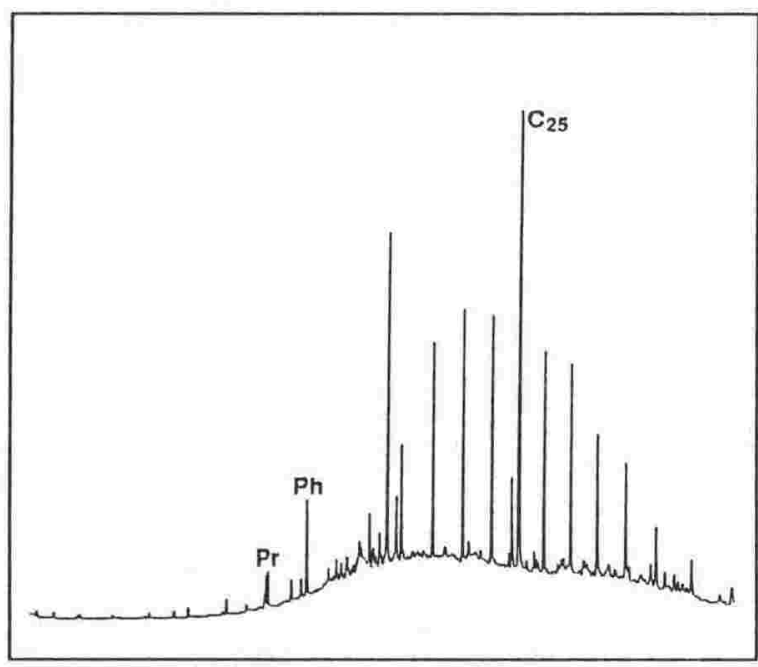

e. NE82 - Flags Formation

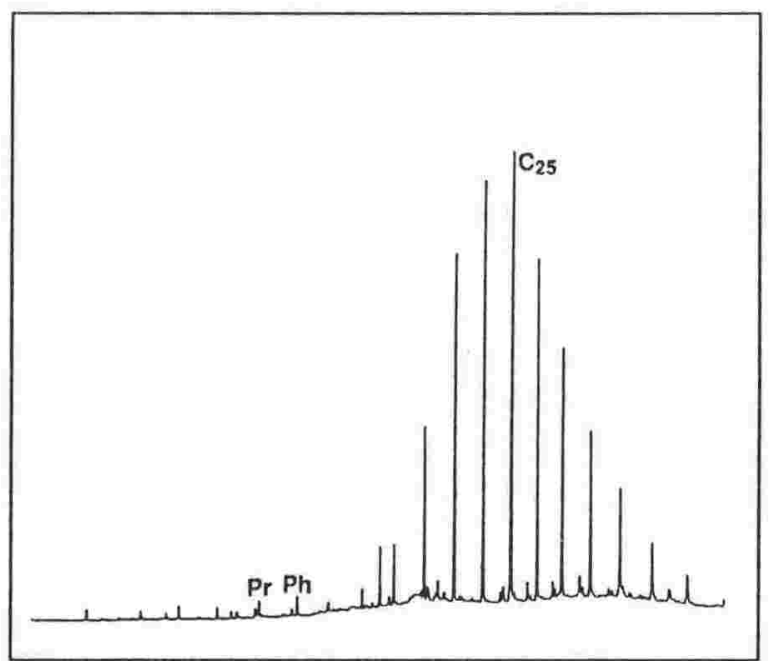

f. NE108 - Conway Siltstone

Figure 5.6 Gas chromatograms showing the saturate fractions of the possible source rocks from Marlborough. 
molecular weight $n$-alkanes (including $\mathrm{Pr} / n-\mathrm{C}_{17}$ and $\mathrm{Ph} / n-\mathrm{C}_{18}$ ) may result from immature organic matter. Low relative abundances of low molecular weight $n$-alkanes may be the result of loss due to weathering.

Amuri Limestone: The saturate fractions are characterised by unimodal $n$-alkane distributions with maxima at about $\mathrm{C}_{23}$ (e.g. NE100, Figure 5.6b). Predominantly high $\mathrm{C}_{21}+\mathrm{C}_{22} / \mathrm{C}_{28}+\mathrm{C}_{29}$ ratios (0.8-2.99) indicate a strong marine influence. High relative abundances of $n$-alkanes from $\mathrm{C}_{11}-\mathrm{C}_{16}$ in some samples may indicate an algal source of organic matter. Low $\mathrm{Pr} / \mathrm{Ph}$ ratios predominate which may indicate deposition in an anoxic environment.

Undifferentiated Whangai Formation: This formation is generally characterised by unimodal $n$-alkane distributions with low relative abundances of $\mathrm{C}_{13}-\mathrm{C}_{18} n$-alkanes. Low $\mathrm{C}_{21}+\mathrm{C}_{22} / \mathrm{C}_{28}+\mathrm{C}_{29}$ ratios indicate a predominantly terrestrial contribution of organic matter. NE86 (Figure 5.6c) is dominated by isoprenoids, possibly as a result of biodegradation of the $n$-alkanes but more probably as a result of low thermal maturity.

Mata Series: The saturate fractions are characterised by unimodal $n$-alkane distributions with maxima at about $\mathrm{C}_{23}$ and low relative abundances of the low molecular weight component $\left(\mathrm{C}_{13}-\mathrm{C}_{19}\right)$. Variable $\mathrm{C}_{21}+\mathrm{C}_{22} / \mathrm{C}_{28}+\mathrm{C}_{29}$ ratios (0.65-3.15) indicate a predominance of marine but also occasionally strong terrestrial contributions of organic matter. Generally low $\mathrm{Pr} / \mathrm{Ph}$ ratios may indicate deposition under anoxic conditions. NE78 (Figure 5.6d) has an $n$-alkane distribution with maximum at $\mathrm{C}_{26}$, a slight odd-overeven predominance between $\mathrm{C}_{14}$ and $\mathrm{C}_{26}$, and low relative abundances of the higher molecular weight component $\left(>\mathrm{C}_{26}\right)$.

Flags Formation: The saturate fraction (NE82, Figure 5.6e) is characterised by a unimodal $n$-alkane distribution with a maximum at $\mathrm{C}_{23}$, a moderately low $\mathrm{C}_{21}+\mathrm{C}_{22} / \mathrm{C}_{28}+\mathrm{C}_{29}$ ratio (1.06) and an odd-over-even predominance between $\mathrm{C}_{23}$ and $\mathrm{C}_{31}$, which suggests a terrestrial contribution of organic matter. This interpretation, however, and the low relative abundances of pristane, phytane and low molecular weight $n$-alkanes are substantially affected by loss due to weathering. A low $\mathrm{Pr} / \mathrm{Ph}$ ratio $(0.33)$ may indicate deposition under anoxic conditions.

Conway Siltstone: This chromatogram (NE108, Figure 5.6f) shows a unimodal $n$-alkane distribution with a maximum at $\mathrm{C}_{25}$. The distribution is skewed towards the higher molecular weight components, resulting in a low $\mathrm{C}_{21}+\mathrm{C}_{22} / \mathrm{C}_{28}+\mathrm{C}_{29}$ ratio (0.63), which is indicative of a higher plant contribution. Once again, this interpretation, is 


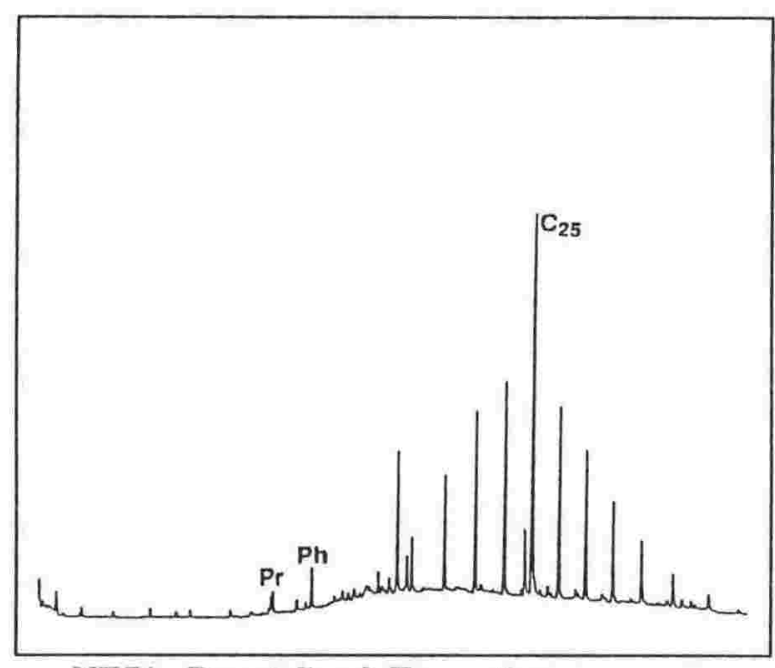

a. NE71 - Burnt Creek Formation

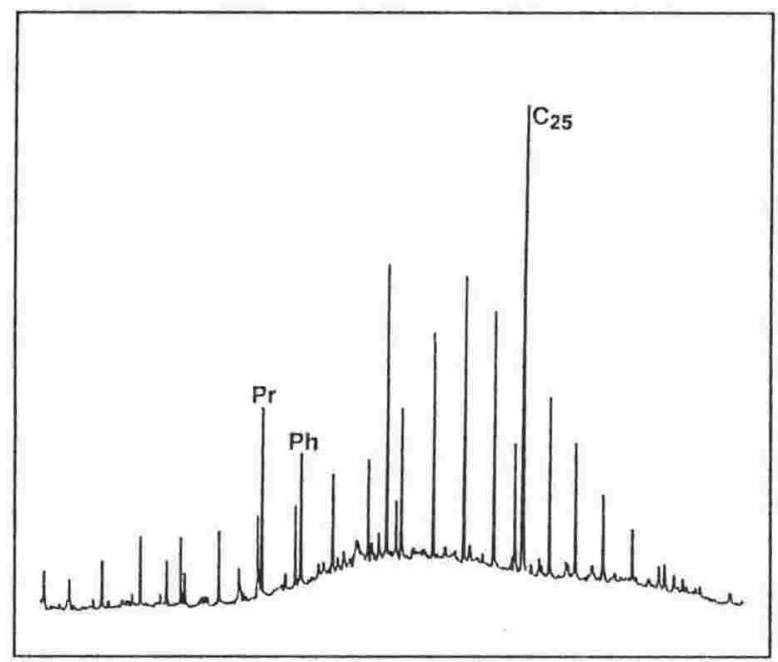

b. NE94 - Split Rock Formation, Swale

Siltstone Member

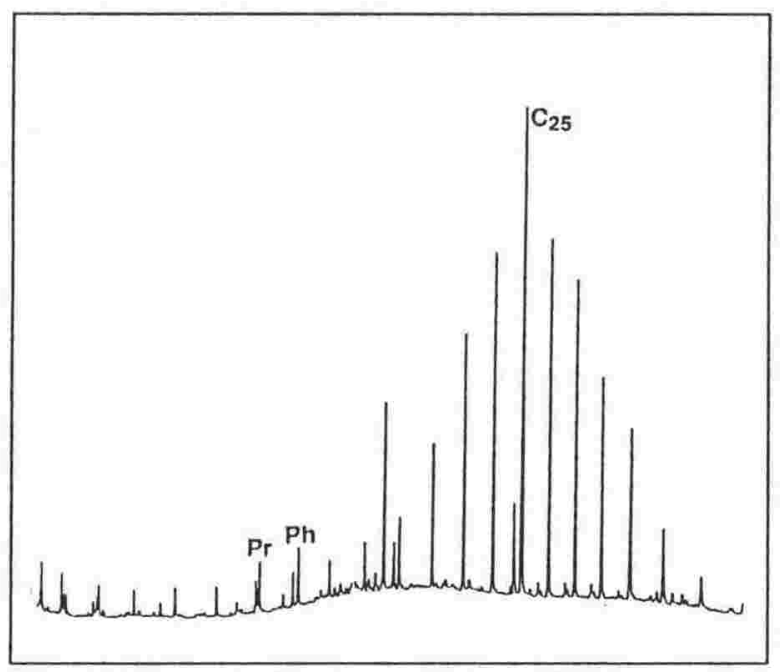

c. NE90 - Split Rock Formation, Champagne Member

Figure 5.7 Gas chromatograms showing the saturate fractions of the possible source rocks from Marlborough.

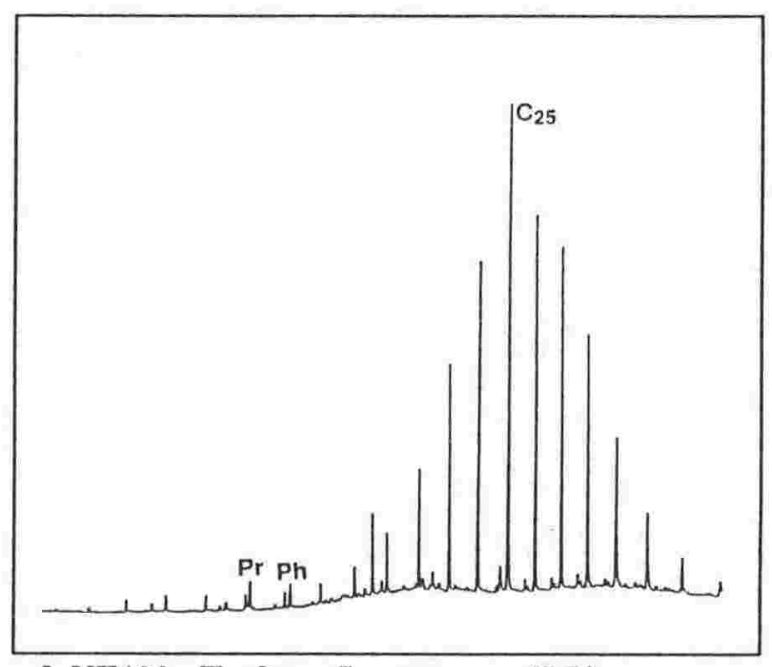

d. NE102 - Torlesse Supergroup (S.I.) 
affected by a distribution that is considered to have suffered loss of the lower molecular weight $n$-alkanes (and pristane and phytane) due to weathering.

Burnt Creek Formation: The saturate fractions (e.g. NE71, Figure 5.7a) are characterised by unimodal $n$-alkane distributions with maxima at $\mathrm{C}_{24}$. High $\mathrm{C}_{21}+\mathrm{C}_{22} / \mathrm{C}_{28}+\mathrm{C}_{29}$ ratios indicate marine organic matter. Low relative abundances of pristane, phytane and the low molecular weight $n$-alkanes may result from loss due to weathering. Low $\mathrm{Pr} / \mathrm{Ph}$ ratios (0.44-0.50) may indicate deposition under anoxic conditions.

Split Rock Formation: The upper part of this formation (Swale Siltstone Member, NE94, Figure 5.7b) is characterised by a unimodal $n$-alkane distribution with a maximum at $\mathrm{C}_{23}$ and a high $\mathrm{C}_{21}+\mathrm{C}_{22} / \mathrm{C}_{28}+\mathrm{C}_{29}$ ratio (2.04), indicative of marine organic matter. Moderate relative abundances of lower molecular weight $n$-alkanes $\left(\mathrm{C}_{13}-\mathrm{C}_{15}\right)$ and low relative abundances of the higher molecular weight component $\left(\mathrm{C}_{28}-\mathrm{C}_{31}\right)$ may indicate a predominantly marine, possibly algal input. There are moderate to high relative abundances of pristane and phytane. The basal part of this formation (Champagne Member, NE90, Figure 5.7c) is characterised by a unimodal $n$-alkane distribution with a maximum at $\mathrm{C}_{25}$, a low $\mathrm{C}_{21}+\mathrm{C}_{22} / \mathrm{C}_{28}+\mathrm{C}_{29}$ ratio (0.62) and an odd-over-even predominance in the higher molecular weight component. These are all indicative of a predominance of terrestrial organic matter. Low relative abundances of pristane, phytane and low molecular weight $n$-alkanes may result from loss due to weathering.

Torlesse Supergroup: The saturate fractions (e.g. NE102, Figure 5.7d) are characterised by both unimodal and bimodal $n$-alkane distributions. A wide range of $\mathrm{C}_{21}+\mathrm{C}_{22} / \mathrm{C}_{28}+\mathrm{C}_{29}$ ratios (0.37-3.50) indicates varying contributions of terrestrial and marine organic matter. Some samples show an odd-over-even predominance between $\mathrm{C}_{23}$ and $\mathrm{C}_{31}$, indicating a terrestrial contribution, while others have moderate relative abundances of low molecular weight $n$-alkanes $\left(\mathrm{C}_{13}-\mathrm{C}_{18}\right)$ and low relative abundances of the high molecular weight component $\left(>\mathrm{C}_{26}\right)$, indicating a predominance of marine organic matter. Bimodal $n$-alkane distributions indicate contributions of both marine and terrestrial organic matter. Low to moderate $\mathrm{Pr} / \mathrm{Ph}$ ratios were recorded. Samples with meaningful CPIs average 1.1 indicating they are thermally mature (although a contribution of marine organic matter would exaggerate the true maturity). 


\subsection{Summary of results and discussion}

\subsubsection{Geochemistry of the oils}

The gas chromatograms of the Knights Stream, Isolation Creek and Kerosene Rock oils show three different $n$-alkane distributions, possibly indicating three different origins. The $\mathrm{Pr} / \mathrm{Ph}$ ratios of the three oils lie between 0.6 and 3 and, therefore, are not conclusive indicators of depositional environment (Peters and Moldowan, 1993). The $\mathrm{C}_{21}+\mathrm{C}_{22} / \mathrm{C}_{28}+\mathrm{C}_{29}$ ratios of the Knights Stream and Isolation Creek oils, however, indicate a predominance of marine organic matter, while that of the Kerosene Rock oil indicates predominantly terrestrial organic matter, and these results are supported by $\mathrm{C}_{\max }$ data. Although mild degradation of the Isolation Creek and Kerosene Rock oils has the effect of reducing the relative abundances of the lower molecular weight $n$-alkanes in these oils and suggests a lower contribution of marine organic matter than is indicated, at least two major oil types have been clearly distinguished based on the different origins of contributing organic matter.

The Westcott, Tiraumea and Okau Stream oils are at least moderately biodegraded, with only trace $n$-alkane and isoprenoids remaining. As a result, no interpretations regarding source or maturity are possible. Mass chromatograms of the oils, produced by GC-MS analysis (see Figure 6.13), indicate that the sterane and triterpane distributions have been largely unaffected and, therefore, biodegradation has reached an upper limit of about 5 (moderate) on the ten point scale of Peters and Moldowan (1993) (Table 6.1).

Previous GC analyses of southern East Coast Basin oils have yielded different results to those of the present study and the collection of nonbiodegraded oil samples from surface outcrops appears to be a matter of good fortune. The Isolation Creek and Okau Stream oils were shown to be biodegraded with only trace $n$-alkanes and isoprenoids remaining [see Gibbons and Fry (1983) and Zumberge (1990) respectively]. The Kerosene Rock oil, with a largely unaffected isoprenoid distribution (see Lipke, 1989), was shown to have suffered slightly less biodegradation than either the Isolation Creek or Okau Stream oils but is still greater than that demonstrated by the present study.

Rogers (1995) analysed four oil samples from the northern part of the basin and, with the exception of the Totangi oil seep which was found to be moderately biodegraded, their $n$-alkane and isoprenoid biomarker parameters are shown in Table 5.2. Data from the southern East Coast Basin oils are included for comparison. The northern oils show unimodal $n$-alkane distributions most abundant between $\mathrm{C}_{10}$ and $\mathrm{C}_{20}$ with maxima 
commonly at $\mathrm{C}_{15}$, and this was attributed to an algal contribution in a marine depositional environment (Rogers, 1995). The $C_{21}+C_{22} / C_{28}+C_{29}$ ratios (1.19-1.48), however, suggest there were both marine and terrestrial contributions of organic matter to the Waitangi and Motu Valley oils.

\begin{tabular}{|c|c|c|c|c|c|c|}
\hline Oil seeps & $\mathrm{Pr} / \mathrm{Ph}$ & $\mathrm{Pr} / n-\mathrm{C}_{17}$ & $\mathrm{Ph} / n-\mathrm{C}_{18}$ & CPI & $\begin{array}{c}n \text {-alkane } \\
\max \end{array}$ & $\frac{C_{21}+C_{22}}{C_{28}+C_{29}}$ \\
\hline \multicolumn{7}{|l|}{ Rogers (1995)* } \\
\hline Waitangi & 0.95 & 2.63 & 1.83 & 1.1 & 23 & 1.19 \\
\hline Rotokautuku & 4.58 & 2.97 & 0.83 & 0.96 & 15 & \\
\hline Motu Valley & 1.93 & 2.02 & 1.15 & 0.99 & 15 & 1.48 \\
\hline \multicolumn{7}{|l|}{ This study } \\
\hline Knights Stream & 2.57 & 3.66 & 1.57 & 1.02 & 16 & 2.73 \\
\hline Isolation Creek & 0.99 & 0.38 & 0.42 & 1.05 & 24 & 2.14 \\
\hline Kerosene Rock & 2.17 & 6.12 & 2.11 & 0.97 & 27 & 0.38 \\
\hline
\end{tabular}

$\mathrm{Pr}=$ Pristane; $\mathrm{Ph}=$ Phytane.

Table 5.2 Comparison of the $n$-alkane and isoprenoid biomarker parameters of oils from the northern East Coast Basin (from Rogers, 1995) with those from the southern region.

\section{Oil-oil correlations}

Although the northern and southern East Coast Basin oils are not able to be correlated by their $n$-alkane and isoprenoid biomarker parameters alone, the Knights Stream oil gas chromatogram is similar in appearance to those of the northern oils, while the Kerosene Rock oil has a much greater terrestrial signature and appears completely unrelated. The Isolation Creek oil gas chromatogram is also different from the northern oils, possibly as a result of migration, biodegradation or weathering, and correlation is again not possible.

\subsubsection{Geochemistry of the possible source rocks}

A summary of the $n$-alkane and isoprenoid biomarker parameters of eastern North Island and Marlborough strata appears in Tables 5.3 and 5.4 respectively. Trends are not obvious, particularly regarding the $\mathrm{Pr} / \mathrm{Ph}$ and $\mathrm{Pr} / n-\mathrm{C}_{17}$ ratios. $\mathrm{Pr} / \mathrm{Ph}$ ratios suggest that the Te Uri Member and the Tangaruhe Formation, from eastern North Island, and the Woodside Formation, Amuri Limestone, Flags and Burnt Creek formations, from Marlborough, were deposited under anoxic conditions. The Waipawa Black Shale, Porangahau Member, Glenburn Formation and the Torlesse Supergroup, from eastern North Island, and the Waima Siltstone, Mata Series and Conway Siltstone, from 


\begin{tabular}{|c|c|c|c|c|}
\hline Formation & $\mathbf{P r} / \mathbf{P h}$ & $\mathrm{Pr} / n-\mathrm{C}_{17}$ & $\begin{array}{l}n \text {-alkane } \\
\max \end{array}$ & $\frac{C_{21}+C_{22}}{C_{28}+C_{29}}$ \\
\hline Miocene coal & 0.7 & 1.1 & $\begin{array}{c}29 \\
\text { terrestrial }\end{array}$ & $\begin{array}{c}0.2 \\
\text { terrestrial }\end{array}$ \\
\hline Whakataki & 1.9 & 4.2 & - & - \\
\hline Weber & 1.6 & 1.3 & $\begin{array}{c}14 \text { or } 25 \\
\text { marine/terrest. }\end{array}$ & $\begin{array}{c}0.3 \\
\text { terrestrial }\end{array}$ \\
\hline Wanstead & 1.1 & 1.5 & $\begin{array}{c}15 \text { or } 23 \\
\text { marine/terrest. }\end{array}$ & $\begin{array}{c}2.3 \\
\text { marine }\end{array}$ \\
\hline Waipawa Black Shale & 0.8 & 3.5 & $\begin{array}{c}\sim 24 \text { or } 26+ \\
\text { ?marine/terrest }\end{array}$ & $\begin{array}{c}0.9 \\
\text { terrestrial }\end{array}$ \\
\hline $\begin{array}{l}\text { Whangai } \\
\text { Te Uri Mem. }\end{array}$ & $\begin{array}{c}0.4 \\
\text { ?anoxic }\end{array}$ & 1.7 & $\begin{array}{c}24 \\
\text { marine }\end{array}$ & $\begin{array}{c}1.2 \\
\text { terrestrial }\end{array}$ \\
\hline Porangahau Mem. & 0.7 & 3.3 & $\begin{array}{c}23 \\
\text { marine }\end{array}$ & $\begin{array}{c}5.3 \\
\text { marine }\end{array}$ \\
\hline Upper Calc. Mem. & 1.1 & 3.1 & $\begin{array}{c}24 \\
\text { marine }\end{array}$ & $\begin{array}{c}3.3 \\
\text { marine }\end{array}$ \\
\hline Rakauroa Mem. & 1.7 & 4.0 & $\begin{array}{c}23 \\
\text { marine }\end{array}$ & $\begin{array}{c}6.1 \\
\text { marine }\end{array}$ \\
\hline Tangaruhe & $\begin{array}{c}0.5 \\
\text { ?anoxic }\end{array}$ & 1.6 & $\begin{array}{c}25-26 \\
?\end{array}$ & $\begin{array}{c}0.4 \\
\text { terrestrial }\end{array}$ \\
\hline Te Mai & 2.5 & 2.4 & $\begin{array}{c}27 \\
\text { terrestrial }\end{array}$ & $\begin{array}{c}0.3 \\
\text { terrestrial }\end{array}$ \\
\hline Glenburn & 0.6 & 2.8 & $\begin{array}{c}29 \\
\text { terrestrial }\end{array}$ & $\begin{array}{c}0.6 \\
\text { terrestrial }\end{array}$ \\
\hline Pahaoa Group & 2.2 & 2.4 & $\begin{array}{c}27 \\
\text { terrestrial }\end{array}$ & $\begin{array}{c}0.6 \\
\text { terrestrial }\end{array}$ \\
\hline Torlesse Supergroup & 0.7 & 0.4 & $\begin{array}{c}26 \\
?\end{array}$ & $\begin{array}{c}0.4 \\
\text { terrestrial }\end{array}$ \\
\hline
\end{tabular}

Table 5.3 Summary of the $n$-alkane and isoprenoid biomarker parameters of eastern North Island formations. 
Marlborough, are also indicated to have been deposited under conditions of reduced oxygen. Other parameters of bottom-water oxygenation, however, such as 28,30-bisnorhopane (see Section 6.6.3), S/C and Ni/V, V/Cr and U/Th trace metal ratios (see Section 7.4), indicate that of the formations mentioned above, only the Waipawa Black Shale and Conway Siltstone were deposited under anoxic conditions, while the Waima Siltstone and some Mata Series samples were deposited under conditions of reduced oxygen. Discrepancies in these results are likely for a number of reasons. Postdepositional alteration of the saturate fraction, through weathering and biodegradation, is likely to be an inherent problem in a high proportion of outcrop samples (although both pristane and phytane are considerably more resistant than $n$-alkanes to biodegradation). The most important factor, though, is that of thermal maturity and biomarker ratios determined through GC-MS (see Section 6.6.4) indicate that the majority of samples are immature with respect to hydrocarbon generation and, therefore, their $\mathrm{Pr} / \mathrm{Ph}$ ratios are generally inaccurate as environmental indicators (Peters and Moldowan, 1993). Similarly, the low thermal maturities suggest that the $\mathrm{Pr} / n-\mathrm{C}_{17}$ ratios are also likely to be unreliable.

The $\mathrm{C}_{21}+\mathrm{C}_{22} / \mathrm{C}_{28}+\mathrm{C}_{29}$ ratios from eastern North Island show a predominance of terrestrial organic matter in sediments from the Lower Cretaceous Torlesse Supergroup to the Upper Cretaceous Tangaruhe Formation. Marine organic matter is then predominant in sediments from the uppermost Cretaceous Whangai Formation to the Eocene Wanstead Formation, with the exception of the Paleocene Te Uri Member (Whangai Formation) and particularly the Waipawa Black Shale, which contain mainly terrestrial organic matter (70\% of Waipawa Black Shale samples comprise predominantly terrestrial organic matter). This trend is then reversed with an increased proportion of terrestrial organic matter in strata of Oligocene age and younger. These trends are largely supported by the $\mathrm{C}_{\max }$ data. The $\mathrm{C}_{21}+\mathrm{C}_{22} / \mathrm{C}_{28}+\mathrm{C}_{29}$ ratios of the Marlborough strata, however, do not provide the same definite trends as those from eastern North Island. It appears that marine organic matter is predominant in sediments from the Lower Cretaceous Torlesse Supergroup to middle Cretaceous Burnt Creek Formation. The Upper Cretaceous formations indicate variable proportions of marine and terrestrial organic matter. The Conway Siltstone and Whangai Formation contain predominantly terrestrial organic matter, possibly representing more proximal depositional environments. The Flags Formation comprises both marine and terrestrial organic matter and Mata Series sediments contain predominantly marine organic matter, suggesting a more distal depositional environment. The uppermost Cretaceous to Oligocene Amuri Limestone and Woodside formations comprise predominantly marine organic matter, while that present in the Miocene Waima Siltstone is mainly terrestrial in origin. The $\mathrm{C}_{\max }$ data also support these findings. 


\begin{tabular}{|c|c|c|c|c|}
\hline Formation & $\mathrm{Pr} / \mathrm{Ph}$ & $\mathrm{Pr} / n-\mathrm{C}_{17}$ & $\begin{array}{c}n \text {-alkane } \\
\max \end{array}$ & $\frac{C_{21}+C_{22}}{C_{28}+C_{29}}$ \\
\hline Waima Siltstone & 0.8 & 6.2 & $\begin{array}{c}22 \\
\text { marine }\end{array}$ & $\begin{array}{c}0.6 \\
\text { terrestrial }\end{array}$ \\
\hline Woodside & $\begin{array}{c}0.2 \\
\text { ?anoxic }\end{array}$ & 1.4 & $\begin{array}{c}22 \\
\text { marine }\end{array}$ & $\begin{array}{c}2.9 \\
\text { marine }\end{array}$ \\
\hline Amuri Limestone & $\begin{array}{c}0.5 \\
\text { ?anoxic }\end{array}$ & 2.2 & $\begin{array}{c}23 \\
\text { marine }\end{array}$ & $\begin{array}{c}1.6 \\
\text { marine }\end{array}$ \\
\hline Whangai & 1.2 & 2.4 & $\begin{array}{l}25 \\
?\end{array}$ & $\begin{array}{c}0.6 \\
\text { terrestrial }\end{array}$ \\
\hline Mata Series & 0.8 & 2.3 & $\begin{array}{c}24 \\
\text { ?marine }\end{array}$ & $\begin{array}{c}1.6 \\
\text { marine }\end{array}$ \\
\hline Flags & $\begin{array}{c}0.3 \\
\text { ?anoxic }\end{array}$ & 2.1 & $\begin{array}{c}23 \\
\text { marine }\end{array}$ & $\begin{array}{c}1.1 \\
?\end{array}$ \\
\hline Conway Siltstone & 0.8 & 2.0 & $\begin{array}{c}25 \\
?\end{array}$ & $\begin{array}{c}0.6 \\
\text { terrestrial }\end{array}$ \\
\hline Burnt Creek & $\begin{array}{c}0.5 \\
\text { ?anoxic }\end{array}$ & 2.2 & $\begin{array}{c}24 \\
\text { ?marine }\end{array}$ & $\begin{array}{c}2.1 \\
\text { marine }\end{array}$ \\
\hline Split Rock & 1.5 & 2.4 & $\begin{array}{c}24 \\
\text { ?marine }\end{array}$ & $\begin{array}{c}1.9 \\
\text { marine }\end{array}$ \\
\hline Torlesse Supergroup & 1.1 & 2.1 & $\begin{array}{c}25 \\
? \\
\end{array}$ & $\begin{array}{c}1.8 \\
\text { marine }\end{array}$ \\
\hline
\end{tabular}

Table 5.4 Summary of the $n$-alkane and isoprenoid biomarker parameters of Marlborough formations. 
In general, the depositional environments indicated by the $\mathrm{C}_{21}+\mathrm{C}_{22} / \mathrm{C}_{28}+\mathrm{C}_{29}$ ratios and $\mathrm{C}_{\max }$ data are well supported by the physical characteristics of the sediment (such as paleontology and sedimentology) (see Chapter 2). A noticeable discrepancy, perhaps, is the marine signature of the Lower Cretaceous Torlesse Supergroup to middle Cretaceous Burnt Creek Formation of Marlborough which appears to be contradictory to the highly carbonaceous nature of some Torlesse Supergroup and Split Rock Formation samples.

Few previous GC analyses have been done on possible source rocks in the southern East Coast Basin and there has been almost no discussion of the results. Lipke (1989) and Zumberge (1990) present gas chromatograms of southern East Coast Basin samples which are very similar to those obtained in the present study. Gas chromatograms from samples of the Waipawa Black Shale, Te Mai and Glenburn formations show a predominance of high molecular weight $n$-alkanes indicating terrestrial organic matter, while a Whangai Formation sample shows a higher proportion of lower molecular weight $n$-alkanes indicating a greater marine contribution (Lipke, 1989; Zumberge, 1990).

The best possible comparisons are with those of Rogers' (1995) geochemical study of the northern East Coast Basin, as samples were analysed on the same equipment under the same conditions. Based on $\mathrm{C}_{21}+\mathrm{C}_{22} / \mathrm{C}_{28}+\mathrm{C}_{29}$ ratios and $n$-alkane maxima, Rogers (1995) showed the Lower Cretaceous Torlesse Supergroup to comprise organic matter of predominantly marine origin. The uppermost Cretaceous Whangai Formation and Eocene Wanstead Formation were shown to comprise predominantly marine organic matter, while mainly terrestrial organic matter is present in the Paleocene Waipawa Black Shale. These conclusions are very similar to those of the present study, although the sole Torlesse Supergroup sample from eastern North Island from the present study comprises organic matter of terrestrial origin.

\section{Oil-source rock correlation}

The interpretation of $n$-alkane and isoprenoid biomarker parameters is necessarily tentative, primarily due to the relative ease with which these biomarkers are affected by post-depositional alteration through maturation, migration and biodegradation. All 'source-specific' biomarker parameters are affected to some extent by these factors, and establishing a positive correlation between mature oils and their immature possible source rocks based on these parameters alone is considered impossible. Despite this, however, the relatively strong marine signatures of both the Knights Stream and Isolation Creek oils suggest their possible source rocks are limited to the uppermost Cretaceous to Eocene strata in eastern North Island (excluding the Waipawa Black Shale). A 
consideration of the hydrocarbon potential of this strata (see Chapter 4), further limits the possibilities to that of the Whangai Formation. Further support comes from the similarity of the Knights Stream oil gas chromatogram to those of the major seep oils in the northern part of the basin, which have been correlated to the Whangai Formation, and the Upper Calcareous Member in particular (Rogers, 1995). In Marlborough, there are no formations with both a predominance of marine organic matter and suitable hydrocarbon potential. The Whangai Formation is oil-prone but appears to be dominated by terrestrial organic matter, while Mata Series sediments comprise marine organic matter, but are only gas-prone. These formations are lateral equivalents of each other and it is considered likely that the source is in fact the Whangai Formation, but one which is dominated by marine organic matter, much like that present in eastern North Island.

Kerosene Rock oil has a predominance of terrestrial organic matter, with a possible minor algal input. The Lower to Upper Cretaceous and Miocene strata of eastern North Island, including the Torlesse Supergroup, Pahaoa Group, Glenburn, Te Mai, Tangaruhe and Whakataki formations, have a predominance of terrestrial organic matter, although the only formation of these that has been identified as being oil-prone is the Paleocene Waipawa Black Shale. Definitive oil-oil and oil-source rock correlations require the more diagnostic results of GC-MS and stable carbon isotope analyses and these are discussed in the following chapters. 


\subsection{Conclusions}

- The Knights Stream, Isolation Creek and Kerosene Rock oils differ in their biomarker characteristics and cannot be correlated. The Knights Stream and Isolation Creek oils appear to be derived predominantly from marine organic matter, while Kerosene Rock oil indicates a dominant terrestrial contribution with a minor marine, possibly algal component;

- The Westcott, Tiraumea and Okau Stream oils are at least moderately biodegraded oils (with both $n$-alkanes and isoprenoids absent);

- The biomarker parameters $\left(\mathrm{C}_{21}+\mathrm{C}_{22} / \mathrm{C}_{28}+\mathrm{C}_{29}\right.$ and $\left.\mathrm{C}_{\max }\right)$ of possible source rocks from eastern North Island show a trend of an increasing proportion of marine organic matter from the Lower Cretaceous Torlesse Supergroup, which contains predominantly terrestrially-derived organic matter, through to the strongly marinedominated Eocene Wanstead Formation. The Paleocene Waipawa Black Shale and Te Uri Member are exceptions with a predominance of terrestrial organic matter. This trend is then reversed to an increasing proportion of terrestrial organic matter in the Oligocene Weber Formation and Miocene Whakataki Formation. These results are largely supported by the physical characteristics of the sediments, such as the paleontology and sedimentology (see Chapter 2);

- The biomarker parameters $\left(\mathrm{C}_{21}+\mathrm{C}_{22} / \mathrm{C}_{28}+\mathrm{C}_{29}\right.$ and $\left.\mathrm{C}_{\max }\right)$ of possible source rocks from Marlborough do not show as clear trends as the eastern North Island formations. Lower Cretaceous Torlesse Supergroup to middle Cretaceous Burnt Creek Formation have a predominance of marine organic matter. This is unusual considering the carbonaceous nature of some of the Torlesse Supergroup and Split Rock Formation samples. The Upper Cretaceous formations show variable proportions of terrestrial and marine organic matter, and this is followed by a predominance of marine organic matter in the uppermost Cretaceous to Eocene Amuri Limestone;

- The gas chromatogram of the Kerosene Rock oil is similar to many formations which show a predominance of terrestrial organic matter. Of these, however, only the Waipawa Black Shale has been identified as oil-prone and having sufficient hydrocarbon generative potential to produce petroleum; 
- The gas chromatogram of the Knights Stream oil is similar in appearance to those of the northern seep oils (Waitangi, Totangi and Rotokautuku) which have previously been correlated to the Whangai Formation. The marine signatures of the Knights Stream and Isolation Creek oils also support a Whangai Formation source as other possible source rocks lack sufficient hydrocarbon generative potential; and

- Anoxic depositional conditions, as indicated by low $(<0.6) \mathrm{Pr} / \mathrm{Ph}$ ratios, are described for the many of the possible source rocks of the southern East Coast Basin. These results are not considered reliable, however, as most samples have not reached sufficient maturity to allow a confident interpretation. Only in a few samples of the Waipawa Black Shale and Upper Calcareous Member of the Whangai Formation, where 28,30-bisnorhopane is present, are anoxic conditions more fully supported. 
Chapter 6

\section{Biomarker investigations using gas chromatography- mass spectrometry (GC-MS)}

\subsection{Application of GC-MS to the investigation of biomarkers}

\subsubsection{Introduction}

Biomarker research has grown rapidly over the past decade, developing into a highly specialised discipline. The present investigation can represent only a preliminary introduction to the biomarker characteristics of oils and possible source rocks of southern East Coast Basin. However, even this initial approach can greatly enhance our knowledge of source rocks and environment of deposition, organic maturity, and biodegradation, especially when used in conjunction with other analytical techniques. Furthermore, since biomarker studies involve the analysis of soluble organic matter (bitumen) rather than kerogen, they provide an opportunity for direct comparison between oils and their possible source rocks and therefore give a means of oil-oil and oilsource rock correlation.

\subsubsection{Principles of GC-MS}

The amount of information derived from any biomarker class is proportional to its chemical complexity. Individual $n$-alkanes or acyclic isoprenoids yield relatively little information, while steranes and terpanes, through their stereochemical variability, are capable of yielding very specific information (Seifert and Moldowan, 1986). Although GC has demonstrated its ability to characterise the distributions of $n$-alkanes and acyclic isoprenoids (see Chapter 5), saturated cyclic hydrocarbons occur in much smaller quantities and their detection and structural elucidation by GC alone is simply not possible. Technological advances during the 1970s saw the coupling of GC units with mass spectrometers to create gas chromatography-mass spectrometry (GC-MS) (Figure 6.1), a very powerful analytical technique used to separate and identify trace amounts of specific organic compounds in complex hydrocarbon mixtures (Philp and Gilbert, 1986a; Noble, 1991). 


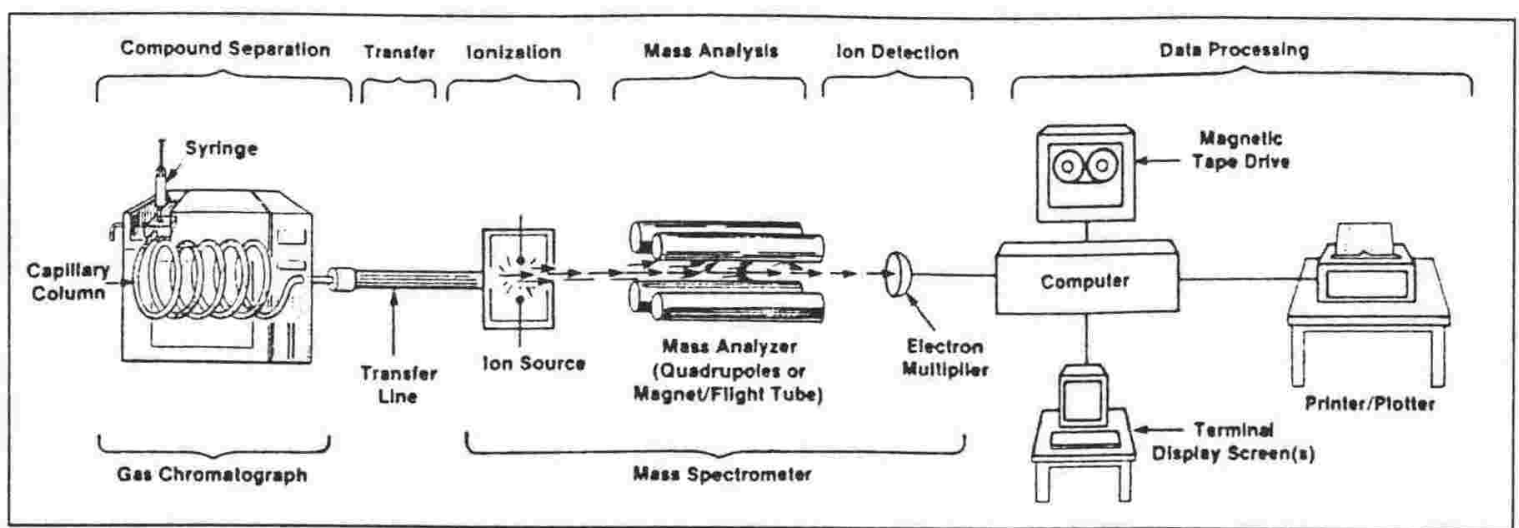

Figure 6.1 A gas chromatograph-mass spectrometer showing its six essential functions (from Peters and Moldowan, 1993).

The gas chromatography part of a GC-MS system is virtually identical to conventional GC (see Chapter 5). However, rather than combusting in a FID, compounds emerging from the column are transferred to the ionisation chamber of a mass spectrometer where they are ionised by an electron beam (Peters and Moldowan, 1993). The molecular ions formed then fragment to form more stable ions which are passed through an electromagnetic field, deflected according to their mass/charge $(\mathrm{m} / \mathrm{z})$ ratio and subsequently analysed. By varying the electromagnetic field a sweep over a range of $\mathrm{m} / \mathrm{z}$ values can be achieved and the ion current, which is proportional to the number of ions produced, is recorded for each $\mathrm{m} / \mathrm{z}$ value during the sweep, allowing a mass spectrum to be constructed (Peters and Moldowan, 1993).

The detection of trace quantities of biomarkers is possible because certain classes of biomarkers fragment in a systematic manner to produce one, or more, fragment ions characteristic of those biomarkers (Philp, 1985a; Philp and Gilbert, 1986a). By monitoring the intensity of these characteristic fragment ions during an analysis, a quick assessment can be made of their presence or absence (Philp and Gilbert, 1986a). As more biomarkers have become identified and their characteristic fragmentation patterns known, this technique of Selected Ion Monitoring (SIM) has become increasingly common (Mackenzie et al., 1982; Peters and Moldowan, 1993) and has the additional benefit of significant gains in sensitivity (Philp, 1985a). Biomarker distributions are recorded as mass chromatograms with plots of specific ions against gas chromatographic retention time (Peters and Moldowan, 1993). More detailed discussions of GC-MS can be found in Philp (1985a), Philp and Gilbert (1986a) and Peters and Moldowan (1993). 


\subsection{Sterane and triterpane biomarkers}

\subsubsection{Introduction}

Steranes and triterpanes, two of the most frequently studied compound classes in biomarker research, provide the focus of this investigation. Steranes and triterpanes are derived from living organisms, during diagenesis, from the closely related precursor compounds sterols and triterpenoids, (Waples and Machihara, 1991). If the types of organisms from which specific steroids and triterpenoids are derived are known, an understanding of paleoenvironments can be achieved (Waples and Machihara, 1991). Additionally, complex stereochemical changes occur in steranes and triterpanes during catagenesis and an understanding of these can provide detailed information regarding the thermal maturation histories of sediments and oils.

Steranes and triterpanes characteristically fragment to form major ions with $\mathrm{m} / \mathrm{z} 217$ and $\mathrm{m} / \mathrm{z} 191$ respectively (Figure 6.2) and analysis by GC-MS is possible by scanning for these two ions in SIM mode.

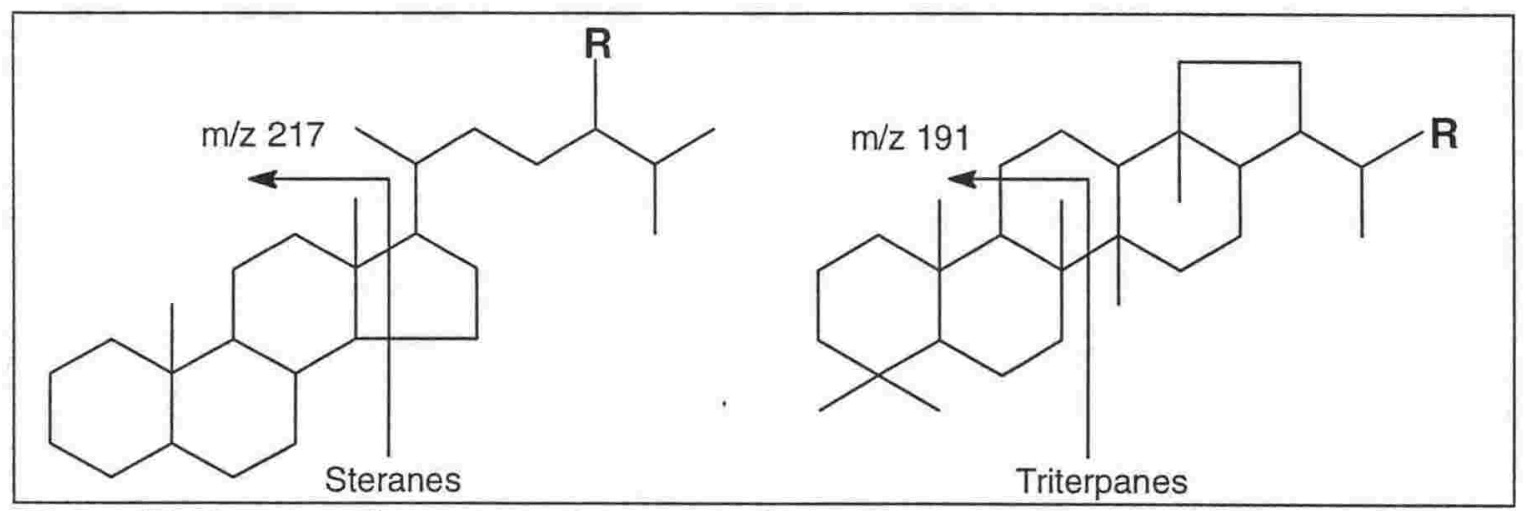

Figure 6.2 Fragmentation pattern of steranes and triterpanes.

\subsubsection{Steranes $(\mathrm{m} / \mathrm{z} 217)$}

Steranes are derived from sterols that are found in algae, plankton, zooplankton and most higher plants but are generally absent in bacteria and blue-green algae (cyanobacteria) (Seifert and Moldowan, 1986; Volkman, 1986). Four main sterol precursors containing 27-30 carbon atoms have been identified and these give rise to four different 'regular' steranes during diagenesis (Figure 6.3) (Waples and Machihara, 1991). 


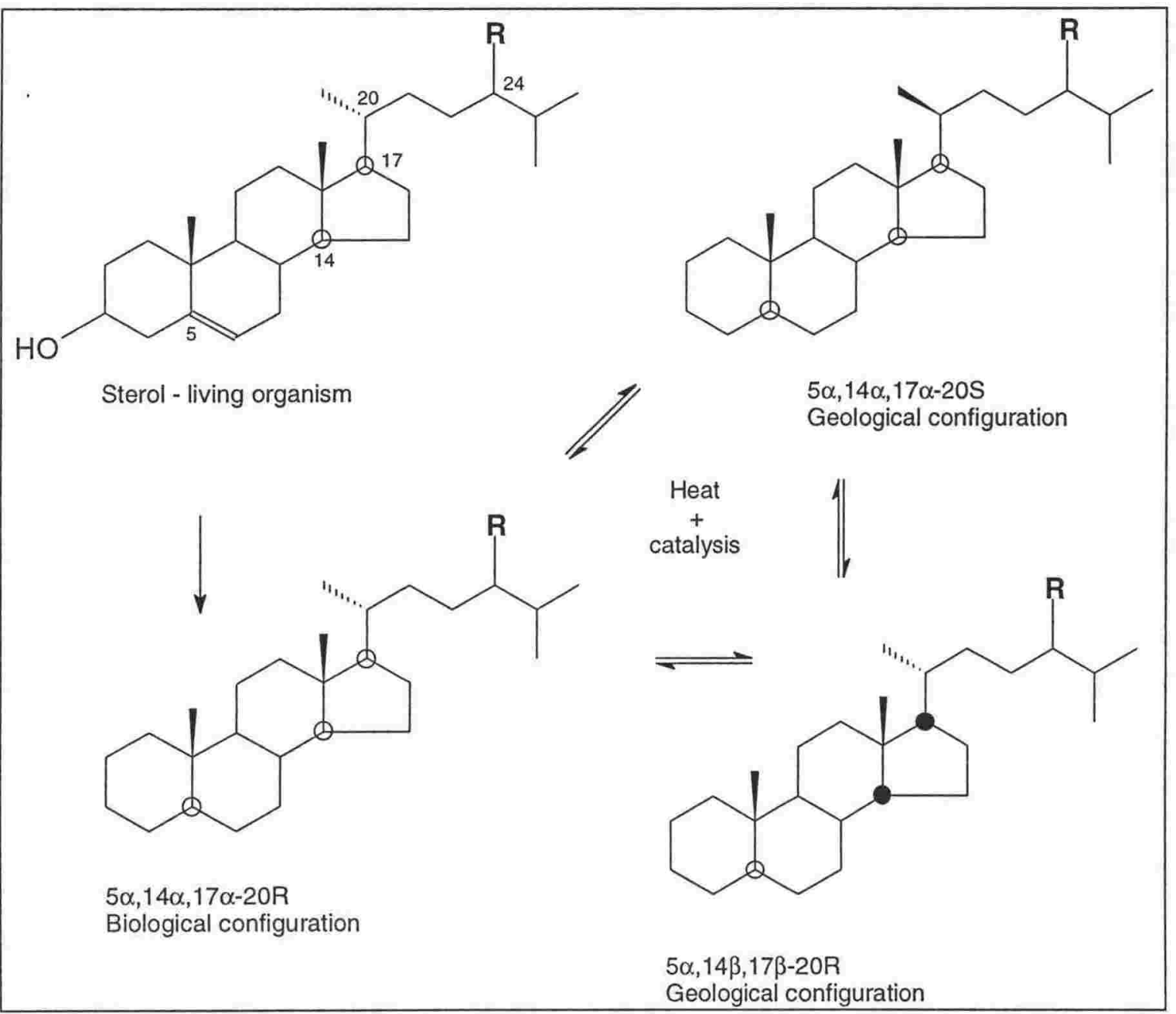

Figure 6.4 The precursor sterol and the biological and geological configurations of the sterane biomarker molecules and the equilibrium pathways between the different configurations (after Philp, 1985a). 


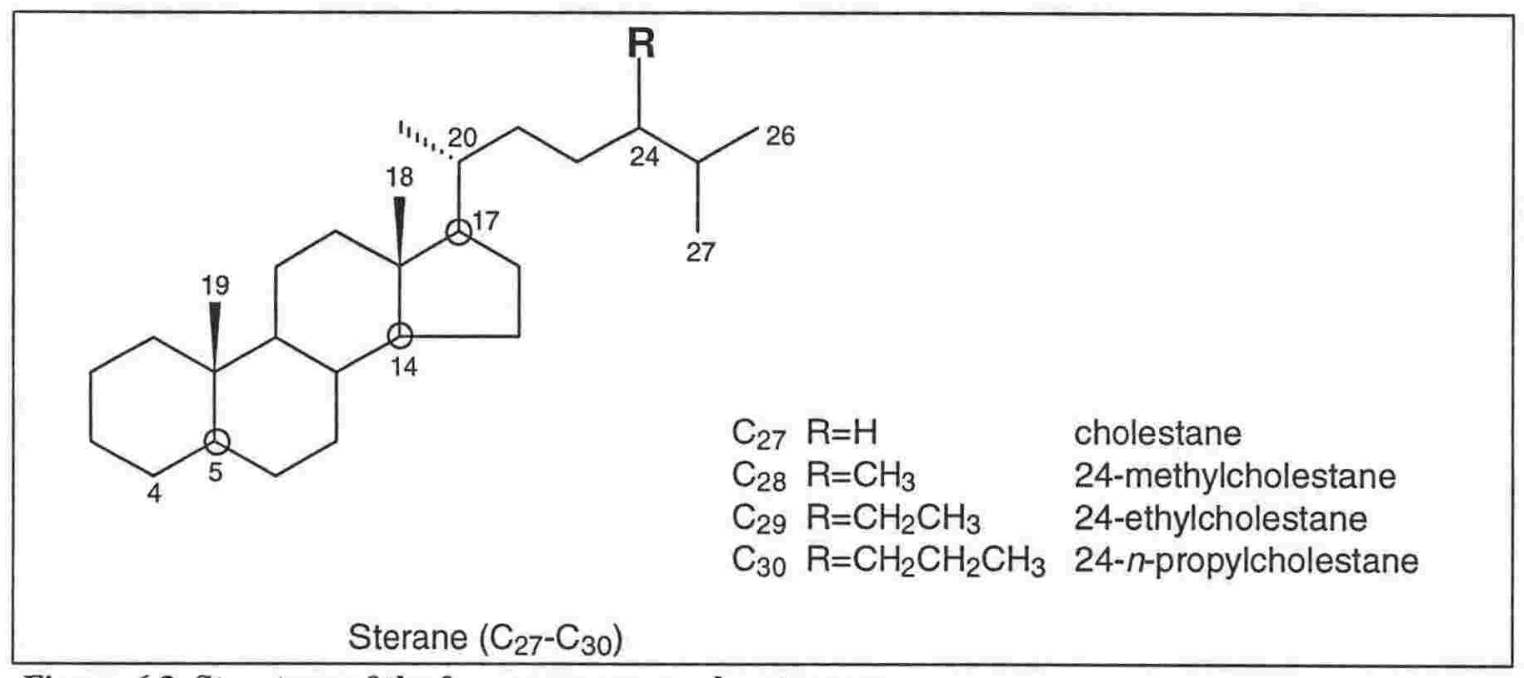

Figure 6.3 Structure of the four common regular steranes.

With only minor changes (loss of functional group and hydrogenation of double bond), the structures of newly-formed steranes are virtually identical to their precursor sterols (Figure 6.4) (Seifert and Moldowan, 1986; Waples and Machihara, 1991). Because sterol functionality occurs in the rings, interconversion between $\mathrm{C}_{27}, \mathrm{C}_{28}$ and $\mathrm{C}_{29}$ steranes is unlikely (Seifert and Moldowan, 1986). Steranes are therefore very useful as source indicators and for oil-oil and oil-source rock correlations (see Section 6.3.4).

Although stereoisomerism exists at the C-5, -8, -9, -14, -17, -20 and -24 positions, thermodynamic stability is such that the C-8 and C-9 positions are always in the $\beta$ (up) and $\alpha$ (down) configurations respectively, and there appears to be little stereopreference for C-24 isomers (Mackenzie, 1984). Hence steranes are often described according to their C-5, $-14,-17$ and -20 positions only.

The C-5 chiral centre is not particularly stereospecific and hence there are two 'biological' configurations of steranes. The dominant isomer is $5 \alpha(\mathrm{H}), 14 \alpha(\mathrm{H}), 17 \alpha(\mathrm{H})-20 \mathrm{R} \quad$ (or $\quad \alpha \alpha \alpha-20 \mathrm{R}$ ) while $5 \beta(\mathrm{H}), 14 \alpha(\mathrm{H}), 17 \alpha(\mathrm{H})-20 \mathrm{R} \quad$ (or $\beta \alpha \alpha-20 \mathrm{R})$ ( $\mathrm{R}=$ right and $\mathrm{S}=\mathrm{left}$ ) is a very minor isomer. Only the $-20 \mathrm{R}$ epimers are produced biologically. The $\beta \alpha \alpha$ isomer coelutes with $\alpha \beta \beta$ isomers and is not easily quantified. However, it is less stable than the $\alpha \alpha \alpha$ configuration and is thought to convert at higher temperatures (mature samples only have $5 \alpha$ configuration).

Although most diagenetically-produced steranes are of the $\alpha \alpha \alpha$ form, $\alpha \beta \beta$ forms may also be produced. With increasing thermal stress the 'geological' configurations ( $\alpha \alpha \alpha-20 \mathrm{~S}$ and $\alpha \beta \beta-20 \mathrm{R}$ ) become more favoured at the expense of the biological configuration (Seifert and Moldowan, 1986). 


\subsubsection{Triterpanes $(\mathrm{m} / \mathrm{z} 191)$}

Triterpanes are believed to originate mostly from bacteria and blue-green algae, some specifically from the cell membranes (Philp, 1985a; Rohmer et al., 1992). Triterpanes are a class of terpane comprising approximately 30 carbon atoms (depending on side chains), and are divided into three distinct families based on the number of rings; tricyclic, tetracyclic and pentacyclic (Waples and Machihara, 1991). By far the most abundant and the most studied are the pentacyclic triterpanes with five rings (Waples and Machihara, 1991).

\section{Pentacyclic triterpanes}

Pentacyclic triterpanes commonly comprise $\mathrm{C}_{27}-\mathrm{C}_{35}$ compounds although they have been reported up to $\mathrm{C}_{40}$ (Philp, 1985a; Waples and Machihara, 1991) (Figure 6.5). Pentacyclic triterpanes are further divided into the 'hopanoids' and 'nonhopanoids' with the hopanoids including both $17 \alpha(\mathrm{H}), 21 \beta(\mathrm{H})$ 'hopanes' and the $17 \beta(\mathrm{H}), 21 \alpha(\mathrm{H})$ 'moretanes'.

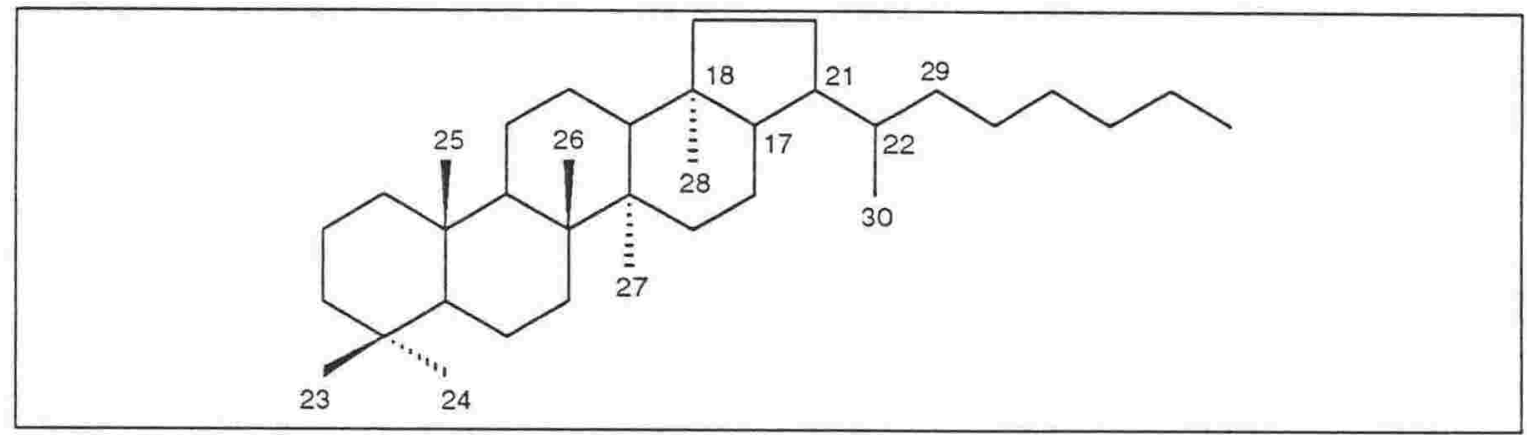

Figure 6.5 Pentacyclic triterpane with additional side chain.

The most common pentacyclic triterpanes are the hopanes which are derived largely from bacteria and blue-green algae but also from higher plants and cryptogams (ferns, mosses, lichens and fungi) (Rohmer et al., 1992). The most commonly analysed hopanes contain $\mathrm{C}_{27}$ to $\mathrm{C}_{35}$ compounds which form a homologous series with the $17 \alpha(\mathrm{H}), 21 \beta(\mathrm{H})$ configuration.

Because bacteria are ubiquitous in most depositional environments hopanes are not so useful in source and depositional environment investigations. Their usefulness however has been in maturity studies. Like that of the steranes, the molecular structure of triterpanes is little affected by diagenesis. The most common biological configuration is $17 \beta(\mathrm{H}), 21 \beta(\mathrm{H})$ and this is present only in very immature samples. With increasing maturity, conversion to a more stable 'geological' configuration occurs, forming $17 \alpha(\mathrm{H}), 21 \beta(\mathrm{H})$ (hopanes) and $17 \beta(\mathrm{H}), 21 \alpha(\mathrm{H})$ (moretanes) (Figure 6.6). The $\mathrm{C}_{29}$ and $\mathrm{C}_{30}$ hopanes have no chiral carbon atoms in their side chains but the $\mathrm{C}_{31}$ - $\mathrm{C}_{40}$ hopanes 
('homohopanes' or 'extended hopanes'), however, all have a single chiral carbon atom (C-22) in the side chain, and can exist as both $-22 \mathrm{R}$ and $-22 \mathrm{~S}$ epimers. The biological configuration consists only of the $-22 R$ epimer but with greater maturity the $-22 \mathrm{~S}$ epimer increasingly appears.

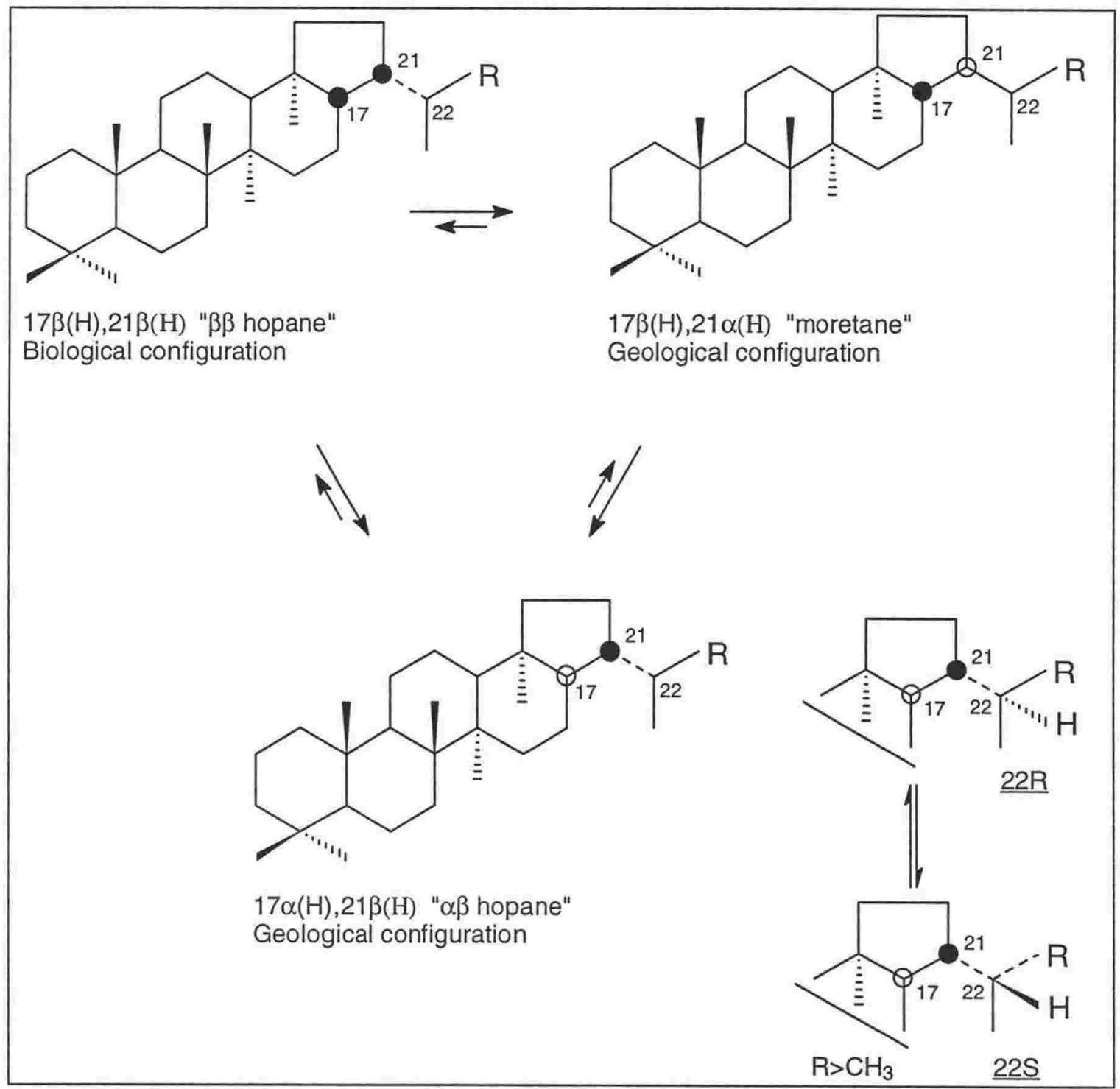

Figure 6.6 The biological and geological configurations of the hopane biomarkers and the equilibrium pathways between the different configurations. 


\subsection{Source, maturity and biodegradation: What the biomarker parameters can tell us}

\subsubsection{Source-specific biomarkers}

Biomarkers represent the remains of living organisms that existed under certain conditions and the dominance of a single or restricted assemblage can, therefore, be used as both source and/or environmental indicators (Peters and Moldowan, 1993). Usually, however, there is not a unique interpretation for most biomarkers and it is more likely there are multiple precursors that come from different organisms from a wide range of environments. Therefore, the presence or absence of a single biomarker is not completely diagnostic and it is common to use an assemblage of biomarker data (Waples and Machihara, 1991). Although there are many source-specific biomarkers described in the literature, a brief discussion of selected biomarkers identified in the present study is included below. The term 'source-specific' is used in reference to both source and/or environmental indicators for, in some cases, certain biomarkers have been linked to specific depositional environments (such as 28,30-bisnorhopane with regards to anoxic environments) without the actual source (organism) having been positively identified.

\section{Steranes $(\mathbf{m} / \mathbf{z} 217)$ \\ $\mathrm{C}_{27}-\mathrm{C}_{28}-\mathrm{C}_{29}$ steranes}

Huang and Meinschein (1979) showed that the relative proportions of the $C_{27}$ to $C_{29}$ regular sterols in living organisms were related to specific environments and suggested that steranes in sediments might provide paleoenvironmental information. They proposed that a predominance of $\mathrm{C}_{29}$ sterols (or steranes) indicates a strong higher plant contribution, a dominance of $\mathrm{C}_{27}$ sterols indicates largely marine zooplankton and $\mathrm{C}_{28}$ sterols, where abundant, indicate a strong contribution of lacustrine algae (Figure 6.7). This initial study, however, has proved to be somewhat simplistic as Moldowan et al. (1985) have demonstrated that an increased proportion of $\mathrm{C}_{28}$ steranes may indicate a greater contribution of marine organic matter, and Volkman (1986) has shown that both $\mathrm{C}_{27}$ and $\mathrm{C}_{29}$ sterols are produced by marine organisms. Despite its limitations, the $\mathrm{C}_{27}-\mathrm{C}_{28}-\mathrm{C}_{29}$ sterane ternary diagram is still commonly used in source studies and, therefore, is utilised in the present study.

Geotech (1992) used the $\mathrm{C}_{27} / \mathrm{C}_{29}$ sterane ratio as a source indicator, with values below 0.85 indicative of terrestrial organic matter, values between 0.85 and 1.43 for mixed marine and terrestrial organic matter, and values greater than 1.43 for predominantly 
marine organic matter. They also urged caution with this simplistic approach and noted the need for corroborative data.

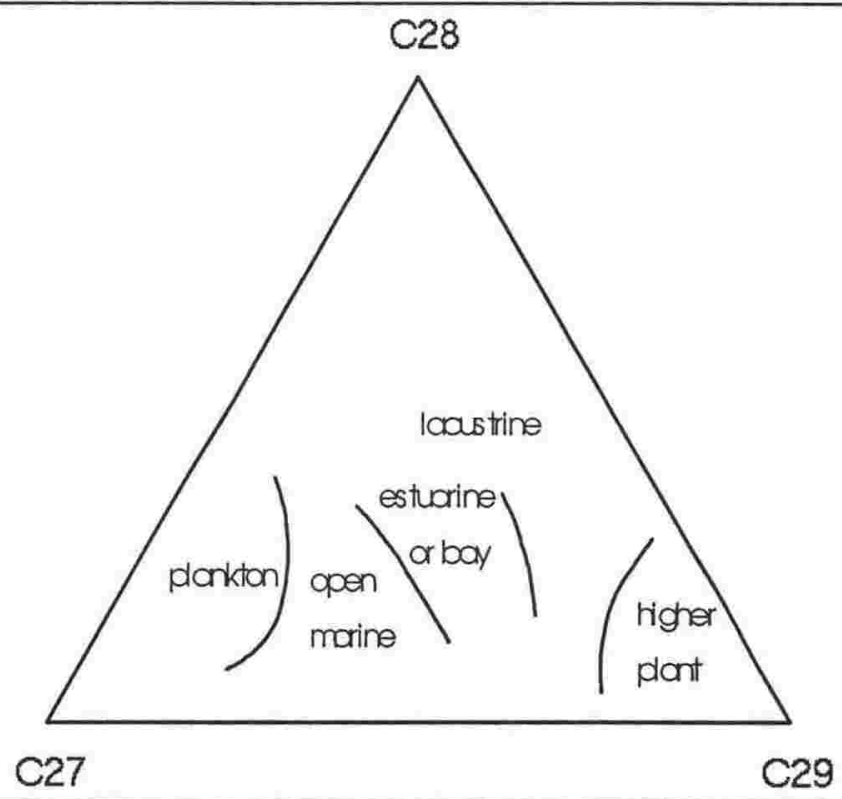

Figure 6.7 Relationship between sterol compositions in organisms and the environment in which they exist (after Huang and Meinschein, 1979).

\section{$\mathrm{C}_{30}$ steranes}

$\mathrm{C}_{30}$ steranes are common, although usually in low quantities, in marine sediments. A number of $\mathrm{C}_{30}$ steranes have been identified including predominantly 4-desmethyl steranes such as 24-n-propylcholestane and 24-isopropylcholestane but also 4-methyl

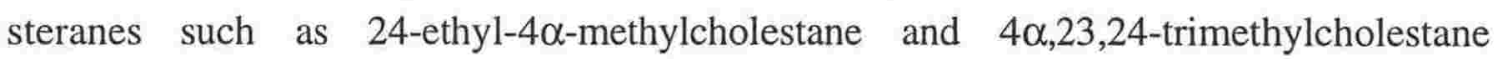
(dinosterane). 24- $n$-propylcholestane, a regular $\mathrm{C}_{30}$ sterane, is derived from 24-n-propylcholestrol which is synthesised by marine Chrysophyte algae and is highly specific for marine organic matter (Moldowan et al., 1990). 24-isopropylcholestane is thought to be derived from certain Porifera (sponges) and appears to dominate 24- $n$-propylcholestane from the Late Proterozoic up until the Early Cambrian. This pattern is reversed in younger rocks and 24-isopropycholestane appears to be a minor component in Cretaceous and Cenozoic sediments (McCaffrey et al., 1994). Dinosteranes appear to be derived from dinoflagellates and are useful biomarkers for Mesozoic and Cenozoic marine organic matter (Summons et al., 1992). The origin of 24-ethyl-4 $\alpha$-methylcholestane, common in both marine and lacustrine sediments, is still unknown, although a dinoflagellate source has been suggested (Summons et al., 1992). The complex structures of these $\mathrm{C}_{30}$ steranes cannot be resolved through (SIM) GC-MS and require the use of GC-MS/MS. 


\section{$\mathrm{C}_{30} /\left(\mathrm{C}_{27}\right.$ to $\left.\mathrm{C}_{30}\right)$ steranes $\left(\mathrm{C}_{30}\right.$ sterane index $)$}

The $\mathrm{C}_{30}$ sterane index is a measure of the relative amounts of the $\mathrm{C}_{30}$ regular steranes as a proportion of the total common $\left(\mathrm{C}_{27}-\mathrm{C}_{30}\right)$ regular steranes. $\mathrm{A} \mathrm{C}_{30}$ index of zero indicates a sample of terrestrial origin (Peters and Moldowan, 1993). Indices for the $C_{27}$, $\mathrm{C}_{28}$ and $\mathrm{C}_{29}$ steranes can also be used to indicate their relative proportion of the regular steranes.

\section{Triterpanes $(\mathrm{m} / \mathrm{z} 191)$}

\section{8,30-Bisnorhopane}

Although the source of 28,30-bisnorhopane remains uncertain its presence in high concentrations is typical of highly reducing to anoxic depositional environments although its absence does not exclude anoxia (Peters and Moldowan, 1993). It appears 28,30-bisnorhopane is not generated from kerogen but passed on from free bitumen in the source rock to the oil, and therefore the concentration of this compound drops as source rocks generate oil during maturation. The three epimeric forms of 28,30-bisnorhopane $[17 \alpha, 21 \beta(\mathrm{H})-, \quad 17 \beta, 21 \alpha(\mathrm{H})-$, and $17 \beta, 21 \beta(\mathrm{H})-]$ cannot be distinguished by their mass spectra and special conditions are required to separate them by gas chromatography (Moldowan et al., 1984). The diagenetically first-formed is thought to be the $17 \alpha, 21 \beta(\mathrm{H})$ - epimer because it predominates in immature shales (Moldowan et al., 1984). All three epimers are present in petroleum.

\section{$17 \alpha(\mathbf{H})$-Diahopane (previously compound ' $\mathrm{X}$ ')}

$17 \alpha(\mathrm{H})$-Diahopane, a rearranged hopane previously referred to as compound ' $\mathrm{X}$ ' or 'X-C 30 ' (Philp and Gilbert, 1986b; Collier, 1989; Waples and Machihara, 1991), has only recently been structurally elucidated. Philp and Gilbert (1986b) considered the compound to be a possible terrestrial biomarker as it is present in coals and terrestrially-sourced oils. Peters and Moldowan (1993), however, concluded that $17 \alpha(\mathrm{H})$-diahopane is derived from bacterial input into clay-rich sediments deposited under oxic to suboxic conditions, which is also consistent with the terrestrial setting proposed by Philp and Gilbert (1986b). Although depositional environments appear to exert a major control on the relative concentration of $17 \alpha(\mathrm{H})$-diahopane, it has been found to be more stable than $17 \alpha(\mathrm{H})$-hopanes and is expected to increase relative to both $\mathrm{C}_{29}$ and $\mathrm{C}_{30} \alpha \beta$-hopanes with increasing maturity.

\section{Oleanane}

Oleanane, a $\mathrm{C}_{30}$ 'nonhopanoid' pentacyclic triterpane, is thought to be derived from terrestrial higher plants, especially angiosperms (Moldowan et al., 1994). Evolution of angiosperms occurred during the Cretaceous with oleanane becoming prominent in the 
Late Cretaceous. Oleanane is not found in rocks older than Cretaceous, although the absence of oleanane does not necessarily imply generation from rocks Cretaceous or older (Peters and Moldowan, 1993). The relative concentration of oleanane increases (compared with $\mathrm{C}_{30} \alpha \beta$-hopane) with maturity and therefore should not be used to compare the relative higher plant input between immature and mature samples (Peters and Moldowan, 1993). Both $18 \alpha(\mathrm{H})$ - and $18 \beta(\mathrm{H})$ - epimers exist, with the $18 \alpha(\mathrm{H})$ - form the more thermally stable. In the present study, the epimers are not differentiated and they are recorded simply as oleanane. Other pentacyclic triterpanes with similar retention times and mass spectra can interfere with (SIM) GC-MS analysis (ten Haven et al., 1993; Moldowan et al., 1994) and so the identification of oleanane is, at best, only tentative.

\section{Gammacerane}

Gammacerane, a $\mathrm{C}_{30}$ 'nonhopanoid' pentacyclic triterpane like oleanane, appears to be a marker for highly saline marine and nonmarine depositional environments (Peters and Moldowan, 1993). It is thought to be derived from tetrahymanol which is present in certain protozoans and bacteria (Peters and Moldowan, 1993). Due to the structural symmetry of gammacerane two identical m/z 191 fragments are generated in the mass spectrometer and this can result in a large peak on the $\mathrm{m} / \mathrm{z} 191$ mass chromatogram despite low concentrations of gammacerane compared to other terpanes (Peters and Moldowan, 1993).

\subsubsection{Maturity biomarker parameters}

Biomarker distributions are sensitive to the time-temperature history of sedimentary rocks. With increasing burial in the subsurface, biomarker ratios often change in a systematic way which can be used to infer maturation trends (Noble, 1991). The number of maturity biomarker parameters proposed in the literature is huge and many have yet to be properly investigated to determine whether they are completely dependent on source. Only the more common, and least disputed, maturity biomarker parameters obtained from either the $\mathrm{m} / \mathrm{z} 191$ or 217 chromatograms are used in this study.

\section{Steranes $(\mathbf{m} / \mathbf{z} 217)$}

\section{$20 \mathrm{~S} /(20 \mathrm{~S}+20 \mathrm{R})$ sterane isomerization}

Isomerization at $\mathrm{C}-20$ in the $\mathrm{C}_{29} 5 \alpha(\mathrm{H}), 14 \alpha(\mathrm{H}), 17 \alpha(\mathrm{H})$-steranes causes the $20 \mathrm{~S} /(20 \mathrm{~S}+20 \mathrm{R})$ ratio to rise from 0 to about 0.5 with increasing maturity (Seifert and Moldowan, 1986) (Figure 6.8). A value of 0.25 indicates the onset of oil generation, with peak oil generation at 0.5 (Geotech, 1992). This ratio is most commonly reported for the $\mathrm{C}_{29}$ steranes because the $\mathrm{C}_{27}$ and $\mathrm{C}_{28}$ steranes often show interference by 
coeluting peaks (Seifert and Moldowan, 1986). For example $\mathrm{C}_{29}(-20 \mathrm{~S})$ diasterane coelutes with $\mathrm{C}_{27} \alpha \beta \beta-20 \mathrm{R}$.

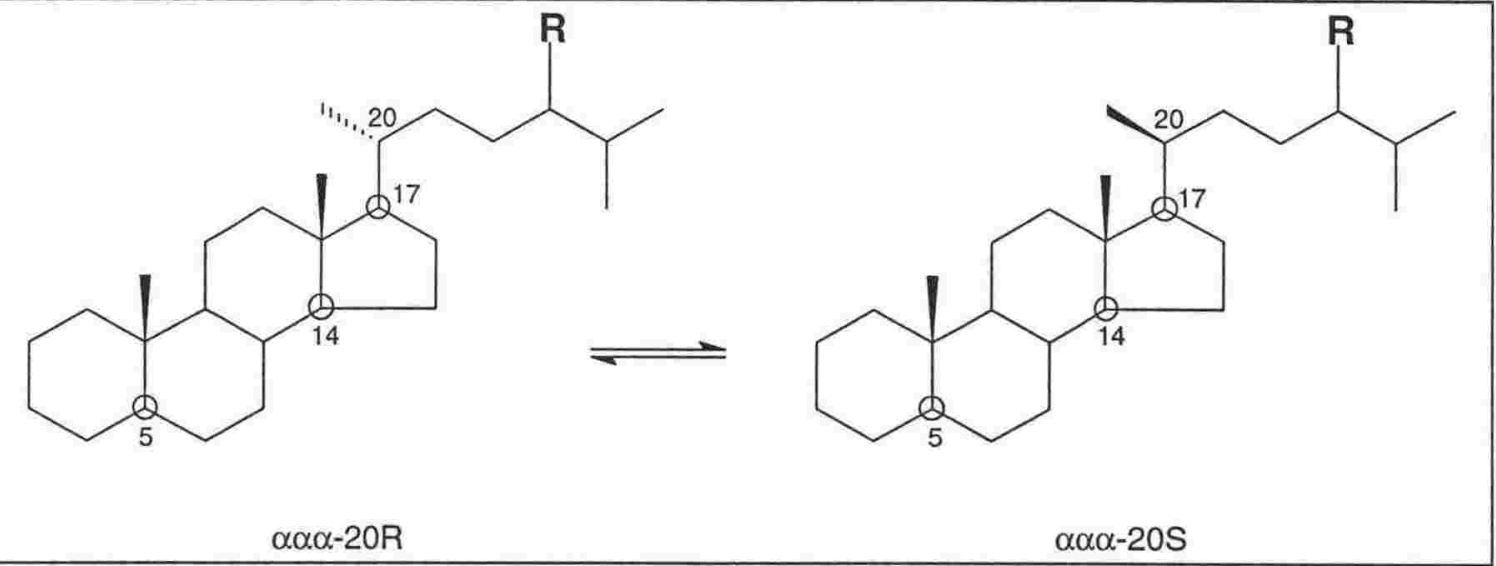

Figure $6.820 \mathrm{~S} /(20 \mathrm{~S}+20 \mathrm{R})$ sterane isomerization.

\section{$\% \beta \beta$ sterane isomerization}

Isomerization at the $\mathrm{C}-14$ and $\mathrm{C}-17$ positions in the $-20 \mathrm{~S}$ and $-20 \mathrm{R}$ regular steranes (Figure 6.9) causes an increase in the ratio $\beta \beta /(\beta \beta+\alpha \alpha)$ from nonzero values to about 0.7 (Seifert and Moldowan, 1986).

$$
\% \beta \beta=\frac{\alpha \beta \beta-20 \mathrm{R}+\alpha \beta \beta-20 \mathrm{~S}}{\alpha \beta \beta-20 \mathrm{R}+\alpha \beta \beta-20 \mathrm{~S}+\alpha \alpha \alpha-20 \mathrm{R}+\alpha \alpha \alpha-20 \mathrm{~S}}
$$

This ratio appears to be independent of source organic matter input and somewhat slower to reach equilibrium than the $20 \mathrm{~S} /(20 \mathrm{~S}+20 \mathrm{R})$ ratio, with a ratio of 0.7 equivalent to a maturity of peak oil generation (about $0.9 \% \mathrm{R}_{\mathrm{o}}$ ) (Geotech, 1992).

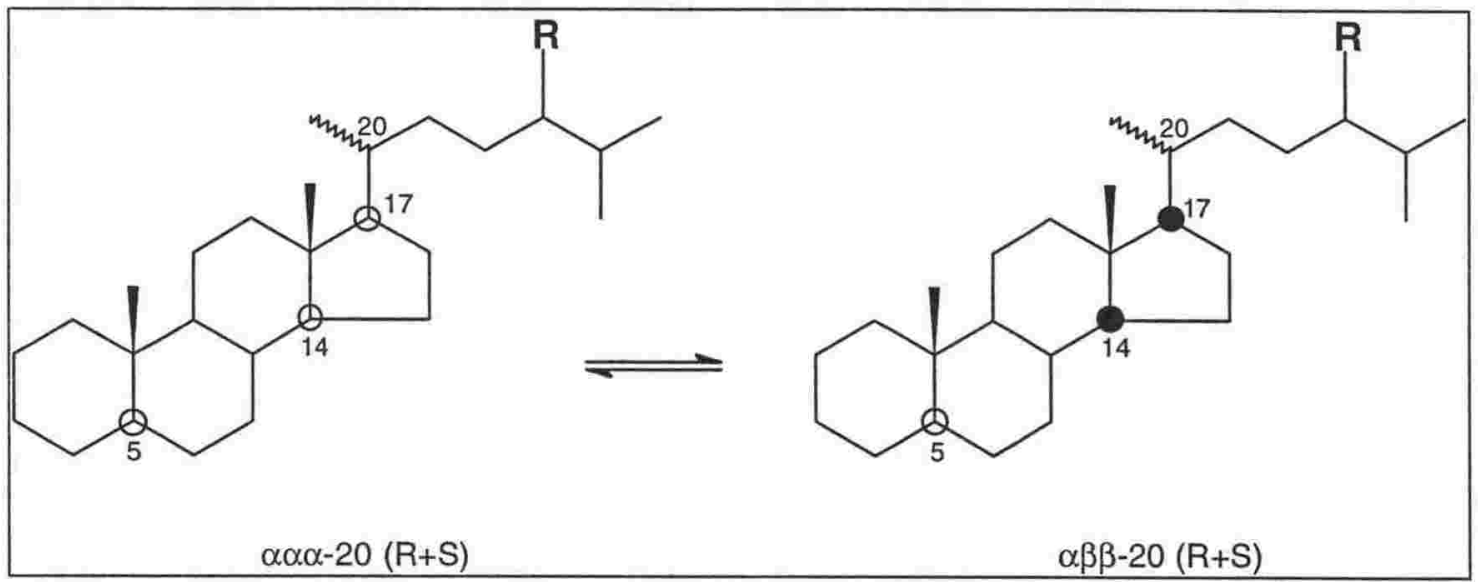

Figure $6.9 \% \beta \beta$ sterane isomerization.

$\% \beta \beta$ ratio for $\mathrm{C}_{27}$ steranes is occasionally not reliable due to coelution of $\mathrm{C}_{27} \alpha \beta \beta-20 \mathrm{R}$ isomer with $\mathrm{C}_{29}(-20 \mathrm{~S})$ diasterane. This has the effect of increasing the $\% \beta \beta$ ratio, and 
falsely inflating the maturity of the sample under investigation. Chromatograms showing high concentrations of $\mathrm{C}_{29}$ diasteranes should be examined carefully, and more emphasis given to the $\% \beta \beta$ ratio of $\mathrm{C}_{29}$ steranes. In hypersaline environments $\alpha \beta \beta$-steranes have been shown to form directly from precursor sterenes during diagenesis (ten Haven et al., 1986), and therefore providing immature samples with a mature appearance by increasing the $\% \beta \beta$ ratio.

\section{Diasteranes}

Diasteranes are rearranged steranes with methyl groups at C-5 and -14 . They are thought to be formed from clay catalysis during diagenesis and catagenesis and are both source and maturity dependent. Diasteranes are more abundant in clay-rich clastic sediments than clay-poor carbonate sequences (Peters and Moldowan, 1993). Diasteranes appear to be more stable than regular steranes and become more dominant with increasing maturity (Waples and Machihara, 1991). They are known to occur from $\mathrm{C}_{27}$ to $\mathrm{C}_{30}$ but are most easily observed as $\mathrm{C}_{27}$ compounds due to minimal interference. Like regular steranes, the $\mathrm{C}_{27} / \mathrm{C}_{29}$ diasterane ratio can be used as a source indicator with a predominance of $\mathrm{C}_{27}$ diasteranes indicative of a marine organic matter and $\mathrm{C}_{29}$ steranes of terrestrial organic matter (Geotech, 1992). Once again, interpretation of source by this method needs to be supported by other evidence.

\section{Triterpanes $(\mathrm{m} / \mathrm{z} 191)$}

\section{$22 S /(22 S+22 R)$ homohopane isomerization}

Isomerization at the $\mathrm{C}-22$ position in the $\mathrm{C}_{31}-\mathrm{C}_{35} 17 \alpha(\mathrm{H}), 21 \beta(\mathrm{H})$-hopanes occurs with the biological $-22 \mathrm{R}$ configuration gradually converting to a mixture of $-22 \mathrm{R}$ and $-22 \mathrm{~S}$ diastereomers (Figure 6.10).

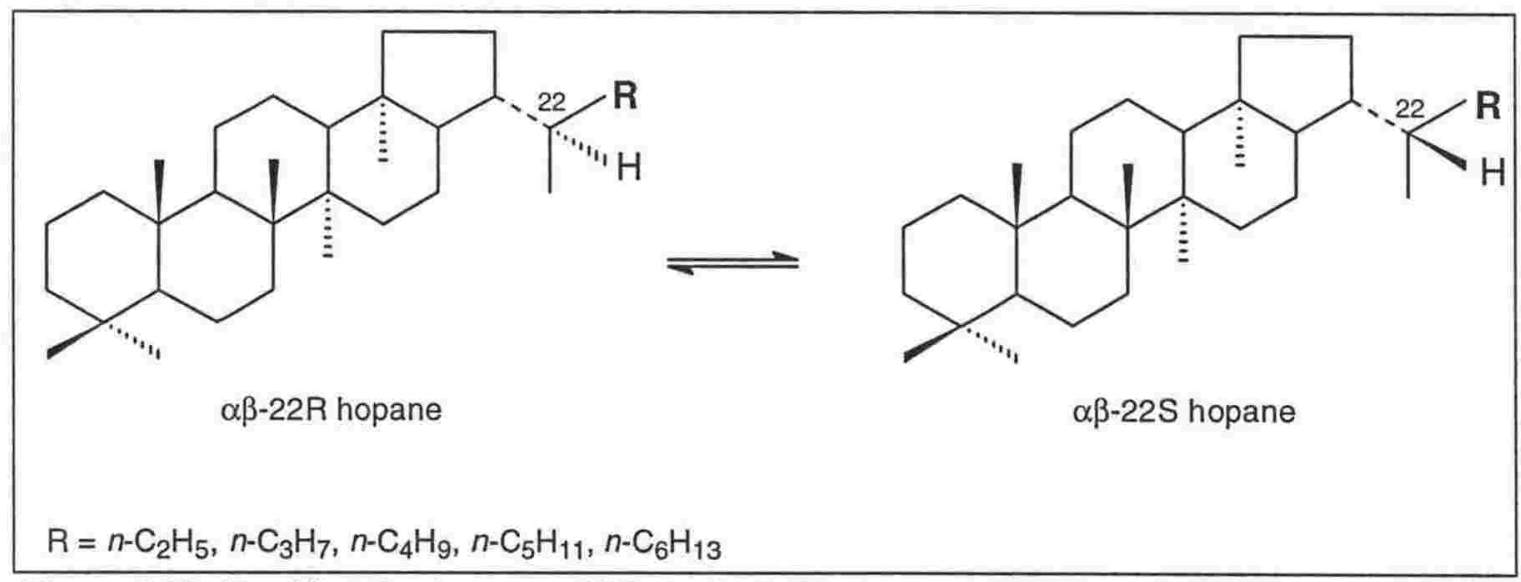

Figure 6.10 Equilibration between -22R (biological epimer) and -22S (geological epimer) for the $\mathrm{C}_{31}$ to $\mathrm{C}_{35}$ homohopanes (from Peters and Moldowan, 1993). 
The $22 \mathrm{~S} /(22 \mathrm{~S}+22 \mathrm{R})$ homohopane ratio rises from 0-0.6 during maturation with equilibrium occurring at $0.6 \% \mathrm{R}_{\mathrm{o}}$ (onset of oil generation), and is therefore used as a qualitative assessment for minimal thermal maturity. The ratio is typically calculated for the $\mathrm{C}_{31}$ and $\mathrm{C}_{32}$ homohopanes although the $\mathrm{C}_{32}$ ratio is often more reliable as coelution sometimes affects the $C_{31}$ ratio. For example gammacerane may coelute with the $-22 R$ epimer of the $C_{31}$ homohopane (Peters and Moldowan, 1993).

\section{$\beta \beta$-hopanes and $\beta \alpha$-moretanes $/ \alpha \beta$-hopanes}

The biological $\beta \beta$-hopane configuration is very unstable and readily converts to either $\beta \alpha$-moretane or $\alpha \beta$-hopane during diagenesis. Moretane and hopane have different thermal stabilities and the moretane/hopane ratio is controlled by their differing rates of destruction during catagenesis (Peters and Moldowan, 1993). Moretane is lost more rapidly than hopane and the ratio decreases from about 0.8 in immature bitumens to less than 0.15 in mature source rocks and 0.05 in oils. Moretane loss occurs early and is used mainly as a qualitative indicator of immaturity where, if the moretane/hopane ratio is above about 0.15 , the maturity level of the sample is below the onset of oil generation (less than 0.6\% $\mathrm{R}_{0}$ ) (Waples and Machihara, 1991). The moretane/hopane ratio can be used for both $\mathrm{C}_{29}$ and $\mathrm{C}_{30}$ compounds.

\section{$\mathrm{Tm} / \mathrm{Ts}$}

The $17 \alpha(\mathrm{H})-22,29,30$-trisnorhopane/ $18 \alpha(\mathrm{H})-22,29,30$-trisnorneohopane $(\mathrm{Tm} / \mathrm{Ts}$ ) ratio (see also Figure 6.11) is both maturity and source-dependent and is, therefore, most reliable as a maturity indicator when evaluating samples containing similar types of organic matter (Philp, 1985a; Peters and Moldowan, 1993). Tm is less stable than Ts, causing a decrease in the $\mathrm{Tm} / \mathrm{Ts}$ ratio with increasing thermal maturation (Waples and Machihara, 1991).

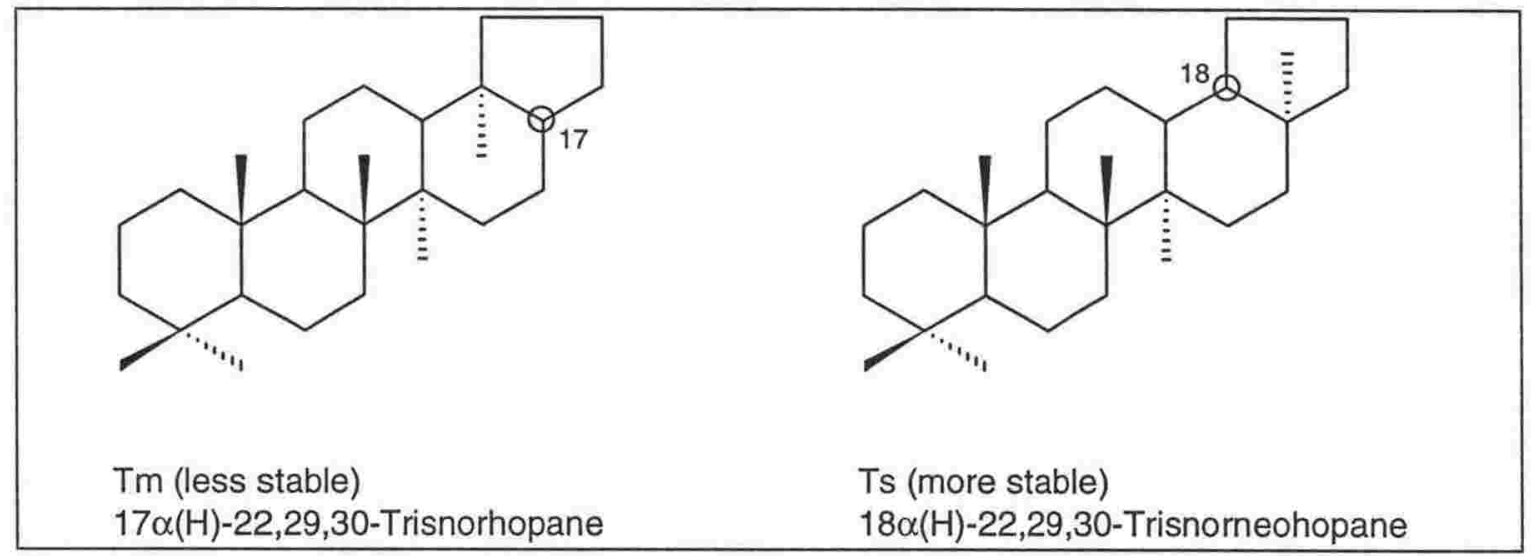

Figure 6.11 Structural forms of $17 \alpha(\mathrm{H})-22,29,30$-trisnorhopane $(\mathrm{Tm})$ and $18 \alpha(\mathrm{H})-22,29,30$ trisnorneohopane (Ts). 
Another compound related to $\mathrm{Tm}$ and $\mathrm{Ts}$ is $17 \beta(\mathrm{H})-22,29,30$-trisnorhopane. This compound shows greater stability than $\beta \beta$-hopane but has less stability than $\mathrm{Tm}$ and $\mathrm{Ts}$ and its concentration approaches zero at maturities equivalent to the onset of oil generation (Peters and Moldowan, 1993).

Biomarker maturation parameters respond in different maturity ranges (Figure 6.12). Maturity ranges are not linear in scale and inferring vitrinite reflectance values from the biomarker ratios is inadvisable (Peters and Moldowan, 1993).

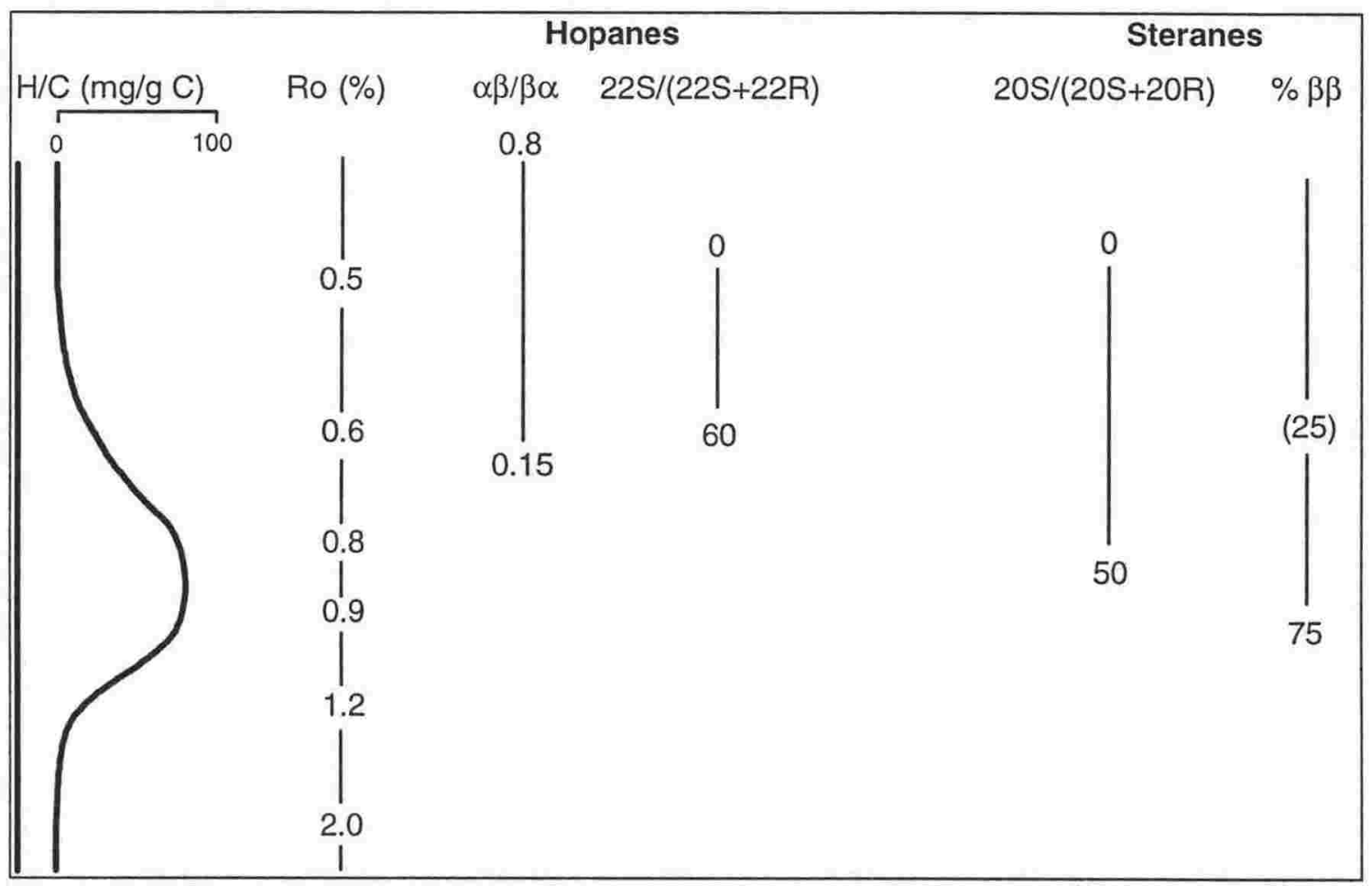

Figure 6.12 Approximate correlation of selected maturity parameters plotted against the hydrocarbon generation curve and corresponding vitrinite reflectance values (after Mackenzie, 1984; Killops and Killops, 1993; and Peters and Moldowan, 1993).

Waples and Machihara (1991) observed a retardation of molecular transformations in clay-free and organic-poor rocks (typically carbonates) and caution the use of biomarker maturities for these rock types. Either the absence of clays (and hence clay catalysis) may inhibit the formation of stable biomarker epimers from less stable ones, or organic-poor rocks prevent the formation of new hydrocarbons with more stable configurations (Waples and Machihara, 1991).

\subsubsection{Biodegradation biomarker parameters}

Different biomarker compound classes have different susceptibilities to biodegradation and Table 6.1 shows a ten point scale, proposed by Peters and Moldowan (1993), to 
rank its extent. Biodegradation occurs in a manner such that degradation of the next most resistant class of biomarkers may start before the previous group have been completely removed.

Selectivity in biodegradation has also been reported within biomarker compound groups. For example, Rullkötter and Wendisch (1982) describe the selective removal of $\alpha \alpha \alpha-20 \mathrm{R}$ steranes by bacterial degradation, thereby affecting sterane maturity parameters.

\begin{tabular}{|c|c|c|}
\hline & $\begin{array}{l}\text { Extent of biodegradation } \\
\text { (from Peters and Moldowan, 1993) }\end{array}$ & $\begin{array}{l}\text { Degree of biodegradation } \\
\text { (from Volkman } \text { et al., 1983) }\end{array}$ \\
\hline 1. (least) & Short chain $n$-alkanes depleted & minor biodegradation \\
\hline 2. & General depletion of $n$-alkanes & \\
\hline 3. & Only traces of $n$-alkanes remain & moderate biodegradation \\
\hline 4. & No $n$-alkanes, acyclic isoprenoids intact & \\
\hline 5. & Acyclic isoprenoids absent & \\
\hline 6. & Steranes partly degraded & \\
\hline 7. & Steranes degraded, diasteranes intact & extensive biodegradation \\
\hline 8. & Hopanes partly degraded & severe biodegradation \\
\hline & Hopanes absent, diasteranes attacked & extreme biodegradation \\
\hline 10. (most) & $\mathrm{C}_{26}-\mathrm{C}_{29}$ aromatic steroids attacked & \\
\hline
\end{tabular}

Table 6.1 Ten point scale ranking the extent of biodegradation (from Peters and Moldowan, 1993), with comparison to the biodegradation scale of Volkman et al. (1983).

\subsubsection{Oil-oil and oil-source rock correlation}

Oils are formed from the organic matter in source rocks, and hence the biomarker 'fingerprints' of each should be very similar. These fingerprints usually involve those compounds that are not affected by maturity, and typically include source-specific biomarkers such as those outlined in Section 6.3.1.

The distribution of $\mathrm{C}_{27}-\mathrm{C}_{28}-\mathrm{C}_{29}$ homologous steranes in oils have been shown to represent the distribution of corresponding sterols from the original organic matter and these plots do not change significantly with thermal maturation. Hence the $C_{27}-C_{28}-C_{29}$ sterane ternary diagram can be used in oil-oil and oil-source rock correlations (Peters and Moldowan, 1993). Where $C_{30}$ steranes are important, ternary diagrams with $C_{27}-C_{29}-C_{30}$ or $\left(\mathrm{C}_{27}+\mathrm{C}_{28}\right)-\mathrm{C}_{29}-\mathrm{C}_{30}$ may be more appropriate (e.g. Killops, 1996). 


\subsection{Methods}

Sample preparation prior to analysis by GC-MS has been outlined in Chapter 3. Analyses were performed using a Hewlett Packard 5995C GC-MS system fitted with a J\&W DB1 ( $30 \mathrm{~m}, 0.2 \mathrm{~mm}$ I.D., $0.25 \mu \mathrm{m}$ film thickness) fused silica capillary column, using helium as the carrier gas and the following temperature programme:

\begin{tabular}{|ll|}
\hline Initial temperature & $50^{\circ} \mathrm{C}$ (held for $15 \mathrm{~min}$.) \\
Initial rate & $4^{\circ} \mathrm{C} / \mathrm{min}$. for $45 \mathrm{~min}$. (to $230^{\circ} \mathrm{C}$ ) \\
Final rate & $2^{\circ} \mathrm{C} / \mathrm{min}$. for $25 \mathrm{~min}$. (to $280^{\circ} \mathrm{C}$ ) \\
Final temperature & $280^{\circ} \mathrm{C}$ (held for $4 \mathrm{~min}$.) \\
Total time & $90 \mathrm{~min}$. \\
\hline
\end{tabular}

The mass spectrometer was used in SIM mode, analysing for ions of $\mathrm{m} / \mathrm{z} 123,191$ and 217. Data acquisition and analysis were conducted using HP59970 MS-ChemStation software, and data manipulation through macros written by Collier (1989) helped in the repetitious work of peak identifications, integrations and biomarker ratio calculations. 


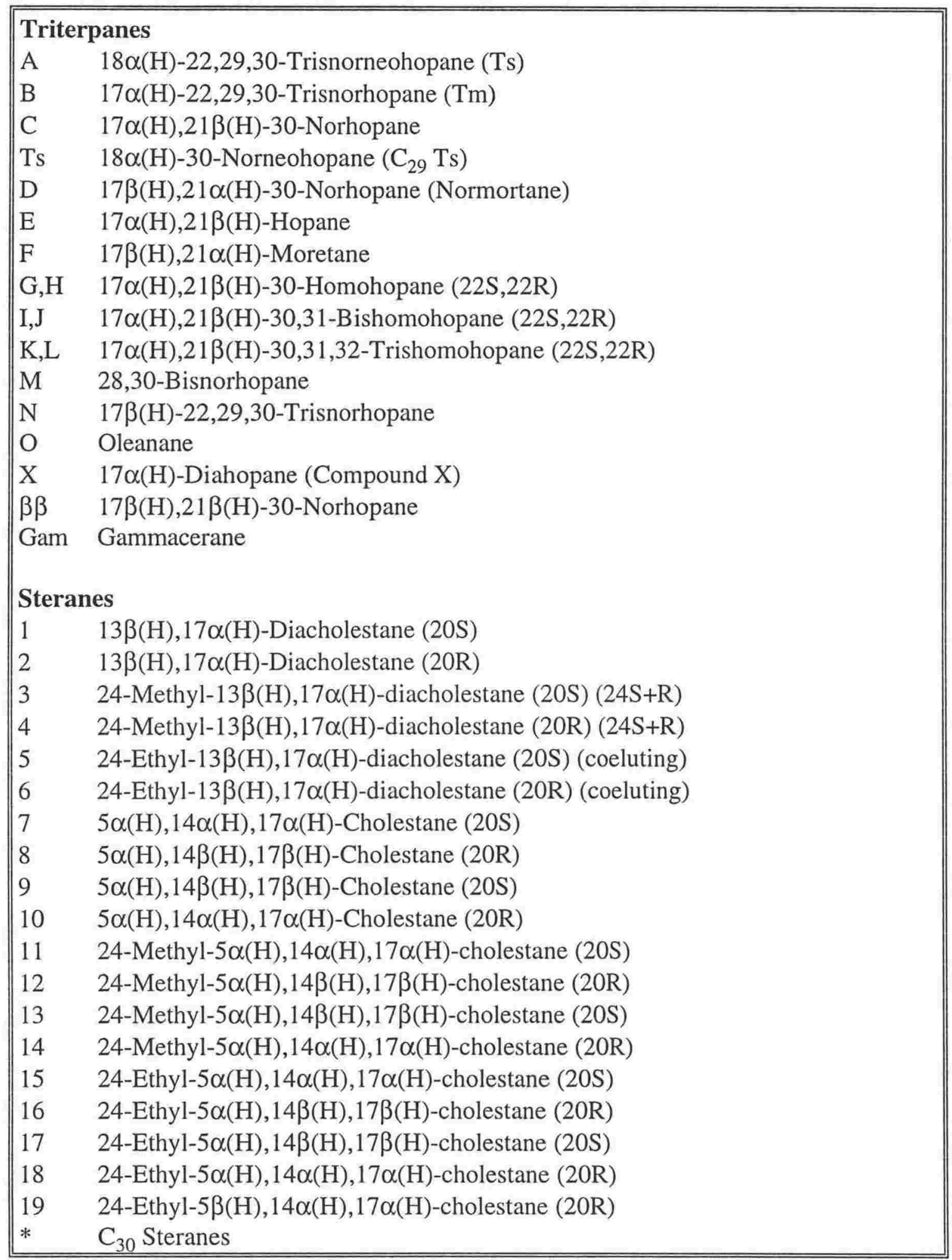

Table 6.2 Biomarker identification of triterpanes and steranes. 


\subsection{Results - biomarker geochemistry of the oils}

\subsubsection{Introduction}

Descriptions of the biomarker characteristics of the individual oils are presented in Section 6.5.2, with tentative interpretations based on the discussion and references given in Section 6.3. A more general interpretation of the results is included in Sections 6.5.3 to 6.5.6, with a final summary and discussion in Section 6.7.

Peak identification is achieved through retention times and comparison with existing chromatograms and is, therefore, only tentative and necessarily limited to common biomarkers that are well documented in the literature. Coelution of biomarker compounds remains a problem, however, and is mentioned where it is suspected to have occurred. For ease of comparison with Rogers (1995), a similar system of peak nomenclature is used (see Table 6.2 and the pull-out card on the inside back cover). Tables of selected biomarker ratios and relative abundances appear in Appendix 5 while the mass chromatograms (m/z 191 and 217) are presented in Appendix 9.

For most biomarker applications 'quantitative' interpretations are obtained by simply using ratios of observed peak intensities from a particular chromatogram. These ratios may not represent the true relative concentrations, but they will be comparable from sample to sample (Waples and Machihara, 1991); true quantitative assessments are uncommon. The use of biomarker ratios is particularly useful in maturation studies but is often complicated in source studies where differences in maturity may also influence the results (such as the oleanane index).

In the present study maturation studies are 'quantified' through the use of ratios [such as $(22 S / 22 S+22 R)$ homohopanes and $(20 S / 20 S+20 R)$ steranes]. This approach is also used in source studies, particularly where there are no maturation influences (such as the $\mathrm{C}_{30}$ index). Where considered appropriate, though, a more 'qualitative' approach is taken whereby ratios are not calculated but relative abundances are determined visually. For example, a comparison of angiosperm contribution between samples of different maturity is complicated because the oleanane index is also maturity dependent. For this reason, in general, only the presence (or absence) of oleanane is examined in the present study, and therefore the calculation of the oleanane index is considered unnecessary. Terms such as 'low', 'low-moderate', 'moderate', 'moderate-high' and 'high' relative abundances are used in reference to the relative concentration of certain biomarkers compared with other major compounds represented on the same chromatogram. 

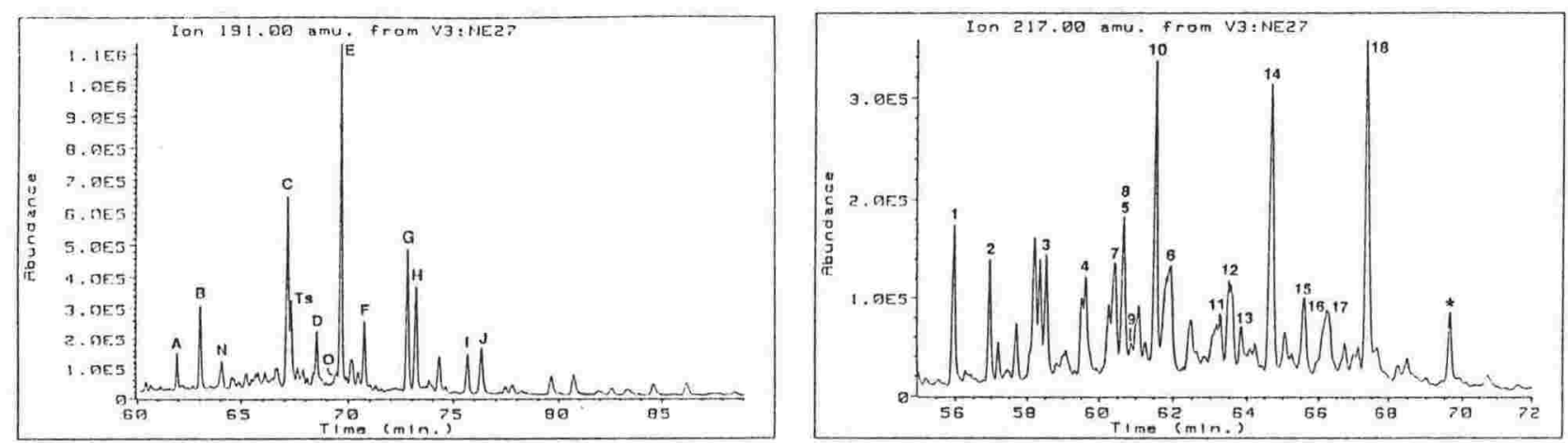

\section{a. Knights Stream oil}
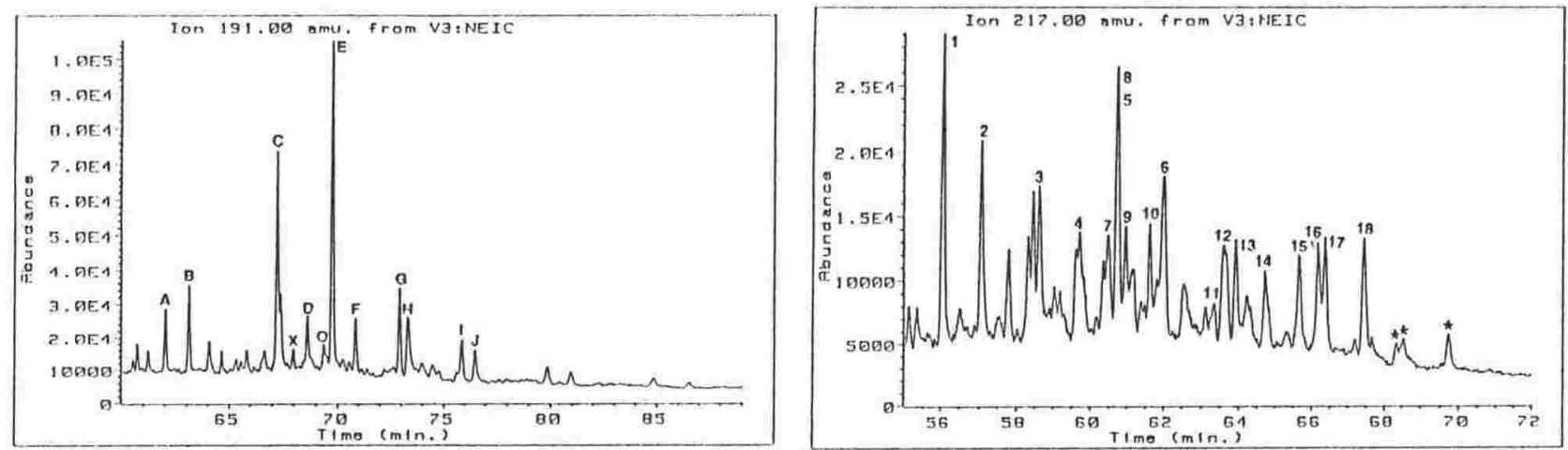

b. Isolation Creek oil
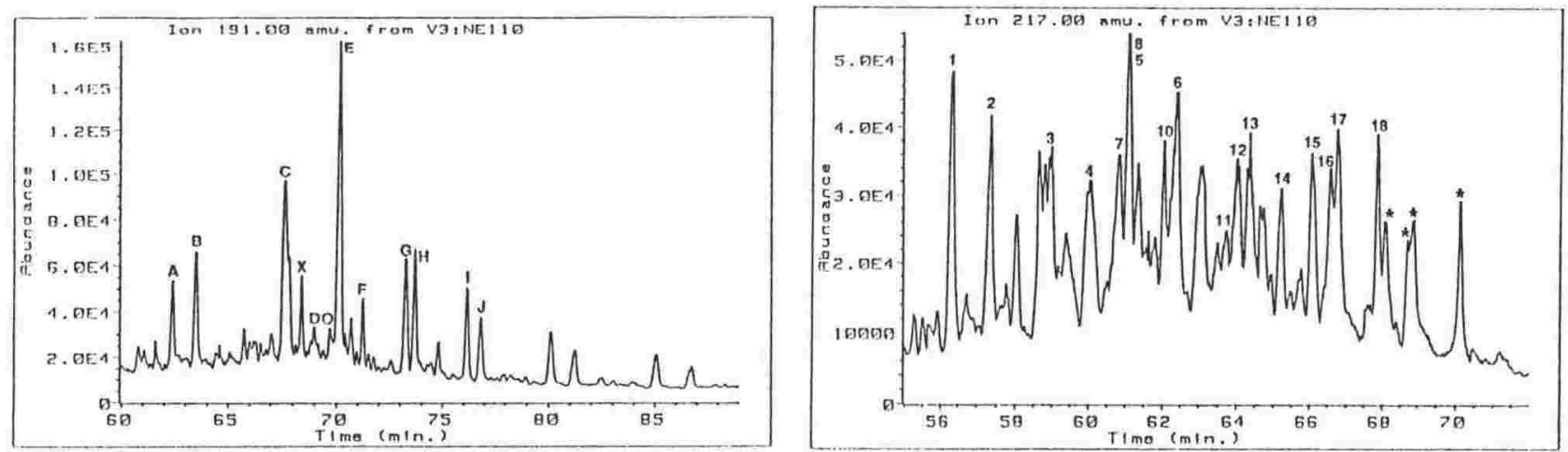

\section{c. Kerosene Rock oil}
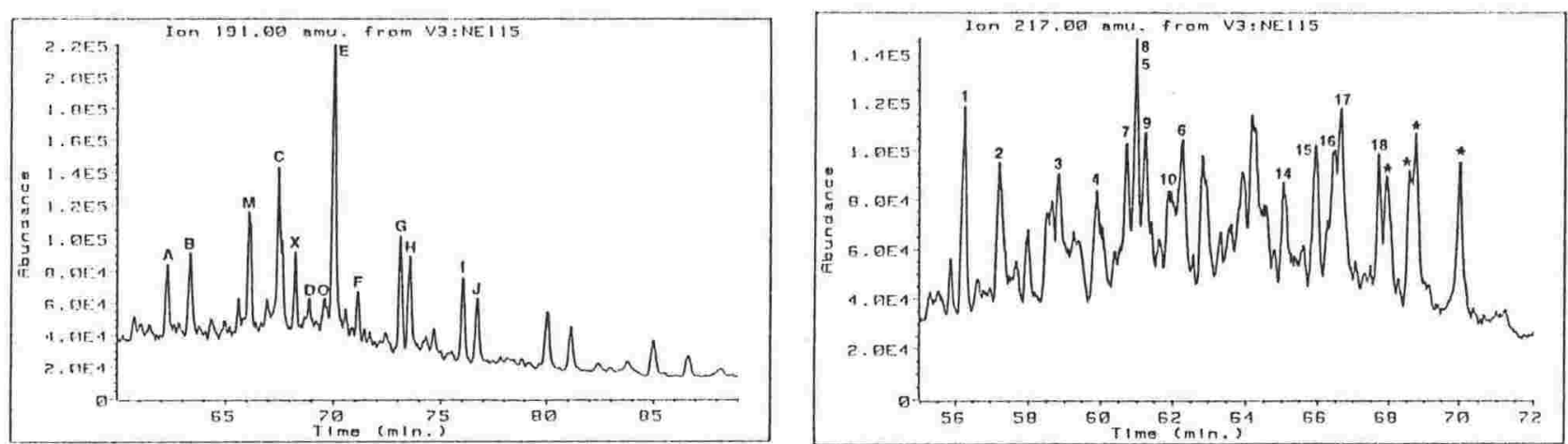

d. Westcott oil

Figure 6.13 GC-MS m/z 191 and 217 mass chromatograms of the oils. 


\subsubsection{Biomarker geochemistry of the oils}

Knights Stream oil (Figure 6.13a): The m/z 191 chromatogram shows low-moderate relative abundances of $\mathrm{Ts}$ and $\mathrm{Tm}$, low 28,30-bisnorhopane, $17 \alpha(\mathrm{H})$-diahopane and oleanane. The m/z 217 chromatogram is characterised by a $\mathrm{C}_{29}>\mathrm{C}_{28}>\mathrm{C}_{27}>\mathrm{C}_{30}$ sterane distribution pattern, a low $\mathrm{C}_{27} / \mathrm{C}_{29}$ sterane ratio (0.71), and a low $\mathrm{C}_{30}$ index (0.06). The dominance of $\mathrm{C}_{29}$ steranes suggests a predominance of terrestrial organic matter, although a relatively high proportion of $\mathrm{C}_{28}$ steranes (0.33) (of the $\mathrm{C}_{27}-\mathrm{C}_{30}$ regular steranes) also suggests a strong marine influence. Despite the dominance of $\mathrm{C}_{29}$ steranes the relative abundances of $\mathrm{C}_{27}, \mathrm{C}_{28}$ and $\mathrm{C}_{29}$ steranes are similar and much greater than $\mathrm{C}_{30}$ steranes. Diasteranes occur in moderate relative abundances, with similar proportions of $\mathrm{C}_{27}$ and $\mathrm{C}_{29}$ homologues. The moretane/hopane and $22 \mathrm{~S} /(22 \mathrm{~S}+22 \mathrm{R})$ homohopane ratios have not reached thermodynamic equilibrium and therefore indicate a maturity of below the onset of oil generation $\left(<0.6 \% \mathrm{R}_{0}\right)$. The maturity of the Knights Stream oil is greater than that of NE28 (see Appendix 5), a nearby sample of the same formation in which the oil was found, and this suggests that the Knights Stream oil has migrated into its present location. Neither the sterane nor triterpane distributions appear to be affected by biodegradation.

Isolation Creek oil (Figure 6.13b): The m/z 191 chromatogram shows moderate relative abundances of $\mathrm{Ts}$ and $\mathrm{Tm}$, low 28,30-bisnorhopane, $17 \alpha(\mathrm{H})$-diahopane and oleanane. The m/z 217 chromatogram is characterised by a $\mathrm{C}_{29}>\mathrm{C}_{27}>\mathrm{C}_{28}>\mathrm{C}_{30}$ sterane distribution pattern, a low $\mathrm{C}_{27} / \mathrm{C}_{29}$ sterane ratio (0.83) and a low $\mathrm{C}_{30}$ index (0.12). The dominance of $\mathrm{C}_{29}$ steranes suggests a predominant terrestrial contribution although, like Knights Stream oil, a moderate to high proportion of $\mathrm{C}_{28}$ steranes $(0.27)$ may indicate a significant marine contribution. The relative abundances of $\mathrm{C}_{27}, \mathrm{C}_{28}$ and $\mathrm{C}_{29}$ steranes are similar and greater than $\mathrm{C}_{30}$ steranes. High relative abundances of diasteranes, with similar proportions of $\mathrm{C}_{27}$ and $\mathrm{C}_{29}$ homologues, dominate the chromatogram. The $\% \beta \beta C_{27}$ sterane ratio is unreliable, inflated by coelution of the $\mathrm{C}_{29}(-20 \mathrm{~S})$ diasterane with $\mathrm{C}_{27} \alpha \beta \beta-20 \mathrm{R}$ sterane. Both the moretane/hopane and $22 \mathrm{~S} /(22 \mathrm{~S}+22 \mathrm{R})$ homohopane ratios indicate a maturity above the onset of oil generation $\left(0.6 \% \mathrm{R}_{\mathrm{o}}\right)$, while the $20 \mathrm{~S} /(20 \mathrm{~S}+20 \mathrm{R})$ sterane ratios indicates a maturity of at least peak oil generation $\left(0.8 \% \mathrm{R}_{\mathrm{o}}\right)$. The sterane and triterpane distributions do not appear to have suffered any biodegradation.

Kerosene Rock oil (Figure 6.13c): The $\mathrm{m} / \mathrm{z} 191$ chromatogram shows moderate relative abundances of Ts and $\mathrm{Tm}$, low 28,30-bisnorhopane, moderate $17 \alpha(\mathrm{H})$-diahopane and low oleanane. The $\mathrm{m} / \mathrm{z} 217$ sterane chromatogram is characterised by a 

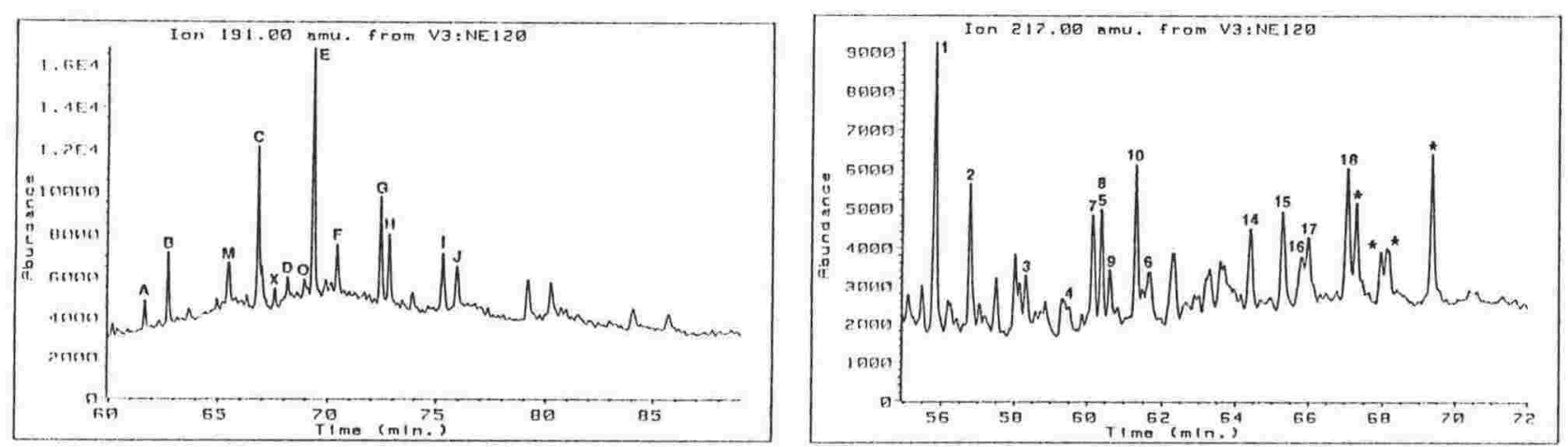

e. Tiraumea oil
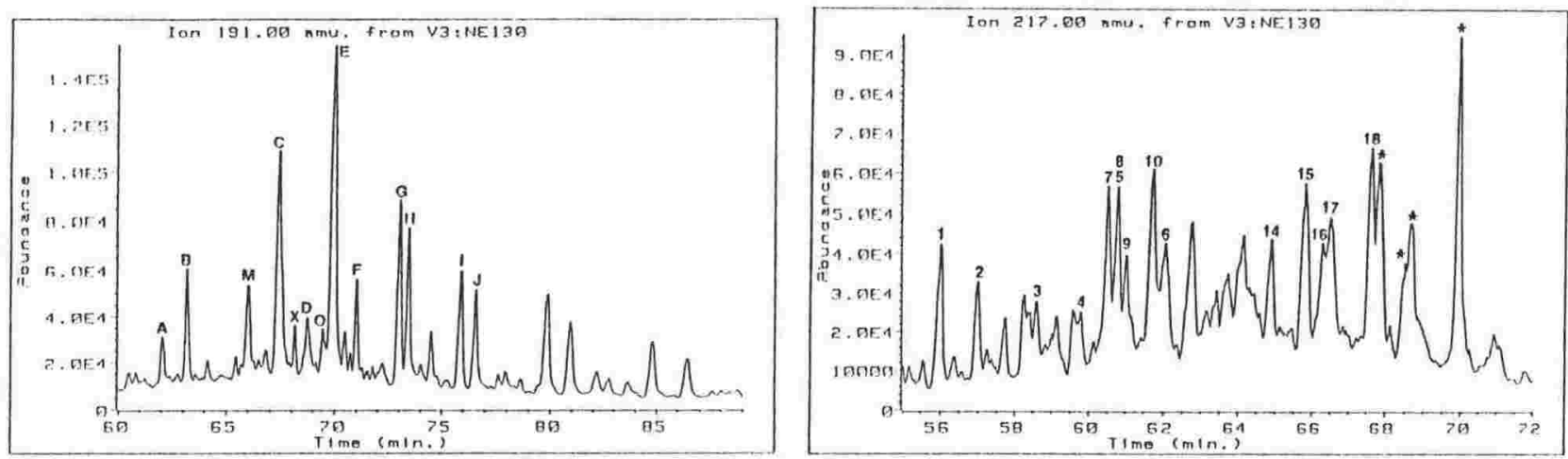

f. Okau Stream oil

Figure 6.13 cont. GC-MS m/z 191 and 217 mass chromatograms of the oils. 
$\mathrm{C}_{29}>\mathrm{C}_{27}>\mathrm{C}_{30}>\mathrm{C}_{28}$ sterane distribution pattern, a low $\mathrm{C}_{27} / \mathrm{C}_{29}$ sterane ratio (0.85) and a moderate to high $\mathrm{C}_{30}$ index (0.24). The $\mathrm{C}_{27} / \mathrm{C}_{29}$ sterane ratio suggests mixed marine and terrestrial organic matter. High relative abundances of diasteranes, with $\mathrm{C}_{29}$ predominant over $\mathrm{C}_{27}$ homologues, dominate the chromatogram and inflate the $\% \beta \beta \mathrm{C}_{27}$ sterane ratio through coelution. The $\mathrm{C}_{30}$ moretane/hopane and $22 \mathrm{~S} /(22 \mathrm{~S}+22 \mathrm{R})$ homohopane ratios indicate a maturity above the onset of oil generation $\left(>0.6 \% \mathrm{R}_{\mathrm{o}}\right)$, while the $20 \mathrm{~S} /(20 \mathrm{~S}+20 \mathrm{R})$ sterane ratios indicates a maturity of at least peak oil generation $\left(>0.8 \% \mathrm{R}_{0}\right)$. In general, the sterane and triterpane distributions do not appear significantly affected by biodegradation. However, the preferential removal of the $\alpha \alpha \alpha-20 \mathrm{R}$ isomer through partial biodegradation may be responsible for the $20 \mathrm{~S} /(20 \mathrm{~S}+20 \mathrm{R})$ sterane ratios exceeding their equilibration maxima.

Westcott oil (Figure 6.13d): The $\mathrm{m} / \mathrm{z} 191$ chromatogram shows moderate relative abundances of Ts and Tm, high 28,30-bisnorhopane, moderate $17 \alpha(\mathrm{H})$-diahopane and low oleanane. The m/z 217 chromatogram is characterised by a $C_{30}>C_{29}>C_{27}>C_{28}$ sterane distribution pattern, a low $\mathrm{C}_{27} / \mathrm{C}_{29}$ sterane ratio (0.85) and a very high $\mathrm{C}_{30}$ index (0.35). $\mathrm{A} \mathrm{C}_{27} / \mathrm{C}_{29}$ sterane ratio indicates organic matter of mixed marine and terrestrial origin, although $\mathrm{C}_{30}$ steranes predominate and are generally indicative of marine organic matter. $\mathrm{C}_{28}$ steranes occur in low proportions (0.19) of the $\mathrm{C}_{27}-\mathrm{C}_{30}$ regular steranes. Diasteranes are present in high relative abundances, with $C_{29}$ predominant over $C_{27}$ homologues which may indicate a mainly terrestrial organic matter. Moretane/hopane and $22 \mathrm{~S} /(22 \mathrm{~S}+22 \mathrm{R})$ homohopane ratios indicate a maturity above the onset of oil generation. $20 \mathrm{~S} /(20 \mathrm{~S}+20 \mathrm{R})$ and $\% \beta \beta$ sterane ratios also indicate a maturity of peak oil generation $\left(0.8-0.9 \% \mathrm{R}_{\mathrm{o}}\right)$. Biodegradation of the sterane and triterpane distributions is not apparent but, like the Kerosene Rock oil, the 20S/(20S+20R) sterane ratios exceed their equilibration maxima and this may be due to the preferential removal of the $\alpha \alpha \alpha-20 \mathrm{R}$ isomer.

Tiraumea oil (Figure 6.13e): The $\mathrm{m} / \mathrm{z} 191$ chromatogram shows moderate relative abundances of Ts and Tm, moderate 28,30-bisnorhopane, low-moderate $17 \alpha(\mathrm{H})$ diahopane and oleanane. The $\mathrm{m} / \mathrm{z} 217$ chromatogram is characterised by a $\mathrm{C}_{29}>\mathrm{C}_{30}>\mathrm{C}_{27}>\mathrm{C}_{28}$ sterane distribution pattern, a low $\mathrm{C}_{27} / \mathrm{C}_{29}$ sterane ratio (0.85) and a high $\mathrm{C}_{30}$ index (0.28). The $\mathrm{C}_{27} / \mathrm{C}_{29}$ sterane ratio indicates mixed marine and terrestrial organic matter. $C_{28}$ steranes are present in low proportions (0.19). High relative abundances of $\mathrm{C}_{27}$ diasteranes predominate over $\mathrm{C}_{29}$ homologues and dominate the chromatogram. The moretane/hopane and $22 \mathrm{~S} /(22 \mathrm{~S}+22 \mathrm{R})$ homohopane ratios indicate a maturity above the onset of oil generation $\left(0.6 \% \mathrm{R}_{\mathrm{o}}\right)$, while the $20 \mathrm{~S} /(20 \mathrm{~S}+20 \mathrm{R})$ sterane 
ratios indicate a maturity of peak oil generation $\left(\sim 0.8 \% \mathrm{R}_{\mathrm{o}}\right)$. Neither the sterane nor triterpane distributions appear to have been affected by biodegradation.

Okau Stream oil (Figure 6.13f): The $\mathrm{m} / \mathrm{z} 191$ chromatogram shows moderate relative abundances of Ts and Tm, moderate 28,30-bisnorhopane, and low-moderate $17 \alpha(\mathrm{H})$ diahopane and oleanane. The $\mathrm{m} / \mathrm{z} 217$ chromatogram is characterised by a $\mathrm{C}_{30}>\mathrm{C}_{29}>\mathrm{C}_{27}>\mathrm{C}_{28}$ sterane distribution pattern, a low $\mathrm{C}_{27} / \mathrm{C}_{29}$ sterane ratio (0.94), and a very high $\mathrm{C}_{30}$ index (0.40). $\mathrm{A} \mathrm{C}_{27} / \mathrm{C}_{29}$ sterane ratio indicates the presence of mixed marine and terrestrial organic matter. $\mathrm{C}_{28}$ steranes are present in low proportions $(0.12)$. Moderate relative abundances of diasteranes, with $C_{29}$ in greater proportions than $C_{27}$ homologues, are consistent with sterane distributions and inflate the $\% \beta \beta \mathrm{C}_{27}$ sterane ratio through coelution. The moretane/hopane ratios indicate a maturity below the onset of oil generation $\left(0.6 \% \mathrm{R}_{\mathrm{o}}\right)$, while the $22 \mathrm{~S} /(22 \mathrm{~S}+22 \mathrm{R})$ homohopane and $20 \mathrm{~S} /(20 \mathrm{~S}+20 \mathrm{R})$ sterane ratios indicate a maturity of early oil generation $\left(0.6-0.7 \% \mathrm{R}_{\mathrm{o}}\right)$. Sterane and triterpane distributions do not appear to have been affected by biodegradation.

\subsubsection{Source-specific biomarkers}

Selected source-specific biomarkers and biomarker ratios, determined from m/z 191 and 217 chromatograms are summarised in Table 6.3.

\begin{tabular}{|c|c|c|c|c|c|c|c|c|}
\hline \multirow[t]{2}{*}{ Oil sample } & \multirow[t]{2}{*}{$\mathrm{BNH}$} & \multirow{2}{*}{$\begin{array}{c}17 \alpha(\mathbf{H})- \\
\text { Diahopane }\end{array}$} & \multirow[t]{2}{*}{ Oleanane } & \multicolumn{5}{|c|}{ steranes } \\
\hline & & & & $\% \mathrm{C}_{27}$ & $\% \mathrm{C}_{28}$ & $\% \mathrm{C}_{29}$ & $\% \mathrm{C}_{30} *$ & $\mathrm{C}_{27} / \mathrm{C}_{29}$ \\
\hline Knights Stream & low & low & low & 25 & 33 & 36 & 6 & 0.71 \\
\hline Isolation Creek & low & low & low & 28 & 27 & 33 & 12 & 0.83 \\
\hline Kerosene Rock & low & $\bmod$ & low & 25 & 21 & 30 & 24 & 0.85 \\
\hline Westcott & high & $\bmod$ & low & 21 & 19 & 25 & 35 & 0.85 \\
\hline Tiraumea & $\bmod$ & low-mod & low-mod & 24 & 19 & 29 & 28 & 0.85 \\
\hline Okau Stream & $\bmod$ & low-mod & low-mod & 23 & 12 & 25 & 40 & 0.94 \\
\hline
\end{tabular}

$\mathrm{BNH}=28,30$-Bisnorhopane; $\%$ steranes includes the $\mathrm{C}_{27}-\mathrm{C}_{30}$ steranes $\left(* \% \mathrm{C}_{30}\right.$ is the same as the $\mathrm{C}_{30}$ index). Based on $\mathrm{m} / \mathrm{z} 217$ response of $\alpha \alpha \alpha-20 \mathrm{R}$ steranes.

Table 6.3 Summary of selected source-specific biomarker parameters of the oils.

The presence of oleanane in every sample indicates that the oils are likely to be sourced from sediments of Late Cretaceous age or younger and have a contribution of angiosperm-derived terrestrial organic matter (Peters and Moldowan, 1993; Moldowan et al., 1994). Slightly higher relative abundances of oleanane are present in the Tiraumea and Okau Stream oils than the other oils, which is considered to be more source than 
A.

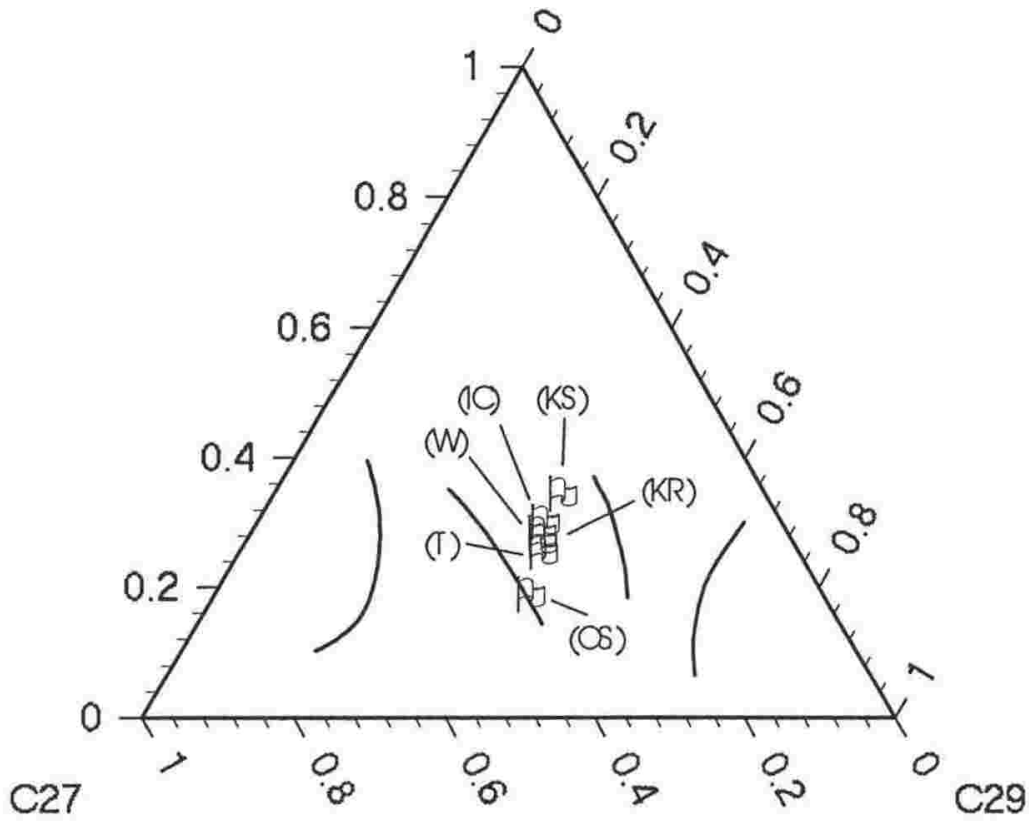

B.

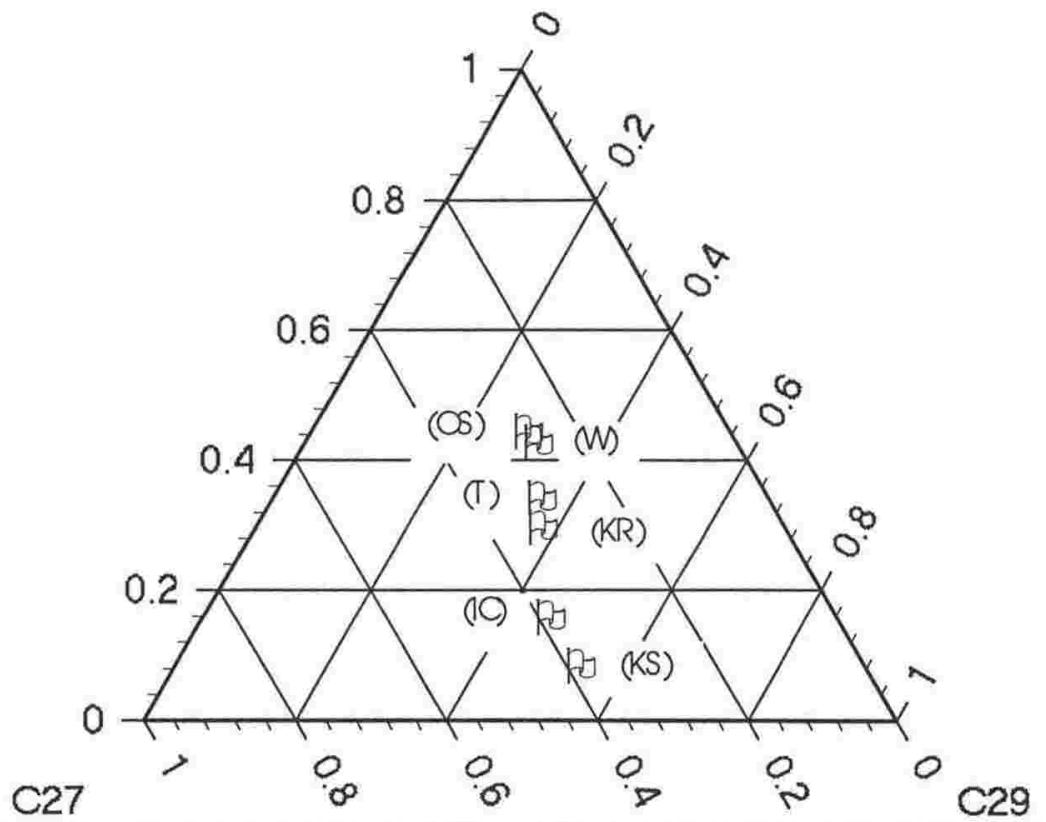

Figure 6.14 Ternary diagrams showing the composition of oils. $A . C_{27}-C_{28}-C_{29}$ steranes, with superimposed ecological boundaries of Huang and Meinschein (1979) (see Figure 6.7 for field classification). B. $\mathrm{C}_{27}-\mathrm{C}_{29}-\mathrm{C}_{30}$ steranes. $\mathrm{KS}=\mathrm{Knights} \mathrm{Stream}, \mathrm{IC}=\mathrm{Isolation}$ Creek, KR=Kerosene Rock, W=Westcott, $T=$ Tiraumea, OS=Okau Stream. Based on the m/z 217 response of $\alpha \alpha \alpha-20 R$ steranes. 
maturity-related [the Westcott, Kerosene Rock and Isolation Creek oils are of greater or equivalent maturity (see Section 6.5.4), yet show lower relative abundances of oleanane]. The relative abundances of $17 \alpha(\mathrm{H})$-diahopane in the oils are generally low and appear to be related to sample maturity. Slightly higher relative abundances present in the Kerosene Rock, Westcott, Tiraumea and Okau Stream oils, however, may also reflect that a portion of the contributing organic matter (presumably the terrestrial component) was initially deposited under oxic conditions prior to redeposition and burial. The relative

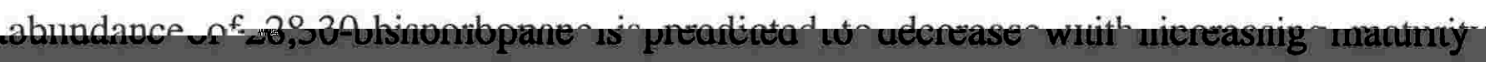
(Peters and Moldowan, 1993) yet Westeat ail the mast mature sample (sere Section 6.5.4), has a high relative abundance of 28,30-bisnorhopane indicating that deposition of the original organic matter may have occurred under reduced oxygen or

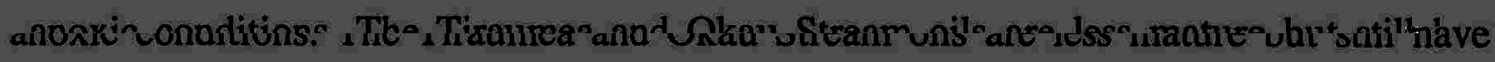
moderate relative abundances of 28,30-bisnorhopane and may also indicate deposition under anoxic conditions. The apparent ambiguity between both oxic and anoxic depositional environments for the Westcott, Tiraumea and Okau Stream oils can be explained by the presence of organic matter of two different origins. A terrestrial contribution of organic matter deposited under initially oxic conditions may have been redeposited in a marine environment and combined with marine organic matter in an anoxic or reduced oxygen depositional environment.

The $\mathrm{C}_{27}-\mathrm{C}_{28}-\mathrm{C}_{29}$ sterane ternary diagram (Figure 6.14a) shows all six oils plot in the 'estuarine or bay' field of Huang and Meinschein (1979) which demonstrates the general mixed marine and terrestrial nature of the contributing organic matter. Low $\mathrm{C}_{27} / \mathrm{C}_{29}$ sterane ratios suggest a predominantly terrestrial influence in the $\mathrm{Knights}$ Stream and Isolation Creek oils, with a mixed marine and terrestrial contribution to the Kerosene Rock, Westcott, Tiraumea and Okau Stream oils. The presence of high proportions of $\mathrm{C}_{28}$ steranes in the Knights Stream and Isolation Creek oils, however, (see Figure 6.14a) indicate a stronger marine contribution than is suggested by the $C_{27} / C_{29}$ sterane ratios. Similarly, the Kerosene Rock, Westcott, Tiraumea and Okau Stream oils have high proportions of $\mathrm{C}_{30}$ steranes which are also generally considered to be marine indicators. The $\mathrm{C}_{30}$ index and the $\mathrm{C}_{27}-\mathrm{C}_{29}-\mathrm{C}_{30}$ sterane ternary diagram (Figure 6.14b) define three pairs of oils, the Knights Stream and Isolation Creek oils with low $\mathrm{C}_{30}$ indices, the Kerosene Rock and Tiraumea oils with high $\mathrm{C}_{30}$ indices, and the Westcott and Okau Stream oils with very high $\mathrm{C}_{30}$ indices.

From the manner in which the samples bisect the sterane ternary diagrams (Figure 6.14a and b), it is apparent that the oils of the southern East Coast Basin have essentially similar proportions of $C_{27}$ and $C_{29}$ steranes $\left(C_{27} / C_{29}\right.$ sterane ratio of $\left.\sim 0.85\right)$ and the 
main compositional differences lies in their proportions of $\mathrm{C}_{28}$ and $\mathrm{C}_{30}$ steranes. The Knights Stream and Isolation Creek oils have a high proportion of $\mathrm{C}_{28}$ steranes while the Kerosene Rock, Westcott, Tiraumea and Okau Stream oils have a high proportion of $\mathrm{C}_{30}$ steranes. The differences in the sterane composition of the oils are most easily shown in Figure 6.15.

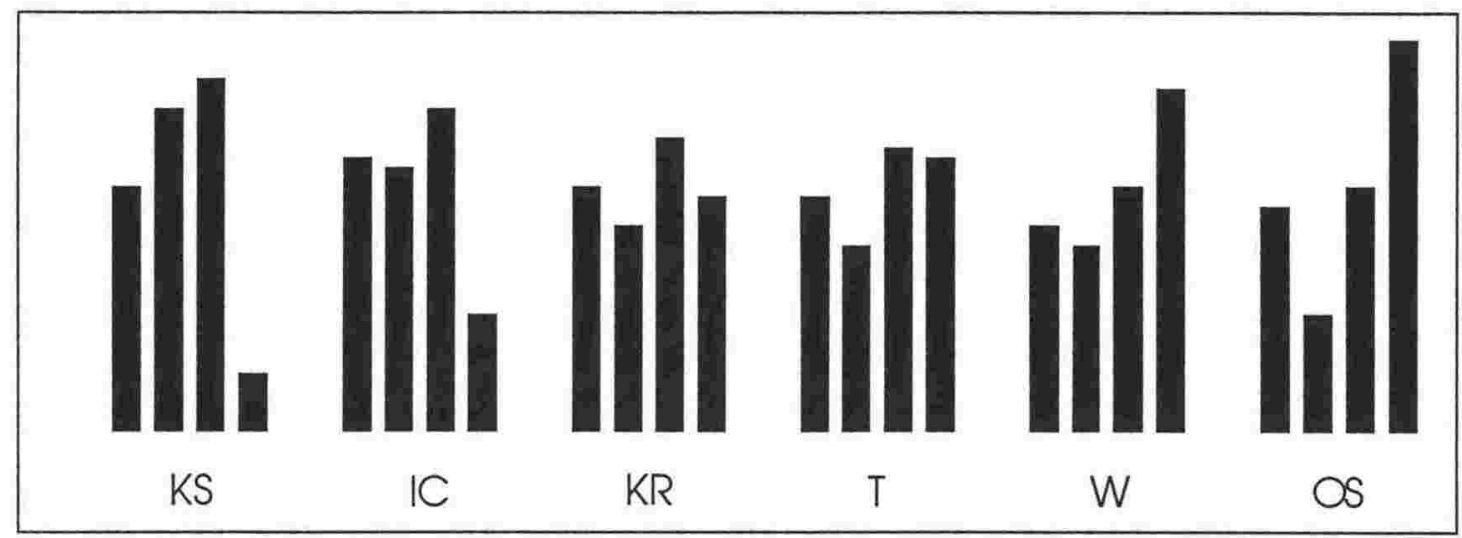

KS=Knights Stream, IC=Isolation Creek, KR=Kerosene Rock, W=Westcott, T=Tiraumea, OS=Okau Stream. Based on $\mathrm{m} / \mathrm{z} 217$ response of $\alpha \alpha \alpha-20 \mathrm{R}$ steranes.

Figure 6.15 Diagrammatic representation of the relative proportion of steranes in each of the oil samples. From left to right the four bars represent $C_{27}, C_{28}, C_{29}, C_{30}$ steranes respectively.

In summary, the oils can be divided into at least two major families based on their source biomarker characteristics. The Knights Stream and Isolation Creek oil samples have low relative abundances of 28,30-bisnorhopane, $17 \alpha(\mathrm{H})$-diahopane and oleanane, low $\mathrm{C}_{27} / \mathrm{C}_{29}$ sterane ratios (0.71-0.83), high proportions of $\mathrm{C}_{28}$ steranes $(0.27-0.33)$ and a low $\mathrm{C}_{30}$ index $(0.06-0.12)$. This appears to indicate deposition under open marine conditions with a moderate terrestrial contribution. The Kerosene Rock, Westcott, Tiraumea and Okau Stream oils, however, generally have moderate-high relative abundances of 28,30-bisnorhopane, low-moderate $17 \alpha(\mathrm{H})$-diahopane, low-moderate oleanane, low $\mathrm{C}_{27} / \mathrm{C}_{29}$ sterane ratios $(0.85-0.94)$, low to moderate proportions of $\mathrm{C}_{28}$ steranes (0.12-0.21) and a high $\mathrm{C}_{30}$ index (0.24-0.40). This suggests deposition of both terrestrial and marine organic matter under predominantly low oxygen or anoxic conditions.

\subsubsection{Maturity biomarker parameters}

Four biomarker parameters, each using two homologous compounds for increased reliability, are used to determine oil maturity (Table 6.4). The $\mathrm{Tm} / \mathrm{Ts}$ ratio is not used as it is also affected by source, which has been shown to differ amongst samples. 
The moretane/hopane and 22S/(22S+22R) homohopane ratios of the Westcott, Isolation Creek, Kerosene Rock and Tiraumea oils have reached thermodynamic equilibrium (hereafter simply referred to as 'equilibrium'), indicating maturities of at least the onset of oil generation $\left(\sim 0.6 \% \mathrm{R}_{\mathrm{o}}\right)$. Only the $22 \mathrm{~S}(22 \mathrm{~S}+22 \mathrm{R})$ homohopane ratio has reached equilibrium in Okau Stream oil, while neither biomarker parameter has reached equilibrium in Knights Stream oil indicating a maturity below the onset of oil generation.

\begin{tabular}{||l|c|c|c|c|c|c|c|c||}
\hline \multirow{2}{*}{ Oil sample } & \multicolumn{2}{|c|}{ moretane/hopane } & \multicolumn{2}{|c|}{ 22S/(22S+22R) } & \multicolumn{2}{c|}{ 20S/(20S+20R) } & \multicolumn{2}{c||}{$\% \beta \beta$} \\
\cline { 2 - 9 } & $\mathbf{C}_{29}$ & $\mathrm{C}_{30}$ & $\mathbf{C}_{31}$ & $\mathbf{C}_{32}$ & $\mathbf{C}_{27}$ & $\mathbf{C}_{29}$ & $\mathbf{C}_{27}$ & $\mathbf{C}_{29}$ \\
\hline & & & & & & & & \\
Knights Stream & 0.30 & 0.22 & 0.55 & 0.45 & 0.35 & 0.24 & 0.34 & 0.28 \\
Isolation Creek & 0.18 & 0.18 & 0.50 & 0.48 & 0.53 & 0.48 & 0.64 & 0.51 \\
Kerosene Rock & 0.37 & 0.14 & 0.55 & 0.56 & 0.62 & 0.52 & 0.53 & 0.51 \\
Westcott & 0.06 & 0.15 & 0.51 & 0.55 & 0.58 & 0.57 & 0.62 & 0.55 \\
Tiraumea & 0.15 & 0.21 & 0.59 & 0.58 & 0.51 & 0.48 & 0.37 & 0.39 \\
Okau Stream & 0.48 & 0.38 & 0.56 & 0.55 & 0.44 & 0.51 & 0.35 & 0.40 \\
\hline
\end{tabular}

Table 6.4 Maturity parameters from triterpane and sterane biomarker ratios.

20S/(20S+20R) sterane ratios of the Kerosene Rock, Westcott, and probably Isolation Creek and Tiraumea oils have reached equilibrium and therefore indicate they have reached a maturity of peak oil generation $\left(\sim 0.8 \% \mathrm{R}_{\mathrm{o}}\right)$. The $20 \mathrm{~S} /(20 \mathrm{~S}+20 \mathrm{R})$ sterane ratio in Okau Stream oil has almost reached equilibrium, while Knights Stream oil is shown to be of low maturity. The $\% \beta \beta$ sterane ratios demonstrate a pattern similar to that shown by the $20 \mathrm{~S} /(20 \mathrm{~S}+20 \mathrm{R})$ sterane ratios, although Tiraumea oil appears to have a maturity intermediate between the Isolation Creek-Kerosene Rock-Westcott and the Okau Stream-Knights Stream samples. No samples have equilibrated $\% \beta \beta$ sterane ratios and, therefore, are all below a maturity of $0.9 \% \mathrm{R}_{\mathrm{o}}$. The rank of the oils in order of decreasing maturity is:

Westcott $>$ Kerosene Rock $>$ Tiraumea $\sim$ Isolation Creek $>$ Okau Stream $>$ Knights Stream

Westcott oil appears the most mature sample, equivalent to peak oil generation at about $0.8-0.9 \% \mathrm{R}_{\mathrm{o}}$. Kerosene Rock is slightly less mature, but still reaches a maturity of peak oil generation $\left(>0.8 \% \mathrm{R}_{\mathrm{o}}\right.$ ). The Tiraumea and Isolation Creek samples appear to have reached a maturity at, or just below, peak oil generation $\left(0.8 \% \mathrm{R}_{\mathrm{o}}\right)$. Although Okau Stream oil does not appear to have reached equilibrium in its moretane/hopane ratios, the $22 \mathrm{~S} /(22 \mathrm{~S}+22 \mathrm{R})$ homohopane ratios are at equilibrium and the $20 \mathrm{~S} /(20 \mathrm{~S}+20 \mathrm{R})$ sterane ratios have almost reached equilibrium. This probably indicates a maturity of early oil generation $\left(0.6-0.7 \% \mathrm{R}_{0}\right)$. Knights Stream oil has not reached equilibrium in either 
moretane/hopane or $22 \mathrm{~S} /(22 \mathrm{~S}+22 \mathrm{R})$ homohopane ratios and appears to be an immature oil $\left(<0.6 \% \mathrm{R}_{\mathrm{o}}\right)$.

\subsubsection{Biodegradation biomarker parameters}

The gas chromatograms of the Knights Stream, Isolation Creek and Kerosene Rock oils indicate biodegradation, if any, has been minimal, certainly no more than level 1 on the ten point scale of Peters and Moldowan (1993) (see Table 6.1). The gas chromatograms of the Westcott, Tiraumea and Okau Stream oils (e.g. Figure 5.2d) show unresolved humps with only trace $n$-alkanes and isoprenoids remaining, indicating the extent of biodegradation has reached at least level 5. Sterane and hopane compounds of these oils appear to be largely unaffected by biodegradation, however, and indicate an upper limit of about level 5-6. The Kerosene Rock and Westcott oils, however, do show $20 \mathrm{~S} /(20 \mathrm{~S}+20 \mathrm{R})$ sterane ratios that have exceeded their equilibration maxima and this may be due to partial biodegradation, with the preferential removal of the $\alpha \alpha \alpha-20 \mathrm{R}$ isomer (Rullkötter and Wendisch, 1982).

\subsubsection{Oil-oil correlations}

The similarity of source-specific biomarker characteristics (Table 6.3) in the Kerosene Rock, Westcott, Tiraumea and Okau Stream oils, especially the high relative abundances of $\mathrm{C}_{30}$ steranes $\left(\mathrm{C}_{30}\right.$ indices from $\left.0.24-0.40\right)$, low proportions of $\mathrm{C}_{28}$ steranes $(0.12$ 0.21 ), high relative abundances of 28,30-bisnorhopane and, to a lesser extent, lowmoderate $17 \alpha(\mathrm{H})$-diahopane, indicate they can be correlated to a common source. Within this grouping, the sterane distribution pattern (Figure 6.15) further defines two closely matched pairs of oils: the Kerosene Rock and Tiraumea oils with high $\mathrm{C}_{30}$ indices (0.24 and 0.28 respectively); and the Westcott and Okau Stream oils with very high $\mathrm{C}_{30}$ indices ( 0.35 and 0.40 respectively).

The Knights Stream and Isolation Creek oils also have similar biomarker characteristics (Table 6.3) including low relative abundances of $\mathrm{C}_{30}$ steranes $\left(\mathrm{C}_{30}\right.$ indices from 0.06 0.12 ), moderate to high proportions of $\mathrm{C}_{28}$ steranes (0.27-0.33), and low relative abundances of 28,30-bisnorhopane and $17 \alpha(\mathrm{H})$-diahopane. These characteristics clearly indicate a negative correlation with the Kerosene Rock, Westcott, Tiraumea and Okau Stream oils. The common absence (or low relative abundances) of diagnostic biomarkers, however, is not considered sufficient to establish a positive correlation and, therefore, the correlation between the Knights Stream and Isolation Creek oils is only tentative. 

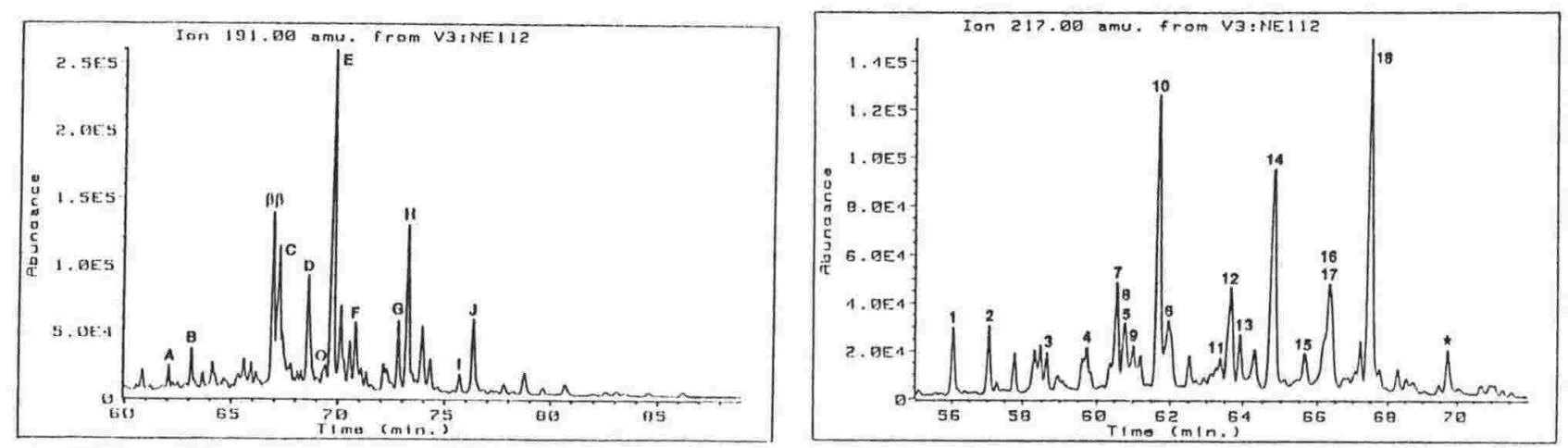

a. Whakataki Formation - NE112
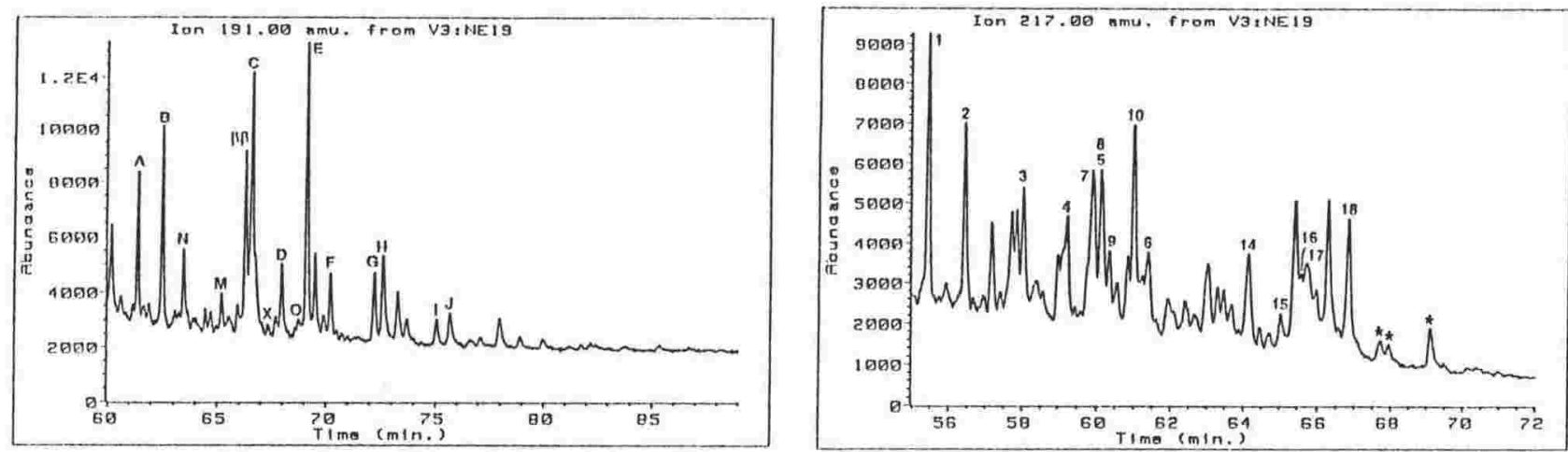

b. Weber Formation - NE19
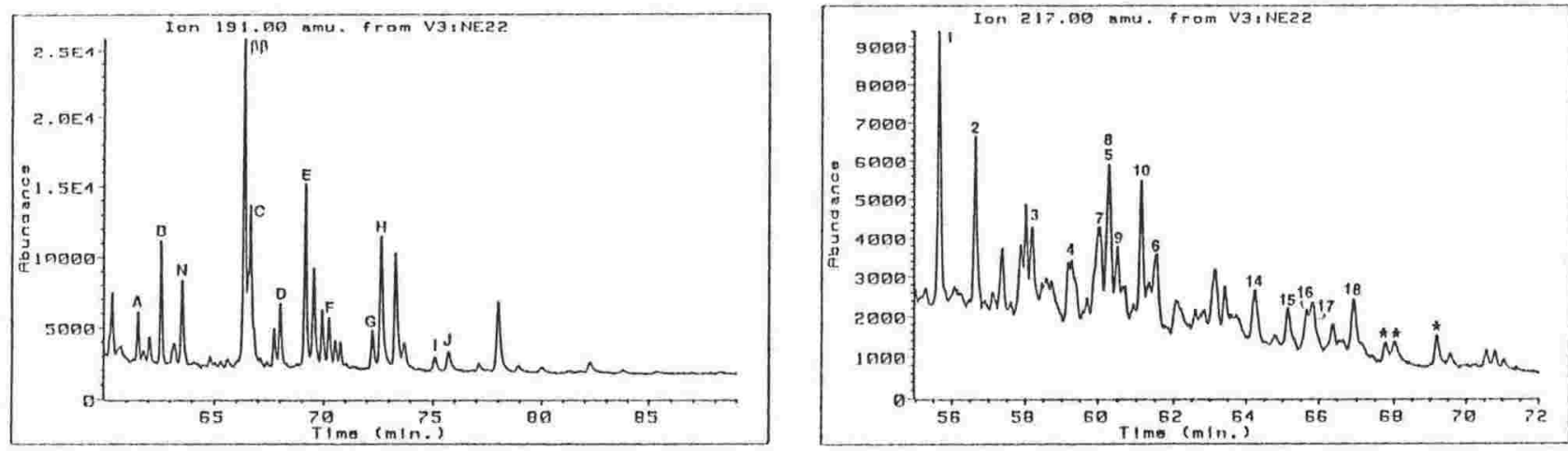

c. Wanstead Formation - NE22

Figure 6.16 GC-MS m/z 191 and 217 mass chromatograms of the possible source rocks (N.I.). 


\subsection{Results - biomarker geochemistry of the possible source rocks}

Descriptions of the biomarker characteristics of the individual formations are presented in Sections 6.6.1 and 6.6.2 with tentative interpretations based on the discussion and references given in Section 6.3. A more general interpretation of the results is included in Sections 6.6.3 to 6.6.6, with a final summary and discussion in Section 6.7.

\subsubsection{North Island possible source rocks}

Whakataki Formation (e.g. NE112, Figure 6.16a): The m/z 191 chromatograms are characterised by variable relative abundances of 28,30-bisnorhopane, low $17 \alpha(\mathrm{H})$ diahopane and oleanane. High relative abundances of 28,30-bisnorhopane are present in a low maturity sample and, therefore, does not necessarily indicate anoxic depositional conditions. The presence of oleanane indicates an angiosperm-derived terrestrial contribution of organic matter. The $\mathrm{m} / \mathrm{z} 217$ chromatograms show a $\mathrm{C}_{29} \sim \mathrm{C}_{27}>\mathrm{C}_{28}>\mathrm{C}_{30}$ sterane distribution pattern and variable $\mathrm{C}_{27} / \mathrm{C}_{29}$ sterane ratios (0.82-1.50) which may indicate fluctuating marine and terrestrial contributions of organic matter. $\mathrm{C}_{30}$ steranes are present in low relative abundances $\left(\mathrm{C}_{30}\right.$ indices average 0.05$)$. Diasteranes are present often in low relative abundances which may be partly due to low sample maturity. Low maturities are indicated by the high relative abundances of $C_{29} \beta \beta$-hopane and occasionally high relative abundances of $17 \beta(\mathrm{H})-22,29,30$-trisnorhopane. Moretane/hopane and $22 \mathrm{~S} /(22 \mathrm{~S}+22 \mathrm{R})$ homohopane ratios have not reached equilibrium indicating maturities below the onset of oil generation $\left(<0.6 \% \mathrm{R}_{\mathrm{o}}\right) \cdot 20 \mathrm{~S} /(20 \mathrm{~S}+20 \mathrm{R})$ and $\% \beta \beta$ sterane ratios also indicate low maturities with the $\mathrm{m} / \mathrm{z} 217$ chromatograms showing dominant $\alpha \alpha \alpha-20 \mathrm{R}$ forms and unresolved $\mathrm{C}_{29} \alpha \beta \beta-20 \mathrm{R}$ and $-20 \mathrm{~S}$ epimers.

Weber Formation (e.g. NE19, Figure 6.16b): The m/z 191 chromatograms show variable relative abundances of 28,30-bisnorhopane and low $17 \alpha(\mathrm{H})$-diahopane and oleanane. Again, low maturity samples may show high relative abundances of 28,30-bisnorhopane but this does not necessarily indicate anoxic depositional conditions. The presence of oleanane indicates an angiosperm-derived terrestrial contribution of organic matter. The $\mathrm{m} / \mathrm{z} 217$ chromatograms are characterised by a sterane distribution pattern showing $\mathrm{C}_{27}>\mathrm{C}_{29}>\mathrm{C}_{28}>\mathrm{C}_{30}$, and $\mathrm{C}_{27} / \mathrm{C}_{29}$ sterane ratios (1.33-1.97) indicative of either mixed marine and terrestrial or predominantly marine organic matter. $\mathrm{C}_{30}$ steranes are present in low relative abundances $\left(C_{30}\right.$ indices average 0.07$)$. The presence of moderate to high relative abundances of both $\mathrm{C}_{29} \beta \beta$-hopane and $17 \beta(\mathrm{H})-22,29,30$ trisnorhopane qualitatively indicates very low maturities. Consistent with this the 


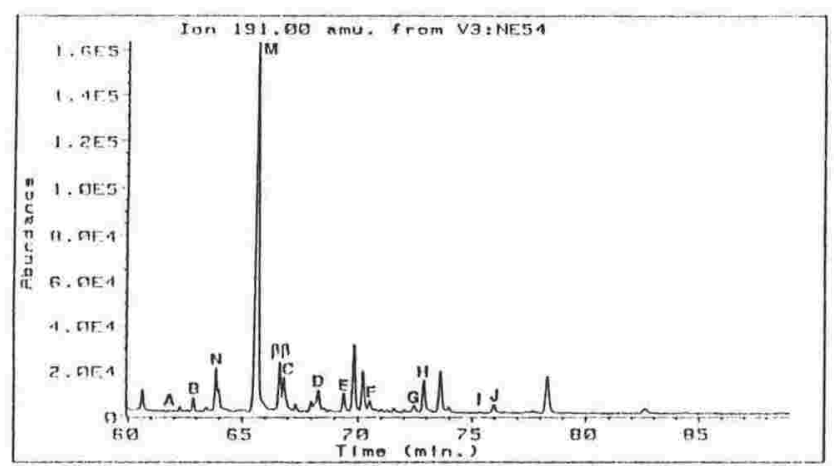

a. Waipawa Black Shale - NE54 m/z 191

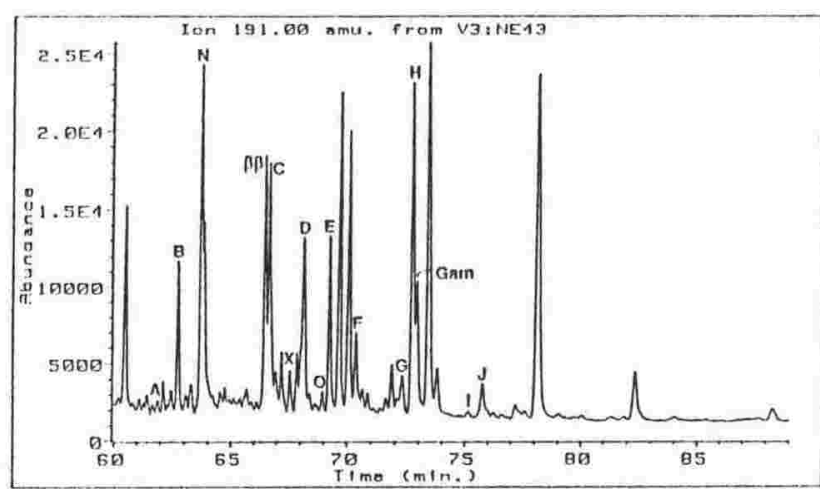

b. Waipawa Black Shale - NE43 m/z 191

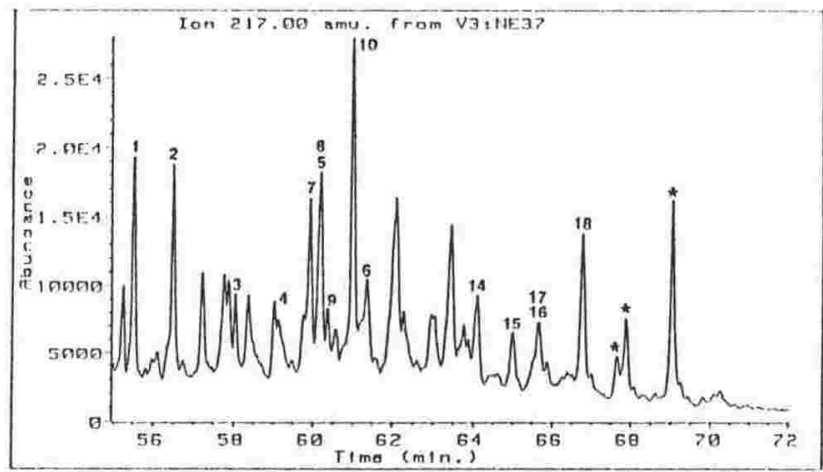

c. Waipawa Black Shale - NE37 m/z, 217

Figure 6.17 GC-MS m/z 191 and 217 mass chromatograms of the possible source rocks (N.I.). 
moretane/hopane and $22 \mathrm{~S} /(22 \mathrm{~S}+22 \mathrm{R})$ homohopane ratios indicate maturities below the onset of oil generation $\left(<0.6 \% \mathrm{R}_{\mathrm{o}}\right)$.

Wanstead Formation (e.g. NE22, Figure 6.16c): The m/z 191 chromatograms are characterised by low relative abundances of 28,30-bisnorhopane, $17 \alpha(\mathrm{H})$-diahopane and an absence of oleanane. A single low maturity sample shows high relative abundances of 28,30-bisnorhopane, but again this does not necessarily indicate anoxic depositional conditions. The absence of oleanane may indicate deposition distant from shore and/or a terrestrial input of predominantly gymnosperm flora. The $\mathrm{m} / \mathrm{z} 217$ chromatograms show a $\mathrm{C}_{27}>\mathrm{C}_{29}>\mathrm{C}_{28}>\mathrm{C}_{30}$ sterane distribution pattern and high $\mathrm{C}_{27} / \mathrm{C}_{29}$ sterane ratios (1.813.54) indicating a predominance of marine organic matter. $\mathrm{C}_{30}$ steranes are present in low relative abundances $\left(C_{30}\right.$ indices average 0.09). High relative abundances of $\mathrm{C}_{27}$ diasteranes often dominate the chromatograms despite low maturities and this may be due to the high clay content of the Wanstead Formation. Low maturities are indicated by occasionally high relative abundances of $C_{29} \beta \beta$-hopane and $17 \beta(H)-22,29,30$ trisnorhopane. Moretane/hopane and $22 \mathrm{~S} /(22 \mathrm{~S}+22 \mathrm{R})$ homohopane ratios have not equilibrated which indicates maturities are below the onset of oil generation $\left(<0.6 \% \mathrm{R}_{\mathrm{o}}\right)$. $20 \mathrm{~S} /(20 \mathrm{~S}+20 \mathrm{R})$ and $\% \beta \beta$ sterane ratios also indicate low maturities.

Waipawa Black Shale: The $\mathrm{m} / \mathrm{z} 191$ chromatograms show variable relative abundances of 28,30-bisnorhopane. 28,30-Bisnorhopane completely dominate the chromatograms of several samples (e.g. NE54, Figure 6.17a) and may indicate deposition under sometimes low oxygen, possibly anoxic conditions. $17 \alpha(\mathrm{H})$-Diahopane is generally present in low relative abundances but in some samples (e.g. NE43, Figure 6.17b), despite low maturity may show moderate abundances. This may indicate that a portion of contributing organic matter was initially deposited under oxic and possibly terrestrial conditions. Oleanane is observed in about half the samples, confirming an angiosperm-derived terrestrial contribution to organic matter. A compound coeluting with, or on the shoulder of, $\mathrm{C}_{31} \alpha \beta-22 \mathrm{R}$ in a number of samples (e.g. NE43, Figure 6.17b) is tentatively identified as gammacerane, an indicator of deposition under conditions of elevated salinity. The most notable biomarker characteristic of the $\mathrm{m} / \mathrm{z} 217$ chromatograms are the high relative abundances of $C_{30}$ steranes $\left(C_{30}\right.$ indices average 0.20) (e.g. NE37, Figure 6.17c). The sterane distribution pattern of $\mathrm{C}_{27}>\mathrm{C}_{30} \sim \mathrm{C}_{29}>\mathrm{C}_{28}$ shows $\mathrm{C}_{30}$ steranes are second in abundance only to $\mathrm{C}_{27}$ steranes. $\mathrm{C}_{27} / \mathrm{C}_{29}$ sterane ratios (0.74-2.59) generally indicate mixed marine and terrestrial or predominantly marine organic matter, although a few samples with low ratios may predominantly comprise higher plant organic matter. $\mathrm{C}_{28}$ steranes form a low proportion (0.16) of the $\mathrm{C}_{27}-\mathrm{C}_{30}$ regular steranes. Diasteranes are generally present in low relative abundances, with $\mathrm{C}_{27}$ in greater concentrations than 

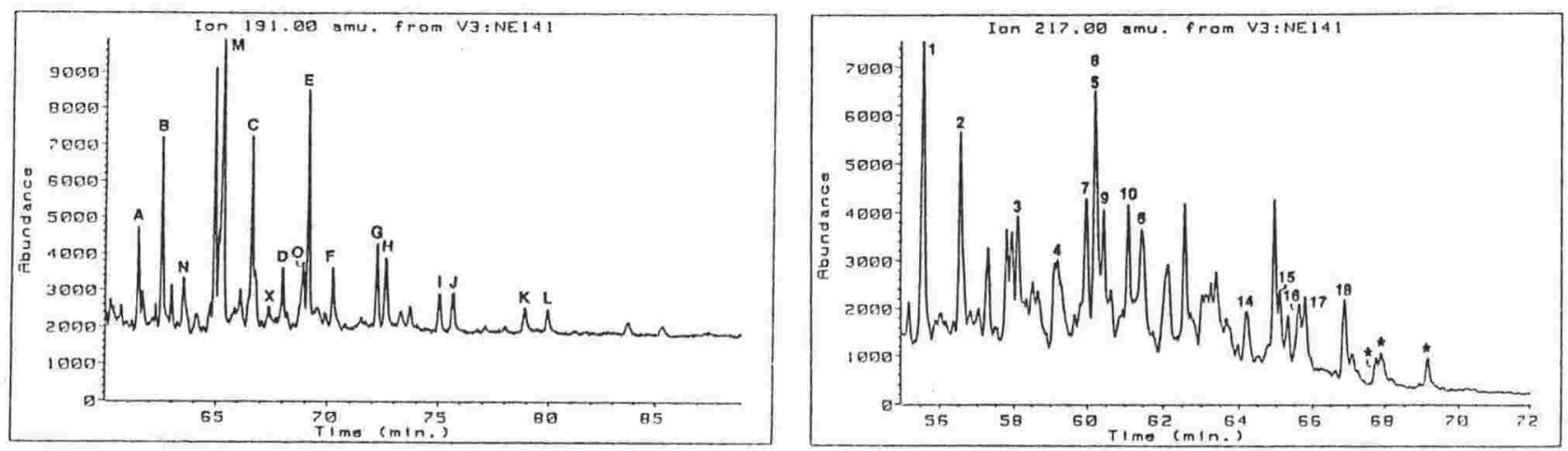

a. Kandahar Formation - NE141
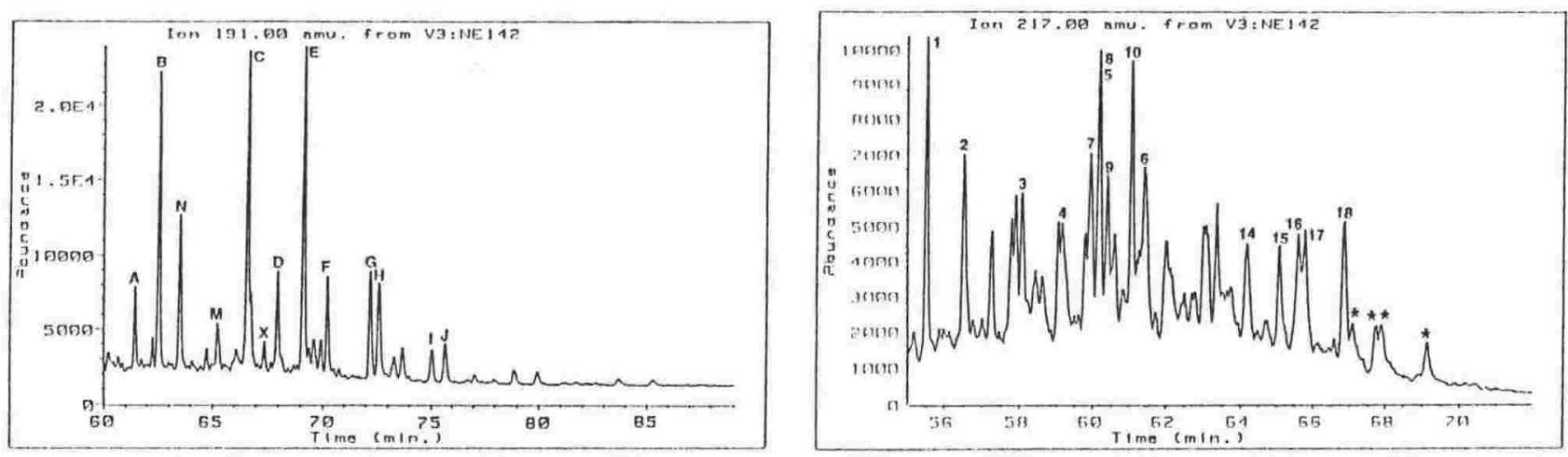

b. Awhea Formation - NE142
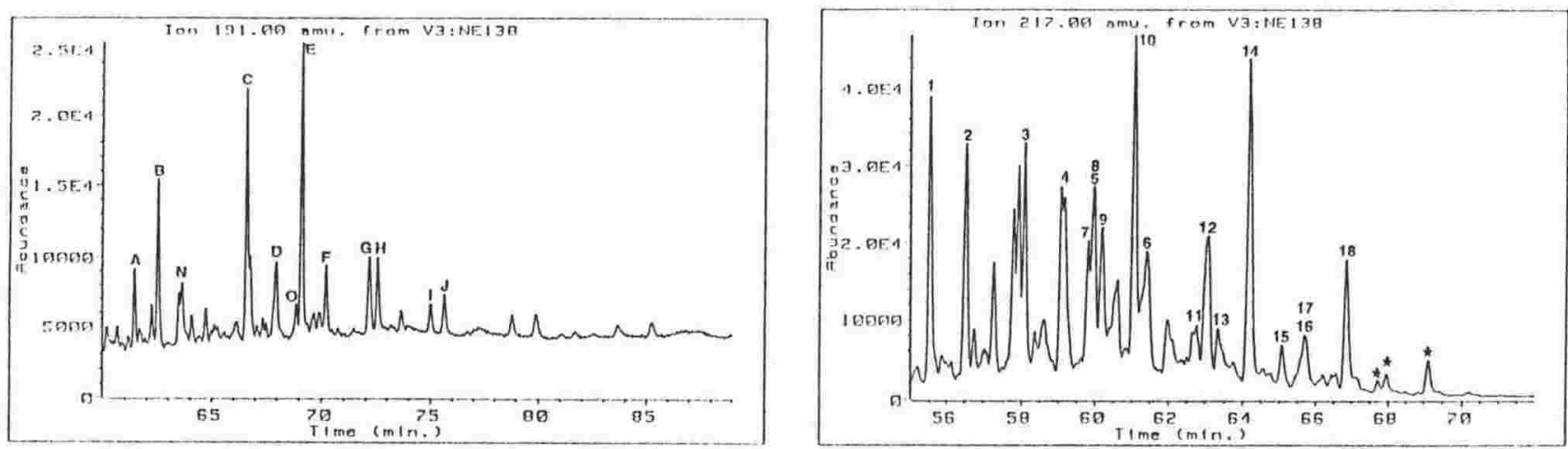

c. Mungaroa Member (Awhea Formation) - NE138
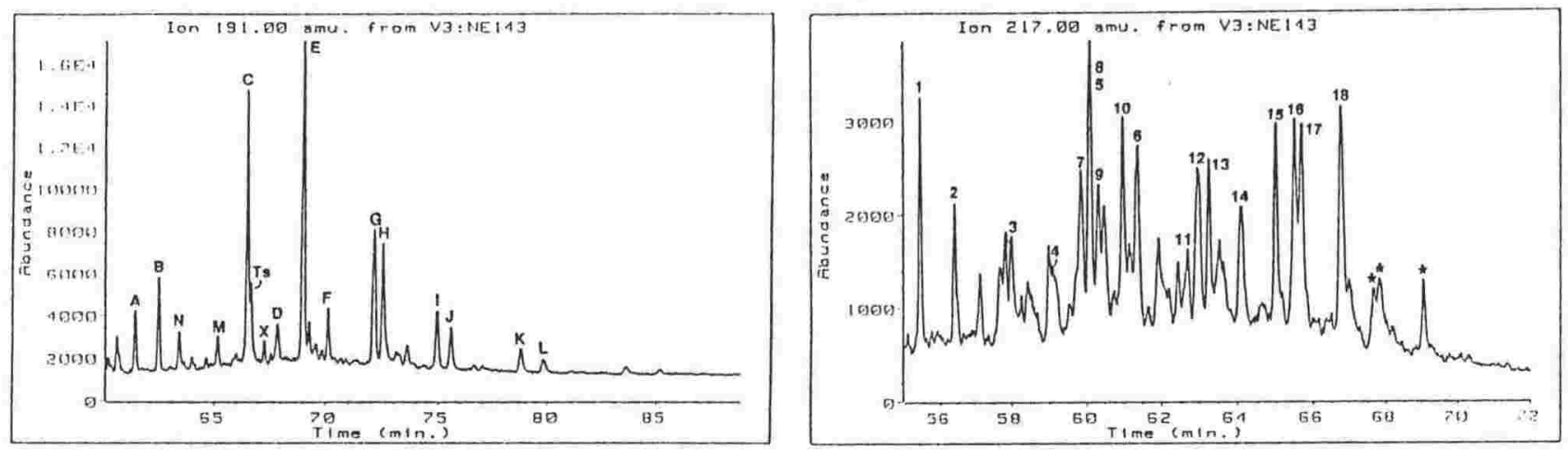

d. Manurewa Formation - NE143

Figure 6.18 GC-MS m/z 191 and 217 mass chromatograms of the possible source rocks (N.I.). 
$\mathrm{C}_{29}$ homologues, although this appears to be partially maturity related. Low maturities are indicated by occasionally high relative abundances of $C_{29} \beta \beta$-hopane and $17 \beta(\mathrm{H})$ 22,29,30-trisnorhopane. No samples have reached equilibrium in either their moretane/hopane or $22 \mathrm{~S} /(22 \mathrm{~S}+22 \mathrm{R})$ homohopane ratios, indicating maturities below the onset of oil generation $\left(<0.6 \% \mathrm{R}_{\mathrm{o}}\right)$. Sterane biomarker ratios confirm the low maturities and the $\mathrm{m} / \mathrm{z} 217$ chromatograms are characterised by the dominance of $\alpha \alpha \alpha-20 \mathrm{R}$ isomers.

\section{(Tora Block possible source rocks)}

(Kandahar Formation) (NE141, Figure 6.18a): The $\mathrm{m} / \mathrm{z} 191$ chromatogram shows a high relative abundance of 28,30-bisnorhopane, low $17 \alpha(\mathrm{H})$-diahopane and moderate oleanane. Oleanane occurs in one of the highest relative abundances observed and indicates an angiosperm-derived terrestrial contribution of organic matter. Relatively high abundances of 28,30-bisnorhopane may indicate deposition under reduced oxygen conditions. The $\mathrm{m} / \mathrm{z} 217$ chromatogram is characterised by a sterane distribution pattern showing $\mathrm{C}_{27}>\mathrm{C}_{29}>\mathrm{C}_{28}>\mathrm{C}_{30}$ and a high $\mathrm{C}_{27} / \mathrm{C}_{29}$ sterane ratio (2.06) indicating the predominance of marine organic matter. $\mathrm{C}_{30}$ steranes are present in low relative abundances $\left(\mathrm{C}_{30}\right.$ index of 0.08). High relative abundances of diasteranes dominate the $\mathrm{m} / \mathrm{z} 217$ chromatogram, with $\mathrm{C}_{27}$ in greater concentrations than $\mathrm{C}_{29}$ homologues. Moretane/hopane (0.29) and $22 \mathrm{~S} /(22 \mathrm{~S}+22 \mathrm{R})$ homohopane ratios (0.50) indicate equilibrium has almost been reached, and therefore a maturity just below the onset of oil generation $\left(\sim 0.6 \% \mathrm{R}_{0}\right)$. This is supported by a high relative abundance of $17 \beta(\mathrm{H})$ 22,29,30-trisnorhopane. 20S/(20S+20R) sterane ratios $(\sim 0.48)$, however, indicate a maturity approaching peak oil generation $\left(\sim 0.8 \% \mathrm{R}_{\mathrm{o}}\right)$.

(Awhea Formation) (NE142, Figure 6.18b): The $\mathrm{m} / \mathrm{z} 191$ chromatogram is characterised by a low-moderate relative abundance of 28,30-bisnorhopane, low $17 \alpha(\mathrm{H})$ diahopane and trace oleanane. The presence of oleanane indicates an angiosperm-derived terrestrial contribution of organic matter. The $\mathrm{m} / \mathrm{z} 217$ chromatogram has a sterane distribution pattern showing $\mathrm{C}_{27}>\mathrm{C}_{29}>\mathrm{C}_{28}>\mathrm{C}_{30}$ with a low $\mathrm{C}_{30}$ index. The $\mathrm{C}_{27} / \mathrm{C}_{29}$ sterane ratio (1.46) indicates a predominance of marine organic matter. High relative abundances of diasteranes, with similar concentrations of $C_{27}$ and $C_{29}$ homologues, dominate the sterane chromatogram. Neither moretane/hopane or $22 \mathrm{~S} /(22 \mathrm{~S}+22 \mathrm{R})$ homohopane ratios have reached equilibrium, indicating a maturity below the onset of oil generation $\left(<0.6 \% \mathrm{R}_{0}\right)$. This is supported by a moderate-high relative abundance of $17 \beta(\mathrm{H})-22,29,30$-trisnorhopane. 20S/(20S+20R) sterane ratios (0.46-0.50), however, indicate a maturity approaching peak oil generation $\left(0.8 \% \mathrm{R}_{\mathrm{o}}\right)$. 
(Mungaroa Member of the Awhea Formation) (NE138, Figure 6.18c): The $\mathrm{m} / \mathrm{z} 191$ chromatogram shows low relative abundances of 28,30-bisnorhopane, $17 \alpha(\mathrm{H})$-diahopane and oleanane. The presence of oleanane indicates an angiosperm-derived terrestrial contribution. The $\mathrm{m} / \mathrm{z} 217$ chromatogram is characterised by a sterane pattern showing $\mathrm{C}_{28}>\mathrm{C}_{27}>\mathrm{C}_{29}>\mathrm{C}_{30}$ and a high $\mathrm{C}_{27} / \mathrm{C}_{29}$ ratio (2.41), indicating a large predominance of marine organic matter. $\mathrm{C}_{30}$ steranes are present in low relative abundances $\left(\mathrm{C}_{30}\right.$ index of 0.04). High relative abundances of diasteranes with $C_{27}$ compounds in greater concentrations than $\mathrm{C}_{29}$ homologues also indicate marine organic matter. Moretane/hopane and $22 \mathrm{~S} /(22 \mathrm{~S}+22 \mathrm{R})$ homohopane ratios indicate equilibration has not been reached and maturity is below the onset of oil generation $\left(<0.6 \% \mathrm{R}_{0}\right)$. This is supported by a moderate relative abundance of $17 \beta(\mathrm{H})-22,29,30$-trisnorhopane. $20 \mathrm{~S} /(20 \mathrm{~S}+20 \mathrm{R})$ sterane and $\% \beta \beta$ sterane ratios also indicate a low maturity, with $\alpha \alpha \alpha-20 \mathrm{R}$ isomers dominant and $\mathrm{C}_{29} \alpha \beta \beta-20 \mathrm{R}$ and $-20 \mathrm{~S}$ epimers not yet resolved.

(Manurewa Formation) (e.g. NE143, Figure 6.18d): The $\mathrm{m} / \mathrm{z} 191$ chromatograms show low-moderate relative abundances of 28,30-bisnorhopane, low $17 \alpha(\mathrm{H})$-diahopane and trace or an absence of oleanane. The m/z 217 chromatograms are characterised by variable sterane distribution pattern showing $\mathrm{C}_{29} \sim \mathrm{C}_{27}>\mathrm{C}_{28}>\mathrm{C}_{30}$ and variable $\mathrm{C}_{27} / \mathrm{C}_{29}$ sterane ratios (0.45-1.88) indicating fluctuating contributions of marine and terrestrial organic matter. $\mathrm{C}_{30}$ steranes are present in low relative abundances $\left(C_{30}\right.$ indices average $\left.<0.12\right)$. High relative abundances of $C_{27}$ and $C_{29}$ diasteranes. may result from high maturity. Both moretane/hopane and $22 \mathrm{~S} /(22 \mathrm{~S}+22 \mathrm{R})$ homohopane ratios (about 0.17 and 0.56 respectively) indicate NE143 has reached a maturity greater than $0.6 \% \mathrm{R}_{\mathrm{o}} .20 \mathrm{~S} /(20 \mathrm{~S}+20 \mathrm{R})$ sterane ratios have almost reached equilibrium indicating a maturity of peak oil generation $\left(\sim 0.8 \% \mathrm{R}_{\mathrm{o}}\right)$.

\section{Whangai Formation}

Te Uri Member (e.g. NE21, Figure 6.19a): The $\mathrm{m} / \mathrm{z} 191$ chromatograms are characterised by low-moderate relative abundances of 28,30-bisnorhopane, low $17 \alpha(\mathrm{H})$ diahopane and an absence of oleanane. The $\mathrm{m} / \mathrm{z} 217$ chromatograms show high $\mathrm{C}_{27} / \mathrm{C}_{29}$ sterane ratios (1.73-1.91), and a $\mathrm{C}_{27}>\mathrm{C}_{28}>\mathrm{C}_{29}>\mathrm{C}_{30}$ sterane distribution pattern, although $\mathrm{C}_{28}$ steranes may also be predominant. This indicates a predominant marine contribution of organic matter. $\mathrm{C}_{30}$ steranes are present in low relative abundances $\left(\mathrm{C}_{30}\right.$ indices average 0.05$)$. Diasteranes are present in low to moderate abundances with $\mathrm{C}_{27}$ in greater concentrations than $\mathrm{C}_{29}$ compounds. Low maturities are indicated by the high relative abundances of $\mathrm{C}_{29} \beta \beta$-hopanes and moderate relative abundances of $17 \beta(\mathrm{H})-22,29,30$-trisnorhopane. Neither the moretane/hopane or $22 \mathrm{~S} /(22 \mathrm{~S}+22 \mathrm{R})$ homohopane ratios have reached equilibrium, indicating maturities are below the onset of 

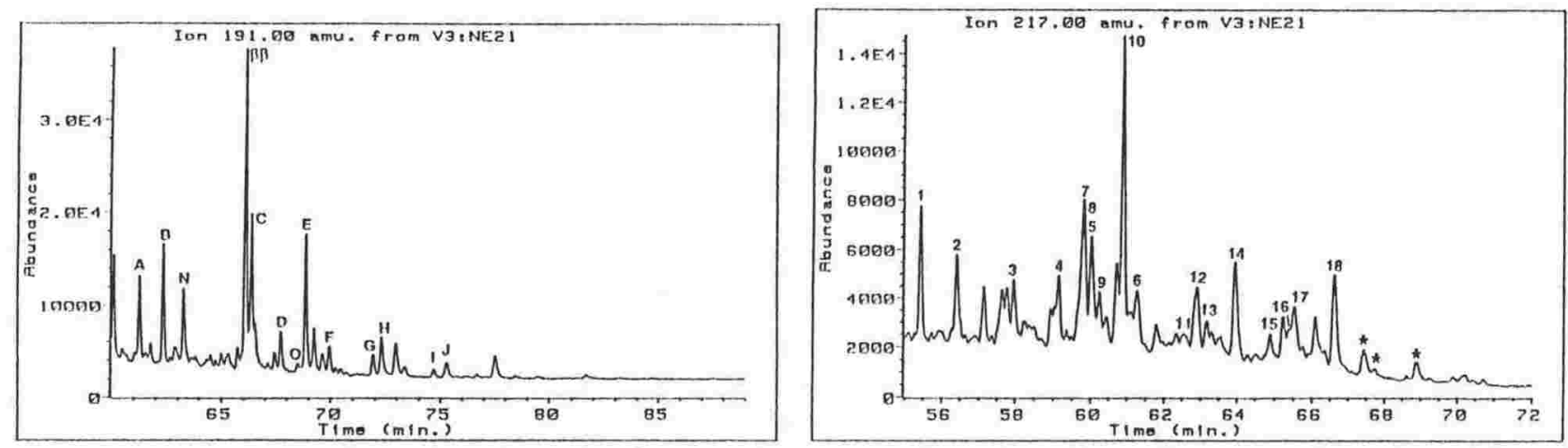

a. Te Uri Member (Whangai Formation) - NE21
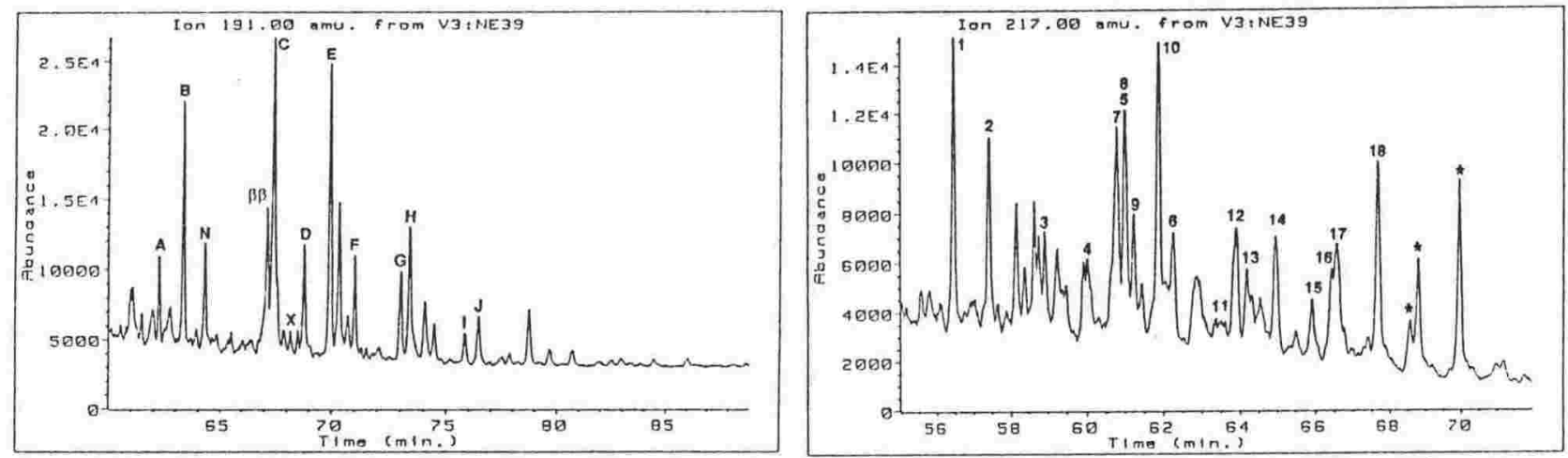

b. Porangahau Member (Whangai Formation) - NE39
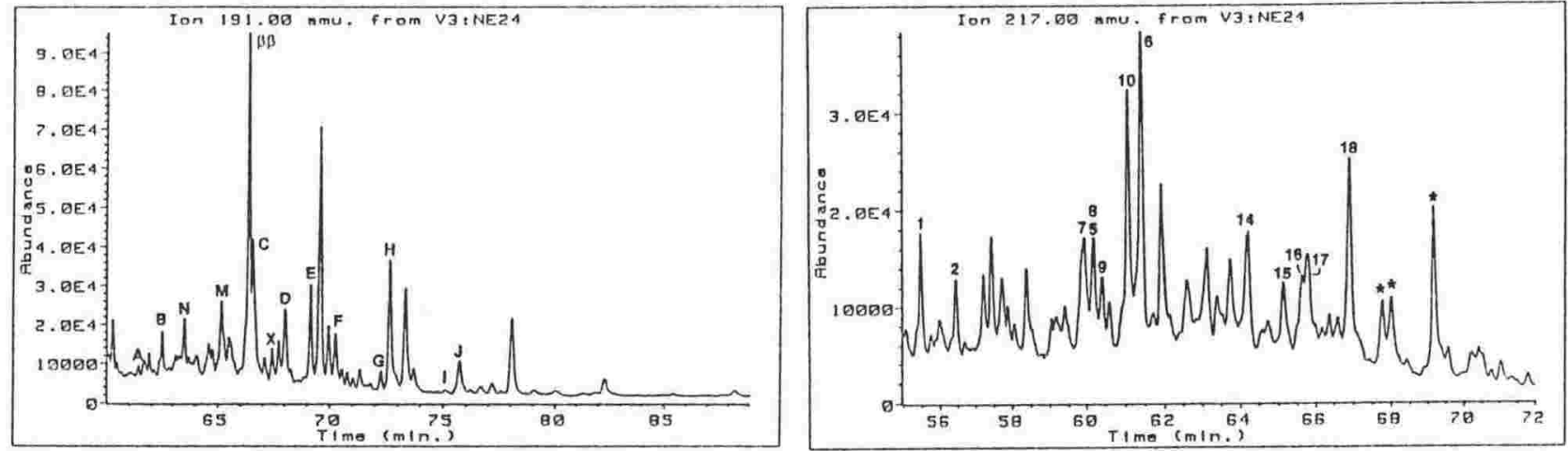

c. Upper Calcareous Member (Whangai Formation) - NE24
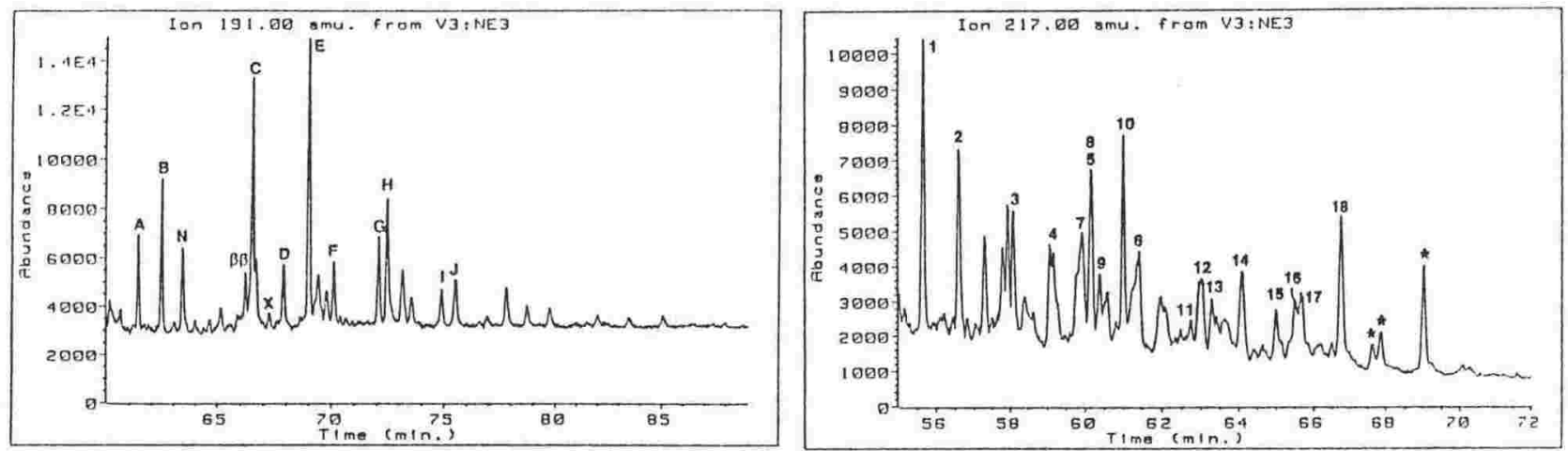

d. Rakauroa Member (Whangai Formation) - NE3

Figure 6.19 GC-MS m/z 191 and 217 mass chromatograms of the possible source rocks (N.I.). 
oil generation $\left(<0.6 \% \mathrm{R}_{\mathrm{o}}\right)$. $\alpha \alpha \alpha-20 \mathrm{R}$ steranes dominate the $\mathrm{m} / \mathrm{z} 217$ chromatograms and $\mathrm{C}_{29} \alpha \beta \beta-20 \mathrm{R}$ and $-20 \mathrm{~S}$ epimers are not resolved.

Porangahau Member (e.g. NE39, Figure 6.19b): The m/z 191 chromatograms show low relative abundances of 28,30-bisnorhopane and $17 \alpha(\mathrm{H})$-diahopane, and lowmoderate oleanane. Although absent in NE39, the presence of oleanane in all other samples indicates an angiosperm-derived contribution of organic matter. The $\mathrm{m} / \mathrm{z} 217$ chromatograms show a $\mathrm{C}_{29}>\mathrm{C}_{27}>\mathrm{C}_{30}>\mathrm{C}_{28}$ sterane distribution pattern and low $\mathrm{C}_{27} / \mathrm{C}_{29}$ sterane ratios (0.23-1.31) indicating the predominance of terrestrial organic matter. $\mathrm{C}_{30}$ steranes are present in variable, but generally high, relative abundances $\left(\mathrm{C}_{30}\right.$ indices average 0.20$)$. Moderate to high abundances of diasteranes with $\mathrm{C}_{27}$ in greater concentrations than $\mathrm{C}_{29}$ homologues are contrary to the pattern of low $\mathrm{C}_{27} / \mathrm{C}_{29}$ sterane ratios. Sample maturities vary with most not reaching equilibrium in both moretane/hopane and $22 \mathrm{~S} /(22 \mathrm{~S}+22 \mathrm{R})$ homohopane ratios, indicating maturities below the onset of oil generation $\left(<0.6 \% \mathrm{R}_{\mathrm{o}}\right)$. This is supported by moderate-high relative abundances of $17 \beta(\mathrm{H})-22,29,30$-trisnorhopane. The $\mathrm{m} / \mathrm{z} 217$ chromatograms show moderate relative abundances of $\alpha \beta \beta$-steranes and partially resolved $C_{29} \alpha \beta \beta-20 \mathrm{R}$ and -20S epimers.

Upper Calcareous Member (e.g. NE24, Figure 6.19c): The m/z 191 chromatograms show occasionally high relative abundances of 28,30-bisnorhopane, low $17 \alpha(\mathrm{H})$ diahopane and either trace amounts or an absence of oleanane. 28,30-Bisnorhopane dominates the chromatogram of NE46 and may indicate conditions of anoxic bottom water. The $\mathrm{m} / \mathrm{z} 217$ chromatograms have a sterane distribution pattern showing $\mathrm{C}_{28}>\mathrm{C}_{27}>\mathrm{C}_{29}>\mathrm{C}_{30}$ (although $\mathrm{C}_{27}$ steranes may also be dominant) and a variable but generally high $\mathrm{C}_{27} / \mathrm{C}_{29}$ sterane ratio (0.75-2.39) indicating a predominance of either mixed marine and terrestrial or marine organic matter. This is supported by the high relative abundance of $\mathrm{C}_{28}$ steranes. $\mathrm{C}_{30}$ steranes are generally present in low to moderate relative abundances $\left(C_{30}\right.$ indices average 0.09). Diasteranes are present in low relative abundances and may also be maturity affected. A depositional environment distant from land, with minimal terrestrial input is suggested by high $\mathrm{C}_{27} / \mathrm{C}_{29}$ sterane ratios and an absence of oleanane. Maturities are generally low as indicated by the moderate to high relative abundance of $\mathrm{C}_{29} \beta \beta$-hopane and occasionally high relative abundances of $17 \beta(\mathrm{H})-22,29,30$-trisnorhopane. Moretane/hopane and $22 \mathrm{~S} /(22 \mathrm{~S}+22 \mathrm{R})$ homohopane ratios have not reached equilibrium, indicating maturities below the onset of oil generation $\left(<0.6 \% \mathrm{R}_{\mathrm{o}}\right.$ ). The $\mathrm{m} / \mathrm{z} 217$ chromatograms show steranes dominated by the biologically-formed $\alpha \alpha \alpha-20 \mathrm{R}$ isomers and unresolved $\mathrm{C}_{29} \alpha \beta \beta-20 \mathrm{R}$ and -20S epimers. 

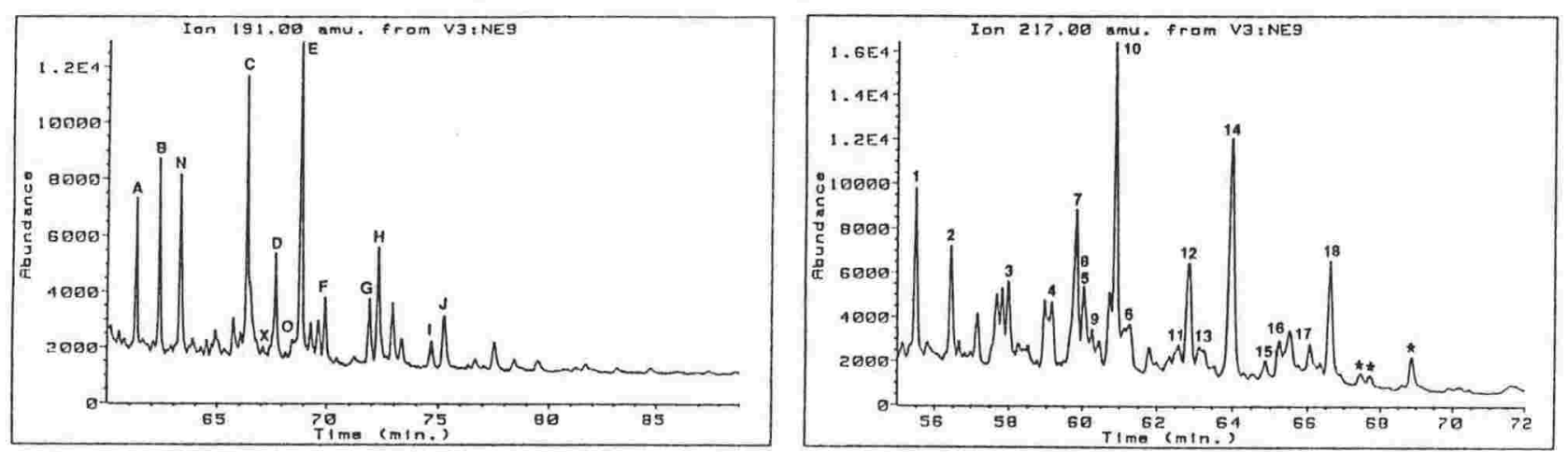

a. Tangaruhe Formation - NE9
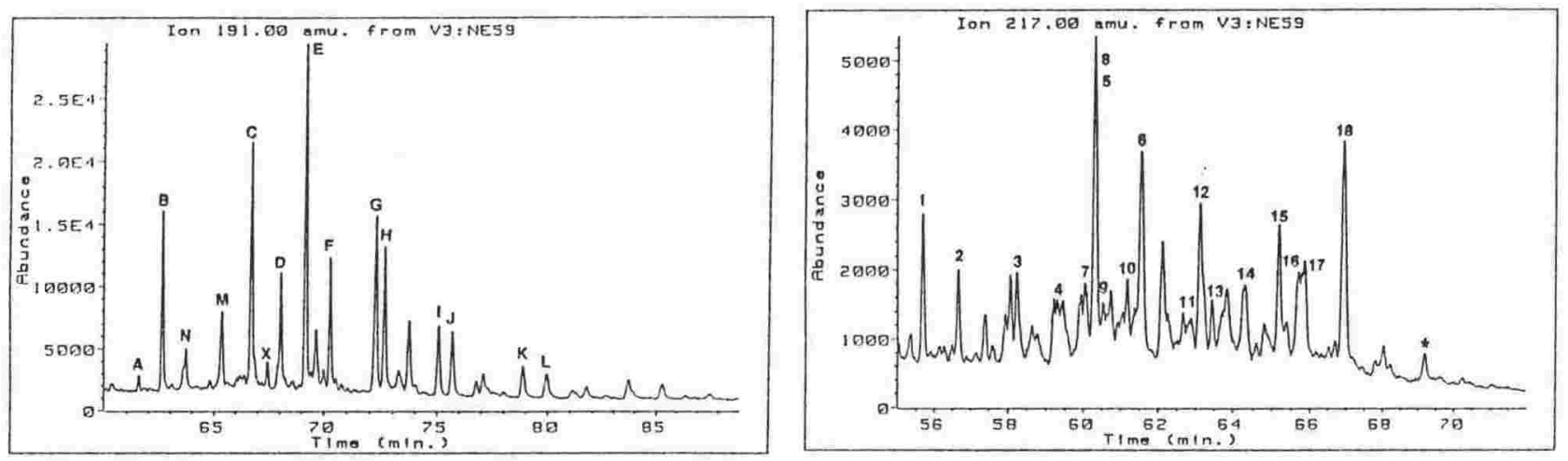

b. Te Mai Formation - NE59
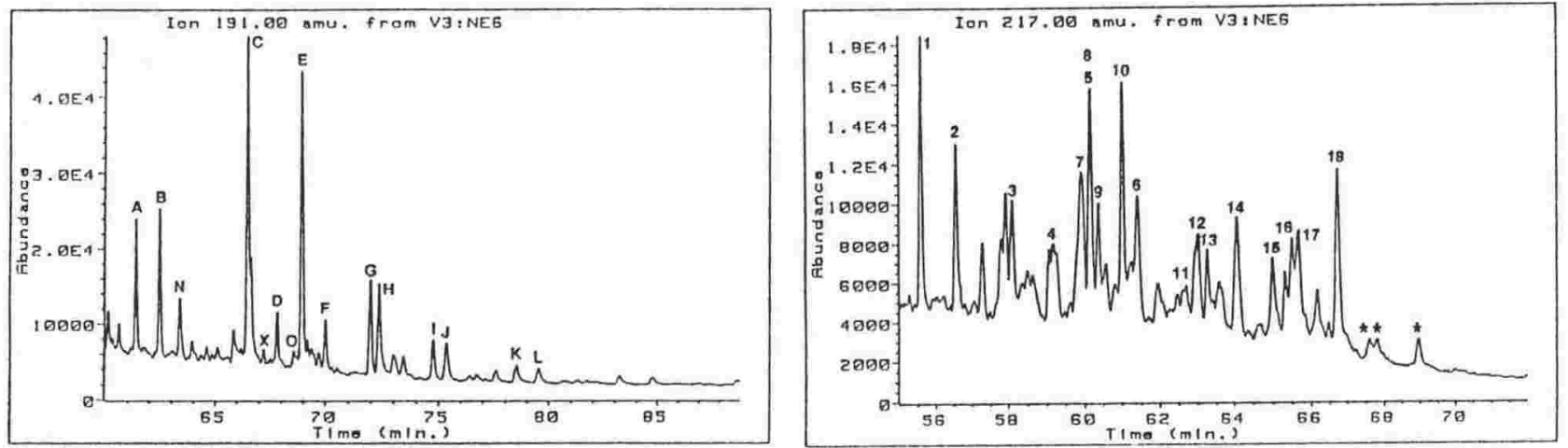

c. Glenburn Formation - NEG
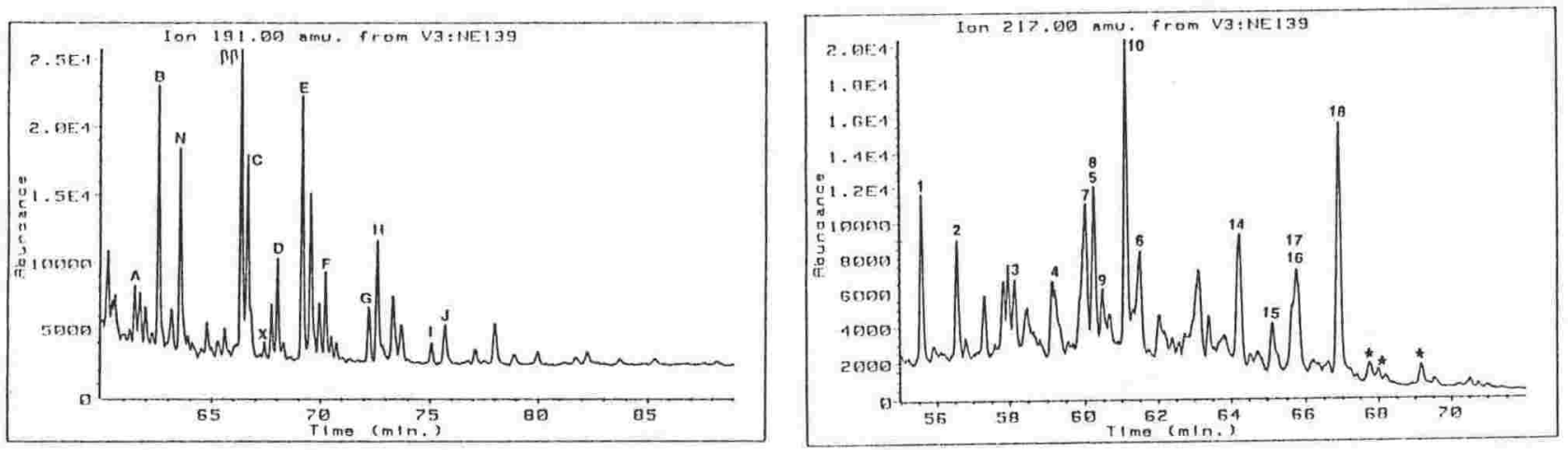

d. Springhill Formation - NE139

Figure 6.20 GC-MS m/z 191 and 217 mass chromatograms of the possible source rocks (N.I.). 
Rakauroa Member (e.g. NE3, Figure 6.19d): The $\mathrm{m} / \mathrm{z} 191$ chromatograms are characterised by low to moderate relative abundances of 28,30-bisnorhopane, low $17 \alpha(\mathrm{H})$-diahopane and low or low-moderate oleanane. The presence of oleanane indicates the presence of angiosperm-derived terrestrial organic matter. The $\mathrm{m} / \mathrm{z} 217$ chromatograms have a $\mathrm{C}_{27}>\mathrm{C}_{29}>\mathrm{C}_{28}>\mathrm{C}_{30}$ sterane distribution pattern although some samples have high proportions of $\mathrm{C}_{28}$ and $\mathrm{C}_{30}$ steranes. Predominantly high $\mathrm{C}_{27} / \mathrm{C}_{29}$ sterane ratios (0.88-3.02) indicate either mixed marine and terrestrial or marine organic matter. $\mathrm{C}_{30}$ steranes are present in low to moderate relative abundances $\left(C_{30}\right.$ indices average 0.10$)$. The relative abundances of diasteranes are generally high and appear to be at least partly determined by maturity. Sample maturities are generally low indicated by moderate to high relative abundances of $\mathrm{C}_{29} \beta \beta$-hopane and moderate relative abundances of $17 \beta(\mathrm{H})$-22,29,30-trisnorhopane. Moretane/hopane and $22 \mathrm{~S} /(22 \mathrm{~S}+22 \mathrm{R})$ homohopane ratios indicate no samples have reached equilibrium and therefore have maturities below the onset of oil generation $\left(<0.6 \% R_{\mathrm{o}}\right) . \alpha \alpha \alpha-20 \mathrm{R}$ steranes dominate $\mathrm{m} / \mathrm{z} 217$ chromatograms and $\mathrm{C}_{29} \alpha \beta \beta-20 \mathrm{R}$ and $-20 \mathrm{~S}$ epimers are only partly resolved.

Tangaruhe Formation (e.g NE9, Figure 6.20a): The $\mathrm{m} / \mathrm{z} 191$ chromatograms are characterised by low relative abundances of 28,30-bisnorhopane, $17 \alpha(\mathrm{H})$-diahopane and oleanane. The presence of oleanane indicates an angiosperm-derived terrestrial contribution of organic matter. The $\mathrm{m} / \mathrm{z} 217$ chromatograms have a $\mathrm{C}_{27}>\mathrm{C}_{28}>\mathrm{C}_{29}>\mathrm{C}_{30}$ sterane distribution pattern and the $\mathrm{C}_{27} / \mathrm{C}_{29}$ sterane ratios (0.88-2.18) are indicative of either mixed marine and terrestrial or marine organic matter. $\mathrm{C}_{30}$ steranes are present in low relative abundances $\left(\mathrm{C}_{30}\right.$ indices average 0.05$)$. Diasteranes are present in moderate relative abundances with $\mathrm{C}_{27}$ in greater concentrations than $\mathrm{C}_{29}$ homologues, also suggesting a predominance of marine organic matter. Moretane/hopane and $22 \mathrm{~S} /(22 \mathrm{~S}+22 \mathrm{R})$ homohopane ratios have not reached equilibrium, indicating maturities below the onset of oil generation $\left(<0.6 \% \mathrm{R}_{0}\right)$. This is supported by occasionally high relative abundances of $\mathrm{C}_{29} \beta \beta$-hopane and moderate to high relative abundances of $17 \beta(\mathrm{H})-22,29,30$-trisnorhopane. The $\mathrm{m} / \mathrm{z} 217$ chromatograms show steranes dominated by the $\alpha \alpha \alpha-20 \mathrm{R}$ isomers, and unresolved $\mathrm{C}_{29} \alpha \beta \beta-20 \mathrm{R}$ and $-20 \mathrm{~S}$ epimers.

Te Mai Formation (e.g. NE59, Figure 6.20b): The m/z 191 chromatograms show low to moderate relative abundances of 28,30-bisnorhopane, low $17 \alpha(\mathrm{H})$-diahopane and trace or an absence of oleanane. Samples with oleanane indicate an angiosperm-derived terrestrial contribution of organic matter. The $\mathrm{m} / \mathrm{z} 217$ chromatograms have either high (1.65-2.46) or low (0.29-0.88) $\mathrm{C}_{27} / \mathrm{C}_{29}$ sterane ratios, indicative of fluctuating contributions of marine and terrestrial organic matter. Diasteranes are present in mostly 
high relative abundances and also fluctuate between $\mathrm{C}_{27}$ and $\mathrm{C}_{29}$ homologue dominance. $C_{30}$ steranes are present in low relative abundances $\left(C_{30}\right.$ indices average 0.07$)$. Sample maturities are generally low with occasionally high relative abundances of $C_{29} \beta \beta$-hopane and $17 \beta(\mathrm{H})-22,29,30$-trisnorhopane. Only one sample has reached equilibrium in moretane/hopane and $22 \mathrm{~S} /(22 \mathrm{~S}+22 \mathrm{R})$ homohopane ratios and therefore a maturity of the onset of oil generation $\left(0.6 \% \mathrm{R}_{0}\right) .20 \mathrm{~S} /(20 \mathrm{~S}+20 \mathrm{R})$ sterane ratios also vary with almost all the $\mathrm{C}_{27}$ sterane ratios reaching equilibrium, while $\mathrm{C}_{29}$ sterane ratios remain considerably below. This appears to be caused by preferential biodegradation of both the lower molecular weight steranes and $\alpha \alpha \alpha-20 \mathrm{R}$ isomers. $\% \beta \beta \mathrm{C}_{27}$ sterane ratios overestimate maturities, compared with $\mathrm{C}_{29}$ steranes, probably as a result of coelution of the $\mathrm{C}_{27} \alpha \beta \beta-20 \mathrm{R}$ sterane with $\mathrm{C}_{29}(-20 \mathrm{~S})$ diasterane and/or reduction of the $\mathrm{C}_{27} \alpha \alpha \alpha-20 \mathrm{R}$ sterane through biodegradation. Most samples have $\mathrm{m} / \mathrm{z} 217$ chromatograms with steranes dominated by $\alpha \alpha \alpha-20 \mathrm{R}$ isomers, and poorly or unresolved $\mathrm{C}_{29} \alpha \beta \beta-20 \mathrm{R}$ and $-20 \mathrm{~S}$ epimers.

Glenburn Formation (e.g. NE6, Figure 6.20c): The m/z 191 chromatograms show low relative abundances 28,30-bisnorhopane and generally low $17 \alpha(\mathrm{H})$-diahopane. The presence of oleanane, in some samples, confirms an angiosperm-derived terrestrial contribution. The $\mathrm{m} / \mathrm{z} 217$ chromatograms have a sterane distribution pattern that usually shows $\mathrm{C}_{29}>\mathrm{C}_{27}>\mathrm{C}_{28}>\mathrm{C}_{30}$, although $\mathrm{C}_{27}$ steranes are often dominant. Predominantly low $\mathrm{C}_{27} / \mathrm{C}_{29}$ sterane ratios (0.30-2.49) indicate a mainly terrestrial contribution of organic matter. High $\mathrm{C}_{27} / \mathrm{C}_{29}$ sterane ratios indicating strong marine contributions are also common. $\mathrm{C}_{30}$ steranes are present in variable relative abundances $\left(\mathrm{C}_{30}\right.$ indices average 0.13). Diasteranes, particularly $C_{27}$ homologues tend to dominate $\mathrm{m} / \mathrm{z} 217$ chromatograms. Sample maturities vary considerably with only half reaching equilibrium in both moretane/hopane and $22 \mathrm{~S} /(22 \mathrm{~S}+22 \mathrm{R})$ homohopane ratios and therefore maturities of early oil generation $\left(>0.6 \% \mathrm{R}_{\mathrm{o}}\right)$. Moderate relative abundances of $\mathrm{C}_{29} \beta \beta$-hopane and $17 \beta(\mathrm{H})-22,29,30$-trisnorhopane are common, qualitatively indicating low maturities. 20S/(20S+20R) sterane ratios indicate that only NE117 and NE118 have reached equilibrium and maturities equivalent to peak oil generation $\left(0.8 \% \mathrm{R}_{\mathrm{o}}\right)$, but lower than $0.9 \% \mathrm{R}_{\mathrm{o}}$, the maturity at which $\% \beta \beta$ equilibration occurs.

Springhill Formation (e.g. NE139, Figure 6.20d): The m/z 191 chromatograms show low-moderate relative abundances of 28,30-bisnorhopane, low $17 \alpha(\mathrm{H})$-diahopane and an absence of oleanane. The $\mathrm{m} / \mathrm{z} 217$ chromatograms are characterised by a $\mathrm{C}_{29}>\mathrm{C}_{27}>\mathrm{C}_{28}>\mathrm{C}_{30}$ sterane distribution pattern and low $\mathrm{C}_{27} / \mathrm{C}_{29}$ sterane ratios (0.66-0.89) indicating a predominance of terrestrial organic matter. $\mathrm{C}_{30}$ steranes are present in low relative abundances $\left(\mathrm{C}_{30}\right.$ indices average 0.04$)$. Moderate relative abundances of 

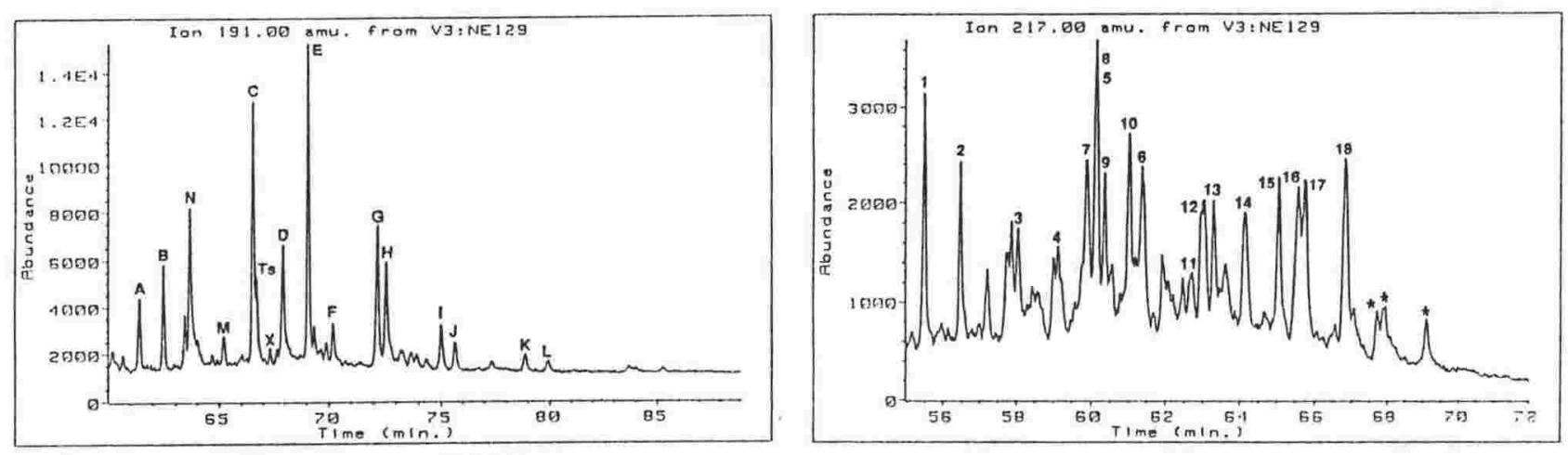

a. Gentle Annie Formation - NE129
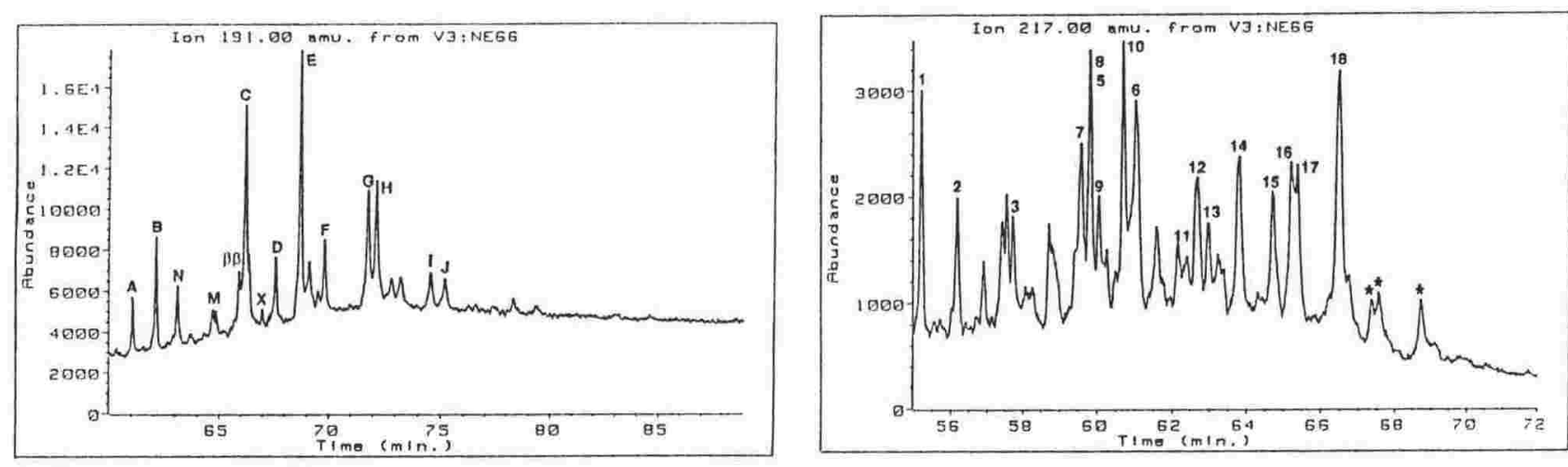

\section{b. Pahaoa Group - NE66}
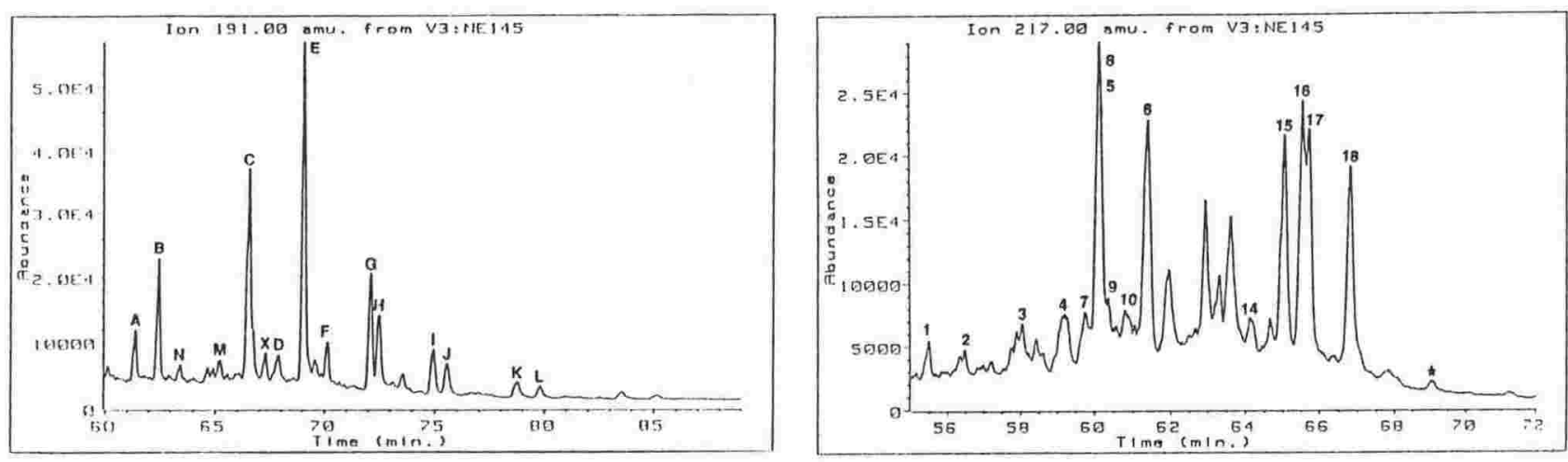

\section{c. Whatarangi Formation - NE145}
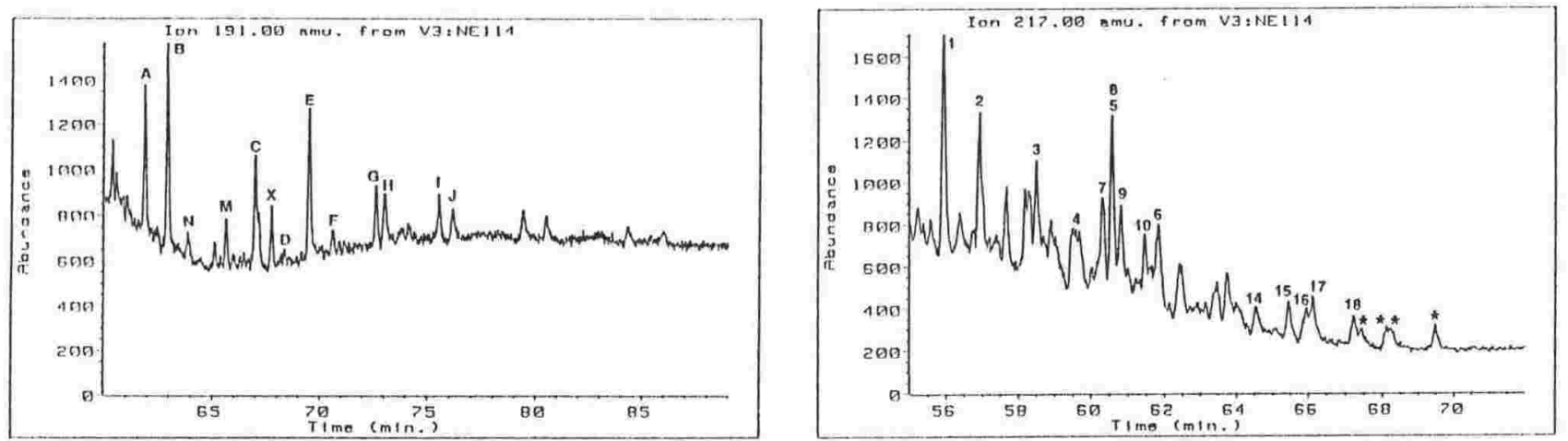

d. Torlesse Supergroup - NE114

Figure 6.21 GC-MS m/z 191 and 217 mass chromatograms of the possible source rocks (N.I.). 
diasteranes are present with $\mathrm{C}_{29}$ in greater concentrations than $\mathrm{C}_{27}$ homologues, which is indicative of terrestrial organic matter. Both $C_{29} \beta \beta$-hopane and $17 \beta(H)-22,29,30-$ trisnorhopane are present in moderate to high relative abundances indicating low sample maturities. Equilibriation of moretane/hopane and $22 \mathrm{~S} /(22 \mathrm{~S}+22 \mathrm{R})$ homohopane ratios has not been reached and indicates maturities below the onset of oil generation $\left(<0.6 \% \mathrm{R}_{\mathrm{o}}\right)$. The low maturity of NE139 is demonstrated by the dominance of steranes with $\alpha \alpha \alpha-20 \mathrm{R}$ isomers in the $\mathrm{m} / \mathrm{z} 217$ chromatogram.

Gentle Annie Formation (NE129, Figure 6.21a): The m/z 191 chromatogram shows low relative abundances of 28,30-bisnorhopane and $17 \alpha(\mathrm{H})$-diahopane and an absence of oleanane. The $\mathrm{m} / \mathrm{z} 217$ chromatogram is characterised by a sterane distribution pattern showing $\mathrm{C}_{27}>\mathrm{C}_{29}>\mathrm{C}_{28}>\mathrm{C}_{30}$ and $\mathrm{C}_{27} / \mathrm{C}_{29}$ sterane ratio (1.15) indicating mixed marine and terrestrial organic matter, and a low $\mathrm{C}_{30}$ index (0.09). Both $\mathrm{C}_{27}$ and $\mathrm{C}_{29}$ diasteranes are present in high relative abundances, possibly as a result of maturity. A moderate-high relative abundance of $17 \beta(\mathrm{H})-22,29,30$-trisnorhopane indicates a low maturity. The $\mathrm{C}_{30}$ moretane/hopane ratio $(0.13)$ and $22 \mathrm{~S} /(22 \mathrm{~S}+22 \mathrm{R})$ homohopane ratios (0.55-0.57) have reached equilibrium, while the $\mathrm{C}_{29} 20 \mathrm{~S} /(20 \mathrm{~S}+20 \mathrm{R})$ sterane ratio has almost reached equilibrium (0.46), indicating a maturity of almost peak oil generation $\left(\sim 0.8 \% \mathrm{R}_{\mathrm{o}}\right)$. The $\mathrm{C}_{27}$ sterane ratio is not considered reliable as it is affected by coelution with $\mathrm{C}_{29}(-20 \mathrm{~S})$ diasterane.

Pahaoa Group (e.g. NE66, Figure 6.21b): The m/z 191 chromatograms are characterised by variable relative abundances of 28,30-bisnorhopane (low to high), generally low $17 \alpha(\mathrm{H})$-diahopane, and an absence of oleanane. The $\mathrm{m} / \mathrm{z} 217$ chromatograms are characterised by a $\mathrm{C}_{29}>\mathrm{C}_{27}>\mathrm{C}_{28}>\mathrm{C}_{30}$ sterane distribution pattern and low $\mathrm{C}_{27} / \mathrm{C}_{29}$ sterane ratios $(0.31-1.36)$ indicative of predominantly mixed marine and terrestrial or terrestrial organic matter. $\mathrm{C}_{30}$ steranes are present in low relative abundances $\left(\mathrm{C}_{30}\right.$ indices average 0.09$)$. Variable relative abundances of diasteranes, with $\mathrm{C}_{29}$ dominating $\mathrm{C}_{27}$ homologues, may also indicate a largely terrestrial contribution. Maturity also appears to partially control the relative abundance of diasteranes with low concentrations present in low maturity samples. Low sample maturities are indicated by occasionally high relative abundances of both $C_{29} \beta \beta$-hopane and $17 \beta(H)-22,29,30$ trisnorhopane. Only NE60 and NE66 have reached equilibrium in moretane/hopane and $22 \mathrm{~S} /(22 \mathrm{~S}+22 \mathrm{R})$ homohopane ratios, with all other samples significantly less mature and below the onset of oil generation $\left(<0.6 \% \mathrm{R}_{\mathrm{o}}\right) .20 \mathrm{~S} /(20 \mathrm{~S}+20 \mathrm{R})$ and $\% \beta \beta$ sterane ratios indicate that no sample is near equilibration and that maturities in general are low. 
Whatarangi Formation (NE145, Figure 6.21c): The m/z 191 chromatogram shows low relative abundances of 28,30-bisnorhopane and $17 \alpha(\mathrm{H})$-diahopane and an absence of oleanane. The $\mathrm{m} / \mathrm{z} 217$ chromatogram is characterised by a sterane distribution pattern showing $\mathrm{C}_{29}>\mathrm{C}_{28}>\mathrm{C}_{27}>\mathrm{C}_{30}$, a very low $\mathrm{C}_{27} / \mathrm{C}_{29}$ sterane ratio (0.12) indicative of predominantly terrestrial organic matter, and a low $\mathrm{C}_{30}$ index (0.03). High relative abundances of diasteranes, with $\mathrm{C}_{29}$ dominating $\mathrm{C}_{27}$ homologues, may also indicate a large terrestrial contribution. Both moretane/hopane and 22S/(22S+22R) homohopane ratios have reached equilibrium, indicating the maturity is at least the onset of oil generation $\left(>0.6 \% \mathrm{R}_{0}\right) .20 \mathrm{~S} /(20 \mathrm{~S}+20 \mathrm{R})$ sterane ratios have also reached equilibrium, but $\% \beta \beta \mathrm{C}_{29}$ sterane ratios are about 0.46 [the $\% \beta \beta \mathrm{C}_{27}$ sterane ratio is unreliable as it is affected by the coeluting $\mathrm{C}_{29}(-20 \mathrm{~S})$ diasterane]. This indicates a maturity of peak oil generation $\left(0.8-0.9 \% \mathrm{R}_{0}\right)$.

Torlesse Supergroup (NE114, Figure 6.21d): The m/z 191 chromatogram shows moderate relative abundances of 28,30-bisnorhopane, moderate $17 \alpha(\mathrm{H})$-diahopane and an absence of oleanane. The $\mathrm{m} / \mathrm{z} 217$ chromatogram is characterised by a sterane distribution pattern showing $\mathrm{C}_{27}>\mathrm{C}_{28}>\mathrm{C}_{29}>\mathrm{C}_{30}$, a $\mathrm{C}_{27} / \mathrm{C}_{29}$ sterane ratio (1.31) indicative of mixed marine and terrestrial organic matter, and a moderately high $\mathrm{C}_{30}$ index $(0.21)$. High relative abundances of diasteranes are present, with $\mathrm{C}_{27}$ in greater concentrations than $\mathrm{C}_{29}$ homologues, indicates a predominance of marine organic matter. Moretane/hopane and 22S/(22S+22R) homohopane ratios are have reached equilibrium indicating a maturity of at least the onset of oil generation $\left(>0.6 \% \mathrm{R}_{\mathrm{o}}\right)$. $20 \mathrm{~S} /(20 \mathrm{~S}+20 \mathrm{R})$ sterane ratios have also reached equilibrium, and $\% \beta \beta$ sterane ratios are about 0.6 which indicate a maturity of peak oil generation $\left(\sim 0.9 \% \mathrm{R}_{0}\right) .20 \mathrm{~S} /(20 \mathrm{~S}+20 \mathrm{R})$ sterane ratios reached values greater than 0.5 , possibly through the preferential biodegradation of the $\alpha \alpha \alpha-20 \mathrm{R}$ isomers. Coelution of the $\mathrm{C}_{29}(-20 \mathrm{~S})$ diasterane with $\mathrm{C}_{27} \alpha \beta \beta-20 \mathrm{R}$ sterane affects the $\% \beta \beta \mathrm{C}_{27}$ sterane ratio and, therefore, the (lower) $\% \beta \beta \mathrm{C}_{29}$ sterane ratio is more reliable.

\subsubsection{South Island possible source rocks}

Waima Siltstone (NE85, Figure 6.22a): The $\mathrm{m} / \mathrm{z} 191$ chromatogram shows low relative abundances of 28,30-bisnorhopane, low-moderate $17 \alpha(\mathrm{H})$-diahopane and moderate-high oleanane. This sample had the highest relative abundance of oleanane in the present study and its presence confirms a contribution of angiosperm-derived terrestrial organic matter. The $\mathrm{m} / \mathrm{z} 217$ chromatogram is characterised by a sterane distribution pattern showing $\mathrm{C}_{28}>\mathrm{C}_{29}>\mathrm{C}_{27}>\mathrm{C}_{30}$, a low $\mathrm{C}_{27} / \mathrm{C}_{29}$ sterane (0.81) ratio, and a low $\mathrm{C}_{30}$ index (0.03). Although the low $\mathrm{C}_{27} / \mathrm{C}_{29}$ sterane ratio is indicative of a terrestrial 

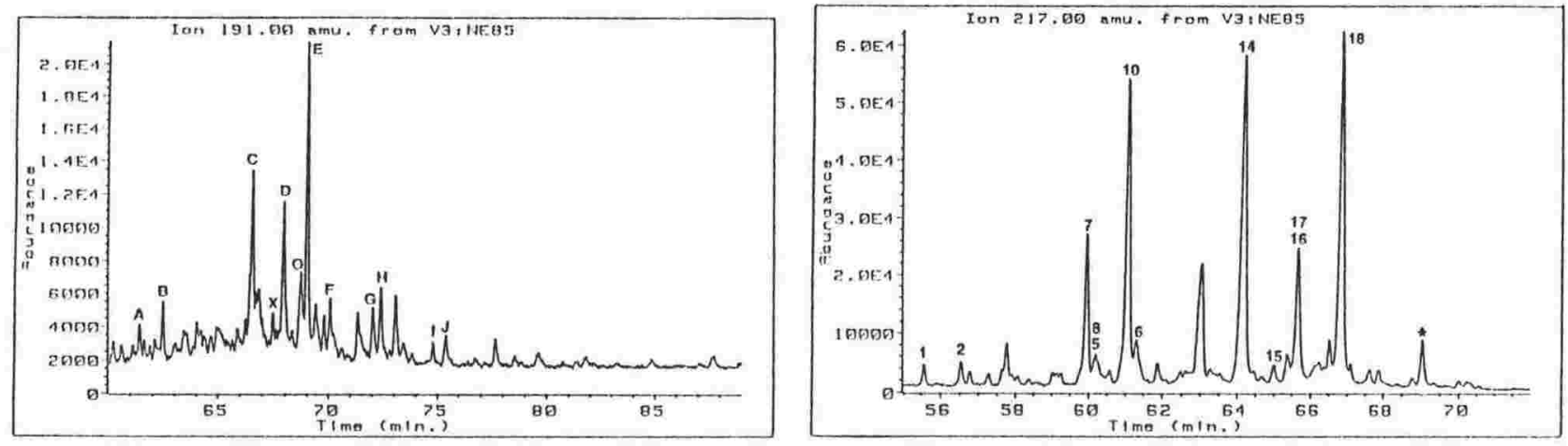

a. Waima Siltstone - NE85
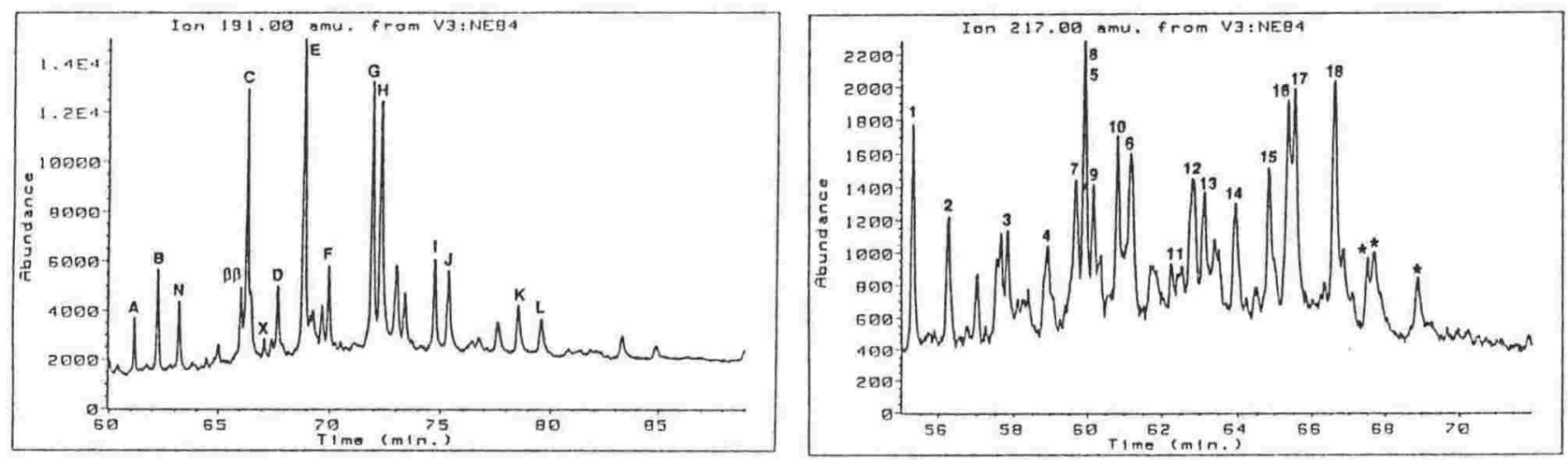

b. Woodside Formation - NE84
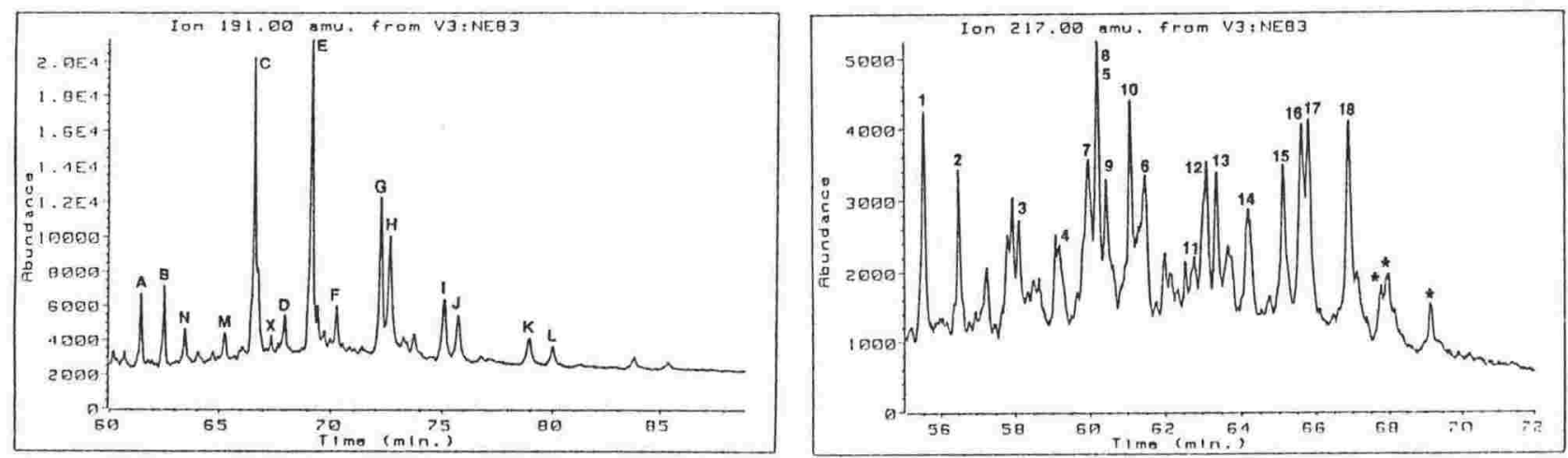

c. Amuri Limestone - NE83
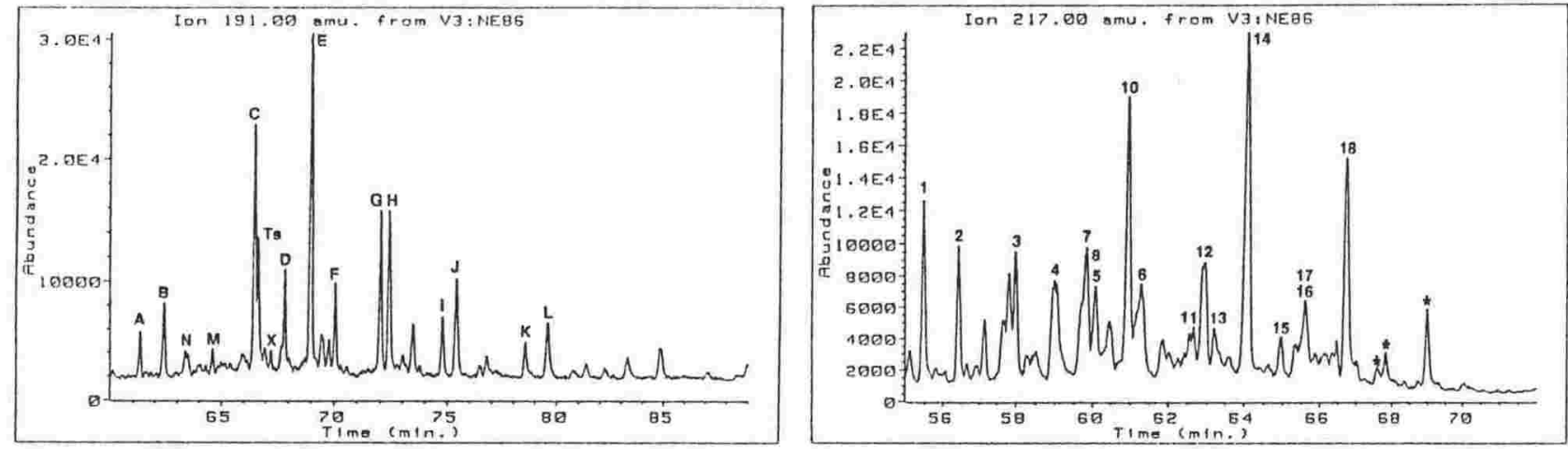

d. Undifferentiated Whangai Formation - NE86

Figure 6.22 GC-MS m/z 191 and 217 mass chromatograms of the possible source rocks (S.I.). 
contribution of organic matter, $\mathrm{C}_{28}$ steranes are predominant and are indicative of marine organic matter. Low relative abundances of diasteranes may be partly maturity related. A low maturity is indicated by the presence of a high relative abundance of $\mathrm{C}_{29} \beta \beta$-hopane. Neither the moretane/hopane or $22 \mathrm{~S} /(22 \mathrm{~S}+22 \mathrm{R})$ ratios have reached equilibrium, indicating a maturity below the onset of oil generation $\left(<0.6 \% \mathrm{R}_{\mathrm{o}}\right)$. Steranes with $\alpha \alpha \alpha-20 \mathrm{R}$ forms dominate the $\mathrm{m} / \mathrm{z} 217$ chromatogram, and $\mathrm{C}_{29} \alpha \beta \beta-20 \mathrm{R}$ and $-20 \mathrm{~S}$ epimers are not resolved.

Woodside Formation (NE84, Figure 6.22b): The $\mathrm{m} / \mathrm{z} 191$ chromatogram shows moderate relative abundances of $17 \beta(\mathrm{H})-22,29,30$-trisnorhopane, low 28,30-bisnorhopane and $17 \alpha(\mathrm{H})$-diahopane and a trace or absence of oleanane. The $\mathrm{m} / \mathrm{z} 217$ sterane chromatogram is characterised by a $\mathrm{C}_{29}>\mathrm{C}_{27}>\mathrm{C}_{28}>\mathrm{C}_{30}$ sterane distribution pattern and a low $\mathrm{C}_{27} / \mathrm{C}_{29}$ sterane ratio (0.77) indicative of a terrestrial contribution of organic matter (but see Amuri Limestone below). $\mathrm{C}_{30}$ steranes are present in low relative abundances. $\mathrm{C}_{29}$ diasteranes are present in greater relative abundance than the $\mathrm{C}_{27}$ homologues, and may indicate a terrestrial contribution. Moretane/hopane and $22 \mathrm{~S} /(22 \mathrm{~S}+22 \mathrm{R})$ homohopane ratios have not reached equilibrium, indicating a maturity below the onset of oil generation, yet the $20 \mathrm{~S} /(20 \mathrm{~S}+20 \mathrm{R})$ sterane ratios have reached equilibrium and indicate a maturity equivalent to peak oil generation $\left(\sim 0.8 \% \mathrm{R}_{\mathrm{o}}\right)$.

Amuri Limestone (e.g. NE83, Figure 6.22c): The m/z 191 chromatograms show low relative abundances of 28,30-bisnorhopane and $17 \alpha(\mathrm{H})$-diahopane and a general absence of oleanane. The $\mathrm{m} / \mathrm{z} 217$ chromatograms are characterised by a sterane distribution pattern showing $\mathrm{C}_{29}>\mathrm{C}_{27}>\mathrm{C}_{28}>\mathrm{C}_{30}$ and variable $\mathrm{C}_{27} / \mathrm{C}_{29}$ sterane ratios (0.20-1.43) indicative of either mixed marine and terrestrial or terrestrial organic matter. The high relative abundances of $\mathrm{C}_{29}$ steranes are unusual considering the general absence of oleanane and the minimal clastic input. $\mathrm{C}_{30}$ steranes are present in low relative abundances $\left(\mathrm{C}_{30}\right.$ indices average 0.07$)$. Diasterane relative abundances vary, usually with $\mathrm{C}_{27}$ in greater concentrations than $\mathrm{C}_{29}$ homologues, contrary to the pattern of sterane abundance. Moretane/hopane and $22 \mathrm{~S} /(22 \mathrm{~S}+22 \mathrm{R})$ homohopane ratios vary, and only reaching equilibrium in NE79 and NE83 and, therefore, maturities of at least the onset of oil generation $\left(>0.6 \% \mathrm{R}_{\mathrm{o}}\right.$ ). Only NE83 has reached equilibrium in $20 \mathrm{~S} /(20 \mathrm{~S}+20 \mathrm{R})$ sterane ratios, and therefore a maturity of peak oil generation $\left(0.8 \% \mathrm{R}_{\mathrm{o}}\right)$.

Undifferentiated Whangai Formation (e.g. NE86, Figure 6.22d): The m/z 191 chromatograms show low relative abundances of 28,30-bisnorhopane, low $17 \alpha(\mathrm{H})$ diahopane and trace or an absence of oleanane. Samples with oleanane indicate an 

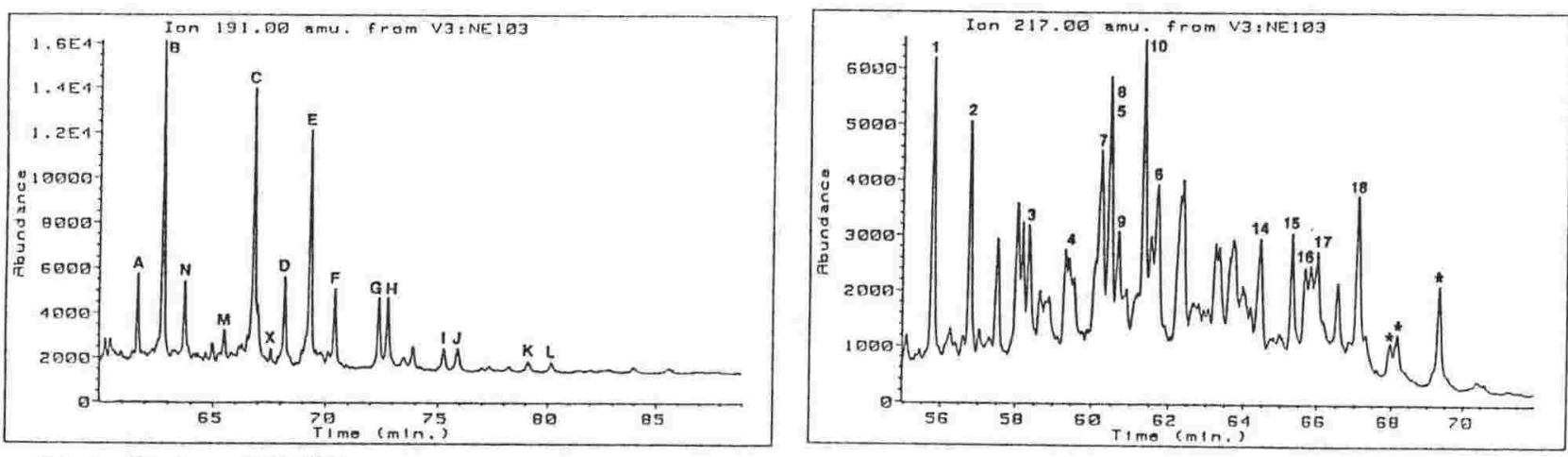

a. Mata Series - NE103
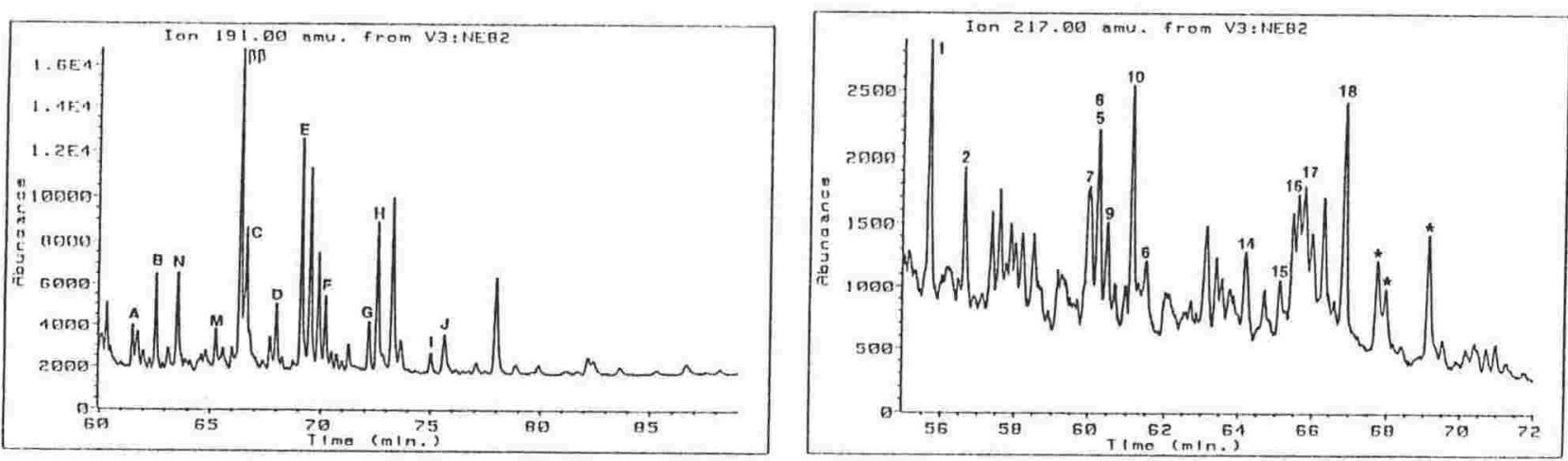

\section{b. Flags Formation - NE82}
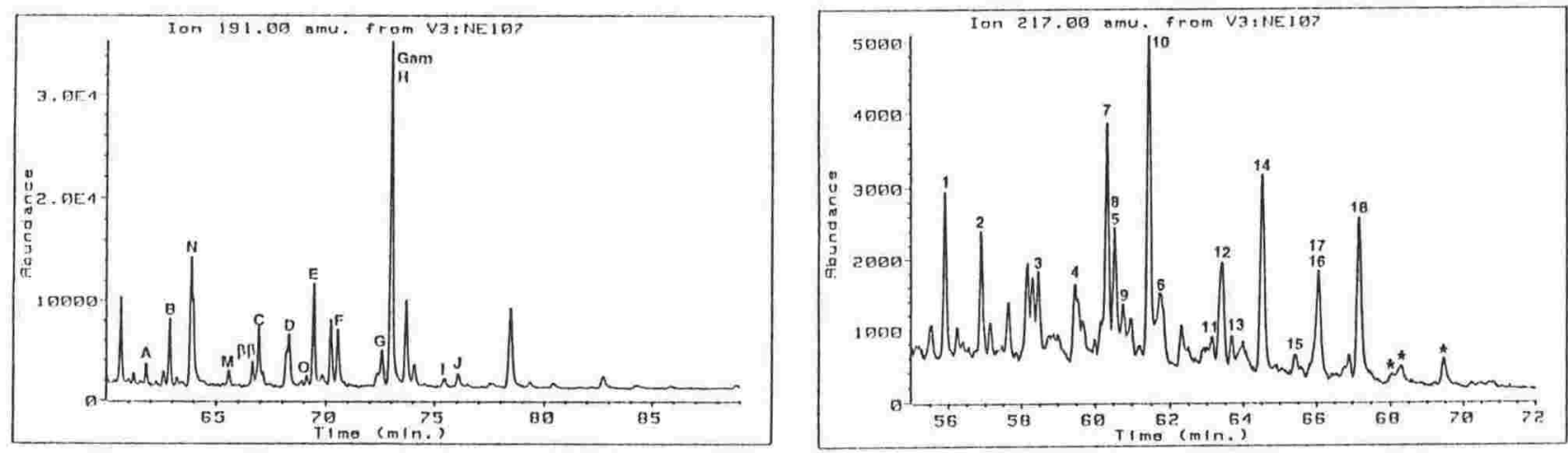

\section{c. Claverley Sandstone - NE107}
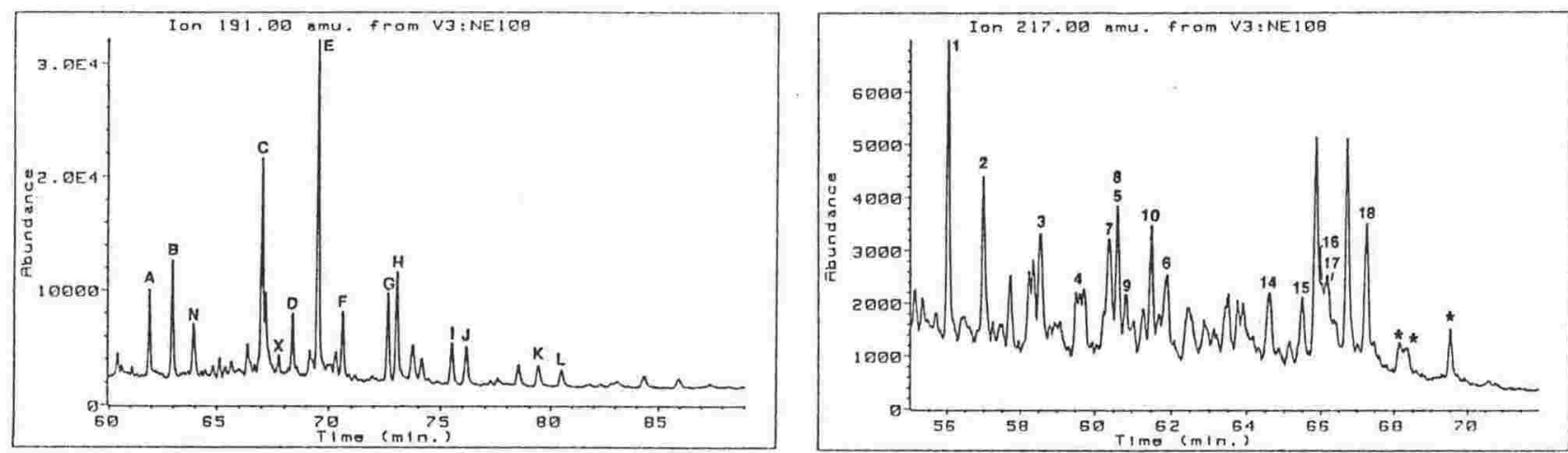

\section{d. Conway Siltstone - NE108}

Figure 6.23 GC-MS m/z 191 and 217 mass chromatograms of the possible source rocks (S.I.). 
angiosperm-derived terrestrial contribution of organic matter. The $\mathrm{m} / \mathrm{z} 217$ chromatograms are characterised by a sterane distribution pattern showing $\mathrm{C}_{27}>\mathrm{C}_{29}>\mathrm{C}_{28}>\mathrm{C}_{30}$ and $\mathrm{C}_{27} / \mathrm{C}_{29}$ sterane ratios (0.90-1.24) indicative of mixed marine and terrestrial organic matter. NE86 shows a high proportion of $\mathrm{C}_{28}$ steranes indicating a significant marine contribution. $\mathrm{C}_{30}$ steranes are present in low relative abundances $\left(\mathrm{C}_{30}\right.$ indices average 0.07$)$. Diasteranes are present in low relative abundances but this may be maturity related as NE86, the most mature sample, has the highest diasterane concentrations. Low maturities in general are indicated by the presence of high relative abundances of $\mathrm{C}_{29} \beta \beta$-hopane and low-moderate relative abundances of $17 \beta(\mathrm{H})$ 22,29,30-trisnorhopane. Moretane/hopane and 22S/(22S+22R) homohopane ratios show that equilibrium has not been reached and the samples have maturities below the onset of oil generation $\left(<0.6 \% \mathrm{R}_{\mathrm{o}}\right)$. The $\mathrm{m} / \mathrm{z} 217$ chromatograms show steranes with dominant $\alpha \alpha \alpha-20 \mathrm{R}$ isomers, and $\mathrm{C}_{29} \alpha \beta \beta-20 \mathrm{R}$ and $-20 \mathrm{~S}$ epimers that are not properly resolved.

Mata Series (e.g. NE103, Figure 6.23a): The m/z 191 chromatograms show low relative abundances of 28,30-bisnorhopane, $17 \alpha(\mathrm{H})$-diahopane and low or an absence of oleanane. Samples with oleanane demonstrate an angiosperm-derived terrestrial contribution of organic matter. The $\mathrm{m} / \mathrm{z} 217$ chromatograms are characterised by generally low $\mathrm{C}_{27} / \mathrm{C}_{29}$ sterane ratios (0.61-2.37) indicative of a predominance of terrestrial organic matter, although occasional high ratios indicate samples with a significant marine contribution. $\mathrm{C}_{30}$ steranes are present in variable relative abundances $\left(\mathrm{C}_{30}\right.$ indices range from 0.03-0.19). High relative abundances of diasteranes, particularly $\mathrm{C}_{27}$ diasteranes, are present which is contrary to the sterane pattern. Sample maturities are generally low with less than half the samples reaching equilibrium in both moretane/hopane and $22 \mathrm{~S} /(22 \mathrm{~S}+22 \mathrm{R})$ homohopane ratios. Of these, only NE78 has reached equilibrium in the $20 \mathrm{~S} /(20 \mathrm{~S}+20 \mathrm{R})$ sterane ratio, reaching a maturity equivalent to peak oil generation $\left(0.8 \% \mathrm{R}_{\mathrm{o}}\right)$. Those samples which have not reached equilibrium in their hopane maturity parameters have dominant $\alpha \alpha \alpha-20 \mathrm{R}$ steranes, and poorly or unresolved $\mathrm{C}_{29} \alpha \beta \beta-20 \mathrm{R}$ and $-20 \mathrm{~S}$ epimers in the $\mathrm{m} / \mathrm{z} 217$ chromatogram.

Flags Formation (NE82, Figure 6.23b): The $\mathrm{m} / \mathrm{z} 191$ chromatogram shows low relative abundances of 28,30-bisnorhopane, oleanane and $17 \alpha(\mathrm{H})$-diahopane. The presence of oleanane indicates an angiosperm-derived terrestrial contribution of organic matter. The $\mathrm{m} / \mathrm{z} 217$ chromatogram is characterised by a sterane distribution pattern showing $\mathrm{C}_{29}>\mathrm{C}_{27}>\mathrm{C}_{30}>\mathrm{C}_{28}$ and a low $\mathrm{C}_{27} / \mathrm{C}_{29}$ sterane ratio (0.75) indicative of terrestrial organic matter. $\mathrm{C}_{30}$ steranes are present in high relative abundances $\left(\mathrm{C}_{30}\right.$ index of 0.23). Diasteranes are present in high relative abundances, with $\mathrm{C}_{27}$ dominating $\mathrm{C}_{29}$ homologues, contrary to the pattern of sterane abundance. The presence of 
$\mathrm{C}_{29} \beta \beta$-hopane in high relative abundances and $17 \beta(\mathrm{H})$-22,29,30-trisnorhopane in moderate relative abundances suggests a low maturity. Moretane/hopane and $22 \mathrm{~S} /(22 \mathrm{~S}+22 \mathrm{R})$ homohopane ratios indicate that equilibrium has not been reached and a maturity below the onset of oil generation $\left(<0.6 \% \mathrm{R}_{\mathrm{o}}\right) .20 \mathrm{~S} /(20 \mathrm{~S}+20 \mathrm{R})$ sterane ratios also have not reached equilibrium, indicating low maturity, and $\alpha \alpha \alpha-20 \mathrm{R}$ isomers dominate the $\mathrm{m} / \mathrm{z} 217$ chromatogram.

Claverley Sandstone (NE107, Figure 6.23c): The m/z 191 chromatogram shows high relative abundances of $17 \beta(\mathrm{H})$-22,29,30-trisnorhopane, low 28,30-bisnorhopane, an absence of $17 \alpha(\mathrm{H})$-diahopane, low oleanane and, most obviously, high relative abundances of a compound coeluting with $\mathrm{C}_{31} \alpha \beta-22 \mathrm{R}$ homohopane. Gammacerane is known to coelute with this biomarker (Peters and Moldowan, 1993), and if present may indicate a depositional environment with conditions of elevated salinity. The presence of oleanane indicates an angiosperm-derived terrestrial contribution of organic matter. The $\mathrm{m} / \mathrm{z} 217$ chromatogram is characterised by a sterane distribution pattern showing $\mathrm{C}_{27}>\mathrm{C}_{28}>\mathrm{C}_{29}>\mathrm{C}_{30}$ and high $\mathrm{C}_{27} / \mathrm{C}_{29}$ sterane ratio (1.74), indicative of marine organic matter. $C_{30}$ steranes are present in low relative abundances $\left(C_{30}\right.$ index of 0.04$)$. Diasteranes are present in moderate relative abundances. A low maturity is indicated by the presence of $\mathrm{C}_{29} \beta \beta$-hopane and high relative abundance and $17 \beta(\mathrm{H})-22,29,30$ trisnorhopane. Moretane/hopane and $22 \mathrm{~S} /(22 \mathrm{~S}+22 \mathrm{R})$ homohopane ratios indicate a maturity of below the onset of oil generation $\left(<0.6 \% R_{o}\right) .20 S /(20 S+20 R)$ and $\% \beta \beta$ sterane ratios also indicate low maturity, with the $\mathrm{m} / \mathrm{z} 217$ chromatogram showing predominantly $\alpha \alpha \alpha-20 \mathrm{R}$ isomers, and unresolved $\mathrm{C}_{29} \alpha \beta \beta-20 \mathrm{R}$ and $-20 \mathrm{~S}$ epimers.

Conway Siltstone (NE108, Figure 6.23d): The m/z 191 chromatogram shows moderate relative abundances of 28,30-bisnorhopane, $17 \alpha(\mathrm{H})$-diahopane and oleanane. The presence of oleanane confirms an angiosperm-derived terrestrial contribution of organic matter. The $\mathrm{m} / \mathrm{z} 217$ chromatogram is characterised by a sterane distribution pattern showing $\mathrm{C}_{29}>\mathrm{C}_{27}>\mathrm{C}_{28}>\mathrm{C}_{30}$ and a low $\mathrm{C}_{27} / \mathrm{C}_{29}$ sterane ratio (0.68) indicative of a predominance of terrestrial organic matter. $\mathrm{C}_{30}$ steranes are present in low relative abundances $\left(\mathrm{C}_{30}\right.$ index of 0.09$)$. The presence of high relative abundances of $\mathrm{C}_{27}$ diasteranes (greatly dominating $\mathrm{C}_{29}$ compounds) is contrary to the pattern of sterane abundance. Moretane/hopane and $22 \mathrm{~S} /(22 \mathrm{~S}+22 \mathrm{R})$ homohopane ratios indicate the sample has not reached equilibrium and has a maturity of below the onset of oil generation $\left(<0.6 \% \mathrm{R}_{\mathrm{o}}\right)$. This is supported by a moderate relative abundance of $17 \beta(\mathrm{H})$ $22,29,30$-trisnorhopane. The $\mathrm{C}_{27} 20 \mathrm{~S} /(20 \mathrm{~S}+20 \mathrm{R})$ sterane ratio is anomalously high (0.59) as a result of coelution with $\mathrm{C}_{29}(-20 \mathrm{~S})$ diacholestane. 

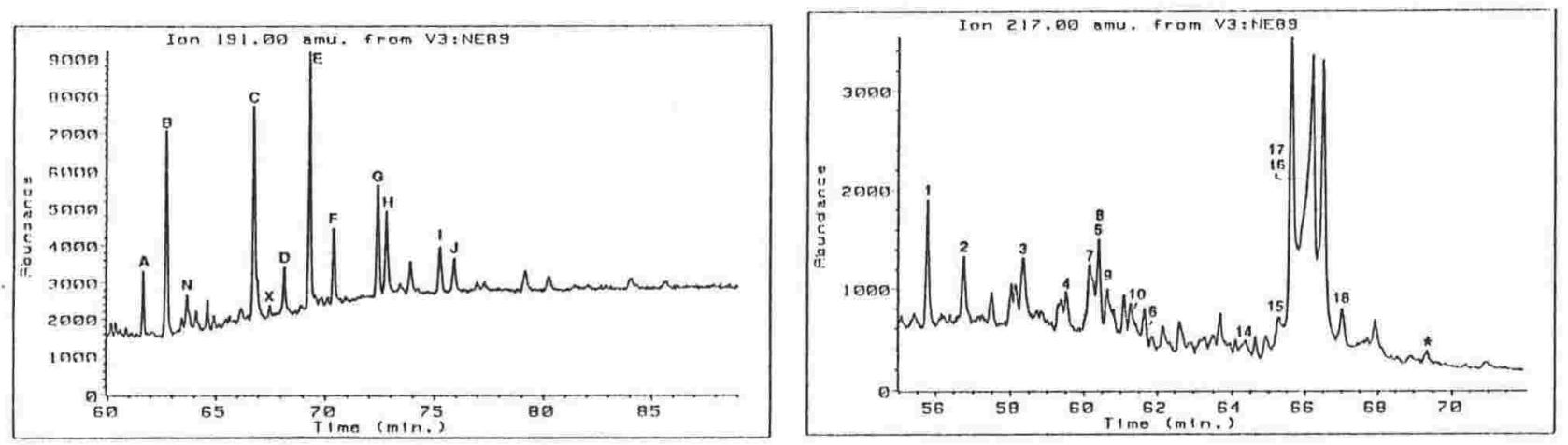

\section{a. Burnt Creek Formation - NE89}
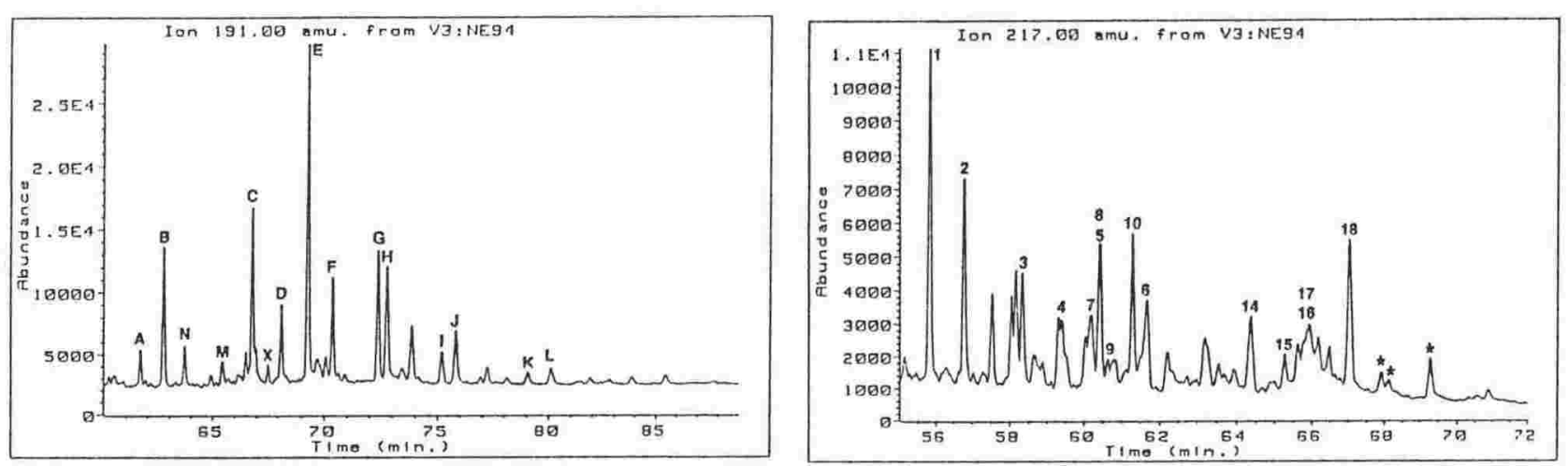

\section{b. Split Rock Formation - NE94}
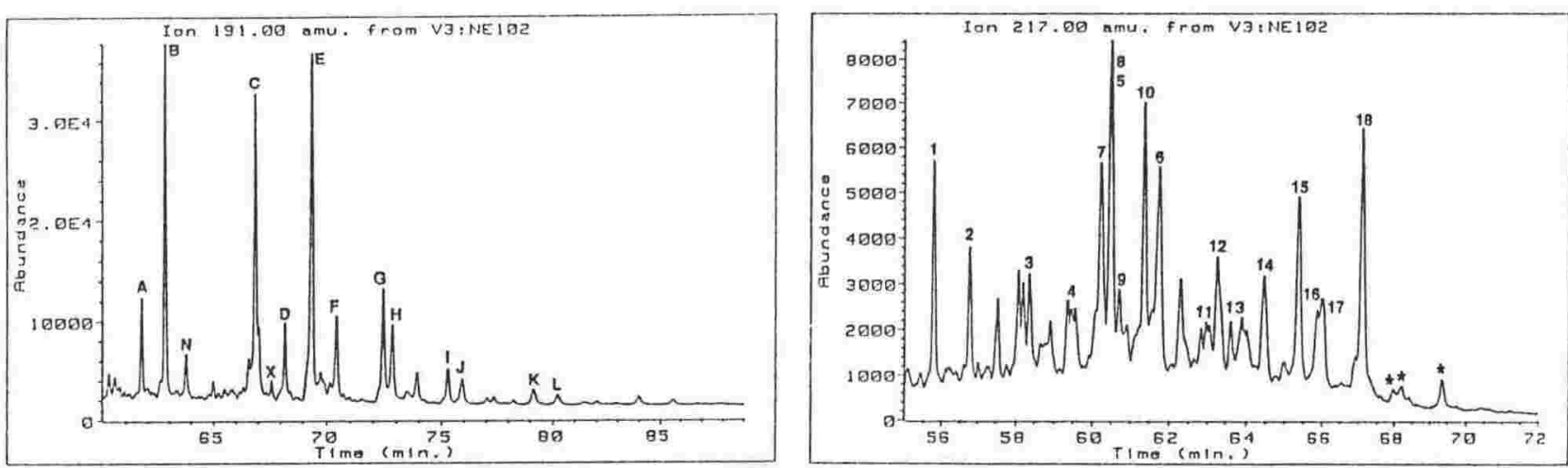

c. Torlesse Supergroup - NE102

Figure 6.24 GC-MS m/z 191 and 217 mass chromatograms of the possible source rocks (S.I.). 
Burnt Creek Formation (e.g. NE89, Figure 6.24a): The m/z 191 chromatograms show low relative abundances of 28,30-bisnorhopane, $17 \alpha(\mathrm{H})$-diahopane and oleanane. The presence of oleanane indicates an angiosperm-derived terrestrial contribution of organic matter. The $\mathrm{m} / \mathrm{z} 217$ chromatograms are characterised by a sterane distribution pattern showing $\mathrm{C}_{29}>\mathrm{C}_{27}>\mathrm{C}_{30}>\mathrm{C}_{28} . \mathrm{C}_{30}$ steranes are present in variable abundances $\left(\mathrm{C}_{30}\right.$ indices range from 0.07-0.26). Low $\mathrm{C}_{27} / \mathrm{C}_{29}$ sterane ratios (0.71-0.98) are indicative of either terrestrial or mixed marine and terrestrial organic matter. Diasteranes are present in low to moderate relative abundances. Sample maturity is variable with $22 \mathrm{~S} /(22 \mathrm{~S}+22 \mathrm{R})$ homohopane ratios at equilibrium in sample NE89 and 20S/(20S+20R) sterane ratios just at equilibrium. The $\% \beta \beta \mathrm{C}_{29}$ sterane ratio appears affected by coelution and is therefore not a reliable maturity indicator, but the $\% \beta \beta C_{27}$ sterane ratio is 0.55 , not yet at equilibrium. Together these two maturity parameters indicate a maturity of peak oil generation $\left(0.8-0.9 \% \mathrm{R}_{\mathrm{o}}\right)$.

Split Rock Formation (e.g. NE94, Figure 6.24b): The m/z 191 chromatograms show low relative abundances of 28,30-bisnorhopane, low $17 \alpha(\mathrm{H})$-diahopane and a general absence of oleanane. Where present, oleanane indicates an angiosperm-derived terrestrial contribution of organic matter The $\mathrm{m} / \mathrm{z} 217$ chromatograms are characterised by a $\mathrm{C}_{29}>\mathrm{C}_{27}>\mathrm{C}_{28}>\mathrm{C}_{30}$ sterane distribution pattern and low $\mathrm{C}_{27} / \mathrm{C}_{29}$ sterane ratios (0.28-1.44) indicating a predominance of terrestrial organic matter. $\mathrm{C}_{30}$ steranes are present in low relative abundances $\left(\mathrm{C}_{30}\right.$ indices average 0.09). Samples NE91 and NE94, comprising mainly mudstone or siltstone lithologies, have a predominance of $\mathrm{C}_{27}$ diasteranes, while NE90 and NE92, comprising predominantly sandstone lithology, have a predominance of $\mathrm{C}_{29}$ diasteranes. Moretane/hopane and $22 \mathrm{~S} /(22 \mathrm{~S}+22 \mathrm{R})$ homohopane ratios have just reached equilibrium indicating all samples have reached maturities of the onset of oil generation. 20S/(20S+20R) sterane ratios, however, show that only Ouse and Champagne Member samples have reached equilibrium indicating maturities of peak oil generation $\left(>0.8 \% \mathrm{R}_{\mathrm{o}}\right.$ ). $\% \beta \beta \mathrm{C}_{27}$ sterane ratios do not provide an accurate measure of maturity due to coelution of the $\mathrm{C}_{27} \alpha \beta \beta-20 \mathrm{R}$ isomer with $\mathrm{C}_{29}$ (20S) diasterane, but $\% \beta \beta C_{29}$ sterane ratios range from about $0.45-0.49$, indicating they are not yet at equilibrium. Wharfe Sandstone and Swale Siltstone members may have reached maturities of early oil generation $\left(0.6-0.7 \% \mathrm{R}_{0}\right)$.

Torlesse Supergroup (e.g. NE102, Figure 6.24c): The $\mathrm{m} / \mathrm{z} 191$ chromatograms show low relative abundances of 28,30-bisnorhopane, low $17 \alpha(\mathrm{H})$-diahopane and an absence of oleanane. The $\mathrm{m} / \mathrm{z} 217$ chromatograms are characterised by a sterane distribution pattern showing $\mathrm{C}_{29}>\mathrm{C}_{27}>\mathrm{C}_{28}>\mathrm{C}_{30}$ and low $\mathrm{C}_{27} / \mathrm{C}_{29}$ sterane ratios (0.23-0.78) indicating a predominance of terrestrial organic matter. $\mathrm{C}_{30}$ steranes are present in low relative 
A.

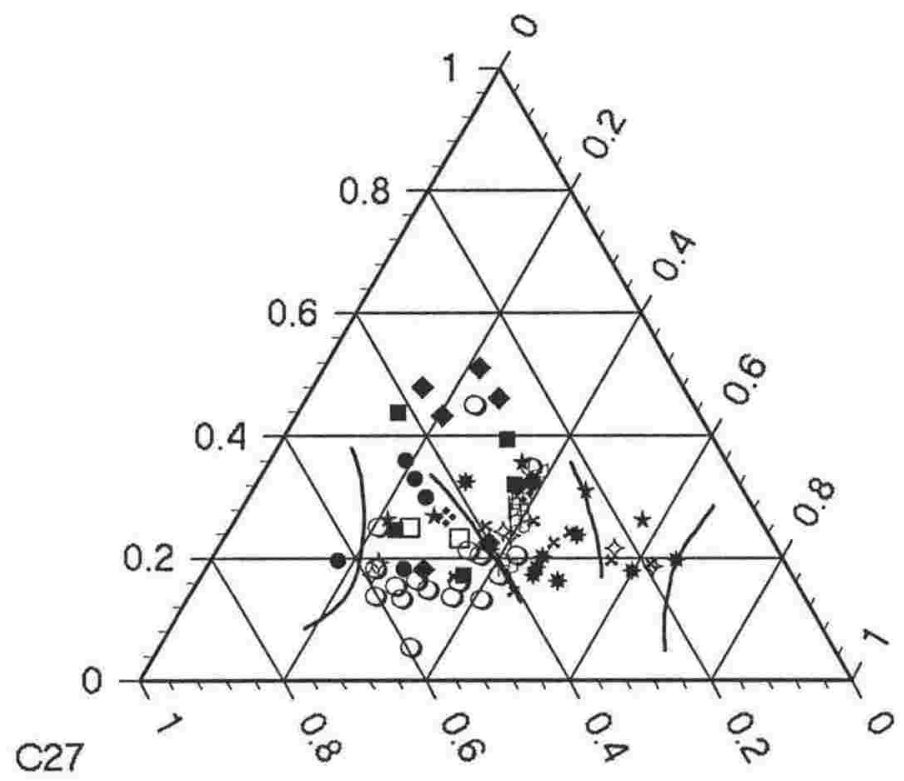

B.
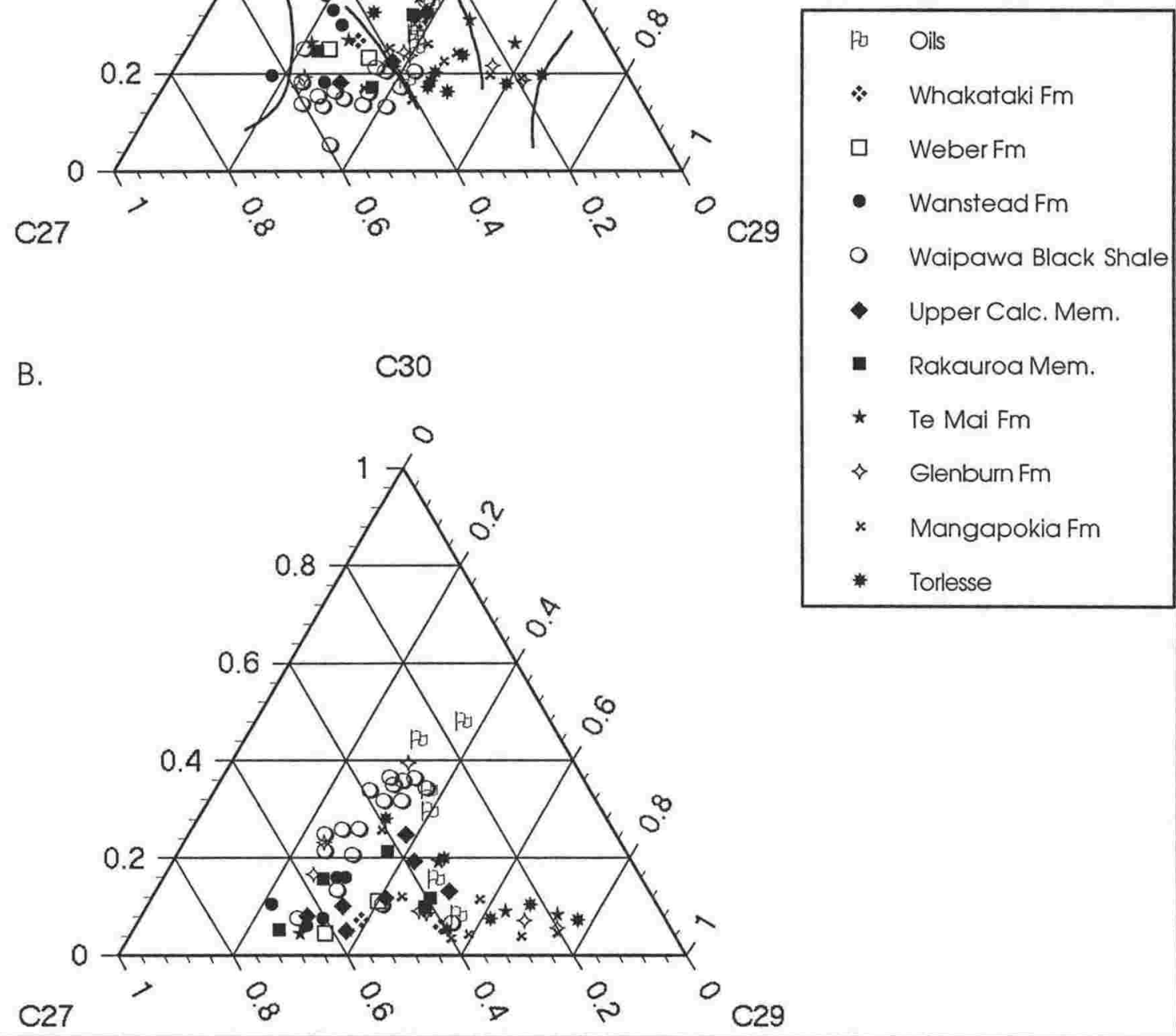

Figure 6.25 Ternary diagrams showing the sterane compositions of selected East Coast Basin formations and the six oil samples. $A . C_{27}-C_{28}-C_{29}$ steranes with superimposed ecological boundaries of Huang and Meinschein (1979); and B. $\mathrm{C}_{27}-\mathrm{C}_{29}-\mathrm{C}_{30}$ steranes. Based on the $\mathrm{m} / \mathrm{z} 217$ response of $\alpha \alpha \alpha-20 \mathrm{R}$ steranes. 
abundances $\left(\mathrm{C}_{30}\right.$ indices average $\left.<0.08\right)$. High relative abundances of $\mathrm{C}_{29}$ diasteranes are present, which support a predominantly terrestrial contribution to the organic matter. Moretane/hopane and 22S/(22S+22R) homohopane ratios show variable maturity, with the majority of samples not having reached equilibrium. Samples NE96 and NE102, however, indicate they have reached minimum maturities of early oil generation $\left(>0.6 \% \mathrm{R}_{\mathrm{o}}\right)$. The $\mathrm{m} / \mathrm{z} 217$ chromatograms of the low maturity samples show steranes with dominant $\alpha \alpha \alpha-20 \mathrm{R}$ forms and unresolved $\mathrm{C}_{29} \alpha \beta \beta-20 \mathrm{R}$ and $-20 \mathrm{~S}$ epimers. The chromatograms of NE96 and NE102 show steranes with reduced $\alpha \alpha \alpha-20 \mathrm{R}$ forms and partially resolved $\mathrm{C}_{29} \alpha \beta \beta-20 \mathrm{R}$ and $-20 \mathrm{~S}$ epimers. Although $20 \mathrm{~S} /(20 \mathrm{~S}+20 \mathrm{R})$ sterane ratios range between 0.39 and 0.76 , equilibrium has not been reached (as demonstrated by the $\mathrm{C}_{29}$ sterane ratios), with the high values possibly due to the preferential biodegradation of $\alpha \alpha \alpha-20 \mathrm{R}$ isomers. Also, occasional coelution of $\mathrm{C}_{29}$ (20S) diasteranes with $\mathrm{C}_{27} \alpha \beta \beta-20 \mathrm{R}$ inflates the $\% \beta \beta \mathrm{C}_{27}$ sterane ratio, and hence the lower $\mathrm{C}_{29} \% \beta \beta$ ratios are probably more reliable. Samples NE96 and NE102 have maturities of early oil generation $\left(\sim 0.7 \% \mathrm{R}_{\mathrm{o}}\right)$.

\subsubsection{Source-specific biomarkers}

The $\mathrm{C}_{27}-\mathrm{C}_{28}-\mathrm{C}_{29}$ sterane ternary diagram (Figure 6.25a) shows selected eastern North Island formations and the six oils, with the ecological boundaries of Huang and Meinschein (1979) superimposed (refer to Figure 6.7). The samples are centrally clustered, demonstrating the general mixed marine and terrestrial origin of the contributing organic matter. Within this central cluster, though, are noticeable groupings. Samples of Weber and Wanstead formations and Waipawa Black Shale have a high proportion of $\mathrm{C}_{27}$ steranes and cluster in the 'open marine' field, with Waipawa Black Shale samples depleted in $\mathrm{C}_{28}$ steranes relative to other formations. Samples of Te Mai, Glenburn and Mangapokia formations and Torlesse Supergroup have high proportions of $\mathrm{C}_{29}$ steranes and generally plot in the 'terrestrial' or the low $\mathrm{C}_{28}$ sterane region of the 'estuarine or bay' field. Whangai Formation samples, particularly the Upper Calcareous Member have a high proportion of $\mathrm{C}_{28}$ steranes relative to the other samples and plot in the 'lacustrine' field. The ecological fields determined by Huang and Meinschein (1979) are here shown not to be entirely accurate. For example, faunal evidence (e.g. Moore, 1988b) indicates that the Whangai Formation was deposited in a marine, not lacustrine, environment and the high proportion of $\mathrm{C}_{28}$ steranes is more likely to represent a strong marine contribution of organic matter as proposed by Moldowan et al. (1985). The $\mathrm{C}_{27}-\mathrm{C}_{28}-\mathrm{C}_{29}$ and $\mathrm{C}_{27}-\mathrm{C}_{29}-\mathrm{C}_{30}$ sterane ternary diagrams (Figures 6.25a and $\mathrm{b}$ respectively), however, do cluster samples according to their respective formations, 


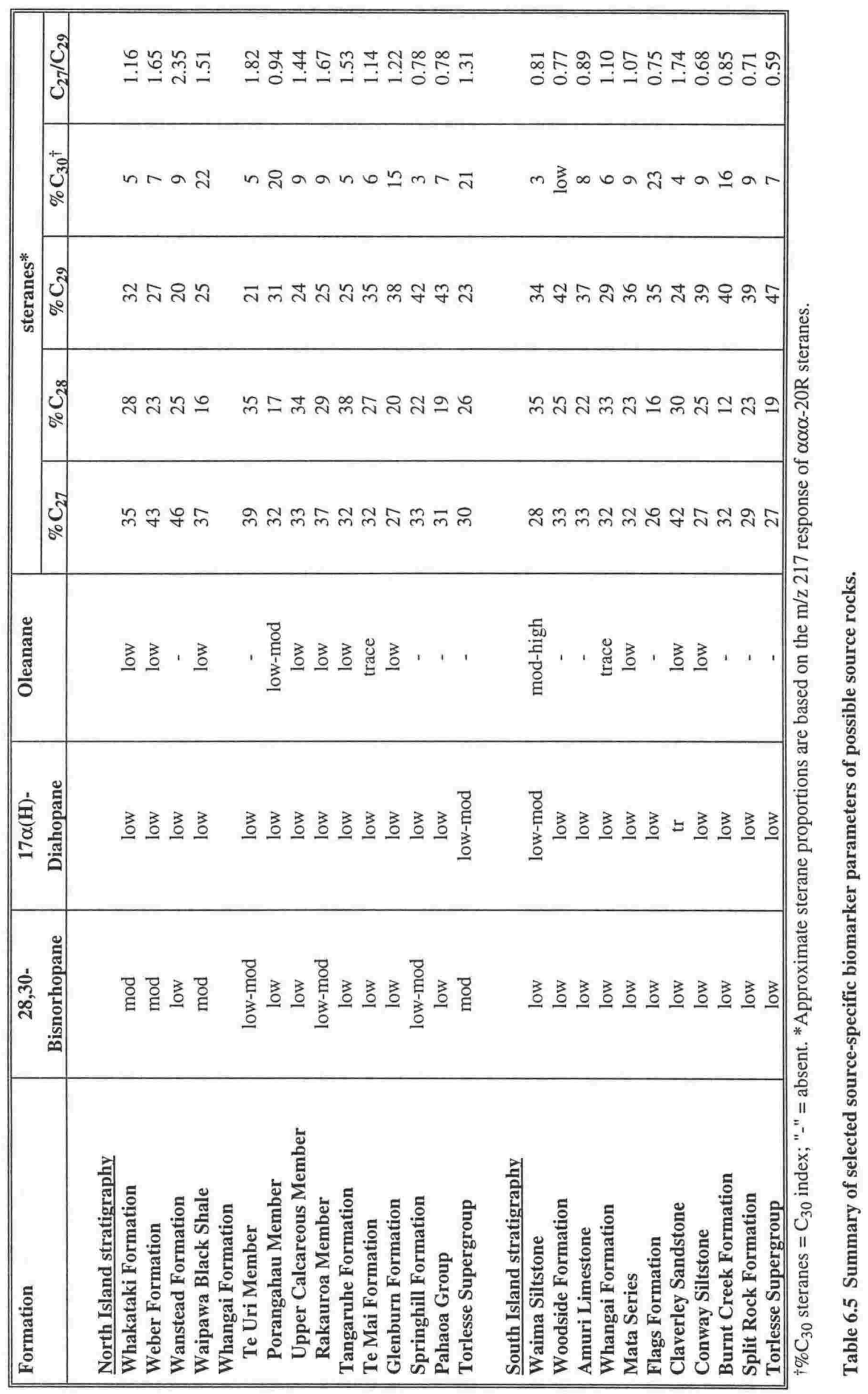


presumably because of biotic assemblages that were controlled by different depositional environments.

Assuming $\mathrm{C}_{27}$ steranes are indicative of marine organic matter and $\mathrm{C}_{29}$ steranes are indicative of terrestrial organic matter, the average $\mathrm{C}_{27} / \mathrm{C}_{29}$ sterane ratios of eastern North Island formations (Table 6.5) show predominantly terrestrial organic matter is present in the Lower Cretaceous formations. A general trend of increasing marine influence (increase in the $\mathrm{C}_{27} / \mathrm{C}_{29}$ sterane ratio) is apparent in Lower Cretaceous to Eocene strata (Wanstead Formation). This trend is then reversed to an increasing terrestrial influence in the Oligocene Weber Formation and Miocene Whakataki Formation. Exceptions include the uppermost Cretaceous Porangahau Member of the Whangai Formation and possibly the Paleocene Waipawa Black Shale which indicate an increased terrestrial contribution compared with vertically adjacent units. A similar but less distinct trend, and with a greater overall proportion of terrestrial organic matter, occurs in Marlborough strata. A strong terrestrial influence in the Lower Cretaceous Torlesse Supergroup and Split Rock Formation is replaced by mixed marine and terrestrial organic matter in the uppermost Cretaceous Whangai Formation and its lateral equivalents. A change to an increasing terrestrial influence is suggested by a decrease in $\mathrm{C}_{27} / \mathrm{C}_{29}$ sterane ratios in the uppermost Cretaceous to lowermost Miocene Amuri Limestone, Eocene Woodside Formation and Miocene Waima Siltstone.

The Porangahau Member of the Whangai Formation, Amuri Limestone and Woodside Formation have unusually high proportions of $\mathrm{C}_{29}$ steranes considering their carbonate lithologies. While carbonate-rich formations generally result from a low clastic (and hence low terrestrial) input, the high proportions of $\mathrm{C}_{29}$ steranes in the above-mentioned formations suggests a significant contribution of terrestrial organic matter. High proportions of $\mathrm{C}_{29}$ steranes have been identified in oils of marine carbonate origin and explained by specific algal distributions, synthesising $\mathrm{C}_{29}$ sterols, at the time of deposition (Moldowan et al., 1985) and this may explain the sterane distribution pattern in samples of the Porangahau Member, Woodside Formation and Amuri Limestone.

The presence of oleanane in most Upper Cretaceous and Tertiary formations of the southern East Coast Basin indicate a proportion of angiosperm-derived (terrestrial higher plant) organic matter, despite a marine depositional environment. Oleanane, however, is notably absent from the Wanstead Formation, Mungaroa Member of the Awhea Formation and the Amuri Limestone, and this may be due to a relative isolation from terrigenous input, as indicated by a high clay content (Wanstead Formation) or limestone lithology. Furthermore, the absence of oleanane in Amuri Limestone lends support to an 
algal origin for the $\mathrm{C}_{29}$ steranes, although it is also possible that gymnosperms may have been predominant at this time. The presence of oleanane in the Porangahau Member, however, indicates a terrestrial contribution is present and at least partially explains the member's relatively high proportion of $\mathrm{C}_{29}$ steranes. Oleanane is generally absent from the Lower Cretaceous Torlesse Supergroup, Pahaoa Group, Springhill, Split Rock and Burnt Creek formations, presumably due to age, which is just prior to the widespread evolution of angiosperms.

The present study shows that high relative abundances of $\mathrm{C}_{30}$ steranes are not restricted to the Paleocene Waipawa Black Shale (see Table 6.5). In eastern North Island, low relative abundances of $\mathrm{C}_{30}$ steranes are present in the Lower Cretaceous Pahaoa Group to Upper Cretaceous Tangaruhe Formation. Increased relative abundances of $\mathrm{C}_{30}$ steranes are present in the uppermost Cretaceous Upper Calcareous and Rakauroa members of the Whangai Formation, peaking in the Porangahau Member and Waipawa Black Shale $\left(C_{30}\right.$ indices average 0.20$)$. The proportion of $C_{30}$ steranes then decreases between the Eocene Wanstead and Miocene Whakataki formations. In Marlborough, where the Waipawa Black Shale is absent, the relative abundance of $\mathrm{C}_{30}$ steranes peaks in the uppermost Cretaceous Flags Formation and Mata Series sediments.

Although recognition of high relative abundances of $\mathrm{C}_{30}$ steranes in both the Waipawa Black Shale and a group of oils from southern East Coast Basin was made early during the present study, structural elucidation was not possible by (SIM) GC-MS. However, Murray et al. (1994), using GC-MS/MS techniques, determined the $\mathrm{C}_{30}$ steranes present in the Waipawa Black Shale and the Westcott and Okau Stream oils to be predominantly 4-desmethyl steranes, which was assumed to be $24-n$-propylcholestane. This biomarker has been linked to chrysophyte algae, a highly diagnostic marine indicator (Peters and Moldowan, 1993). Although Murray et al. (1994) do not appear to have distinguished between the 24- $n$-propylcholestane and 24-isopropylcholestane structures, which are attributable to different sources, it does appear that 24-n-propylcholestane is largely predominant in Cretaceous and Cenozoic oils and bitumens (McCaffrey et al., 1994) and is, therefore, likely to be the compound present in the southern East Coast Basin samples. The distribution of $\mathrm{C}_{30}$ steranes in southern East Coast Basin strata suggests that Chrysophyte algae flourished during the latest Cretaceous and Paleocene, presumably due to favourable environmental conditions such as changes in ocean-water circulation (Killops et al., 1996).

High relative abundances of 28,30-bisnorhopane are present in samples of the Weber and Wanstead formations, Waipawa Black Shale, Upper Calcareous Member of the Whangai 
Formation and Pahaoa Group, although it is likely that its presence in many are due to low thermal maturity and not anoxic depositional conditions. $\mathrm{S} / \mathrm{C}$ and $\mathrm{Ni} / \mathrm{V}, \mathrm{V} / \mathrm{Cr}$ and U/Th trace metal ratios (Section 7.4) indicate that, of the formations mentioned, only samples of the Waipawa Black Shale and Upper Calcareous Member of the Whangai Formation were deposited in an anoxic or low oxygen depositional environment.

Although the identification of gammacerane is not certain, a compound eluting at the expected position (coeluting with, or on the shoulder of, $\mathrm{C}_{31} \alpha \beta-22 \mathrm{R}$ homohopane) occurs in a number of Waipawa Black Shale samples and also in Claverley Sandstone. If present, gammacerane may indicate deposition under conditions of elevated salinity.

\subsubsection{Maturity biomarker parameters}

Biomarker parameters used for maturity assessments are generally chosen for their selectivity such that they are not influenced by other factors. In the present study, however, biodegradation has been shown to affect the maturity biomarker parameters. Variations in the 20S/(20S+20R) sterane ratios of samples have been observed, with the $\mathrm{C}_{27}$ sterane ratios almost always higher than the $\mathrm{C}_{29}$ sterane ratios. This is thought to be caused by the preferential degradation of the $\alpha \alpha \alpha-20 \mathrm{R}$ isomer (Rullkötter and Wendisch, 1982) which occurs first in $\mathrm{C}_{27}$ steranes, followed later by $\mathrm{C}_{29}$ steranes. The loss of the $\alpha \alpha \alpha-20 \mathrm{R}$ isomer also increases the corresponding $\% \beta \beta$ sterane value and, therefore, overestimates the actual maturity of the sample. Where discrepancies occur, the $\mathrm{C}_{29}$ sterane maturity biomarker parameters are usually considered to be the more accurate as the $\mathrm{C}_{29}$ steranes are the last affected.

The majority of samples analysed demonstrate low maturities, below the onset of oil generation $\left(<0.6 \% \mathrm{R}_{\mathrm{o}}\right)$. Obvious trends such as an overall increase in sample maturities of progressively older formations were observed. However, not even the oldest formations consistently reached maturities equivalent to the onset of oil generation and, assuming a constant geothermal gradient throughout the basin, sample maturity appears to be very much controlled by the tectonic history of individual structural blocks. Regions of greater maturity include:

- Tora Block sediments of Eocene age (Kandahar Formation) have reached the maturity of the onset of oil generation $\left(0.6 \% \mathrm{R}_{\mathrm{o}}\right)$, and the Early Cretaceous Gentle Annie Formation has reached the maturity of peak oil generation $\left(>0.8 \% \mathrm{R}_{\mathrm{o}}\right)$; 
- The Early Cretaceous Whatarangi Formation from the southern Aorangi Block has reached the maturity of peak oil generation $\left(0.8-0.9 \% \mathrm{R}_{\mathrm{o}}\right)$;

- Within the Coastal Block at Waimarama Beach and Porangahau, the latest Cretaceous Whangai Formation has reached the maturity of the onset of oil generation $\left(0.6 \% \mathrm{R}_{\mathrm{o}}\right)$, while middle to Late Cretaceous Glenburn Formation has reached the maturity of peak oil generation $\left(>0.8 \% \mathrm{R}_{\mathrm{o}}\right)$ at Mangakuri Beach; and

- Within Marlborough, latest Cretaceous to Tertiary Mata Series sediments, Whangai Formation and Amuri Limestone have reached maturities of the onset of oil generation $\left(0.6 \% \mathrm{R}_{\mathrm{o}}\right)$ at Cape Campbell and inland from the Clarence River mouth. At Coverham sediments of Early Cretaceous age have reached maturities of peak oil generation (>0.8\% $\mathrm{R}_{\mathrm{o}}$ ).

Basin thickness has been estimated to reach $10,000 \mathrm{~m}$, with considerable thicknesses of Miocene sediments in some regions. Cretaceous and Paleogene units should therefore reach a maturity sufficient for generation and expulsion in deeper parts of the basin.

\subsubsection{Biodegradation biomarker parameters}

Apart from the general depletion of $n$-alkanes and isoprenoids, such as that shown for the Westcott oil (Figure 5.2d), an assessment of the extent of biodegradation from a sample's gas chromatogram is problematic because $n$-alkane distributions are easily modified and it is often difficult to determine the causal factors. Advanced levels of biodegradation are determined through changes to the sterane and hopane distributions as described in Section 6.3.3. In the present study, apart from minor alteration shown to occur in the $\mathrm{C}_{27}$ sterane distributions, none of the samples have chromatograms that show seriously degraded sterane and hopane distributions and, therefore, biodegradation does not appear to exceed level 6 on the ten point scale of Peters and Moldowan (1993) (see Table 6.1).

\subsubsection{Oil-source rock correlations}

The Kerosene Rock, Westcott, Tiraumea and Okau Stream oils are correlated with the Waipawa Black Shale based primarily on the sterane distribution pattern, in particular the high relative abundance $\mathrm{C}_{30}$ steranes and low proportion of $\mathrm{C}_{28}$ steranes, the high relative abundance of 28,30-bisnorhopane and, to a lesser extent, the low-moderate abundance of $17 \alpha(\mathrm{H})$-diahopane. In particular, the highly diagnostic $\mathrm{C}_{30}$ steranes and 
28,30-bisnorhopane present in the oils are invaluable for correlation purposes and only occur together in the Waipawa Black Shale providing a positive correlation. Discrepancies in correlation parameters include the higher average $\mathrm{C}_{27} / \mathrm{C}_{29}$ sterane ratio for the Waipawa Black Shale (1.51) compared with the oils (0.83-0.94), but this may be explained by the considerable variation of ratios in the Waipawa Black Shale samples (0.74-2.59).

The Knights Stream and Isolation Creek oils lack unusual source-specific biomarkers (such as 28,30 -bisnorhopane or $\mathrm{C}_{30}$ steranes) and, therefore, they are not readily correlated with each other or with a possible source. Their sterane distribution patterns, however, do show high proportions of $\mathrm{C}_{28}$ steranes, a feature characteristic particularly of the Whangai Formation (Upper Calcareous and Rakauroa members), Tangaruhe Formation and Waima Siltstone (Figure 6.25a and b and Table 6.5). Total organic carbon studies (Section 4.1) indicate that the Tangaruhe Formation and the Waima Siltstone are 'poor' potential source rocks and are unlikely to source any hydrocarbons. This leaves the Whangai Formation as the most likely source rock for these oils. Differences in sterane abundances are apparent, though, with $\mathrm{C}_{29}$ steranes dominant in both the Knights Stream and Isolation Creek oils, while Whangai Formation samples generally have a predominance of $\mathrm{C}_{27}$ or $\mathrm{C}_{28}$ steranes. The lack of diagnostic biomarker compounds in both the Knights Stream and Isolation Creek oils and the Whangai Formation (Upper Calcareous and Rakauroa members) means that, despite a general similarity in biomarker characteristics, the correlation is only tentative. 


\subsection{Summary of results and discussion}

\subsubsection{Source/depositional environment}

\section{Oils}

The sterane and triterpane biomarkers indicate that the Knights Stream and Isolation Creek oils comprise predominantly marine organic matter with a moderate terrestrial component and were deposited under open marine conditions. Support for a predominantly marine source of organic matter for these oils, with a possible algal contribution to the Knights Stream oil, is also provided by the $n$-alkane distribution pattern $\left(\mathrm{C}_{21}+\mathrm{C}_{22} / \mathrm{C}_{28}+\mathrm{C}_{29}\right.$ and $\mathrm{C}_{\max }$ data) described in Chapter 5. The northern seep oils, which have similar biomarker characteristics to the Knights Stream and Isolation Creek oils, contain $\mathrm{C}_{30}$ steranes that have been determined by GC-MS/MS to comprise predominantly 24-ethyl-4 $\alpha$-methylcholestanes with varying minor amounts of 24- $n$-propylcholestanes and dinosteranes, which were interpreted to indicate a mainly dinoflagellate contribution with a slight algal input (Rogers, 1995).

The Kerosene Rock, Westcott, Tiraumea and Okau Stream oils comprise organic matter of predominantly marine algal origin with a moderate terrestrial higher plant contribution, deposited in an anoxic or low oxygen depositional environment. The $n$-alkane distribution pattern of the Kerosene Rock oil also indicates a mixed marine and terrestrial source of organic matter, but differs from the sterane and triterpane biomarkers in that it indicates a mainly terrestrial higher plant with a minor marine, possibly algal contribution. This discrepancy may be explained by the differential production of $n$-alkanes between marine and terrestrial organisms, with a higher proportion of $n$-alkanes present in terrestrial higher plant material compared with marine organisms (Tissot and Welte, 1978).

\section{Possible source rocks}

A high proportion of terrestrial organic matter is indicated for the Lower Cretaceous southern East Coast Basin formations. An increasing marine influence in Upper Cretaceous to Paleogene strata culminates in the Eocene Wanstead Formation and, possibly Amuri Limestone/Woodside Formation (defined by the general absence of oleanane). This trend is then reversed with an increasing terrestrial contribution of organic matter in Oligocene and Miocene strata. These results are consistent with the $n$-alkane biomarker data $\left(\mathrm{C}_{21}+\mathrm{C}_{22} / \mathrm{C}_{28}+\mathrm{C}_{29}\right.$ and $\left.\mathrm{C}_{\max }\right)$ from eastern North Island strata (Chapter 5), with even the slight increase in terrestrially-derived organic matter identified in the Waipawa Black Shale. The trends indicated in Marlborough strata, however, are 
not fully consistent with the $n$-alkane biomarker data. The sterane distribution patterns indicate a strong terrestrial proportion of organic matter in middle to Lower Cretaceous strata (Burnt Creek and Split Rock formations and Torlesse Supergroup), while the $n$-alkane distribution patterns indicate predominantly marine organic matter. The sterane data is considered more reliable for several reasons: compared with the $n$-alkanes, the sterane compounds are less likely to have suffered post-depositional alteration; the trends determined from the sterane distribution patterns are more consistent with those determined from eastern North Island strata; and the interpretations of the sterane distribution patterns are consistent with field observations of the presence of carbonised woody material in the Split Rock Formation and Torlesse Supergroup samples. These trends can also be closely correlated to the known basin history (see Chapter 2), whereby an increased supply of terrigenous sediment resulted from uplift and erosion during the Rangitata Orogeny that persisted into the Early Cretaceous. During the Late Cretaceous and Paleogene a passive margin existed with a decreasing supply of terrigenous sediment following a marine transgression. Renewed tectonic activity during the Oligocene with the onset of subduction caused uplift, erosion and hence an increased supply of terrigenous sediment. While Rogers (1995) did not note a similar trend in northern East Coast Basin strata she did describe a predominantly marine contribution of organic matter, with a minor terrestrial component in the Cretaceous formations, and an increased proportion of terrestrial organic matter in the Waipawa Black Shale. The increased proportion of terrestrial organic matter indicated for the Waipawa Black Shale has been interpreted to result from the flooding of nonmarine areas (Leckie et al., 1992).

Open marine depositional conditions generally existed throughout much of the basin's history. However, reduced oxygen conditions and minor anoxic episodes prevailed during deposition of the uppermost Cretaceous Upper Calcareous and Rakauroa members of the Whangai Formation and Mata Series sediments, and this developed into predominantly anoxic conditions during deposition of the Paleocene Waipawa Black Shale. Coinciding with reduced oxygen depositional conditions during the latest Cretaceous were the widespread increase in $\mathrm{C}_{30}$ sterane-synthesising algae, which peaked during the Paleocene. Both the onset of anoxic depositional conditions and the increase in Chrysophyte algae may be related to changes in oceanic circulation patterns during the Paleocene as proposed by Killops et al. (1996).

\subsubsection{Maturity}

Sterane and triterpane biomarker ratios provide the most complete maturity data in the present study, and the only data of significance for the oils. Maturities of the southern 
East Coast Basin oils are at about peak oil generation $\left(0.8-0.9 \% \mathrm{R}_{\mathrm{o}}\right)$, with the immature $\left(<0.6 \% \mathrm{R}_{\mathrm{o}}\right)$ Knights Stream oil and early generation of the Tiraumea oil $\left(0.6-0.7 \% \mathrm{R}_{\mathrm{o}}\right)$ the exceptions. These data indicate that the mature southern East Coast Basin oils, in general, are slightly more mature than the oils analysed by Rogers (1995) from the northern East Coast Basin $\left(\sim 0.8 \% \mathrm{R}_{\mathrm{o}}\right)$.

The majority of the possible source rock samples analysed show low maturities, below the onset of oil generation $\left(<0.6 \% \mathrm{R}_{0}\right)$ which is consistent with the $\mathrm{T}_{\max }$ and PI results from Rock-Eval pyrolysis (see Section 4.2.3). A comparison of the maturity values of samples from the northern East Coast Basin (from Rogers, 1995) with those from the present study show that, assuming a similar geothermal gradient, roughly similar burial depths have been reached in both northern and southern parts of the basin. In general, formations common to both regions show slightly greater maturities in samples from the northern part of the basin, but the most mature samples $\left(\sim 0.9 \% \mathrm{R}_{\mathrm{o}}\right)$ are from the Whatarangi Formation and Torlesse Supergroup from the southern Aorangi Block of the southern East Coast Basin.

\subsubsection{Oil-oil and oil-source rock correlations}

\section{Oil-oil correlations}

In the present study, the Kerosene Rock, Westcott, Tiraumea and Okau Stream oils are correlated primarily on the presence of high relative abundances of unusual and highly diagnostic $\mathrm{C}_{30}$ steranes and 28,30-bisnorhopane. These same biomarker characteristics are used to differentiate these oils from the Knights Stream and Isolation Creek oils and also the northern seep oils (Waitangi, Totangi and Rotokautuku). Recent confidential studies by Amoco (e.g. Lipke, 1989; Zumberge, 1990) also used $\mathrm{C}_{30}$ steranes and 28,30-bisnorhopane to further correlate the Waipatiki oil, from south-east of Dannevirke, with the Kerosene Rock and Okau Stream oils. Other oils reported to have high relative abundances of $\mathrm{C}_{30}$ steranes include those from Angora Stream and Riversdale in the southern East Coast Basin and Te Weraroa Stream, the only reported occurrence from the northern East Coast Basin (Killops, 1996). A similarity between the Kora-1 oil, from the northern Taranaki Basin (reported by Reed, 1992), and the oil stains of the southern East Coast Basin was noted by both Murray et al., (1994) and Rogers et al., (1994), particularly the high relative abundance of $\mathrm{C}_{30}$ steranes. The Kora-1 oil is, therefore, also included in this family of oils with the implication that there is a regional, rather than simply a basinwide, source for these oils. 
Unlike the Kerosene Rock, Westcott, Tiraumea and Okau Stream oils, the Knights Stream and Isolation Creek oils do not have highly diagnostic biomarkers useful for correlation purposes. However, these two oils are tentatively correlated based on the high proportion of $\mathrm{C}_{28}$ steranes and low relative abundances of $\mathrm{C}_{30}$ steranes and 28,30-bisnorhopane. The Waitangi, Totangi, Rotokautuku and Motu Valley oil, from the northern East Coast Basin, previously correlated by Rogers (1995) are also included in this family of oils based on similar biomarker characteristics. High $\mathrm{C}_{27} / \mathrm{C}_{29}$ sterane ratios (0.91-1.99) present in the northern oils, however, do not match the lower ratios present in the Knights Stream (0.71) and Isolation Creek (0.83) oils. This suggests a greater terrestrial contribution to the southern East Coast Basin oils, and is consistent with the dominance of isopimarane, a terrestrial biomarker, in a diterpane distribution in the Isolation Creek oil (Killops, 1996).

\section{Oil-source rock correlations}

Fry (1982) may have been the first to note high relative abundances of $\mathrm{C}_{30}$ steranes in samples of Waipawa Black Shale and from an oil stain from Tunakore Stream in the Whangai Range of southern East Coast Basin, but no correlation was mentioned. Oilsource rock correlations linking the Waipawa Black Shale with the oil stains of the southern East Coast Basin, based on the high relative abundance of $\mathrm{C}_{30}$ steranes and 28,30-bisnorhopane have only recently been reported (e.g. Lipke, 1989; Zumberge, 1990; Rogers et al., 1994; Murray et al., 1994; Rogers, 1995; this study).

Murray et al. (1994) noted the high relative abundances of $\mathrm{C}_{30}$ steranes (4-desmethyl steranes) and also the presence of 28,30-bisnorhopane both in the Westcott and Okau Stream oils and in the Waipawa Black Shale but, because no other formations were investigated, they could not discount the possibility of an older formation as the source for the oils. Rogers et al. (1994) noted that Waipawa Black Shale was the only formation sampled in the northern East Coast Basin with high relative abundances of $\mathrm{C}_{30}$ steranes and 28,30-bisnorhopane, and that both of these biomarker characteristics are absent from the major seep oils (Waitangi, Totangi and Rotokautuku) but present in oil stains from the southern East Coast Basin.

The Kora-1 oil from the northern Taranaki Basin has been correlated to the Turi Formation, which contains an organic-rich shale equivalent to the Waipawa Black Shale (Killops et al., 1994). Although the Waipawa Black Shale and its equivalents have been recognised in the Northland, Canterbury, Great South and possibly south Westland basins, no oils sampled from these regions are characterised by high relative abundances of $\mathrm{C}_{30}$ steranes. 
The results of this biomarker study support a tentative correlation between the Knights Stream and Isolation Creek oils and the Upper Calcareous and Rakauroa members of the Whangai Formation. Following the correlation between these oils and the Waitangi, Totangi, Rotokautuku and Motu Valley oils from the northern East Coast Basin, the oilsource rock correlation proposed here is consistent with the findings of Rogers (1995), who also correlated between the northern seep oils and the Upper Calcareous Member of the Whangai Formation. 


\subsection{Conclusions}

- At least two families of oils are present in the southern East Coast Basin: The first comprises both Knights Stream and Isolation Creek oils, which are characterised by high proportions of $\mathrm{C}_{28}$ steranes and low relative abundances of $\mathrm{C}_{30}$ steranes $\left(\mathrm{C}_{30}\right.$ indices from 0.06-0.12), 28,30-bisnorhopane, oleanane and $17 \alpha(\mathrm{H})$-diahopane. These indicate deposition of predominantly marine organic matter with a moderate terrestrial component under open marine conditions. The Knights Stream oil is an immature oil with maturity below the onset of oil generation $\left(<0.6 \% \mathrm{R}_{\mathrm{o}}\right)$, while the Isolation Creek oil has a maturity of about peak oil generation $\left(\sim 0.8 \% \mathrm{R}_{\mathrm{o}}\right)$. Although these oils have similar biomarker characteristics the mutual lack of unusual source-specific biomarkers is such that the correlation is tentative. Also included in this family are the major seep oils of the northern East Coast Basin (Waitangi, Totangi, and Rotokautuku);

- The second family comprises the Kerosene Rock, Westcott, Tiraumea and Okau Stream oils, which are characterised by low proportions of $\mathrm{C}_{28}$ steranes, high relative abundances of $\mathrm{C}_{30}$ steranes $\left(\mathrm{C}_{30}\right.$ indices from 0.24-0.40) and 28,30-bisnorhopane, and low-moderate relative abundances of oleanane and $17 \alpha(\mathrm{H})$-diahopane. These are considered to indicate the deposition of predominantly marine algal material and a moderate terrestrial component under anoxic or low oxygen conditions. These oils generally have a maturity of peak oil generation $\left(0.8-0.9 \% \mathrm{R}_{\mathrm{o}}\right)$. Included in the second family are a number of other oils from both the northern and southern East Coast Basin, including the Waipatiki and Tunakore oils from southern Hawke's Bay. Significantly, the Kora-1 oil from the northern Taranaki Basin is also correlated with these oils and demonstrates a regional rather than simply basinwide source;

- A high proportion of terrestrial organic matter is indicated for the Lower Cretaceous southern East Coast Basin formations. An increasing marine influence in Upper Cretaceous to Paleogene strata culminates in the Eocene Wanstead Formation and, possibly Amuri Limestone/Woodside Formation (defined by the general absence of oleanane). The exception to this trend is a slight but noticeable increase in terrestrial organic matter in the Waipawa Black Shale. This trend is then reversed with an increasing terrestrial contribution of organic matter in Oligocene and Miocene strata;

- Maturity biomarker ratios indicate that the majority of possible source rocks analysed show maturities below the onset of oil generation $\left(<0.6 \% \mathrm{R}_{\mathrm{o}}\right)$. Sample maturity is controlled by the tectonic history of individual structural blocks, and regions of 
greater maturity include the northern Coastal, Tora and southern Aorangi blocks of eastern North Island, and the Cape Campbell, Coverham and inland Clarence River regions of Marlborough;

- The Waipawa Black Shale is characterised by high relative abundances of $\mathrm{C}_{30}$ steranes $\left(\mathrm{C}_{30}\right.$ indices from $\left.0.05-0.33\right)$, low proportions of $\mathrm{C}_{28}$ steranes, variable $\mathrm{C}_{27} / \mathrm{C}_{29}$ sterane ratios (0.74-2.59), high relative abundances of 28,30-bisnorhopane and occasionally low-moderate relative abundances of a compound thought to be gammacerane. These biomarkers indicate deposition of varying proportions of terrestrial higher plant and marine algal organic matter under conditions of anoxia or low oxygen and possibly elevated salinity;

- The Upper Calcareous and Rakauroa members of the Whangai Formation are characterised by high proportions of $\mathrm{C}_{28}$ steranes (averaging 0.32 ), generally high $\mathrm{C}_{27} / \mathrm{C}_{29}$ sterane ratios (0.75-3.02), and variable, sometimes high, relative abundances of $\mathrm{C}_{30}$ steranes, and 28,30-bisnorhopane. These are thought to indicate deposition of predominantly marine organic matter under intermittently low oxygen or anoxic conditions;

- The unusual $\mathrm{C}_{30}$ steranes present in the Waipawa Black Shale and Westcott and Okau Stream oils have been identified as 24-n-propylcholestanes and are thought to be derived from Chrysophyte algae (Murray et al., 1994). It is likely that 24- $n$-propylcholestane is also predominant in the other oils with high relative abundances of $\mathrm{C}_{30}$ steranes. It appears that due to favourable environmental conditions present during the latest Cretaceous and Paleocene, possibly a result of a change in ocean currents, this usually rare algae flourished; and

- The Kerosene Rock, Westcott, Tiraumea and Okau Stream oils are correlated with the Waipawa Black Shale based on similar biomarker characteristics, particularly the high relative abundances of $\mathrm{C}_{30}$ steranes and 28,30-bisnorhopane. The Knights Stream and Isolation Creek oils are tentatively correlated with the Upper Calcareous and Rakauroa members of the Whangai Formation based on their high proportions of $\mathrm{C}_{28}$ steranes. 


\section{Chapter 7}

\section{Other analytical techniques}

\subsection{Stable carbon isotopes}

\subsubsection{Introduction}

Stable isotope ratios describe small variations in isotope abundance in different materials and are used by the oil exploration industry for correlation, maturation and alteration studies, and in the evaluation of source rock depositional environments (Sofer, 1991). Carbon, hydrogen and sulphur stable isotopes are all used but of these, carbon is by far the most common. Stable carbon isotopic compositions of rock bitumens and oil fractions (saturates, aromatics, NSOs and asphaltenes) generally range between -17 and $-36 \%$, with most samples falling between -23 and $-32 \%$ (Sofer, 1991).

\subsubsection{Uses of stable carbon isotopes}

\section{Oil-source rock and oil-oil correlations}

Isotopic compositions can be used to establish genetic relationships between source rocks and oils and among various oils. An oil generated from a particular source rock will have a similar $\delta^{13} \mathrm{C}$ value to that of the source rock (Philp, 1993). The isotopic composition of oils can vary as a result of maturity, migration and biodegradation but these changes can often be predicted and compensated for during correlation (Philp, 1993).

A genetic relationship between oils is usually indicated when the isotopic composition differs by less than $1 \%$ (Peters and Moldowan, 1993), although nonmarine oils can differ by as much as $4 \%$ and still be related (Sofer, 1984). Significant differences in maturation, migration and biodegradation can result in genetically-related marine oils or oils and source rocks having $\delta$ values that differ by as much as $2 \%$ (Sofer, 1984; 1991). Both maturation and migration tend to increase the $\delta$ value of saturate, aromatic and whole-oil fractions, while biodegradation does not cause systematic change in the isotopic composition of genetically different oils but does cause similar changes in genetically-related oils (Sofer, 1984). Oils are generally 0 to $1.5 \%$ depleted in ${ }^{13} \mathrm{C}$ compared to their corresponding bitumens, which, in turn, are 0.5 to $1.5 \%$ o depleted in ${ }^{13} \mathrm{C}$ compared to their source kerogens (Peters and Moldowan, 1993). 


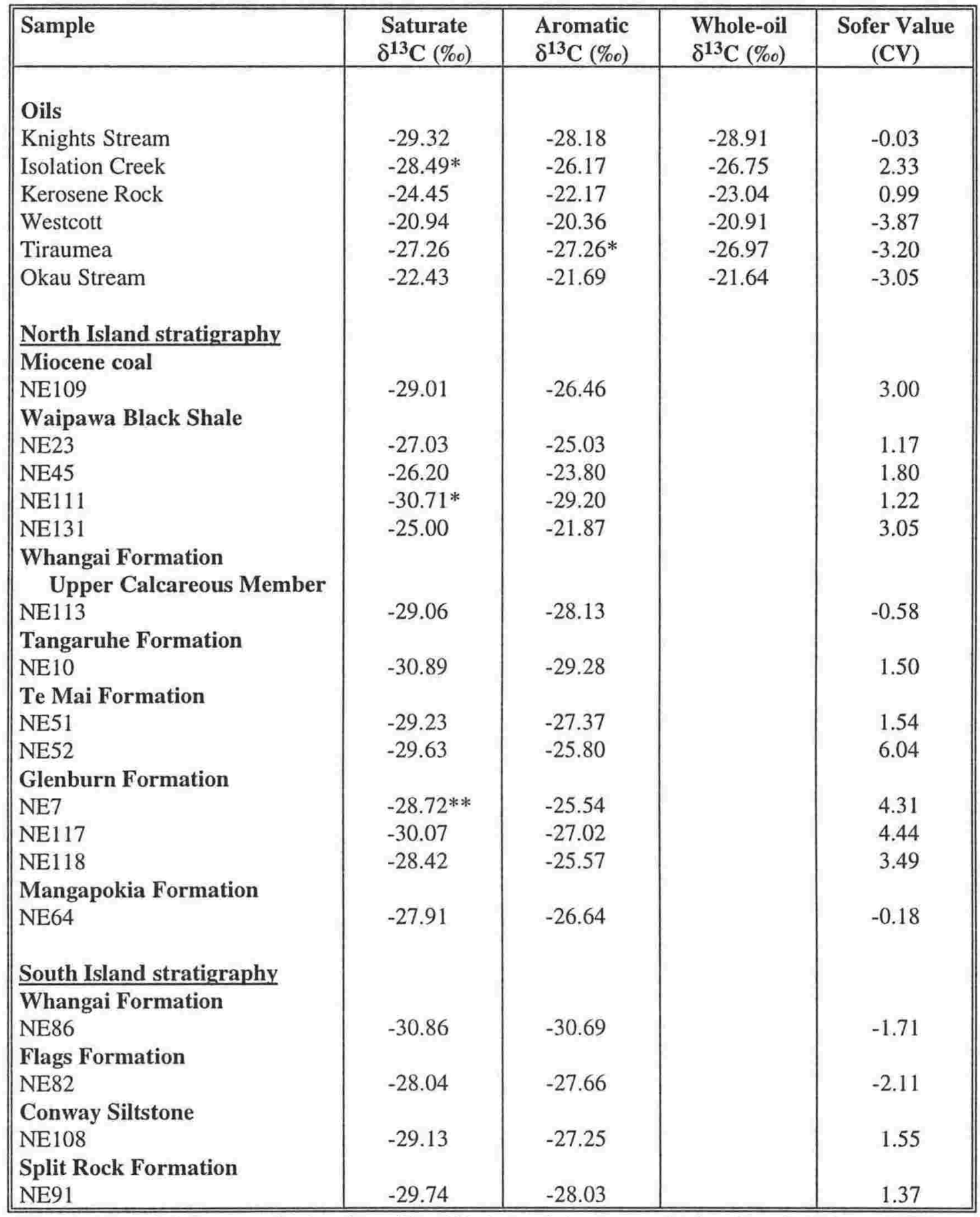

*just below minimum required carbon; ** well below minimum required carbon. Relative to PDB.

Table 7.1 Stable carbon isotope analyses from Waikato University. 


\section{Depositional environment}

Carbon isotopes can be used to differentiate oils derived from marine and nonmarine organic matter (Sofer, 1991). Early workers (e.g. Silverman and Epstein, 1958; Tissot and Welte, 1978) suggested that nonmarine organic matter is, on average, lighter in ${ }^{13} \mathrm{C}$ than marine organic matter. Sofer (1984) evaluated 339 oils and found the difference in isotopic compositions negligible and, therefore, insufficient to be used as a reliable source rock indicator. He did find, however, that the differences between marine and nonmarine oils are apparent in the relationship between isotopic composition of the saturate and aromatic fractions and developed the canonical variable (CV), now referred to as the Sofer Value, which describes the following relationship:

$$
\mathrm{CV}=-2.53 \delta^{13} \mathrm{C}_{\mathrm{sat}}+2.22 \delta^{13} \mathrm{C}_{\text {aro }}-11.65
$$

Sofer Values larger than 0.47 indicate a mostly terrestrial source for an oil, whereas values smaller than 0.47 indicate a mostly algal marine or nonmarine source. Alternatively, on a cross-plot of $\delta^{13} C_{\text {aro }}$ vs $\delta^{13} C_{\text {sat }}$ ( $C_{15+}$ fractions), the line that best separates marine oils from nonmarine oils has the following equation:

$$
\delta^{13} \mathrm{C}_{\text {aro }}=1.14 \delta^{13} \mathrm{C}_{\mathrm{sat}}+5.46
$$

Nonmarine oils plot above this line, while marine oils plot below.

It has since been recognised that lacustrine and marine oils follow this relationship in about $90 \%$ of the cases (Sofer, 1991). Among the incorrectly classified oils, however, were the waxy oils from Indonesia and Australia (Sofer, 1984), and Hirner and Lyon (1989) were only able to correctly classify $42 \%$ of the waxy New Zealand oils using this method. Also, deltaic oils which were expected to indicate terrestrially-sourced organic matter often did not (Sofer, 1991). In cases involving rock bitumens the relationship held true less than $90 \%$ of the time (Sofer, 1991).

The simple marine versus nonmarine classification provided by Sofer Values is not strictly accurate, due to the presence of allochthonous organic matter (usually where terrestrial organic matter is incorporated into marine sediments) (Peters et al., 1986). Allochthonous organic matter affects all studies that attempt to classify oils by the type of organic matter in the source rock but, provided this is recognised, such classifications are still useful in petroleum exploration (Peters et al., 1986). Hirner and Lyon (1989) suggested that, for New Zealand oils, the Sofer Values may be better interpreted in terms 
of varying degrees of marine influence during the deposition and maturation of terrigenous organic matter.

\section{Age}

Variations in bulk stable carbon isotope compositions with age have been described (e.g. Arthur et al., 1988), but these trends are not diagnostic as it has been found that there is at least as much variability among samples of the same age (Peters and Moldowan, 1993).

\subsubsection{Methods}

Seventeen rock and 6 oil samples were prepared for ${ }^{13} \mathrm{C}$ analysis (see Chapter 3 for methods). Saturate and aromatic fractions of rock bitumens and an additional 'whole-oil' fraction from oil samples were forwarded to the Stable Isotope Unit at the University of Waikato for analysis. Samples that did not contain the minimum required carbon were reextracted (in double quantity) and sent for repeat analysis. Details of the analytical equipment and analyses are provided in Appendix 6.

\subsubsection{Results}

A summary of results with calculated Sofer Values is presented in Table 7.1 while full results appear in Appendix 6. Data interpreted are from those samples with sufficient carbon for reliable results unless otherwise noted (see Table 7.1). Furthermore, isotope ratios were taken from saturate/aromatic pairs rather than from individual fractions of different analyses.

\section{Sofer Values}

Samples of the Miocene coal, Waipawa Black Shale, the Tangaruhe, Te Mai and Glenburn formations, Conway Siltstone and Split Rock Formation all have positive Sofer Values indicating a predominance of terrestrially-sourced organic matter. In contrast, samples of the Whangai, Flags and Mangapokia formations have negative Sofer Values indicating marine-sourced organic matter. Of the oils, the Knights Stream sample has a slightly negative Sofer Value and the Westcott, Tiraumea and Okau Stream samples show strongly negative Sofer Values indicating a predominance of marine-sourced organic matter. The Isolation Creek and Kerosene Rock oil samples have positive Sofer Values indicating a predominance of terrestrially-sourced organic matter. 


\section{Oil-oil correlation}

The saturate vs aromatic cross-plot (Figure 7.1) identifies three oils (Kerosene Rock, Westcott and Okau Stream) from southern Hawke's Bay/Wairarapa that are enriched in ${ }^{13} \mathrm{C}$ (whole-oil values of -20.91 to $-23.04 \%$ ) compared with the Knights Stream, Isolation Creek and Tiraumea oils (whole-oil values of -26.75 to $-28.91 \%$ ). A second analysis on a greater quantity of Tiraumea oil, however, produced an aromatic fraction $\delta^{13} \mathrm{C}$ value of $-23.45 \%$, considerably heavier than the initial $-27.26 \%$ o value obtained from the first analysis. It, therefore, appears that the Tiraumea oil may group with the ${ }^{13} \mathrm{C}$-enriched oils.

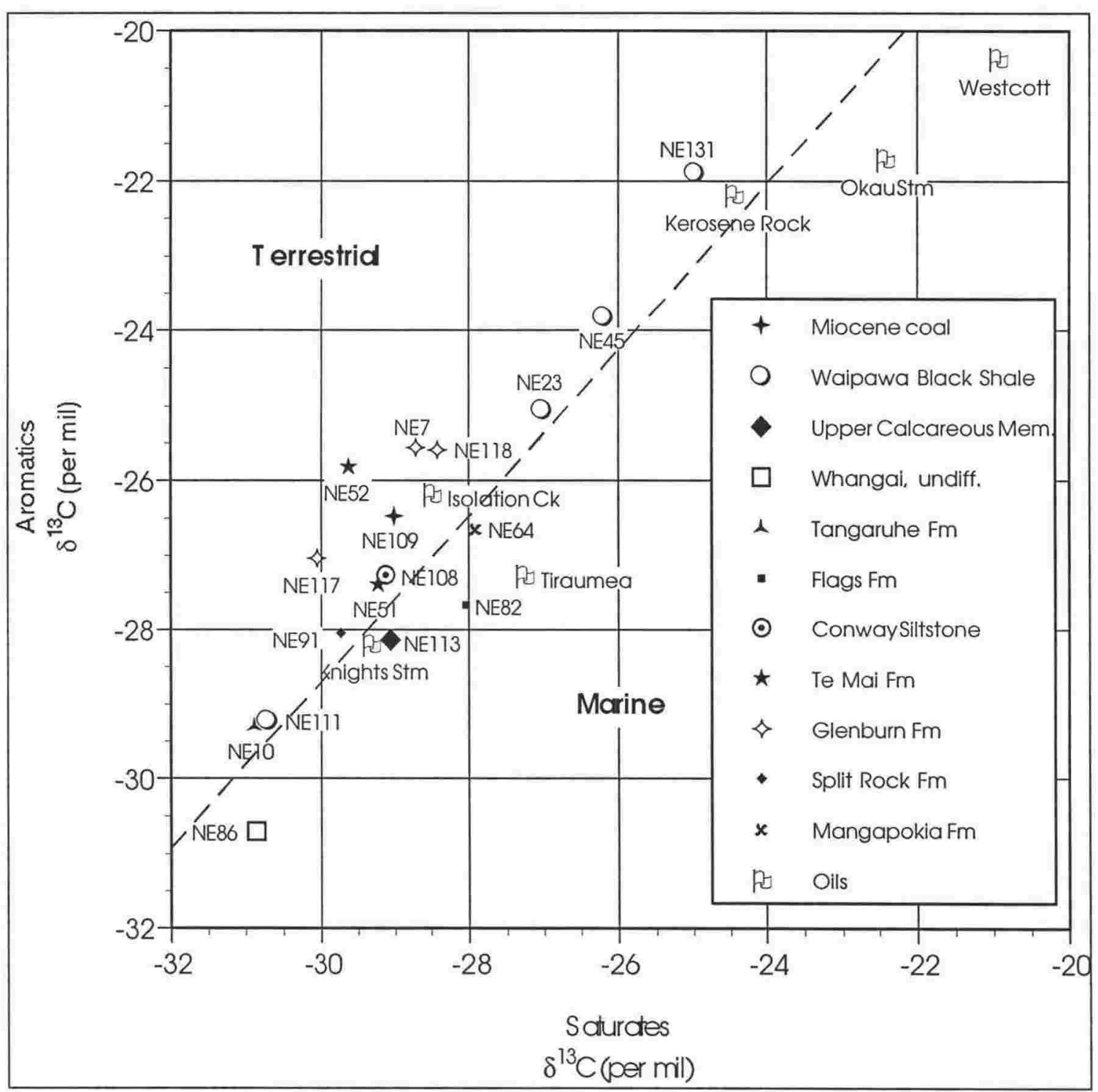

Figure 7.1 Saturate vs aromatic cross-plot of $\delta^{13} \mathrm{C}(\% o)$ values of the oils and possible source rocks. Dashed line delineates marine from terrestrially-derived organic matter (after Sofer, 1984).

A positive correlation is only possible between the Westcott and Okau Stream oils with whole-oil $\delta^{13} \mathrm{C}$ values of -20.91 and $-21.64 \%$ respectively. The Kerosene Rock oil is 
more depleted in ${ }^{13} \mathrm{C}(-23.04 \%$ ) than both the Westcott or Okau Stream oils, but is considerably more enriched than the Knights Stream and Isolation Creek oils. Therefore, although a positive correlation by stable carbon isotope values alone is not possible, it appears that the Kerosene Rock oil is genetically-related to the Westcott and Okau Stream oils. By comparison the Knights Stream $(-28.91 \%$ ) and Isolation Creek oils $\left(-26.75 \%\right.$ ) have isotopically light $\delta^{13} \mathrm{C}$ values but these are sufficiently different to prevent a positive correlation, according to the guidelines of Peters and Moldowan (1993) (Section 7.1.2).

\section{Oil-source rock correlation}

According to Peters and Moldowan (1993), oils should be depleted in ${ }^{13} \mathrm{C}$ relative to their source rocks. With the exception of the Waipawa Black Shale, all possible source rocks analysed are considerably more depleted in ${ }^{13} \mathrm{C}$ than the Westcott, Okau Stream and Kerosene Rock oils and are unlikely to be their source. Although the Waipawa Black Shale was the only formation analysed with $\delta$ values that plot near the ${ }^{13} \mathrm{C}$-enriched oils, a positive correlation is only possible with the Kerosene Rock oil. The apparent similarity between the Kerosene Rock oil and the Westcott and Okau Stream oils, however, suggests that they are also genetically-related to Waipawa Black Shale.

The $\delta^{13} \mathrm{C}$ values of the Knights Stream, Isolation Creek and Tiraumea oils plot within the main grouping of possible source rocks, in the -26 to $-29 \%$ range, where any number of formations could be correlated. Therefore no positive correlation could be made on carbon isotope values alone.

\subsubsection{Discussion}

\section{Source/depositional environment}

The predominance of terrestrial organic matter in the Miocene coal, the Te Mai and Glenburn formations, Conway Siltstone and Split Rock Formation, as indicated by Sofer Values, is consistent with the $n$-alkane, sterane and triterpane biomarker results. The Waipawa Black Shale samples also plot within the terrestrial field of the saturate vs aromatic cross-plot but close to the marine/terrestrial line, and is consistent with contributions of both marine and terrestrial organic matter and the results of the biomarker studies. The Tangaruhe Formation, however, which has been determined to comprise both predominantly marine and terrestrial organic matter (from the sterane and $n$-alkane distribution patterns respectively), plots inside the terrestrial field and close to the dividing line suggesting that both marine and terrestrial organic matter are present and that the terrestrial component is predominant. 
The Whangai, Flags and Mangapokia formations are indicated by their Sofer Values to comprise predominantly marine organic matter. The results for the Whangai Formation are consistent with the $n$-alkane and sterane biomarker results, while the Flags Formation has been determined to comprise both predominantly marine and terrestrial organic matter by $n$-alkane and sterane biomarker parameters respectively. Once again it appears likely that both marine and terrestrial organic matter are present in the Flags Formation, although a predominantly marine contribution is supported here. The Mangapokia Formation is indicated to comprise predominantly marine organic matter. Both the $n$-alkane and sterane biomarker parameters, however, indicate the presence of predominantly terrestrial organic matter.

The slightly negative Sofer Value of the Knights Stream oil indicates a predominantly marine source of organic matter, which is consistent with the biomarker results. The Westcott, Okau Stream and Tiraumea oils also indicate a marine origin for their organic matter, while the Kerosene Rock oil indicates a terrestrial origin. Biomarker results, however, generally indicate either a predominantly terrestrial, or mixed marine and terrestrial origin for these oils and, therefore, are not consistent with the Sofer Values.

The interpretation of Sofer Values are clearly not totally consistent with the results of other more diagnostic studies, such as sterane and triterpane biomarker analysis. This may be because the formations of the southern East Coast Basin have been shown to comprise both marine and terrestrial organic matter, despite a predominantly marine depositional environment. While this is generally shown by the close proximity with which the samples plot to the marine/terrestrial line on the saturate vs aromatic crossplot (Figure 7.1), the organic matter can only be classified as either marine or terrestrial in origin.

\section{Oil-oil correlations}

Variation in $\delta^{13} \mathrm{C}$ values (up to $2 \%$ ) of the ${ }^{13} \mathrm{C}$-enriched (Kerosene Rock, Westcott and Okau Stream) oils is such that a positive correlation is only possible between the Westcott and Okau Stream oils. The relative isolation of these oils on the saturate vs aromatic cross-plot does suggest, however, that they are related. The correlation of the Westcott and Okau Stream oils here is consistent with the specific correlation of these two oils by an almost identical sterane distribution pattern, and with the correlation of all the ${ }^{13} \mathrm{C}$-enriched oils, including the Tiraumea oil, by their sterane and triterpane biomarker characteristics in general (see Section 6.5.6). 


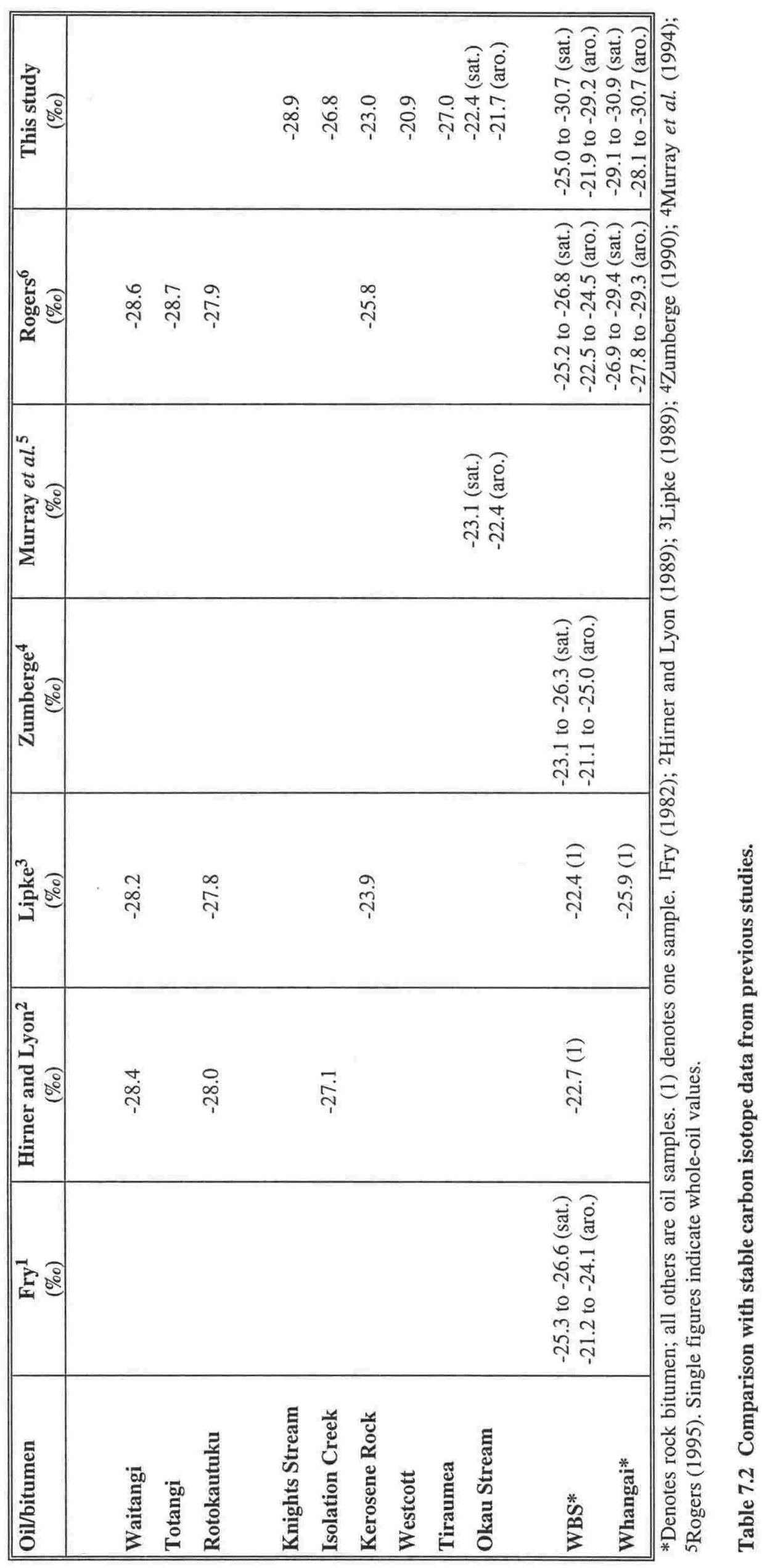


Hirner and Lyon (1989) conducted a stable carbon isotope study on 26 oils from throughout New Zealand which showed a range in whole-oil $\delta^{13} \mathrm{C}$ values of -25.4 to $-29.0 \%$. The Kerosene Rock, Westcott, Tiraumea and Okau Stream oils, therefore, form a unique family of isotopically heavy oils in New Zealand. The Kora-1 oil, from the northern Taranaki Basin, is also isotopically heavy with a whole-oil $\delta^{13} \mathrm{C}$ value of $-22.7 \%$ (Reed, 1992). The correlation of the Kora-1 oil to the Kerosene Rock, Westcott, Tiraumea and Okau Stream oil based on high relative abundances of $\mathrm{C}_{30}$ steranes (see Section 6.7.3) and is further supported here by their characteristic $\delta^{13} \mathrm{C}$-enriched values.

Despite both the Knights Stream and Isolation Creek oils being relatively depleted in ${ }^{13} \mathrm{C}$, they could not be positively correlated by stable carbon isotope ratios alone, based on the criteria discussed in Section 7.1.2. These oils, however, have been tentatively correlated through similarities in their sterane and triterpane biomarker characteristics (Section 6.5.6). Both the Knights Stream and Isolation Creek oils, however, can be correlated with the major seep oils from the northern East Coast Basin (Waitangi, Totangi and Rotokautuku) which have whole-oil $\delta^{13} \mathrm{C}$ values of -27.9 to -28.7 (Table 7.2). A correlation of the Knights Stream and Isolation Creek oils with the northern seep oils, based on their stable carbon isotope ratios, is consistent with similarities in their respective biomarker characteristics (Section 6.7.3).

\section{Oil-source rock correlations}

Although a positive oil-source rock correlation was only possible between the Kerosene Rock oil and the Waipawa Black Shale, the subsequent correlation of the Kerosene Rock, Westcott, Tiraumea and Okau Stream oils also suggests that the Waipawa Black Shale is the source for all these oils, and is consistent with this oil-source rock correlation based on the results of the $n$-alkane, sterane and triterpane biomarker characteristics (see Sections 5.5.3 and 6.6.6). Furthermore, Hirner and Lyon (1989) analysed a number of possible source rocks from throughout New Zealand, from which the Waipawa Black Shale was the most ${ }^{13} \mathrm{C}$-enriched sample analysed $(-22.7 \%$ o), by more than $2 \%$. This indicates that the Waipawa Black Shale is unusual for its enriched ${ }^{13} \mathrm{C}$ values and supports the evidence for a family of ${ }^{13} \mathrm{C}$-enriched oils which are sourced from the Waipawa Black Shale and its lateral equivalents.

\subsubsection{Conclusions}

- Stable carbon isotope data are best used for correlation purposes. Corroborating data is required when using Sofer Values to determine types of contributing organic matter; 
- The Kerosene Rock, Westcott, Tiraumea and Okau Stream oils are characterised by isotopically heavy $\delta^{13} \mathrm{C}$ whole-oil values $(-20.9$ to $-23.0 \%$ ) and are correlated on this basis. With the exception of the Kora-1 oil $(-22.7 \%$ ) from the northern Taranaki Basin, which is also correlated with these oils, these represent the most ${ }^{13} \mathrm{C}$-enriched oils in New Zealand;

- The Knights Stream and Isolation Creek oils are characterised by relatively depleted $\delta^{13} \mathrm{C}$ whole-oil values ( -28.9 and $-26.8 \%$ respectively). These oils are correlated with the Waitangi, Totangi and Rotokautuku oils from the northern East Coast Basin based on similar depleted $\delta^{13} \mathrm{C}$ whole-oil values ( -27.9 to $-28.7 \%$ ); and

- The Waipawa Black Shale has the most $\delta^{13} \mathrm{C}$-enriched values (to $<-23 \%$ ) of any formation analysed from the southern East Coast Basin and possibly New Zealand. This formation is correlated with the Kerosene Rock, Westcott, Tiraumea and Okau Stream oils. 


\subsection{Visual kerogen analysis (VKA)}

\subsubsection{Introduction}

Kerogen is defined as the component of sedimentary organic matter that is insoluble in common organic solvents (Tissot and Welte, 1978; Jacobson, 1991; Killops and Killops, 1993; Senftle et al., 1993). It is the precursor to oil and gas and is the most abundant form of organic carbon on earth, more than a thousand times as abundant as coal (Killops and Killops, 1993; Whelan and Thompson-Rizer, 1993). Kerogen comprises the altered remains of living matter and therefore contains information about the depositional, geological and geothermal history of sediments (Whelan and ThompsonRizer, 1993).

Traditional bulk geochemical methods (such as Rock-Eval pyrolysis and elemental composition) describe four types of kerogen, Types I-IV (Peters, 1986). Although these are roughly equivalent to the maceral groups liptinite, exinite, vitrinite and inertinite respectively (Killops and Killops, 1993), kerogen is not homogeneous and comprises a complex mixture of organic material (Tissot and Welte, 1978; Larter and Horsfield, 1993). This complex mixture of organic material undergoes diagenetic, catagenic and metagenic changes at different rates and hence maturation influences the chemical composition of kerogen (Senftle et al., 1993). Geochemical analyses record only the present condition of organic matter and cannot always differentiate between source rocks with different kerogen and maturity (Senftle et al., 1993).

The accurate identification of organic matter is of fundamental importance in the evaluation of the hydrocarbon potential of possible source rocks (Senftle et al., 1993). Visual kerogen analysis (VKA) is a technique that describes the quantity, quality and thermal maturity of organic matter through the use of optical microscopy. It is valuable because it involves the identification of various components within the kerogen mixture not possible by conventional chemical methods (Peters and Moldowan, 1993; Tyson, 1995). It becomes especially important when dealing with mature source rocks because, with increasing maturity, organic matter type becomes progressively more difficult to determine by chemical analyses due to the convergence of kerogen maturation pathways (see Figure 4.1). Visual kerogen analysis itself, however, does not determine the hydrocarbon potential of the kerogen and hence is complimentary to bulk geochemical methods (Peters and Moldowan, 1993). 
Several kerogen classification schemes are currently in use (Senftle et al., 1993). In the present study kerogen composition was recorded in terms of seven components: amorphous, structured aqueous, biodegraded terrestrial, spore/pollen, structured terrestrial, semi-opaque and opaque. Definitions of the seven kerogen components and additional terms [described by Mike Hannah (pers. comm.) and also used by Rogers (1995)] are as follows:

Amorphous: Unstructured kerogen which has been derived from biodegraded aquatic matter such as algae and phytoplankton, and terrestrial matter deposited in aquatic systems which has decomposed due to aerobic bacteria in oxic environments.

Structured aqueous: Kerogen which has preserved the original cell structures of marine organic matter, such as aquatic plants including dinoflagellates.

Biodegraded terrestrial: Kerogen which has partially degraded to amorphous material, but with the original terrestrial structure such as wood tissue or plant cells still recognisable.

Spore/pollen: Kerogen which contains spore and pollens, indicative of a terrestrial contribution.

Structured terrestrial: Kerogen which shows the structure of the original terrestrial components such as wood, leaves and plant tissue.

Semi-opaque: Kerogen derived from terrestrial matter which has experienced some thermal alteration causing the tissue to oxidise and resemble charcoal.

Opaque: Kerogen which has undergone significantly more thermal alteration than semiopaque kerogen and is almost converted to charcoal.

Fines: This represents material which is too fine or broken up to be characterised.

Thermal Alteration Index (TAI): Thermal maturation results in a gradual colouring and progressive darkening of organic matter. This colour change can be used to determine thermal maturation on a scale known as the thermal alteration index (TAI) (Table 7.3). The advantages of this method is that it is possible to distinguish reworked from in situ organic matter. 


\begin{tabular}{|c|c|c|c|c|c|c|c|c|c|c|c|}
\hline$\frac{\Xi}{2}$ & $\vec{\circ}$ & 若总 & 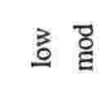 & 总 & 总 & 咅葛 & 菃 & 萻 & $\stackrel{z}{\underline{a}}$ & 흠 & : \\
\hline$\Xi$ & $\begin{array}{l}\text { İ } \\
\text { ป் }\end{array}$ & & $\frac{i}{i}$ i & $\stackrel{i}{i}$ & & & $\stackrel{\pi}{\pi}$ & & & สี & \\
\hline 递 & 粋 & & & & 1 & & & & & & \\
\hline 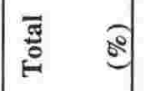 & $\stackrel{8}{\circ}$ & 용 & 응 & 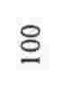 & $\cong$. & 용 & $\stackrel{8}{ }$ & $\stackrel{8}{\circ}$ & 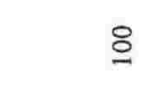 & $\stackrel{8}{\circ}$ & $\stackrel{\circ}{-}$ \\
\hline 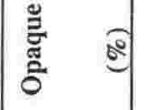 & 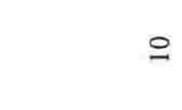 & in in & $\cong 0$ & $\because$ & 오 & & n & $\simeq$ & $\cong$ & $\approx$ & 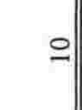 \\
\hline 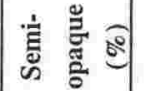 & $\therefore 8$ & $\simeq 2$ & 요 & $\therefore$ & $\infty$ in & $\approx \approx$ & ㅇ & 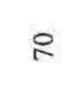 & 2 & n & $\approx$ \\
\hline 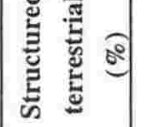 & 요 & $\therefore \approx$ & $\cong q$ & 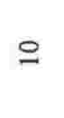 & 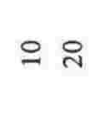 & $n 8$ & 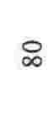 & $\simeq$ & q & ¿ & $\stackrel{m}{0}$ \\
\hline 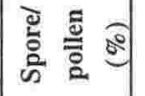 & 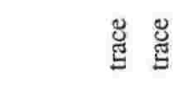 & 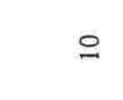 & 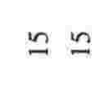 & in & n & in & $n$ & : & n & n & त) \\
\hline 要 & & & & & & & & & & & \\
\hline 窇言 & & $\subseteq \stackrel{\circ}{\circ}$ & n & : & & : & & & 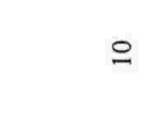 & r & \\
\hline 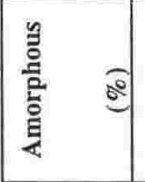 & & & & & & & & & & & \\
\hline 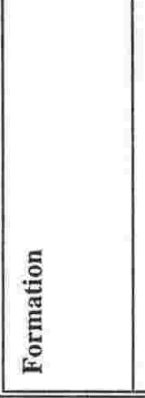 & 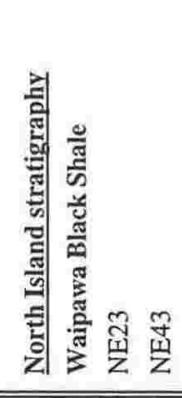 & 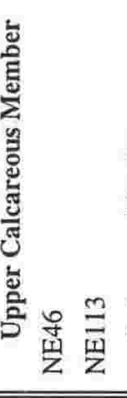 & 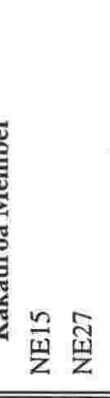 & & 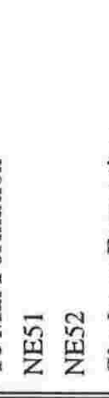 & $\frac{\infty}{ \pm=}$ & & 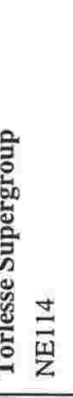 & 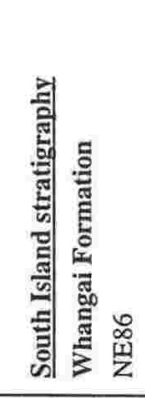 & & : \\
\hline
\end{tabular}




\begin{tabular}{||l|c|c|l||}
\hline \hline Maturity & $\mathbf{R}_{0}(\%)$ & TAI & \multicolumn{1}{|c||}{ Colour } \\
\hline Immature & & & \\
Immature & 0.22 & 1.0 & unaltered \\
Onset of oil generation & 0.32 & 2.0 & yellow \\
End of oil generation & 0.55 & 2.5 & \\
Postmature & 1.3 & 3.0 & brown \\
Postmature & 2.5 & 4.0 & dark brown - black \\
\hline \hline
\end{tabular}

Table 7.3 Correlation of TAI and associated spore/pollen colour with vitrinite reflectance maturation parameters (after Senftle and Landis, 1991).

Yield: This is an indication of the confidence that the kerogen on the slide is representative of the sample.

\subsubsection{Methods}

Sixteen samples were prepared for visual kerogen analysis. Identifications were made by Dr. Mike Hannah of the Geology Department, Victoria University of Wellington. Samples were chosen specifically from the uppermost Cretaceous to Paleocene sequence with favourable TOC and Rock-Eval pyrolysis results. Samples from the Te Mai, Glenburn and Mangapokia formations and Torlesse Supergroup were also included to help determine the nature of their organic matter. Kerogen isolation was achieved through standard methods of acid treatment $(\mathrm{HF} / \mathrm{HCl})$ followed by flotation in a heavy liquid and is fully described in Appendix 7.

\subsubsection{Results}

The results of visual kerogen analysis are presented in Table 7.4 and also in Appendix 7.

Both Waipawa Black Shale samples are almost devoid of kerogen Types I and II (amorphous, structured aqueous, biodegraded terrestrial and spore/pollen) and comprise predominantly structured terrestrial and semi-opaque kerogen. The complete absence of marine organic matter in these samples appears to indicate a marginal marine depositional environment.

The Upper Calcareous Member (Whangai Formation) samples have no amorphous or biodegraded terrestrial kerogen but contain high levels of structured terrestrial kerogen and moderate levels of structured aqueous kerogen. Only small amounts of semi-opaque and opaque kerogen were recorded. 
The two Rakauroa Member (Whangai Formation) samples are virtually identical in composition with no amorphous or biodegraded terrestrial and little structured aqueous kerogen. The samples are dominated by structured terrestrial and semi-opaque kerogen with moderate levels of spore/pollen. Kerogen compositions differ from those of the Upper Calcareous Member in that they have less structured aqueous and more semiopaque and opaque kerogen and this suggests a more proximal depositional environment for the Rakauroa Member.

The Tangaruhe Formation sample shows trace or no amorphous, structured aqueous or biodegraded terrestrial kerogen. Spore/pollen constitutes half the sample, with the remainder comprising moderate amounts of structured terrestrial, semi-opaque and opaque kerogen.

Te Mai Formation samples are devoid of amorphous, structured aqueous or biodegraded terrestrial kerogen. Minor spore/pollen is present in the mudstone unit sample and both contain high levels of semi-opaque and moderate levels of structured terrestrial and opaque kerogen. The Glenburn Formation samples are also devoid of amorphous or biodegraded terrestrial kerogen. The sandstone unit sample (NE117) comprises almost entirely semi-opaque kerogen with minor structured terrestrial kerogen. The mudstone unit sample (NE118) comprises dominantly structured terrestrial kerogen with high levels of semi-opaque kerogen. Minor spore/pollen and trace amounts of structured aqueous kerogen are also present but no opaque kerogen was recorded. The high levels of semi-opaque and opaque kerogen in the Te Mai and Glenburn formations indicate recycled or highly weathered organic matter of terrestrial origin and clearly demonstrate their inert nature.

The Mangapokia Formation sample comprises dominantly structured terrestrial kerogen with only minor spore/pollen, semi-opaque and opaque kerogen and an absence of marine-sourced kerogen. Unlike the Te Mai and Glenburn formations, however, only a minor proportion of the kerogen in the Mangapokia Formation sample appears to be recycled or degraded by oxidation.

The Torlesse Supergroup sample contains mainly semi-opaque kerogen with equal and minor amounts of structured terrestrial and opaque kerogen, indicating predominantly terrestrially-sourced and recycled or oxidised organic matter.

The Conway Siltstone sample contains moderate levels of structured aqueous kerogen and moderate to high levels of spore/pollen, structured terrestrial and semi-opaque 
kerogen and a small amount of opaque kerogen. As a lateral equivalent of the Whangai Formation it is not surprising that the organic matter content is similar, with perhaps a slightly stronger terrestrial signature than the Upper Calcareous Member.

The Flags Formation sample is dominated by a high proportion of structured aqueous kerogen, comprising mainly dinoflagellates (Mike Hannah, pers. comm.) with moderate levels of structured terrestrial and opaque kerogen and small amounts of spore/pollen and semi-opaque kerogen. This indicates a predominantly marine influenced depositional environment. A moderate level of opaque kerogen shows an input of recycled or oxidised organic matter.

TAI measurements (2.0-2.3) on samples of Early Cretaceous (Mangapokia Formation) to Paleocene (Waipawa Black Shale) age indicate they are immature for oil generation. In particular, NE27 is a sample of the Rakauroa Member of the Whangai Formation which contains the Knights Stream oil but has a TAI of only $2.0\left(\sim 0.32 \% \mathrm{R}_{\mathrm{o}}\right)$. This indicates that the sample is immature for hydrocarbon generation and implies that the oil has migrated either up dip or into this unit from another formation, consistent with the maturity biomarker data in Section 6.5.2.

\subsubsection{Discussion}

The results of VKA indicate that an overwhelming majority of southern East Coast Basin formations are dominated by kerogen of terrestrial origin and, although this appears to be inconsistent with the results of $n$-alkane, sterane and triterpane biomarker distributions, it must be noted that VKA is an analysis of kerogen while GC and GC-MS techniques analyse the bitumen. Semi-opaque and opaque kerogen may not contribute significantly to any bitumen produced in a sample due to the inert nature of this organic matter, and consequently much of this terrestrially-sourced material is not recognised in biomarker investigations.

Visual kerogen analysis of the two Waipawa Black Shale samples indicates that only terrestrial organic matter is present and this is not entirely consistent with the sterane and $n$-alkane distribution patterns of these samples (see Appendix 4 and 5), probably for the reasons cited above. Leckie et al. (1992) also noted a high proportion of terrestrial plant debris in the Waipawa Black Shale, while other workers have reported somewhat different results. Fry (1982) showed that the Waipawa Black Shale samples are dominated by amorphous kerogen of marine algal origin, while Zumberge (1990) also reported predominantly amorphous kerogen, but with variable proportions of fluorescing 


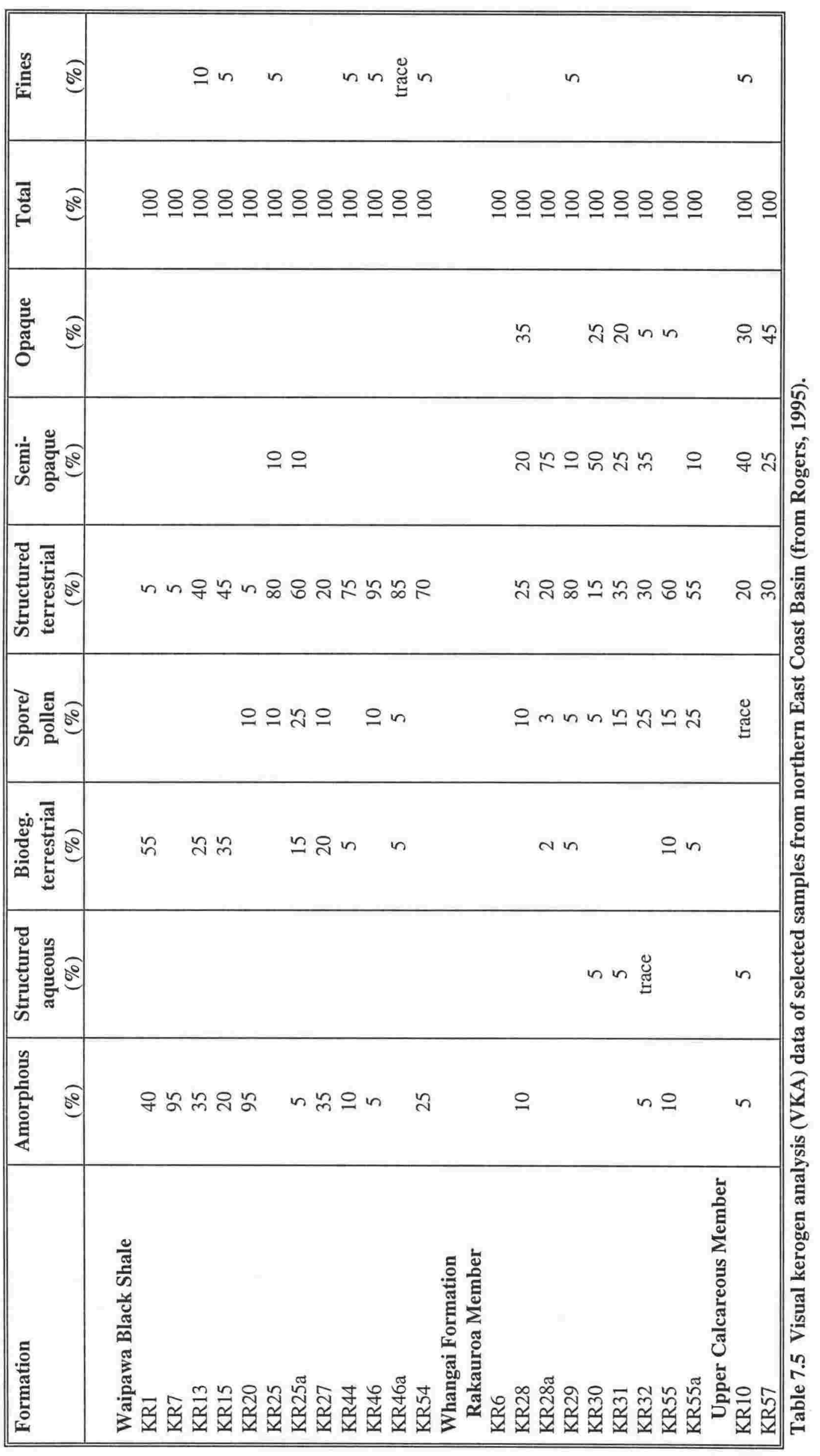


and nonfluorescing amorphous matter, and only trace or minor amounts of vitrinite and inertinite. Fluorescing kerogen is considered oil-prone while nonfluorescing kerogen may result from biodegraded terrestrial organic matter. Rogers (1995) reported on the kerogen contents of 12 Waipawa Black Shale samples from the northern East Coast Basin (Table 7.5). Half of the samples were found to contain high levels of structured terrestrial kerogen and are similar to the samples examined in the present study, while the other half were found to have a high proportion of amorphous and biodegraded terrestrial kerogen. These contrasting results suggest a changing organofacies within the Waipawa Black Shale with variable influxes of terrestrial organic matter, and this variation in kerogen type may be responsible for the highly variable $S_{2}$ and $\mathrm{HI}$ parameter values reported by different authors (see Section 4.2.4).

Although the Whangai Formation samples demonstrate that they have a greater proportion of marine organic matter than the Waipawa Black Shale samples, they are still very much dominated by terrestrial organic matter with up to $45 \%$ of the total organic matter comprising semi-opaque and opaque kerogen. These results are also generally inconsistent with the results of the $n$-alkane and sterane distribution patterns (Sections 5.5.2 and 6.6.3), presumably for the reasons already explained. The greater marine influence indicated for the Upper Calcareous Member compared to the Rakauroa Member, however, is consistent with the VKA results of Rogers (1995) (Table 7.5), but this trend is not apparent in the $\mathrm{C}_{21}+\mathrm{C}_{22} / \mathrm{C}_{28}+\mathrm{C}_{29}$ n-alkane and $\mathrm{C}_{27} / \mathrm{C}_{29}$ sterane ratios of their bitumens (Sections 5.5.2 and 6.6.3).

The Tangaruhe, Te Mai, Glenburn and Mangapokia formations and Torlesse Supergroup all indicate a predominance of terrestrial organic matter and this is consistent with the $n$-alkane, sterane and triterpane biomarker characteristics (Sections 5.5.2 and 6.6.3). The Te Mai and Glenburn formations and Torlesse Supergroup, in particular, have semiopaque and opaque kerogen comprising up to $95 \%$ of the total organic matter, consistent with the low hydrocarbon generative potential $(\mathrm{HI}<50)$ of these units (see Section 4.2.3).

The Flags Formation, a lateral equivalent of the Whangai Formation, shows the greatest contribution of marine (structured aqueous) kerogen of any of the formations analysed and has a very similar kerogen composition to sample NE113 (Upper Calcareous Member). The Conway Siltstone demonstrates a significant proportion of spore/pollen and suggests a more proximal depositional environment than the Whangai Formation, which is consistent with the $\mathrm{C}_{27} / \mathrm{C}_{29}$ sterane ratios for their bitumens (Section 6.6.3). 


\subsubsection{Conclusions}

- Formations of the southern East Coast Basin comprise an overwhelming majority of terrestrially-derived kerogen despite bitumen analyses (by GC and GC-MS) often indicating a significant marine contribution of organic matter. It appears that semiopaque and opaque kerogen do not contribute significantly to any bitumen produced in a sample due to the inert nature of this organic matter, and consequently much of the terrestrially-sourced material is not recognised in biomarker investigations;

- The two Waipawa Black Shale samples are shown to comprise predominantly structured terrestrial or semi-opaque kerogen, which is inconsistent with the sometimes oil-prone nature and high hydrocarbon generative potential of this formation. Results of other studies, however, show that amorphous kerogen is also a significant and sometimes dominant component of the Waipawa Black Shale kerogen and may explain the high hydrocarbon generative potential of this unit;

- The Whangai and Flags formations show the greatest proportion of marine-derived (structured aqueous) kerogen (up to $45 \%$ ) of all the formations analysed;

- The Te Mai and Glenburn formations and the Torlesse Supergroup comprise up to 95\% semi-opaque and opaque kerogen which demonstrates their very low hydrocarbon generative potential; and

- The few TAI measurements taken indicate the samples have a maturity of below the onset of oil generation $\left(<0.6 \% \mathrm{R}_{\mathrm{o}}\right)$, consistent with the general findings of $\mathrm{T}_{\max }$ and the sterane and triterpane maturity biomarker ratios. 


\subsection{Vitrinite reflectance $\left(\mathbf{R}_{0}\right)$}

\subsubsection{Introduction}

Thermal maturation, through the progressive burial of sediments, results in irreversible changes in both the physical and chemical composition of kerogen (Senftle and Landis, 1991). These physico-chemical changes can be studied through vitrinite reflectance, and have been for decades in the coal industry in determining the maturation level of coals. More recently, the petroleum industry has used vitrinite reflectance as a method of determining the level of organic maturation of kerogen in sedimentary sequences. Vitrinite is the preferred kerogen maceral due to its widespread occurrence and abundance, large particle size and typically homogeneous appearance. Furthermore, its thermal range encompasses the entire sequence of organic maturation, from early diagenesis through to metamorphism (Senftle and Landis, 1991) (Table 7.6).

\begin{tabular}{||l|c||}
\hline Stages of oil generation & Vitrinite reflectance* $(\%)$ \\
\hline Immature & $<0.6$ \\
Early oil generation & 0.6 \\
Peak oil generation & 0.9 \\
End of oil generation & 1.35 \\
\hline \hline
\end{tabular}

*Depends on type of organic matter.

Table 7.6 Correlation of vitrinite reflectance values with main stages of oil generation (after Peters and Moldowan, 1993).

\section{Suppression of vitrinite reflectance}

Vitrinite reflectance is considered one of the most powerful tools available to petroleum organic geochemistry, yet there are major problems with its use (Price and Barker, 1985). Suppression of vitrinite reflectance is one such problem that has been observed in New Zealand coals (Newman and Newman, 1982); it has been thoroughly discussed by Price and Barker (1985). Suppression refers to vitrinite having a lower reflectance than expected for the level of thermal maturity determined by other methods. It appears that suppression occurs where measurements are made on hydrogen-rich vitrinite macerals. Hydrogen-rich vitrinite macerals may result from either vitrinite impregnated with bitumen from associated Types I or II (hydrogen-rich) kerogen, or diagenesis of vitrinite macerals under anoxic conditions (Price and Barker, 1985). However, not only is vitrinite reflectance suppressed, but the rate of thermal maturation of hydrogen-rich macerals is reduced. This occurs primarily as a result of the greater energy involved in breaking the greater proportion of carbon-carbon bonds present in hydrogen-rich 
macerals, compared with the greater proportion of carbon-oxygen bonds in oxygen-rich macerals (Price and Barker, 1985). Therefore, use of vitrinite reflectance values as an indicator of the various stages of petroleum generation is limited without knowledge of the composition of the kerogen (Price and Barker, 1985).

\section{Principles of vitrinite reflectance}

Vitrinite reflectance is probably the most common optical technique used to characterise organic matter (Senftle and Landis, 1991). Reflectance is the proportion of normally incident light (with a wavelength of $546 \mathrm{~nm}$ ) reflected by a flat, polished surface of the sample, and is measured as a percentage (which is usually under 4\%). The samples are prepared as whole-rock mounts, in which chips are embedded and polished in epoxy pellets. Generally a minimum of 20 measurements per sample are required, and the data is presented as histograms, with the mean and standard deviation recorded.

\subsubsection{Methods and results}

\section{Methods}

The feasibility of vitrinite reflectance analyses on the organic-poor, marine sediments that are predominant in the East Coast Basin was discussed with Dr. Jane Newman of Coal Research Ltd, University of Canterbury. This resulted in eleven samples being forwarded for analysis. A visit by the author to the Coal Research Institute was made for familiarisation with the equipment and methodology, although all vitrinite reflectance determinations were made by Dr. Newman.

\section{Results}

Of the eleven samples forwarded, only seven were analysed, the results of which are shown in Table 7.7. With the exception of the Waipawa Black Shale samples, the standard deviations recorded for each analysis are very large, and this makes the accuracy of results and the following interpretations very uncertain.

Waipawa Black Shale samples NE23 and NE31 have mean vitrinite reflectance values of $0.35 \%$ and $0.33 \%$ respectively, indicating maturity levels are low, and are considered fairly typical of Waipawa Black Shale samples (Jane Newman, pers. comm.). Although the maturity level is too low for significant suppression to have developed, the vitrinites in the Waipawa Black Shale are of a type that is likely to be suppressed at higher maturity levels (Jane Newman, pers. comm.). 


\begin{tabular}{|c|c|c|c|c|}
\hline Formation & $\begin{array}{c}\mathbf{R}_{\mathbf{0}} \\
(\%)\end{array}$ & $\begin{array}{l}\text { S.D. } \\
(\%)\end{array}$ & $\begin{array}{c}\text { Number of } \\
\text { measurements }\end{array}$ & $\begin{array}{l}\text { Maturity indicated } \\
\text { by biomarker ratios }\end{array}$ \\
\hline North Island stratigraphy & & & & \\
\hline Waipawa Black Shale & & & & \\
\hline NE23 & 0.35 & 0.071 & 30 & $<0.6 \% \mathrm{R}_{\mathrm{o}}$ \\
\hline NE31 & 0.33 & 0.080 & 20 & $<0.6 \% \mathrm{R}_{\mathrm{o}}$ \\
\hline $\begin{array}{l}\text { Whangai Formation } \\
\text { Rakauroa Member }\end{array}$ & & & & \\
\hline NE27 & 0.64 & 0.207 & 30 & $<0.6 \% \mathrm{R}_{0}$ \\
\hline $\begin{array}{l}\text { Te Mai Formation } \\
\text { NE51 }\end{array}$ & 0.70 & 0.184 & 30 & $<0.6 \% \mathrm{R}_{0}$ \\
\hline $\begin{array}{l}\text { Mangapokia Formation } \\
\text { NE64 }\end{array}$ & 0.70 & 0.174 & 30 & $<0.6 \% \mathrm{R}_{\mathrm{o}}$ \\
\hline South Island stratigraphy & & & & \\
\hline $\begin{array}{l}\text { Split Rock Formation } \\
\text { Wharfe Sandstone Member }\end{array}$ & & & & \\
\hline $\begin{array}{l}\text { NE91 } \\
\text { Torlesse Supergroup }\end{array}$ & 0.70 & 0.145 & 20 & $\sim 0.6 \% \mathrm{R}_{\mathrm{o}}$ \\
\hline NE75 & 0.76 & 0.244 & 26 & $\sim 0.6 \% \mathrm{R}_{0}$ \\
\hline
\end{tabular}

Interval spacing was $0.01 \%$; S.D. $=$ standard deviation.

Table 7.7 Results of vitrinite reflectance $\left(\mathbf{R}_{0}\right)$ analyses compared with maturity biomarker ratios.

The Whangai Formation sample (NE27) is oil-stained (Knights Stream oil), which should have the effect of suppressing reflectance. Vitrinite reflectance for this sample is $0.64 \%$, yet biomarker ratios for an adjacent, non-stained sample of the same formation, indicate a very low level of thermal maturation (considerably below onset of oil generation). Not only is suppression not evident, but the level of maturity is overestimated by vitrinite reflectance. The Te Mai Formation sample (NE51) has a vitrinite reflectance mode at about $0.6 \% \mathrm{R}_{\mathrm{o}}$ which, in the case of samples with widespread data such as this, may be a more accurate measure of thermal maturity. The Mangapokia Formation sample (NE64) recorded a vitrinite reflectance value of $0.7 \%$, considerably above that determined from biomarker ratios, which indicate a maturity below the onset of oil generation. The Split Rock Formation sample (NE91) comprises a quantity of recycled vitrinite with $>1.0 \% \mathrm{R}_{\mathrm{o}}$ which was omitted from measurement, yet still recorded a maturity of $0.7 \% \mathrm{R}_{\mathrm{o}}$. Biomarker ratios for this sample indicate a lower maturity, approaching the onset of oil generation $\left(\sim 0.6 \% \mathrm{R}_{\mathrm{o}}\right)$. The Torlesse Supergroup sample (NE75) recorded a maturity of $0.76 \% \mathrm{R}_{\mathrm{o}}$, considerably higher than the $\sim 0.6 \% \mathrm{R}_{\mathrm{o}}$ determined from biomarker ratios.

\subsubsection{Discussion}

Rogers (1995) also forwarded samples to Dr. Newman for vitrinite reflectance determinations. Suppression of vitrinite reflectance (by 50\%) in a Waipawa Black Shale 
sample was demonstrated in a comparison with maturity biomarker ratios. Rogers (1995) concluded that an accurate measurement of the thermal maturity of the Waipawa Black Shale is, therefore, not possible by this method, especially at higher maturities (Jane Newman, pers. comm.). The sample analysed by Rogers comprised $35 \%$ amorphous kerogen, $40 \%$ biodegraded terrestrial kerogen and $25 \%$ structured terrestrial kerogen, which compares with $90 \%$ structured terrestrial kerogen and $10 \%$ semi-opaque kerogen in NE23. At greater levels of maturity, suppression of vitrinite reflectance in NE23 may be expected to be less than those samples containing a greater proportion of hydrogenrich (amorphous) kerogen. The findings of Rogers (1995) are inconsistent with those of Zumberge (1990) who analysed 18 Waipawa Black Shale samples with results $\left(0.42-0.57 \% \mathrm{R}_{\mathrm{o}}\right)$ considered high compared with corresponding biomarker and $\mathrm{T}_{\max }$ values. It was thought that weathering may have affected the vitrinite reflectance readings.

If suppression of vitrinite reflectance occurs in Waipawa Black Shale greater temperatures would be required before it reaches the various stages of oil generation, and this appears to contradict reports of early oil generation associated with this formation [e.g. Frances, 1995a; Rogers, 1995; Killops et al., 1996; this study (Section 2.2.2)]. Additional analyses, such as VKA and Rock-Eval pyrolysis that can provide information on kerogen composition, need to be conducted to determine whether suppression of vitrinite reflectance is likely to be occurring as this may be crucial in determining hydrocarbon kitchen areas within the East Coast Basin. A new technique combining reflectance and quantitative vitrinite fluorescence (VRF) has recently been developed which allows differentiation of Types III and IV kerogen into suppressed vitrinite, normal vitrinite, recycled vitrinite and inertinite (Newman, 1997), and this may prove very useful in future source rock investigations.

\subsubsection{Conclusions}

- Maturity values determined by vitrinite reflectance are, in general, not consistent with those determined by biomarker ratios although, with only seven measurements taken, the findings are not conclusive; and

- Suppression of vitrinite reflectance in the Waipawa Black Shale samples was not shown in the present study, although it appears the vitrinites are of a type that is likely to show suppression at higher maturity levels. 


\subsection{X-ray fluorescence (XRF) spectroscopy}

\subsubsection{Introduction}

The understanding of depositional environments, including paleo-oxygenation conditions of bottom-water, is a fundamental aim in source rock investigations. Water-column oxygenation not only exerts a major control on the abundance of organic matter preserved in sediments, but also controls the concentrations of some trace metals and minor elements, such as sulphur. Therefore an investigation of the trace and minor element compositions of ancient sediments may reveal information regarding their depositional environment and also their suitability as petroleum source rocks (Jones and Manning, 1994).

Whole-rock trace element analyses were conducted by X-ray fluorescence (XRF) spectroscopy from which a number of geochemical indices, including $\% \mathrm{~S}, \mathrm{~S} / \mathrm{C}, \mathrm{U} / \mathrm{Th}$, $\mathrm{V} / \mathrm{Cr}$ and $\mathrm{Ni} / \mathrm{V}$, are used to investigate the depositional environment of possible source rocks of southern East Coast Basin.

\subsubsection{Geochemical indices}

Ideal paleo-oxygenation indices should be sensitive to bottom-water oxygen concentration alone, and therefore independent of physical properties of the host sediment (such as grainsize) and other factors such as post-depositional burial history (Jones and Manning, 1994). A number of these paleo-oxygenation indices have been described in the literature, such as C/S, DOP (degree of pyritisation), U/Th, authigenic uranium, $\mathrm{V} / \mathrm{Cr}, \mathrm{Ni} / \mathrm{Co}, \mathrm{Ni} / \mathrm{V}$ and $(\mathrm{Cu}+\mathrm{Mo}) / \mathrm{Zn}$. A comparison of these eight geochemical indices, in an interpretation of paleoredox conditions of Jurassic mudstones from the North Sea and onshore England, concluded that DOP, U/Th, authigenic uranium, V/Cr and $\mathrm{Ni} / \mathrm{Co}$ are the most reliable indices while $\mathrm{C} / \mathrm{S}, \mathrm{Ni} / \mathrm{V}$ and $(\mathrm{Cu}+\mathrm{Mo}) / \mathrm{Zn}$ may be affected by other environmental factors and therefore unreliable (Jones and Manning, 1994). Despite these recent findings both the $\mathrm{C} / \mathrm{S}$ and Ni/V ratios have been included in the present study to provide a wider range of geochemical indices to help determine the depositional conditions of southern East Coast Basin sediments.

A wide range of terms have been used in the literature to describe bottom-water oxygenation and the terminology of Tyson and Pearson (1991) (see Table 7.8) is used here. Bottom-water is defined as being within one metre of the sediment surface. 


\begin{tabular}{||l|c||}
\hline \hline Term & $\begin{array}{c}\text { Oxygen concentration } \\
(\mathbf{m l} / \mathbf{l})\end{array}$ \\
\hline & \\
Oxic & $8.0-2.0$ \\
Dysoxic & $2.0-0.2$ \\
Suboxic & $0.2-0.0$ \\
Anoxic & $0.0\left(\mathrm{H}_{2} \mathrm{~S}\right)$ \\
\hline \hline
\end{tabular}

Table 7.8 Definitions of bottom-water oxygenation (from Tyson and Pearson, 1991).

\section{$\% \mathrm{~S}$}

Although some sulphur may be derived from the original organic matter in sediments most sulphur is produced by sulphate-reducing bacteria, usually in highly reducing to anoxic marine sediments (Peters and Moldowan, 1993). Hydrogen sulphide produced by bacteria reacts with any available iron to form pyrite. In most clastic sediments there is adequate iron to combine with sulphur but in some sediments (especially carbonates), where the iron content is low, excess sulphur is incorporated into organic matter or lost into the water column. Sulphur bound to kerogen may then be passed on to any hydrocarbons generated (Perrodon, 1988), and kerogen rich in sulphur tend to produce sulphur-rich oils, while low sulphur kerogen gives rise to sulphur-nonr nils (fransch and

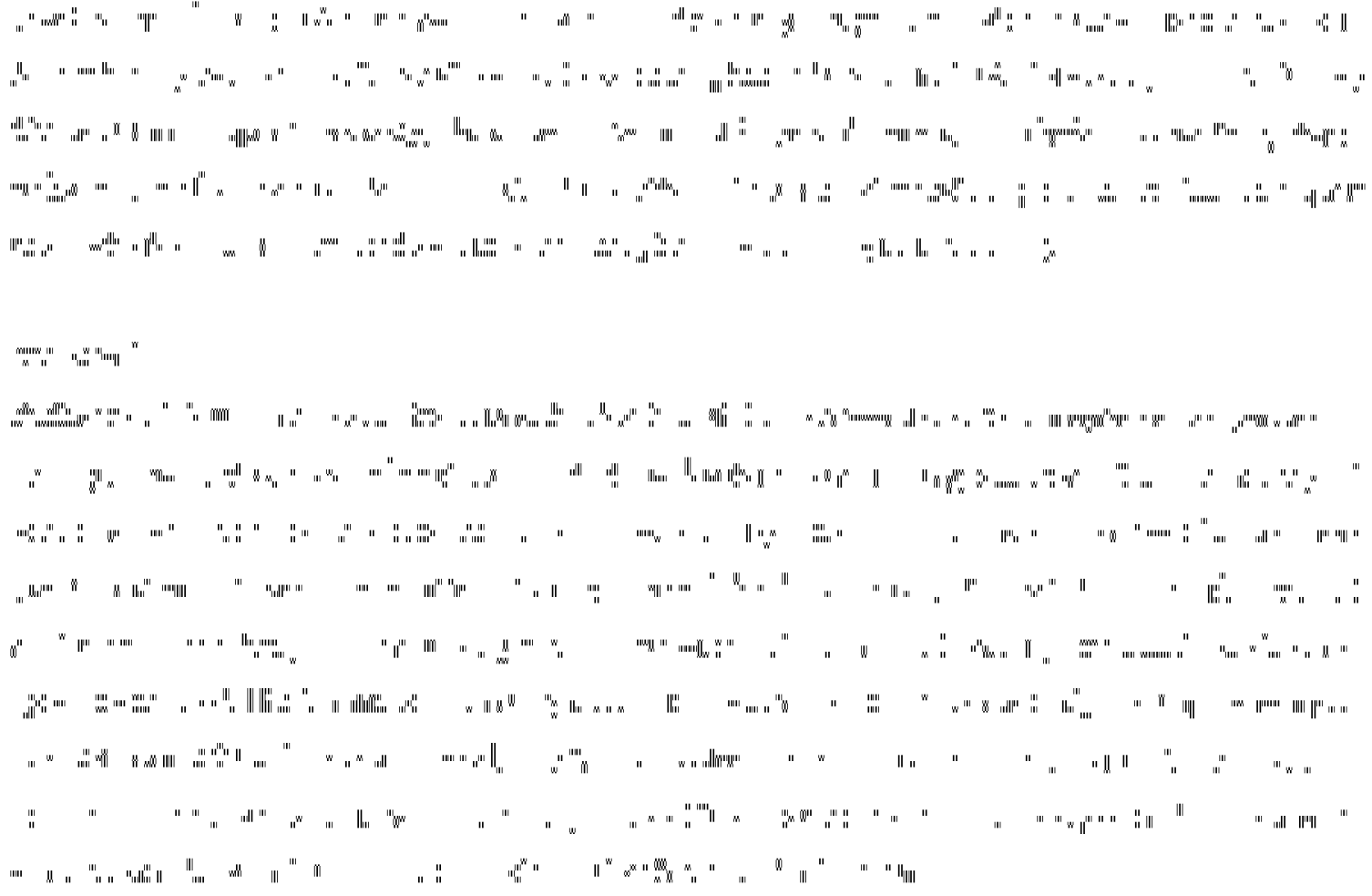




\section{$\mathrm{S} / \mathrm{C}$}

Sulphur vs organic carbon can be used to infer the environment of deposition (Leventhal, 1983 ; 1993). Figure 7.2 shows a cross-plot of sulphur vs organic carbon with three fields representing different depositional settings. 'Anoxic' environments (free $\mathrm{H}_{2} \mathrm{~S}$ in system) are characterised by high $\mathrm{S} / \mathrm{C}$ ratios and a positive intercept on the $\mathrm{S}$ axis at approximately $1 \%$. 'Normal marine' conditions are characterised by moderate S/C ratios with an intercept close to $0 \%$ on the $\mathrm{S}$ axis, while 'nonmarine' environments are distinguished by low $\mathrm{S} / \mathrm{C}$ ratios that intercept at the origin.

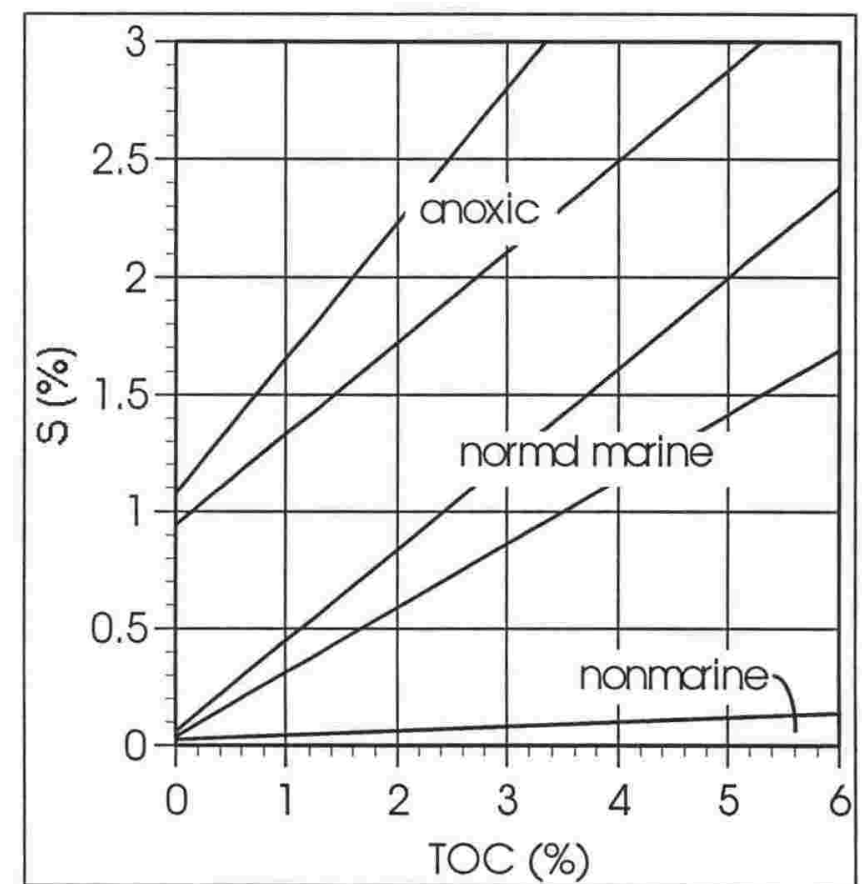

Figure 7.2 Sulphur vs organic carbon plot, showing three different environments of deposition (after Leventhal, 1993).

Problems associated with the interpretation of these plots are caused by high organic carbon or a lack of sulphate or iron (Leventhal, 1993). Additionally, the S/C ratio alters with increasing burial, with carbon loss due to the decomposition of organic matter (Raiswell and Berner, 1987; Jones and Manning, 1994).

\section{$\mathrm{Ni} / \mathrm{V}$}

Nickel and vanadium are supplied to sediments from the overlying water column where both are fixed to organic matter by forming porphyrin complexes (Jones and Manning, 1994), although nickel can also occur in pyrite (Leventhal, 1993). The Ni/V ratio decreases as the depositional environment becomes more reducing (Lewan, 1984). Marine source rocks have high concentrations of nickel and vanadium and low $(<1)$ $\mathrm{Ni} / \mathrm{V}$ ratios while lacustrine source rocks have moderate concentrations and high $(>2)$ 
ratios (see Table 7.9). Nickel and vanadium appear in low concentrations in nonmarine sediments (Barwise, 1990).

\section{U/Th}

Uranium and thorium are often associated with heavy minerals or clays in fine-grained sediments (Jones and Manning, 1994), although uranium is also associated with organic matter (Leventhal, 1993). While thorium is relatively inert, uranium is partially soluble under oxidising conditions but is insoluble under reducing conditions. The U/Th ratio is therefore higher in sediments deposited under anoxic conditions. Jones and Manning (1994) define a U/Th ratio $>1.25$ to indicate suboxic to anoxic environments, $0.75-1.25$ dysoxic and a ratio $<0.75$ as indicative of oxic environments (see Table 7.9).

\section{$\mathrm{V} / \mathrm{Cr}$}

Vanadium is mainly concentrated under reducing conditions in organic matter but can be contained in detrital minerals. Chromium often substitutes for aluminium in clays but is also found as chromite. $\mathrm{V} / \mathrm{Cr}$ ratios $>2$ are thought to represent anoxic conditions, while values $<2$ are indicative of more oxidising conditions (Ernst, 1970 as cited in Jones and Manning, 1994). Jones and Manning (1994) however concluded that $\mathrm{V} / \mathrm{Cr}$ ratios $>4.25$ were indicative of suboxic to anoxic conditions and values $<2.00$ indicate oxic conditions (see Table 7.9). It appears the $\mathrm{V} / \mathrm{Cr}$ ratio is affected by grain size, with a decrease in the V/Cr ratio for coarser sediments (Dill et al., 1988).

\begin{tabular}{||l|c|c|c|c|l|c||}
\hline Term & \%S & \% TOC1 & S/C 2 & V/Cr ${ }^{3}$ & Ni/V4 & $\mathrm{U}^{4} \mathrm{Th}^{3}$ \\
\hline Oxic & & & & & & \\
Dysoxic & (low) & $0.2-0.4$ & (low) & $<2.00$ & $>2$ (lacustrine) & $<0.75$ \\
Suboxic & $\downarrow$ & $\downarrow$ & $\mid$ & $2.00-4.25$ & $<1$ (marine) & $0.75-1.25$ \\
Anoxic & $\downarrow$ & $>1$ & $\downarrow$ & $>4.25$ & & $>1.25$ \\
\hline
\end{tabular}

1'Demaison and Moore (1988); ${ }^{2}$ Leventhal (1993); ${ }^{3 J}$ Jones and Manning (1994); ${ }^{4}$ Barwise (1990).

Table 7.9 Correlation of paleo-oxygenation indices.

\subsubsection{Methods}

Whole-rock trace element analyses by XRF spectroscopy were routinely conducted on all rock samples. Whole-rock fractions were crushed by hydraulic press and then finely powdered in a tungsten carbide mill (see Section 3.1.3 for details). The powdered samples were then pressed into $\mathrm{KBr}$ pellets. Samples were analysed for $\mathrm{S}, \mathrm{Sc}, \mathrm{V}, \mathrm{Cr}, \mathrm{Ba}$, $\mathrm{La}, \mathrm{Ce}, \mathrm{Ni}, \mathrm{Cu}, \mathrm{Zn}, \mathrm{Zr}, \mathrm{Nb}, \mathrm{Ga}, \mathrm{Pb}, \mathrm{Rb}, \mathrm{Sr}, \mathrm{Th}, \mathrm{U}, \mathrm{Y}$ and As. Analyses were conducted 


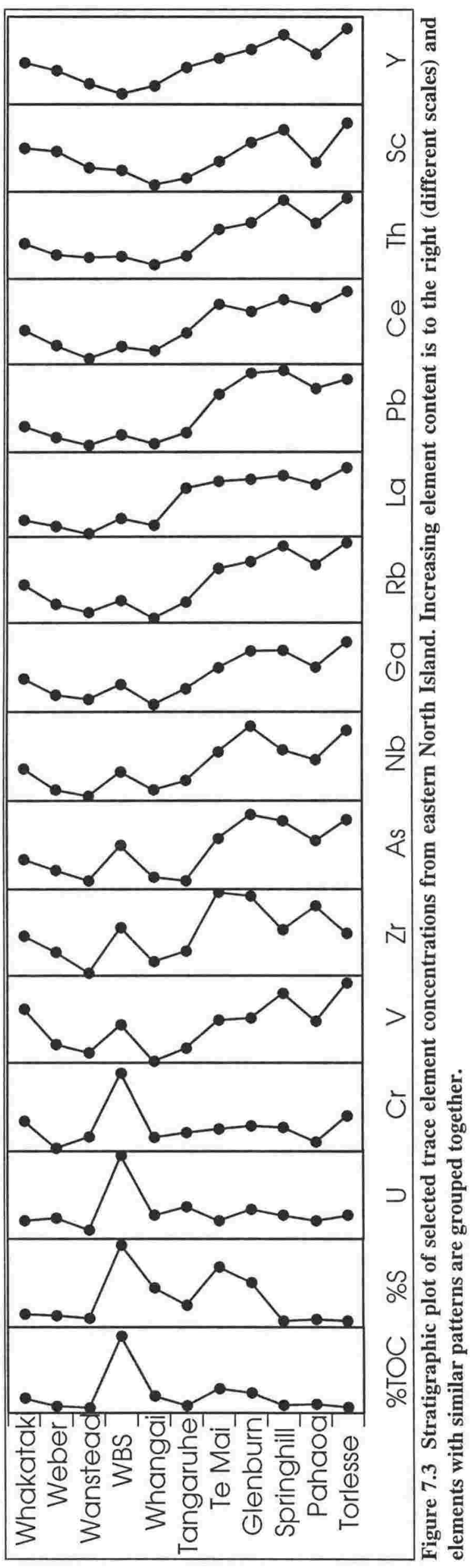


on a Philips PW1404 Sequential X-ray Spectrometer in the Analytical Facility of Victoria University of Wellington.

\subsubsection{Results}

Table 7.10 includes a summary of the paleo-oxygenation indices for each formation, while full results of XRF spectroscopy and derived paleo-oxygenation indices appear in Appendix 8.

The inorganic geochemistry of sedimentary rocks is influenced by a host of factors such as climate, tectonism (and volcanism), parent rock composition, sedimentation rate, grain size, biological aspects, diagenesis and surficial weathering (Moore, 1988b). Figure 7.3 shows a stratigraphic plot of selected trace element concentrations from southern East Coast Basin. There appears to be a trend of decreasing quantities of trace elements from Lower Cretaceous units through to the Eocene Wanstead Formation, with a distinctive spike at Waipawa Black Shale. Trace element concentrations then progressively increase through the Oligocene Weber Formation and Miocene Whakataki formations. On a simplistic level, this pattern follows the depositional history of the East Coast Basin (see Chapter 2) with Early Cretaceous sediments deposited during and immediately after the Rangitata orogeny, a period of rapid uplift and erosion and hence sediment supply. This was followed by a Late Cretaceous to Tertiary marine transgression which eventually culminated in a slowly eroding, low relief landmass with reduced sediment supply and hence diminished source of trace elements. With the onset of convergence and subduction during the Oligocene and Miocene, greater rates of uplift and erosion and cause an increase in sediment supply. Not all trace element concentrations, however, are related to sediment supply; seawater is a source for moderate quantities of trace metals in sediments, providing certain conditions prevail (Leventhal, 1993). The increased trace metal content in the Waipawa Black Shale is not unexpected as, worldwide, black shales tend to have increased concentrations of metals as a result of increased sites for bonding through high clay, sulphur and organic matter content (Leventhal, 1993). Although the Waipawa Black Shale is not a true shale (it is classed as a siltstone) and has a very high silica content $(\sim 75 \%)$ (Moore, 1989), the increased concentrations of trace metals are probably due to elevated TOC and sulphur contents.

Trace metals are usually abundant in fine-grained sediments containing clays and are low in clay-poor carbonate-rich sediments and this pattern is partially recognised in the average trace element content of formations of southern East Coast Basin. The Amuri Limestone and Mungaroa Member of the Awhea Formation are notably depleted in trace 


\begin{tabular}{|c|c|c|c|c|c|c|}
\hline Formation & $\% \mathrm{~S}$ & \% TOC & $\mathrm{S} / \mathrm{C}$ & $\mathrm{V} / \mathrm{Cr}$ & $\mathrm{Ni} / \mathrm{V}$ & U/Th \\
\hline \multicolumn{7}{|l|}{ North Island stratigraphy } \\
\hline Miocene coal (1) & 1.22 & 4.70 & 0.26 & 2.35 & 0.13 & 0.21 \\
\hline \multirow[t]{2}{*}{ Whakataki Formation (2) } & $\bullet 0.15$ & $\bullet 0.52$ & - 0.34 & - 1.84 & $\bullet 0.23$ & • 0.29 \\
\hline & $\Delta 0.01-0.28$ & $\Delta 0.44-0.60$ & $\Delta 0.22-0.46$ & $\Delta 1.60-2.07$ & $\Delta 0.18-0.27$ & $\Delta 0.27-0.30$ \\
\hline \multirow[t]{2}{*}{ Weber Formation (2) } & $\bullet 0.13$ & $\bullet 0.22$ & $\bullet 0.81$ & $\cdot 2.18$ & $\bullet 0.25$ & $\bullet 0.73$ \\
\hline & $\Delta 0.01-0.24$ & $\Delta 0.15-0.29$ & $\Delta 0.05-1.57$ & $\Delta 1.94-2.41$ & $\Delta 0.21-0.28$ & $\Delta 0.20-1.26$ \\
\hline \multirow[t]{2}{*}{ Wanstead Formation (5) } & $\bullet 0.10$ & $\bullet 0.17$ & $\bullet 0.86$ & $\cdot 1.63$ & $\bullet 0.25$ & $\bullet 0.36$ \\
\hline & $\Delta 0.01-0.33$ & $\Delta 0.03-0.24$ & $\Delta 0.04-2.47$ & $\Delta 1,20-2.04$ & $\Delta 0.15-0.32$ & $\Delta 0.14-0.49$ \\
\hline \multirow[t]{2}{*}{ Waipawa Black Shale (17) } & $\bullet 0.93$ & $\cdot 2.67$ & $\bullet 0.43$ & $\cdot 1.00$ & $\bullet 0.21$ & $\bullet 0.67$ \\
\hline & $\Delta 0.02-1.90$ & $\Delta 0.28-5.69$ & $\Delta 0.10-1.33$ & $\Delta 0.63-1.67$ & $\Delta 0.05-0.53$ & $\Delta 0.27-1.40$ \\
\hline \multicolumn{7}{|l|}{ [Tora Block stratigraphy] } \\
\hline [Kandahar Formation (1)] & 0.01 & 0.19 & 0.05 & 1.39 & 0.29 & 0.17 \\
\hline [Awhea Formation (1)] & 0.01 & 0.14 & 0.07 & 1.18 & 0.22 & 0.43 \\
\hline [Mungaroa Member (1)] & 0.03 & 0.15 & 0.19 & 1.81 & 0.66 & 0.50 \\
\hline \multirow[t]{2}{*}{ [Manurewa Formation (2)] } & $\cdot 0.22$ & $\bullet 0.15$ & - 1.49 & - 1.44 & $\bullet 0.19$ & $\cdot 0.34$ \\
\hline & $\Delta 0.04-0.40$ & $\Delta 0.14-0.15$ & $\Delta 0.31-2.66$ & $\Delta 1.38-1.50$ & $\Delta 0.18-0.19$ & $\Delta 0.29-0.38$ \\
\hline \multicolumn{7}{|l|}{ Whangai Formation } \\
\hline \multirow[t]{2}{*}{ Te Uri Member (2) } & $\bullet 0.27$ & $\bullet 0.31$ & $\bullet 0.87$ & $\cdot 1.60$ & $\bullet 0.25$ & -0.62 \\
\hline & $\Delta 0.17-0.38$ & $\Delta 0.28-0.33$ & $\Delta 0.59-1.14$ & $\Delta 1.52-1.68$ & $\Delta 0.19-0.30$ & $\Delta 0.56-0.67$ \\
\hline \multirow[t]{2}{*}{ Porangahau Member (4) } & - 0.03 & $\bullet 0.17$ & $\bullet 0.31$ & $\bullet 1.56$ & $\bullet 0.64$ & $\cdot 0.41$ \\
\hline & $\Delta 0.01-0.06$ & $\Delta 0.03-0.32$ & $\Delta 0.09-0.70$ & $\Delta 1.37-1.86$ & $\Delta 0.29-1.38$ & $\Delta 0.33-0.51$ \\
\hline \multirow[t]{2}{*}{ Upper Calcareous Member (7) } & $\bullet 0.58$ & $\bullet 0.62$ & $\cdot 0.98$ & - 1.44 & $\bullet 0.32$ & - 0.57 \\
\hline & $\Delta 0.36-0.98$ & $\Delta 0.36-1.19$ & $\Delta 0.75-1.24$ & $\Delta 0.92-1.87$ & $\Delta 0.28-0.36$ & $\Delta 0.35-0.83$ \\
\hline \multirow[t]{2}{*}{ Rakauroa Member (5) } & $\cdot 0.47$ & • 0.62 & $\cdot 0.93$ & $\cdot 1.71$ & $\bullet 0.27$ & - 0.49 \\
\hline & $\Delta 0.02-0.90$ & $\Delta 0.09-1.19$ & $\Delta 0.18-1.44$ & $\Delta 1.51-1.90$ & $\Delta 0.18-0.36$ & $\Delta 0.24-0.62$ \\
\hline \multirow[t]{2}{*}{ Tangaruhe Formation (2) } & $\bullet 0.25$ & $\bullet 0.36$ & $\bullet 0.63$ & $\cdot 1.57$ & $\bullet 0.19$ & $\bullet 0.44$ \\
\hline & $\Delta 0.02-0.47$ & $\Delta 0.32-0.40$ & $\Delta 0.08-1.17$ & $\Delta 1.50-1.64$ & $\Delta 0.12-0.26$ & $\Delta 0.40-0.47$ \\
\hline \multirow[t]{2}{*}{ Te Mai Formation (5) } & $\bullet 0.68$ & $\bullet 0.85$ & $\cdot 1.57$ & $\bullet 1.91$ & $\bullet 0.27$ & - 0.25 \\
\hline & $\Delta 0.08-1.58$ & $\Delta 0.19-1.52$ & $\Delta 0.09-4.89$ & $\Delta 1.24-2.39$ & $\Delta 0.10-0.56$ & $\Delta 0.23-0.28$ \\
\hline \multirow[t]{2}{*}{ Glenburn Formation (7) } & $\bullet 0.50$ & $\bullet 0.72$ & - 0.59 & $\bullet 1.81$ & $\bullet 0.27$ & $\bullet 0.26$ \\
\hline & $\Delta 0.01-1.08$ & $\Delta 0.09-1.30$ & $\Delta 0.06-1.24$ & $\Delta 1.64-2.00$ & $\Delta 0.22-0.32$ & $\Delta 0.21-0.33$ \\
\hline \multirow[t]{2}{*}{ Springhill Formation (2) } & $\bullet 0.07$ & $\bullet 0.26$ & $\bullet 0.28$ & $\cdot 2.21$ & $\bullet 0.21$ & $\bullet 0.19$ \\
\hline & $\Delta 0.03-0.11$ & $\Delta 0.24-0.27$ & $\Delta 0.14-0.42$ & $\Delta 2.09-2.32$ & $\Delta 0.21$ & $\Delta 0.17-0.20$ \\
\hline Gentle Annie Formation (1) & 0.01 & 0.06 & 0.17 & 1.81 & 0.19 & 0.47 \\
\hline
\end{tabular}

- mean; $\Delta$ range.

Table 7.10 Summary of paleo-oxygenation indices for southern East Coast Basin formations. 
elements, with the exception of barium and strontium which are associated with calcium (and hence carbonate-rich sediments).

\section{$\% \mathrm{~S}$}

Fifteen samples have $>1.0 \% \mathrm{~S}$, nine are from the Waipawa Black Shale and one each from the Miocene coal, undifferentiated Whangai, Te Mai and Glenburn formations, Mata Series and Claverley Sandstone. Another 24 samples record between 0.5-1.0\% S, and these are mainly from the Waipawa Black Shale, Whangai (Upper Calcareous, Rakauroa and undifferentiated) and Glenburn formations, Waima Siltstone, Mata Series and Conway Siltstone. These formations are interpreted to have been deposited under relatively reducing (low oxygen) conditions. In contrast, 39 samples have $<0.05 \% \mathrm{~S}$, and these are predominantly from the Weber, Wanstead, Whangai (Porangahau Member) and Tangaruhe formations, Pahaoa Group, Whatarangi Formation, Amuri Limestone, Mata Series, and Torlesse Supergroup. These formations are interpreted to have been deposited under relatively oxic conditions. The Mata Series samples exhibit considerable variability in sulphur content, and the low sulphur content in some of these samples and other carbonate-rich formations may result from low iron and organic carbon, to which sulphur readily combines.

\section{\% TOC (see Section 4.1)}

Twenty one samples have $>1 \%$ TOC, with 13 from the Waipawa Black Shale and the remainder from the Miocene coal, Whangai (Upper Calcareous, Rakauroa and undifferentiated), Te Mai and Glenburn formations and Pahaoa Group. These formations are considered to have been deposited under reduced oxygen (dysoxic-anoxic) conditions.

Another 23 samples record between $0.5-1.0 \%$ TOC, and are from the Whakataki Formation, Waipawa Black Shale, Whangai (Upper Calcareous, Rakauroa, undifferentiated and. South Island), Te Mai and Glenburn formations, Mata Series, Flags Formation and Conway Siltstone. Seventy three samples recorded $<0.4 \%$ TOC, and these are from the Weber, Wanstead, Kandahar, Awhea (including Mungaroa Member), Manurewa, Whangai (Te Uri and Porangahau members), Tangaruhe, Springhill and Gentle Annie formations, Pahaoa Group, Whatarangi Formation, Torlesse Supergroup (N.I.), Woodside Formation, Amuri Limestone, Mata Series, Claverley Sandstone, Burnt Creek and Split Rock formations, and Torlesse Supergroup (S.I.). These formations are considered to have been deposited under oxic conditions. 


\begin{tabular}{|c|c|c|c|c|c|c|}
\hline Formation & $\% \mathrm{~S}$ & $\%$ TOC & $\mathrm{S} / \mathrm{C}$ & $\mathrm{V} / \mathrm{Cr}$ & $\mathrm{Ni} / \mathrm{V}$ & $\mathrm{U} / \mathrm{Th}$ \\
\hline Pahaoa Group (12) & $\begin{array}{c}\bullet 0.09 \\
\Delta 0.02-0.42\end{array}$ & $\begin{array}{c}\cdot 0.30 \\
\Delta 0.05-1.54\end{array}$ & $\begin{array}{c}\cdot 0.35 \\
\Delta 0.24-0.52\end{array}$ & $\begin{array}{c}\cdot 2.47 \\
\Delta 21.90-3.80\end{array}$ & $\begin{array}{c}\cdot 0.18 \\
\Delta 0.12-0.22\end{array}$ & $\begin{array}{c}\cdot 0.23 \\
\Delta 0.16-0.36\end{array}$ \\
\hline Whatarangi Formation (1) & 0.04 & 0.19 & 0.21 & 2.13 & 0.16 & 0.14 \\
\hline Torlesse Supergroup (1) & 0.07 & 0.19 & 0.34 & 1.98 & 0.22 & 0.19 \\
\hline South Island stratigraphy & & & & & & \\
\hline Waima Formation (1) & 0.53 & 0.41 & 1.28 & 1.67 & 0.35 & 0.64 \\
\hline Woodside Formation (1) & 0.03 & 0.06 & 0.45 & 1.50 & 0.27 & 0.07 \\
\hline Amuri Limestone (10) & $\begin{array}{c}\bullet 0.06 \\
\Delta 0.02-0.21\end{array}$ & $\begin{array}{c}\cdot 0.09 \\
\Delta 0.03-0.15\end{array}$ & $\begin{array}{c}\bullet 0.81 \\
\Delta 0.26-2.36\end{array}$ & $\begin{array}{c}\cdot 1.59 \\
\Delta 1.34-1.97\end{array}$ & $\begin{array}{c}\bullet 0.69 \\
\Delta 0.45-1.14\end{array}$ & $\begin{array}{c}\bullet 0.24 \\
\Delta-0.12-0.67\end{array}$ \\
\hline Whangai Formation (4) & $\begin{array}{c}\cdot 0.49 \\
\Delta 0.20-0.69\end{array}$ & $\begin{array}{c}\cdot 0.47 \\
\Delta 0.40-0.51\end{array}$ & $\begin{array}{c}\cdot 1.16 \\
\Delta 0.73-1.44\end{array}$ & $\begin{array}{c}\cdot 1.74 \\
\Delta 1.62-1.96\end{array}$ & $\begin{array}{c}\bullet 0.30 \\
\Delta 0.20-0.44\end{array}$ & $\begin{array}{c}\cdot 0.38 \\
\Delta 0.17-0.52\end{array}$ \\
\hline Mata Series (8) & $\begin{array}{c}\cdot 0.25 \\
\Delta 0.01-1.37\end{array}$ & $\begin{array}{c}\bullet 0.31 \\
\Delta 0.03-0.96\end{array}$ & $\begin{array}{c}\cdot 0.65 \\
\Delta 0.02-1.99\end{array}$ & $\begin{array}{c}\cdot 1.89 \\
\Delta 1.65-2.28\end{array}$ & $\begin{array}{c}\bullet 0.34 \\
\Delta 0.06-0.92\end{array}$ & $\begin{array}{c}\cdot 0.47 \\
\Delta 0.19-1.38\end{array}$ \\
\hline Flags Formation (1) & 0.09 & 0.52 & 0.17 & 1.57 & 0.22 & 0.31 \\
\hline Claverley Sandstone (1) & 1.32 & 0.39 & 0.98 & 1.86 & 0.10 & 0.44 \\
\hline Conway Siltstone (1) & 0.54 & 0.55 & 3.39 & 1.62 & 0.07 & 0.30 \\
\hline Burnt Creek Formation (2) & $\begin{array}{c}\cdot 0.10 \\
\Delta 0.01-0.19\end{array}$ & $\begin{array}{c}\bullet 0.33 \\
\Delta 0.25-0.41\end{array}$ & $\begin{array}{c}\cdot 0.25 \\
\Delta 0.03-0.47\end{array}$ & $\begin{array}{c}\cdot 1.70 \\
\Delta 1.60-1.79\end{array}$ & $\begin{array}{c}\cdot 0.28 \\
\Delta 0.26-0.30\end{array}$ & $\begin{array}{c}\bullet 0.21 \\
\Delta 0.19-0.22\end{array}$ \\
\hline Split Rock Formation (5) & $\begin{array}{c}\cdot 0.08 \\
\Delta 0.04-0.12\end{array}$ & $\begin{array}{c}\bullet 0.36 \\
\Delta 0.29-0.41\end{array}$ & $\begin{array}{c}\bullet 0.23 \\
\Delta 0.09-0.41\end{array}$ & $\begin{array}{c}\cdot 1.81 \\
\Delta 1.50-2.01\end{array}$ & $\begin{array}{c}\cdot 0.23 \\
\Delta 0.19-0.28\end{array}$ & $\begin{array}{c}\cdot 0.22 \\
\Delta 0.19-0.27\end{array}$ \\
\hline Torlesse Supergroup (7) & $\begin{array}{c}\cdot 0.07 \\
\Delta 0.01-0.15\end{array}$ & $\begin{array}{c}\bullet 0.35 \\
\Delta 0.26-0.45 \\
\end{array}$ & $\begin{array}{c}\cdot 0.18 \\
\Delta 0.03-0.37 \\
\end{array}$ & $\begin{array}{c}\cdot 2.06 \\
\Delta 1.85-2.26\end{array}$ & $\begin{array}{c}\bullet 0.21 \\
\Delta 0.18-0.23 \\
\end{array}$ & $\begin{array}{c}\cdot 0.28 \\
\Delta 0.21-0.55 \\
\end{array}$ \\
\hline
\end{tabular}

- mean; $\Delta$ range.

Table 7.10 cont. Summary of paleo-oxygenation indices for southern East Coast Basin formations. 
$\mathrm{S} / \mathrm{C}$

The sulphur vs organic carbon plot (Figure 7.4) shows a considerable scatter of data. Samples that fall within the 'anoxic' field are from the Waipawa Black Shale, Te Mai Formation, Mata Series and Claverley Sandstone. The Waipawa Black Shale and Te Mai Formation samples, however, range from 'anoxic' to almost 'nonmarine' fields. A large cluster of data occurs near the origin with low sulphur and organic carbon including the Weber, Wanstead, Kandahar, Awhea (including Mungaroa Member), Whangai (Porangahau Member), Tangaruhe and Springhill formations, Pahaoa Group, Torlesse Supergroup (N.I.), Woodside Formation, Amuri Limestone, Flags, Burnt Creek and Split Rock formations, and Torlesse Supergroup (S.I.). These formations are considered to have been deposited largely under oxic conditions. Samples from the Whangai (Upper Calcareous, Rakauroa and undifferentiated), Te Mai and Glenburn formations, Waima Siltstone and Mata Series make up the intermediate data points that extend from the 'normal marine' toward the 'anoxic' field, but remain below $0.8 \% \mathrm{~S}$ and $1 \%$ TOC. These formations are interpreted to have been deposited under mildly reducing conditions.

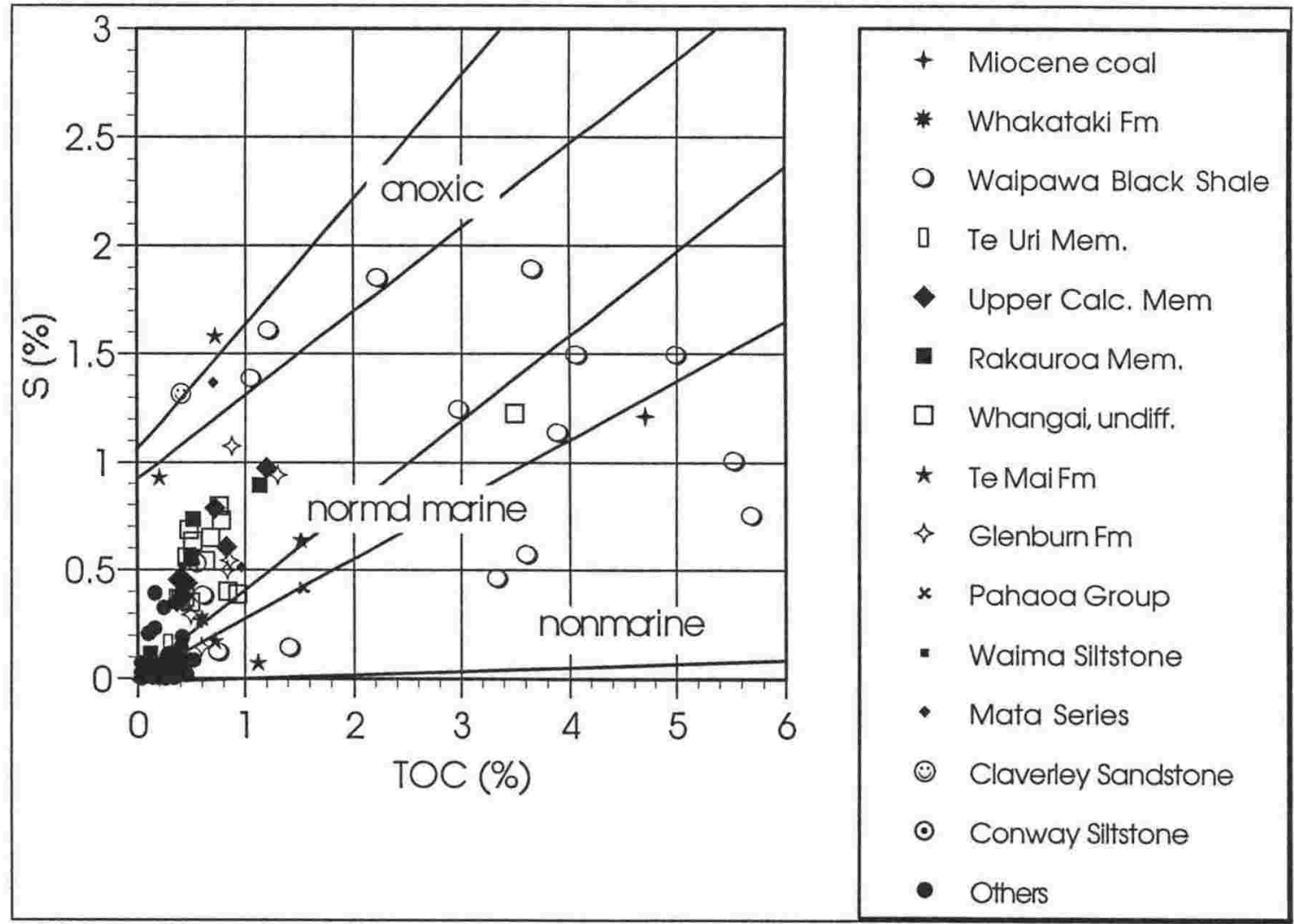

Figure 7.4 Sulphur vs organic carbon plot.

\section{$\mathrm{Ni} / \mathrm{V}$}

Samples of southern East Coast Basin formations have Ni/V ratios ranging from 0.05 1.38 , indicating an overwhelming predominance of marine sediments. Samples with low $(<0.15)$ ratios, indicative of relatively reducing conditions, are mainly from the Miocene 
coal, Wanstead Formation, Waipawa Black Shale, Whangai, Tangaruhe and Te Mai formations, Pahaoa Group, Whatarangi Formation, Mata Series, Claverley Sandstone and Conway Siltstone. Samples with higher $(>0.5)$ ratios, indicating relatively oxidising conditions, are from the carbonate-rich units of the Whangai Formation (Porangahau Member), Mungaroa Member of the Awhea Formation and Amuri Limestone, and also one each from the Waipawa Black Shale and Te Mai Formation.

\section{$\mathrm{V} / \mathrm{Cr}$}

$\mathrm{V} / \mathrm{Cr}$ ratios range from 0.63-3.80 in southern East Coast Basin formations which, according to Jones and Manning (1994), imply none were deposited under suboxic or anoxic conditions. Thirty samples have $\mathrm{V} / \mathrm{Cr}$ ratios $>2.00$ and are mainly from the $\mathrm{Te}$ Mai and Springhill formations, Pahaoa Group, Whatarangi Formation and Torlesse Supergroup, but also Miocene coal, Whakataki, Weber and Wanstead formations, Mata Series and Split Rock Formation, indicating deposition under dysoxic conditions. The remaining samples are indicative of oxic conditions and include the Waipawa Black Shale, Whangai, Tangaruhe and Glenburn formations, Amuri Limestone and Split Rock Formation. Of these, fourteen samples had ratios $<1.00$ (most oxic), 12 of which are from the Waipawa Black Shale. The remaining two samples are from the Whangai Formation, one from the Upper Calcareous Member the other undifferentiated. This is considered very unusual as the Waipawa Black Shale is generally considered to have been deposited under reduced oxygen levels (e.g. Moore, 1988b). The low V/Cr ratios in the Waipawa Black Shale (and Whangai Formation) samples are due to unusually high levels of chromium. The possibility of chromium contamination (a common occurrence) is possible but this is difficult to determine.

\section{$\mathrm{U} / \mathrm{Th}$}

$\mathrm{U} / \mathrm{Th}$ ratios of analysed samples range between $0.07-1.40$. Only four samples from the Wanstead Formation, Waipawa Black Shale and Mata Series have U/Th ratios $>1.25$, which indicate deposition under anoxic conditions. A further seven samples, mainly from the Waipawa Black Shale, undifferentiated and Upper Calcareous Member of the Whangai Formation have U/Th ratios between 0.75-1.25, indicative of deposition under dysoxic conditions. All remaining samples have $\mathrm{U} / \mathrm{Th}$ ratios that are indicative of deposition under oxic environments.

Samples with relatively high $(>0.6) \mathrm{U} / \mathrm{Th}$ ratios are dominated by the Waipawa Black Shale and Whangai Formation (Te Uri, Upper Calcareous, Rakauroa and undifferentiated) with the remainder from the Weber Formation, Waima Siltstone, Amuri Limestone and Mata Series sediments. These formations are interpreted to have been 
deposited under the least oxic conditions. Samples with low $(<0.3)$ U/Th ratios comprise mainly the Wanstead, Te Mai, Glenburn and Springhill formations, Pahaoa Group, Amuri Limestone, Burnt Creek and Split Rock formations, and Torlesse Supergroup, with a few from the Waipawa Black Shale and Whangai Formation. These formations are interpreted to have been deposited under the most oxic conditions.

\subsubsection{Discussion}

Although there are several notable inconsistencies, there does appear to be a general trend in the relative ordering of formations with regard to paleo-oxygenation conditions at the time of deposition. The absolute values, determined by Jones and Manning (1994), for correlating paleo-oxygenation indices indicate that very few samples appear to have been deposited under anoxic conditions, with the majority appearing to have been deposited under open marine, oxic conditions. However, the indices are still very useful in determining a relative ordering of oxia or anoxia amongst East Coast Basin sediments. Using Table 7.10 and ranking the stratigraphic units for each paleo-oxygenation index, if the indices are considered equal then the relative order of increasing oxia is as follows:

\footnotetext{
Claverley Sandstone < Miocene coal < Conway Siltstone $\sim$ Te Mai < Waipawa Black Shale < Rakauroa Mem. < Weber < Waima Siltstone < Upper Calcareous Mem. < Tangaruhe < Te Uri Mem. Whangai (S.I.) Glenburn < Pahaoa Group < Mata Series < Whakataki < Manurewa < Torlesse Supergroup (S.I.) < Wanstead Springhill < Flags < Split Rock Torlesse Supergroup (N.I.) < Whatarangi < Gentle Annie < Burnt Creek < Mungaroa Mem. < Awhea < Porangahau Mem. < Amuri Limestone < Woodside < Kandahar
}

This ranking should only be considered an approximate guide only as the number of samples comprising each data set is too small to be statistically robust. Classifying bottom-water oxygenation conditions that existed during deposition of the each of the formations is hindered because the paleo-oxygenation indices indicate conditions varied. In particular, the relative position of the Mata Series sediments is not entirely accurate as a number of samples indicate deposition under reduced oxygen levels while others indicating deposition under highly oxic conditions. It does appear however that the Miocene coal, Weber Formation, Waipawa Black Shale, Whangai Formation (Upper Calcareous and Rakauroa members), Te Mai Formation, Waima Siltstone, Claverley Sandstone, Conway Siltstone and possibly the Glenburn Formation were deposited under conditions of reduced oxygen, with possible brief anoxic episodes. The remaining formations appear to have been deposited under largely oxic open marine conditions, 
although isolated reduced oxygen depositional conditions may also have occurred. These results are generally consistent with the results of the biomarker studies (Section 6.6.3) which, of the above mentioned formations, high relative abundances of 28,30-bisnorhopane were present in the Weber Formation, Waipawa Black Shale and Upper Calcareous and Rakauroa members of the Whangai Formation, indicating anoxic or reduced oxygen depositional conditions.

\section{Sulphur}

Although whole-rock sulphur contents have been determined the distribution of sulphur within each sample, particularly the differentiation between organic sulphur (that is sulphur which has been incorporated into the kerogen matrix) and pyritic sulphur, remains uncertain. Baskin and Peters (1992) have reported that source rocks with high kerogen sulphur contents generate hydrocarbons at lower temperatures than source rocks with low kerogen sulphur contents (Figure 7.5), and explained that this may be due to the lower energy required to break C-S bonds than C-C bonds. Sulphur-rich kerogens are typical in source rocks with high carbonate contents that are deposited in highly reducing environments (Baskin and Peters, 1992). In these source rocks the sulphur bonds with the organic matter due to the unavailability of iron. The Waipawa Black Shale, however, is non-calcareous and has sufficient available iron [average $3.8 \%$ recalculated anhydrous (Moore, 1988b)], consistent with the report of Zumberge (1990) which indicated moderate to high quantities of pyrite in the Waipawa Black Shale.

Hirner and Robinson (1989) reported a kerogen sulphur content of 2.07 wt. \% for a single Waipawa Black Shale sample. Using the relationship shown on Figure 7.5, this value suggests the onset of oil generation for Waipawa Black Shale is at a $T_{\max }$ value of $435-440^{\circ} \mathrm{C}$. This coincides with the normally accepted value (see Table 4.6) and shows that neither significant early generation (as a result of a high kerogen sulphur content) nor late generation [as proposed by the suppression of vitrinite reflectance (discussed in Section 7.3)] is predicted.

A low kerogen sulphur content for the Waipawa Black Shale is also suggested by oil-oil and oil-source rock correlations. The low sulphur content $(0.27 \%)$ of the Kora-1 oil (Killops et al., 1994), from the northern Taranaki Basin, implies it was sourced from a low sulphur kerogen. The Turi Formation, a lateral equivalent of the Waipawa Black Shale has been identified as the source of the Kora-1 oil, and this suggests that the Waipawa Black Shale may also have a low kerogen sulphur content. Furthermore, the correlation of the Kora-1 oil with the Kerosene Rock, Westcott, Tiraumea and Okau Stream oils suggests that the latter may also have low sulphur contents. 


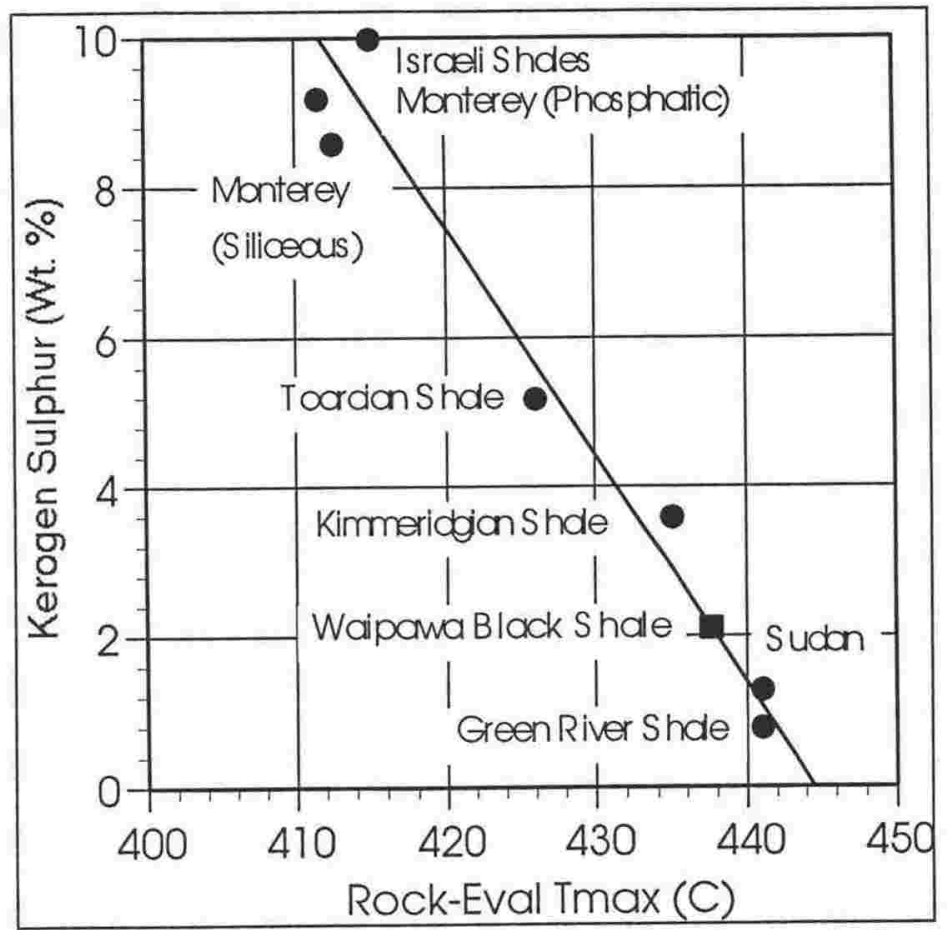

Figure 7.5 Correlation between the amount of organicallybonded sulphur in kerogen and the onset of oil generation for known source rocks (from Baskin and Peters, 1992). Waipawa Black Shale has been superimposed on the curve using this relationship (data from Hirner and Robinson, 1989).

These results are contrary to the findings of both Rogers (1995) and Killops et al. (1996) who reported lower $T_{\max }$ values for Waipawa Black Shale samples compared to the adjacent Wanstead and Whangai formations and suggested this may be due to the presence of significant kerogen sulphur in the Waipawa Black Shale. Field observations of strong hydrocarbon smells emanating from Waipawa Black Shale outcrops, which were later shown by biomarker ratios to be of low maturity, also suggest early generation. Variability in organofacies of the Waipawa Black Shale may prove to be partially responsible for these different findings.

\section{V/Cr ratios}

While most paleo-oxygenation indices indicate that the Waipawa Black Shale was deposited under reduced oxygen conditions, the $\mathrm{V} / \mathrm{Cr}$ ratios strongly indicate that deposition occurred under oxic conditions (the most oxic conditions experienced by any of the East Coast Basin formations during deposition). It appears that the Waipawa Black Shale and some Upper Calcareous Member samples have high concentrations of chromium which adversely affects the $\mathrm{V} / \mathrm{Cr}$ ratios. The ranking of formations according to their paleo-oxygenation depositional conditions as determined by $\mathrm{V} / \mathrm{Cr}$ ratios is, in some cases, quite different to those determined from other paleo-oxygenation indices. For example, the Springhill and Whatarangi formations, and Torlesse Supergroup are at 
the 'reduced oxygen' end of the paleo-oxygenation scale according to $\mathrm{V} / \mathrm{Cr}$ ratios, while the other paleo-oxygenation indices place them at the more 'oxic' end of the scale. In these cases it appears that low concentrations of chromium are responsible. The reason for these anomalies remains uncertain but, as previously mentioned, provenance and grain size as well as paleo-oxygenation conditions are likely to be influencing factors.

In a comparison with 'normal shales' Moore (1988b) noted the Whangai Formation comprises slightly elevated concentrations of chromium. The Rakauroa Member samples record $\mathrm{V} / \mathrm{Cr}$ ratios averaging 1.27, while Upper Calcareous Member samples average 1.12 (Moore, 1988b). These values are lower than those determined in the present study (1.44 and 1.71 respectively) and indicate an even more oxic depositional environment. Moore (1988b) could find no evidence for a volcanic origin for the chromium as it is not associated with magnetite or pyrite, and suggested it was associated with the clay minerals.

\subsubsection{Conclusions}

- There is a trend of reducing quantities of trace elements in eastern North Island formations between Lower Cretaceous and Eocene strata, with a sudden increase in the Paleocene Waipawa Black Shale. Increased quantities of trace elements then occur in Oligocene and Miocene strata. This trend follows the uplift, erosion and sediment supply history of the basin and is consistent with the $n$-alkane, sterane and triterpane biomarker characteristics;

- Elevated quantities of trace elements are present in the Waipawa Black Shale as a result of increased quantities of organic carbon due to reduced oxygen or anoxic depositional conditions;

- $\%$ TOC, \%S, S/C and the Ni/V, V/Cr and U/Th trace metal ratios appear to be good indicators of depositional environment with generally consistent results. Their usefulness, however, lies in their combined use rather than individually as local variations may render one or more of the ratios inaccurate;

- \%TOC, \%S, S/C and the Ni/V, V/Cr and U/Th trace metal ratios indicate that the Miocene coal, Weber Formation, Waipawa Black Shale, Whangai Formation (Upper Calcareous Member and Rakauroa members), Te Mai Formation, Waima Siltstone, some Mata Series samples, Claverley Sandstone, Conway Siltstone and possibly the 
Glenburn Formation were deposited under conditions of reduced oxygen, with possible anoxic episodes;

- Despite a high \%S content in the Waipawa Black Shale, data on the kerogen sulphur content is lacking; the single value reported indicates neither early or late generation of hydrocarbons. A low sulphur content for the Kora-1 oil, however, suggests that the related southern East Coast Basin oils will also have low sulphur contents and that the high sulphur content of the Waipawa Black Shale occurs as pyrite. These findings are inconsistent with reports of early generation due to high kerogen sulphur contents and field observations of hydrocarbon smells emanating from low maturity Waipawa Black Shale outcrops; and

- Contrary to the other paleo-oxygenation indices, $\mathrm{V} / \mathrm{Cr}$ ratios indicate that the Waipawa Black Shale and some Upper Calcareous Member samples were deposited under oxic conditions. This is thought to be due to elevated quantities of $\mathrm{Cr}$ in both these formations, although the source remains uncertain. 


\section{Chapter 8}

\section{Discussion and summary}

The following are summaries of the geochemical characteristics of the oils and possible source rocks, associated oil-oil and oil-source rock correlations, and potential source rocks, and is included here for those interested in specific formations or regions within the southern East Coast Basin. A discussion of hydrocarbon generation and prospectivity of the southern East Coast Basin appears in Sections 8.3 and 8.4.

\subsection{Geochemistry of the oils}

\subsubsection{Geochemical characterisation of the oils}

A summary of the geochemical parameters characterising the source and depositional environments of the oils is shown in Table 8.1, and maturity data is summarised in Table 8.2.

\section{Knights Stream oil}

Mainly marine organic matter with a moderate terrestrial higher plant component is indicated by a predominance of low molecular weight $n$-alkanes with a minor odd-overeven predominance in $n$-alkanes extending to $\mathrm{C}_{31}$, a high proportion of $\mathrm{C}_{28}$ steranes (0.33) despite a low $\mathrm{C}_{27} / \mathrm{C}_{29}$ sterane ratio, and a slightly negative Sofer Value. The presence of oleanane confirms a terrestrial angiosperm component and also indicates source rocks of Late Cretaceous age or younger. A moderately high $\mathrm{Pr} / \mathrm{Ph}$ ratio and the absence of 28,30-bisnorhopane indicates an open marine depositional environment. Sterane and hopane biomarker ratios indicate an immature oil $\left(<0.6 \% \mathrm{R}_{\mathrm{o}}\right)$ and the high relative abundances of pristane and phytane (high $\mathrm{Pr} / n-\mathrm{C}_{17}$ and $\mathrm{Ph} / n-\mathrm{C}_{18}$ ratios) probably result from the sparse generation of $n$-alkanes, although this may also be the result of minor biodegradation or weathering. A comparison of the maturity biomarker ratios between the Knights Stream oil and an adjacent sample of the formation from which the oil was collected revealed significantly different maturities and demonstrates that the oil has migrated.

\section{Isolation Creek oil}

A predominance of marine organic matter with a moderate terrestrial angiosperm component is indicated by a high proportion of $\mathrm{C}_{28}$ steranes $(0.27)$ despite a low 

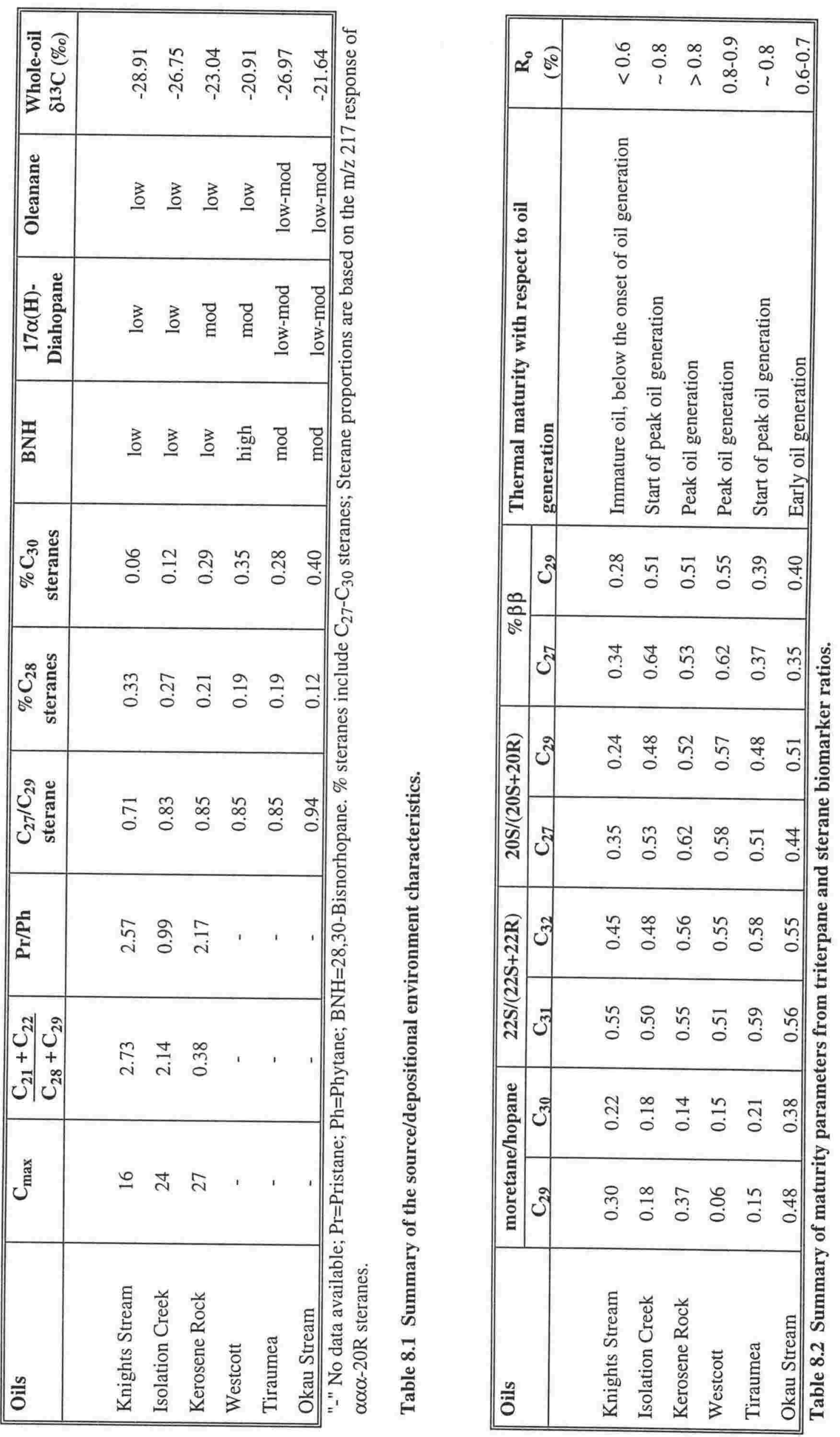
$\mathrm{C}_{27} / \mathrm{C}_{29}$ sterane ratio, a saturate fraction that has a predominance of lower molecular weight $n$-alkanes, and the presence of oleanane which also indicates a source rock of Late Cretaceous age or younger. Sterane and hopane biomarker ratios demonstrate a maturity of peak oil generation $\left(0.8 \% \mathrm{R}_{\mathrm{o}}\right)$. The Isolation Creek oil appears to have migrated as it was found seeping from the organic-poor Amuri Limestone and may be responsible for the unusual $n$-alkane distribution.

\section{Kerosene Rock, Westcott, Tiraumea and Okau Stream oils}

A predominance of marine organic matter with an occasionally strong terrestrial component is indicated by high relative abundances of $\mathrm{C}_{30}$ steranes $\left(\mathrm{C}_{30}\right.$ indices between 0.24-0.40), moderate $\mathrm{C}_{27} / \mathrm{C}_{29}$ sterane ratios (0.83-0.94), both positive and negative Sofer Values and a saturate fraction dominated by higher molecular weight $n$-alkanes. The presence of oleanane in all samples confirms a terrestrial angiosperm component and indicates source rocks of Late Cretaceous age or younger. The unusual $\mathrm{C}_{30}$ steranes comprise predominantly $24-n$-propylcholestane and are of marine algal origin. Anoxic depositional conditions are indicated by high relative abundances of 28,30-bisnorhopane, while low-moderate relative abundances of $17 \alpha(\mathrm{H})$-diahopane indicate a portion of the organic matter (presumably the higher plant material) was initially deposited and transported under oxic conditions. Biomarker ratios indicate the Kerosene Rock and Westcott oils have reached the maturity of peak oil generation $\left(0.8-0.9 \% \mathrm{R}_{\mathrm{o}}\right)$. The Tiraumea oil is slightly less mature at peak oil generation $\left(0.8 \% \mathrm{R}_{\mathrm{o}}\right)$, while the Okau Stream oil has the maturity of early oil generation $\left(0.6-0.7 \% \mathrm{R}_{\mathrm{o}}\right)$. These oils appear to have migrated as they were collected from sandstone units. The Kerosene Rock oil is not biodegraded while the Westcott, Tiraumea and Okau Stream oils are moderately biodegraded with only trace $n$-alkanes and isoprenoids remaining.

\subsubsection{Oil-oil correlations}

The Kerosene Rock, Westcott, Tiraumea and Okau Stream oils are correlated through similarity of source-specific geochemical characteristics which include high relative abundances of $\mathrm{C}_{30}$ steranes and 28,30-bisnorhopane (with the exception of Kerosene Rock), low proportions of $\mathrm{C}_{28}$ steranes (0.12-0.21), and isotopically heavy $\delta^{13} \mathrm{C}$ values $(-20.9$ to $-23.0 \%$ o). In particular, the Westcott and Okau Stream oils have almost identical sterane distribution patterns and stable carbon isotope values, while the Kerosene Rock and Tiraumea oils are also close relatives. Based on similar geochemical characteristics the Waipatiki and Tunakore oils from the southern East Coast Basin and the Kora-1 oil from the northern Taranaki Basin are also correlated to this group of oils and, together, form a major family of oils within the East Coast Basin and New Zealand. 
The Knights Stream and Isolation Creek oils have different geochemical characteristics to the Kerosene Rock, Westcott, Tiraumea and Okau Stream oils and are, therefore, unrelated. They are characterised by a predominance of $\mathrm{C}_{29}$ steranes, a high proportion of $\mathrm{C}_{28}$ steranes (0.27-0.33), a low relative abundance of $\mathrm{C}_{30}$ steranes and isotopically light whole-oil $\delta^{13} \mathrm{C}$ values $(-26.8$ to $-28.9 \%$ ). The absence of highly diagnostic geochemical characteristics in the Knights Stream and Isolation Creek oils necessarily makes this correlation tentative. The major seep oils (Waitangi, Totangi and Rotokautuku) of the northern East Coast Basin have similar geochemical characteristics to the Knights Stream and Isolation Creek oils (with the exception that $\mathrm{C}_{27}$ steranes are predominant in the northern oils indicating a greater marine influence), and it is proposed that they form a major family of oils within the East Coast Basin. 


\subsection{Geochemistry of the possible source rocks}

\subsubsection{Geochemical characterisation of the possible source rocks}

\section{Whakataki Formation}

Variable $\mathrm{C}_{27} / \mathrm{C}_{29}$ sterane ratios (0.82-1.50), the presence of oleanane, and an odd-overeven predominance in the $n$-alkane distribution indicate variable contributions of marine and terrestrial organic matter to the Whakataki Formation, consistent with periodic influxes of terrestrial higher plant material from turbidity currents. $\mathrm{S} / \mathrm{C}$ and $\mathrm{Ni} / \mathrm{V}, \mathrm{V} / \mathrm{Cr}$ and U/Th trace metal ratios and low whole-rock sulphur contents (averaging $0.15 \%$ ) indicate deposition under normal marine conditions. Despite a 'fair' TOC content (averaging $0.52 \%$ ) the predominance of gas-prone Type III and IV kerogen results in low $\mathrm{S}_{1}$ and $\mathrm{S}_{2}$ values and, therefore, a 'poor' hydrocarbon generative potential.

\section{Weber Formation}

A predominance of marine organic matter with a minor terrestrial higher plant component in the Weber Formation is indicated by generally high $\mathrm{C}_{27} / \mathrm{C}_{29}$ sterane ratios (1.33-1.97), an odd-over-even predominance in the $n$-alkane distribution and the presence of oleanane. This is generally consistent with deposition in quiet conditions, distant from shore, and receiving only minor terrestrial higher plant material. The S/C ratios are variable, indicating both oxic and anoxic depositional conditions, while the $\mathrm{Ni} / \mathrm{V}, \mathrm{V} / \mathrm{Cr}$ and $\mathrm{U} / \mathrm{Th}$ trace metal ratios and presence of 28,30-bisnorhopane indicate deposition under reducing conditions. A TOC content averaging $0.22 \%$ indicates that the Weber Formation is unlikely to be a source of hydrocarbons in the southern East Coast Basin.

\section{Wanstead Formation}

A predominance of marine organic matter is indicated by saturate fractions with a predominance of lower molecular weight $n$-alkanes, and high $\mathrm{C}_{27} / \mathrm{C}_{29}$ sterane ratios (1.81-3.54). The absence of oleanane is significant considering its widespread occurrence in Tertiary strata of the southern East Coast Basin. This, together with the predominance of marine biomarker indicators, is interpreted to indicate a depositional environment remote from land, consistent with the fine-grained sediments, lack of macrofossils and abundant foraminifera reported by Johnson (1980). The absence of oleanane may also be partially due to the widespread occurrence of gymnosperms during this time (Mildenhall, 1980), although the high $C_{27} / C_{29}$ sterane ratios preclude a large contribution from these flora. The high relative abundance of diasteranes, despite low sample maturity is thought to indicate clay catalysis due to the high clay content of this formation. S/C and $\mathrm{Ni} / \mathrm{V}$, 
$\mathrm{V} / \mathrm{Cr}$ and U/Th trace metal ratios and low whole-rock sulphur content (averaging $0.1 \%$ ) indicate deposition under normal marine conditions. A low TOC content averaging $0.17 \%$ indicates the Wanstead Formation is a 'poor' source rock.

\section{Waipawa Black Shale}

Both marine and terrestrial higher plant organic matter are indicated by variable $\mathrm{C}_{27} / \mathrm{C}_{29}$ sterane ratios (0.74-2.59), bimodal $n$-alkane distributions and the presence of highly diagnostic marine and terrestrial biomarkers (such as $\mathrm{C}_{30}$ steranes and oleanane). High relative abundances of $C_{30}$ steranes $\left(C_{30}\right.$ index averaging 0.20$)$, comprising predominantly 24- $n$-propylcholestane (Murray et al., 1994) appear to be derived from marine Chrysophyte algae (Moldowan et al., 1990), while the presence of oleanane indicates a terrestrial angiosperm contribution. High relative abundances of 28,30-bisnorhopane, elevated trace metal concentrations and high whole-rock sulphur contents (averaging $0.93 \%$ ), $\mathrm{S} / \mathrm{C}$, and $\mathrm{Ni} / \mathrm{V}$ and $\mathrm{U} / \mathrm{Th}$ trace metal ratios generally indicate deposition under conditions of reduced oxygen with significant anoxic episodes, and are consistent with a restricted faunal assemblage (Moore, 1988b). Bioturbated sediments, however, indicate that conditions were not so severe so as to depopulate the sediment surface. Moderate relative abundances of $17 \alpha(\mathrm{H})$-diahopane in some samples may indicate a portion of the contributing organic matter (presumably the allochthonous terrestrial component) was initially transported and deposited in an oxidising environment. Low abundances of a compound thought to be gammacerane are present which may indicate deposition under conditions of elevated salinity and would support the outer shelf/upper slope depositional environment suggested by Killops et al. (1996) rather than the estuarine setting proposed by Moore (1988b). A TOC content averaging $2.67 \%$, with values up to $5.69 \%$, indicate a 'very good' source rock, although oil and gas-prone (structured terrestrial) kerogen show variable $S_{1}$ and $S_{2}$ values demonstrating 'poor' to 'fair' but occasionally 'good' to 'very good' hydrocarbon generative potential. Although a predominance of structured terrestrial and semi-opaque kerogen was shown in the present study, significant proportions of amorphous kerogen have been reported by Fry (1982), Zumberge (1990) and Rogers (1995) indicating highly variable kerogen compositions are present in the Waipawa Black Shale.

\section{Kandahar Formation}

A high $\mathrm{C}_{27} / \mathrm{C}_{29}$ sterane ratio (2.06) indicates the predominance of marine organic matter while a moderate abundance of oleanane indicates a minor terrestrial angiosperm contribution. S/C and $\mathrm{Ni} / \mathrm{V}, \mathrm{V} / \mathrm{Cr}$ and $\mathrm{U} / \mathrm{Th}$ trace metal ratios, and a very low wholerock sulphur content $(0.01 \%)$ indicate deposition under highly oxic conditions. The low 
TOC content $(0.19 \%)$ indicates the Kandahar Formation is unlikely to be a source of hydrocarbons in the southern East Coast Basin.

\section{Awhea Formation}

A high $\mathrm{C}_{27} / \mathrm{C}_{29}$ sterane ratio (1.46) indicates the predominance of marine organic matter, although the presence of oleanane suggests a minor terrestrial angiosperm contribution. $\mathrm{S} / \mathrm{C}$ and $\mathrm{Ni} / \mathrm{V}, \mathrm{V} / \mathrm{Cr}$ and $\mathrm{U} / \mathrm{Th}$ trace metal ratios and a very low whole-rock sulphur content $(0.01 \%)$ indicate deposition under oxic conditions. A TOC content of $0.14 \%$ indicates a 'poor' source rock.

\section{Mungaroa Member}

A high $\mathrm{C}_{27} / \mathrm{C}_{29}$ sterane ratio (2.41) and high proportion of $\mathrm{C}_{28}$ steranes indicates the predominance of marine organic matter, consistent with its fine-grained limestone lithology. The presence of oleanane, however, suggests a minor terrestrial angiosperm contribution. S/C and $\mathrm{Ni} / \mathrm{V}, \mathrm{V} / \mathrm{Cr}$ and $\mathrm{U} / \mathrm{Th}$ trace metal ratios, and a very low wholerock sulphur content $(0.03 \%)$ indicate deposition under oxic conditions. A low TOC content $(0.15 \%)$ indicates the Mungaroa Member is a 'poor' source rock.

\section{Manurewa Formation}

Variable $\mathrm{C}_{27} / \mathrm{C}_{29}$ sterane ratios (0.45-1.88) indicate fluctuating contributions of marine and terrestrial organic matter. $\mathrm{S} / \mathrm{C}$ and $\mathrm{Ni} / \mathrm{V}, \mathrm{V} / \mathrm{Cr}$ and $\mathrm{U} / \mathrm{Th}$ trace metal ratios and low whole-rock sulphur contents (averaging $0.22 \%$ ) indicate deposition under normal marine conditions. A TOC content averaging $0.15 \%$ indicates a 'poor' source rock.

\section{Whangai Formation, Te Uri Member}

A predominance of marine organic matter with a minor terrestrial contribution is indicated by high $\mathrm{C}_{27} / \mathrm{C}_{29}$ sterane ratios (1.73-1.91) and the $n$-alkane distributions. Oleanane is absent. S/C and $\mathrm{Ni} / \mathrm{V}, \mathrm{V} / \mathrm{Cr}$ and $\mathrm{U} / \mathrm{Th}$ trace metal ratios and low whole-rock sulphur contents (averaging $0.27 \%$ ) indicate deposition under normal marine conditions. A TOC content averaging $0.15 \%$ indicates the Te Uri Member is a 'poor' source of hydrocarbons.

\section{Whangai Formation, Porangahau Member}

The predominance of $\mathrm{C}_{29}$ steranes (0.23-1.65) in a carbonate-rich unit is interpreted to indicate a contribution from marine $\mathrm{C}_{29}$ sterol-synthesising algae, although the presence of oleanane and some saturate fractions dominated by high molecular weight $n$-alkanes indicate a minor terrestrial angiosperm contribution. High relative abundances of $\mathrm{C}_{30}$ steranes, considered to be identical to those present in the Waipawa Black Shale (i.e. 
24- $n$-propylcholestane) also support a predominance of marine algal material. S/C and $\mathrm{Ni} / \mathrm{V}, \mathrm{V} / \mathrm{Cr}$ and $\mathrm{U} / \mathrm{Th}$ trace metal ratios and very low whole-rock sulphur contents (averaging $0.03 \%$ ) indicate deposition under oxic conditions. A TOC content averaging $0.17 \%$ indicates the Porangahau Member is a 'poor' source rock.

\section{Whangai Formation, Upper Calcareous Member}

A predominance of marine organic matter is indicated by high $\mathrm{C}_{27} / \mathrm{C}_{29}$ sterane ratios $(0.75-2.39)$, a saturate fraction with a predominance of low molecular weight $n$-alkanes and a negative Sofer Value, while a terrestrial component is indicated by low to trace abundances of oleanane. $\mathrm{S} / \mathrm{C}$, and $\mathrm{Ni} / \mathrm{V}$ and $\mathrm{U} / \mathrm{Th}$ trace metal ratios and moderate wholerock sulphur contents (averaging $0.58 \%$ ), low $\mathrm{Pr} / \mathrm{Ph}$ ratios and the presence of occasionally high relative abundances of 28,30-bisnorhopane indicate deposition under reduced oxygen and periodically anoxic conditions. A TOC content averaging $0.62 \%$ indicates a 'fair' source rock, although a predominance of oil and gas-prone Types II and III (structured terrestrial and structured aqueous) kerogen result in a 'poor' but occasionally 'fair' hydrocarbon generative potential.

\section{Whangai Formation, Rakauroa Member}

A predominance of marine organic matter with an occasionally significant terrestrial component is indicated by high $\mathrm{C}_{27} / \mathrm{C}_{29}$ sterane ratios (0.88-3.02) and saturate fractions dominated by low molecular weight $n$-alkanes. S/C and Ni/V, V/Cr and U/Th trace metal ratios and moderate whole-rock sulphur contents (averaging $0.47 \%$ ) indicate deposition under moderately reducing conditions. A TOC content averaging $0.62 \%$ indicates a 'fair' source rock and a predominance of oil and gas-prone Type II kerogen, however, are inconsistent with the low $\mathrm{S}_{1}$ and $\mathrm{S}_{2}$ values demonstrating on average 'poor' but occasionally 'fair' hydrocarbon generative potential demonstrated by a predominance of structured terrestrial and semi-opaque kerogen, with moderate spore/pollen kerogen and minor structured aqueous kerogen. The slightly higher proportion of terrestrial organic matter compared with the Upper Calcareous Member may indicate a more proximal depositional environment.

\section{Tangaruhe Formation}

A predominantly mixed marine and terrestrial contribution of organic matter is indicated by variable $\mathrm{C}_{27} / \mathrm{C}_{29}$ sterane ratios (0.88-2.18), high proportion os $\mathrm{C}_{28}$ steranes and saturate fractions dominated by higher molecular weight $n$-alkanes which indicate a terrestrial contribution, and is confirmed by the presence of oleanane. $\mathrm{S} / \mathrm{C}$ and $\mathrm{Ni} / \mathrm{V}$, $\mathrm{V} / \mathrm{Cr}$ and $\mathrm{U} / \mathrm{Th}$ trace metal ratios and low whole-rock sulphur contents (averaging 
$0.25 \%$ ) indicate essentially normal marine conditions. A TOC content averaging $0.36 \%$ indicates a 'poor' source rock.

\section{Te Mai Formation}

Variable, but generally low $\mathrm{C}_{27} / \mathrm{C}_{29}$ sterane ratios (0.29-2.46) and saturate fractions showing predominantly high but sometimes low molecular weight $n$-alkanes indicate a predominance of terrestrial organic matter with an occasionally significant marine component. Positive Sofer Values and trace abundances of oleanane also indicate a predominance of terrestrial angiosperm organic matter. Moderate whole-rock sulphur contents (averaging $0.68 \%$ ) and the $\mathrm{Ni} / \mathrm{V}, \mathrm{V} / \mathrm{Cr}$ and $\mathrm{U} / \mathrm{Th}$ trace metal ratios indicate predominantly anoxic depositional conditions, while variable $\mathrm{S} / \mathrm{C}$ ratios indicate oxic to anoxic depositional conditions. Deposition under reduced oxygen conditions is inconsistent with the shallow current-swept tidal strait depositional environment described by Johnston (1980) and appear more consistent with the bathyal setting proposed by Neef (1992) (see Section 2.1.4). Despite a 'fair' TOC content (averaging $0.85 \%$ ) inert Types III and IV (structured terrestrial and semi-opaque) kerogen with low $S_{1}$ and $S_{2}$ values demonstrate a 'poor' hydrocarbon generative potential and is consistent with observed carbonised plant fragments.

\section{Glenburn Formation}

Generally low $\mathrm{C}_{27} / \mathrm{C}_{29}$ sterane ratios (0.30-2.49) and saturate fractions with predominantly high molecular weight $n$-alkanes indicate a predominance of terrestrial organic matter but also an occasionally significant marine component. Positive Sofer Values and the presence of oleanane confirms a terrestrial angiosperm contribution. Moderate whole-rock sulphur contents (averaging $0.50 \%$ ) and the $\mathrm{Ni} / \mathrm{V}, \mathrm{V} / \mathrm{Cr}$ and $\mathrm{U} / \mathrm{Th}$ trace metal ratios generally indicate deposition under normal marine conditions. S/C ratios are highly variable, indicating very reducing to oxic depositional environments. A TOC content averaging $0.72 \%$ indicates a 'fair' source rock, although a predominance of inert Types III and IV (structured terrestrial and semi-opaque) kerogen show low $\mathrm{S}_{1}$ and $S_{2}$ values and demonstrate a 'poor' hydrocarbon generative potential, consistent observed carbonaceous plant material.

\section{Springhill Formation}

The low $\mathrm{C}_{27} / \mathrm{C}_{29}$ sterane ratios (0.60-0.89) indicate a predominance of terrestrial organic matter, despite an absence of oleanane. S/C and $\mathrm{Ni} / \mathrm{V}, \mathrm{V} / \mathrm{Cr}$ and $\mathrm{U} / \mathrm{Th}$ trace metal ratios and low whole-rock sulphur contents (averaging 0.07\%) indicate deposition under normal marine conditions. A TOC content averaging $0.26 \%$ indicates a 'poor' source rock. 


\section{Gentle Annie Formation}

The $\mathrm{C}_{27} / \mathrm{C}_{29}$ sterane ratio (1.15) indicates mixed marine and terrestrial organic matter, while the $\mathrm{S} / \mathrm{C}$ and $\mathrm{Ni} / \mathrm{V}, \mathrm{V} / \mathrm{Cr}$ and $\mathrm{U} / \mathrm{Th}$ trace metal ratios and a low whole-rock sulphur content $(0.01 \%)$ indicate deposition under normal marine conditions. The low TOC content $(0.06 \%)$ indicates a 'poor' source rock.

\section{Pahaoa Group}

Variable proportions of terrestrial and marine organic matter are indicated by low $\mathrm{C}_{27} / \mathrm{C}_{29}$ sterane ratios (0.31-1.36) and saturate fractions with dominant low and high molecular weight $n$-alkane distributions. Oleanane is absent, presumably due to its Early Cretaceous age. S/C and $\mathrm{Ni} / \mathrm{V}, \mathrm{V} / \mathrm{Cr}$ and $\mathrm{U} / \mathrm{Th}$ trace metal ratios, low whole-rock sulphur contents (averaging 0.09\%) and high $\mathrm{Pr} / \mathrm{Ph}$ ratios indicate deposition under normal marine (oxic) conditions. A TOC content averaging $0.30 \%$ indicates a 'poor' source rock and a predominance of inert Type IV (structured terrestrial, with minor spore/pollen, semi-opaque and opaque) kerogen show low $S_{1}$ and $S_{2}$ values demonstrating a 'poor' hydrocarbon generative potential.

\section{Whatarangi Formation}

The very low $\mathrm{C}_{27} / \mathrm{C}_{29}$ sterane ratio (0.12) indicates a predominance of terrestrial organic matter, despite an absence of oleanane (presumably due to its Early Cretaceous age) and is consistent with observed carbonised plant fragments. $\mathrm{S} / \mathrm{C}$ and $\mathrm{Ni} / \mathrm{V}, \mathrm{V} / \mathrm{Cr}$ and $\mathrm{U} / \mathrm{Th}$ trace metal ratios and a very low whole-rock sulphur content $(0.04 \%)$ indicate deposition under open marine conditions. The low TOC content $(0.19 \%)$ indicates a 'poor' source rock.

\section{Torlesse Supergroup}

A predominance of mixed marine and terrestrial organic matter is indicated by the $\mathrm{C}_{27} / \mathrm{C}_{29}$ sterane ratio (1.31), while the predominance of high molecular weight $n$-alkanes indicate a predominance of terrestrial organic matter. $\mathrm{S} / \mathrm{C}$ and $\mathrm{Ni} / \mathrm{V}, \mathrm{V} / \mathrm{Cr}$ and $\mathrm{U} / \mathrm{Th}$ trace metal ratios and a low whole-rock sulphur content $(0.07 \%)$ indicate deposition under normal marine conditions. The low TOC content $(0.19 \%)$ indicates a 'poor' source rock. Maturity biomarker ratios indicate the organic matter, despite a predominance of semi-opaque kerogen, is not postmature, but that maturity has reached the peak of oil generation $\left(0.8-0.9 \% \mathrm{R}_{\mathrm{o}}\right)$. 


\section{South Island stratigraphy Waima Siltstone}

A mixed marine and terrestrial contribution of organic matter is indicated by a predominance of $\mathrm{C}_{28}$ steranes, a low $\mathrm{C}_{27} / \mathrm{C}_{29}$ sterane ratio (0.81) and a saturate fraction with dominant high molecular weight $n$-alkanes. The presence of oleanane confirms a terrestrial angiosperm contribution. $\mathrm{S} / \mathrm{C}$ and $\mathrm{Ni} / \mathrm{V}, \mathrm{V} / \mathrm{Cr}$ and $\mathrm{U} / \mathrm{Th}$ trace metal ratios and moderate whole-rock sulphur content $(0.53 \%)$ indicate deposition under moderately reducing conditions. Low-moderate relative abundances of $17 \alpha(\mathrm{H})$-diahopane, despite low sample maturity, may indicate a contribution of allochthonous organic matter that was transported under oxic conditions. The low TOC content $(0.41 \%)$ indicates a 'poor' source rock.

\section{Woodside Formation}

The low $\mathrm{C}_{27} / \mathrm{C}_{29}$ sterane ratio (0.77) is interpreted to indicate a predominance of $\mathrm{C}_{29}$ sterol-synthesising algae, which are sometimes favoured in carbonate depositional environments (Moldowan et al., 1985), and is consistent with the fine-grained carbonate sequence and the absence of oleanane that suggest a depositional environment remote from land. S/C and $\mathrm{Ni} / \mathrm{V}, \mathrm{V} / \mathrm{Cr}$ and $\mathrm{U} / \mathrm{Th}$ trace metal ratios and a very low whole-rock sulphur content $(0.03 \%)$ indicate deposition under highly oxic conditions. The low TOC content $(0.06 \%)$ indicates a 'poor' source rock.

\section{Amuri Limestone}

The low $\mathrm{C}_{27} / \mathrm{C}_{29}$ sterane ratios (0.20-1.43) are interpreted to indicate a predominance of marine organic matter from $\mathrm{C}_{29}$ sterol-synthesising algae, consistent with the sedimentological features (fine-grained carbonate sequence with little clastic input) and the absence of oleanane which indicate a depositional environment remote from land. A marine depositional environment is supported by the saturate fractions which show a predominance of low molecular weight $n$-alkanes. S/C and Ni/V, V/Cr and U/Th trace metal ratios and very low whole-rock sulphur contents (averaging 0.03\%) indicate deposition under highly oxic conditions. A TOC content averaging $0.09 \%$ indicates the Amuri Limestone is a 'poor' source rock.

\section{Whangai Formation, undifferentiated}

Mixed marine and terrestrial organic matter is indicated by the $\mathrm{C}_{27} / \mathrm{C}_{29}$ sterane ratios (0.90-1.24) while saturate fractions showing mainly lower molecular weight $n$-alkanes and a negative Sofer Value indicate a predominance of marine organic matter. A terrestrial angiosperm contribution is confirmed by the presence of oleanane. S/C and $\mathrm{Ni} / \mathrm{V}, \mathrm{V} / \mathrm{Cr}$ and U/Th trace metal ratios and moderate whole-rock sulphur contents 
(averaging $0.49 \%$ ) indicate deposition under open marine conditions. A TOC content averaging $0.47 \%$ indicates a 'poor' source rock, and oil and gas-prone Types II and III (mainly structured terrestrial) kerogen show low $\mathrm{S}_{1}$ and $\mathrm{S}_{2}$ values and demonstrate 'poor' hydrocarbon generative potential.

\section{Mata Series}

Mata Series sediments vary considerably in appearance, from Conway Siltstone to Amuri Limestone-like sediments, and the organic geochemistry varies accordingly. Variable $\mathrm{C}_{27} / \mathrm{C}_{29}$ sterane ratios $(0.61-2.37)$ and $n$-alkane distributions indicate a predominance of terrestrial organic matter with occasionally strong marine contributions. S/C and $\mathrm{Ni} / \mathrm{V}$, $\mathrm{V} / \mathrm{Cr}$ and U/Th trace metal ratios and variable whole-rock sulphur contents (0.01$1.37 \%$ ) indicate oxic to anoxic depositional conditions. Total organic carbon contents (0.03-0.96) indicate a 'poor' to 'fair' source rock while gas-prone mixed Types III and IV kerogen, with low $S_{1}$ and $S_{2}$ values, demonstrate 'poor' hydrocarbon generative potential.

\section{Flags Formation}

A predominance of marine algae is indicated by the presence of high relative abundances of $\mathrm{C}_{30}$ steranes $\left(\mathrm{C}_{30}\right.$ index of 0.23$)$, the saturate fraction with mainly low molecular weight $n$-alkanes and a negative Sofer Value. The presence of oleanane and a slight oddover-even predominance in the $n$-alkane distribution does indicate a minor terrestrial angiosperm contribution of organic matter. $\mathrm{S} / \mathrm{C}$ and $\mathrm{Ni} / \mathrm{V}, \mathrm{V} / \mathrm{Cr}$ and $\mathrm{U} / \mathrm{Th}$ trace metal ratios, and a low whole-rock sulphur content $(0.09 \%)$ indicate deposition under normal marine conditions. The TOC content of $0.52 \%$ indicates a 'fair' source rock, although gas-prone mixed Types III and IV (structured aqueous and structured terrestrial) kerogen, with low $S_{1}$ and $S_{2}$ values demonstrate a 'poor' hydrocarbon generative potential.

\section{Claverley Sandstone}

The bitumen extract shows a high $\mathrm{C}_{27} / \mathrm{C}_{29}$ sterane ratio (1.74) indicating a predominance of marine organic matter, while the presence of oleanane indicates a minor terrestrial angiosperm contribution. $\mathrm{S} / \mathrm{C}$ and $\mathrm{Ni} / \mathrm{V}, \mathrm{V} / \mathrm{Cr}$ and $\mathrm{U} / \mathrm{Th}$ trace metal ratios and a high whole-rock sulphur content (1.32\%) indicate an anoxic depositional environment, and the tentative identification of gammacerane suggests deposition under elevated salinity. These characteristics are consistent with deposition of predominantly marine organic matter in a basin with restricted bottom-water circulation receiving little terrestrial organic matter. The low TOC content $(0.39 \%)$ indicates a 'poor' source rock. 


\section{Conway Siltstone}

A low $\mathrm{C}_{27} / \mathrm{C}_{29}$ sterane ratio (0.68), the saturate fraction with mainly high molecular weight $n$-alkanes, the presence of oleanane, and a positive Sofer Value all indicate a predominance of terrestrial angiosperm-derived organic matter. $\mathrm{S} / \mathrm{C}$ and $\mathrm{Ni} / \mathrm{V}, \mathrm{V} / \mathrm{Cr}$ and $\mathrm{U} / \mathrm{Th}$ trace metal ratios and a moderate whole-rock sulphur content $(0.54 \%)$ indicate deposition under anoxic conditions. These characteristics are consistent with deposition in a nearshore basin with restricted bottom-water circulation. The TOC content of $0.55 \%$ indicates a 'fair' source rock although results of Rock-Eval pyrolysis show inert Type IV (structured terrestrial, spore/pollen and semi-opaque) kerogen with low $S_{1}$ and $S_{2}$ values demonstrating 'poor' hydrocarbon generative potential.

\section{Burnt Creek Formation}

A predominance of terrestrial organic matter with a minor marine contribution is indicated by low $\mathrm{C}_{27} / \mathrm{C}_{29}$ sterane ratios (0.71-0.98), while the $n$-alkane distributions indicate a predominance of marine organic matter. The presence of oleanane indicates a terrestrial angiosperm contribution of organic matter. $\mathrm{S} / \mathrm{C}$ and $\mathrm{Ni} / \mathrm{V}, \mathrm{V} / \mathrm{Cr}$ and $\mathrm{U} / \mathrm{Th}$ trace metal ratios and low whole-rock sulphur contents (averaging $0.10 \%$ ) indicate deposition under normal marine conditions. A TOC content averaging $0.33 \%$ indicates the Burnt Creek Formation is a 'poor' source rock.

\section{Split Rock Formation}

Low $\mathrm{C}_{27} / \mathrm{C}_{29}$ sterane ratios $(0.28-1.44)$, the presence of oleanane (Wharfe Sandstone Member) and a positive Sofer Value indicate a predominance of terrestrial organic matter, consistent with observed plant fragments. The general absence of oleanane is presumably due to the Early Cretaceous age. S/C and Ni/V, V/Cr and U/Th trace metal ratios and low whole-rock sulphur contents (averaging $0.08 \%$ ) indicate deposition under normal marine conditions. A TOC content averaging $0.36 \%$ indicates a 'poor' source rock and, although Rock-Eval pyrolysis was not conducted, it is thought that the carbonised plant material would indicate a predominance of inert Type IV kerogen and have little hydrocarbon generative potential.

\section{Torlesse Supergroup}

Low $\mathrm{C}_{27} / \mathrm{C}_{29}$ sterane ratios (0.23-0.78) indicate a predominance of terrestrial organic matter while $n$-alkane distributions indicate variable contributions of both marine and terrestrial organic matter. Oleanane is absent presumably due to age. This is consistent with deposition from turbidity currents of predominantly terrestrial higher plant material transported across the shelf during a period of rapid uplift, erosion. $\mathrm{S} / \mathrm{C}$ and $\mathrm{Ni} / \mathrm{V}, \mathrm{V} / \mathrm{Cr}$ and U/Th trace metal ratios and low whole-rock sulphur contents (averaging 0.07\%) 


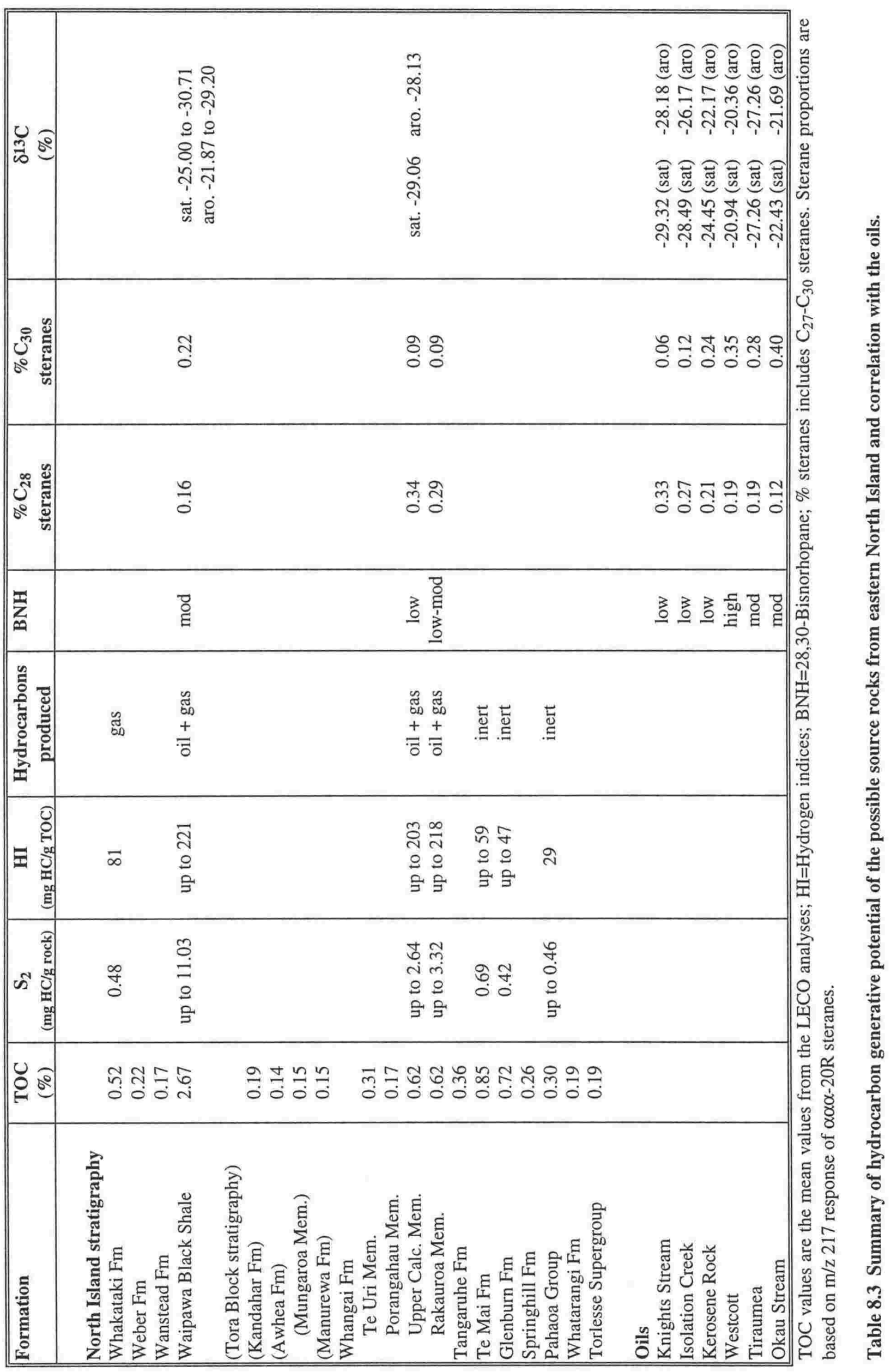


indicate deposition under normal marine conditions. Biomarker maturity ratios indicate that the organic matter is not postmature and, in many cases, has not even reached the maturity of the onset of oil generation $\left(0.6 \% \mathrm{R}_{\mathrm{o}}\right)$. A TOC averaging $0.35 \%$ indicates a 'poor' source rock.

\subsubsection{Potential source rocks in the southern East Coast Basin}

The results of the present study demonstrate that there are many potential source rocks but only a few with moderate to high generative potential in the southern East Coast Basin. Total organic carbon analyses indicate that possible good source rocks of eastern North Island include the Paleocene Waipawa Black Shale, Late Cretaceous Whangai Formation, especially the Upper Calcareous and Rakauroa members, and the middle to Late Cretaceous Te Mai and Glenburn formations. Minor source potential may be present in the Miocene Whakataki Formation. Possible source rocks of Marlborough are restricted to the Late Cretaceous Whangai Formation and its lateral equivalents, the Mata Series sediments, Flags Formation and Conway Siltstone. Results of Rock-Eval pyrolysis, however, further eliminate organic-rich formations that contain kerogen with only minor hydrocarbon generative potential. Inert kerogens (HI values $<50$ ) are present in the Te Mai and Glenburn formations and Conway Siltstone. Thus, only the Waipawa Black Shale, Upper Calcareous and Rakauroa members of the Whangai Formation, and undifferentiated (S.I.) Whangai Formation have oil and gas potential (HI values > 150). Pyrolysis data $\left(\mathrm{S}_{2}\right)$ indicate the Waipawa Black Shale is able to produce up to $11 \mathrm{~kg} /$ tonne hydrocarbons and the Whangai Formation up to $3.66 \mathrm{~kg} /$ tonne hydrocarbons. The Whakataki Formation, Whangai-like Mata Series and Flags Formation, with HI values between 50 and 150, demonstrate gas potential. In summary, good potential source rocks of the southern East Coast Basin appear limited to the uppermost Cretaceous to Paleocene strata.

\subsubsection{Oil-source rock correlations}

Biomarker and stable carbon isotope data indicate a genetic relationship between the Kerosene Rock, Westcott, Tiraumea and Okau Stream oils and the Waipawa Black Shale (Table 8.3). The unique biomarker characteristics (notably the high relative abundances of $\mathrm{C}_{30}$ steranes and 28,30-bisnorhopane and low proportions of $\mathrm{C}_{28}$ steranes) that were used to correlate the oils can also be used to link these oils with the Waipawa Black Shale. Although stable carbon isotopes could only provide a positive correlation between the Waipawa Black Shale and Kerosene Rock oil, both the oils and the Waipawa Black Shale samples are characterised by isotopically heavy $\delta^{13} \mathrm{C}$ values, with the oils typically 


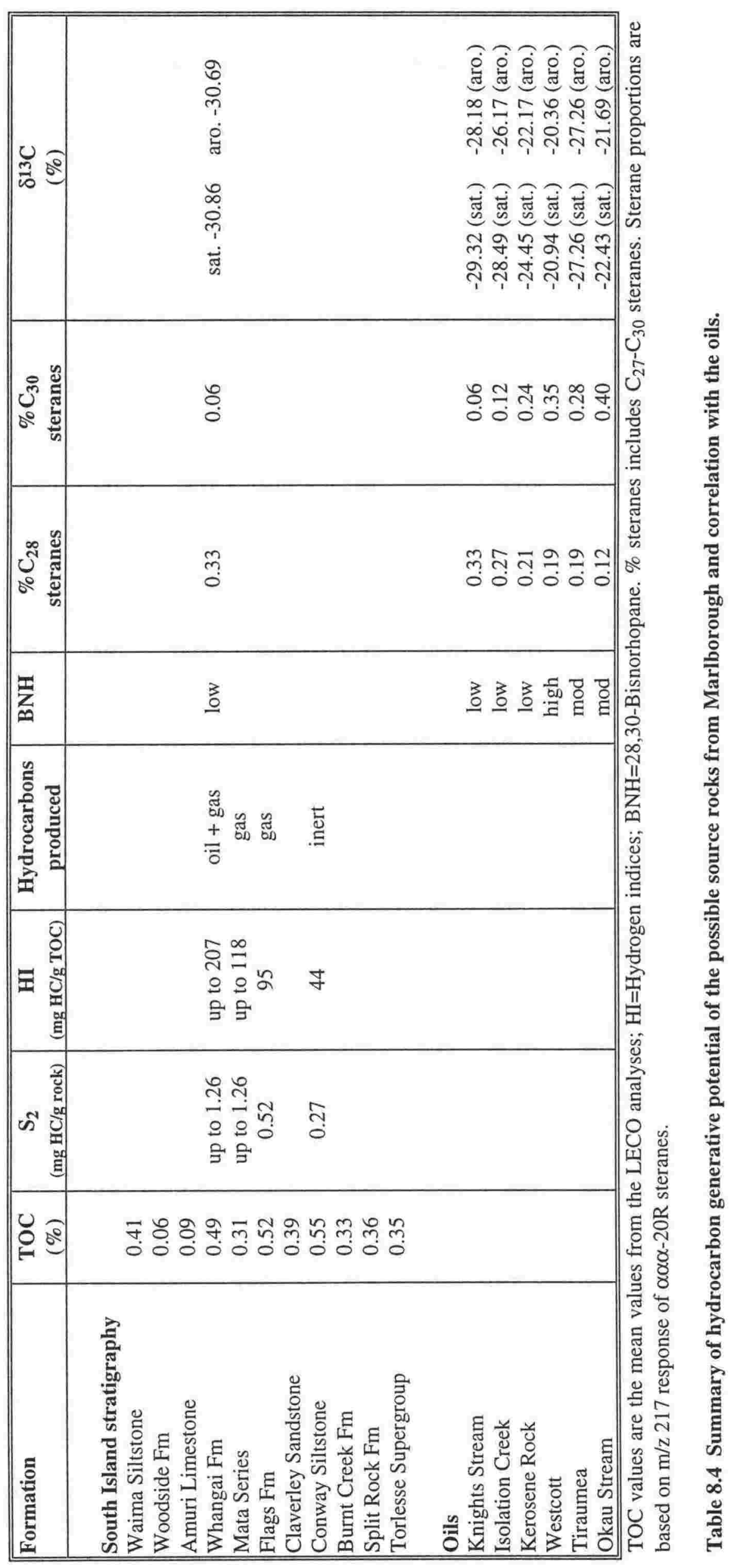


between -21 to $-23 \%$, and Waipawa Black Shale samples as low as $-23 \%$ and enriched by up to $4 \%$ compared to the other formations sampled.

A tentative correlation exists between Knights Stream oil and the Upper Calcareous and Rakauroa members of the Whangai Formation (Table 8.3). The Knights Stream oil has a high proportion of $\mathrm{C}_{28}$ steranes (0.33) and the only formation analysed with both hydrocarbon generative potential and a similarly high proportion of $\mathrm{C}_{28}$ steranes is the Upper Calcareous Member (0.34) and the Rakauroa Member (0.29) of the Whangai Formation. This correlation is supported by similar $\delta^{13} \mathrm{C}$ values between the Knights Stream oil [-29.32\%o (sat) and $-28.18 \%$ (aro)] and the Upper Calcareous Member sample [-29.06\%o (sat) and -28.13\%o (aro)] (see Figure 7.1).

Although the Isolation Creek oil is not readily correlated to any formation, like the Knights Stream oil and Upper Calcareous and Rakauroa members of the Whangai Formation, it also has a high proportion of $\mathrm{C}_{28}$ steranes (0.27) (Table 8.4). Furthermore, of the samples collected from Marlborough, only the Whangai Formation is oil-prone, although the Upper Chert Member of the Amuri Limestone from the Mead Stream area [the Waipawa Black Shale equivalent in Marlborough (Leckie et al., 1992)] was not sampled. 


\subsection{Hydrocarbon generation in the East Coast Basin}

Two distinct families of oils have been described in the East Coast Basin. The Waipawa Black Shale-sourced oils are predominant in the southern part of the basin and manifest themselves as oil stains, while the Whangai-sourced oils are predominant in the northern part of the basin as seep oils. Although geographic variations in source rock quality (TOC, HI values) and maturation have been described (e.g. Moore, 1988b), these do not fully explain the distribution of oil occurrences within the basin. Rogers (1995) concluded that the absence of Waipawa Black Shale-sourced oils in the northern East Coast Basin may be due to either the absence or immaturity of Waipawa Black Shale in the subsurface. Another possibility may be that the distribution of oils may be a function of chemical composition of the potential source rocks which controls the timing of hydrocarbon generation.

The possibility of early generation in the Waipawa Black Shale as a result of a high kerogen sulphur content has been discussed in Section 7.4.5 and, although the available evidence suggests that the sulphur is present as pyrite (and not organically-bound), considerable uncertainty remains about the processes operating here. Early generation of the Waipawa Black Shale, or at least earlier generation compared with the Whangai Formation, may possibly explain the distribution of the two oil families in the East Coast Basin. In the southern East Coast Basin, where maturation of the source rock sequence is low, the Waipawa Black Shale-sourced oils are dominant possibly due to early generation, while there is no generation from the Whangai Formation. Although potentially the most prolific source rock in the basin, the small volume of the Waipawa Black Shale present means that only small quantities of hydrocarbons are produced which are manifested as oil stains. In the northern East Coast Basin, the Waipawa Black Shale and Whangai Formation present in the autochthonous sequence are buried by up to $5000 \mathrm{~m}$ of allochthonous strata (Geosearch, 1991) and have probably passed into the oil generation window. Despite the greater hydrocarbon generative potential of the Waipawa Black Shale, oil generation is dominated by the volumetrically greater Whangai Formation and oil occurrences are manifested as more prolific oil seepages (such as the Waitangi, Totangi and Rotokautuku oil seeps) rather than oil stains (see Rogers, 1995).

Further research into hydrocarbon generation from the Waipawa Black Shale is required, as early or late temperature generation clearly has implications in the development of exploration concepts. This could be undertaken by determining the kerogen sulphur content and also by conducting vitrinite reflectance and fluorescence (VRF) analyses to determine whether suppression of vitrinite reflectance is occurring. 
Results of both the present study and Rogers (1995) demonstrate a maturity of within the oil generation window for the Torlesse Supergroup which is considerably lower than that proposed by others (e.g. Katz, 1968). Hydrocarbon generation from this unit, both within the East Coast Basin and elsewhere in New Zealand, may be possible given sufficient organic matter of the correct type. 


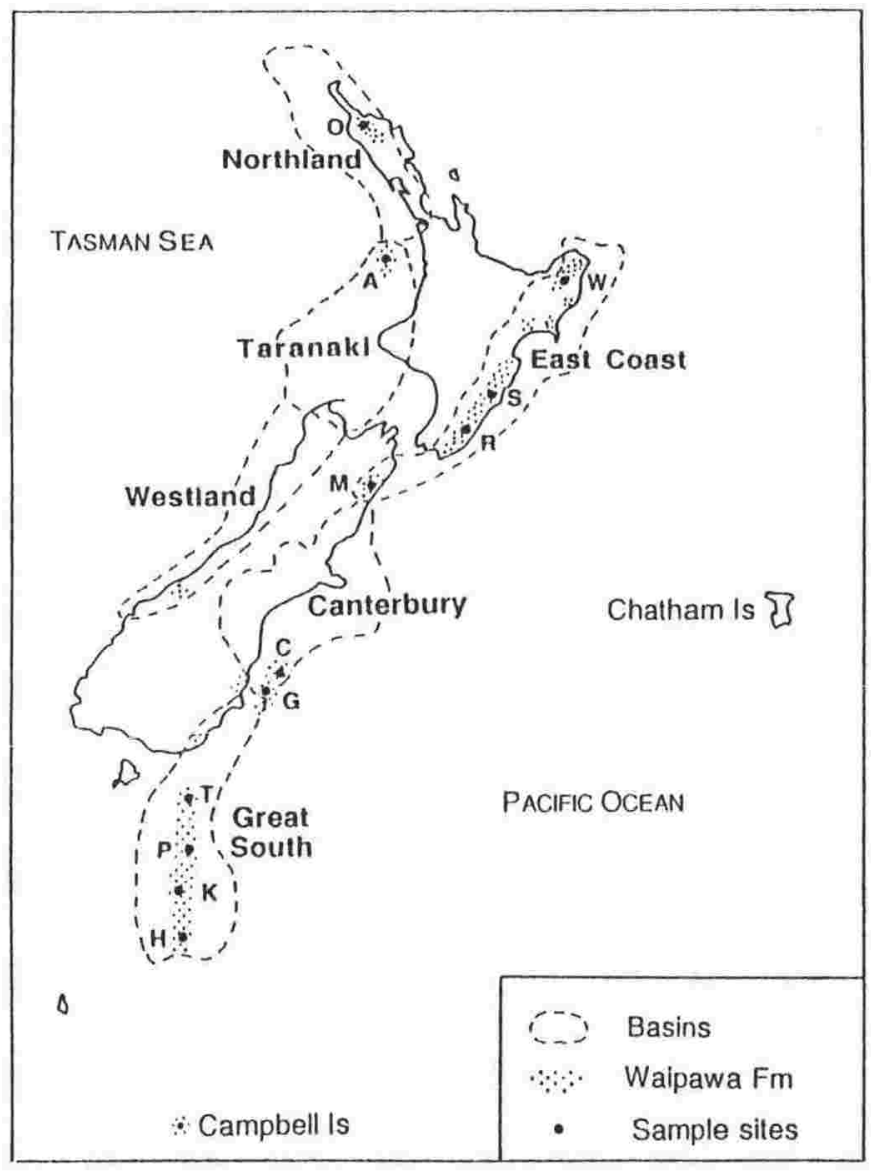

Figure 8.1 Known distrilsution of the Waipawa Black Shale (from Killops et al., 1996).

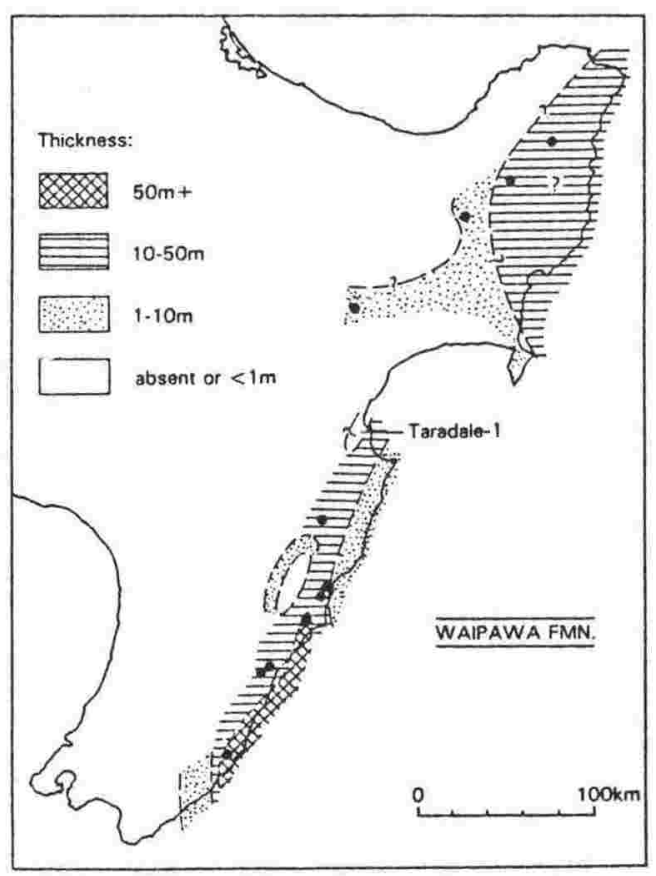

a. Waipawa Black Shale

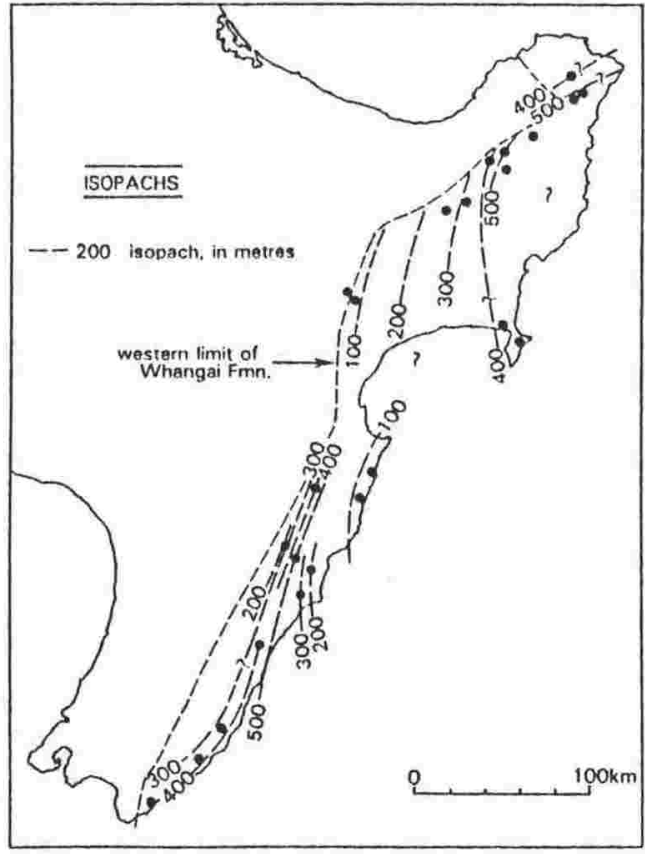

b. Whangai Formation

Figure 8.2 Thickness maps of: a. Waipawa Black Shale and b. Whangai Formation (from Moore, 19881)). 


\subsection{Southern East Coast Basin prospectivity}

\subsubsection{Distribution and thickness of potential source rocks}

The reported geographic distribution of the prospective Waipawa Black Shale and Whangai Formation is considerable, extending well beyond the boundary of the East Coast Basin. The Waipawa Black Shale and its equivalents have been recognised from the Northland, northern Taranaki, Canterbury, Great South and possibly southern Westland basins (Killops et al., 1996) (Figure 8.1). The Whangai Formation and its equivalents have been recognised in the Northland, North Canterbury and Great South basins, and similar sediments have been found on the Lord Howe Rise and Campbell Plateau (Moore, 1988b). Within the southern East Coast Basin the Upper Calcareous and Rakauroa members have been identified in the Pongaroa and southern Coastal blocks, while the northern Coastal Block contains predominantly the Porangahau Member. Although the subsurface distribution is largely unknown due to the scarcity of well data, existing evidence indicates that the uppermost Cretaceous to Paleocene sequence is absent from the southern Woodville and Aorangi blocks.

Moore (1988b) has shown the distribution and thickness of the Waipawa Black Shale and Whangai Formation in eastern North Island. The Waipawa Black Shale is thickest $(>50 \mathrm{~m})$ in coastal northern Wairarapa, while it is absent from the Whangai Range and southern Wairarapa (Figure 8.2a). The Whangai Formation reaches a maximum thickness of $500 \mathrm{~m}$ in coastal northern Wairarapa and about $400 \mathrm{~m}$ in Otane, southern Hawke's Bay, while less than $100 \mathrm{~m}$ is present in coastal southern Hawke's Bay (Figure 8.2b).

\subsubsection{Burial and maturation of potential source rocks}

Based on a present day geothermal gradient of $23.1^{\circ} \mathrm{C} / \mathrm{km}$, Geosearch (1991) calculated the oil generation window occurs at burial depths of between $3000-4500 \mathrm{~m}$. The lack of seismic survey coverage across the southern East Coast Basin prevents a detailed knowledge of sediment thicknesses, and hence burial depths of the prospective source rock sequence. Existing seismic, however, does delineate broad regions of greater sediment thicknesses and these have recently been summarised by Uruski (1996).

The greatest sediment thicknesses appear to be present offshore, with up to $3 \mathrm{~s}$ TWT recorded from offshore southern Wairarapa, increasing to $5 \mathrm{~s}$ TWT offshore southern Hawke's Bay and possibly $>6 \mathrm{~s}$ TWT in Hawke Bay itself (Uruski, 1996). Seismic coverage and quality is poor in southern Wairarapa with no greater than $1 \mathrm{~s}$ TWT 
recorded. In the Woodville Block of southern Hawke's Bay, Takapau-1, Rakaiatai-1, Ongaonga- 1 and Mason Ridge-1 all encountered basement rocks after drilling Miocene or younger sediments, while Taradale- 1 terminated at $1660 \mathrm{~m}$ in sediments of Late Eocene age; no significant hydrocarbon shows were encountered. As in the offshore region, onshore sediment thicknesses appear to increase to the north reaching a maximum in the northern Hawke's Bay region.

In summary, sediment thicknesses are greatest offshore and to the north (Hawke Bay) of the southern East Coast Basin and it is here that the prospective source rock sequence is more likely to be present and buried to a depth sufficient for significant hydrocarbon generation.

\subsubsection{Southern East Coast Basin prospectivity}

It is beyond the scope of this thesis to delineate prospective regions based on the sum of the factors that comprise the petroleum system. However, in a review of the East Coast Basin licence blocks offered in 1995, Uruski (1996) concluded that none could be written off as non-prospective. In a subjective rating of the prospectivity of the blocks, Uruski (1996) favoured (in descending order of prospectivity) the offshore Hawke Bay region, and offshore southern Hawke's Bay, followed by the onshore Hawke's Bay and southern Hawke's Bay regions. Least prospective were onshore northern Wairarapa, offshore northern Wairarapa, offshore southern Wairarapa, and onshore southern Wairarapa regions. Of the factors contributing to the petroleum system, source rock and maturation are likely to be favourable in the Hawke Bay and offshore southern Hawke's Bay region and also onshore Hawke's Bay, where the greatest sediment thicknesses are more likely to contain a thermally mature and well developed source rock sequence.

To the author's knowledge no major seismic surveys have been conducted in the Marlborough region, and consequently sediment thicknesses and subsurface structures remain largely unknown. In a review of the petroleum prospects of Marlborough, Stoneley (1960) suggested the most prospective regions, based on known reservoir rocks, are in the north of the region such as the Ward Syncline, with little prospectivity to the south of the Ure River. Marlborough is virtually unexplored and clearly represents a high risk venture. Considerable exploration work needs to be carried out before credible plays can be developed.

If hydrocarbon generation in the East Coast Basin occurs in a manner similar to that suggested in the previous section, then exploration efforts should target regions where 
the Whangai Formation has reached sufficient depth for petroleum generation and expulsion. These regions should have additional source potential from the Waipawa Black Shale. Shallower burial depths may result in a less mature source sequence with hydrocarbon generation only from the Waipawa Black Shale and this may not be sufficient for commercial accumulations. Again, the regions of greatest sediment thickness are most prospective and these include the Hawke Bay region and those areas immediately adjacent to the north and south, and also the East Coast Allochthon in the northern part of the Basin. 


\subsection{Summary}

- Results of TOC and Rock-Eval pyrolysis indicate the latest Cretaceous Whangai Formation (the Upper Calcareous and Rakauroa members in particular) and the Paleocene Waipawa Black Shale are the only good potential petroleum source rocks in the southern East Coast Basin;

- The middle to Late Cretaceous Glenburn and Te Mai formations, previously considered good potential source rocks due to their carbonaceous nature (TOC contents up to 1.30 and $1.52 \%$ respectively), comprise predominantly Types III and IV (structured terrestrial and semi-opaque) kerogen and have little hydrocarbon generative potential $(\mathrm{HI}$ values $<50$ );

- The latest Cretaceous Flags Formation and Mata Series sediments, and the Miocene Whakataki Formation are gas-prone $(\mathrm{HI}<150)$, while all remaining formations analysed are organically-lean and have little source potential;

- Although low in organic carbon the Torlesse Supergroup has organic matter that is not postmature but has a maturity, in at least some cases, below the onset of oil generation;

- The Waipawa Black Shale is immature for hydrocarbon generation in outcrop, but is organic-rich (TOC contents up to 5.69\%) and is both oil and gas-prone (HI values up to 221). Kerogen composition is highly variable, with both dominant amorphous (Rogers, 1995) and structured terrestrial (this study) compositions, and this may explain the variable hydrocarbon generative potential of this formation. The Waipawa Black Shale has a unique biomarker assemblage showing high relative abundances of $\mathrm{C}_{30}$ steranes, 28,30-bisnorhopane, and low proportions of $\mathrm{C}_{28}$ steranes, and the bitumen extracts are characterised by isotopically heavy $\delta^{13} \mathrm{C}$ values. $\mathrm{S} / \mathrm{C}$ and trace metal ratios (with the exception of $\mathrm{V} / \mathrm{Cr}$ ), a high sulphur content, and high relative abundances of 28,30-bisnorhopane indicate dysoxic and periodically anoxic depositional conditions;

- The Whangai Formation is immature to marginally mature in outcrop. The Upper Calcareous and Rakauroa members have a 'fair' TOC content (up to 1.37\%) and are both oil and gas-prone (HI values up to 218) with kerogen Types II and III. Organic matter comprises predominantly structured terrestrial kerogen with variable contributions of structured aqueous and semi-opaque kerogen. Structured aqueous 
kerogen is more abundant in the Upper Calcareous Member than the Rakauroa Member and indicates a greater marine influence. The Whangai Formation is characterised by high proportions of $\mathrm{C}_{28}$ steranes and low relative abundances of $\mathrm{C}_{30}$ steranes and 28,30-bisnorhopane and bitumen extracts with isotopically light $\delta^{13} \mathrm{C}$ values. S/C and trace metal ratios, moderate sulphur contents and occasionally high relative abundances of 28,30-bisnorhopane indicate deposition under conditions of reduced oxygen;

- At least two families of oils are present in the southern East Coast Basin. The first family of oils, comprising the Kerosene Rock, Westcott, Tiraumea and Okau Stream oils, contain both marine and terrestrial organic matter and appears to have been deposited under largely anoxic conditions. These oils are characterised by high relative abundances of $\mathrm{C}_{30}$ steranes and 28,30-bisnorhopane, low proportions of $\mathrm{C}_{28}$ steranes and have isotopically heavy $\delta^{13} \mathrm{C}$ values. The Waipatiki oil, from the southern East Coast Basin, and Kora-1 oil from the northern Taranaki Basin are included in this family of oils. The second family, comprising the Knights Stream and Isolation Creek oils, is derived from predominantly marine organic matter with a moderate terrestrial contribution. These oils are characterised by low relative abundances of $\mathrm{C}_{30}$ steranes and 28,30-bisnorhopane, high proportions of $\mathrm{C}_{28}$ steranes and isotopically light $\delta^{13} \mathrm{C}$ values. The correlation of these oils is tentative due to the lack of unusual biomarker compounds. The major seep oils of the northern East Coast Basin (Waitangi, Totangi and Rotokautuku) have similar geochemical characteristics and are also included in this family of oils;

- The Kerosene Rock, Westcott, Tiraumea and Okau Stream oils are correlated to the Waipawa Black Shale by similar geochemical characteristics including high relative abundances of $\mathrm{C}_{30}$ steranes and 28,30-bisnorhopane, low proportions of $\mathrm{C}_{28}$ steranes and isotopically heavy $\delta^{13} \mathrm{C}$ values. The Waipatiki and Kora-1 oils are also correlated to the Waipawa Black Shale and its lateral equivalents;

- The Knights Stream and Isolation Creek oils are tentatively correlated to the Upper Calcareous Member and possibly the Rakauroa Member of the Whangai Formation on the basis of low relative abundances of $\mathrm{C}_{30}$ steranes, high proportions of $\mathrm{C}_{28}$ steranes and isotopically light $\delta^{13} \mathrm{C}$ values. Although these characteristics are also apparent in a number of other possible source rocks, only the Whangai Formation has suitable hydrocarbon potential; and 
- Although the Waipawa Black Shale has a greater hydrocarbon generative potential it appears that the thicker Whangai Formation is the greater source of hydrocarbons in the East Coast Basin. 


\section{References}

Adams, A. G. and Ballance, P. F. (1988): A study of sedimentary rocks 70 to 110 million years old in southern Hawkes Bay, with comment on their hydrocarbon-generating potential. Publication P132. New Zealand Energy Research and Development Committee, Ministry of Energy: 22pp.

Alexander, R., Kagi, R. I. and Woodhouse, G. W. (1981): Geochemical correlation of Windalia oil and extracts of Winning Group (Cretaceous) potential source rocks, Barrow subbasin, Western Australia. American Association of Petroleum Geologists Bulletin, Vol. 65: pp. 235-250.

Alexander, S. (1990): The late Cenozoic structure of an area in southeast Wairarapa, New Zealand. Unpublished B.Sc (Hons) thesis, Victoria University of Wellington.

Amoco Staff (1990): PPL 38318 East Coast Basin discussion of results from June 1989 field program North Island, New Zealand. Amoco New Zealand Exploration Co. Ltd. New Zealand unpublished open-file Petroleum Report No. 1677.

Anders, D. (1991): Geochemical exploration methods. In, Merrill, R. K. (Ed.), Source and Migration Processes and Evaluation Techniques. Treatise of Petroleum Geology. Handbook of Petroleum Geology. American Association of Petroleum Geologists, Tulsa, Oklahoma: pp. 89-95.

Andrews, P. B. (1982): Revised guide to recording field observations in sedimentary sequences. Report NZGS 102. Department of Scientific and Industrial Research, New Zealand: 74pp.

Arthur, M. A., Dean, W. E. and Pratt, L. M. (1988): Geochemical and climatic effects of increased marine organic carbon burial at the Cenomanian/Turonian boundary. Nature, Vol. 335: pp. 714-717.

Ballance, P. F. (1993a): The paleo-Pacific, post-subduction, passive margin thermal relaxation sequence (Late Cretaceous - Paleogene) of the drifting New Zealand continent. In, Ballance, P. F. (Ed.), South Pacific Sedimentary Basins. Sedimentary Basins of the World, 2. Elsevier Science Publishers B. V., Amsterdam: pp. 93-110.

Ballance, P. F. (1993b): The New Zealand Neogene forearc basins. In, Ballance, P. F. (Ed.), South Pacific Sedimentary Basins. Sedimentary Basins of the World, 2. Elsevier Science Publishers B. V., Amsterdam: pp. 177-193.

Barker, C. (1979): Organic Geochemistry in Petroleum Exploration. AAPG Education Course Note Series No. 10. American Association of Petroleum Geologists, Tulsa, Oklahoma: 159pp.

Barwise, A. J. G. (1990): Role of nickel and vanadium in petroleum classification. Energy and Fuels, Vol. 4: pp. 647-652.

Baskin, D. K. and Peters, K. E. (1992): Early generation characteristics of a sulfur-rich Monterey kerogen. American Association of Petroleum Geologists Bulletin, Vol. 76, No. 1: pp. 1-13.

Biros, D., Cuevas, R. and Moehl, B. (1994): Well completion report, Titihaoa-1, PPL 38318. Amoco New Zealand Exploration Co. Ltd. New Zealand unpublished open-file Petroleum Report No. 2081 .

Brooks, G. G. and Remus, D. (1985): Hydrocarbon potential of PPL 38082 and vicinity (Gisborne) New Zealand. Petroleum Corporation of New Zealand (Exploration) Ltd. New Zealand unpublished open-file Petroleum Report No. 1134: 68pp. 
Collier, R. J. (1989): Geochemical biomarker studies of oils and potential source rocks of the Taranaki Basin, New Zealand. Unpublished Ph.D thesis, Victoria University of Wellington: 180pp.

Cook, R. A. (1987): The geology and geochemistry of the crude oils and source rocks of western New Zealand. Unpublished Ph.D thesis, Victoria University of Wellington: $214 \mathrm{pp}$.

Croft Staff (1992): Petroleum Prospecting Licence PPL 38320 Onshore New Zealand Information Brochure. Croft Oil and Gas PLC. New Zealand unpublished open-file Petroleum Report No. 1837.

Cutten, H. N. C. (1992): Geological structure of the East Coast, North Island, New Zealand. In, Ministry of Commerce, 1991 New Zealand Oil Exploration Conference Proceedings. The Publicity Unit, Crown Minerals Operations Group, Energy and Resources Division, Ministry of Commerce: pp. 72-79.

Darley, J. H. (1969a): Taradale No. 1 well completion report. BP Shell Aquitaine and Todd Petroleum Development Limited. New Zealand unpublished open-file Petroleum Report No. 331.

Darley, J. H. (1969b): Rakaiatai No. 1 well completion report. BP Shell Aquitaine and Todd Petroleum Development Limited. New Zealand unpublished open-file Petroleum Report No. 330.

Demaison, G. J. and Moore, G. T. (1988): Anoxic environments and oil source bed genesis. In, Beaumont, E. A. and Foster, N. H. (Compilers). Geochemistry. Treatise of Petroleum Geology Reprint Series, No. 8. American Association of Petroleum Geologists, Tulsa, Oklahoma: pp. 135-165.

Dill, H., Teschner, M. and Wehner, H. (1988): Petrography, inorganic and organic geochemistry of Lower Permian carbonaceous fan sequences ("Brandschiefer Series") - Federal Republic of Germany: Constraints to their paleogeography and assessment of their source rock potential. Chemical Geology, Vol. 67: pp. 307-325.

Erdman, C. F. and Kelsey, H. M. (1992): Pliocene and Pleistocene stratigraphy and tectonics, Ohara Depression and Wakarara Range, North Island, New Zealand. New Zealand Journal of Geology and Geophysics, Vol. 35: pp. 177-192.

Espitalié, J., Madec, M., and Tissot, B. (1980): Role of mineral matrix in kerogen pyrolysis: Influence on petroleum generation and migration. The American Association of Petroleum Geologists Bulletin, Vol. 64, No. 1: pp. 59-66.

Field, B. (1995): Reservoir potential of the East Coast oil and gas province. Petroleum Exploration in New Zealand News. The Publicity Unit, New Zealand Crown Minerals, Ministry of Commerce, Vol. 45: pp. 11-19.

Field, B., Uruski, C. and Delteil, J. (1995): East Coast hydrocarbon potential - an updated interpretation. Petroleum Exploration in New Zealand News. The Publicity Unit, Crown Minerals Operations Group, Ministry of Commerce, Vol. 44: pp. 10-17.

Francis, D. A. (1992a): Oil seeps and oil impregnations in the Dannevirke-Castlepoint area, southern East Coast Basin. Petroleum Exploration in New Zealand News. The Publicity Unit, Crown Minerals Operation Group, Ministry of Commerce, Vol. 34: pp. 28-32.

Francis, D. A. (1992b): The East Coast: An old challenge with new prospects. In, Ministry of Commerce, 1991 New Zealand Oil Exploration Conference Proceedings. The Publicity Unit, Crown Minerals Operations Group, Energy and Resources Division, Ministry of Commerce: pp. 80-88. 
Francis, D. A. (1993a): Historic oil exploration in the East Coast Basin - part 1: 1874-1932. Petroleum Exploration in New Zealand News. The Publicity Unit, Crown Minerals Operations Group, Ministry of Commerce, Vol. 38: pp. 21-27.

Francis, D. A. (1993b): Report on the geology of the Waimarama-Kidnappers area, Hawkes Bay adjacent to PPL 38321. Conquest Exploration Ltd. New Zealand unpublished open-file Petroleum Report No. 1926.

Francis, D. A. (1993c): Report on the geology of the Mangaone-Opoutama area, northern Hawkes Bay adjacent to offshore PPL 38321. Conquest Exploration Ltd. New Zealand unpublished openfile Petroleum Report No. 1927.

Francis, D. A. (1993d): Report on the geology of the Mahia area, northern Hawkes Bay adjacent to offshore PPL 38321. Conquest Exploration Ltd. New Zealand unpublished open-file Petroleum Report No. 1928.

Francis, D. A. (1994): Historic oil exploration in the East Coast Basin - part 2: 1932-1940. Petroleum Exploration in New Zealand News. The Publicity Unit, Crown Minerals Operations Group, Ministry of Commerce, Vol. 39: pp. 22-26.

Francis, D. A. (1995a): Oil and gas seeps of northern and central East Coast Basin. In, Petroleum Exploration in New Zealand News. The Publicity Unit, Crown Minerals Operations Group, Ministry of Commerce, Vol. 44: pp. 21-27.

Francis, D. A. (1995b): Petroleum exploration in the East Coast Basin - part 3: 1940-1994. Petroleum Exploration in New Zealand News. The Publicity Unit, New Zealand Crown Minerals, Ministry of Commerce, Vol. 45: pp. 20-27.

Francis, D. A. and Johansen, A. (1996): The petroleum geology of onshore and offshore Hawke's Bay, East Coast Basin, New Zealand. In, Ministry of Commerce, 1996 New Zealand Petroleum Conference Proceedings. The Publicity Unit, New Zealand Crown Minerals, Ministry of Commerce: pp. 63-70.

Fry, S. (1982): The geochemistry of outcrop samples from the East Coast Basin of North Island, New Zealand. BP Shell Todd (Canterbury) Services Ltd. New Zealand unpublished open-file Petroleum Report No. 916.

Gehman, H. M. (1962): Organic matter in limestones. Geochimica et Cosmochimica Acta, Vol. 26: pp. 885-897.

Geosearch (1991): Petroleum Resources of New Zealand. Resource Information Report 10. Energy and Resources Division, Ministry of Commerce.

Geotech (1992): Source rock characterisation study Opoutama-1. Geotechnical Services Pty Ltd. Confidential report prepared for Petrocorp Exploration Ltd.

Gibbons, M. J. (1980): A review of the maturity and source rock potential in the Gisborne region, East Coast Basin, North Island, New Zealand. In, Hoolihan, K., Proposed study of source rock potential in the Gisborne region, East Coast Basin, North Island, New Zealand. Petrocorp Exploration Ltd. New Zealand unpublished open-file Petroleum Report No. 835: pp. 75-81.

Gibbons, M. J. and Fry, S. (1983): A compilation of the geochemical characteristics of the oils and condensates of New Zealand. BP Oil Exploration Co. of NZ. New Zealand unpublished openfile Petroleum Report No. 989.

Gransch, J. A. and Posthuma, J. (1974): On the origin of sulphur in crudes. In, Tissot, B. and Bienner, F. (Eds.), Advances in Organic Geochemistry: pp. 727-739. 
Gregory, M. R. and Johnston, K. A. (1987): A nontoxic substitute for hazardous heavy liquids - aqueous sodium polytungstate $\left(3 \mathrm{Na}_{2} \mathrm{WO}_{4} \cdot 9 \mathrm{WO}_{3} \cdot \mathrm{H}_{2} \mathrm{O}\right)$ solution. New Zealand Journal of Geology and Geophysics, Vol. 30: pp. 317-320.

Hall, W. D. M. (1964): The geology of Coverham and the upper Waima Valley, Marlborough. Unpublished M.Sc thesis, Victoria University of Wellington.

ten Haven, H. L., de Leeuw, J. W., Peakman, T. M. and Maxwell, J. R. (1986): Anomalies in steroid and hopanoid maturity indices. Geochimica et Cosmochimica Acta, Vol. 50: pp. 853-855.

ten Haven, H. L., de Leeuw, J. W., Rullkötter, J. and Sinninghe Damsté, J. S. (1987): Restricted utility of the pristane/phytane ratio as a palaeoenvironmental indicator. Nature, Vol. 330: pp. 641643.

ten Haven, H. L., Lafargue, E. and Kotarba, M. (1993): Oil/oil and oil/source rock correlations in the Carpathian Foredeep and Overthrust, south-east Poland. Organic Geochemistry, Vol. 20, No. 7: pp. 935-959.

Heffer, K., Milne, A. D. and Simpson, C. (1976): Well completion report Hawke Bay-1. BP Shell Aquitaine and Todd Petroleum Development Limited. New Zealand unpublished open-file Petroleum Report No. 667.

Hirner, A. V. and Lyon, G. L. (1989): Stable isotope geochemistry of crude oils and of possible source rocks from New Zealand - 1: carbon. Applied Geochemistry, Vol. 4: pp. 109-120.

Hirner, A. V. and Robinson, B. W. (1989): Stable isotope geochemistry of crude oils and of possible source rocks from New Zealand - 2: sulphur. Applied Geochemistry, Vol. 4: pp. 121-130.

Hornibrook, N. de B. (1959): Waipawa Black Shale (Siltstone). In, Flemming, C. A. (Ed.), Lexique Stratigraphique International, Vol. 6, No. 4: pp. 443-444.

Horsfield, B. and Rullkötter, J. (1994): Diagenesis, catagenesis, and metagenesis of organic matter. In, Magoon, L. B. and Dow, W. G. (Eds.), The Petroleum System - From Source to Trap. AAPG Memoir 60. American Association of Petroleum Geologists, Tulsa, Oklahoma: pp. 189-199.

Huang, W.-Y. and Meinschein, W. G. (1979): Sterols as ecological indicators. Geochimica et Cosmochimica Acta, Vol. 43: pp. 739-745.

Hutson, R. J. (1989): PPL 38318, East Coast Basin. Assessment of hydrocarbon prospectivity. North Island, New Zealand. Amoco New Zealand Exploration Co. Ltd. New Zealand unpublished open-file Petroleum Report No. 1516.

Jackson, L. L. and Roof, S. R. (1992): Determination of the forms of carbon in geologic materials. Geostandards Newsletter, Vol. 16, No. 2: pp. 317-323.

Jackson, R. G. (1982): The geochemistry of Cretaceous to Miocene outcrop samples from the East Coast Fold Belt of North Island, New Zealand. BP Shell Todd (Canterbury) Services. New Zealand unpublished open-file Petroleum Report No. 916.

Jacobson, S. R. (1991): Petroleum source rocks and organic facies. In, Merrill, R. K. (Ed), Source and Migration Processes and Evaluation Techniques. Treatise of Petroleum Geology. Handbook of Petroleum Geology. American Association of Petroleum Geologists, Tulsa, Oklahoma: pp. 311.

Jarvie, D. M. (1991): Total organic carbon (TOC) analysis. In, Merrill, R. K. (Ed.), Source and Migration Processes and Evaluation Techniques. Treatise of Petroleum Geology. Handbook of Petroleum Geology. American Association of Petroleum Geologists, Tulsa, Oklahoma: pp. 113-118. 
Johnston, J. H., Rogers, K. M., Francis, D. A. and Collen, J. D. (1992): A comparison of some crude oils and potential source rocks in the East Coast Basin, using geochemical biomarkers. In, Ministry of Commerce, 1991 New Zealand Oil Exploration Conference Proceedings. The Publicity Unit, Crown Minerals Operations Group, Energy and Resources Division, Ministry of Commerce: pp. 299-309.

Johnston, M. R. (1975): Sheet N159 and part sheet N158 Tinui-Awatoitoi. Geological map of New Zealand 1:63 360. New Zealand Department of Scientific and Industrial Research, Wellington.

Johnston, M. R. (1980): Geology of the Tinui-Awatoitoi district. New Zealand Geological Survey Bulletin 94: 62pp.

Jones, B. and Manning, A. C. (1994): Comparison of geochemical indices used for the interpretation of paleoredox conditions in ancient mudstones. Chemical Geology, Vol. 111: pp. 111-129.

Kamp, P. J. (1992): Landforms of Hawke's Bay and their origin: A plate tectonic interpretation. In, Soons, J. M. and Selby, M. J. (Eds.), Landforms of New Zealand (2nd Ed.). Longman Paul Limited, Auckland: pp. 344-366.

Katz, B. J. (1983): Limitations of Rock-Eval pyrolysis for typing of organic matter. Organic Geochemistry, Vol. 4: pp. 195-199.

Katz, H. R. (1968): Potential oil formations in New Zealand, and their stratigraphic position as related to basin evolution. New Zealand Journal of Geology and Geophysics, Vol. 11, No. 5: pp. 1077-1133.

Katz, H. R. (1976): Sedimentary basins and petroleum prospects onshore and offshore New Zealand. In, Halbouty, M. T., Maher, J. C., Lian, H. M. (Eds.), Circum-Pacific Energy and Mineral Resources. AAPG Memoir 25. American Association of Petroleum Geologists, Tulsa, Oklahoma: pp. 217-228.

Katz, H. R.(1981): Probable gas hydrate in continental slope east of the North Island, New Zealand. Journal of Petroleum Geology, Vol. 3, No. 3: pp. 315-324.

Katz, H. R. (1983): The East Coast Fold Belt - or "East Coast Deformed belt"? Comment. New Zealand Journal of Geology and Geophysics, Vol. 26: pp. 321-322.

Killops, S. (1996): A geochemical perspective of oil generation in New Zealand basins. In, Ministry of Commerce, 1996 New Zealand Petroleum Conference Proceedings. The Publicity Unit, New Zealand Crown Minerals, Ministry of Commerce: pp. 179-187.

Killops, S. D. and Killops, V. J. (1993): An Introduction to Organic Geochemistry. Longman Group UK Ltd, Harlow: 265pp.

Killops, S. D., Woolhouse, A. D., Weston, R. J. and Cook, R. A.. (1994): A geochemical appraisal of oil generation in the Taranaki Basin, New Zealand. American Association of Petroleum Geologists Bulletin, Vol. 78, No. 10: pp. 1560-1585.

Killops, S., Morgans, H. and Leckie, D. (1996): The Waipawa Black Shale - a ubiquitous super source rock? In, Ministry of Commerce, 1996 New Zealand Petroleum Conference Proceedings. The Publicity Unit, New Zealand Crown Minerals, Ministry of Commerce: pp. 12-21.

Kingma, J. T. and Speden, I. G. (1978): (Cretaceous) Eastern North Island. In, Suggate, R. P., Stevens, G. R. and Te Punga, M. T. (Eds.), The Geology of New Zealand. Government Printer, Wellington: pp. 368-375. 
Laing, A. C. M. (1961): The geology and petroleum prospects of the Dannevirke area. BP Shell and Todd Petroleum Development Ltd. New Zealand unpublished open-file Petroleum Report No. 318: 55pp.

Laing, A. C. M. (1991): Weber stratigraphic drilling report PPL 38317. East Coast Petroleum Ltd. New Zealand unpublished open-file Petroleum Report No. 1676.

Laird, M. G. (1992): Cretaceous stratigraphy and evolution of the Marlborough segment of the East Coast region. In, Ministry of Commerce, 1991 New Zealand Oil Exploration Conference Proceedings. The Publicity Unit, Crown Minerals Operations Group, Energy and Resources Division, Ministry of Commerce: pp. 89-100.

Langford, F. F. and Blanc-Valleron, M. -M. (1990): Interpreting Rock-Eval pyrolysis data using graphs of pyrolizable hydrocarbons vs total organic carbon. American Association of Petroleum Geologists Bulletin, Vol. 74, No. 6: pp. 799-804.

Larter, S. R. and Horsfield, B. (1993): Determination of structural components of kerogens by the use of analytical pyrolysis methods. In, Engel, M. H. and Macko, S. A. (Eds), Organic Geochemistry. Principles and Applications. Plenum Press, New York: pp. 271-287.

Leckie, D. A., Morgans, H. E. G., Wilson, G. J., Uruski, C. I. (1992): Stratigraphic framework and source-rock potential of Maastrichtian to Paleocene marine shale, East Coast, North Island, New Zealand: Hydrocarbon prospects. Institute of Geological and Nuclear Sciences Science Report 92/5: 31pp.

Lensen, G. J. (1962): Sheet 16 - Kaikoura (1st edition). Geological Map of New Zealand 1:250,000. Department of Scientific and Industrial Research, Wellington.

Lensen, G. J. (1978a): (Cretaceous) Marlborough. In, Suggate, R. P., Stevens, G. R. and Te Punga, M. T. (Eds.), The Geology of New Zealand. Government Printer, Wellington: pp. 383-390.

Lensen, G. J. (1978b): (Tertiary) Marlborough. In, Suggate, R. P., Stevens, G. R. and Te Punga, M. T. (Eds.), The Geology of New Zealand. Government Printer, Wellington: pp. 482-488.

Leslie, W. C. (1971a): Ongaonga No. 1 well completion report. Beaver Exploration New Zealand Limited/Longreach Oil Limited. New Zealand unpublished open-file Petroleum Report No. 271.

Leslie, W. C. (1971b): Takapau No. 1 well completion report. Beaver Exploration New Zealand Limited/Longreach Oil Limited. New Zealand unpublished open-file Petroleum Report No. 272.

Leslie, W. C. (1971c): Mason Ridge No. 1 well completion report. Beaver Exploration New Zealand Limited/Longreach Oil Limited. New Zealand unpublished open-file Petroleum Report No. 273.

Leslie, W. C. and Hollingsworth, R. J. S. (1972): Exploration in the East Coast Basin, New Zealand. The APEA Journal, Vol. 12, Part 1: pp. 39-44.

Leventhal, J. (1983): An interpretation of carbon and sulphur relationships in Black Sea sediments as indicators of environments of deposition. Geochimica et Cosmochimica Acta, Vol. 47: pp. 133-137.

Leventhal, J. (1993): Metals in Black Shales. In, Engel, M. H. and Macko, S. A. (Eds.), Organic Geochemistry. Principles and Applications. Plenum Press, New York: pp. 581-592.

Lewan, M. D. (1984): Factors controlling the proportionality of vanadium to nickel in crude oils. Geochimica et Cosmochimica Acta, Vol. 48: pp. 2231-2238. 
Lewis, K. B. and Pettinga, J. R. (1993): The emerging, imbricate frontal wedge of the Hikurangi Margin. In, Ballance, P. F. (Ed.), South Pacific Sedimentary Basins. Sedimentary Basins of the World, 2. Elsevier Science Publishers B. V., Amsterdam: pp. 225-247.

Leythaeuser, D., Mackenzie, A., Schaefer, R. G. and Bjorøy, M. (1984): A novel approach for recognition and quantification of hydrocarbon migration effects in shale-sandstone sequences. American Association of Petroleum Geologists Bulletin, Vol. 68, No. 2: pp. 196-219.

Lipke, L. J. (1989): Seep and outcrop samples from PPL 38318, East Coast, North Island, New Zealand. Amoco New Zealand Exploration Co. Ltd. New Zealand unpublished open-file Petroleum Report No. 1516.

Lowe, S. P. and O'Reilly, S. O. (1980): Geochemistry of outcrop samples, well cuttings and an oil seepage sample from the Gisborne area. In, Hoolihan, Proposed study of source rock potential in the Gisborne region, East Coast Basin, North Island, New Zealand. Petrocorp Exploration Ltd. New Zealand unpublished open-file Petroleum Report No. 835: pp. 62-74.

McCaffrey, M. A., Moldowan, J. M., Lipton, P. A., Summons, R. E., Peters, K. E., Jeganathan, A. and Watt, D. S. (1994): Paleoenvironmental implications of novel $C_{30}$ steranes in Precambrian to Cenozoic age petroleum and bitumen. Geochimica et Cosmochimica Acta, Vol. 58, No. 1: pp. 529-532.

Mackenzie, A. S. (1984): Applications of biological markers in petroleum geochemistry. In, Brooks, J. and Welte, D. (Eds.), Advances in Petroleum Geochemistry, Vol. 1. Academic Press, London: pp. 115-214.

Mackenzie, A. S., Disko, U. and Rullkötter, J. (1982): Determination of hydrocarbon distributions in oils and sediment extracts by gas chromatography-high resolution mass spectrometry. Organic Geochemistry, Vol. 5, No. 2: pp. 57-63.

McLernon, C. R. (1978): Indications of petroleum in New Zealand. New Zealand Geological Survey. New Zealand unpublished open-file Petroleum Report No. 839.

McLernon, C. R. (1992): The search for petroleum in the Poverty Bay-East Coast district. The first fifty years: 1872-1921. Gisborne Museum and Arts Centre Occasional Papers No. 1: 55pp.

Magoon, L. B. and Dow, W. G. (1994): The petroleum system. In, Magoon, L. B. and Dow, W. G., (Eds.), The Petroleum System - From Source to Trap. AAPG Memoir 60. American Association of Petroleum Geologists, Tulsa, Oklahoma: pp. 3-24.

Mildenhall, D. C (1980): New Zealand Late Cretaceous and Cenozoic plant biogeography: a contribution. Palaeogeography, Palaeoclimatology, Palaeoecology, Vol. 31: pp. 197-233.

Ministry of Commerce (1993): The East Coast Region. An Introduction to the Petroleum Geology of New Zealand. The New Zealand Petroleum Prospectus 1993. The Publicity Unit, Crown Minerals Operations Group, Energy and Resources Division, Ministry of Commerce: pp. 54-63.

Moldowan, J. M., Seifert, W. K., Arnold, E. and Clardy, J. (1984): Structure proof and significance of stereoisomeric 28,30-bisnorhopanes in petroleum and petroleum source rocks. Geochimica et Cosmochimica Acta, Vol. 48: pp. 1651-1661.

Moldowan, J. M., Seifert, W. K. and Gallegos, E. J. (1985): Relationship between petroleum composition and depositional environment of petroleum source rocks. American Association of Petroleum Geologists Bulletin, Vol. 69, No. 8: pp. 1255-1268. 
Moldowan, J. M., Fago, F. J., Lee, C. Y., Jacobson, S. R., Watt, D. S., Slougui, N.-E., Jeganathan, A. and Young, D. C. (1990): Sedimentary 24-n-propylcholestanes, molecular fossils diagnostic of marine algae. Science, Vol. 247: pp. 309-312.

Moldowan, J. M., Dahl, J., Huizinga, B. J., Fago, F. J., Hickey, L. J., Peakman, T. M. and Taylor, D. W. (1994): The molecular fossil record of oleanane and its relation to angiosperms. Science, Vol. 265: pp. 768-771.

Moore, P. R. (1980): Late Cretaceous-Tertiary stratigraphy, structure, and tectonic history of the area between Whareama and Ngahape, eastern Wairarapa, New Zealand. New Zealand Journal of Geology and Geophysics, Vol. 23: pp. 167-177.

Moore, P. R. (1988a): Structural divisions of eastern North Island. New Zealand Geological Survey Record 30: 24pp.

Moore, P. R. (1988b): Stratigraphy, composition and environment of deposition of the Whangai Formation and associated Late Cretaceous-Paleocene rocks, eastern North Island, New Zealand. New Zealand Geological Survey Bulletin 100: 82pp.

Moore, P. R. (1989): Stratigraphy of the Waipawa Black Shale (Paleocene), eastern North Island, New Zealand. New Zealand Geological Survey Record 38: 19pp.

Moore, P. R. and Speden, I. G. (1979): Stratigraphy, structure, and inferred environments of deposition of the Early Cretaceous sequence, eastern Wairarapa, New Zealand. New Zealand Journal of Geology and Geophysics, Vol. 22, No. 4: pp. 417-433.

Moore, P. R. and Speden, I. G. (1984): The Early Cretaceous (Albian) sequence of eastern Wairarapa, New Zealand. New Zealand Geological Survey Bulletin 97: 98pp.

Moore, P. R., Adams, A. G., Isaac, M. J., Mazengarb, C., Morgans, H. E. G. and Phillips, C. J. (1986): A revised Cretaceous - early Tertiary stratigraphic nomenclature for eastern North Island. New Zealand Geological Survey Report G104: 31pp.

Moore, P. R. and Morgans, H. E. G. (1987): Two new reference sections for the Wanstead Formation (Paleocene-Eocene) in southern Hawkes Bay. New Zealand Geological Survey Record 20: pp. 81-87.

Moore, P. R., Snowdon, L. R. and Osadetz, K. G. (1987): Maturation and petroleum source rock potential of the Whangai and Waipawa formations (Late Cretaceous-Paleocene), eastern North Island. New Zealand Geological Survey Record 20: pp. 17-23.

Morgans, H. E. G. (1977): The stratigraphy and micropaleontology of the Weber Formation in its type locality at Weber, southern Hawkes Bay. Unpublished B.Sc (Hons) thesis, Victoria University of Wellington.

Muirhead, J. M. (1983): An investigation of the methodology required for the classification of New Zealand crude and seep petroleum samples. Chemistry Division Department of Scientific and Industrial Research Report No. C.D. 2331: 40pp.

Murray, A. P., Summons, R. E., Boreham, C. J., Reed, J. D. and Francis, D. A. (1994): Geochemistry of oils and source rocks of the East Coast Basin and implications for the Taranaki Basin, New Zealand. In, Ministry of Commerce, 1994 New Zealand Oil Exploration Conference Proceedings. The Publicity Unit, Crown Minerals Operations Group, Energy and Resources Division, Ministry of Commerce: pp. 338-351.

Murray, S. I. (1992): The geology of the Kairakau/Mangakuri coastal area, southern Hawkes Bay, New Zealand. Unpublished B.SC (Hons), Victoria University of Wellington. 
Neef, G. (1991): Field guide to pre-conference trip: geology of the Pongaroa-Akitio districts, 23rd and 24th November 1991. Geological Society of New Zealand Miscellaneous Publication 59B: pp. 1-15.

Neef, G. (1992): Geology of the Akitio area (1:50 000 metric sheet U25BD, east), northeastern Wairarapa, New Zealand. New Zealand Journal of Geology and Geophysics, Vol. 35: pp. 533548.

Newman, J. (1997): New approaches to detection and correction of suppressed vitrinite reflectance. APPEA Journal: pp. 323-333.

Newman, J. and Newman, N. A. (1982): Reflectance anomalies in Pike River coals: evidence of variability in vitrinite type, with implications for maturation studies and "Suggate rank". New Zealand Journal of Geology and Geophysics, Vol. 25: pp. 233-243.

Noble, R. A. (1991): Geochemical techniques in relation to organic matter. In, Merrill, R. K. (Ed.), Source and Migration Processes and Evaluation Techniques. Treatise of Petroleum Geology. Handbook of Petroleum Geology. American Association of Petroleum Geologists, Tulsa, Oklahoma: pp. 97-102.

North, F. K. (1990): Petroleum Geology. Unwin-Hyman, Boston: $631 \mathrm{pp.}$

Pecsok, R. L., Shields, L. D., Cairns, T. and McWilliam, I. G. (1976): Modern Methods of Chemical Analysis, 2nd Edition. John Wiley and Sons, New York: 573pp.

Perrodon, A. (1988): Hydrocarbons. In, Beaumont, E. A. and Foster, N. H. (Eds.), Geochemistry. Treatise of Petroleum Geology Reprint Series, No. 8. American Association of Petroleum Geologists, Tulsa, Oklahoma: pp. 3-26.

Peters, K. E. (1986): Guidelines for evaluating petroleum source rock using programmed pyrolysis. American Association of Petroleum Geologists Bulletin, Vol. 70, No. 3: pp. 318-329.

Peters, K. E., Moldowan, J. M., Schoell, M. and Hempkins, W. B. (1986): Petroleum isotopic and biomarker composition related to source rock organic matter and depositional environment. Organic Geochemistry, Vol. 10: pp. 17-27.

Peters, K. E. and Moldowan, J. M. (1993): The Biomarker Guide. Interpreting Molecular Fossils in Petroleum and Ancient Sediments. Prentice Hall, Englewood Cliffs: 363pp.

Peters, K. E. and Cassa, M. R. (1994): Applied source rock geochemistry. In, Magoon, L. B. and Dow, W. G. (Eds.), The Petroleum System - From Source to Trap. AAPG Memoir 60. American Association of Petroleum Geologists, Tulsa, Oklahoma: pp. 93-120.

Pettinga, J. (1983): The East Coast Fold Belt - or "East Coast Deformed Belt"? Reply. New Zealand Journal of Geology and Geophysics, Vol. 26: pp. 323-324.

Philp, R. P. (1985a): Fossil Fuel Biomarkers - Applications and Spectra. Methods in Geochemistry and Geophysics, 23. Elsevier Science Publishers B. V., Amsterdam: 294pp.

Philp, R. P. (1985b): Biological markers in fossil fuel production. Mass Spectrometry Reviews, Vol. 4, No. 1: pp. 1-54.

Philp, R. P. (1993): Oil-oil and oil-source rock correlations: Techniques. In, Engel, M. H. and Macko, S. A. (Eds.), Organic Geochemistry. Principles and Applications. Plenum Press, New York: pp. 445-460.

Philp, R. P. and Gilbert, T. D. (1986a): The detection and identification of biological markers by computerized-gas chromatography-mass spectrometry. In, Johns, R. B. (Ed.), Biological 
Markers in the Sedimentary Record. Methods in Geochemistry and Geophysics, 24. Elsevier Science Publishers B.V., Amsterdam: pp. 227-248.

Philp, R. P. and Gilbert, T. D. (1986b): Biomarker distributions in Australian oils predominantly derived from terrigenous source material. Organic Geochemistry, Vol. 10: pp. 73-84.

Philp, R. P and Galvez-Sinibaldi, A. (1991): Characterization of organic matter by various pyrolysis techniques. In, Merrill, R. K. (Ed.), Source and Migration Processes and Evaluation Techniques. Treatise of Petroleum Geology, Handbook of Petroleum Geology. American Association of Petroleum Geologists, Tulsa, Oklahoma: pp. 107-112.

Powell, T. G. and McKirdy, D. M. (1973): Relationship between ratio of pristane to phytane, crude oil composition and geological environment in Australia. Nature, Vol. 243: pp. 37-39.

Prebble, W. M. (1976): The geology of the Kekerengu-Waima River district, north east Marlborough. Unpublished M.Sc thesis, Victoria University of Wellington.

Price, L. C. and Barker, C. E. (1985): Suppression of vitrinite reflectance in amorphous rich kerogen - a major unrecognized problem. Journal of Petroleum Geology, Vol. 8, No. 1: pp. 59-84.

Raiswell, R. and Berner, R. A. (1987): Organic C losses during burial and thermal maturation of normal marine shales. Geology, Vol. 15: pp. 853-856.

Reay, M. B. (1980): Cretaceous and Tertiary stratigraphy of part of the Middle Clarence Valley, Marlborough. Unpublished M.Sc thesis, University of Canterbury.

Reed, J. D. (1992): Exploration geochemistry of the Taranaki Basin with emphasis on Kora. In, Ministry of Commerce, 1991 New Zealand Oil Exploration Conference Proceedings. The Publicity Unit, Crown Minerals Operations Group, Energy and Resources Division, Ministry of Commerce: pp. 364-372.

Ritchie, D. D. (1986): Stratigraphy, structure and geological history of mid-Cretaceous sedimentary rocks across the Torlesse-like/non Torlesse boundary in the Sawtooth Range-Coverham area, Marlborough. Unpublished M.Sc thesis, University of Canterbury.

Rogers, K. M. (1995): Oil seeps and potential source rocks of the northern East Coast Basin, New Zealand; a geochemical study. Unpublished Ph.D thesis, Victoria University of Wellington: 178pp.

Rogers, K. M., Elgar, N. E., Collen, J. D. and Johnston, J. H. (1994): Biomarker geochemistry of seep oils and potential hydrocarbon source rocks from the northern East Coast Basin, New Zealand. In, Ministry of Commerce, 1994 New Zealand Oil Exploration Conference Proceedings. The Publicity Unit, Crown Minerals Operations Group, Energy and Resources Division, Ministry of Commerce: pp. 352-360.

Rohmer, M., Bisseret, P. and Neunlist, S. (1992): The hopanoids, prokaryotic triterpenoids and precursors of ubiquitous molecular fossils. In, Moldowan, J. M., Albrecht, Philp, R. P. (Eds.), Biological Markers in Sediments and Petroleum: A Tribute to Wolfgang K. Seifert. PrenticeHall, New Jersey: pp. 1-17.

Rullkötter, J. (1993): The thermal alteration of kerogen and the formation of oil. In, Engel, M. H. and Macko, S. A. (Eds.), Organic Geochemistry. Principles and Applications. Plenum Press, New York: pp. 373-396.

Rullkötter, J. and Wendisch, D. (1982): Microbial alteration of 17 $\alpha(\mathrm{H})$-hopane in Madagascar asphalts: Removal of C-10 methyl group and ring opening. Geochimica et Cosmochimica Acta, Vol, 46: pp. 1545-1553. 
Saikkonen, R. J. and Rautiainen, I. A. (1990): Determination of total and non-carbonate carbon in rock samples by a method using infrared absorption. Bulletin of the Geological Society of Finland, Vol. 62, Part 2: pp. 149-156.

Seifert, W. K. and Moldowan, J. M. (1986): Use of biological markers in petroleum exploration. In, Johns, R. B. (Ed.), Biological Markers in the Sedimentary Record. Methods in Geochemistry and Geophysics, 24. Elsevier Science Publishers B.V., Amsterdam: pp. 261-290.

Senftle, J. T. and Landis, C. R. (1991): Vitrinite reflectance as a tool to assess thermal maturity. In, Merrill, R. K. (Ed), Source and Migration Processes and Evaluation Techniques. Treatise of Petroleum Geology. Handbook of Petroleum Geology. American Association of Petroleum Geologists, Tulsa, Oklahoma: pp. 119-125.

Senftle, J. T., Landis, C. R. and McLaughlin, R. L. (1993): Organic petrographic approach to kerogen characterization. In, Engel, M. H. and Macko, S. A. (Eds.), Organic Geochemistry. Principles and Applications. Plenum Press, New York: pp. 355-374.

Sigalove, J. J. (1986): Cook Strait Sniffer geochemical survey March/April 1986. BP Oil Exploration Co. of NZ Ltd. New Zealand unpublished open-file Petroleum Report No. 1222.

Silverman, S. R. and Epstein, S. (1958): Carbon isotopic compositions of petroleum and other sedimentary organic materials. American Association of Petroleum Geologists Bulletin, Vol. 42: pp. 998-1012.

Simoneit, B. R. T. (1977): Diterpenoid compounds and other lipids in deep-sea sediments and their geochemical significance. Geochimica et Cosmochimica Acta, Vol. 41: pp. 463-476.

Simpson, J. and Jarvis, J. (1993): Technical review of the East Coast Basin. Petrocorp Exploration Limited. New Zealand unpublished open-file Petroleum Report No. 1972.

Sofer, Z. (1984): Stable carbon isotope compositions of crude oils: Application to source depositional environments and petroleum alteration. American Association of Petroleum Geologists Bulletin, Vol. 68, No. 1: pp. 31-49.

Sofer, Z. (1991): Stable isotopes in petroleum exploration. In, Merrill, R. K. (Ed.), Source and Migration Processes and Evaluation Techniques. Treatise of Petroleum Geology. Handbook of Petroleum Geology. American Association of Petroleum Geologists, Tulsa, Oklahoma: pp. 103-106.

Sparke, M., Wise, S., Bishop, D. and Hill, D. (1984): Palynological sample processing guide. Palaeontological report 1983/43. 0652L. Unpublished report by Esso Australia Ltd.

Speden, I. G. (1976): Fossil localities in Torlesse rocks of the North Island, New Zealand. Journal of the Royal Society of New Zealand, Vol. 6, No. I: pp. 73-91.

Spörli, K. B. (1980): New Zealand and oblique-slip margins: Tectonic development up to and during the Cenozoic. In, Ballance, P. F., Reading, H. G. (Eds.), Sedimentation in oblique slip mobile zones. International Association of Sedimentologists Special Publication 4: pp. 147-170.

Spörli, K. B. (1983): The East Coast Fold Belt - or "East Coast Deformed Belt"? Reply. New Zealand Journal of Geology and Geophysics Vol. 26: pp. 322-323.

Stoneley, R. (1960): Notes on the geology and oil prospects of Marlborough, South Island, New Zealand. B.P. Oil Exploration Co. of N.Z. Ltd. New Zealand unpublished open-file Petroleum Report No. 280.

Suggate, R. P. (1978): (Tertiary) Eastern North Island. In, Suggate, R. P., Stevens, G. R. and Te Punga, M. T. (Eds.), The Geology of New Zealand. Government Printer, Wellington: pp. 471-482. 
Summons, R. E., Thomas, J., Maxwell, J. R. and Boreham, C. J. (1992): Secular and environmental constraints on the occurrence of dinosterane in sediments. Geochimica et Cosmochimica Acta, Vol. 56: pp. 2437-2444.

Terashima, S. (1993): Determination of total nitrogen and carbon in twenty-two sedimentary rock reference samples by combustion elemental analyser. Geostandards Newsletter, Vol. 17, No. 1: pp. 123-125.

Tissot, B. P. and Welte, D. H. (1978): Petroleum Formation and Occurrence. A New Approach to Oil and Gas Exploration. Springer-Verlag, Berlin: 538pp.

Turnbull, R. J. (1988): The geology of the Lower Miocene Whakataki Formation, eastern Wairarapa. Unpublished M.Sc thesis, Victoria University of Wellington.

Tyson, R. V. (1995): Sedimentary Organic Matter, Organic Facies and Palynofacies. Chapman and Hall, London: 615pp.

Tyson, R. V. and Pearson, T. H. (1991): Modern and ancient continental shelf anoxia: an overview. In, Tyson, R. V. and Pearson, T. H. (Eds), Modern and Ancient Continental Shelf Anoxia. Geological Society of London Special Publication No. 58: pp. 1-24.

Uruski, C. (1996): Exploration of the East Coast Basin, North Island, New Zealand. In, Ministry of Commerce, 1996 New Zealand Petroleum Conference Proceedings. The Publicity Unit, New Zealand Crown Minerals, Ministry of Commerce: pp. 31-52.

Volkman, J. K. (1986): A review of sterol markers for marine and terrigenous organic matter. Organic Geochemistry, Vol. 9, No. 2: pp. 83-99.

Volkman, J. K., Alexander, R., Kagi, R. I. and Woodhouse, G. W. (1983): Demethylated hopanes in crude oils and their applications in petroleum geochemistry. Geochimica et Cosmochimica Acta, Vol. 47: pp. 785-794.

Volkman, J. K. and Maxwell, J. R. (1986): Acyclic isoprenoids as biological markers. In, Johns, R. B. (Ed.), Biological Markers in the Sedimentary Record. Methods in Geochemistry and Geophysics, 24. Elsevier Science Publishers B. V., Amsterdam: pp. 1-42.

Wakeham, S. G. and Lee, C. (1993): Production, transport, and alteration of particulate organic matter in the marine water column. In, Engel M. H. and Macko, S. A. (Eds.), Organic Geochemistry. Principles and Applications. Plenum Press, New York: pp. 145-169.

Walcott, R. I. (1978): Geodetic strains and large earthquakes in the Axial Tectonic Belt of North Island, New Zealand. Journal of Geophysical Research, Vol. 83: pp. 4419-4429.

Waples, D. W. and Machihara, T. (1991): Biomarkers for Geologists - A Practical Guide to the Application of Steranes and Triterpanes in Petroleum Geology. AAPG Methods in Exploration, No. 9. American Association of Petroleum Geologists, Tulsa, Oklahoma: 91pp.

Warren, G. and Speden, I. (1977): The Piripauan and Haumurian stratotypes (Mata Series, Upper Cretaceous) and correlative sequences in the Haumuri Bluff district, south Marlborough. New Zealand Geological Survey Bulletin 92: 60pp.

Waterhouse, J. B. and Bradley, J. (1957): Redeposition and slumping in the Cretaceo-Tertiary strata of S. E. Wellington. Transactions of the Royal Society of New Zealand, Vol. 84, No. 3: pp. 519548.

Wellman, H. W. (1955): A revision of the type Clarentian Section at Coverham, Clarence Valley S35. Transactions of the Royal Society of New Zealand, Vol. 83, No. I: pp. 93-118. 
Weston, R. J., Czochanska, Z., Sheppard, C. M., Woolhouse, A. D. and Cook, R. A. (1988): Organic geochemistry of the sedimentary basins of New Zealand. Part III. A biomarker correlation of three petroleum seeps and some rock bitumens from the East Coast of the North Island. Journal of the Royal Society of New Zealand, Vol. 18, No. 2: pp. 225-243.

Whelan, J. K. and Thompson-Rizer, C. L. (1993): Chemical methods for assessing kerogen and protokerogen types and maturity. In, Engel, M. H. and Macko, S. A. (Eds.), Organic Geochemistry. Principles and Applications. Plenum Press, New York: pp. 289-353.

Wright, I. C., Lewis, K. B. and Davy, B. (1992): Seafloor sampling as a window to deeper structure along accretionary systems: An example from offshore East Coast, North Island, New Zealand. In, Ministry of Commerce, 1991 New Zealand Oil Exploration Conference Proceedings. The Publicity Unit, Crown Minerals Operations Group, Energy and Resources Division, Ministry of Commerce: pp. 101-109.

Zumberge, J. (1990): Source rock potential and oil to source evaluation. In, Amoco New Zealand Exploration Co., Ltd, PPL 38318, East Coast Basin. Discussion of results from June 1989 field program, North Island, New Zealand. Amoco New Zealand Exploration Co. Ltd. New Zealand unpublished open-file Petroleum Report No. 1677: pp. 230-332. 


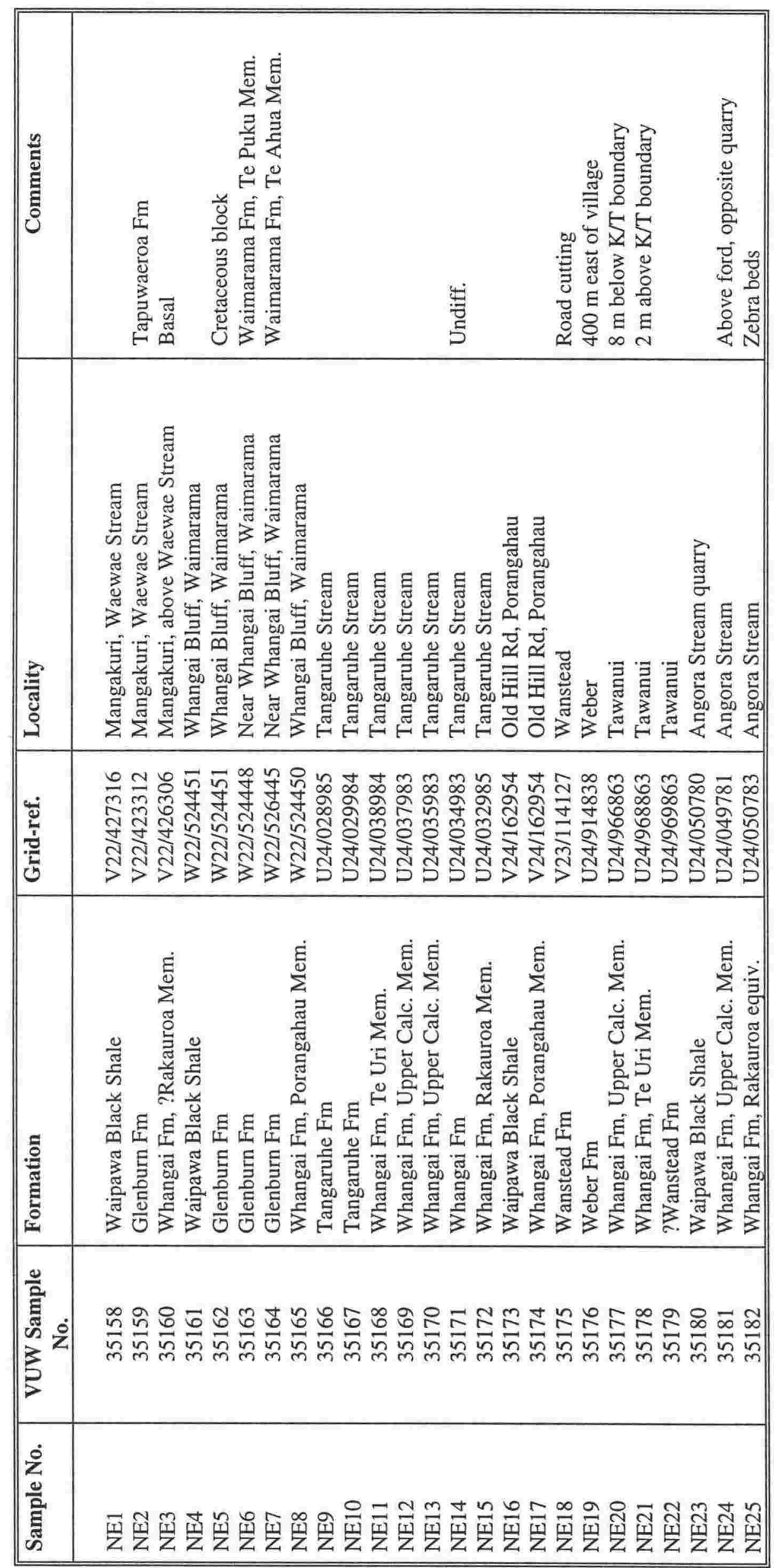




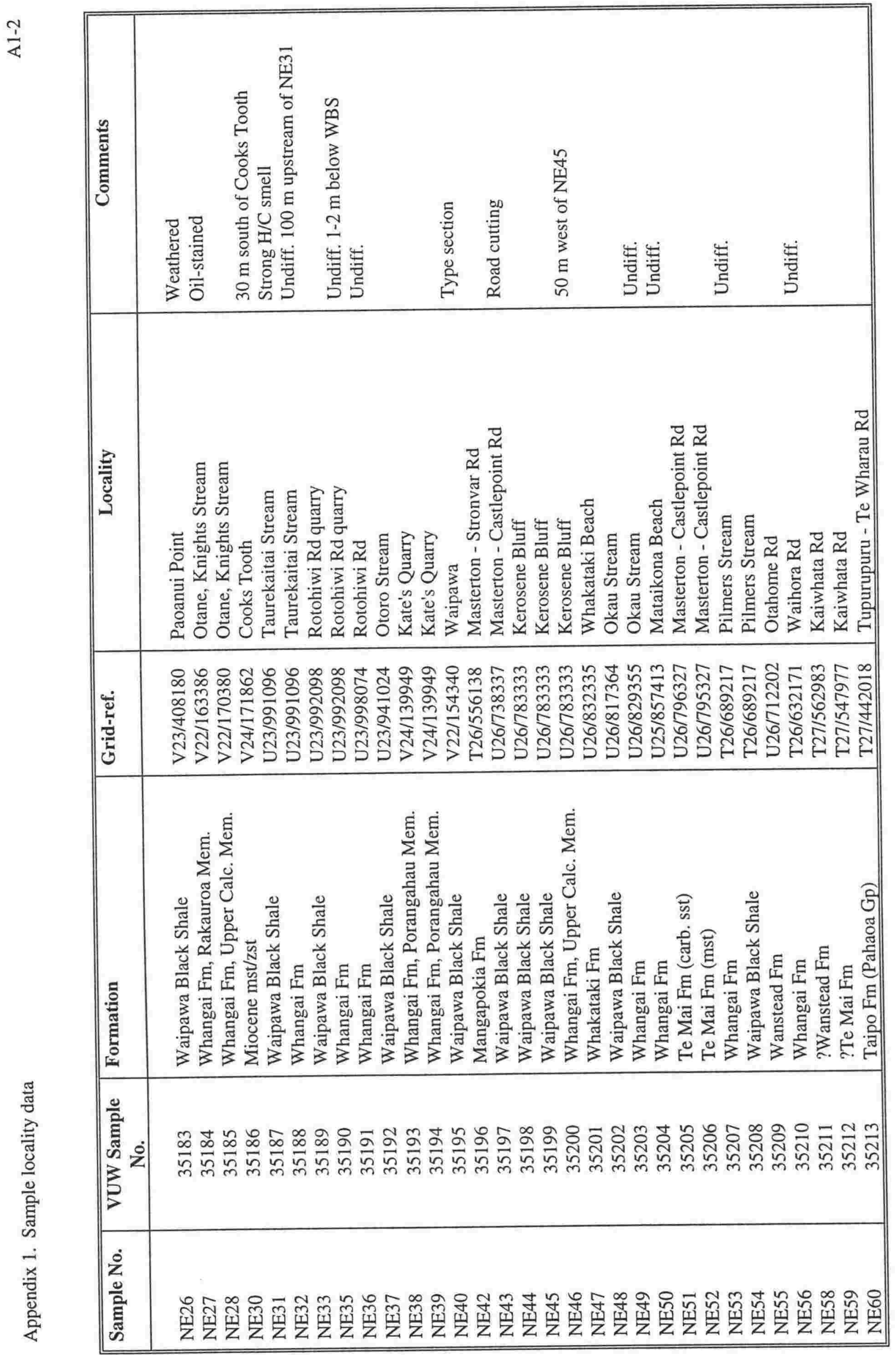




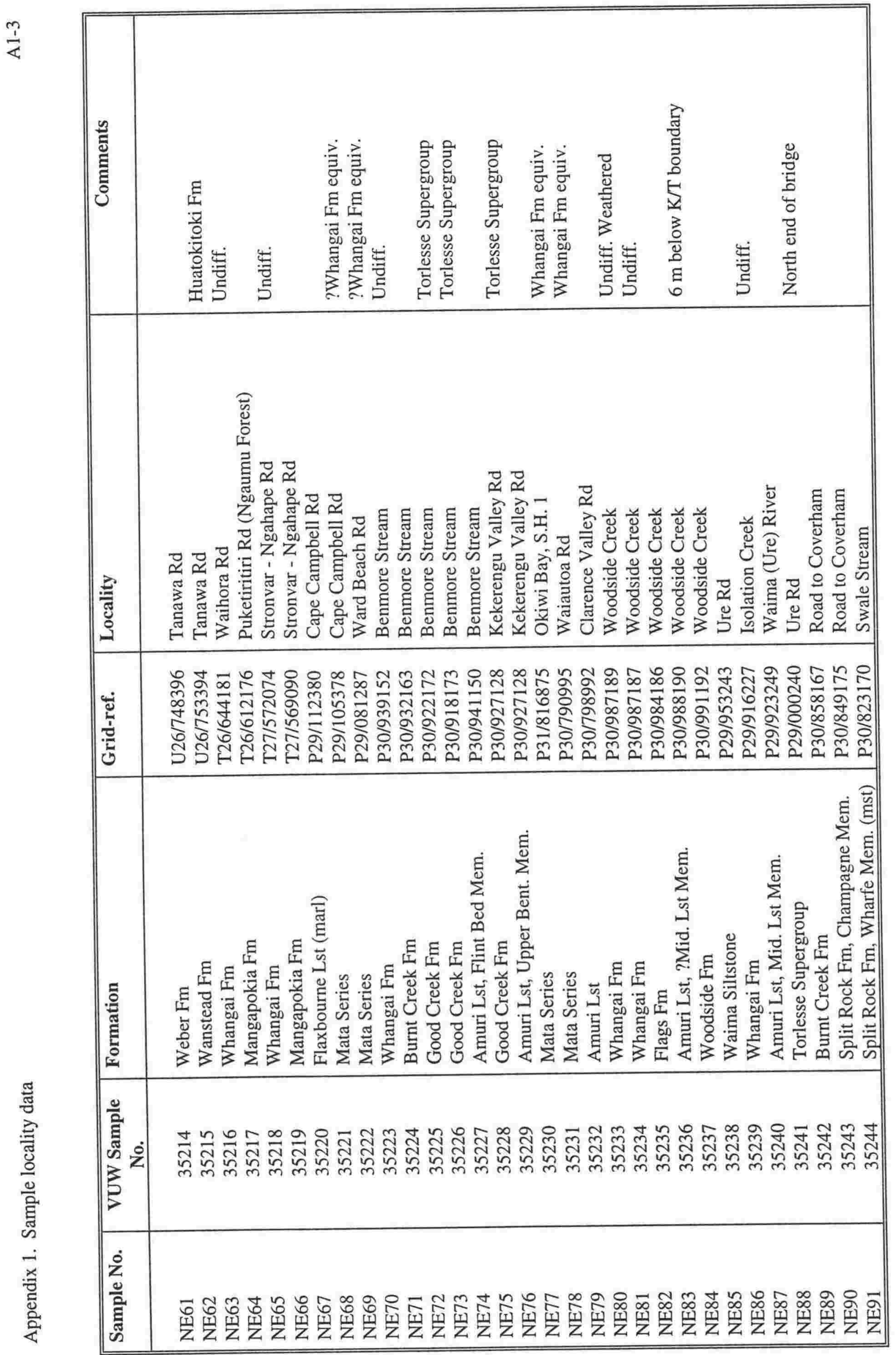




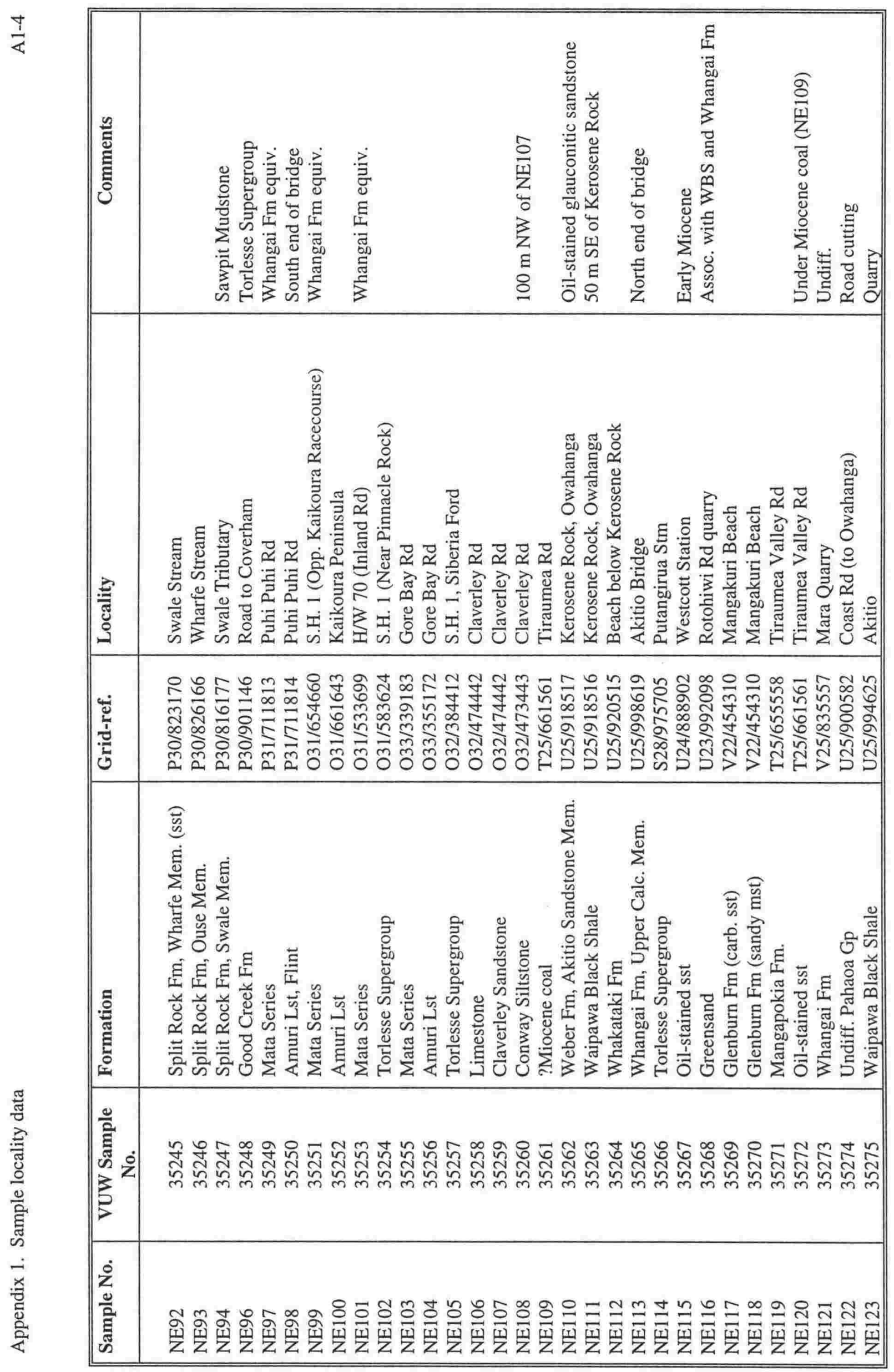




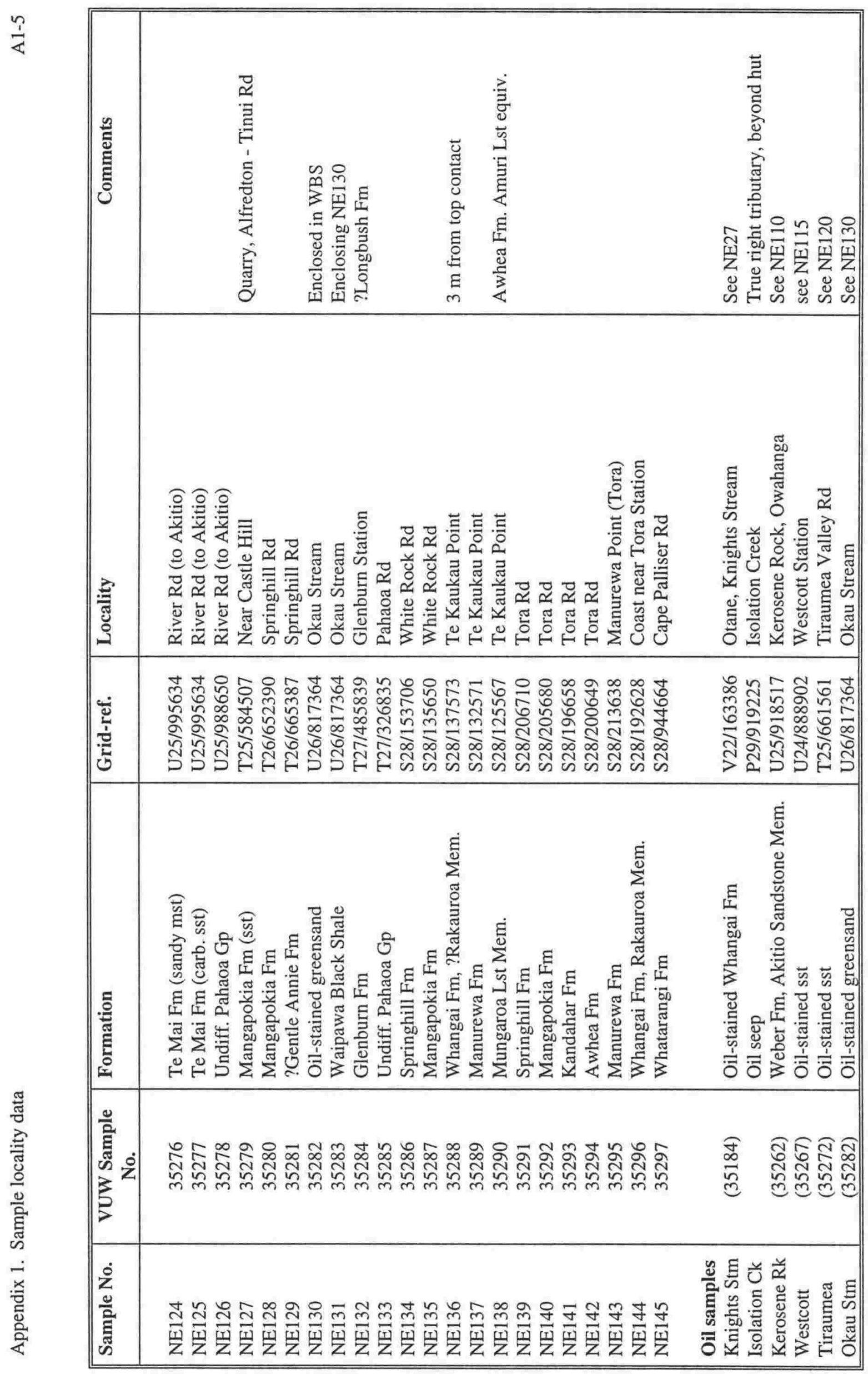




\section{Appendix 2}

\section{Total organic carbon (TOC) and carbonate data}

Initial screening of possible source rocks by TOC analyses were performed on a LECO RC-412 Multiphase Carbon Determinator in the Analytical Facility at Victoria University of Wellington. The principal difference between the LECO RC-412 and conventional carbon analysers is the oven control system; conventional ovens have fixed temperature settings, while the LECO RC-412 has an oven control system which allows precise temperature programming. By controlling the temperature of combustion, organic carbon can be pyrolysed while excluding carbonate carbon, hence the determination of multiphase carbon. The LECO RC-412 is equipped with an infrared (IR) detector which is $\mathrm{CO}_{2}$ specific thereby avoiding the problems typical of TCDs which can also record water and sulphur compounds if not trapped effectively (Jarvie, 1991). Operating conditions used in the analyses are shown below:

\begin{tabular}{|llll|}
\hline Sample size & $\sim 100 \mathrm{mg}$ & & \\
& & & \\
Initial temperature & $500^{\circ} \mathrm{C}$ & $6 \mathrm{~min}$. & (Phase 1 carbon) \\
Rate & $500-900^{\circ} \mathrm{C}$ & $200^{\circ} \mathrm{C} / \mathrm{min}$. & (Phase 2 carbon) \\
Final temperature & $900^{\circ} \mathrm{C}$ & $3 \mathrm{~min}$. & \\
Total time & & $11 \mathrm{~min}$. & \\
& & & \\
Oxygen pressure & $40 \mathrm{psi}$ & & \\
\hline
\end{tabular}

Organic carbon is pyrolysed at $500^{\circ} \mathrm{C}$ and is recorded as phase one carbon. Carbonate carbon is released in the temperature ramp between 500 and $900^{\circ} \mathrm{C}$ and recorded as phase two carbon. The boundary between organic and carbonate carbon was arbitrarily set at $500^{\circ} \mathrm{C}$. An increase in this boundary temperature would have the effect of increasing the quantity of organic carbon and decreasing carbonate carbon while a decrease in boundary temperature would have the opposite effect. An internal standard (MAG-1, Marine mud from the USGS) was run during each session to check for reproducibility. Comparison with other authors using different methods of analysis provided a check for the accuracy (Table A2-1). This method would have the same inherent problems of the Rock-Eval/TOC method where mature samples give poor results due to insufficient temperature for complete combustion. Carbon in mature organic matter is instead recorded as carbonate carbon since it is pyrolysed at 
temperatures greater than $500^{\circ} \mathrm{C}$. Samples collected in this study however are, in general, not of high maturity and error here is considered minimal. An obvious advantage over traditional combustion methods is that this method does not require acid treatment prior to analysis.

\begin{tabular}{|c|c|c|c|}
\hline & $\begin{array}{c}\text { Total carbon } \\
(\%)\end{array}$ & $\begin{array}{c}\text { TOC } \\
(\%)\end{array}$ & $\begin{array}{c}\text { Carbonate carbon } \\
(\%)\end{array}$ \\
\hline This study 1 & $2.18 \pm 0.04$ & $2.01 \pm 0.04$ & $0.171 \pm 0.006$ \\
\hline $\begin{array}{l}\text { Saikkonen and } \\
\text { Rautiainen }(1990)^{2}\end{array}$ & $2.23 \pm 0.02$ & $1.61 \pm 0.01$ & $0.62 \pm 0.02$ \\
\hline \multirow{2}{*}{$\begin{array}{l}\text { Jackson and Roof } \\
\text { (1992) }\end{array}$} & $2.27 \pm 0.02^{3}$ & & \\
\hline & $2.28 \pm 0.014$ & 2.16 & $0.123 \pm 0.0035$ \\
\hline Terashima $(1993)^{6}$ & $2.19 \pm 0.05$ & & \\
\hline
\end{tabular}

1Based on nine analyses. 2Using combustion/IR (and acid-evolution for carbonate). ${ }^{3}$ Using combustion/IR. ${ }^{4}$ Using combustion/coulometry. ${ }^{5}$ Using acid-evolution/coulometry. ${ }^{6}$ Using combustion TCD.

Table A2-1 Comparison of total carbon, TOC and carbonate carbon values of MAG-1 standard by different authors.

This method is acknowledged to be 'home-grown' and undoubtably requires some tuning. Comparison of TOC results from the LECO carbon determinator with the Rock-Eval/TOC method shows that, in general, there is good correlation between the results.

\section{Calculation of carbonate content of samples}

Carbonates are defined as having greater than $50 \% \mathrm{CaCO}_{3}$ (limestone) or $\mathrm{CaMg}\left(\mathrm{CO}_{3}\right)_{2}$ (dolomite) or a mixture (Andrews, 1982). The exact calculation of carbonate content is not easy to determine but an approximation can be reached by regarding any carbonates to comprise only calcium.

$$
\mathrm{M}_{\mathrm{r}}\left(\mathrm{CaCO}_{3}\right)=100.1 \mathrm{~g} / \mathrm{mol} . \quad \mathrm{A}_{\mathrm{r}}(\mathrm{C})=12 \mathrm{~g} / \mathrm{mol}
$$

Therefore a sample which recorded $12 \%$ carbonate carbon on the LECO carbon determinator is a pure limestone, comprising $100 \% \mathrm{CaCO}_{3}$. 
Of 145 samples analysed only 12 were classed as carbonates and all but one were from Amuri Limestone (or its lateral equivalent). A single sample of the Weber Formation was classified as a carbonate. Other formations with high carbonate contents (>10\%) include the Waima Siltstone, Wanstead, Whangai (especially Upper Calcareous and Porangahau members), Woodside and Manurewa formations. 


\begin{tabular}{|c|c|c|c|}
\hline Sample No. & $\begin{array}{c}\text { TOC } \\
(\text { LECO) } \\
(\%) \\
\end{array}$ & $\begin{array}{c}\text { TOC } \\
\text { (Rock-Eval) } \\
(\%) \\
\end{array}$ & $\begin{array}{c}\text { Carbonate } \\
\text { (LECO) } \\
(\%)\end{array}$ \\
\hline \multicolumn{4}{|c|}{ North Island stratigraphy } \\
\hline \multicolumn{4}{|c|}{ Miocene units } \\
\hline NE30 & 0.21 & & 29 \\
\hline NE109 & 4.70 & 5.28 & \\
\hline \multicolumn{4}{|c|}{ Whakataki Formation } \\
\hline NE47 & 0.44 & & \\
\hline NE112 & 0.60 & 0.59 & 23 \\
\hline \multicolumn{4}{|c|}{ Weber Formation } \\
\hline NE19 & 0.15 & & 55 \\
\hline NE61 & 0.29 & & \\
\hline \multicolumn{4}{|c|}{ Wanstead Formation } \\
\hline NE18 & 0.15 & & 31 \\
\hline NE22 & 0.24 & & 26 \\
\hline NE55 & 0.20 & & \\
\hline NE58 & 0.03 & & 19 \\
\hline NE62 & 0.22 & & \\
\hline \multicolumn{4}{|c|}{ Waipawa Black Shale } \\
\hline NE1 & 0.75 & 0.77 & \\
\hline NE4 & 1.21 & 1.35 & \\
\hline NE16 & 0.18 & & \\
\hline NE23 & 4.99 & 4.99 & \\
\hline NE26 & 1.42 & 1.16 & \\
\hline NE31 & 3.66 & 3.69 & \\
\hline NE33 & 1.05 & 1.30 & \\
\hline NE37 & 2.21 & 2.42 & \\
\hline NE40 & 3.89 & 3.73 & \\
\hline NE43 & 5.53 & 5.58 & \\
\hline NE44 & 2.97 & 3.17 & \\
\hline NE45 & 4.06 & 4.24 & \\
\hline NE48 & 3.34 & 3.27 & \\
\hline NE54 & 5.69 & 5.58 & \\
\hline NE111 & 0.61 & 0.76 & \\
\hline NE123 & 0.28 & & \\
\hline NE131 & 3.61 & 3.84 & \\
\hline \multicolumn{4}{|c|}{ (Tora Block stratigraphy) } \\
\hline NE141 & 0.19 & & \\
\hline \multicolumn{4}{|c|}{ (Awhea Formation) } \\
\hline \multicolumn{4}{|c|}{ (Mungaroa Member) } \\
\hline NE138 & 0.15 & & 77 \\
\hline \multicolumn{4}{|c|}{ (Manurewa Formation) } \\
\hline NE137 & 0.15 & & \\
\hline NE143 & 0.14 & & 21 \\
\hline \multicolumn{4}{|c|}{ Whangai Formation } \\
\hline \multicolumn{4}{|c|}{ Te Uri Member } \\
\hline NE11 & 0.33 & & \\
\hline NE21 & 0.28 & & \\
\hline \multicolumn{4}{|c|}{ Porangahau Member } \\
\hline NE8 & 0.25 & & 23 \\
\hline NE17 & 0.03 & & 12 \\
\hline NE38 & 0.32 & & \\
\hline NE39 & 0.06 & & 17 \\
\hline
\end{tabular}




\begin{tabular}{|c|c|c|c|}
\hline Sample No. & $\begin{array}{c}\text { TOC } \\
\text { (LECO) } \\
(\%) \\
\end{array}$ & $\begin{array}{c}\text { TOC } \\
\text { (Rock-Eval) } \\
(\%) \\
\end{array}$ & $\begin{array}{c}\text { Carbonate } \\
\text { (LECO) } \\
(\%)\end{array}$ \\
\hline \multicolumn{4}{|c|}{ Upper Calcareous Member } \\
\hline NE12 & 0.42 & & \\
\hline NE13 & 0.45 & & \\
\hline NE20 & 0.36 & & \\
\hline NE24 & 1.19 & 1.30 & \\
\hline NE28 & 0.37 & & 16 \\
\hline NE46 & 0.82 & 0.95 & \\
\hline NE113 & 0.71 & 1.00 & \\
\hline \multicolumn{4}{|c|}{ Rakauroa Member } \\
\hline NE3 & 0.09 & & \\
\hline NE15 & 0.49 & & \\
\hline NE25 & 0.11 & & \\
\hline NE27 & 1.37 & 1.52 & \\
\hline NE136 & 0.51 & 1.02 & \\
\hline NE144 & 1.13 & 1.64 & \\
\hline \multicolumn{4}{|c|}{ Undifferentiated } \\
\hline NE14 & 0.44 & & \\
\hline NE32 & 0.63 & 0.76 & \\
\hline NE35 & 0.19 & & \\
\hline NE36 & 0.40 & & \\
\hline NE49 & 0.84 & 0.96 & \\
\hline NE50 & 0.93 & 0.84 & \\
\hline NE53 & 0.68 & 0.88 & \\
\hline NE56 & 0.78 & 0.93 & \\
\hline NE63 & 3.50 & 3.79 & \\
\hline NE65 & 0.41 & & \\
\hline NE121 & 0.76 & 1.29 & \\
\hline \multicolumn{4}{|c|}{ Tangaruhe Formation } \\
\hline NE9 & 0.32 & & \\
\hline NE10 & 0.40 & & \\
\hline \multicolumn{4}{|c|}{ Te Mai Formation } \\
\hline NE51 & 0.72 & 0.68 & \\
\hline NE52 & 1.52 & 1.52 & \\
\hline NE59 & 1.12 & 1.17 & \\
\hline NE124 & 0.71 & 1.51 & \\
\hline NE125 & 0.19 & & \\
\hline \multicolumn{4}{|c|}{ Glenburn Formation } \\
\hline NE2 & 0.59 & 0.75 & \\
\hline NE5 & 0.83 & 0.92 & \\
\hline NE6 & 0.49 & & \\
\hline NE7 & 0.85 & 0.90 & \\
\hline NE117 & 0.87 & 1.38 & \\
\hline NE1 18 & 1.30 & 1.86 & \\
\hline NE132 & 0.09 & & \\
\hline \multicolumn{4}{|c|}{ Springhill Formation } \\
\hline NE134 & 0.24 & & \\
\hline NE139 & 0.27 & & \\
\hline \multicolumn{4}{|c|}{ Gentle Annie Formation } \\
\hline NE129 & 0.06 & & \\
\hline
\end{tabular}




\begin{tabular}{|c|c|c|c|}
\hline Sample No. & $\begin{array}{c}\text { TOC } \\
\text { (LECO) } \\
(\%)\end{array}$ & $\begin{array}{c}\text { TOC } \\
\text { (Rock-Eval) } \\
(\%) \\
\end{array}$ & $\begin{array}{c}\text { Carbonate } \\
\text { (LECO) } \\
(\%)\end{array}$ \\
\hline \multicolumn{4}{|c|}{ Mangapokia Formation } \\
\hline NE42 & 0.06 & & \\
\hline NE64 & 1.54 & 1.59 & \\
\hline NE66 & 0.10 & & \\
\hline NE119 & 0.07 & & \\
\hline NE127 & 0.08 & & \\
\hline NE128 & 0.29 & & \\
\hline NE135 & 0.15 & & \\
\hline NE140 & 0.24 & & \\
\hline \multicolumn{4}{|c|}{ Taipo Formation } \\
\hline \multirow{2}{*}{\multicolumn{4}{|c|}{ Undifferentiated Pahaoa Group }} \\
\hline & & & \\
\hline NE122 & 0.40 & & \\
\hline NE126 & 0.35 & & \\
\hline NE133 & 0.26 & & \\
\hline \multicolumn{4}{|c|}{ Whatarangi Formation } \\
\hline NE145 & 0.19 & & \\
\hline \multicolumn{4}{|c|}{ Torlesse Supergroup } \\
\hline NE114 & 0.19 & & \\
\hline \multicolumn{4}{|c|}{ South Island stratigraphy } \\
\hline \multicolumn{4}{|c|}{ Waima Siltstone } \\
\hline NE85 & 0.41 & & 44 \\
\hline \multicolumn{4}{|c|}{ Woodside Formation } \\
\hline NE84 & 0.06 & & 21 \\
\hline \multicolumn{4}{|c|}{ Amuri Limestone } \\
\hline NE67 & 0.16 & & 73 \\
\hline NE74 & 0.08 & & 73 \\
\hline NE76 & 0.07 & & 66 \\
\hline NE79 & 0.04 & & 89 \\
\hline NE83 & 0.06 & & 59 \\
\hline NE87 & 0.03 & & 83 \\
\hline NE98 & 0.05 & & 67 \\
\hline NE100 & 0.09 & & 86 \\
\hline NE104 & 0.11 & & 90 \\
\hline NE106 & 0.09 & & 82 \\
\hline \multicolumn{4}{|c|}{ Whangai Formation } \\
\hline \multicolumn{4}{|c|}{ Undifferentiated } \\
\hline NE70 & 0.51 & 0.63 & \\
\hline NE80 & 0.48 & & \\
\hline NE81 & 0.46 & & \\
\hline NE86 & 0.49 & 0.61 & \\
\hline \multicolumn{4}{|l|}{ Mata Series } \\
\hline NE68 & 0.14 & & \\
\hline NE69 & 0.04 & & 37 \\
\hline NE77 & 0.03 & & \\
\hline NE78 & 0.27 & & \\
\hline NE97 & 0.96 & 1.07 & \\
\hline NE99 & 0.69 & 0.84 & \\
\hline NE101 & 0.24 & & \\
\hline NE103 & 0.13 & & \\
\hline
\end{tabular}




\begin{tabular}{|c|c|c|c|}
\hline Sample No. & $\begin{array}{c}\text { TOC } \\
\text { (LECO) } \\
(\%) \\
\end{array}$ & $\begin{array}{c}\text { TOC } \\
\text { (Rock-Eval) } \\
(\%) \\
\end{array}$ & $\begin{array}{c}\text { Carbonate } \\
\text { (LECO) } \\
(\%)\end{array}$ \\
\hline \multicolumn{4}{|l|}{ Flags Formation } \\
\hline NE82 & 0.52 & 0.55 & \\
\hline Claverley Sandstone & & & \\
\hline NE107 & 0.39 & & \\
\hline Conway Siltstone & & & \\
\hline NE108 & 0.55 & 0.62 & \\
\hline Burnt Creek Formation & & & \\
\hline NE71 & 0.41 & & \\
\hline NE89 & 0.25 & & \\
\hline $\begin{array}{l}\text { Split Rock Formation } \\
\text { Swale Siltstone Member }\end{array}$ & & & \\
\hline $\begin{array}{l}\text { NE94 } \\
\text { Wharfe Sandstone Member }\end{array}$ & 0.33 & & \\
\hline NE91 & 0.41 & & \\
\hline NE92 & 0.29 & & \\
\hline Ouse Member & & & \\
\hline $\begin{array}{l}\text { NE93 } \\
\text { Champagne Member }\end{array}$ & 0.38 & & \\
\hline NE90 & 0.39 & & \\
\hline Torlesse Supergroup & & & \\
\hline NE72 & 0.37 & & \\
\hline NE73 & 0.45 & & \\
\hline NE75 & 0.40 & & \\
\hline NE88 & 0.35 & & \\
\hline NE96 & 0.34 & & \\
\hline NE102 & 0.26 & & \\
\hline NE105 & 0.26 & & \\
\hline
\end{tabular}


Appendix 3

\section{Rock-Eval pyrolysis data}

\begin{tabular}{|c|c|c|c|c|c|c|c|c|c|}
\hline Sample No. & $\begin{array}{l}\text { TOC } \\
(\%) \\
\end{array}$ & $\begin{array}{l}\mathrm{T}_{\max } \\
\left({ }^{\circ} \mathrm{C}\right) \\
\end{array}$ & $\begin{array}{c}\mathrm{S}_{1} \\
(\mathrm{mg} / \mathrm{g})\end{array}$ & $\begin{array}{c}\mathrm{S}_{2} \\
(\mathrm{mg} / \mathrm{g})\end{array}$ & $\begin{array}{c}\mathrm{S}_{3} \\
(\mathrm{mg} / \mathrm{g})\end{array}$ & PI & $\mathrm{S}_{2} / \mathrm{S}_{3}$ & $\begin{array}{c}\text { HI } \\
\text { (mg HC/g TOC) } \\
\end{array}$ & $\begin{array}{c}\text { OI } \\
\left(\mathrm{mg} \mathrm{CO}_{2} / \mathrm{g} \text { TOC) }\right.\end{array}$ \\
\hline \multicolumn{10}{|c|}{ North Island stratigraphy } \\
\hline \multicolumn{10}{|l|}{ Miocene coal } \\
\hline NE109 & 5.28 & 422 & 1.68 & 12.49 & 3.07 & 0.12 & 4.07 & 237 & 58 \\
\hline \multicolumn{10}{|c|}{ Whakataki Formation } \\
\hline NE1 12 & 0.59 & 429 & 0.09 & 0.48 & 0.87 & 0.16 & 0.55 & 81 & 147 \\
\hline \multicolumn{10}{|c|}{ Waipawa Black Shale } \\
\hline NEl & 0.77 & 420 & 0.33 & 0.45 & 1.57 & 0.42 & 0.29 & 58 & 204 \\
\hline NE4 & 1.35 & 411 & 0.16 & 0.30 & 0.97 & 0.35 & 0.31 & 22 & 72 \\
\hline NE23 & 4.99 & 403 & 1.18 & 11.03 & 2.11 & 0.10 & 5.23 & 221 & 42 \\
\hline NE26 & 1.16 & 436 & 0.14 & 0.49 & 3.71 & 0.22 & 0.13 & 42 & 320 \\
\hline NE31 & 3.69 & 398 & 0.79 & 4.80 & 2.40 & 0.14 & 2.00 & 130 & 65 \\
\hline NE33 & 1.30 & 395 & 0.15 & 0.40 & 0.95 & 0.27 & 0.42 & 31 & 73 \\
\hline NE37 & 2.42 & 405 & 0.35 & 1.47 & 2.03 & 0.19 & 0.72 & 61 & 84 \\
\hline NE40 & 3.73 & 407 & 0.67 & 4.65 & 3.29 & 0.13 & 1.41 & 125 & 88 \\
\hline NE43 & 5.58 & 409 & 0.68 & 7.22 & 4.91 & 0.09 & 1.47 & 129 & 88 \\
\hline NE44 & 3.17 & 407 & 0.31 & 3.94 & 1.83 & 0.07 & 2.15 & 124 & 58 \\
\hline NE45 & 4.24 & 413 & 0.51 & 5.36 & 2.74 & 0.09 & 1.96 & 126 & 65 \\
\hline NE48 & 3.27 & 418 & 0.52 & 3.82 & 3.89 & 0.12 & 0.98 & 117 & 119 \\
\hline NE54 & 5.58 & 417 & 0.73 & 8.90 & 4.22 & 0.08 & 2.11 & 159 & 76 \\
\hline NE111 & 0.76 & 411 & 0.07 & 0.27 & 0.69 & 0.21 & 0.39 & 36 & 91 \\
\hline NE131 & 3.84 & 415 & 0.59 & 4.47 & 3.66 & 0.12 & 1.22 & 116 & 95 \\
\hline \multicolumn{10}{|c|}{ Whangai Formation } \\
\hline \multicolumn{10}{|c|}{ Upper Calcareous Member } \\
\hline NE24 & 1.30 & 430 & 0.26 & 2.64 & 0.93 & 0.09 & 2.84 & 203 & 72 \\
\hline NE46 & 0.95 & 428 & 0.13 & 1.29 & 1.16 & 0.09 & 1.11 & 136 & 122 \\
\hline NEI13 & 1.00 & 422 & 0.24 & 1.13 & 0.50 & 0.18 & 2.26 & 113 & 50 \\
\hline \multicolumn{10}{|c|}{ Rakauroa Member } \\
\hline NE27* & 1.52 & 431 & 0.28 & 3.32 & 0.42 & 0.08 & 7.90 & 218 & 28 \\
\hline NE136 & 1.02 & 422 & 0.16 & 1.24 & 0.29 & 0.11 & 4.28 & 122 & 28 \\
\hline NE 144 & 1.64 & 429 & 0.37 & 2.70 & 0.42 & 0.12 & 6.43 & 165 & 26 \\
\hline \multicolumn{10}{|c|}{ Undifferentiated } \\
\hline NE32 & 0.76 & 416 & 0.23 & 0.80 & 0.85 & 0.22 & 0.94 & 105 & 112 \\
\hline NE49 & 0.96 & 430 & 0.11 & 0.86 & 1.11 & 0.11 & 0.77 & 90 & 116 \\
\hline NE50 & 0.84 & 427 & 0.11 & 0.89 & 1.04 & 0.11 & 0.86 & 106 & 124 \\
\hline NE53 & 0.88 & 422 & 0.12 & 1.20 & 0.46 & 0.09 & 2.61 & 136 & 52 \\
\hline NE56 & 0.93 & 418 & 0.08 & 0.52 & 0.72 & 0.13 & 0.72 & 56 & 77 \\
\hline NE63 & 3.79 & 420 & 0.32 & 3.66 & 2.05 & 0.08 & 1.79 & 97 & 54 \\
\hline $\mathrm{NE} 121$ & 1.29 & 412 & 0.13 & 0.53 & 0.41 & 0.20 & 1.29 & 41 & 32 \\
\hline \multicolumn{10}{|c|}{ Te Mai Formation } \\
\hline NE51 & 0.68 & 441 & 0.06 & 0.03 & 1.13 & 0.67 & 0.03 & 4 & 166 \\
\hline NE52 & 1.52 & 429 & 0.04 & 0.33 & 0.94 & 0.11 & 0.35 & 22 & 62 \\
\hline NE59 & 1.17 & 447 & 0.08 & 0.69 & 0.41 & 0.10 & 1.68 & 59 & 35 \\
\hline $\mathrm{NE} 124$ & 1.51 & 420 & 0.05 & 0.29 & 0.37 & 0.15 & 0.78 & 19 & 25 \\
\hline
\end{tabular}




\begin{tabular}{|c|c|c|c|c|c|c|c|c|c|}
\hline Sample No. & $\begin{array}{l}\text { TOC } \\
(\%) \\
\end{array}$ & $\begin{array}{l}\mathbf{T}_{\max } \\
\left({ }^{\circ} \mathbf{C}\right) \\
\end{array}$ & $\begin{array}{c}\mathrm{S}_{1} \\
(\mathrm{mg} / \mathrm{g})\end{array}$ & $\begin{array}{c}\mathrm{S}_{2} \\
(\mathrm{mg} / \mathrm{g})\end{array}$ & $\begin{array}{c}\mathrm{S}_{3} \\
(\mathrm{mg} / \mathrm{g})\end{array}$ & PI & $\mathrm{S}_{2} / \mathrm{S}_{3}$ & $\begin{array}{c}\text { HI } \\
\text { (mg HC/g TOC) }\end{array}$ & $\begin{array}{c}\text { OI } \\
\left(\mathrm{mg} \mathrm{CO}_{2} / \mathrm{g} \mathrm{TOC}^{2}\right)\end{array}$ \\
\hline \multicolumn{10}{|c|}{ Glenburn Formation } \\
\hline NE2 & 0.75 & 431 & 0.07 & 0.22 & 0.30 & 0.24 & 0.73 & 29 & 40 \\
\hline NE5 & 0.92 & 423 & 0.07 & 0.23 & 0.56 & 0.23 & 0.41 & 25 & 61 \\
\hline NE7 & 0.90 & 433 & 0.06 & 0.42 & 0.26 & 0.13 & 1.62 & 47 & 29 \\
\hline NE117 & 1.38 & 433 & 0.05 & 0.26 & 0.39 & 0.16 & 0.67 & 19 & 28 \\
\hline NE118 & 1.86 & 434 & 0.03 & 0.35 & 0.37 & 0.08 & 0.95 & 19 & 20 \\
\hline \multicolumn{10}{|c|}{ Mangapokia Formation } \\
\hline NE64 & 1.59 & 435 & 0.05 & 0.46 & 0.89 & 0.10 & 0.52 & 29 & 56 \\
\hline \multicolumn{10}{|c|}{ South Island stratigraphy } \\
\hline \multicolumn{10}{|c|}{ Whangai Formation } \\
\hline NE70 & 0.63 & 405 & 0.12 & 0.64 & 0.48 & 0.16 & 1.33 & 102 & 76 \\
\hline NE86 & 0.61 & 428 & 0.16 & 1.26 & 0.30 & 0.11 & 4.20 & 207 & 49 \\
\hline \multicolumn{10}{|l|}{ Mata Series } \\
\hline NE97 & 1.07 & 419 & 0.13 & 1.26 & 0.56 & 0.09 & 2.25 & 118 & 52 \\
\hline NE99 & 0.84 & 400 & 0.11 & 0.35 & 0.64 & 0.24 & 0.56 & 42 & 76 \\
\hline \multicolumn{10}{|c|}{ Flags Formation } \\
\hline NE82 & 0.55 & 423 & 0.13 & 0.52 & 0.85 & 0.20 & 0.61 & 95 & 155 \\
\hline \multicolumn{10}{|c|}{ Conway Siltstone } \\
\hline NE108 & 0.62 & 394 & 0.27 & 0.27 & 0.83 & 0.50 & 0.33 & 44 & 134 \\
\hline
\end{tabular}

*Oil-stained sample (with Knights Stream oil) 
Appendix 4

Gas chromatography (GC) data

\begin{tabular}{|c|c|c|c|c|c|c|}
\hline Sample No. & $\mathrm{Pr} / \mathrm{Ph}$ & $\operatorname{Pr} / n-\mathrm{C}_{17}$ & $\mathrm{Ph} / n-\mathrm{C}_{18}$ & CPI & $\begin{array}{c}n \text {-alkane } \\
\max \end{array}$ & $\frac{\mathrm{C}_{21}+\mathrm{C}_{22}}{\mathrm{C}_{28}+\mathrm{C}_{29}}$ \\
\hline \multicolumn{7}{|l|}{ Oil Seeps } \\
\hline Knights Stream & 2.57 & 3.66 & 1.57 & 1.02 & 16 & 2.73 \\
\hline Isolation Creek & 0.99 & 0.38 & 0.42 & 1.05 & 24 & 2.14 \\
\hline Kerosene Rock & 2.17 & 6.12 & 2.11 & 0.97 & 27 & 0.38 \\
\hline \multicolumn{7}{|c|}{ North Island stratigraphy } \\
\hline \multicolumn{7}{|c|}{ Miocene units } \\
\hline NE30 & 0.56 & 1.16 & 1.32 & & 23 & 2.98 \\
\hline NE109 & 0.67 & 1.11 & 1.14 & 1.90 & 29 & 0.18 \\
\hline \multicolumn{7}{|c|}{ Whakataki Formation } \\
\hline NE112 & 1.89 & 4.16 & 1.70 & & & \\
\hline \multicolumn{7}{|c|}{ Weber Formation } \\
\hline NE19 & 1.40 & 1.01 & 0.62 & 0.98 & 25 & 0.33 \\
\hline NE61 & 1.71 & 1.60 & 1.03 & & 14 & \\
\hline \multicolumn{7}{|c|}{ Wanstead Formation } \\
\hline NE18 & 0.45 & 0.34 & 3.11 & 1.39 & $23 *$ & 3.35 \\
\hline NE22 & 0.49 & 2.87 & 3.13 & & $24 *$ & 1.30 \\
\hline NE55 & 2.06 & 1.70 & 0.87 & & 15 & \\
\hline NE58 & 1.25 & 1.17 & 0.98 & & 16 & \\
\hline \multicolumn{7}{|c|}{ Waipawa Black Shale } \\
\hline NE1 & 0.47 & 3.20 & 3.07 & 1.54 & $24 *$ & 1.97 \\
\hline NE4 & 0.27 & 0.46 & 4.56 & 1.27 & $24 *$ & 0.84 \\
\hline NE16 & 0.08 & 0.15 & & & 25 & 1.32 \\
\hline NE23 & 1.11 & 4.32 & 3.02 & 1.02 & 23 & 1.88 \\
\hline NE26 & 0.31 & 1.05 & 1.41 & 1.08 & 23 & 3.72 \\
\hline NE31 & 0.13 & 1.99 & 11.40 & 1.26 & $25^{*}$ & 0.39 \\
\hline NE33 & 0.24 & 0.43 & 8.21 & 1.84 & $24 *$ & 0.52 \\
\hline NE37 & 1.38 & 0.80 & 0.95 & & 15 & 0.14 \\
\hline NE40 & 0.47 & 1.00 & 10.49 & & 24 & 0.73 \\
\hline NE43 & 0.72 & 3.99 & 5.41 & 1.42 & 26 & 0.37 \\
\hline NE44 & 1.32 & 3.75 & 2.32 & 1.20 & 29 & 0.33 \\
\hline NE45 & 0.79 & 6.19 & 5.63 & 1.53 & 27 & 0.39 \\
\hline NE48 & 2.21 & 10.18 & 4.41 & 1.52 & 29 & 0.16 \\
\hline NE54 & 1.72 & 4.36 & 2.08 & & & \\
\hline NE111 & 0.61 & 1.85 & 5.23 & 1.10 & $25 *$ & 0.52 \\
\hline NE131 ${ }^{\dagger}$ & 1.39 & 12.50 & 8.18 & & & \\
\hline \multicolumn{7}{|c|}{$\begin{array}{c}\text { Whangai Formation } \\
\text { Te Uri Member }\end{array}$} \\
\hline $\begin{array}{l}\text { Te Uri Mem } \\
\text { NE11 }\end{array}$ & 0.31 & 1.89 & 286 & 112 & 25 & 0.40 \\
\hline NE21 & 0.54 & 4.63 & 7.42 & 2.24 & $24 *$ & 1.92 \\
\hline \multicolumn{7}{|c|}{ Porangahau Member } \\
\hline NE8 & 0.63 & 3.74 & 5.13 & 1.30 & $27 *$ & 0.29 \\
\hline NE17 & 0.62 & 1.80 & 3.05 & 1.12 & $26^{*}$ & 0.18 \\
\hline NE38 & 0.65 & 6.41 & 4.25 & & $23 *$ & 3.51 \\
\hline NE39 & 0.84 & 1.28 & 1.32 & 1.13 & 23 & 6.63 \\
\hline
\end{tabular}




\begin{tabular}{|c|c|c|c|c|c|c|}
\hline Sample No. & $\mathbf{P r} / \mathbf{P h}$ & $\operatorname{Pr} / n-\mathrm{C}_{17}$ & $\mathrm{Ph} / n-\mathrm{C}_{18}$ & CPI & $\begin{array}{c}n \text {-alkane } \\
\max \end{array}$ & $\frac{\mathrm{C}_{21}+\mathrm{C}_{22}}{\mathrm{C}_{28}+\mathrm{C}_{29}}$ \\
\hline \multicolumn{7}{|c|}{ Upper Calcareous Member } \\
\hline NE12 & 0.55 & 3.65 & 10.68 & 1.91 & $24 *$ & 3.86 \\
\hline NE13 & 1.27 & 1.96 & 1.97 & & 23 & 6.11 \\
\hline NE20 & 1.29 & 2.13 & 1.33 & & 23 & 3.64 \\
\hline NE24 & 0.50 & 6.02 & 8.11 & 1.77 & $24 *$ & 2.41 \\
\hline NE28 & 0.56 & 1.00 & 5.21 & 1.88 & $24 *$ & 0.51 \\
\hline NE46 & 1.45 & 3.23 & 2.33 & & & \\
\hline NE113 & 1.82 & 3.51 & 1.19 & & 19 & \\
\hline \multicolumn{7}{|c|}{ Rakauroa Member } \\
\hline NE3 & 1.02 & 1.25 & 1.11 & & 22 & 7.17 \\
\hline NE15 & 1.28 & 6.04 & 2.63 & 1.18 & 23 & 9.03 \\
\hline NE25 & 0.48 & 1.23 & 1.39 & 1.01 & 23 & 2.21 \\
\hline NE136† & 2.06 & 4.34 & 1.95 & & 25 & \\
\hline NE144† & 3.43 & 6.92 & 2.00 & & 26 & \\
\hline \multicolumn{7}{|c|}{ Undifferentiated } \\
\hline NE14 & 0.46 & 4.02 & 5.07 & 2.04 & $24 *$ & 3.85 \\
\hline NE32 & 1.03 & 1.83 & 1.70 & & 22 & 7.05 \\
\hline NE35 & 0.92 & 1.17 & 0.99 & 1.14 & 22 & 8.19 \\
\hline NE36 & 0.49 & 1.46 & 1.74 & 1.26 & 23 & 12.56 \\
\hline NE49 & 2.14 & 2.13 & 1.04 & 1.56 & 29 & 0.07 \\
\hline NE50 & 2.03 & 3.74 & 2.05 & & & \\
\hline NE53 & 0.96 & 0.64 & 0.86 & 1.23 & $29 *$ & 0.76 \\
\hline NE56 & 1.73 & 2.52 & 1.18 & & & \\
\hline NE63 & 2.47 & 1.76 & 0.99 & 2.46 & 29 & 0.09 \\
\hline NE65 & 1.89 & 1.89 & 1.01 & & & \\
\hline \multicolumn{7}{|c|}{ Tangaruhe Formation } \\
\hline NE9 & 0.46 & 1.99 & 3.41 & 1.20 & $26 *$ & 0.12 \\
\hline NE10 & 0.59 & 1.15 & 3.45 & 1.05 & 25 & 0.66 \\
\hline \multicolumn{7}{|c|}{ Te Mai Formation } \\
\hline NE51 & 1.84 & 1.42 & 0.83 & & 16 & \\
\hline NE52 & 1.93 & 2.51 & 0.80 & & 15 & \\
\hline NE59 & 3.17 & 3.36 & 1.00 & & 14 & \\
\hline NE124† & 2.67 & 3.20 & 1.00 & 1.26 & 27 & 0.05 \\
\hline NE125† & 1.67 & 1.67 & 0.86 & & $27 *$ & 0.64 \\
\hline \multicolumn{7}{|c|}{ Glenburn Formation } \\
\hline NE2 & 0.77 & 2.51 & 3.15 & 1.05 & 25 & 0.23 \\
\hline NE5 & 0.48 & 0.52 & 3.01 & 0.99 & 25 & 0.09 \\
\hline NE6 & 0.59 & 5.03 & 13.68 & 1.98 & $25 *$ & 0.67 \\
\hline NE7 & 0.63 & 4.21 & 10.50 & 2.46 & $23 *$ & 2.94 \\
\hline NE117 ${ }^{\dagger}$ & 0.68 & & & 1.09 & 29 & 0.02 \\
\hline NE118† & 0.63 & 2.00 & 7.00 & 1.39 & $29 *$ & 0.06 \\
\hline NE132† & 0.50 & 2.50 & 0.83 & 1.13 & $29 *$ & 0.18 \\
\hline \multicolumn{7}{|c|}{ Mangapokia Formation } \\
\hline NE42 & 1.56 & 1.97 & 1.48 & & 27 & \\
\hline NE64 & 1.65 & 2.17 & 1.23 & & 16 & \\
\hline NE66 & 1.50 & 0.88 & 0.61 & & 14 & \\
\hline NE119† & 1.60 & 1.78 & 0.63 & 1.44 & $29 *$ & 0.40 \\
\hline NE128† & 2.87 & 3.07 & 0.71 & 1.25 & $27 *$ & 0.84 \\
\hline NE140† & 4.79 & 5.64 & 0.78 & & 19 & \\
\hline \multicolumn{7}{|c|}{ Taipo Formation } \\
\hline NE60 & 1.18 & 1.30 & 1.09 & & 15 & \\
\hline \multicolumn{7}{|c|}{ Whatarangi Formation } \\
\hline $\mathrm{NE} 145^{\dagger}$ & 3.20 & 1.28 & 0.23 & & 23 & \\
\hline \multicolumn{7}{|c|}{ Torlesse Supergroup } \\
\hline NE114 $†$ & 0.67 & 0.44 & 0.52 & 1.07 & $26 *$ & 0.43 \\
\hline
\end{tabular}




\begin{tabular}{|c|c|c|c|c|c|c|}
\hline Sample No. & $\mathrm{Pr} / \mathrm{Ph}$ & $\mathrm{Pr} / n-\mathrm{C}_{17}$ & $\mathrm{Ph} / n-\mathrm{C}_{18}$ & CPI & $\begin{array}{c}n \text {-alkane } \\
\max \end{array}$ & $\frac{\mathrm{C}_{21}+\mathrm{C}_{22}}{\mathrm{C}_{28}+\mathrm{C}_{29}}$ \\
\hline \multicolumn{7}{|c|}{ South Island stratigraphy } \\
\hline \multicolumn{7}{|c|}{ Waima Siltstone } \\
\hline NE85 & 0.77 & 6.16 & 3.42 & 1.48 & $22 *$ & 0.56 \\
\hline \multicolumn{7}{|c|}{ Woodside Formation } \\
\hline NE84 & 0.24 & 1.38 & 1.51 & 1.88 & 22 & 2.89 \\
\hline \multicolumn{7}{|c|}{ Amuri Limestone } \\
\hline NE67 & 0.84 & 1.28 & 0.86 & & 13 & \\
\hline NE74 & 0.34 & 5.31 & 4.14 & 1.74 & $23 *$ & 1.66 \\
\hline NE76 & 0.61 & 4.16 & 4.45 & 1.54 & $24 *$ & 1.13 \\
\hline NE79 & 0.49 & 1.72 & 3.87 & 1.13 & $25 *$ & 0.80 \\
\hline NE83 & 0.30 & 1.51 & 1.85 & 1.63 & $22 *$ & 1.91 \\
\hline NE87 & 0.20 & 1.56 & 4.74 & 1.65 & $24 *$ & 2.99 \\
\hline NE98 & 1.33 & 1.11 & 0.65 & & 22 & \\
\hline NE100 & 0.27 & & 1.95 & & $23 *$ & 1.13 \\
\hline NE106 & 0.21 & 1.47 & 2.08 & 1.79 & $23 *$ & 1.65 \\
\hline \multicolumn{7}{|c|}{ Whangai Formation } \\
\hline \multicolumn{7}{|c|}{ Undifferentiated } \\
\hline NE70 & 0.99 & 3.06 & 3.34 & 1.14 & $25 *$ & 0.47 \\
\hline NE80 & 0.47 & 2.40 & 2.27 & 1.13 & $25 *$ & 0.58 \\
\hline NE8I & 0.34 & 2.35 & 0.55 & 1.20 & $25 *$ & 0.86 \\
\hline NE86 & 2.95 & 1.95 & 0.85 & & 15 & \\
\hline \multicolumn{7}{|l|}{ Mata Series } \\
\hline NE68 & 0.65 & 3.70 & 0.21 & 1.52 & $24^{*}$ & 1.69 \\
\hline NE69 & 0.18 & 0.88 & 3.63 & 1.83 & $23 *$ & 1.84 \\
\hline NE77 & 0.12 & 0.53 & 1.87 & 1.54 & $22 *$ & 3.15 \\
\hline NE78 & 2.30 & 2.28 & 0.89 & 0.86 & 25 & 1.46 \\
\hline NE97 & 1.18 & 5.17 & 7.82 & 1.43 & $22 *$ & 1.57 \\
\hline NE99 & 0.16 & 2.32 & 2.67 & 1.36 & $24 *$ & 1.14 \\
\hline NE 101 & 1.63 & 1.60 & 0.80 & & 19 & \\
\hline NE 103 & 0.44 & 1.53 & 1.59 & 0.91 & $25 *$ & 0.65 \\
\hline \multicolumn{7}{|c|}{ Flags Formation } \\
\hline NE82 & 0.33 & 2.14 & 5.34 & 1.51 & $23 *$ & 1.06 \\
\hline \multicolumn{7}{|c|}{ Conway Siltstone } \\
\hline NE $108^{\circ}$ & 0.81 & 1.96 & 2.47 & 1.03 & 25 & 0.63 \\
\hline \multicolumn{7}{|c|}{ Burnt Creek Formation } \\
\hline NE7! & 0.44 & 2.59 & 1.76 & 1.21 & $25 *$ & 1.24 \\
\hline NE89 & 0.50 & 1.84 & 1.51 & 1.90 & $23^{*}$ & 2.92 \\
\hline \multicolumn{7}{|c|}{$\begin{array}{l}\text { Split Rock Formation } \\
\text { Swale Siltstone Member }\end{array}$} \\
\hline \multicolumn{7}{|c|}{ Wharfe Sandstone Member } \\
\hline NE91 & 1.65 & 3.29 & 1.16 & 1.33 & 24 * & 2.03 \\
\hline NE92 & 0.60 & 2.22 & 1.54 & 1.48 & $22^{*}$ & 3.09 \\
\hline \multicolumn{7}{|c|}{ Ouse Member } \\
\hline Champas & & & & & & \\
\hline NE90 & 0.63 & 1.61 & 1.29 & 1.30 & $25 *$ & 0.62 \\
\hline
\end{tabular}




\begin{tabular}{||lcccccc||}
\hline \hline Sample No. & Pr/Ph & $\mathrm{Pr} / n-\mathrm{C}_{17}$ & $\mathrm{Ph} / n$ - $\mathrm{C}_{18}$ & $\begin{array}{c}\text { CPI } \\
\begin{array}{c}n \text {-alkane } \\
\max \end{array}\end{array}$ & $\frac{\mathrm{C}_{21}+\mathrm{C}_{22}}{\mathrm{C}_{28}+\mathrm{C}_{29}}$ \\
\hline Torlesse Supergroup & & & & & & \\
NE72 & 0.77 & 2.19 & 1.20 & 1.47 & $23^{*}$ & 1.25 \\
NE73 & 0.99 & 2.63 & 1.35 & 1.36 & $24^{*}$ & 3.20 \\
NE75 & 2.28 & 2.94 & 1.32 & 1.15 & 25 & 0.70 \\
NE88 & 0.45 & 2.04 & 1.72 & 1.90 & $23^{*}$ & 3.09 \\
NE96 & 1.28 & 1.41 & 0.98 & 1.05 & $22^{*}$ & 3.50 \\
NE102 & 1.13 & 2.00 & 1.62 & 1.15 & 25 & 0.37 \\
NE105 & 0.72 & 1.64 & 2.10 & 0.97 & 25 & 0.65 \\
\hline \hline
\end{tabular}

$\mathrm{Pr}=$ Pristane; $\mathrm{Ph}=$ Phytane; * Dominant $\mathrm{C}_{25}$-alkane, presumably due to contamination, has been ignored. Adjacent CPI values are therefore also distorted and unreliable. ${ }^{\dagger}$ Samples analysed at CGQ. 
Appendix 5

\section{Gas chromatography-mass spectrometry (GC-MS) data}

Biomarker ratios and relative abundances determined from m/z 191 chromatograms

\begin{tabular}{|c|c|c|c|c|c|c|c|c|c|}
\hline \multirow[t]{2}{*}{ Sample No. } & \multirow[t]{2}{*}{$\mathrm{Tm} / \mathrm{Ts}$} & \multicolumn{2}{|c|}{ moretane/hopane } & \multicolumn{2}{|c|}{$22 S /(22 S+22 R)$} & \multirow{2}{*}{$\begin{array}{c}17 \beta(\mathrm{H})- \\
\text { TNH }\end{array}$} & \multirow[t]{2}{*}{ BNH } & \multirow{2}{*}{$\begin{array}{c}17 \alpha(\mathrm{H})- \\
\text { Diahopane }\end{array}$} & \multirow[t]{2}{*}{ Oleanane } \\
\hline & & $\mathrm{C}_{29}$ & $\mathrm{C}_{30}$ & $\mathrm{C}_{31}$ & $\mathrm{C}_{32}$ & & & & \\
\hline \multicolumn{10}{|l|}{ Oil seeps } \\
\hline Knights Stream & 2.96 & 0.30 & 0.22 & 0.55 & 0.45 & low & low & low & low \\
\hline Isolation Creek & 1.33 & 0.18 & 0.18 & 0.50 & 0.48 & low & low & low & low \\
\hline Kerosene Rock & 1.61 & 0.37 & 0.14 & 0.55 & 0.56 & low & low & $\bmod$ & low \\
\hline Westcott & 1.35 & 0.06 & 0.15 & 0.51 & 0.55 & low & high & $\bmod$ & low \\
\hline Tiraumea & 2.60 & 0.15 & 0.21 & 0.59 & 0.58 & low & $\bmod$ & low-mod & low-mod \\
\hline Okau Stream & 2.55 & 0.48 & 0.38 & 0.56 & 0.55 & low & $\bmod$ & low-mod & low-mod \\
\hline \multicolumn{10}{|c|}{ North Island stratigraphy } \\
\hline \multicolumn{10}{|c|}{ Miocene units } \\
\hline NE30 & 1.18 & 0.23 & 0.17 & 0.43 & 0.48 & $\bmod$ & low & low & low \\
\hline \multicolumn{10}{|c|}{ Whakataki Formation } \\
\hline NE47 & 4.82 & 0.73 & 0.21 & 0.31 & 0.27 & mod-high & mod-high & low & low \\
\hline NE112 & 1.88 & 0.84 & 0.20 & 0.27 & 0.18 & low & low & low & low \\
\hline \multicolumn{10}{|c|}{ Weber Formation } \\
\hline NE19 & 1.42 & 0.21 & 0.19 & 0.45 & 0.55 & $\bmod$ & low & low & low \\
\hline NE61 & 2.83 & 0.48 & 0.25 & 0.38 & 0.36 & high & high & trace & - \\
\hline \multicolumn{10}{|c|}{ Wanstead Formation } \\
\hline NE18 & 1.80 & 0.31 & 0.30 & 0.28 & 0.37 & high & low & low & - \\
\hline NE22 & 2.57 & 0.27 & 0.29 & 0.19 & 0.39 & mod & low & low & - \\
\hline NE55 & 1.49 & 3.02 & 0.26 & 0.33 & 0.26 & mod-high & low & low & low \\
\hline NE58 & 2.18 & 1.15 & 0.22 & 0.51 & 0.47 & high & high & low & - \\
\hline NE62 & 1.59 & 0.34 & 0.27 & 0.43 & 0.43 & high & low & trace & - \\
\hline \multicolumn{10}{|c|}{ Waipawa Black Shale } \\
\hline NE1 & 0.92 & 0.90 & 0.50 & 0.16 & 0.39 & high & high & - & - \\
\hline NE4 & 2.54 & 0.45 & 0.36 & 0.20 & 0.34 & high & low & low & trace \\
\hline NE16 & 1.30 & 0.26 & 0.16 & 0.49 & 0.54 & mod-high & low & low & low \\
\hline NE23 & 8.43 & 0.51 & 0.52 & 0.12 & 0.11 & $\bmod$ & low & low & - \\
\hline NE26 & 6.30 & 1.05 & 0.69 & 0.15 & 0.31 & high & ?low & - & - \\
\hline NE31 & 1.47 & 0.69 & 0.49 & 0.13 & 0.38 & $\bmod$ & - & - & - \\
\hline NE33 & 1.75 & 0.42 & 0.22 & 0.18 & 0.44 & low-mod & low & low & low \\
\hline NE37 & 3.27 & 0.59 & 0.64 & 0.13 & 0.18 & high & low & low & - \\
\hline NE40 & 3.93 & 0.90 & 0.74 & 0.11 & 0.10 & high & low & - & low \\
\hline NE43 & 14.22 & 0.96 & 0.52 & 0.13 & 0.01 & high & low & low-mod & low \\
\hline NE44 & 4.66 & 0.40 & 0.60 & 0.09 & 0.06 & $\bmod$ & high & low & - \\
\hline NE45 & 2.92 & 0.38 & 0.35 & 0.12 & 0.13 & mod & mod & low & - \\
\hline NE48 & 4.99 & 1.04 & 0.33 & 0.11 & 0.06 & high & high & - & trace \\
\hline NE54 & 7.92 & 0.67 & 0.67 & 0.20 & 0.01 & $\bmod$ & high & low & - \\
\hline NE111 & 1.27 & 0.44 & 0.21 & 0.33 & 0.37 & low & low & low & low \\
\hline $\mathrm{NE} 123$ & 1.50 & 0.25 & 0.24 & 0.45 & 0.55 & $\bmod$ & $\bmod$ & low-mod & low \\
\hline NE131 & 2.28 & 0.71 & 0.38 & 0.10 & 0.06 & high & $\bmod$ & mod & low \\
\hline $\begin{array}{l}\text { (Tora Block str } \\
\text { (Kandahar For }\end{array}$ & $\begin{array}{l}\text { graphy) } \\
\text { tion) }\end{array}$ & & & & & & & & \\
\hline NE141 & 1.63 & 0.29 & 0.29 & 0.50 & 0.51 & low-mod & high & low & $\bmod$ \\
\hline (Awhea Forma & & & & & & & & & \\
\hline $\begin{array}{l}\text { NE142 } \\
\text { (Mungaroa }\end{array}$ & $\begin{array}{r}4.10 \\
\text { mber) }\end{array}$ & 0.41 & 0.28 & 0.56 & 0.43 & mod-high & low-mod & low & trace \\
\hline NE138 & 2.32 & 0.43 & 0.24 & 0.54 & 0.41 & mod & low & low & low-mod \\
\hline (Manurewa Fo & ation) & & & & & & & & \\
\hline NE137 & 3.84 & 0.44 & 0.28 & 0.47 & 0.40 & $\bmod$ & low & low & trace \\
\hline NE143 & 1.49 & 0.18 & 0.16 & 0.53 & 0.59 & low-mod & low-mod & low & - \\
\hline $\begin{array}{c}\text { Whangai Form } \\
\text { Te Uri Mem }\end{array}$ & & & & & & & & & \\
\hline NE11 & 1.60 & 0.38 & 0.24 & 0.23 & 0.28 & $\bmod$ & $\bmod$ & low & - \\
\hline NE21 & 1.17 & 0.26 & 0.20 & 0.32 & 0.25 & mod & low & low & - \\
\hline Porangahau & ember & & & & & & & & \\
\hline NE8 & 1.13 & 0.23 & 0.16 & 0.52 & 0.71 & mod & low & low & low-mod \\
\hline NE17 & 1.28 & 0.25 & 0.14 & 0.55 & 0.55 & low-mod & low & low & low-mod \\
\hline NE38 & 1.28 & 0.30 & 0.17 & 0.32 & 0.62 & high & low & low & low \\
\hline NE39 & 3.23 & 0.36 & 0.29 & 0.37 & 0.35 & $\bmod$ & low & low & - \\
\hline
\end{tabular}




\begin{tabular}{|c|c|c|c|c|c|c|c|c|c|}
\hline \multirow[t]{2}{*}{ Sample No. } & \multirow[t]{2}{*}{$\mathrm{Tm} / \mathrm{Ts}$} & \multicolumn{2}{|c|}{ moretane/hopane } & \multicolumn{2}{|c|}{$22 \mathrm{~S} /(22 \mathrm{~S}+22 \mathrm{R})$} & \multirow{2}{*}{$\begin{array}{c}17 \beta(\mathrm{H})- \\
\text { TNH }\end{array}$} & \multirow[t]{2}{*}{ BNH } & \multirow{2}{*}{$\begin{array}{c}17 \alpha(\mathbf{H})- \\
\text { Diahopane }\end{array}$} & \multirow[t]{2}{*}{ Oleanane } \\
\hline & & $\mathrm{C}_{29}$ & $\mathrm{C}_{30}$ & $\mathrm{C}_{31}$ & $\mathrm{C}_{32}$ & & & & \\
\hline Upper $\mathrm{Ca}$ & ous Meml & & & & & & & & \\
\hline $\mathrm{NE} 12$ & 2.17 & 0.48 & 0.33 & 0.20 & 0.21 & $\bmod$ & low & low & trace \\
\hline NE13 & 3.19 & 0.57 & 0.36 & 0.18 & 0.20 & $\bmod$ & low & low & low \\
\hline NE20 & 2.10 & 0.57 & 0.38 & 0.13 & 0.14 & $\bmod$ & low & low & low \\
\hline NE24 & 4.84 & 0.47 & 0.61 & 0.09 & 0.07 & $\bmod$ & $\bmod$ & low & - \\
\hline NE28 & 1.22 & 0.96 & 0.22 & 0.23 & 0.22 & low-mod & low-mod & low & - \\
\hline NE46 & 1.57 & 0.68 & 0.31 & 0.21 & 0.22 & low & high & trace & trace \\
\hline NE113 & 4.12 & 1.82 & 0.35 & 0.13 & 0.12 & mod-high & mod & low & low \\
\hline Rakauroa & ber & & & & & & & & \\
\hline NE3 & 1.62 & 0.26 & 0.21 & 0.38 & 0.45 & $\bmod$ & low & low & trace \\
\hline NE15 & 1.63 & 0.57 & 0.21 & 0.22 & 0.24 & $\bmod$ & low & low & low \\
\hline NE25 & 1.95 & 0.22 & 0.24 & 0.38 & 0.50 & $\bmod$ & $\bmod$ & low & low \\
\hline NE136 & 2.06 & 0.40 & 0.17 & 0.58 & 0.48 & low-mod & low & low & low-mod \\
\hline NEI44 & 4.59 & 0.34 & 0.31 & 0.54 & 0.44 & $\bmod$ & $\bmod$ & low & low \\
\hline Undiffere & & & & & & & & & \\
\hline NE14 & 1.42 & 0.47 & 0.31 & 0.23 & 0.21 & $\bmod$ & $\bmod$ & low & low \\
\hline NE32 & 1.43 & 0.20 & 0.20 & 0.27 & 0.30 & mod-high & low & low & low \\
\hline NE35 & 1.40 & 0.32 & 0.20 & 0.43 & 0.51 & $\bmod$ & $\bmod$ & low & low-mod \\
\hline NE36 & 1.45 & 0.29 & 0.18 & 0.42 & 0.46 & $\bmod$ & low & low & low \\
\hline NE49 & 1.60 & 0.35 & 0.23 & 0.34 & 0.27 & $\bmod$ & low & low & low \\
\hline NE50 & 2.60 & 0.84 & 0.60 & 0.21 & 0.19 & mod-high & mod & low & low \\
\hline NE53 & 1.37 & 0.31 & 0.27 & 0.41 & 0.47 & low-mod & low-mod & low & low \\
\hline NE56 & 1.83 & 1.32 & 0.28 & 0.27 & 0.35 & $\bmod$ & high & low & low \\
\hline NE63 & 6.16 & 0.42 & 1.09 & 0.09 & 0.05 & $\bmod$ & high & low & - \\
\hline NE65 & 4.56 & 1.20 & 0.40 & 0.14 & 0.15 & high & mod & low & low \\
\hline NE121 & 3.42 & 0.07 & 0.48 & 0.19 & 0.13 & $\bmod$ & low & - & - \\
\hline Tangaruhe $\mathrm{F}$ & tion & & & & & & & & \\
\hline NE9 & 1.26 & 0.42 & 0.21 & 0.33 & 0.30 & high & low & low & low \\
\hline NE10 & 1.56 & 0.44 & 0.26 & 0.21 & 0.19 & $\bmod$ & low & low & low \\
\hline Te Mai Form & & & & & & & & & \\
\hline NE51 & 1.12 & 4.92 & 0.13 & 0.75 & 0.54 & high & low & trace & $?$ \\
\hline NE52 & 2.71 & 1.87 & 0.30 & 0.50 & 0.21 & high & mod & low & trace \\
\hline NE59 & 11.40 & 0.50 & 0.35 & 0.56 & 0.51 & low-mod & $\bmod$ & low & trace \\
\hline NE124 & 4.02 & 0.49 & 0.26 & 0.20 & 0.27 & low-mod & low & low & - \\
\hline NE125 & 2.26 & 0.44 & 0.33 & 0.30 & 0.34 & low-mod & low & low & - \\
\hline Glenburn $\mathrm{Fo}_{0}$ & & & & & & & & & \\
\hline NE2 & 1.44 & 0.24 & 0.21 & 0.44 & 0.39 & low-mod & low & low & low \\
\hline NE5 & 1.52 & 0.23 & 0.19 & 0.37 & 0.46 & low-mod & low & low & low \\
\hline NE6 & 1.31 & 0.21 & 0.16 & 0.47 & 0.50 & low-mod & low & low & low \\
\hline NE7 & 2.58 & 0.54 & 0.27 & 0.28 & 0.21 & low-mod & low & low & - \\
\hline NE117 & 1.69 & 0.20 & 0.16 & 0.53 & 0.55 & low-mod & mod & low-mod & low \\
\hline NE118 & 2.32 & 5.48 & 0.15 & 0.91 & 0.41 & high & low & trace & - \\
\hline NE132 & 1.12 & 0.22 & 0.13 & 0.52 & 0.96 & low-mod & low & low & - \\
\hline Springhill Fo & & & & & & & & & \\
\hline NE134 & 2.05 & 0.54 & 0.19 & 0.51 & 0.41 & $\bmod$ & low & low & - \\
\hline NE139 & 7.71 & 0.39 & 0.26 & 0.32 & 0.29 & high & low-mod & low & . \\
\hline Gentle Annie & nation & & & & & & & & \\
\hline NE129 & 1.34 & 0.49 & 0.13 & 0.55 & 0.57 & mod-high & low-mod & low & - \\
\hline Mangapokia & lation & & & & & & & & \\
\hline NE42 & 3.24 & 0.50 & 0.30 & 0.34 & 0.43 & mod-high & high & low & - \\
\hline NE64 & 3.17 & 0.94 & 0.34 & 0.46 & 0.33 & mod-high & high & low & - \\
\hline NE66 & 2.18 & 0.25 & 0.24 & 0.54 & 0.58 & $\bmod$ & low & low & - \\
\hline NE119 & 3.26 & 1.34 & 0.24 & 0.58 & 0.47 & high & low & low & - \\
\hline NE127 & 5.22 & 0.31 & 0.29 & 0.55 & 0.51 & $\bmod$ & low & low & low \\
\hline NE128 & 3.34 & 0.96 & 0.21 & 0.38 & 0.28 & $\bmod$ & low & low & - \\
\hline NE135 & 5.28 & 0.52 & 0.26 & 0.52 & 0.40 & $\bmod$ & low & low-mod & - \\
\hline NE140 & 5.22 & 0.60 & 0.26 & 0.55 & 0.44 & $\bmod$ & low & low-mod & - \\
\hline Taipo Forma & & & & & & & & & \\
\hline NE60 & 2.06 & 0.22 & 0.21 & 0.48 & 0.51 & mod-high & high & low & - \\
\hline Undifferentia & ahaoa Gr & & & & & & & & \\
\hline NE122 & 6.60 & 0.73 & 0.37 & 0.47 & 0.58 & $\bmod$ & low & low & - \\
\hline NE126 & 3.43 & 0.64 & 0.31 & 0.43 & 0.34 & mod-high & low & low & - \\
\hline NE133 & 6.08 & 0.40 & 0.41 & 0.38 & 0.32 & high & low & low & - \\
\hline Whatarangi I & ation & & & & & & & & \\
\hline NE145 & 2.42 & 0.14 & 0.11 & 0.75 & 0.57 & low & low & low-mod & - \\
\hline Torlesse Sup & & & & & & & & & \\
\hline NE114 & 1.48 & 0.06 & 0.13 & 0.31 & 0.72 & low & $\bmod$ & $\bmod$ & - \\
\hline South Island & igraphy & & & & & & & & \\
\hline Waima Siltst & & & & & & & & & \\
\hline NE85 & 1.29 & 0.63 & 0.12 & 0.44 & 0.33 & low & low & low-mod & mod-high \\
\hline
\end{tabular}




\begin{tabular}{|c|c|c|c|c|c|c|c|c|c|}
\hline \multirow[t]{2}{*}{ Sample No. } & \multirow[t]{2}{*}{$\mathrm{Tm} / \mathrm{Ts}$} & \multicolumn{2}{|c|}{ "moretane/hopane } & \multicolumn{2}{|c|}{$22 \mathrm{~S} /(22 \mathrm{~S}+22 \mathrm{R})$} & \multirow{2}{*}{$\begin{array}{c}\text { 17ß(H)- } \\
\text { TNH }\end{array}$} & \multirow[t]{2}{*}{ BNH } & \multirow{2}{*}{$\begin{array}{c}17 \alpha(\mathrm{H})- \\
\text { Diahopane }\end{array}$} & \multirow[t]{2}{*}{ Oleanane } \\
\hline & & $\mathrm{C}_{29}$ & $\mathrm{C}_{30}$ & $\mathrm{C}_{31}$ & $\mathrm{C}_{32}$ & & & & \\
\hline \multicolumn{10}{|c|}{ Woodside Formation } \\
\hline NE84 & 2.19 & 0.26 & 0.26 & 0.46 & 0.52 & $\bmod$ & low & low & - \\
\hline \multicolumn{10}{|c|}{ Amuri Limestone } \\
\hline NE67 & 1.62 & 0.43 & 0.21 & 0.52 & 0.54 & high & low & trace & - \\
\hline NE74 & 1.50 & 0.53 & 0.25 & 0.38 & 0.48 & high & low & trace & ?low \\
\hline NE76 & 1.46 & 0.17 & 0.18 & 0.38 & 0.54 & low & trace & low & trace \\
\hline NE79 & 1.05 & 0.19 & 0.18 & 0.58 & 0.57 & low-mod & low & low & low \\
\hline NE83 & 1.11 & 0.11 & 0.11 & 0.53 & 0.59 & low & low & low & ?trace \\
\hline NE87 & 1.31 & 0.19 & 0.15 & 0.49 & 0.51 & $\bmod$ & low & low & - \\
\hline NE98 & 1.36 & 0.47 & 0.18 & 0.51 & 0.57 & low-mod & low & low & - \\
\hline NE100 & 16.18 & 0.53 & 0.55 & 0.56 & 0.37 & low-mod & low & low & - \\
\hline NE104 & 1.19 & 0.22 & 0.15 & 0.48 & 0.60 & $\bmod$ & low & low & - \\
\hline NE106 & 2.15 & 0.19 & 0.22 & 0.52 & 0.51 & $\bmod$ & low & low & - \\
\hline \multicolumn{10}{|c|}{ Whangai Formation } \\
\hline \multicolumn{10}{|c|}{ Undifferentiated } \\
\hline NE70 & 1.70 & 0.80 & 0.22 & 0.37 & 0.32 & low-mod & low & low & low \\
\hline NE80 & 4.62 & 0.84 & 0.38 & 0.34 & 0.32 & $\bmod$ & low & low & trace \\
\hline NE81 & 4.40 & 0.52 & 0.47 & 0.18 & 0.39 & $\bmod$ & low & trace & - \\
\hline NE86 & 2.02 & 0.33 & 0.22 & 0.50 & 0.35 & low & low & low & trace \\
\hline \multicolumn{10}{|l|}{ Mata Series } \\
\hline NE68 & 2.31 & 0.23 & 0.22 & 0.52 & 0.51 & low-mod & low & low & - \\
\hline NE69 & 1.18 & 0.15 & 0.17 & 0.57 & 0.55 & $\bmod$ & low & low & low \\
\hline NE77 & 1.17 & 0.18 & 0.13 & 0.55 & 0.75 & $\bmod$ & low & low & low \\
\hline NE78 & 1.30 & 0.14 & 0.16 & 0.59 & 0.59 & low & low & low & - \\
\hline NE97 & 2.36 & 0.64 & 0.17 & 0.31 & 0.22 & mod-high & $\bmod$ & low & - \\
\hline NE99 & 7.19 & 1.72 & 0.49 & 0.12 & 0.17 & mod-high & low & low-mod & $\bmod$ \\
\hline NE101 & 1.95 & 0.78 & 0.13 & 0.38 & 0.30 & mod-high & low & low & - \\
\hline NE103 & 4.57 & 0.38 & 0.28 & 0.48 & 0.41 & $\bmod$ & low & low & low \\
\hline \multicolumn{10}{|c|}{ Flags Formation } \\
\hline NE82 & 2.48 & 0.39 & 0.36 & 0.24 & 0.29 & $\bmod$ & low & low & - \\
\hline \multicolumn{10}{|c|}{ Claverley Sandstone } \\
\hline NE107 & 3.47 & 0.93 & 0.55 & 0.10 & 0.38 & high & low & trace & low \\
\hline \multicolumn{10}{|c|}{ Conway Siltstone } \\
\hline NE $108^{\circ}$ & 1.61 & 0.29 & 0.20 & 0.44 & 0.52 & $\bmod$ & low & low & low \\
\hline Burnt Creek & nation & & & & & & & & \\
\hline NE7 I & 13.96 & 1.23 & 0.74 & 0.45 & 0.33 & $\bmod$ & low & low & - \\
\hline NE89 & 4.30 & 0.19 & 0.30 & 0.56 & 0.61 & low-mod & low & low & - \\
\hline $\begin{array}{l}\text { Split Rock F } \\
\text { Swale Sil }\end{array}$ & $\begin{array}{l}\text { tion } \\
\text { Membe }\end{array}$ & & & & & & & & \\
\hline NE94 & 4.13 & 0.38 & 0.31 & 0.50 & 0.22 & low-mod & low & low & - \\
\hline Wharfe S & one Men & & & & & & & & \\
\hline NE91 & 2.51 & 0.26 & 0.24 & 0.55 & 0.52 & low & low & low & - \\
\hline NE92 & 2.69 & 0.28 & 0.23 & 0.52 & 0.49 & $\bmod$ & low & low & ?low \\
\hline Ouse Me & & & & & & & & & \\
\hline NE93 & 5.79 & 0.27 & 0.31 & 0.58 & 0.56 & low & low & low & - \\
\hline Champag & ember & & & & & & & & \\
\hline NE90 & 4.37 & 0.25 & 0.23 & 0.58 & 0.56 & low & low & low & - \\
\hline Torlesse Sur & & & & & & & & & \\
\hline NE72 & 5.65 & 0.78 & 0.33 & 0.49 & 0.45 & $\bmod$ & $\bmod$ & low & - \\
\hline NE73 & 10.08 & 0.35 & 0.41 & 0.55 & 0.48 & low-mod & low & low & - \\
\hline NE75 & 2.01 & 0.34 & 0.26 & 0.52 & 0.50 & low-mod & low & low & low \\
\hline NE88 & 5.61 & 0.37 & 0.37 & 0.50 & 0.35 & mod & low & low & - \\
\hline NE96 & 1.61 & 0.13 & 0.15 & 0.60 & 0.58 & low-mod & low & low & trace \\
\hline NE102 & 3.49 & 0.23 & 0.23 & 0.58 & 0.55 & low-mod & low & low & - \\
\hline NE105 & 1.61 & 0.35 & 0.15 & 0.50 & 0.44 & mod & low & low & - \\
\hline
\end{tabular}

$\mathrm{Tm}=17 \alpha(\mathrm{H})$-22,29,30-Trisnorhopane; Ts=18 $\alpha(\mathrm{H})-22,29,30$-Trisnorneohopane; $17 \beta(\mathrm{H})$-TNH=17 $\beta(\mathrm{H})-22,29,30$-Trisnorhopane; BNH=28,30-Bisnorhopane; "-"=absent. 
Biomarker ratios determined from m/z 217 chromatograms

\begin{tabular}{|c|c|c|c|c|c|c|}
\hline \multirow[t]{2}{*}{ Sample No. } & \multicolumn{2}{|c|}{$20 S /(20 S+20 R)$} & \multicolumn{2}{|c|}{$\% \beta \beta$} & \multirow{2}{*}{$\begin{array}{r}\mathrm{C}_{27} / \mathrm{C}_{29} \\
\alpha \alpha \alpha-20 \mathrm{R} \\
\end{array}$} & \multirow{2}{*}{$\begin{array}{c}\mathrm{C}_{30} / \mathrm{C}_{27}-\mathrm{C}_{30} \\
\alpha \alpha \alpha \cdot-20 \mathrm{R}\end{array}$} \\
\hline & $\mathrm{C}_{27}$ steranes & $\mathrm{C}_{29}$ steranes & $\mathrm{C}_{27}$ steranes & $\mathrm{C}_{29}$ steranes & & \\
\hline \multicolumn{7}{|l|}{ Oil seeps } \\
\hline Knights Stream & 0.35 & 0.24 & 0.34 & 0.28 & 0.71 & 0.06 \\
\hline Isolation Creek & 0.53 & 0.48 & 0.64 & 0.51 & 0.83 & 0.12 \\
\hline Kerosene Rock & 0.62 & 0.52 & 0.53 & 0.51 & 0.85 & 0.24 \\
\hline Westcott & 0.58 & 0.57 & 0.62 & 0.55 & 0.85 & 0.35 \\
\hline Tiraumea & 0.51 & 0.48 & 0.37 & 0.39 & 0.85 & 0.28 \\
\hline Okau Stream & 0.44 & 0.51 & 0.35 & 0.40 & 0.94 & 0.40 \\
\hline \multicolumn{7}{|c|}{ North Island stratigraphy } \\
\hline \multicolumn{7}{|c|}{ Miocene units } \\
\hline NE30 & 0.56 & 0.38 & 0.41 & 0.48 & 1.80 & 0.07 \\
\hline \multicolumn{7}{|c|}{ Whakataki Formation } \\
\hline NE47 & 0.31 & 0.04 & 0.20 & 0.34 & 1.50 & 0.06 \\
\hline NE112 & 0.27 & 0.11 & 0.23 & 0.35 & 0.82 & 0.04 \\
\hline \multicolumn{7}{|c|}{ Weber Formation } \\
\hline NE19 & 0.52 & 0.13 & 0.35 & 0.35 & 1.33 & 0.09 \\
\hline NE61 & 0.35 & 0.08 & 0.16 & 0.31 & 1.97 & 0.04 \\
\hline \multicolumn{7}{|c|}{ Wanstead Formation } \\
\hline NE18 & 0.51 & 0.45 & 0.46 & 0.49 & 3.54 & 0.09 \\
\hline NE22 & 0.41 & 0.47 & 0.58 & 0.52 & 1.81 & 0.12 \\
\hline NE55 & 0.40 & 0.12 & 0.22 & 0.35 & 2.36 & 0.04 \\
\hline NE58 & 0.35 & 0.11 & 0.23 & 0.41 & 1.95 & 0.14 \\
\hline NE62 & 0.46 & 0.26 & 0.49 & 0.39 & 2.08 & 0.05 \\
\hline \multicolumn{7}{|c|}{ Waipawa Black Shale } \\
\hline $\mathrm{NEl}$ & 0.32 & 0.31 & 0.23 & 0.31 & 1.89 & 0.12 \\
\hline NE4 & 0.37 & 0.17 & 0.24 & 0.33 & 1.29 & 0.33 \\
\hline NE16 & 0.56 & 0.45 & 0.42 & 0.53 & 2.59 & 0.06 \\
\hline NE23 & 0.42 & 0.09 & 0.29 & 0.44 & 0.74 & 0.27 \\
\hline NE26 & 0.42 & 0.08 & 0.19 & 0.48 & 1.68 & 0.23 \\
\hline NE31 & 0.48 & 0.11 & 0.40 & 0.42 & 2.01 & 0.23 \\
\hline NE33 & 0.38 & 0.04 & 0.17 & 0.31 & 0.75 & 0.05 \\
\hline NE37 & 0.34 & 0.32 & 0.37 & 0.34 & 2.43 & 0.21 \\
\hline NE40 & 0.45 & 0.09 & 0.33 & 0.46 & 0.99 & 0.32 \\
\hline NE43 & 0.37 & 0.02 & 0.13 & 0.35 & 1.34 & 0.29 \\
\hline NE44 & 0.12 & 0.03 & 0.14 & 0.23 & 2.30 & 0.19 \\
\hline NE45 & 0.48 & 0.15 & 0.41 & 0.50 & 1.73 & 0.18 \\
\hline NE48 & 0.14 & 0.04 & 0.13 & 0.11 & 0.84 & 0.30 \\
\hline NE54 & 0.40 & 0.68 & 0.32 & 0.20 & 1.59 & 0.31 \\
\hline NE111 & 0.42 & 0.14 & 0.23 & 0.33 & 1.27 & 0.06 \\
\hline $\mathrm{NE} 123$ & 0.57 & 0.48 & 0.57 & 0.52 & 1.11 & 0.33 \\
\hline NE131 & 0.10 & 0.04 & 0.09 & 0.07 & 1.23 & 0.30 \\
\hline $\begin{array}{l}\text { (Tora Block str } \\
\text { (Kandahar For }\end{array}$ & $\begin{array}{l}\text { raphy) } \\
\text { ion) }\end{array}$ & & & & & \\
\hline NE141 & 0.49 & 0.46 & 0.56 & 0.51 & 2.06 & 0.08 \\
\hline (Awhea Forma & & & & & & \\
\hline NE 142 & 0.50 & 0.46 & 0.51 & 0.54 & 1.46 & low \\
\hline (Mungaroa & nber) & & & & & \\
\hline NE1 38 & 0.38 & 0.26 & - & 0.37 & 2.41 & 0.04 \\
\hline (Manurewa Fo & tion) & & & & & \\
\hline NE137 & 0.40 & 0.31 & 0.41 & 0.42 & 1.88 & low \\
\hline NE143 & 0.64 & 0.41 & 0.55 & $0.5 \mathrm{I}$ & 0.45 & 0.12 \\
\hline Whangai Form & & & & & & \\
\hline Te Uri Mem & & & & & & \\
\hline NE11 & 0.37 & 0.07 & 0.14 & 0.29 & 1.73 & 0.05 \\
\hline NE21 & 0.48 & 0.17 & 0.29 & 0.35 & 1.91 & 0.05 \\
\hline Porangahau & mber & & & & & \\
\hline NE8 & 0.38 & 0.25 & 0.50 & 0.41 & 0.57 & 0.23 \\
\hline NE17 & 0.74 & 0.27 & 0.38 & 0.41 & 0.23 & 0.31 \\
\hline NE38 & 0.59 & 0.27 & 0.36 & 0.39 & 1.31 & 0.07 \\
\hline NE39 & 0.48 & 0.34 & 0.44 & 0.41 & 1.65 & 0.18 \\
\hline Upper Calc: & us Member & & & & & \\
\hline NE12 & 0.38 & 0.07 & 0.14 & 0.29 & 1.42 & 0.06 \\
\hline NE13 & 0.34 & 0.14 & 0.11 & 0.30 & 1.00 & 0.11 \\
\hline NE2O & 0.38 & 0.06 & 0.20 & 0.27 & 1.77 & 0.06 \\
\hline NE24 & 0.42 & 0.23 & 0.30 & 0.40 & 1.07 & 0.21 \\
\hline NE28 & 0.40 & 0.16 & 0.18 & 0.31 & 2.39 & 0.05 \\
\hline NE46 & 0.48 & 0.20 & 0.30 & 0.39 & 1.67 & 0.05 \\
\hline NEI13 3 & 0.40 & 0.07 & 0.22 & 0.36 & 0.75 & 0.09 \\
\hline
\end{tabular}




\begin{tabular}{|c|c|c|c|c|c|c|}
\hline \multirow[t]{2}{*}{ Sample No. } & \multicolumn{2}{|c|}{$20 \mathrm{~S} /(20 \mathrm{~S}+20 \mathrm{R})$} & \multicolumn{2}{|c|}{$\% \beta \beta$} & \multirow{2}{*}{$\begin{array}{c}\mathrm{C}_{27} / \mathrm{C}_{29} \\
\alpha \alpha \alpha \alpha-20 \mathrm{R}\end{array}$} & \multirow{2}{*}{$\begin{array}{c}\mathrm{C}_{30} / \mathrm{C}_{27}-\mathrm{C}_{30} \\
\alpha . \alpha \alpha-20 \mathrm{R}\end{array}$} \\
\hline & $\mathrm{C}_{27}$ steranes & $\mathrm{C}_{29}$ steranes & $\mathrm{C}_{27}$ steranes & $\mathrm{C}_{29}$ steranes & & \\
\hline \multicolumn{7}{|c|}{ Rakauroa Member } \\
\hline NE3 & 0.41 & 0.18 & 0.45 & 0.49 & 1.27 & 0.19 \\
\hline NE15 & 0.37 & 0.07 & 0.18 & 0.29 & 0.92 & 0.06 \\
\hline NE25 & 0.45 & 0.29 & 0.34 & 0.50 & 2.23 & 0.12 \\
\hline NE136 & 0.38 & 0.26 & 0.27 & 0.35 & 3.02 & 0.03 \\
\hline NE144 & 0.38 & 0.27 & 0.41 & 0.21 & 0.88 & 0.09 \\
\hline \multicolumn{7}{|c|}{ Undifferentiated } \\
\hline NE14 & 0.38 & 0.07 & 0.16 & 0.31 & 2.08 & 0.07 \\
\hline NE32 & 0.37 & 0.04 & 0.17 & 0.31 & 1.18 & 0.03 \\
\hline NE35 & 0.45 & 0.22 & 0.23 & 0.35 & 1.17 & 0.05 \\
\hline NE36 & 0.52 & 0.19 & 0.26 & 0.35 & 0.59 & 0.10 \\
\hline NE49 & 0.72 & 0.25 & 0.36 & 0.48 & 0.51 & 0.07 \\
\hline NE50 & 0.48 & 0.20 & 0.30 & 0.40 & 2.26 & 0.05 \\
\hline NE53 & 0.53 & 0.27 & 0.35 & 0.42 & 0.60 & 0.08 \\
\hline NE56 & 0.51 & 0.17 & 0.28 & 0.38 & 2.57 & 0.03 \\
\hline NE63 & 0.21 & 0.24 & 0.29 & 0.39 & 1.77 & 0.16 \\
\hline NE65 & 0.31 & 0.05 & 0.16 & 0.35 & 1.22 & 0.06 \\
\hline NE121 & 0.51 & 0.12 & 0.29 & 0.48 & 2.52 & 0.04 \\
\hline \multicolumn{7}{|c|}{ Tangaruhe Formation } \\
\hline NE9 & 0.41 & 0.15 & 0.20 & 0.37 & 2.18 & 0.05 \\
\hline \multirow{2}{*}{\multicolumn{7}{|c|}{ Te Mai Formation }} \\
\hline & & & & & & \\
\hline NE51 & 0.55 & 0.40 & 0.53 & 0.52 & 2.46 & 0.04 \\
\hline NE52 & 0.63 & 0.15 & 0.61 & 0.42 & 0.47 & 0.07 \\
\hline NE59 & 0.55 & 0.35 & 0.71 & 0.33 & 0.29 & 0.06 \\
\hline NE124 & 0.47 & 0.25 & 0.32 & 0.34 & 0.81 & 0.13 \\
\hline NE 125 & 0.54 & 0.10 & 0.38 & 0.31 & 1.65 & 0.04 \\
\hline \multicolumn{7}{|c|}{ Glenburn Formation } \\
\hline NE2 & 0.75 & 0.23 & 0.42 & 0.46 & 0.41 & 0.06 \\
\hline NE5 & 0.72 & 0.17 & 0.43 & 0.38 & 0.30 & 0.05 \\
\hline NE6 & 0.53 & 0.33 & 0.42 & 0.43 & 0.96 & 0.07 \\
\hline NE7 & 0.50 & 0.17 & 0.38 & 0.49 & 1.06 & 0.34 \\
\hline NE117 & 0.54 & 0.57 & 0.53 & 0.50 & 2.49 & 0.14 \\
\hline NE1 18 & 0.62 & 0.49 & 0.61 & 0.44 & 0.91 & 0.07 \\
\hline \multirow{2}{*}{\multicolumn{7}{|c|}{ Springhill Formation }} \\
\hline & & & & & & \\
\hline NE134 & 0.40 & 0.18 & 0.52 & 0.27 & 0.66 & 0.04 \\
\hline NE139 & 0.44 & 0.17 & 0.31 & 0.37 & 0.89 & 0.03 \\
\hline \multicolumn{7}{|c|}{ Gentle Annie Formation } \\
\hline NE129 & 0.54 & 0.46 & 0.49 & 0.52 & 1.15 & 0.09 \\
\hline \multicolumn{7}{|c|}{ Mangapokia Formation } \\
\hline NE42 & 0.07 & 0.02 & 0.08 & 0.12 & 1.36 & 0.23 \\
\hline NE64 & 0.56 & 0.26 & 0.56 & 0.60 & 1.10 & 0.10 \\
\hline NE66 & 0.51 & 0.35 & 0.43 & 0.42 & 0.90 & 0.09 \\
\hline NE119 & 0.46 & 0.36 & 0.53 & 0.45 & 0.58 & 0.09 \\
\hline NE127 & 0.45 & 0.25 & 0.55 & 0.31 & 0.31 & 0.04 \\
\hline NE128 & 0.35 & 0.16 & 0.42 & 0.32 & 0.77 & 0.03 \\
\hline NE135 & 0.45 & 0.23 & 0.63 & 0.19 & 0.67 & 0.04 \\
\hline NE140 & 0.47 & 0.20 & 0.73 & 0.37 & 0.43 & 0.03 \\
\hline Taipo Form: & & & & & & \\
\hline NE60 & 0.37 & 0.17 & 0.32 & 0.39 & 1.31 & 0.12 \\
\hline Undifferenti & ahaoa Group & & & & & \\
\hline NE122 & 0.35 & 0.15 & 0.34 & 0.33 & 0.81 & 0.09 \\
\hline NE126 & 0.51 & 0.18 & 0.48 & 0.46 & 0.66 & very low \\
\hline NE133 & 0.38 & 0.09 & 0.60 & 0.38 & 0.48 & very low \\
\hline Whatarangi & ation & & & & & \\
\hline $\mathrm{NE} 145$ & 0.61 & 0.54 & 0.86 & 0.46 & 0.12 & 0.03 \\
\hline Torlesse Sup & & & & & & \\
\hline NE114 & 0.76 & 0.61 & 0.65 & 0.59 & 1.31 & 0.21 \\
\hline$\underline{\text { South Island }}$ & graphy & & & & & \\
\hline Waima Silts & & & & & & \\
\hline NE85 & 0.30 & 0.04 & 0.09 & 0.26 & 0.81 & 0.03 \\
\hline $\begin{array}{l}\text { Woodside F } \\
\text { NE84 }\end{array}$ & $\begin{array}{ll}\text { on } & \\
& 0.56 \\
\end{array}$ & 0.48 & 0.53 & 0.55 & 0.77 & low \\
\hline
\end{tabular}




\begin{tabular}{|c|c|c|c|c|c|c|}
\hline \multirow[t]{2}{*}{ Sample No. } & \multicolumn{2}{|c|}{$20 S /(20 S+20 R)$} & \multicolumn{2}{|c|}{$\% \beta \beta$} & \multirow{2}{*}{$\begin{array}{c}\mathrm{C}_{27} / \mathrm{C}_{29} \\
\alpha \alpha \alpha-20 \mathrm{R} \\
\end{array}$} & \multirow{2}{*}{$\begin{array}{c}\mathrm{C}_{30} / \mathrm{C}_{27}-\mathrm{C}_{30} \\
\alpha \alpha \alpha-20 \mathrm{R}\end{array}$} \\
\hline & $\mathrm{C}_{27}$ steranes & $\mathrm{C}_{29}$ steranes & $\mathrm{C}_{27}$ steranes & $\mathrm{C}_{29}$ steranes & & \\
\hline \multicolumn{7}{|c|}{ Amuri Limestone } \\
\hline NE67 & 0.49 & 0.39 & 0.48 & 0.66 & 1.17 & 0.10 \\
\hline NE74 & 0.59 & 0.21 & 0.53 & 0.55 & 0.59 & 0.10 \\
\hline NE76 & 0.74 & 0.34 & 0.45 & 0.53 & 0.70 & very low \\
\hline NE79 & 0.69 & 0.37 & 0.48 & 0.61 & 0.96 & 0.01 \\
\hline NE83 & 0.52 & 0.51 & 0.46 & 0.54 & 1.28 & low \\
\hline NE87 & 0.48 & 0.19 & 0.36 & 0.35 & 1.43 & very low \\
\hline NE98 & 0.40 & 0.20 & 0.41 & 0.47 & 0.83 & low \\
\hline NEIOO & 0.34 & 0.22 & 0.64 & 0.24 & 0.20 & 0.04 \\
\hline NE104 & 0.46 & 0.42 & 0.46 & 0.55 & 0.87 & low \\
\hline NE 106 & 0.38 & 0.41 & 0.44 & 0.48 & 0.87 & 0.11 \\
\hline \multicolumn{7}{|c|}{ Whangai Formation } \\
\hline \multicolumn{7}{|c|}{ Undifferentiated } \\
\hline NE70 & 0.45 & 0.11 & 0.23 & 0.43 & 0.90 & 0.07 \\
\hline NE80 & 0.32 & 0.06 & 0.18 & 0.41 & 1.15 & 0.06 \\
\hline NE81 & 0.33 & 0.16 & 0.30 & 0.27 & 1.09 & 0.04 \\
\hline NE86 & - & 0.13 & - & 0.25 & 1.24 & 0.08 \\
\hline \multicolumn{7}{|l|}{ Mata Series } \\
\hline NE68 & 0.62 & 0.34 & 0.45 & 0.54 & 0.67 & 0.13 \\
\hline NE69 & 0.65 & 0.41 & 0.43 & 0.38 & 0.80 & 0.06 \\
\hline NE77 & 0.64 & 0.27 & 0.39 & 0.31 & 0.77 & 0.04 \\
\hline NE78 & 0.61 & 0.53 & 0.63 & 0.46 & 0.74 & 0.12 \\
\hline NE97 & 0.36 & 0.24 & 0.38 & 0.38 & 2.37 & 0.03 \\
\hline NE99 & 0.36 & 0.04 & 0.09 & 0.35 & 0.61 & 0.05 \\
\hline NE101 & 0.42 & 0.14 & 0.32 & 0.37 & 0.68 & 0.08 \\
\hline NE103 & 0.45 & 0.41 & 0.44 & 0.36 & 1.93 & 0.19 \\
\hline \multicolumn{7}{|c|}{ Flags Formation } \\
\hline NE82 & 0.31 & 0.13 & 0.52 & 0.55 & 0.75 & 0.23 \\
\hline \multicolumn{7}{|c|}{ Claverley Sandstone } \\
\hline NE107 & 0.42 & 0.10 & 0.26 & 0.43 & 1.74 & 0.04 \\
\hline \multicolumn{7}{|c|}{ Conway Siltstone } \\
\hline NE108 & 0.59 & 0.37 & 0.44 & 0.43 & 0.68 & 0.09 \\
\hline \multicolumn{7}{|c|}{ Burnt Creek Formation } \\
\hline NE71 & 0.16 & 0.11 & 0.28 & 0.21 & 0.98 & 0.26 \\
\hline NE89 & 0.56 & 0.42 & 0.55 & 0.73 & 0.71 & 0.07 \\
\hline \multicolumn{7}{|c|}{ Split Rock Formation } \\
\hline \multicolumn{7}{|c|}{ Swale Siltstone Member } \\
\hline NE94 & 0.43 & 0.20 & 0.44 & 0.45 & 0.86 & 0.09 \\
\hline \multicolumn{7}{|c|}{ Wharfe Sandstone Member } \\
\hline NE91 & 0.53 & 0.33 & 0.44 & 0.23 & 1.44 & 0.08 \\
\hline NE92 & 0.51 & 0.23 & 0.27 & 0.45 & 0.48 & 0.07 \\
\hline \multicolumn{7}{|c|}{ Ouse Member } \\
\hline NE93 & 0.70 & 0.51 & 0.46 & 0.47 & 0.49 & 0.11 \\
\hline \multicolumn{7}{|c|}{ Champagne Member } \\
\hline NE90 & 0.66 & 0.52 & 0.73 & 0.49 & 0.28 & low \\
\hline Torlesse SuI & & & & & & \\
\hline NE72 & 0.40 & 0.24 & 0.46 & 0.42 & 0.77 & 0.17 \\
\hline NE73 & 0.54 & 0.29 & 0.62 & 0.46 & 0.23 & 0.06 \\
\hline NE75 & 0.62 & 0.26 & 0.40 & 0.43 & 0.37 & 0.09 \\
\hline NE88 & 0.48 & 0.18 & 0.43 & 0.33 & 0.73 & very low \\
\hline NE96 & 0.76 & 0.41 & 0.42 & 0.42 & 0.67 & very low \\
\hline NE102 & 0.54 & 0.39 & 0.45 & 0.28 & 0.78 & 0.05 \\
\hline NE105 & 0.47 & 0.18 & 0.49 & 0.33 & 0.55 & 0.06 \\
\hline
\end{tabular}




\section{Appendix 6}

\section{Stable carbon isotope data}

Seventeen rock and six oil samples were prepared for ${ }^{13} \mathrm{C}$ analysis. Saturate and aromatic fractions of rock bitumens, and an additional 'whole-oil' fraction from oil samples were forwarded to the Waikato Stable Isotope Unit at Waikato University for analysis. ${ }^{13} \mathrm{C}$ determinations were carried out on a Dumas elemental analyser (Carlo Erba AnalyserNA1500) interfaced to a stable isotope mass spectrometer (Europa Scientific Tracermass). The samples were analysed against a laboratory standard (calibrated relative to $\mathrm{PDB}$ ) with the instrument automatically drift-correcting data each time it recalibrated after every 12 samples. Instrument error is about $0.3 \delta$ (Anjana Rajendram, pers. comm.) but between-sample $\delta$ error is higher as it is a combination of machine error plus sample heterogeneity.

In fractions that had sufficient carbon for reliable results, reproducibility between the original and repeat analyses was not good. Instrumental error was considered minimal as the internal standards matched well (Anjana Rajendram, pers. comm.). It was also unlikely that error was due to source rock variation because large quantities $(50 \mathrm{~g})$ were used and the samples were homogenised during crushing and powdering. Peters and Moldowan (1993) suggested secondary processes (such as laboratory fractionations) can result in variation of sample isotopic composition and this seems to be the most likely cause of error. Light $\left(<\mathrm{C}_{15}\right)$ hydrocarbons are enriched in ${ }^{13} \mathrm{C}$ compared to the whole oil and these are lost during rotary evaporation (Peters and Moldowan, 1993). If conditions vary during this process then the isotope ratios of the samples will also vary. Another source of error lies in the separation of saturate from aromatic fractions during column chromatography. If the fractions are not thoroughly separated there will be contamination of one by the other, and their isotopic compositions will be affected. These errors were not quantified but reasonable care was taken to maintain uniform conditions during laboratory work. 


\begin{tabular}{|c|c|c|c|c|}
\hline Sample & $\begin{array}{l}\text { Saturate } \\
\delta^{13} \mathrm{C}(\%)\end{array}$ & $\begin{array}{l}\text { Aromatic } \\
\delta^{13} \mathrm{C}(\%)\end{array}$ & $\begin{array}{l}\text { Whole-oil } \\
\delta^{13} \mathrm{C}(\% o)\end{array}$ & $\begin{array}{c}\text { Sofer Value } \\
\text { (CV) }\end{array}$ \\
\hline \multicolumn{5}{|l|}{ Oil seeps } \\
\hline Knights Stream & -29.32 & -28.18 & -28.91 & -0.03 \\
\hline Isolation Creek & $-28.49 *$ & -26.17 & -26.75 & 2.33 \\
\hline Kerosene Rock & -24.45 & -22.17 & -23.04 & 0.99 \\
\hline Westcott & -20.94 & -20.36 & -20.91 & -3.87 \\
\hline Tiraumea & $\begin{array}{l}-27.26 \\
\text { (no value) }\end{array}$ & $\begin{array}{l}-27.26^{*} \\
(-23.45)\end{array}$ & $\begin{array}{l}-26.97 \\
\text { (no value) }\end{array}$ & -3.20 \\
\hline Okau Stream & -22.43 & -21.69 & -21.64 & -3.05 \\
\hline \multicolumn{5}{|l|}{ North Island stratigraphy } \\
\hline \multicolumn{5}{|l|}{ Miocene coal } \\
\hline NE109 & -29.01 & -26.46 & & 3.00 \\
\hline \multicolumn{5}{|l|}{ Waipawa Black Shale } \\
\hline NE23 & -27.03 & -25.03 & & 1.17 \\
\hline NE45 & $\begin{array}{l}-32.43^{*} \\
(-26.20)\end{array}$ & $\begin{array}{l}-23.80 \\
(-23.80)\end{array}$ & & $\begin{array}{l}17.56 \\
(1.80)\end{array}$ \\
\hline NE111 & $\begin{array}{l}-29.32^{* *} \\
\left(-30.71^{*}\right)\end{array}$ & $\begin{array}{l}-28.35 \\
(-29.20)\end{array}$ & & $\begin{array}{l}-0.41 \\
(1.22)\end{array}$ \\
\hline NE131 & -25.00 & -21.87 & & 3.05 \\
\hline \multicolumn{5}{|l|}{ Whangai Formation } \\
\hline \multicolumn{4}{|l|}{ Tangaruhe Formation } & -0.58 \\
\hline NE10 & $\begin{array}{l}-28.79 \\
(-30.89)\end{array}$ & $\begin{array}{l}-28.97 * * \\
(-29.28)\end{array}$ & & $\begin{array}{l}-3.12 \\
(1.50)\end{array}$ \\
\hline \multicolumn{5}{|l|}{ Te Mai Formation } \\
\hline NE51 & $\begin{array}{l}-32.47 * \\
(-29.23)\end{array}$ & $\begin{array}{c}-28.83 \\
(-27.37)\end{array}$ & & $\begin{array}{c}6.50 \\
(1.54)\end{array}$ \\
\hline NE52 & $\begin{array}{l}-28.93 * * \\
(-29.63)\end{array}$ & $\begin{array}{l}-27.80 * \\
(-25.80)\end{array}$ & & $\begin{array}{l}-0.17 \\
(6.04)\end{array}$ \\
\hline \multicolumn{5}{|l|}{ Glenburn Formation } \\
\hline NE7 & $\begin{array}{l}-28.72 * * \\
(-28.92 *)\end{array}$ & $\begin{array}{l}-25.54 \\
\text { (no value) }\end{array}$ & & 4.31 \\
\hline NE117 & $\begin{array}{l}-28.88^{*} \\
(-30.07)\end{array}$ & $\begin{array}{l}-26.97 \\
(-27.02)\end{array}$ & & $\begin{array}{c}1.54 \\
(4.44)\end{array}$ \\
\hline NE118 & $\begin{array}{l}-31.61 * * \\
(-28.42)\end{array}$ & $\begin{array}{l}-28.83 * * \\
(-25.57)\end{array}$ & & $\begin{array}{c}4.32 \\
(3.49)\end{array}$ \\
\hline $\begin{array}{l}\text { Mangapokia Formation } \\
\text { NE64 }\end{array}$ & -27.91 & -26.64 & & -0.18 \\
\hline \multicolumn{5}{|l|}{ South Island stratigraphy } \\
\hline \multicolumn{5}{|l|}{ Flags Formation } \\
\hline NE82 & $\begin{array}{l}-29.14 * * \\
(-28.04)\end{array}$ & $\begin{array}{l}-28.79 \\
(-27.66)\end{array}$ & & $\begin{array}{l}-1.84 \\
(-2.11)\end{array}$ \\
\hline NE108 & $\begin{array}{l}-28.91 * * \\
(-29.13)\end{array}$ & $\begin{array}{l}-28.52 \\
(-27.25)\end{array}$ & & $\begin{array}{l}-1.82 \\
(1.55)\end{array}$ \\
\hline \multicolumn{5}{|l|}{$\begin{array}{l}\text { Split Rock Formation } \\
\text { Wharfe Sandstone Member }\end{array}$} \\
\hline
\end{tabular}

*just below minimum required carbon; ** well below minimum required carbon; repeat analyses in brackets(). Relative to PDB. 


\section{Appendix 7}

\section{Visual kerogen analysis (VKA)}

Sixteen samples were submitted to Dr. M. J. Hannah, Geology Department, Victoria University of Wellington, for visual kerogen analysis (VKA). Samples were chosen specifically from the uppermost Cretaceous to Paleocene sequence which had favourable results from TOC and Rock-Eval analyses. Samples from the Te Mai, Glenburn and Mangapokia formations as well as Torlesse Supergroup were also included to determine the nature of their organic matter.

\begin{tabular}{||l|l|l|c||}
\hline \hline & Sample No. & Formation & Reaction with HCl \\
\hline A & NE9 & Tangaruhe Fm & minor \\
B & NE15 & Whangai Fm, Rakauroa Member & minor \\
C & NE23 & Waipawa Black Shale & \\
D & NE27 & Whangai Fm, Rakauroa Member & \\
E & NE43 & Waipawa Black Shale & minor \\
F & NE46 & Whangai Fm, Upper Calc. Member & \\
G & NE51 & Te Mai Fm (sst. unit) & \\
H & NE52 & Te Mai Fm (mst. unit) & \\
I & NE64 & Mangapokia Fm & \\
J & NE82 & Flags Fm & minor \\
K & NE86 & Whangai Fm & minor \\
L & NE108 & Conway Siltstone & \\
M & NE113 & Whangai Fm, Upper Calc. Member & \\
N & NE114 & Torlesse Supergroup & \\
O & NE117 & Glenburn Fm (sst. unit) & \\
P & NE118 & Glenburn Fm (mst. unit) & \\
\hline \hline
\end{tabular}




\section{Kerogen isolation}

The method used for kerogen isolation, described below, was modified slightly from that of Sparke et al. (1984), with a change to sodium polytungstate as the heavy liquid in the flotation process (see Gregory and Johnston, 1987).

\section{Sample preparation}

Air-dried samples (c. $10 \mathrm{~g}$ ) were gently crushed with a mortar and pestle to a maximum 3-4 mm size taking care to avoid powdering the samples and thereby destroying the kerogen.

\section{Carbonate removal}

Ten percent $\mathrm{HCl}$ was added to each sample and those that reacted had more $\mathrm{HCl}$ added and were left for the reaction to go to completion. Distilled water was then added and the solution decanted to remove the calcium salts which otherwise, on the addition of $\mathrm{HF}$, would result in the precipitation of insoluble $\mathrm{CaF}_{2}$.

\section{Removal of silica and silicates}

Forty percent HF was added to the samples which was then stirred well and left overnight. The HF was then decanted and the samples diluted with distilled water. This was stirred well, left for the fine fraction to settle and then also decanted. This process was repeated four times to dilute remaining HF. The fine fraction of each sample were decanted into large centrifuge test-tubes and centrifuged ( $2600 \mathrm{rpm}$ for $5 \mathrm{~min}$.). Ten millilitres of $10 \% \mathrm{HCl}$ was added, stirred and topped up with distilled water. This was centrifuged ( $2600 \mathrm{rpm}$ for $5 \mathrm{~min}$.) and then decanted. The $\mathrm{HCl}$ is added to remove any acid soluble fluorides which may be present.

\section{Flotation}

A prepared solution of sodium polytungstate and distilled water (S.G. $1.85 \mathrm{~g} / \mathrm{cm}^{3}$ ) was added to the samples and then stirred, centrifuged ( $800 \mathrm{rpm}$ for $15 \mathrm{~min}$.) and left overnight to settle. Kerogen separated from the sediment by floating on the heavy liquid which was removed by pipette. The samples were then washed in distilled water and centrifuged ( $3000 \mathrm{rpm}$ for $3 \mathrm{~min}$.) four times to remove sodium polytungstate salt.

\section{Slide preparation}

Strewn-mount slides of kerogen (two per sample) were made using glycerol gelatin as the mounting media. 


\begin{tabular}{|c|c|c|c|c|c|c|c|c|c|c|c|c|c|}
\hline एँّ & 흍 & : & 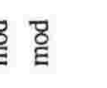 & 奄蒿 & : & & : & 킁 흠 & : & हु & $\underline{\Xi}$ & 뭅 & $\begin{array}{ll}0 \\
\end{array}$ \\
\hline 焉 & 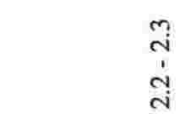 & & & $\stackrel{\stackrel{ }{i}}{\frac{\overrightarrow{4}}{4}} N$ & $\stackrel{i}{i}$ & & & & ते & & & กี & y \\
\hline 米 & $\begin{array}{l}\frac{*}{*} \\
\frac{13}{*}\end{array}$ & & & & & $\frac{*}{4}$ & & & & & & & \\
\hline ब्ञूँ & 응 & 요 & 8 & $\therefore$ & 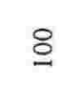 & & 8 & $\therefore 8$ & 응 & $\stackrel{8}{\circ}$ & $\stackrel{8}{\circ}$ & 8 & 5 의 \\
\hline 农 & 으 & & in & $\because \cong$ & 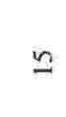 & & 2 & & in & $\cong$ & $\cong$ & 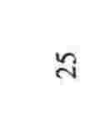 & i 요 \\
\hline 䆙总 & $=8$ & 으 & 2 & 요 & i & & in & 恕 & 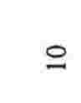 & $\stackrel{2}{2}$ & 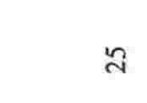 & $n$ & $=\quad 2$ \\
\hline 总 & 요 & & $2 \stackrel{m}{m}$ & $\cong q$ & 으 & 으 & 요 & in 8 & $\infty$ & $\cong$ & $\mathscr{f}$ & 구 & in \\
\hline 巳 & $\underset{\Xi}{\mathscr{E}}$ & & 으 & $\cong \simeq$ & in & & $n$ & in & n & ๕్ & $n$ & $n$ & , तి \\
\hline 造 & & & & & & & & & & & & & \\
\hline 总哀 & & & 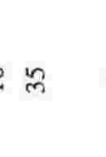 & $n$ & 迆 & & & ष्ठ & & & 으 & if & $\because$ \\
\hline 哭 & & & & & & & & & & & & & \\
\hline 氮 & 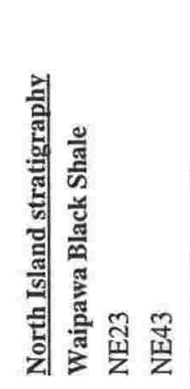 & 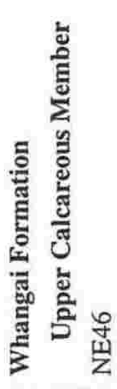 & 焉 & 爱芩 & 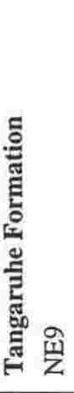 & 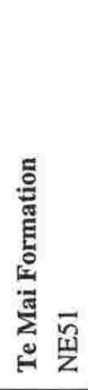 & 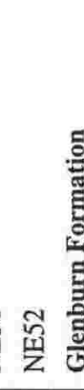 & $\frac{\infty}{7}$ & 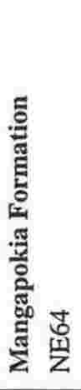 & 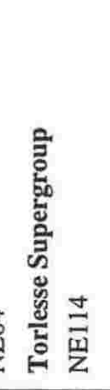 & 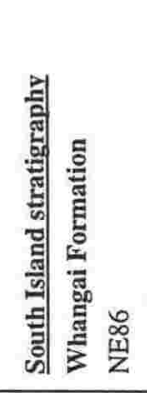 & 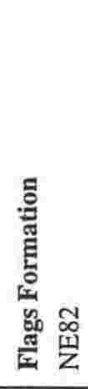 & 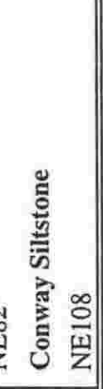 \\
\hline
\end{tabular}




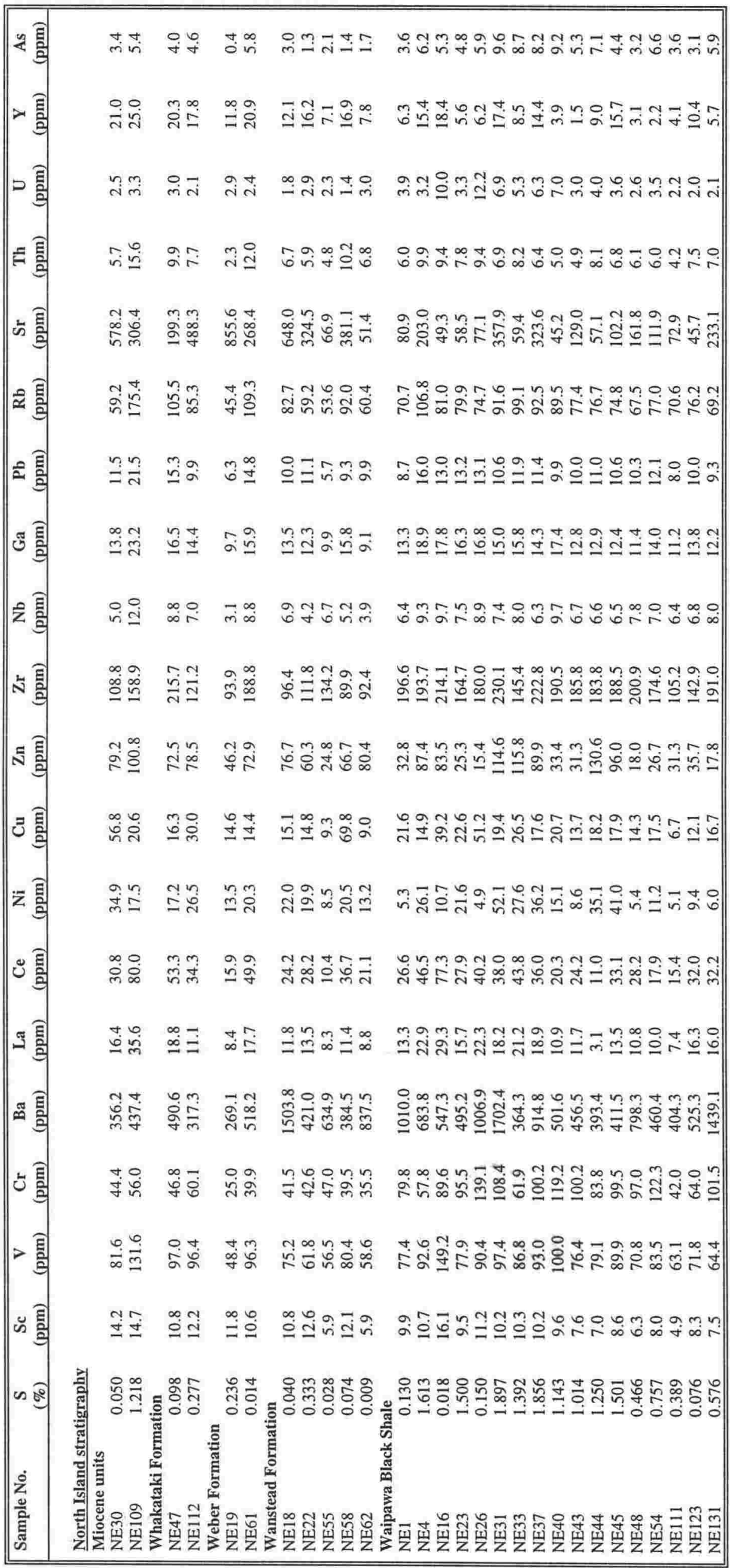




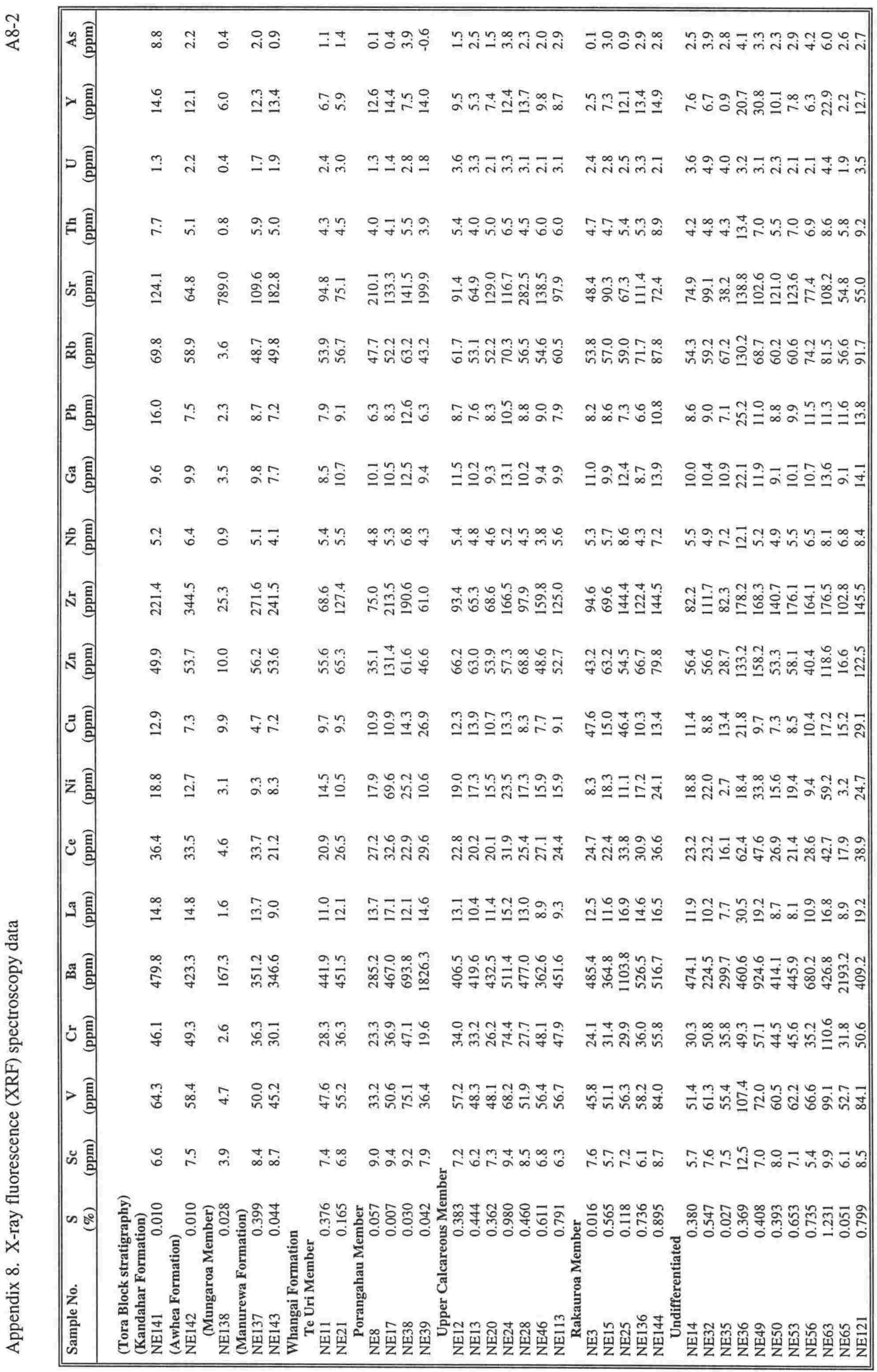




\begin{tabular}{|c|c|c|c|c|c|c|c|c|}
\hline \& & $\overrightarrow{\mathrm{N}} \stackrel{0}{-}$ & 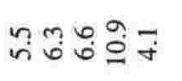 & 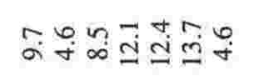 & $\stackrel{\circ}{\infty}$ & 3 & 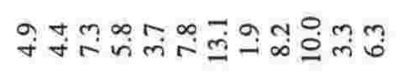 & $\stackrel{\infty}{\infty}$ & $\underset{\infty}{\infty}$ \\
\hline & $\stackrel{\infty}{=} \dot{\nexists j}$ & 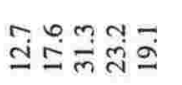 & 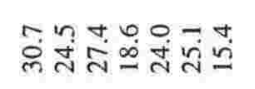 & ำ & $\bar{a}$ & 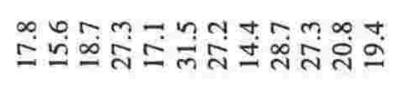 & $\stackrel{9}{=}$ & ली \\
\hline 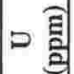 & ปิल & 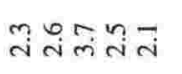 & 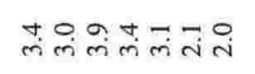 & $\stackrel{\infty}{i}$ & $\tilde{n}$ & 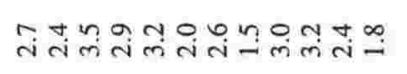 & $\stackrel{I}{I}$ & 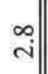 \\
\hline$\approx$ & $\stackrel{m}{\sim} \stackrel{\infty}{\infty}$ & 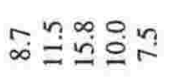 & 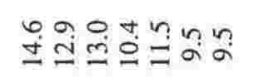 & 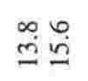 & $m^{m}$ & 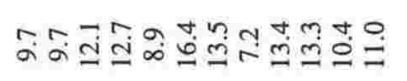 & $\underset{\infty}{+\infty}$ & . \\
\hline is & $\begin{array}{l}\infty \\
\infty \\
\infty\end{array}$ & 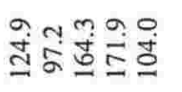 & 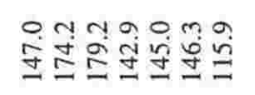 & $\begin{array}{l}0 n \\
\stackrel{0}{0} 0\end{array}$ & $\stackrel{\circ}{5}$ & 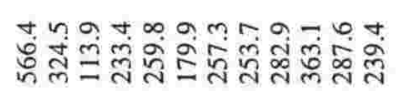 & हิ่ & פे|| \\
\hline दे & 市 & 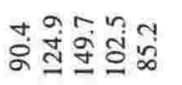 & 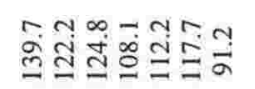 & 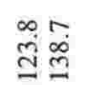 & $\stackrel{+}{\sim}$ & 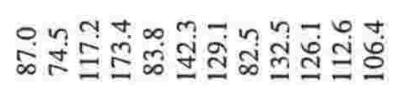 & $\stackrel{\infty}{\circ}$ & :ी \\
\hline 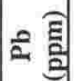 & 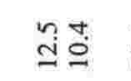 & 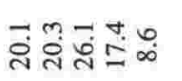 & 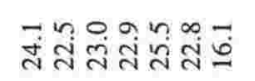 & 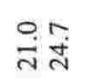 & $\stackrel{\circ}{=}$ & 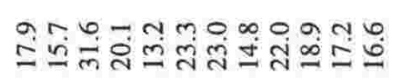 & $\stackrel{\leftrightarrow}{\grave{g}}$ & $\stackrel{\sim}{\sim}$ \\
\hline ङु & $\underset{\dot{I}}{\dot{I} \stackrel{n}{m}}$ & 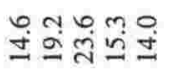 & 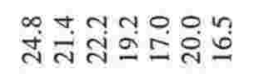 & $\stackrel{n}{2} \frac{0}{4}$ & $\stackrel{9}{\circ}$ & ம் & $\cong$ & ते \\
\hline$\hat{z}$ & 운 & $\vec{\infty}^{\infty}=\vec{I}: 0$. & 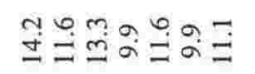 & $\begin{array}{l}+\infty \\
\stackrel{0}{\infty} \infty\end{array}$ & $\stackrel{n}{m}$ & 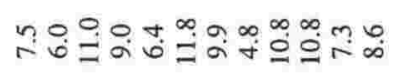 & $\vec{n}$ & $\stackrel{m}{=}$ \\
\hline n & 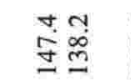 & 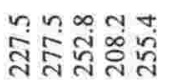 & 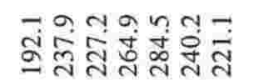 & $\begin{array}{l}\forall \dot{\infty} \\
\sigma \\
\sigma\end{array}$ & బิ่ & 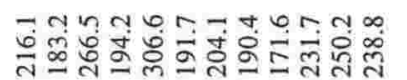 & 亲 & ํํㄹ \\
\hline & ถู่ & 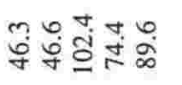 & 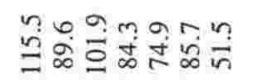 & +⿳亠े冋 & 离 & 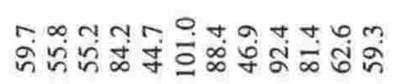 & $\overline{0}$ & 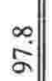 \\
\hline & 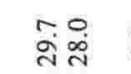 & 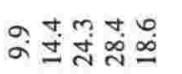 & 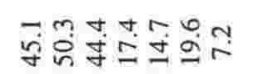 & $\stackrel{\text { dִ }}{\dot{d}}$ & $\ddot{\circ}$ & & $\tilde{6}$ & 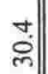 \\
\hline$\ddot{z}$ & $\stackrel{\infty}{\infty} \underset{-\infty}{-\infty}$ & 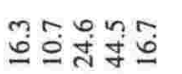 & 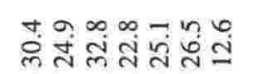 & $\begin{array}{l}\infty \\
\dot{\sim} \\
\dot{\sim}\end{array}$ & 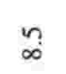 & 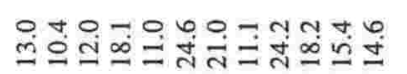 & $\stackrel{0}{r}$ & जें \\
\hline & 它守 & 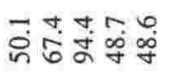 & 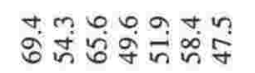 & ㄱํㅇำ & 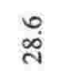 & 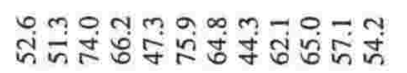 & ñ & ¿े| \\
\hline g & नें ले & 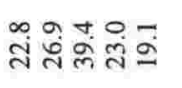 & 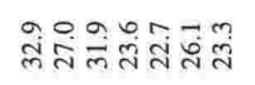 & $\stackrel{m}{\dot{m} \vec{y}}$ & $\stackrel{\Xi}{\mathrm{I}}$ & 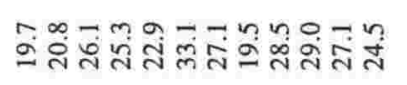 & อे & 官 \\
\hline ๓ & 紋 & 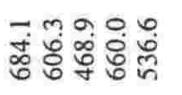 & 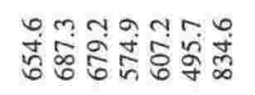 & हैं लें & $\underset{⿱ 亠 凶}{\dot{t}}$ & 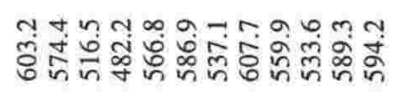 & $\underset{\infty}{\infty}$ & 它 \\
\hline u & 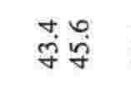 & 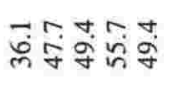 & 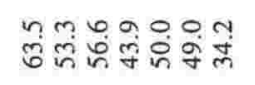 & 宅 & $\stackrel{n}{n}$ & 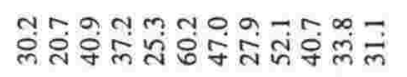 & $\overline{\mathrm{d}}$ & $\stackrel{\infty}{\sim}$ \\
\hline$>$ 园 & ت象 & 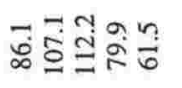 & 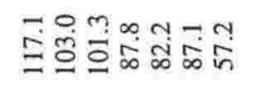 & 家 & $\stackrel{m}{q}$ & 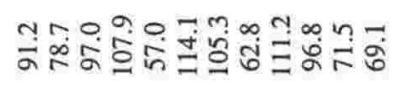 & $\overline{\vec{g}}$ & $\stackrel{?}{\stackrel{?}{=}}$ \\
\hline 品 & केश & 兑导学角 & ம் & $\stackrel{m}{m} \stackrel{+}{m}$ & in & 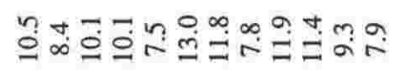 & $\stackrel{\circ}{+}$ & $\underset{ \pm}{ \pm}$ \\
\hline is 8 & \multirow{2}{*}{ 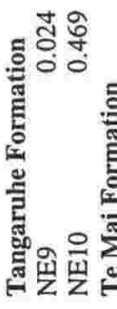 } & \multirow{2}{*}{ 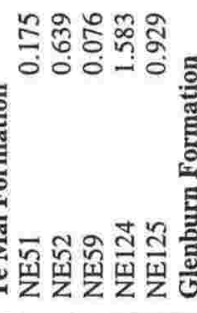 } & \multirow{2}{*}{ 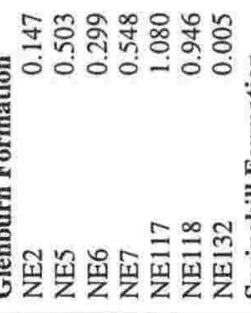 } & \multirow{2}{*}{\multicolumn{2}{|c|}{ 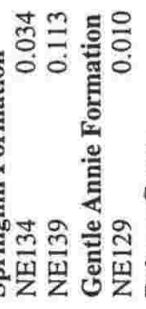 }} & \multirow{2}{*}{\multicolumn{2}{|c|}{ 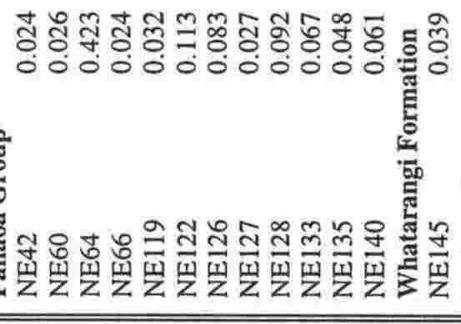 }} & \\
\hline 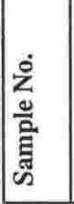 & & & & & & & & \\
\hline
\end{tabular}




\begin{tabular}{|c|c|c|c|c|c|c|c|c|c|c|}
\hline 学司 & $\stackrel{\infty}{i}$ & $\Xi$ & 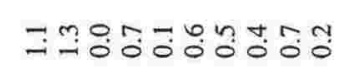 & 곤ำ & 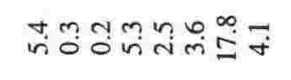 & $\stackrel{\infty}{i}$ & $\stackrel{m}{\forall}$ & $\tilde{b}$ & $\stackrel{n}{0} \overrightarrow{0}$ & 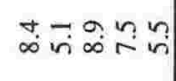 \\
\hline$>$ 言 & $\overline{\underline{I}}$ & $=$ & 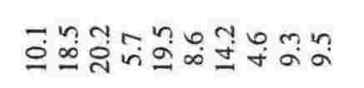 & פேすも气 & 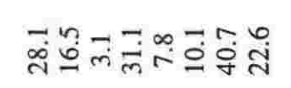 & $\stackrel{\mathfrak{I}}{\mathrm{I}}$ & $\therefore$ & $\stackrel{\pi}{\stackrel{5}{\pi}}$ & लिंग्र & 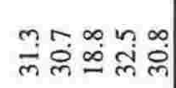 \\
\hline$\supset$ 产 & 3 & n & 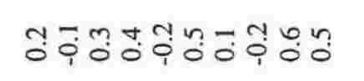 & iेंīi & 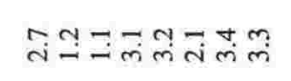 & $\bar{i}$ & $\stackrel{i}{i}$ & i & ํㅛㄹ & 구 \\
\hline$\Xi$ & $\stackrel{\circ}{\leftrightarrow}$ & $\stackrel{\infty}{0}$ & 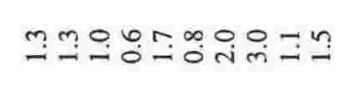 & 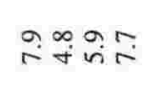 & 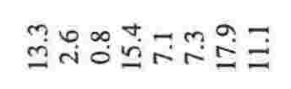 & $\hat{6}$ & $\ddot{n}$ & $\stackrel{\circ}{r}$ & 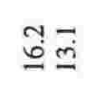 & 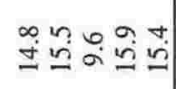 \\
\hline 战 & 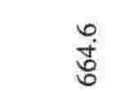 & $\frac{n}{m}$ & 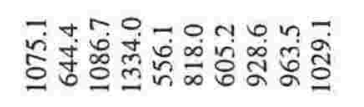 & 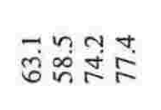 & 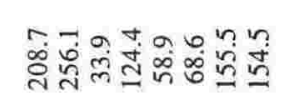 & $\stackrel{\infty}{\stackrel{\infty}{0}}$ & $\overrightarrow{\mathrm{s}}$ & $\stackrel{\infty}{\infty}$ & 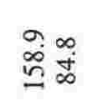 & ปี่ \\
\hline$\vec{\approx}$ & $\overline{\dot{m}}$ & $\overline{5}$ & 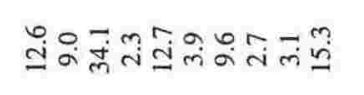 & 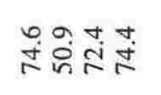 & 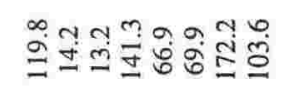 & : & $\hat{8}$ & $\stackrel{\circ}{+}$ & 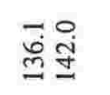 & 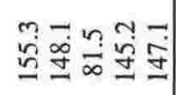 \\
\hline 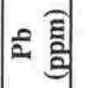 & F & กู & 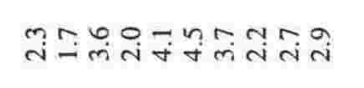 & केलक & 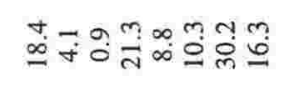 & $m_{\infty}^{2}$ & $\underset{\infty}{m}$ & $\stackrel{\infty}{\varrho}$ & 运a & 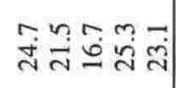 \\
\hline$\pi$ & ปี & กี & 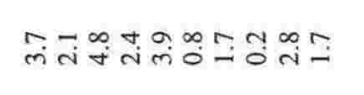 & 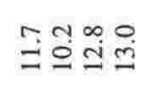 & 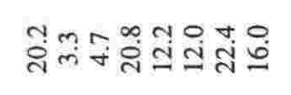 & $\Xi$ & $\stackrel{\infty}{\varrho}$ & $\stackrel{\infty}{\Leftrightarrow}$ & :ंत्र & กัล กั่ \\
\hline$\hat{z}$ & $\stackrel{0}{i}$ & $\stackrel{\circ}{i}$ & 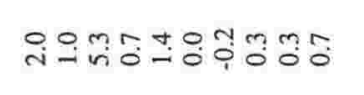 & ุํำํํำำ & 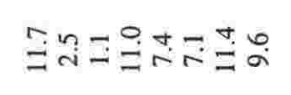 & iे & in & $\bar{a}$ & $\stackrel{\oplus ?}{=}$ & 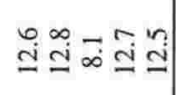 \\
\hline N & Iี & 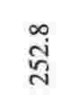 & 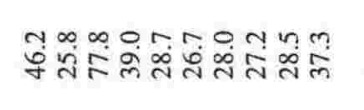 & 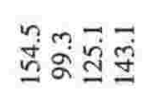 & 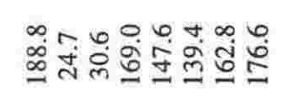 & $\stackrel{g}{\Xi}$ & 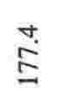 & ஓ्ं் & mू & 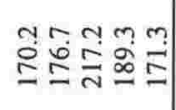 \\
\hline ลี & $\overrightarrow{⿱ 宀 y}$ & $\frac{a}{m}$ & ڤેं & क्वेत्म & 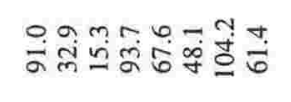 & $\stackrel{n}{n}$ & $\stackrel{g}{\dot{j}}$ & $\stackrel{\infty}{\circ}$ & 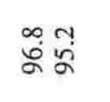 & 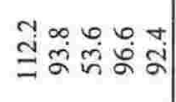 \\
\hline ฮี & กิ & $\stackrel{ \pm}{=}$ & 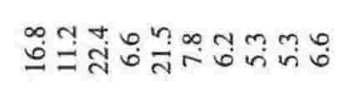 & 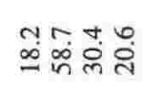 & 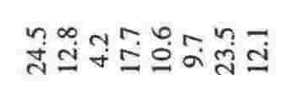 & $\frac{9}{m}$ & กู & $\stackrel{\infty}{i}$ & 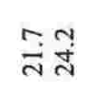 & 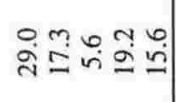 \\
\hline $\bar{z}$ & 吕 & $\stackrel{\infty}{\stackrel{\infty}{\infty}}$ & 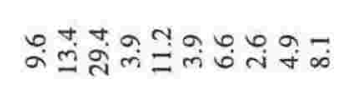 & 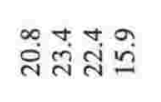 & ñ & $\stackrel{n}{ \pm}$ & $\stackrel{\circ}{i}$ & $\vec{n}$ & 윰 & mે̃ \\
\hline ن & 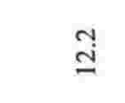 & $\stackrel{+}{4}$ & 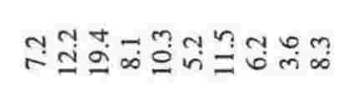 & $\begin{array}{l}\infty \\
\infty \\
\infty \\
\infty \\
\infty\end{array}$ & 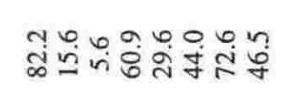 & $\stackrel{\circ}{\text { j }}$ & $\underset{⿱ 丷}{\dot{q}}$ & $\stackrel{\infty}{\stackrel{\sim}{\sim}}$ & 安兑 & 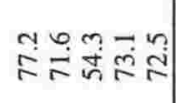 \\
\hline 3 & के & $m$ & ఢి & 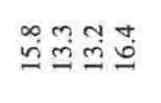 & 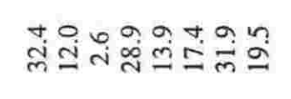 & $\stackrel{m}{m}$ & तें & $\stackrel{\circ}{\circ}$ & 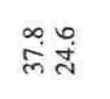 & 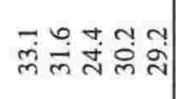 \\
\hline 。园 & कें & ํํํ & $\begin{array}{l}m \sim 0 \\
0 \\
0 \\
0\end{array}$ & 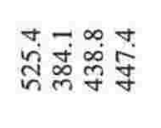 & 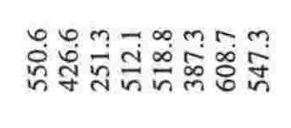 & $\underset{\dot{z}}{\stackrel{4}{2}}$ & مْ & 율 & 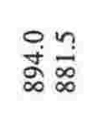 & 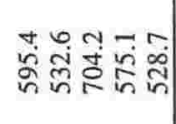 \\
\hline 己园 & के & $\stackrel{n}{\overrightarrow{7}}$ & さ્త & 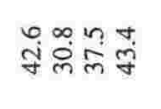 & 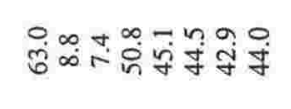 & $\frac{9}{\sigma}$ & $\stackrel{\circ}{\circ}$ & $\begin{array}{l}\stackrel{0}{+} \\
\stackrel{+}{+}\end{array}$ & ज்: & 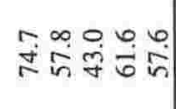 \\
\hline$>$ 司 & $\stackrel{\infty}{\dot{J}}$ & $\frac{9}{6}$ & 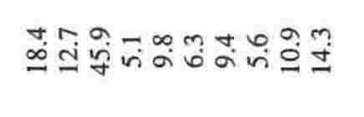 & 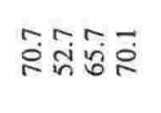 & 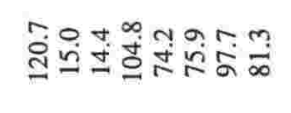 & 뭉 & ㅇ. & à & $\stackrel{n}{\mathscr{m}} \stackrel{\infty}{=}$ & ت்َ \\
\hline 㝘 & $\approx$ & $\overline{0}$ & 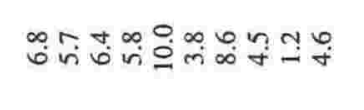 & 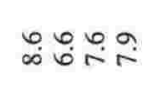 & ตุด & $n$ & 2 & $\stackrel{\circ}{\circ}$ & ড்̇ & 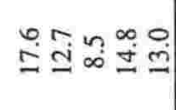 \\
\hline $\cos \theta$ & 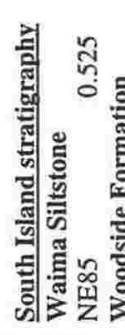 & 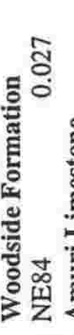 & 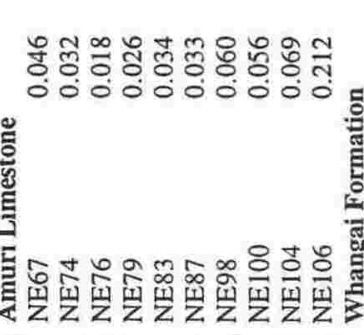 & 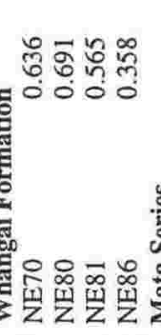 & 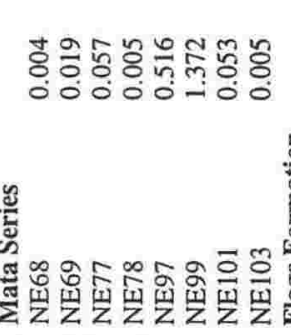 & 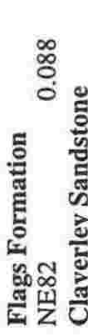 & & 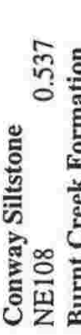 & 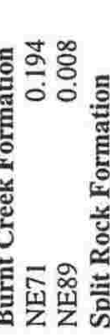 & 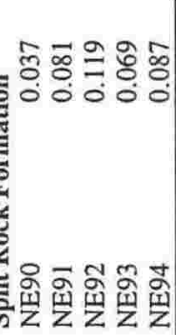 \\
\hline
\end{tabular}




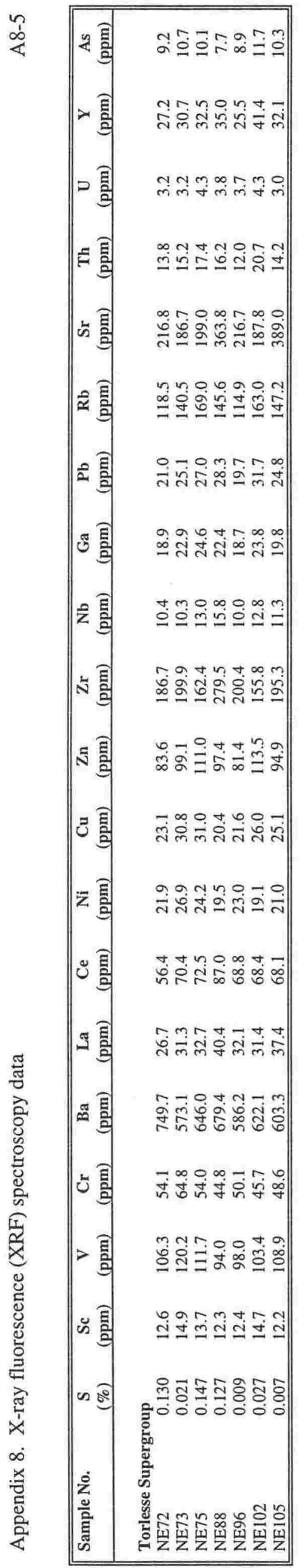




\begin{tabular}{|c|c|c|c|c|c|c|}
\hline Sample No. & $\begin{array}{c}S \\
(\%)\end{array}$ & $\begin{array}{l}\text { TOC } \\
(\%)\end{array}$ & $\mathrm{S} / \mathrm{C}$ & $\mathrm{V} / \mathrm{Cr}$ & $\mathrm{Ni} / \mathrm{V}$ & U/Th \\
\hline \multicolumn{7}{|c|}{ North Island stratigraphy } \\
\hline \multicolumn{7}{|c|}{ Miocene units } \\
\hline NE30 & 0.050 & 0.21 & 0.24 & 1.84 & 0.43 & 0.44 \\
\hline NE109 & 1.218 & 4.70 & 0.26 & 2.35 & 0.13 & 0.21 \\
\hline \multicolumn{7}{|c|}{ Whakataki Formation } \\
\hline NE47 & 0.098 & 0.44 & 0.22 & 2.07 & 0.18 & 0.30 \\
\hline NE112 & 0.277 & 0.60 & 0.46 & 1.60 & 0.27 & 0.27 \\
\hline \multicolumn{7}{|c|}{ Weber Formation } \\
\hline NE19 & 0.236 & 0.15 & 1.57 & 1.94 & 0.28 & 1.26 \\
\hline NE61 & 0.014 & 0.29 & 0.05 & 2.41 & 0.21 & 0.20 \\
\hline \multicolumn{7}{|c|}{ Wanstead Formation } \\
\hline NE18 & 0.040 & 0.15 & 0.27 & 1.81 & 0.29 & 0.27 \\
\hline NE22 & 0.333 & 0.24 & 1.39 & 1.45 & 0.32 & 0.49 \\
\hline NE55 & 0.028 & 0.20 & 0.14 & 1.20 & 0.15 & 0.48 \\
\hline NE58 & 0.074 & 0.03 & 2.47 & 2.04 & 0.25 & 0.14 \\
\hline NE62 & 0.009 & 0.22 & 0.04 & 1.65 & 0.23 & 0.44 \\
\hline \multicolumn{7}{|c|}{ Waipawa Black Shale } \\
\hline NE1 & 0.130 & 0.75 & 0.17 & 0.97 & 0.07 & 0.65 \\
\hline NE4 & 1.613 & 1.21 & 1.33 & 1.60 & 0.28 & 0.32 \\
\hline NE16 & 0.018 & 0.18 & 0.10 & 1.67 & 0.07 & 1.06 \\
\hline NE23 & 1.500 & 4.99 & 0.30 & 0.82 & 0.28 & 0.42 \\
\hline NE26 & 0.150 & 1.42 & 0.11 & 0.65 & 0.05 & 1.30 \\
\hline NE31 & 1.897 & 3.66 & 0.52 & 0.90 & 0.53 & 1.00 \\
\hline NE33 & 1.392 & 1.05 & 1.33 & 1.40 & 0.32 & 0.65 \\
\hline NE37 & 1.856 & 2.21 & 0.84 & 0.93 & 0.39 & 0.98 \\
\hline NE40 & 1.143 & 3.89 & 0.29 & 0.84 & 0.15 & 1.40 \\
\hline NE43 & 1.014 & 5.53 & 0.18 & 0.76 & 0.11 & 0.61 \\
\hline NE44 & 1.250 & 2.97 & 0.42 & 0.94 & 0.44 & 0.49 \\
\hline NE45 & 1.501 & 4.06 & 0.37 & 0.90 & 0.46 & 0.53 \\
\hline NE48 & 0.466 & 3.34 & 0.14 & 0.73 & 0.08 & 0.43 \\
\hline NE54 & 0.757 & 5.69 & 0.13 & 0.68 & 0.13 & 0.58 \\
\hline NE111 & 0.389 & 0.61 & 0.64 & 1.50 & 0.08 & 0.52 \\
\hline NE123 & 0.076 & 0.28 & 0.27 & 1.12 & 0.13 & 0.27 \\
\hline NE131 & 0.576 & 3.61 & 0.16 & 0.63 & 0.09 & 0.30 \\
\hline \multicolumn{7}{|c|}{ (Tora Block stratigraphy) } \\
\hline \multicolumn{7}{|c|}{ (Kandahar Formation) } \\
\hline $\begin{array}{l}\text { NE141 } \\
\text { (Awhea Forn }\end{array}$ & 0.010 & 0.19 & 0.05 & 1.39 & 0.29 & 0.17 \\
\hline $\begin{array}{l}\text { NE142 } \\
\text { (Mungaroa }\end{array}$ & 0.010 & 0.14 & 0.07 & 1.18 & 0.22 & 0.43 \\
\hline \multicolumn{6}{|c|}{ (Manurewa Formation) } & 0.50 \\
\hline NE137 & 0.399 & 0.15 & 2.66 & 1.38 & 0.19 & 0.29 \\
\hline NE143 & 0.044 & 0.14 & 0.31 & 1.50 & 0.18 & 0.38 \\
\hline \multicolumn{7}{|c|}{ Whangai Formation } \\
\hline Te Uri Mer & & & & & & \\
\hline NE11 & 0.376 & 0.33 & 1.14 & 1.68 & 0.30 & 0.56 \\
\hline NE21 & 0.165 & 0.28 & 0.59 & 1.52 & 0.19 & 0.67 \\
\hline
\end{tabular}




\begin{tabular}{|c|c|c|c|c|c|c|}
\hline Sample No. & $\begin{array}{c}S \\
(\%)\end{array}$ & $\begin{array}{c}\text { TOC } \\
(\%)\end{array}$ & $\mathrm{S} / \mathrm{C}$ & $\mathrm{V} / \mathrm{Cr}$ & $\mathrm{Ni} / \mathrm{V}$ & $\mathrm{U} / \mathrm{Th}$ \\
\hline \multicolumn{7}{|c|}{ Porangahau Member } \\
\hline NE8 & 0.057 & 0.25 & 0.23 & 1.42 & 0.54 & 0.33 \\
\hline NE17 & 0.007 & 0.03 & 0.23 & 1.37 & 1.38 & 0.34 \\
\hline NE38 & 0.030 & 0.32 & 0.09 & 1.59 & 0.34 & 0.51 \\
\hline NE39 & 0.042 & 0.06 & 0.70 & 1.86 & 0.29 & 0.46 \\
\hline \multicolumn{7}{|c|}{ Upper Calcareous Member } \\
\hline NE12 & 0.383 & 0.42 & 0.91 & 1.68 & 0.33 & 0.67 \\
\hline NE13 & 0.444 & 0.45 & 0.99 & 1.45 & 0.36 & 0.83 \\
\hline NE20 & 0.362 & 0.36 & 1.01 & 1.84 & 0.32 & 0.42 \\
\hline NE24 & 0.980 & 1.19 & 0.82 & 0.92 & 0.34 & 0.51 \\
\hline NE28 & 0.460 & 0.37 & 1.24 & 1.87 & 0.33 & 0.69 \\
\hline NE46 & 0.611 & 0.82 & 0.75 & 1.17 & 0.28 & 0.35 \\
\hline NE113 & 0.791 & 0.71 & 1.11 & 1.18 & 0.28 & 0.52 \\
\hline \multicolumn{7}{|c|}{ Rakauroa Member } \\
\hline NE3 & 0.016 & 0.09 & 0.18 & 1.90 & 0.18 & 0.51 \\
\hline NE15 & 0.565 & 0.49 & 1.15 & 1.63 & 0.36 & 0.60 \\
\hline NE25 & 0.118 & 0.11 & 1.07 & 1.88 & 0.20 & 0.46 \\
\hline NE136 & 0.736 & 0.51 & 1.44 & 1.62 & 0.30 & 0.62 \\
\hline NE144 & 0.895 & 1.13 & 0.79 & 1.51 & 0.29 & 0.24 \\
\hline \multicolumn{7}{|c|}{ Undifferentiated } \\
\hline NE14 & 0.380 & 0.44 & 0.86 & 1.70 & 0.37 & 0.86 \\
\hline NE32 & 0.547 & 0.63 & 0.87 & 1.21 & 0.36 & 1.02 \\
\hline NE35 & 0.027 & 0.19 & 0.14 & 1.55 & 0.05 & 0.93 \\
\hline NE36 & 0.369 & 0.40 & 0.92 & 2.18 & 0.17 & 0.24 \\
\hline NE49 & 0.408 & 0.84 & 0.49 & 1.26 & 0.47 & 0.44 \\
\hline NE50 & 0.393 & 0.93 & 0.42 & 1.36 & 0.26 & 0.42 \\
\hline NE53 & 0.653 & 0.68 & 0.96 & 1.36 & 0.31 & 0.30 \\
\hline NE56 & 0.735 & 0.78 & 0.94 & 1.89 & 0.14 & 0.30 \\
\hline NE63 & 1.231 & 3.50 & 0.35 & 0.90 & 0.60 & 0.51 \\
\hline NE65 & 0.051 & 0.41 & 0.12 & 1.66 & 0.06 & 0.33 \\
\hline NE121 & 0.799 & 0.76 & 1.05 & 1.66 & 0.29 & 0.38 \\
\hline \multicolumn{7}{|c|}{ Tangaruhe Formation } \\
\hline NE9 & 0.024 & 0.32 & 0.08 & 1.64 & 0.12 & 0.40 \\
\hline NE10 & 0.469 & 0.40 & 1.17 & 1.50 & 0.26 & 0.47 \\
\hline \multicolumn{7}{|c|}{ Te Mai Formation } \\
\hline NE51 & 0.175 & 0.72 & 0.24 & 2.39 & 0.19 & 0.26 \\
\hline NE52 & 0.639 & 1.52 & 0.42 & 2.25 & 0.10 & 0.23 \\
\hline NE59 & 0.076 & 1.12 & 0.07 & 2.27 & 0.22 & 0.23 \\
\hline NE124 & 1.583 & 0.71 & 2.23 & 1.43 & 0.56 & 0.25 \\
\hline NE125 & 0.929 & 0.19 & 4.89 & 1.24 & 0.27 & 0.28 \\
\hline \multicolumn{7}{|c|}{ Glenburn Formation } \\
\hline NE2 & 0.147 & 0.59 & 0.25 & 1.84 & 0.26 & 0.23 \\
\hline NE5 & 0.503 & 0.83 & 0.61 & 1.93 & 0.24 & 0.23 \\
\hline NE6 & 0.299 & 0.49 & 0.61 & 1.79 & 0.32 & 0.30 \\
\hline NE7 & 0.548 & 0.85 & 0.64 & 2.00 & 0.26 & 0.33 \\
\hline NE117 & 1.080 & 0.87 & 1.24 & 1.64 & 0.31 & 0.27 \\
\hline NE118 & 0.946 & 1.30 & 0.73 & 1.78 & 0.30 & 0.22 \\
\hline NE132 & 0.005 & 0.09 & 0.06 & 1.67 & 0.22 & 0.21 \\
\hline \multicolumn{7}{|c|}{ Springhill Formation } \\
\hline NE134 & 0.034 & 0.24 & 0.14 & 2.09 & 0.21 & 0.20 \\
\hline NE139 & 0.113 & 0.27 & 0.42 & 2.32 & 0.21 & 0.17 \\
\hline \multicolumn{7}{|c|}{ Gentle Annie Formation } \\
\hline NE129 & 0.010 & 0.06 & 0.17 & 1.81 & 0.19 & 0.47 \\
\hline
\end{tabular}




\begin{tabular}{|c|c|c|c|c|c|c|}
\hline Sample No. & $\begin{array}{c}\mathbf{S} \\
(\%)\end{array}$ & $\begin{array}{c}\text { TOC } \\
(\%)\end{array}$ & $\mathrm{S} / \mathrm{C}$ & $\mathrm{V} / \mathrm{Cr}$ & $\mathrm{Ni} / \mathrm{V}$ & $\overline{\mathrm{U} / \mathrm{Th}}$ \\
\hline \multicolumn{7}{|c|}{ Pahaoa Group } \\
\hline NE42 & 0.024 & 0.06 & 0.40 & 3.02 & 0.14 & 0.28 \\
\hline NE60 & 0.026 & 0.05 & 0.52 & 3.80 & 0.13 & 0.25 \\
\hline NE64 & 0.423 & 1.54 & 0.27 & 2.37 & 0.12 & 0.29 \\
\hline NE66 & 0.024 & 0.10 & 0.24 & 2.90 & 0.17 & 0.23 \\
\hline NE119 & 0.032 & 0.07 & 0.46 & 2.25 & 0.19 & 0.36 \\
\hline NE122 & 0.113 & 0.40 & 0.28 & 1.90 & 0.22 & 0.12 \\
\hline NE126 & 0.083 & 0.35 & 0.24 & 2.24 & 0.20 & 0.19 \\
\hline NE127 & 0.027 & 0.08 & 0.34 & 2.25 & 0.18 & 0.21 \\
\hline NE128 & 0.092 & 0.29 & 0.32 & 2.13 & 0.22 & 0.22 \\
\hline NE133 & 0.067 & 0.26 & 0.26 & 2.38 & 0.19 & 0.24 \\
\hline NE135 & 0.048 & 0.15 & 0.32 & 2.12 & 0.22 & 0.23 \\
\hline NE140 & 0.061 & 0.24 & 0.25 & 2.22 & 0.21 & 0.16 \\
\hline \multicolumn{7}{|c|}{ Whatarangi Formation } \\
\hline $\begin{array}{l}\text { NE145 } \\
\text { Torlesse Sur }\end{array}$ & 0.039 & 0.19 & 0.21 & 2.13 & 0.16 & 0.14 \\
\hline NE1 14 & 0.064 & 0.19 & 0.34 & 1.98 & 0.22 & 0.19 \\
\hline \multicolumn{7}{|c|}{ South Island stratigraphy } \\
\hline \multicolumn{7}{|c|}{ Waima Siltstone } \\
\hline $\begin{array}{l}\text { NE85 } \\
\text { Woodside Fo }\end{array}$ & 0.525 & 0.41 & 1.28 & 1.67 & 0.35 & 0.64 \\
\hline $\begin{array}{l}\text { NE84 } \\
\text { Amuri Lime }\end{array}$ & 0.027 & 0.06 & 0.45 & 1.50 & 0.27 & 0.07 \\
\hline NE67 & 0.046 & 0.16 & 0.29 & 1.44 & 0.52 & 0.15 \\
\hline NE74 & 0.032 & 0.08 & 0.40 & 1.48 & 1.06 & -0.08 \\
\hline NE76 & 0.018 & 0.07 & 0.26 & 1.44 & 0.64 & 0.30 \\
\hline NE79 & 0.026 & 0.04 & 0.65 & 1.46 & 0.76 & 0.67 \\
\hline NE83 & 0.034 & 0.06 & 0.57 & 1.53 & 1.14 & -0.12 \\
\hline NE87 & 0.033 & 0.03 & 1.10 & 1.97 & 0.62 & 0.63 \\
\hline NE98 & 0.060 & 0.05 & 1.20 & 1.34 & 0.70 & 0.05 \\
\hline NE100 & 0.056 & 0.09 & 0.62 & 1.70 & 0.46 & -0.07 \\
\hline NE104 & 0.069 & 0.11 & 0.63 & 1.79 & 0.45 & 0.55 \\
\hline NE106 & 0.212 & 0.09 & 2.36 & 1.74 & 0.57 & 0.33 \\
\hline \multicolumn{7}{|c|}{ Whangai Formation } \\
\hline NE70 & 0.636 & 0.51 & 1.25 & 1.66 & 0.29 & 0.37 \\
\hline NE80 & 0.691 & 0.48 & 1.44 & 1.71 & 0.44 & 0.52 \\
\hline NE81 & 0.565 & 0.46 & 1.23 & 1.75 & 0.34 & 0.36 \\
\hline NE86 & 0.358 & 0.49 & 0.73 & 1.62 & 0.23 & 0.49 \\
\hline \multicolumn{7}{|l|}{ Mata Series } \\
\hline NE68 & 0.004 & 0.14 & 0.03 & 1.92 & 0.24 & 0.20 \\
\hline NE69 & 0.019 & 0.04 & 0.48 & 1.70 & 0.92 & 0.46 \\
\hline NE77 & 0.057 & 0.03 & 1.90 & 1.95 & 0.06 & 1.38 \\
\hline NE78 & 0.005 & 0.27 & 0.02 & 2.06 & 0.19 & 0.20 \\
\hline NE97 & 0.516 & 0.96 & 0.54 & 1.65 & 0.20 & 0.45 \\
\hline NE99 & 1.372 & 0.69 & 1.99 & 1.71 & 0.15 & 0.29 \\
\hline NE101 & 0.053 & 0.24 & 0.22 & 2.28 & 0.21 & 0.19 \\
\hline NE103 & 0.005 & 0.13 & 0.04 & 1.85 & 0.18 & 0.30 \\
\hline \multicolumn{7}{|c|}{ Flags Formation } \\
\hline \multicolumn{6}{|c|}{ Claverley Sandstone } & 0.31 \\
\hline NE107 & 1.322 & 0.39 & 3.39 & 1.86 & 0.10 & 0.44 \\
\hline
\end{tabular}




\begin{tabular}{||lcccccc||}
\hline Sample No. & $\begin{array}{c}\text { S } \\
(\%)\end{array}$ & $\begin{array}{c}\text { TOC } \\
(\%)\end{array}$ & S/C & V/Cr & Ni/V & U/Th \\
\hline \multicolumn{7}{l}{ Conway Siltstone } \\
NE108 & & & & & & \\
Burnt Creek Formation & 0.537 & 0.55 & 0.98 & 1.62 & 0.07 & 0.30 \\
NE71 & 0.194 & 0.41 & 0.47 & 1.60 & 0.30 & 0.19 \\
NE89 & 0.008 & 0.25 & 0.03 & 1.79 & 0.26 & 0.22 \\
Split Rock Formation & & & & & & \\
NE90 & 0.037 & 0.39 & 0.09 & 1.78 & 0.25 & 0.27 \\
NE91 & 0.081 & 0.41 & 0.20 & 2.01 & 0.19 & 0.19 \\
NE92 & 0.119 & 0.29 & 0.41 & 1.50 & 0.28 & 0.24 \\
NE93 & 0.069 & 0.38 & 0.18 & 1.86 & 0.24 & 0.19 \\
NE94 & 0.087 & 0.33 & 0.26 & 1.92 & 0.21 & 0.22 \\
Torlesse Supergroup & & & & & & \\
NE72 & 0.130 & 0.37 & 0.35 & 1.96 & 0.21 & 0.23 \\
NE73 & 0.021 & 0.45 & 0.05 & 1.85 & 0.22 & 0.21 \\
NE75 & 0.147 & 0.40 & 0.37 & 2.07 & 0.22 & 0.25 \\
NE88 & 0.127 & 0.35 & 0.36 & 2.10 & 0.21 & 0.23 \\
NE96 & 0.009 & 0.34 & 0.03 & 1.96 & 0.23 & 0.31 \\
NE102 & 0.027 & 0.26 & 0.10 & 2.26 & 0.18 & 0.21 \\
NE105 & 0.007 & 0.26 & 0.03 & 2.24 & 0.19 & 0.21 \\
\hline \hline
\end{tabular}


Appendix 9

\section{GC-MS data: m/z 191 and 217 mass chromatograms}

\section{Oil seeps}

Knights Stream oil
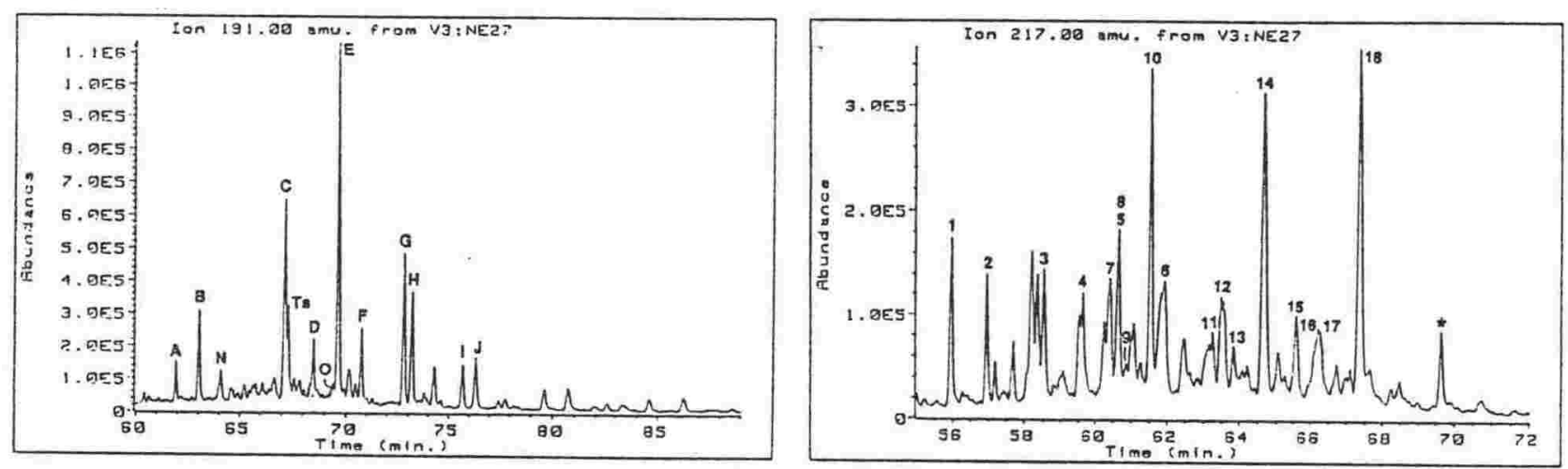

\section{Isolation Creek oil}
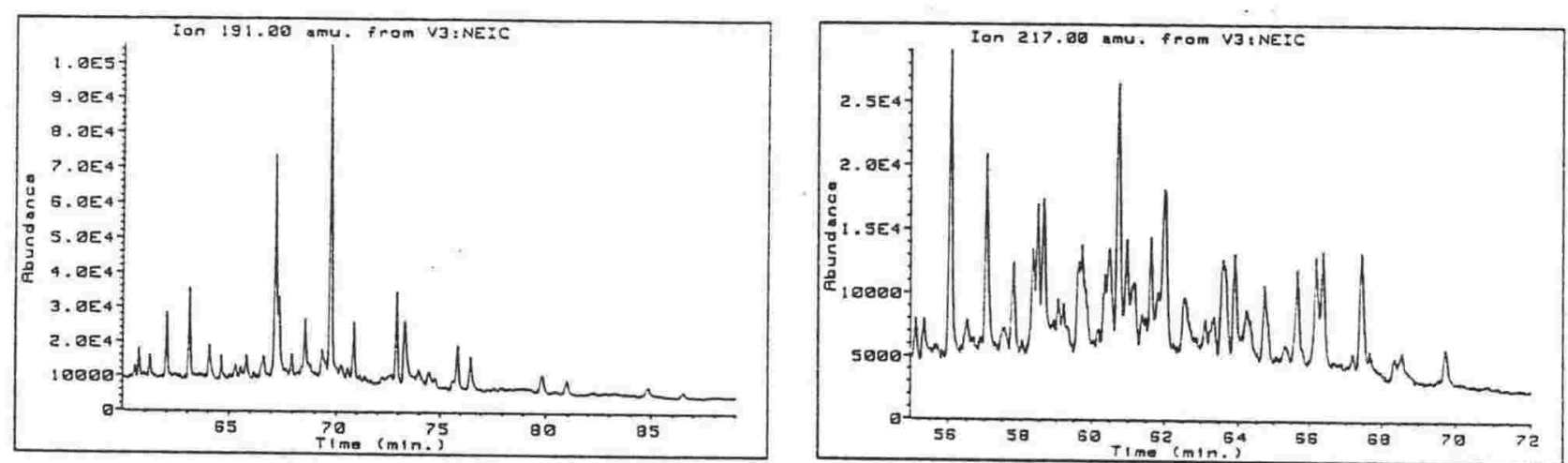

\section{Kerosene Rock oil}
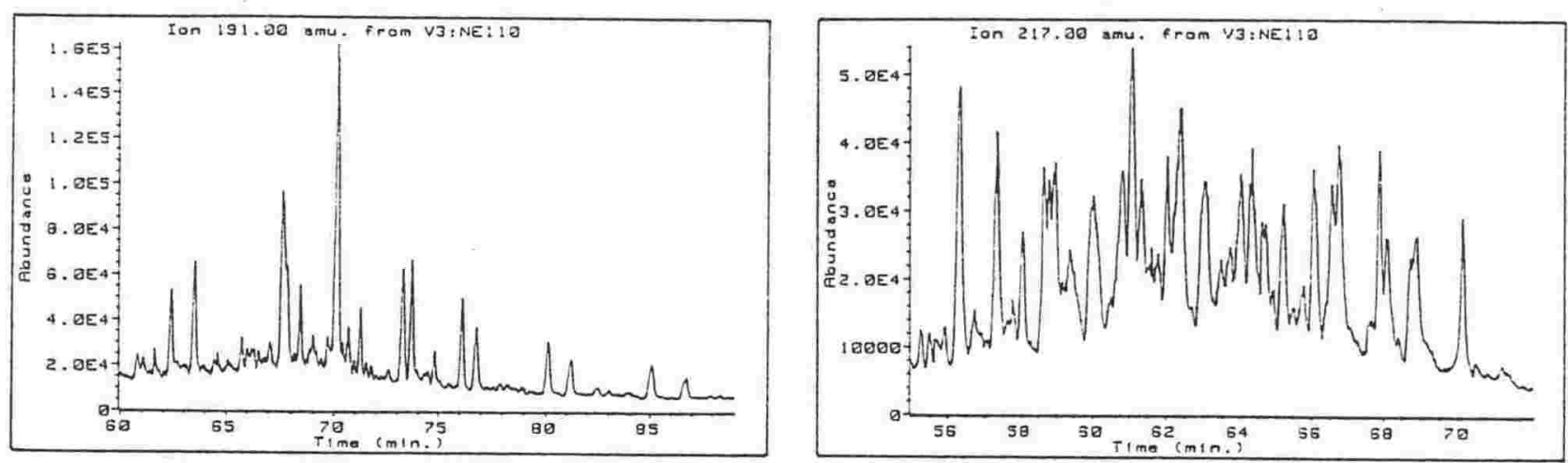


\section{Oil seeps continued}

\section{Westcott oil}
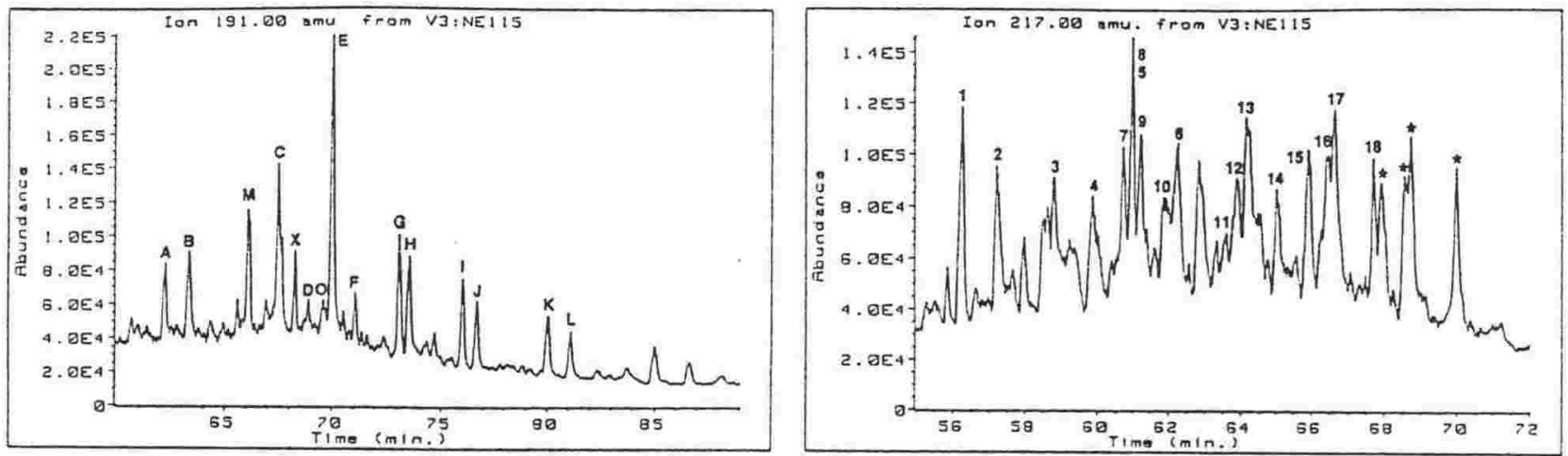

\section{Tiraumea oil}
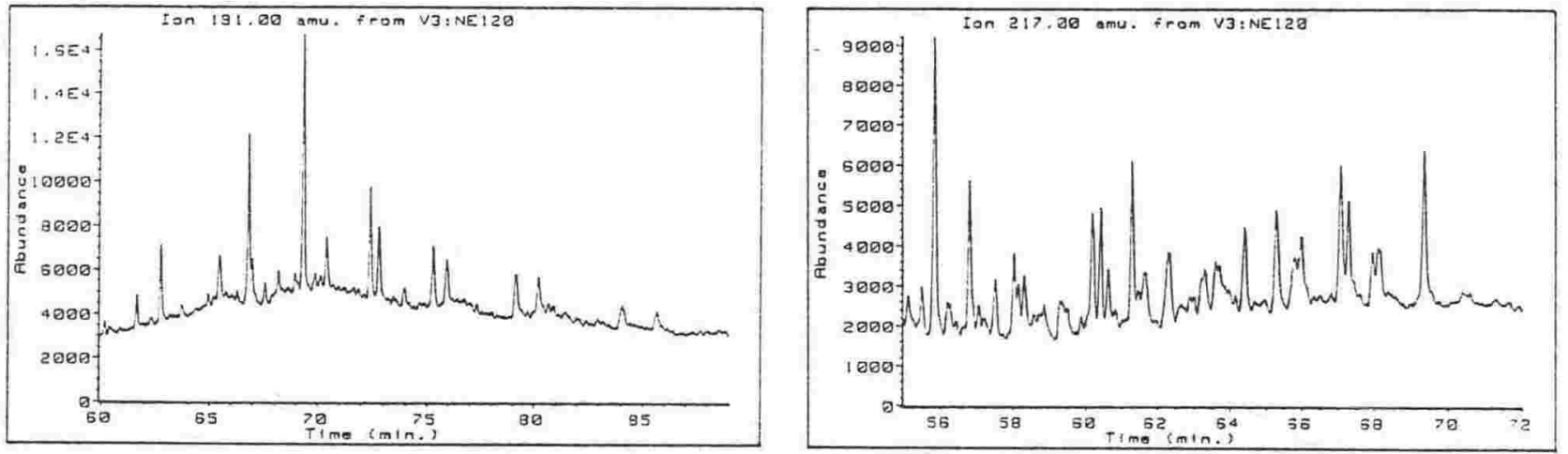

\section{Okau Stream oil}
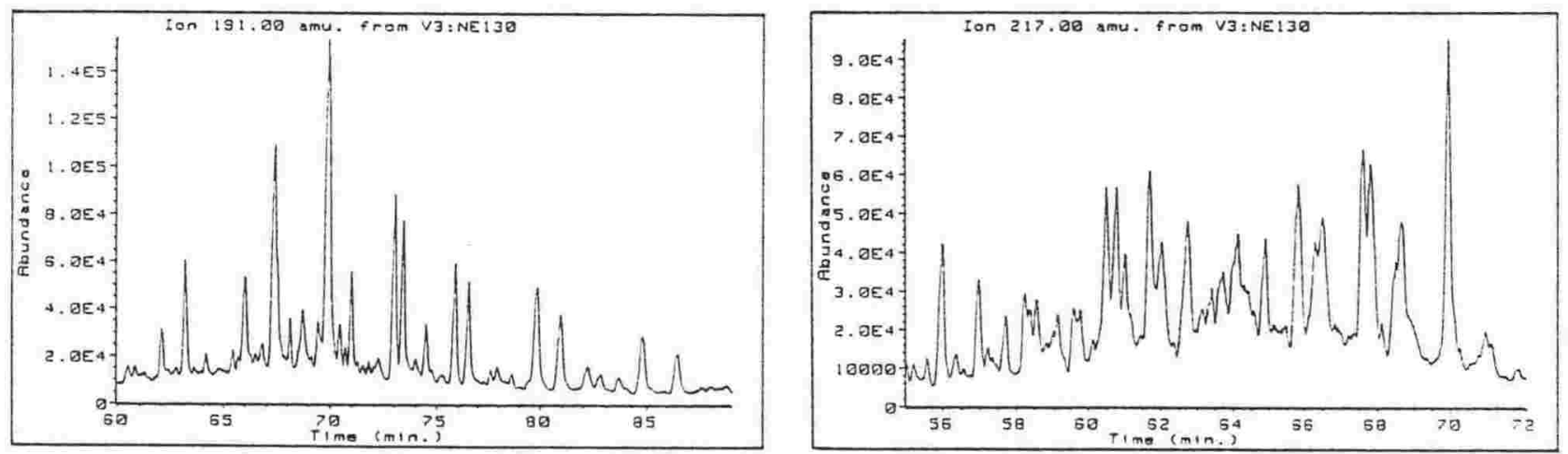

\section{North Island stratigraphy}

\section{Miocene units}
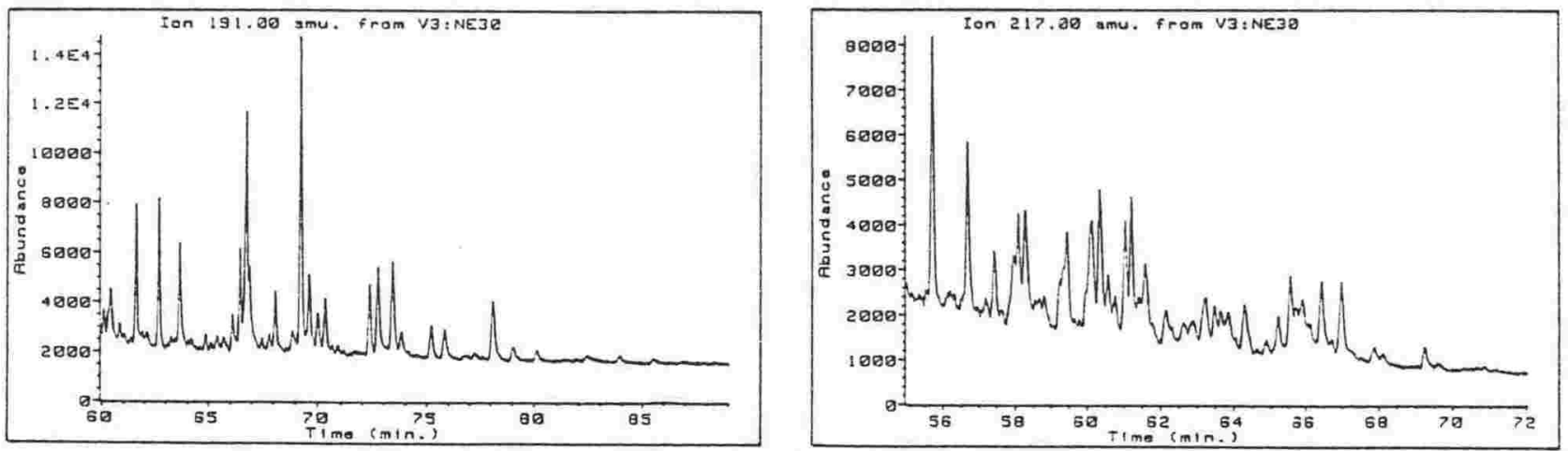


\section{Miocene units continued}

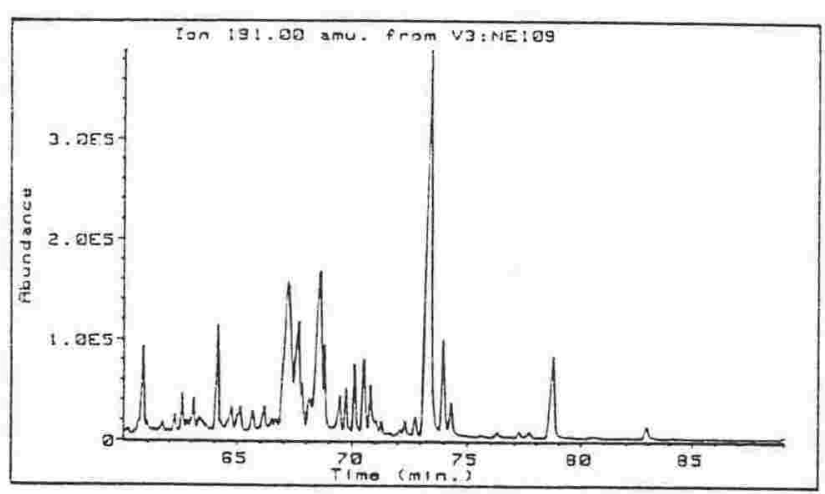

\section{Whakataki Formation}
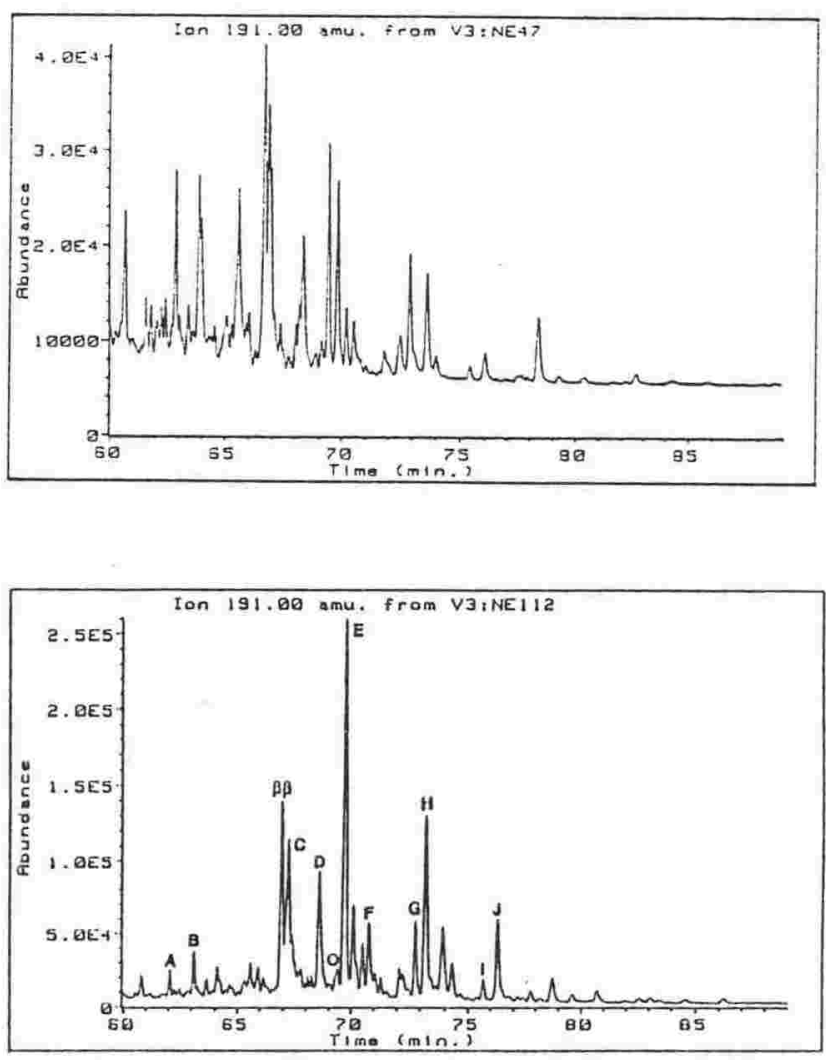

\section{Weber Formation}

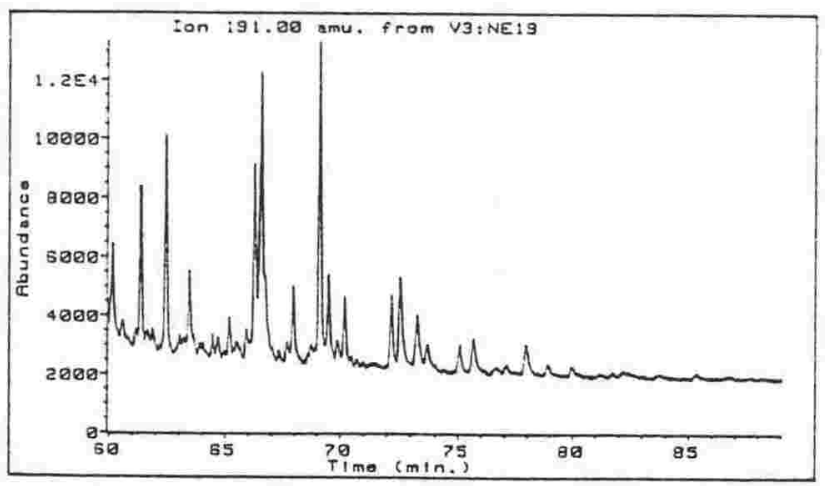

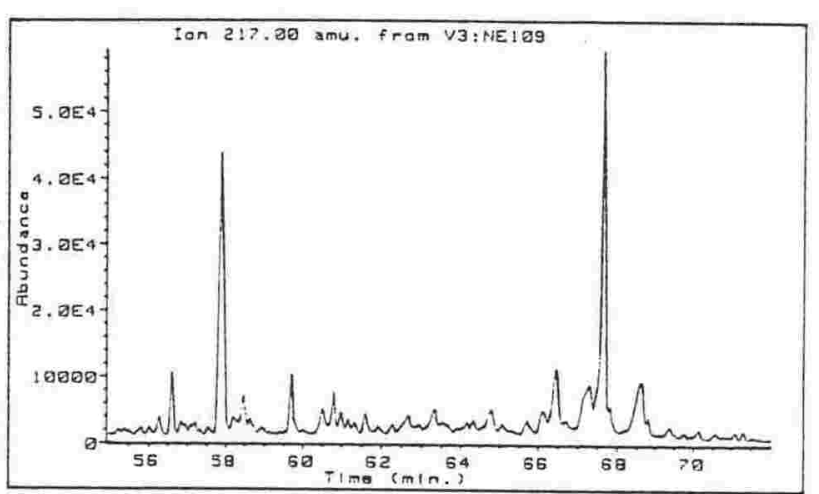
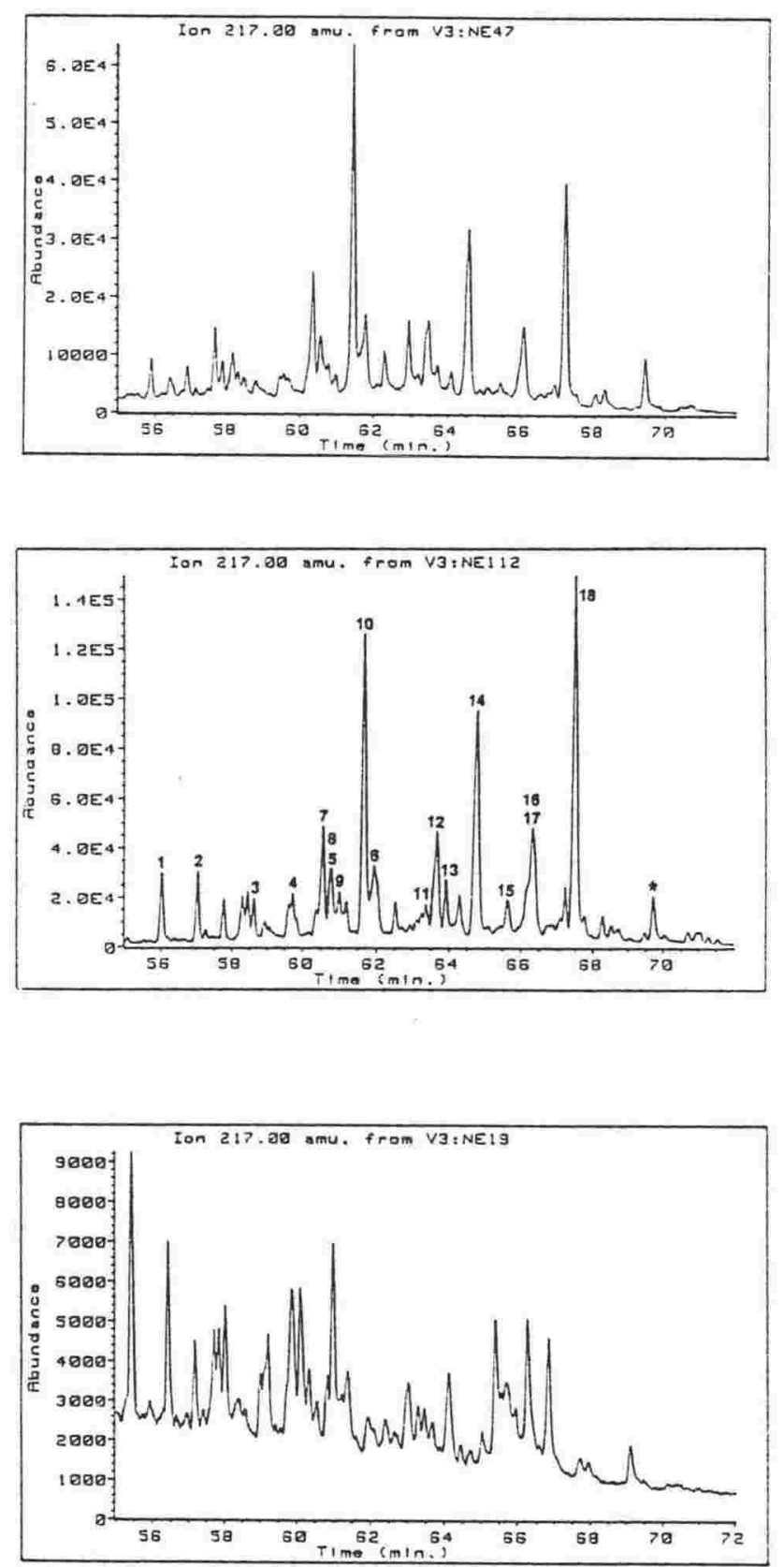


\section{Weber Formation continued}
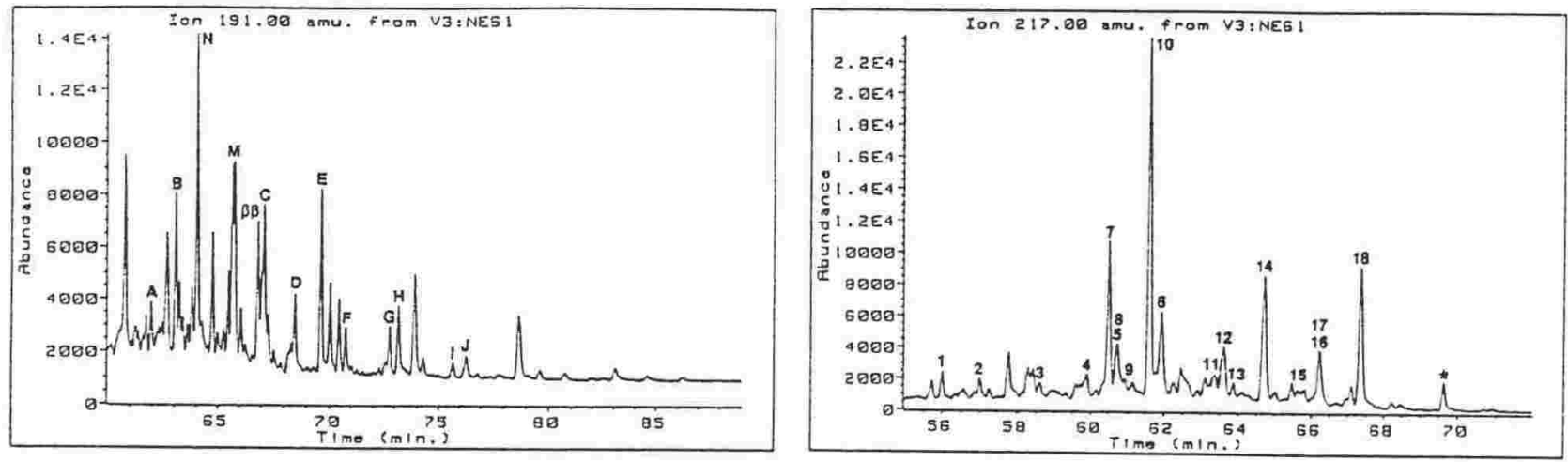

\section{Wanstead Formation}
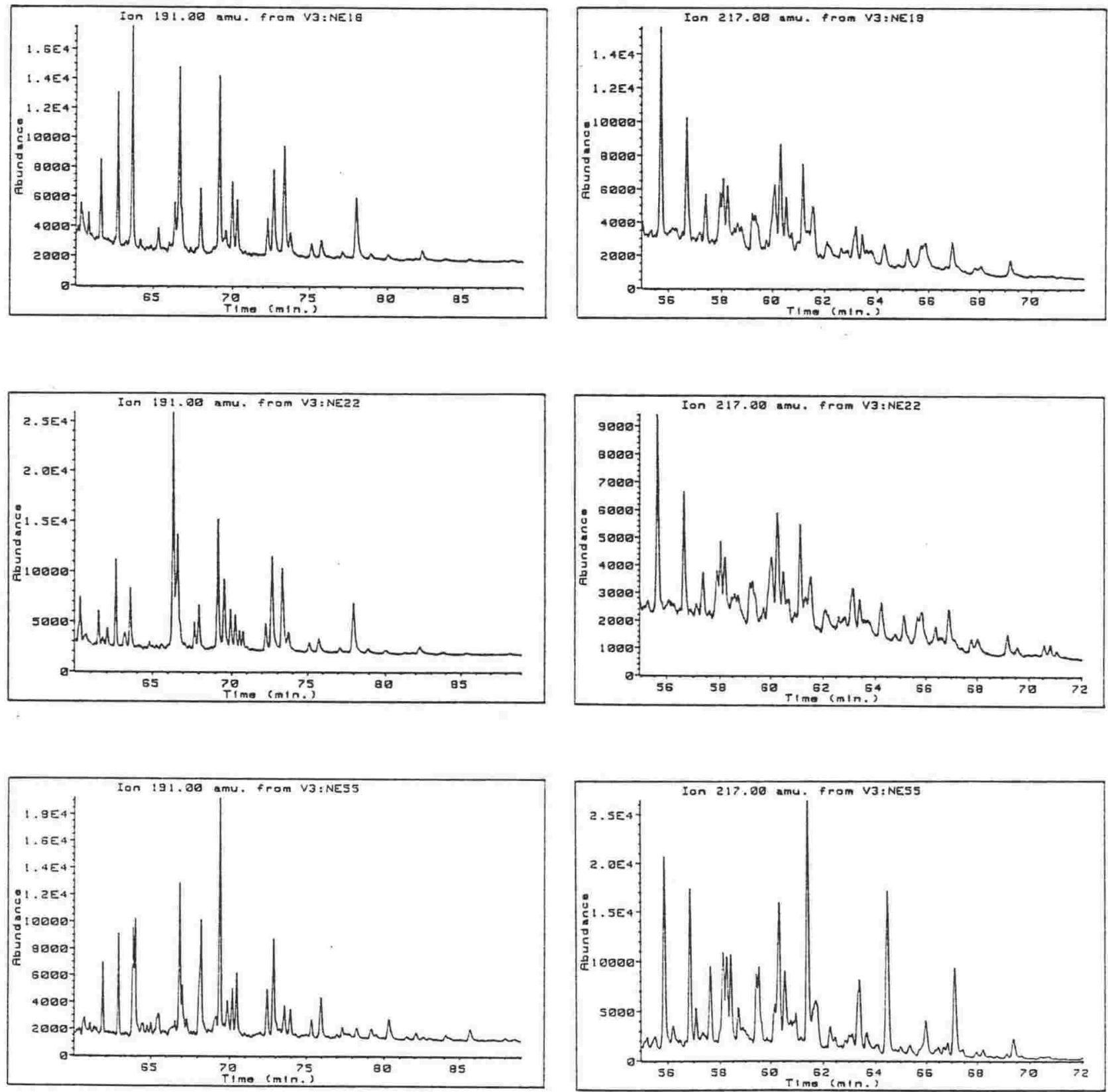


\section{Wanstead Formation continued}
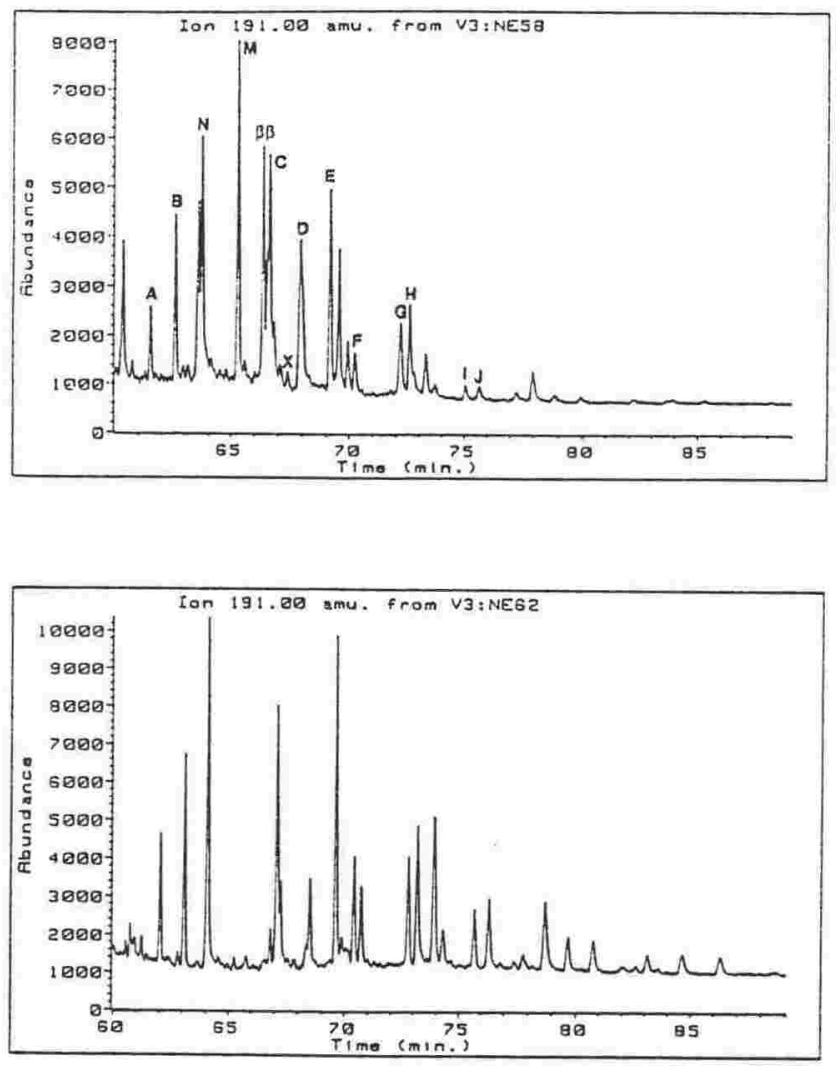

\section{Waipawa Black Shale}
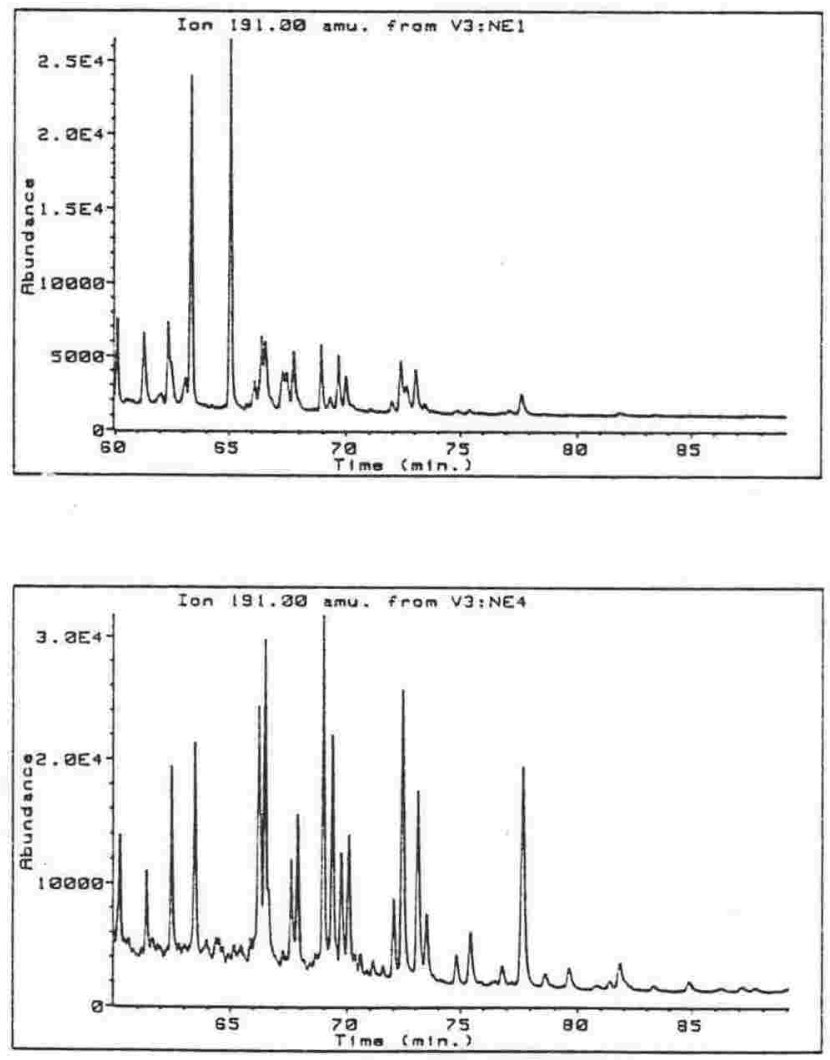
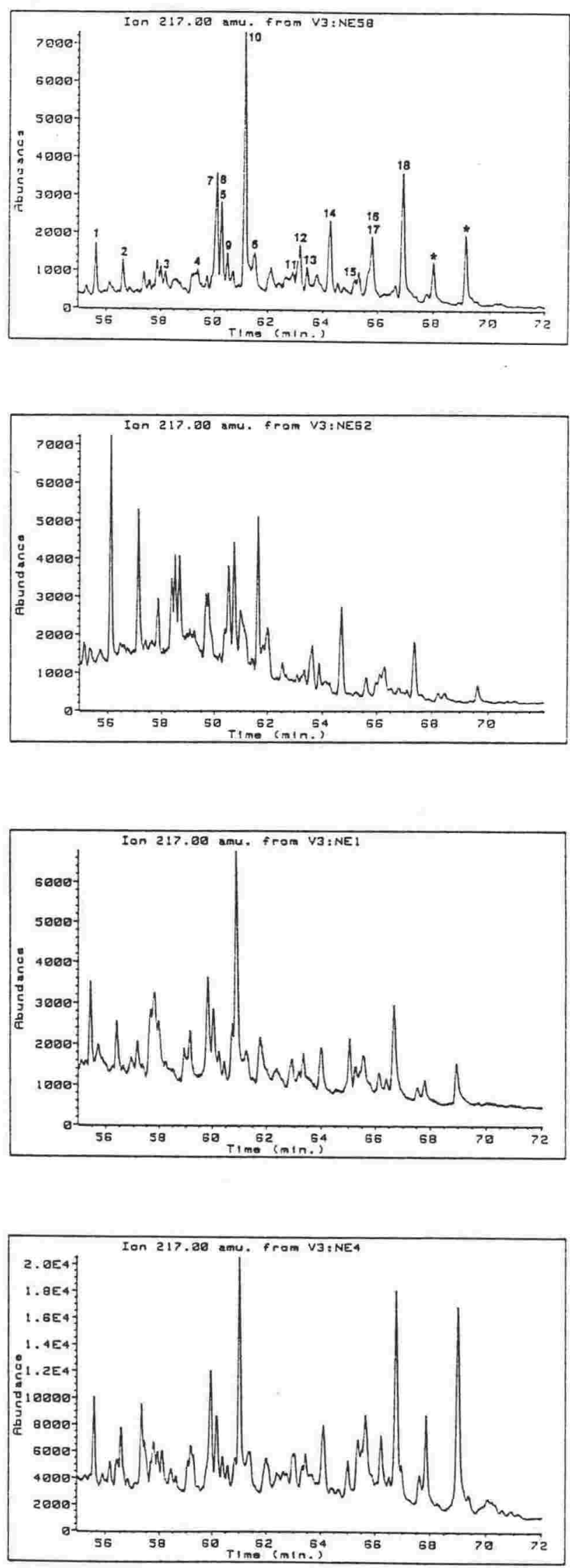


\section{Waipawa Black Shale continued}
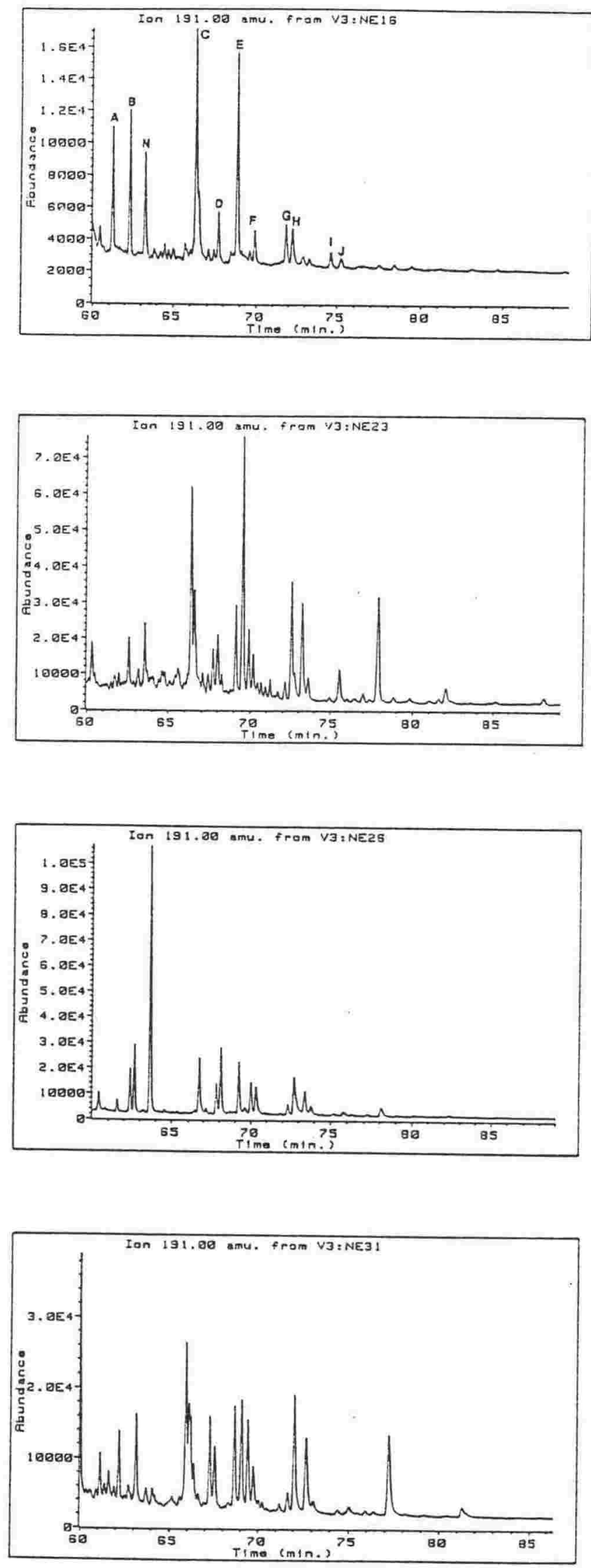
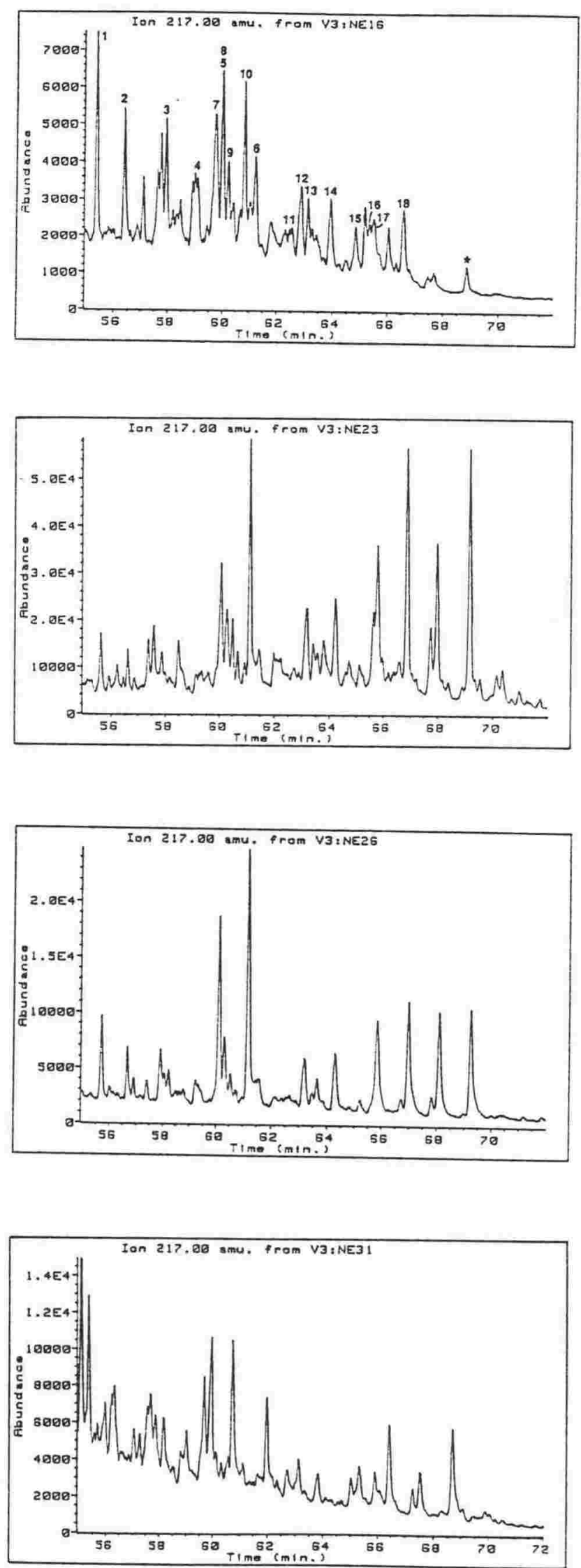


\section{Waipawa Black Shale continued}
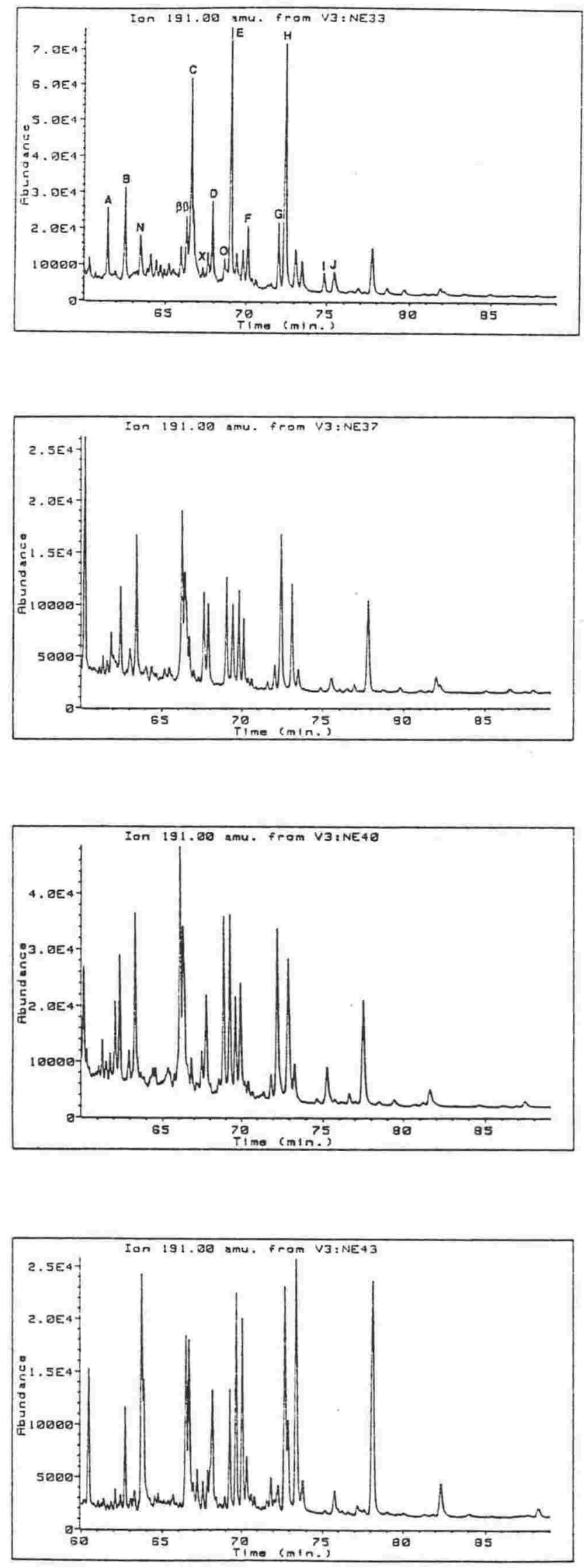
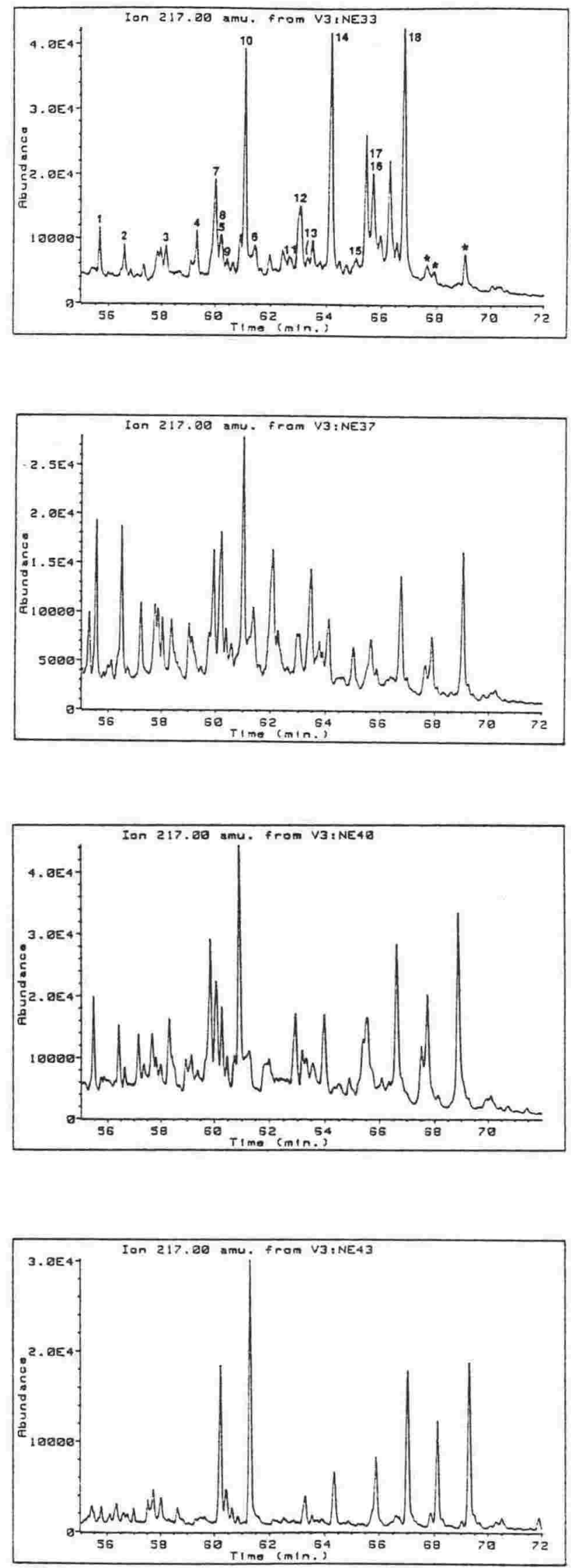


\section{Waipawa Black Shale continued}
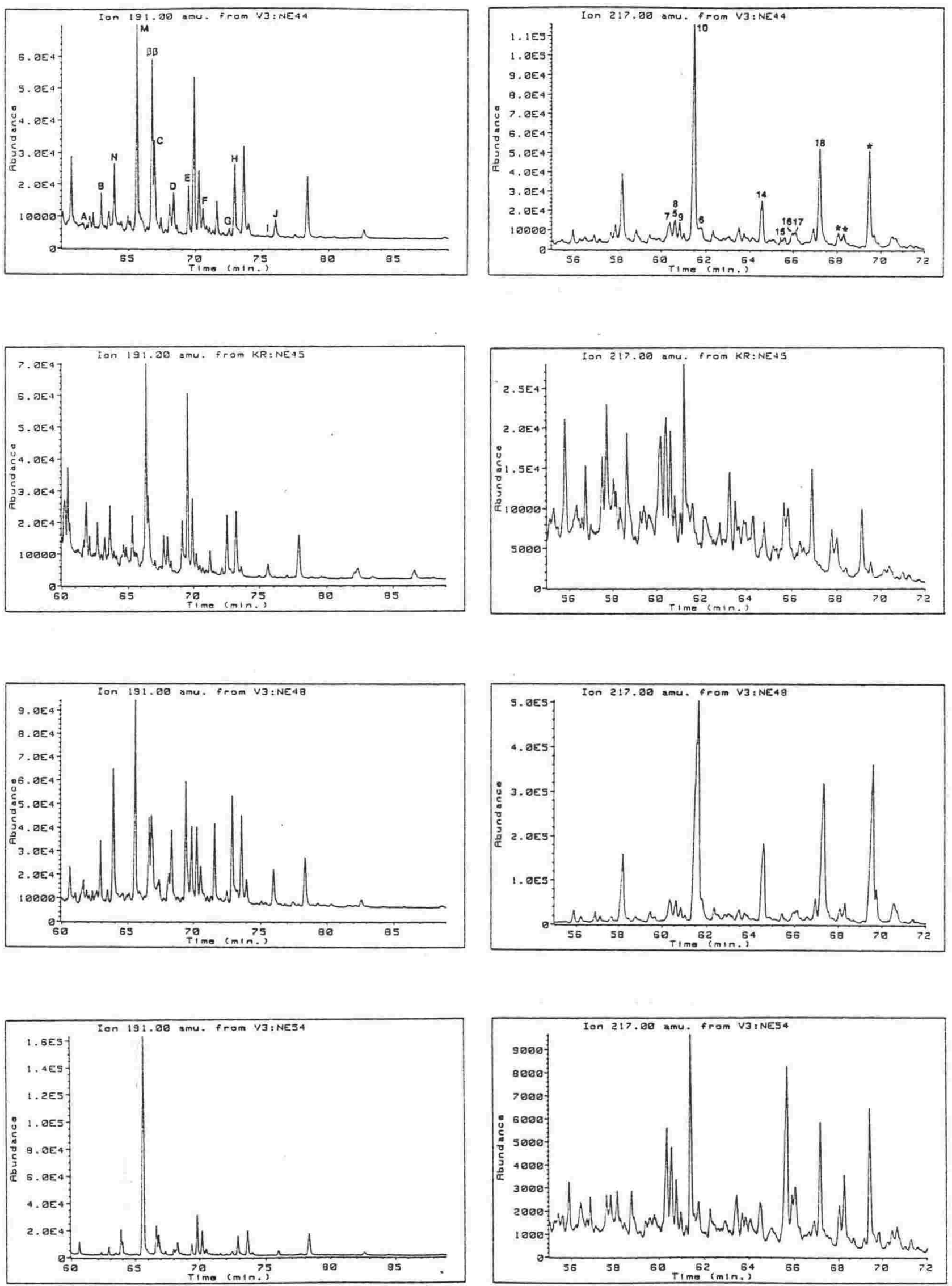


\section{Waipawa Black Shale continued}
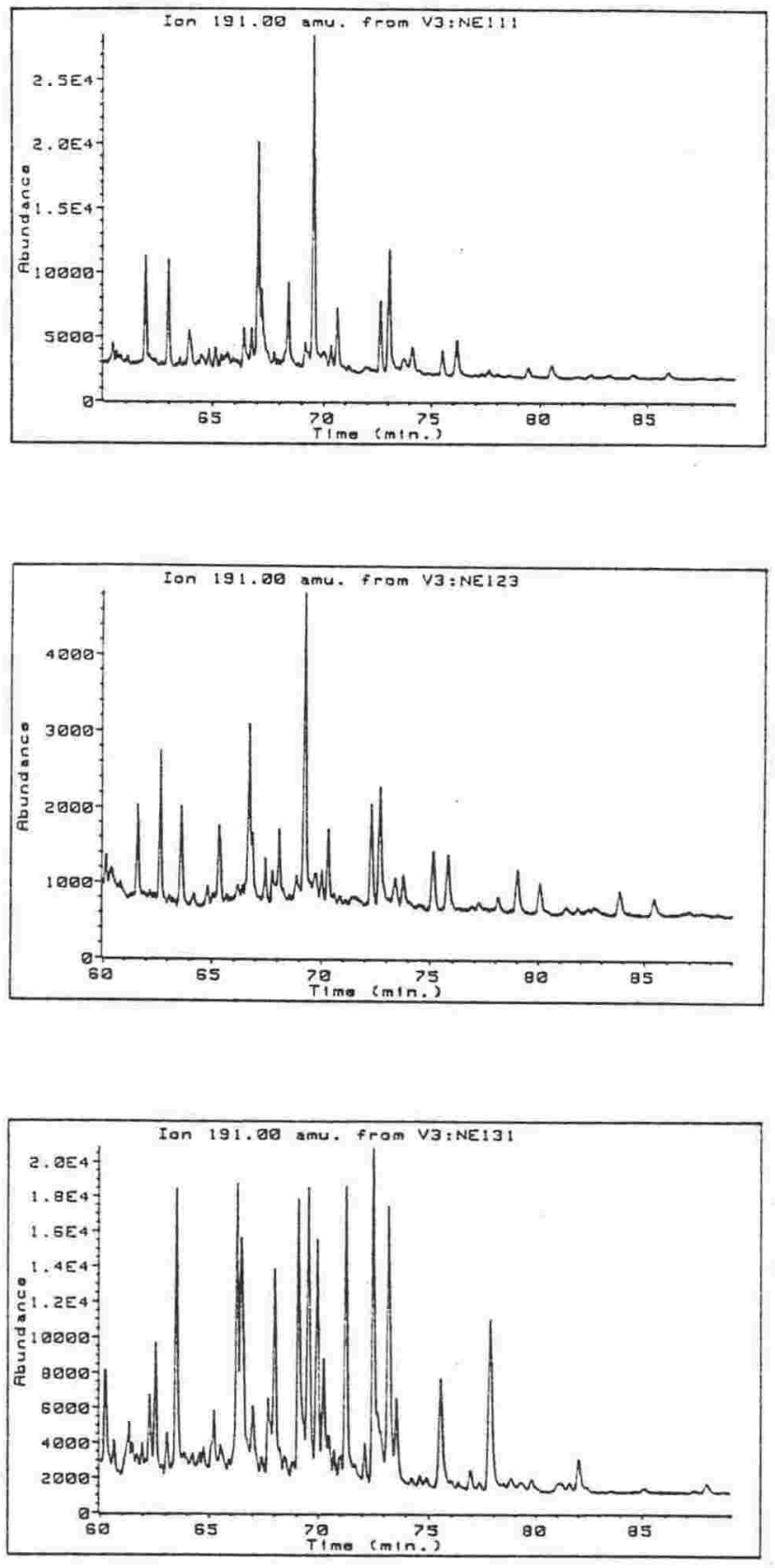

(Tora Block stratigraphy)

(Kandahar Formation)

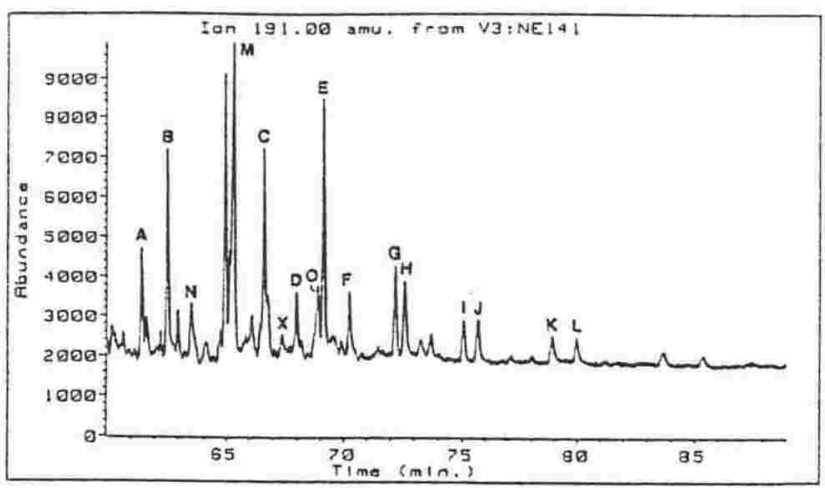

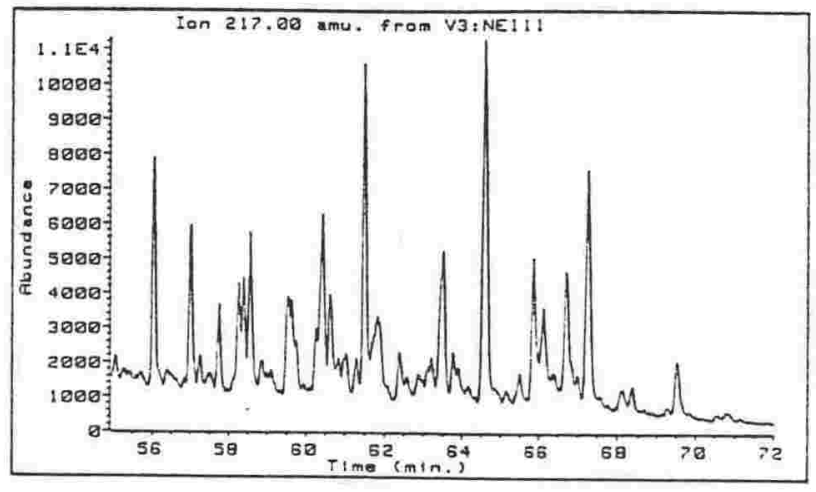
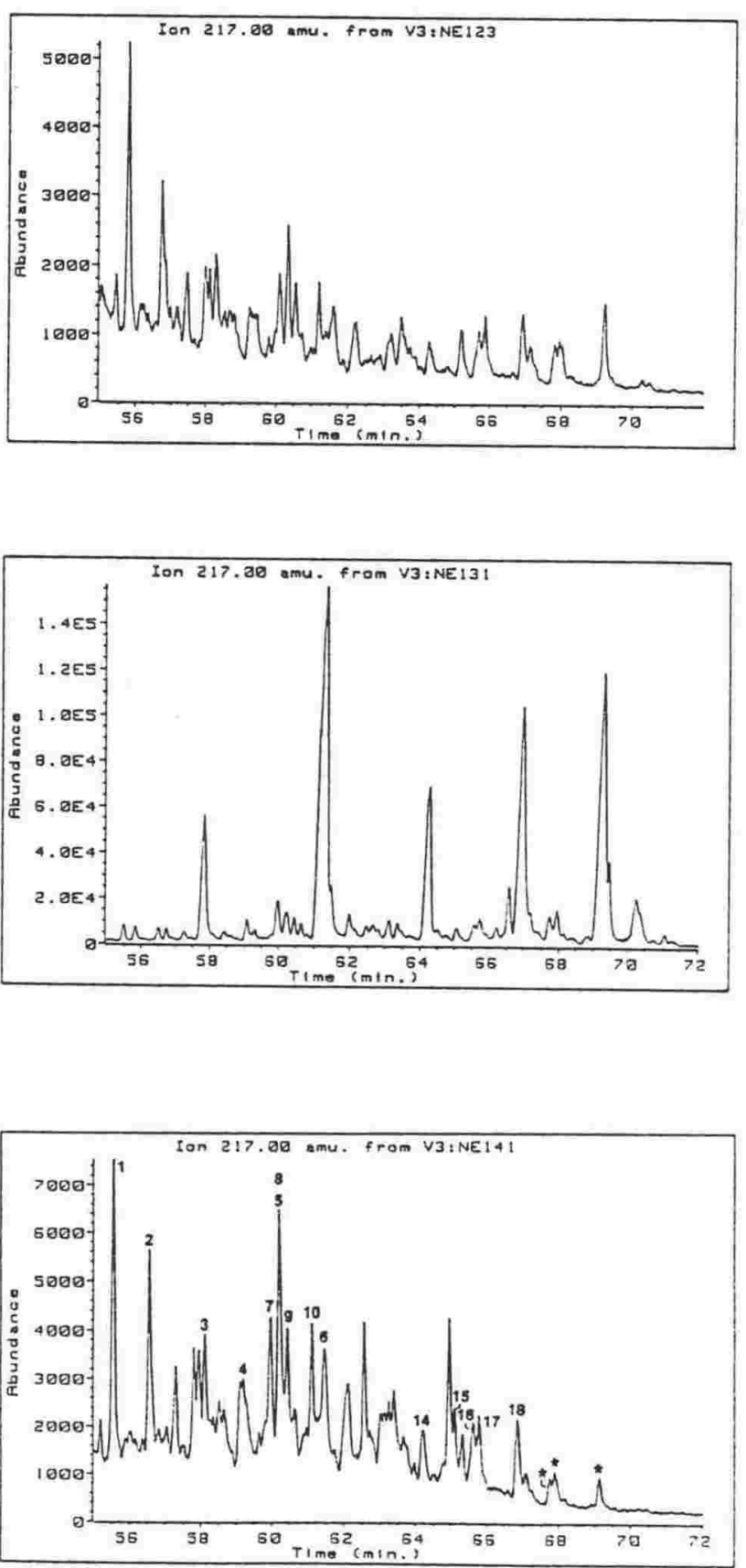


\section{(Awhea Formation)}

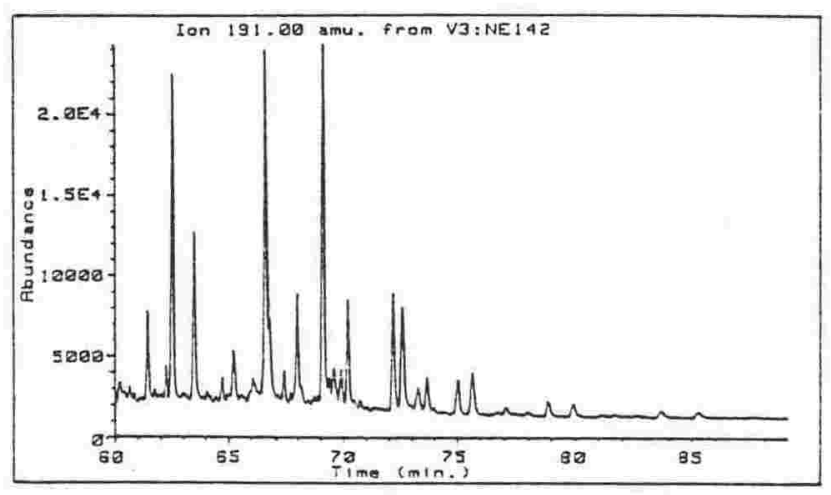

(Mungaroa Member)

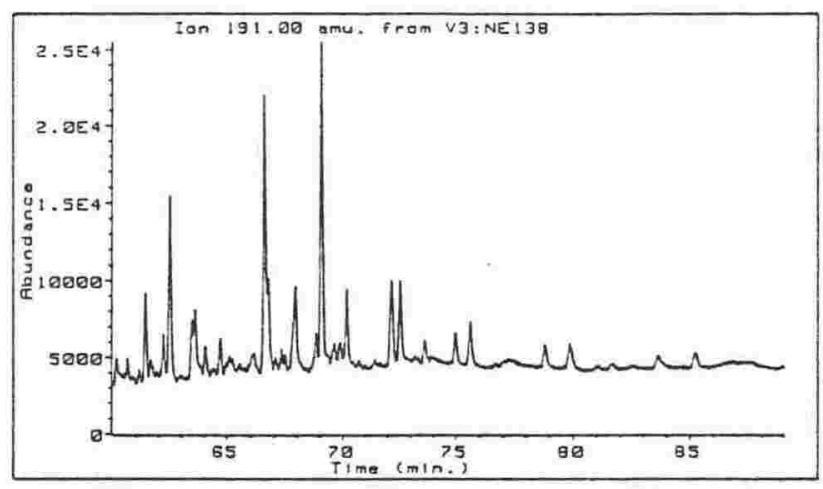

(Manurewa Formation)
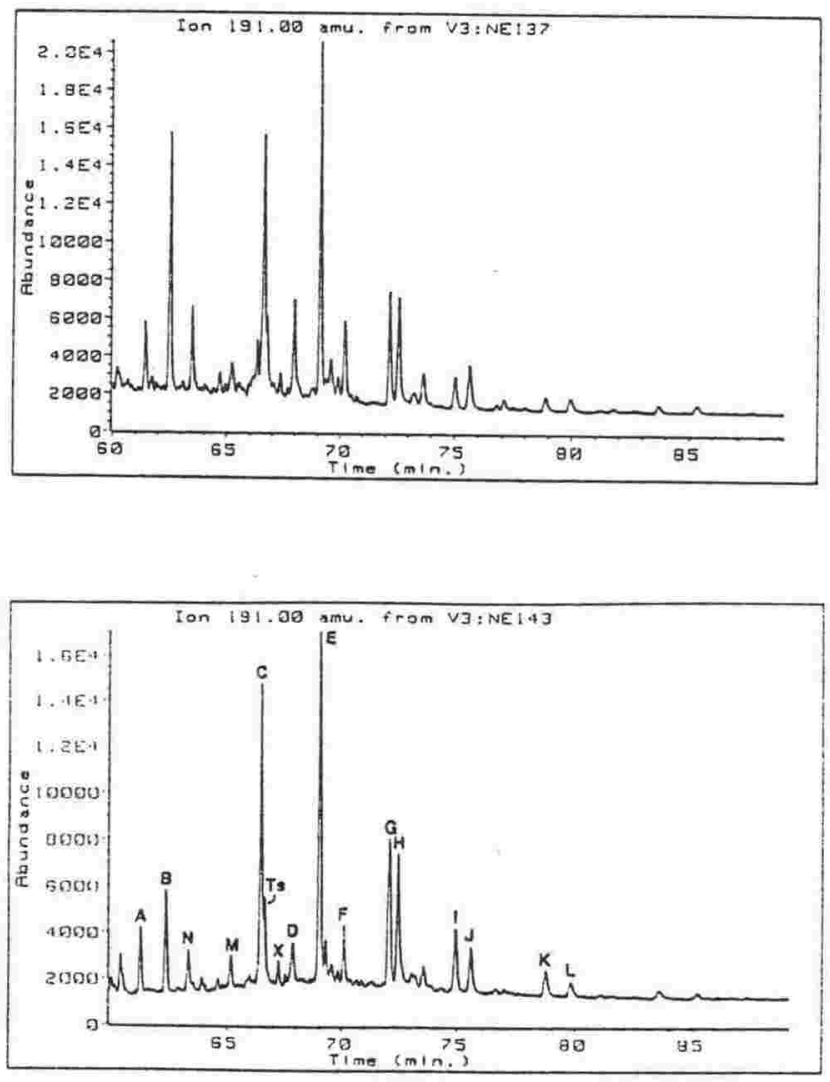
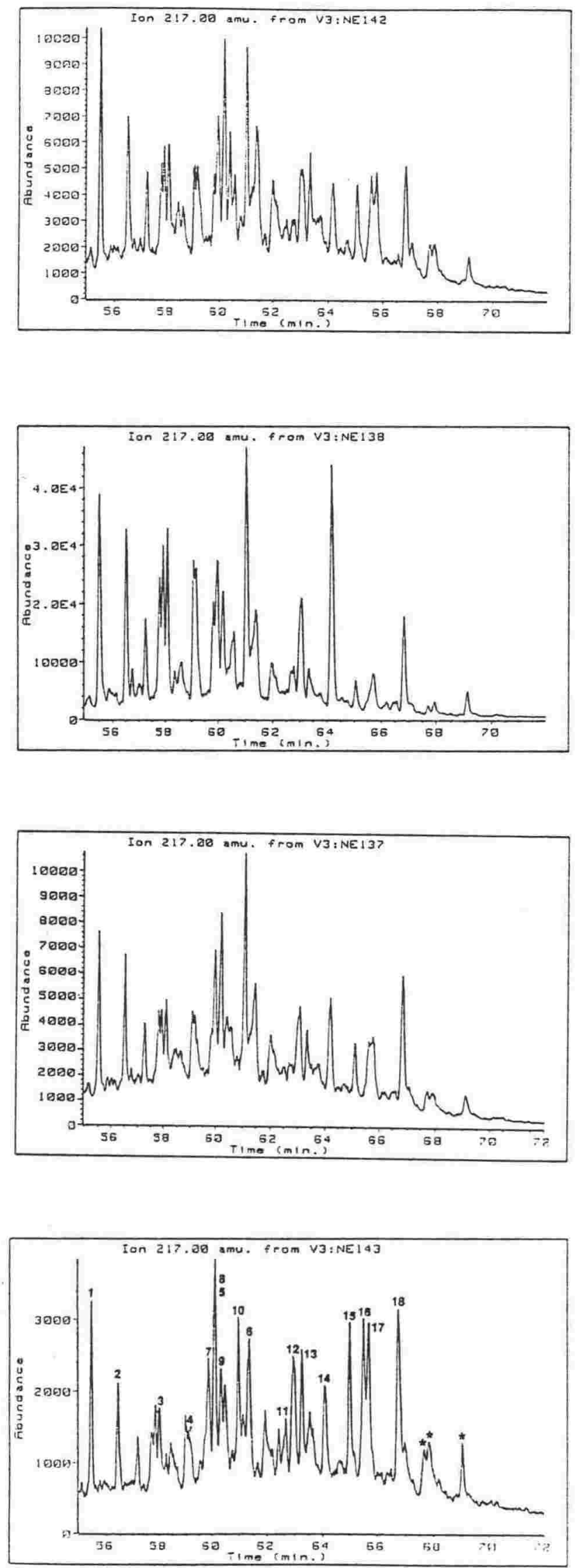


\section{Whangai Formation}

\section{Te Uri Member}
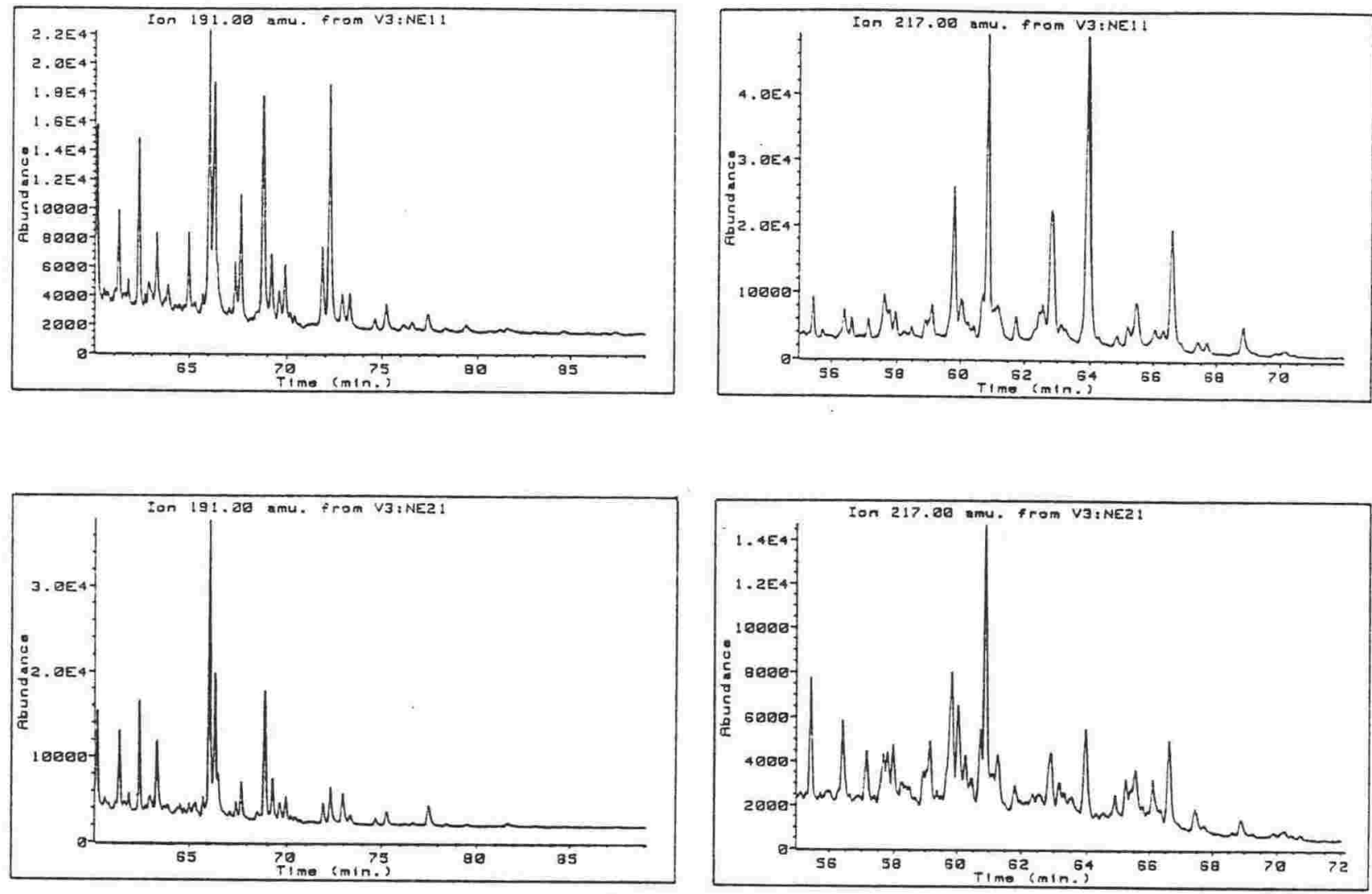

\section{Porangahau Member}
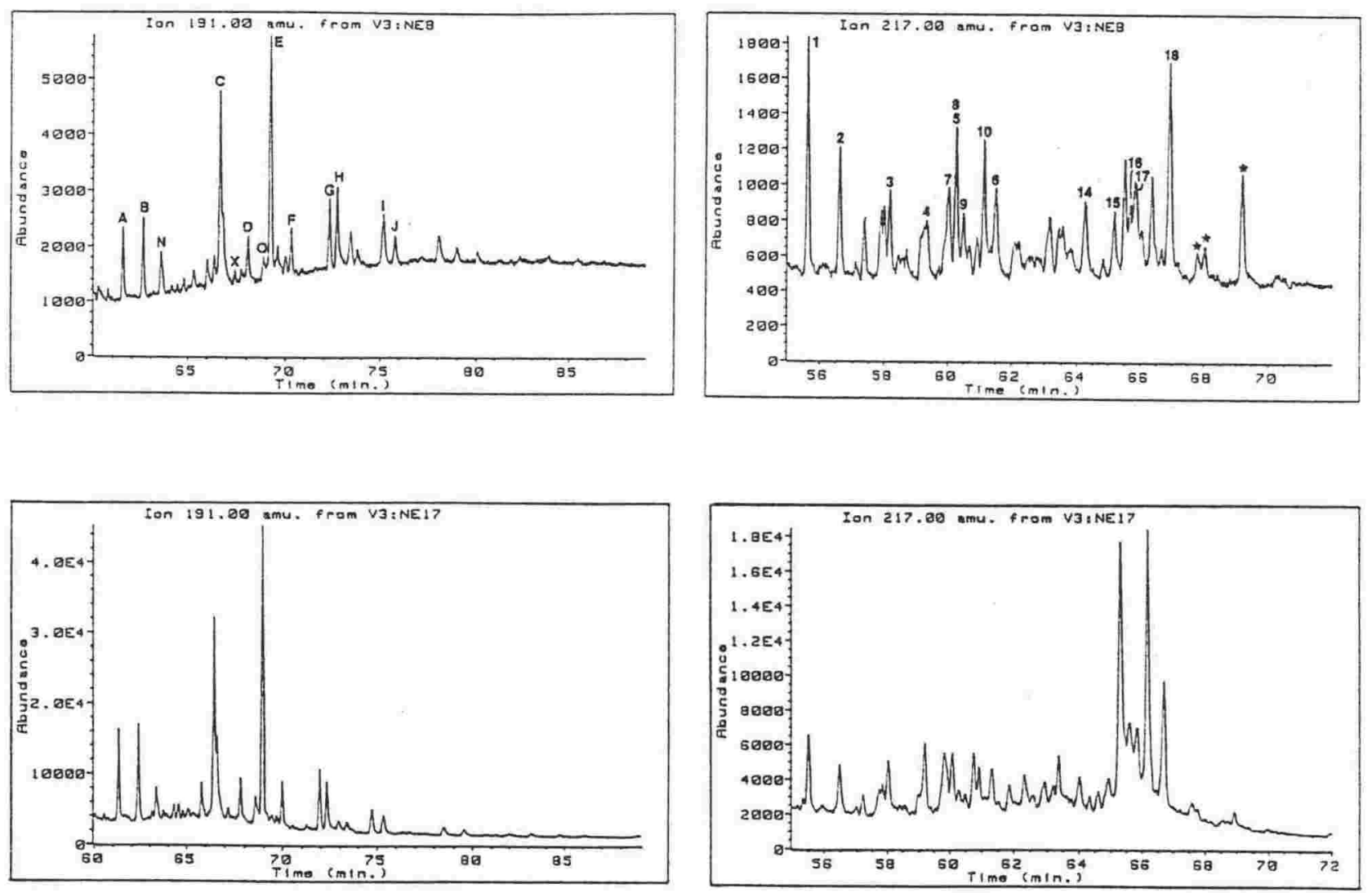
Porangahau Member continued
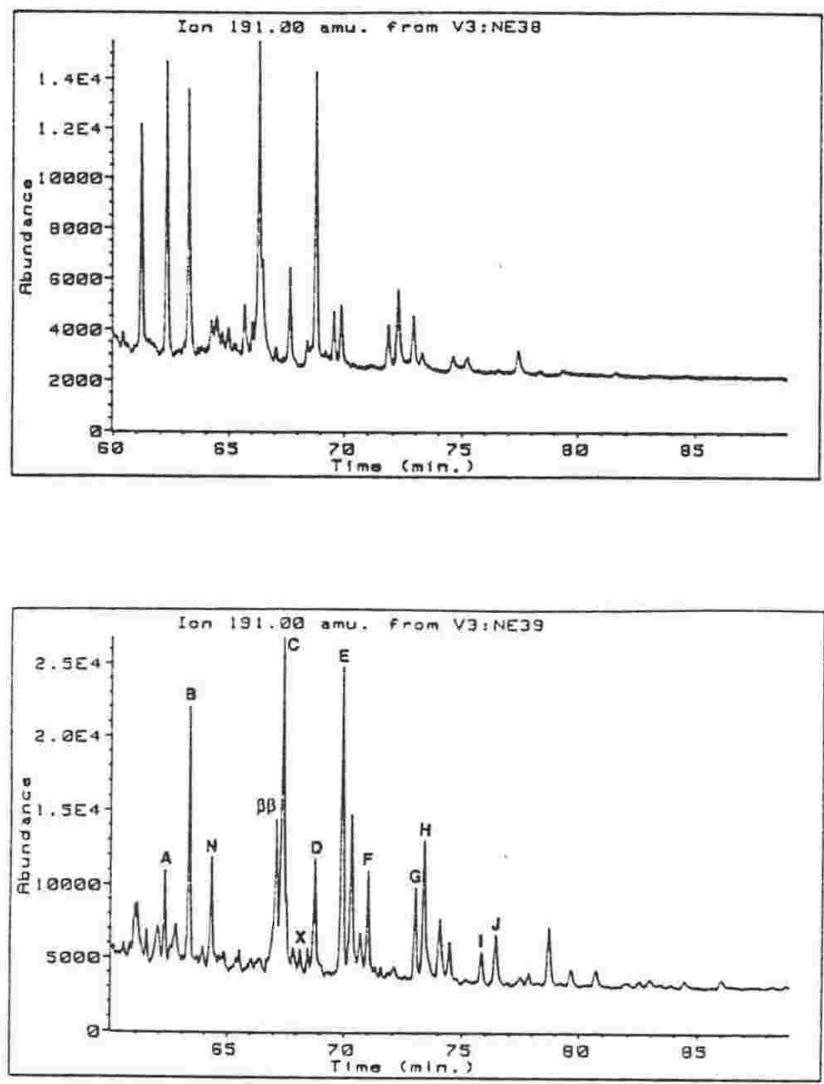

Upper Calcareous Member
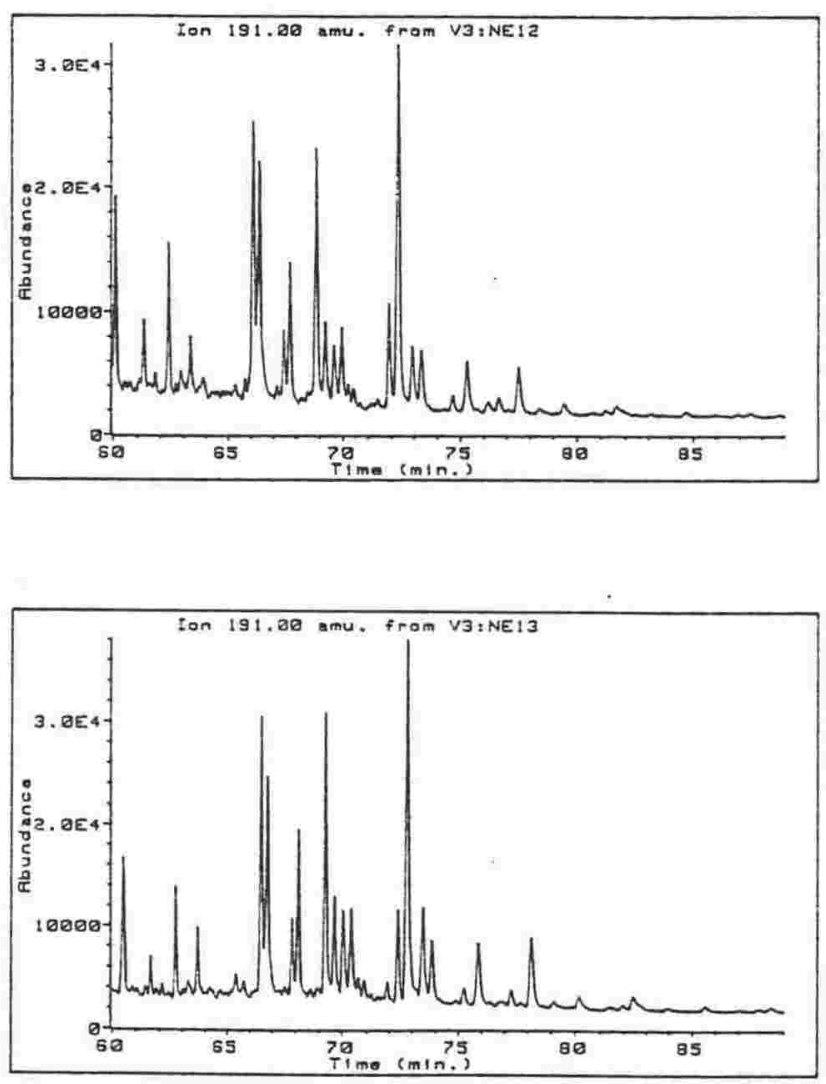
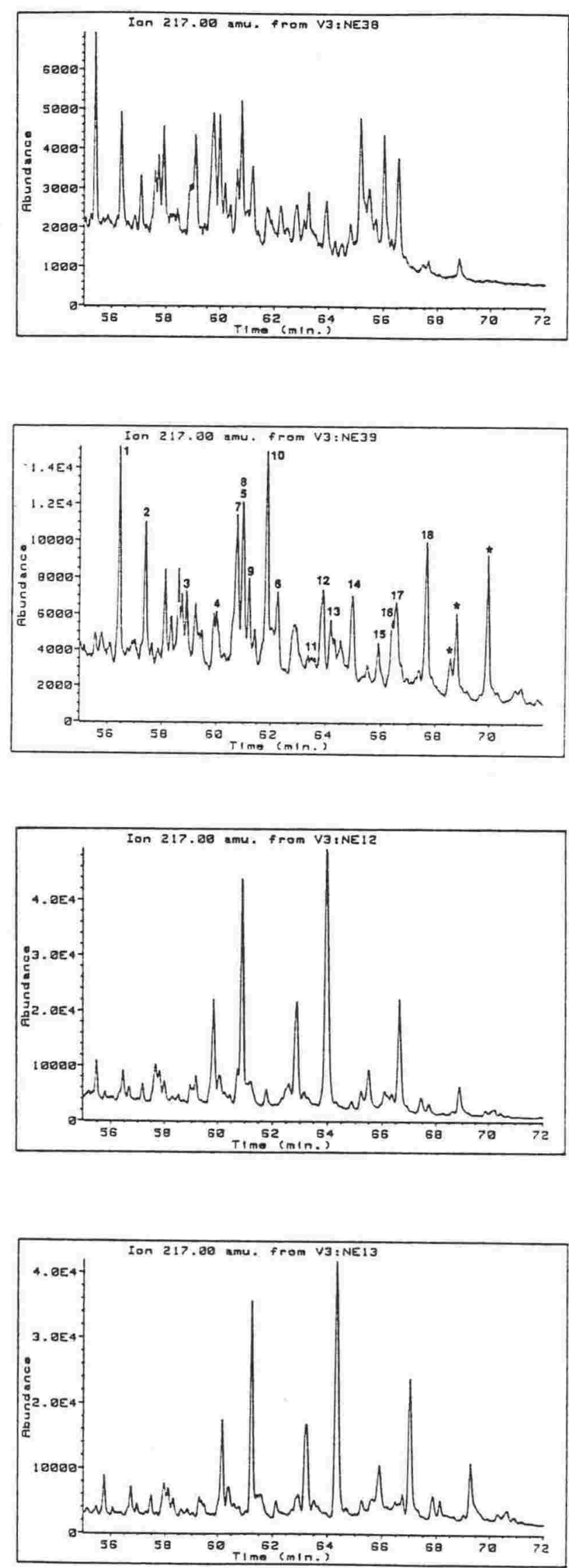


\section{Upper Calcareous Member continued}
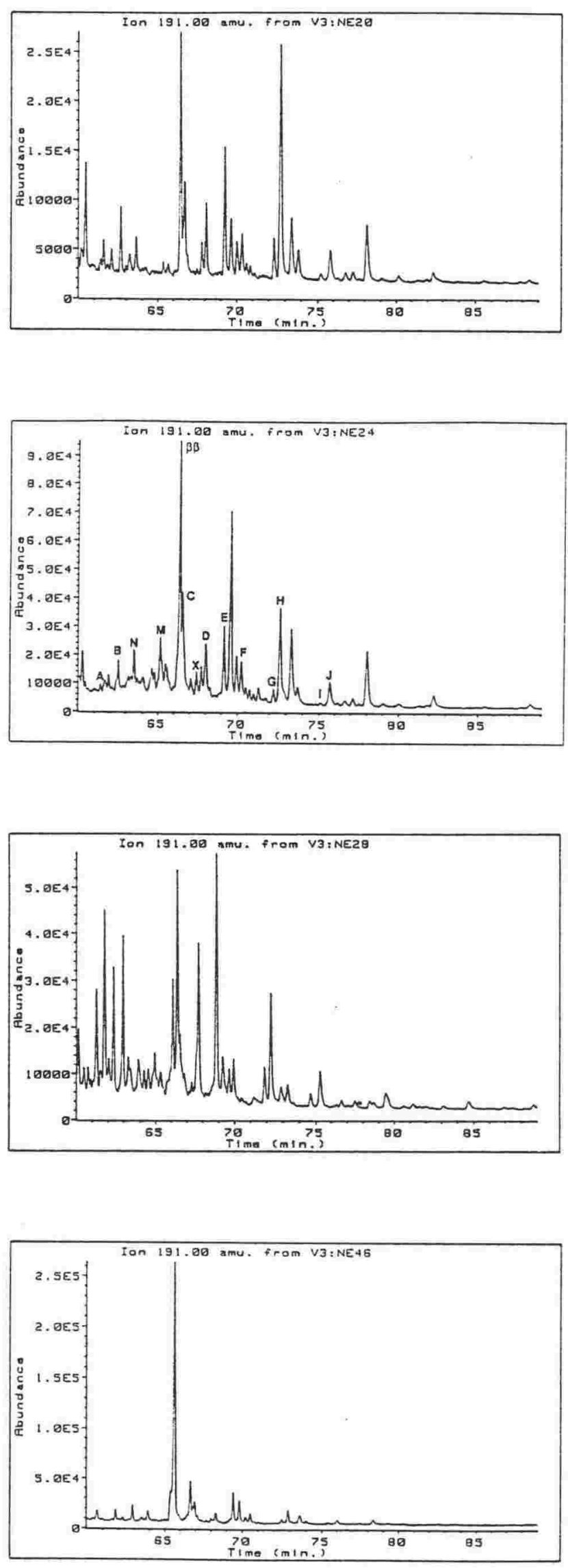
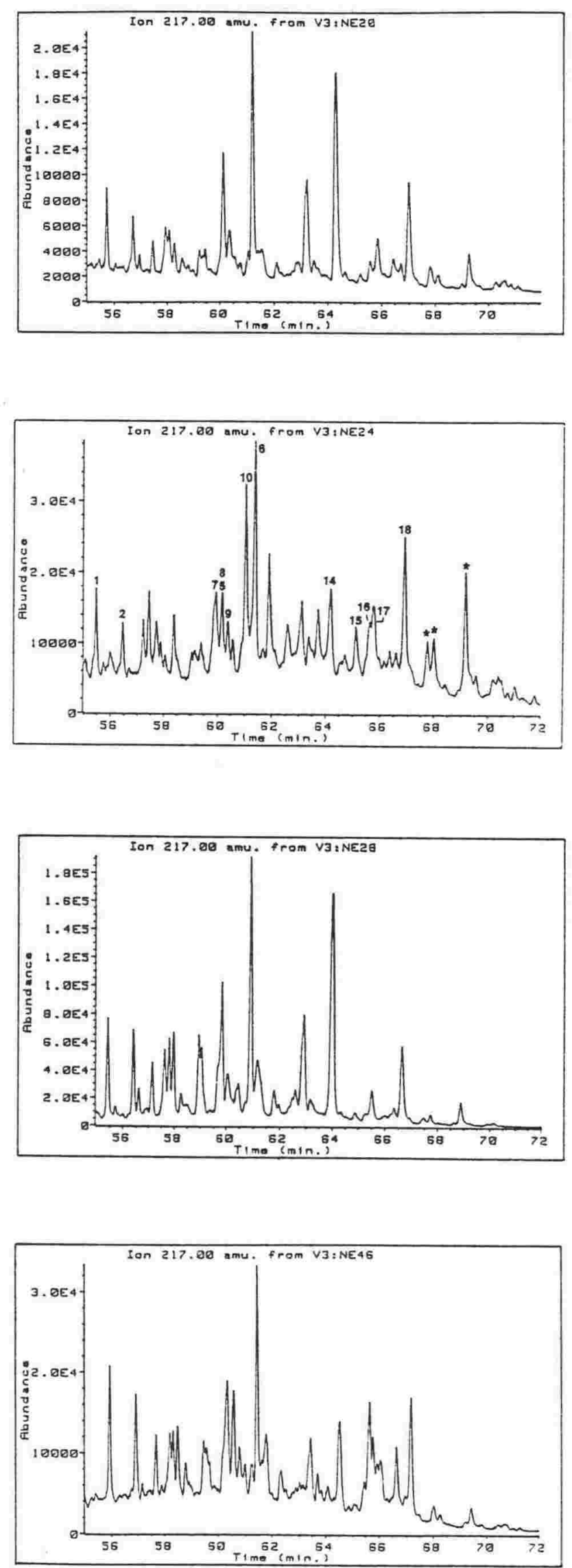


\section{Upper Calcareous Member continued}

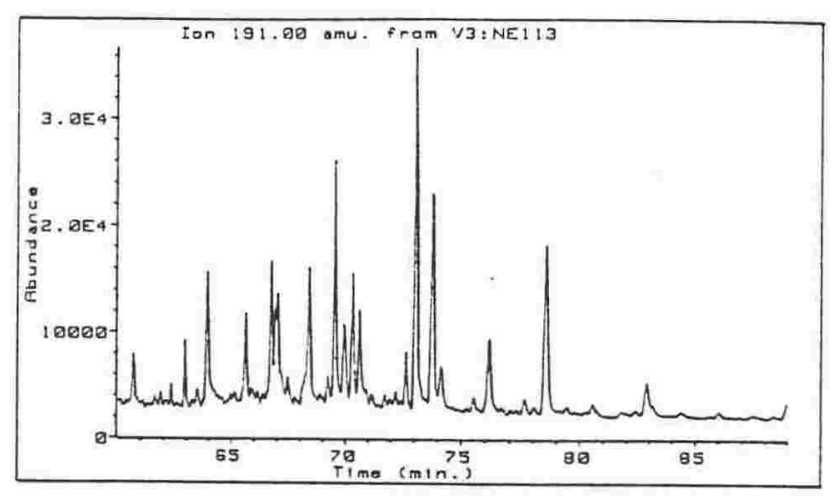

Rakauroa Member
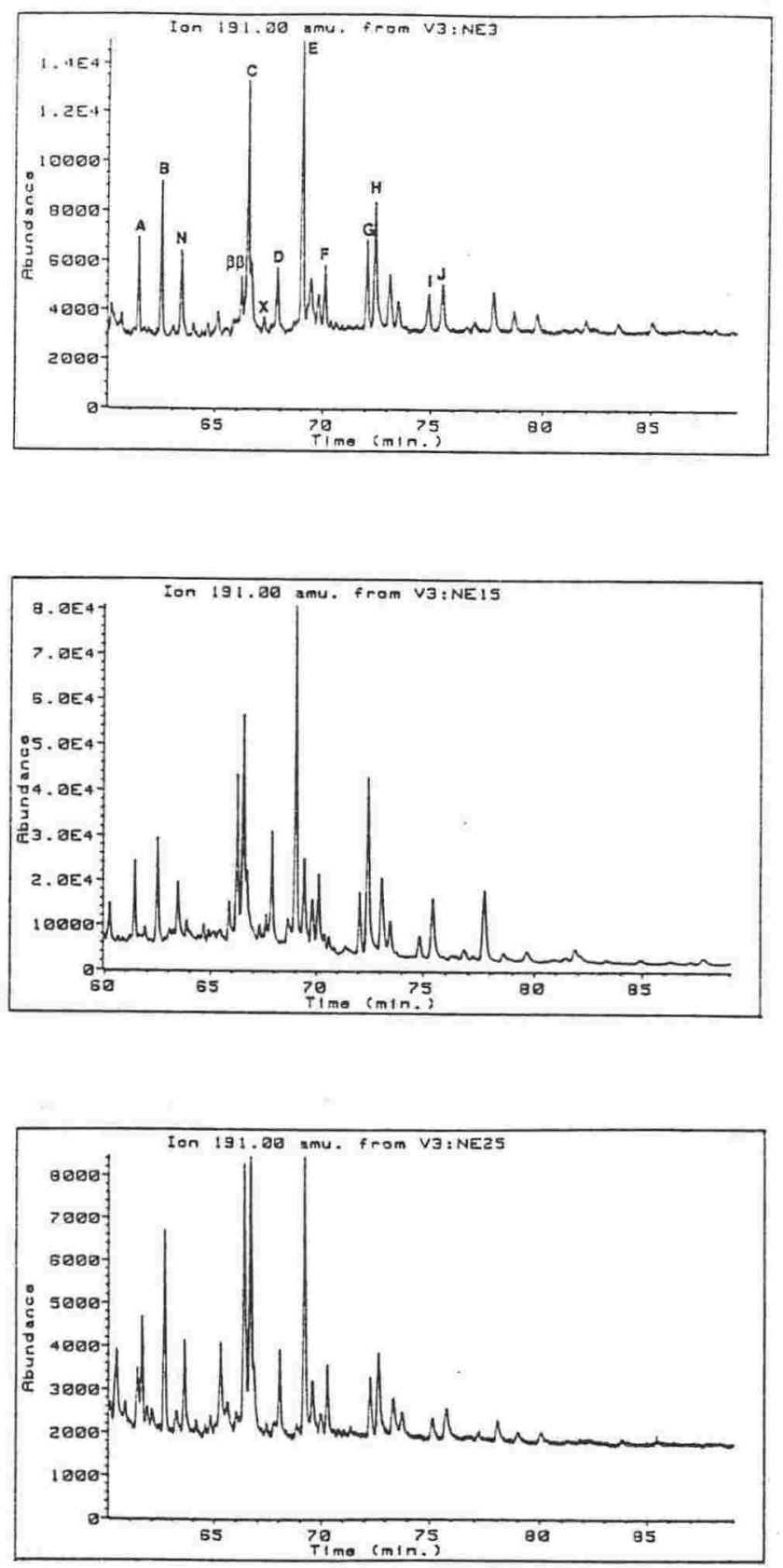
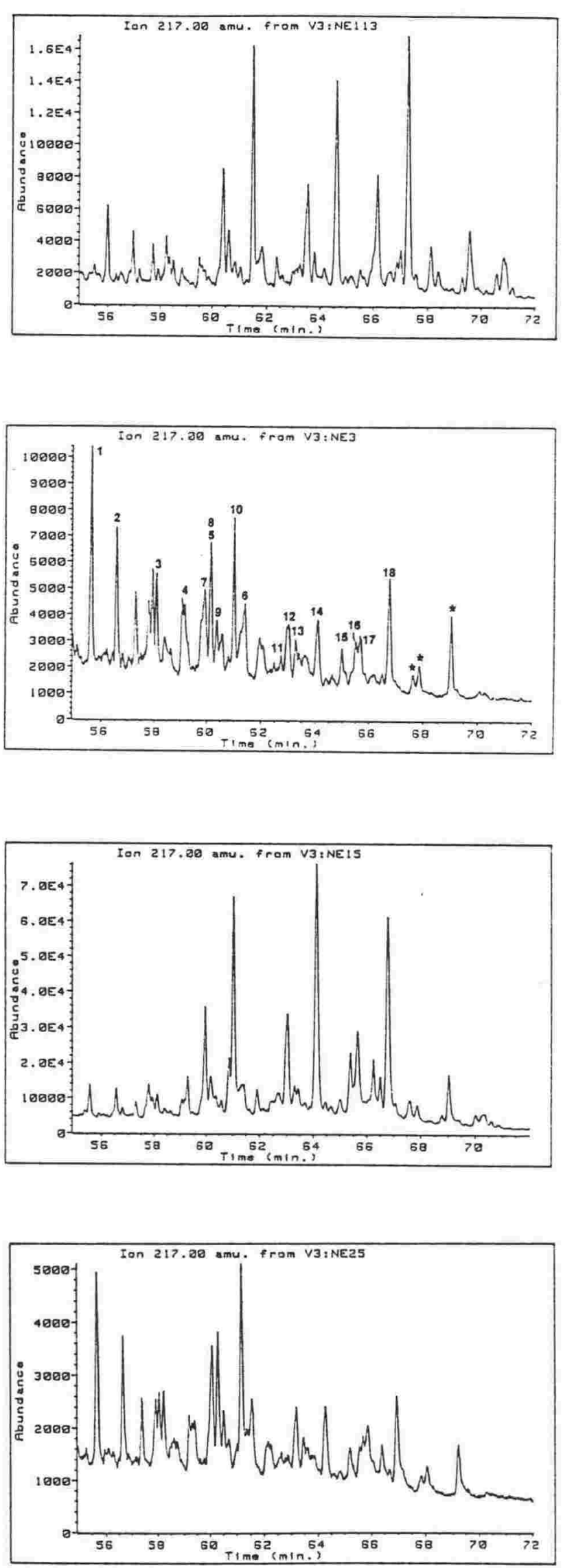


\section{Rakauroa Member continued}
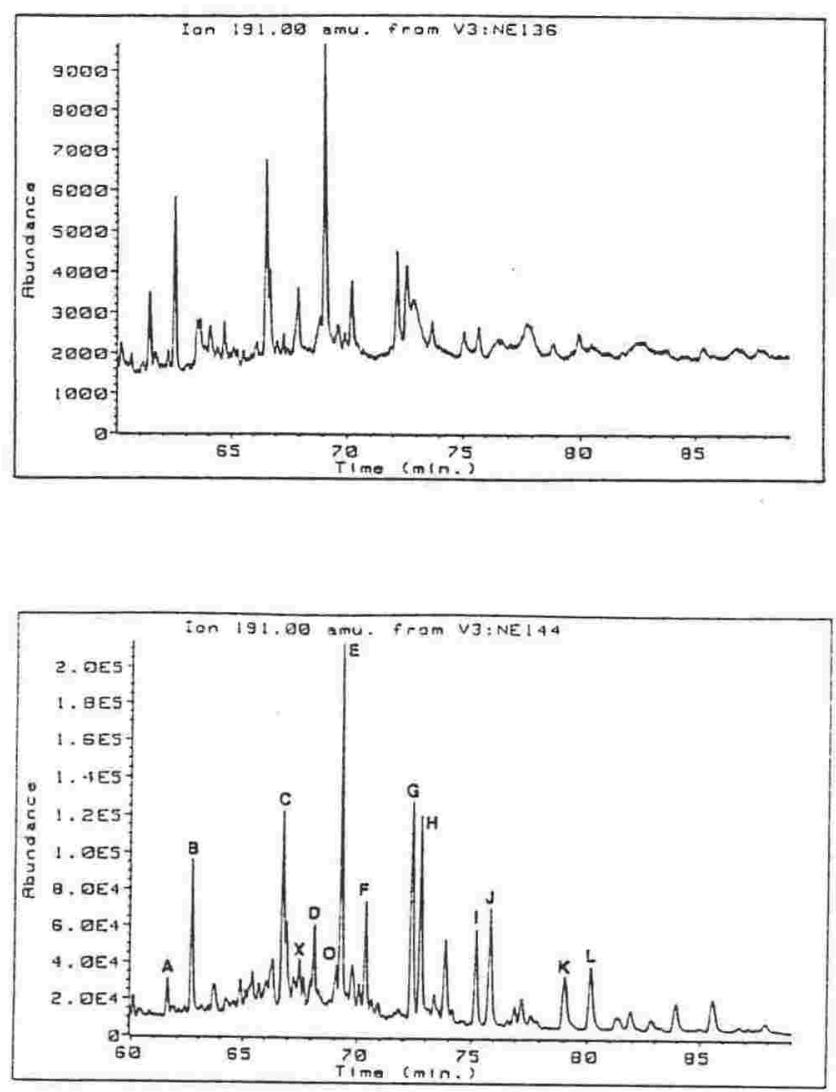

\section{Undifferentiated Whangai}
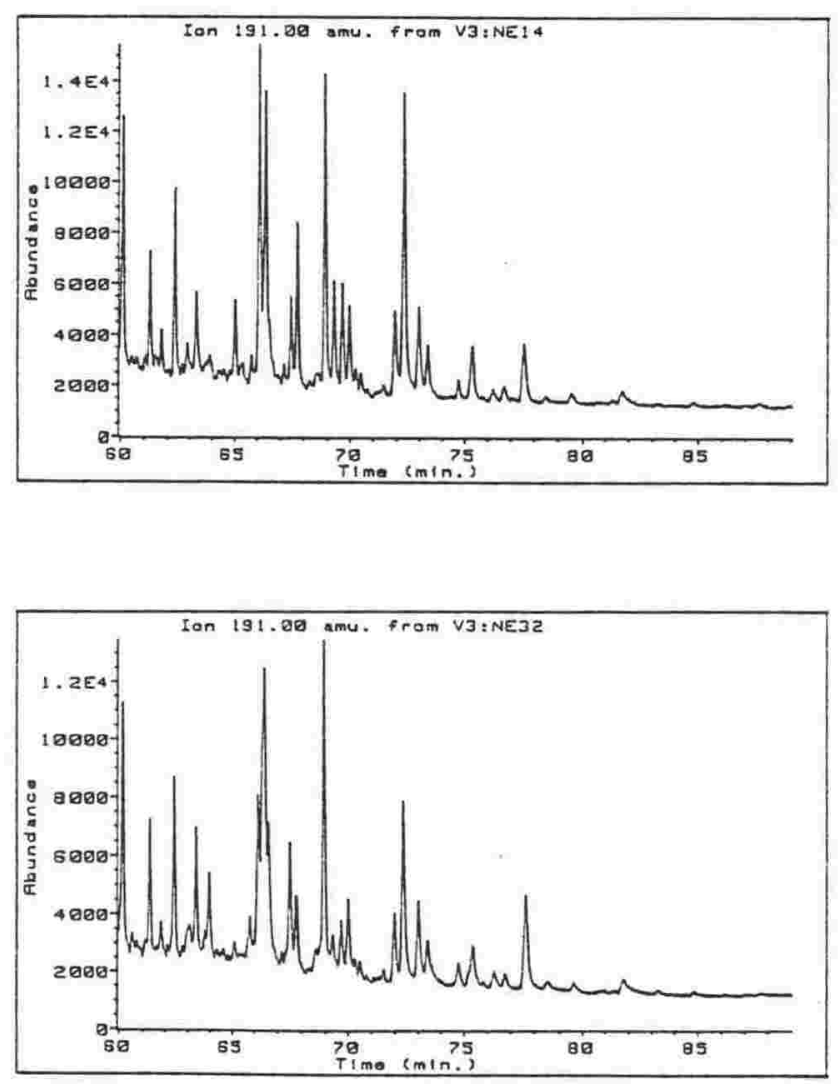
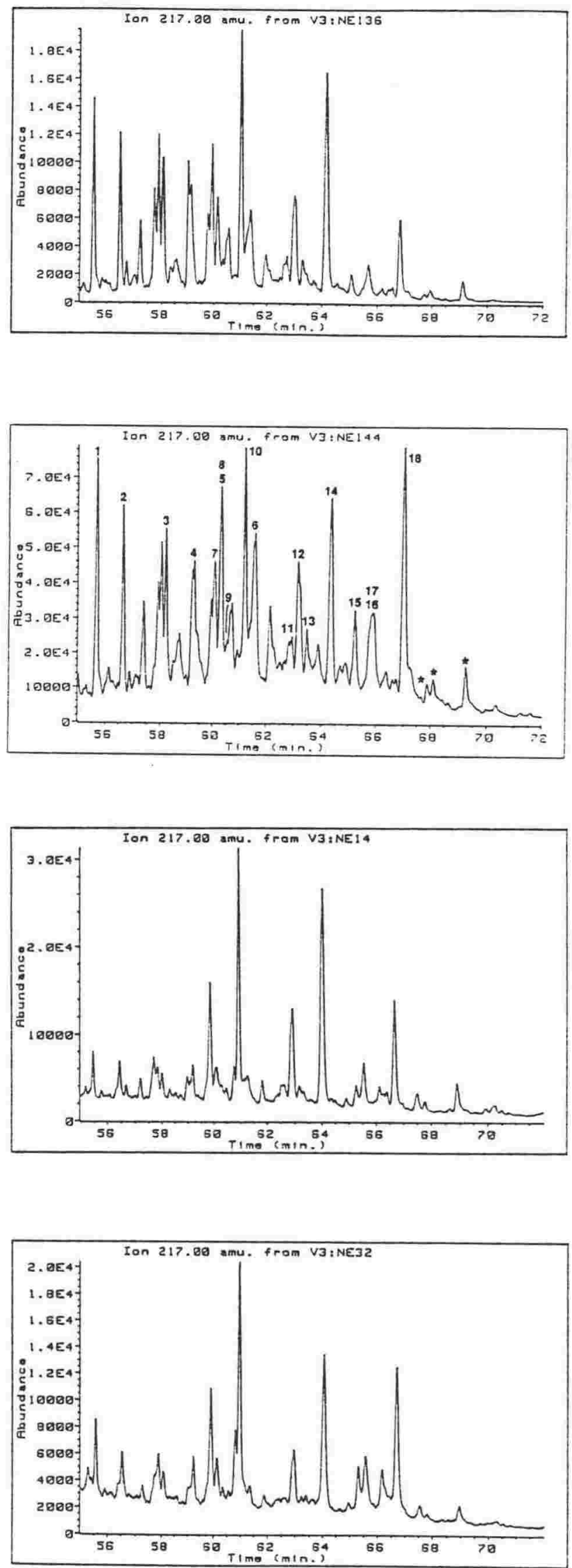


\section{Undifferentiated Whangai continued}
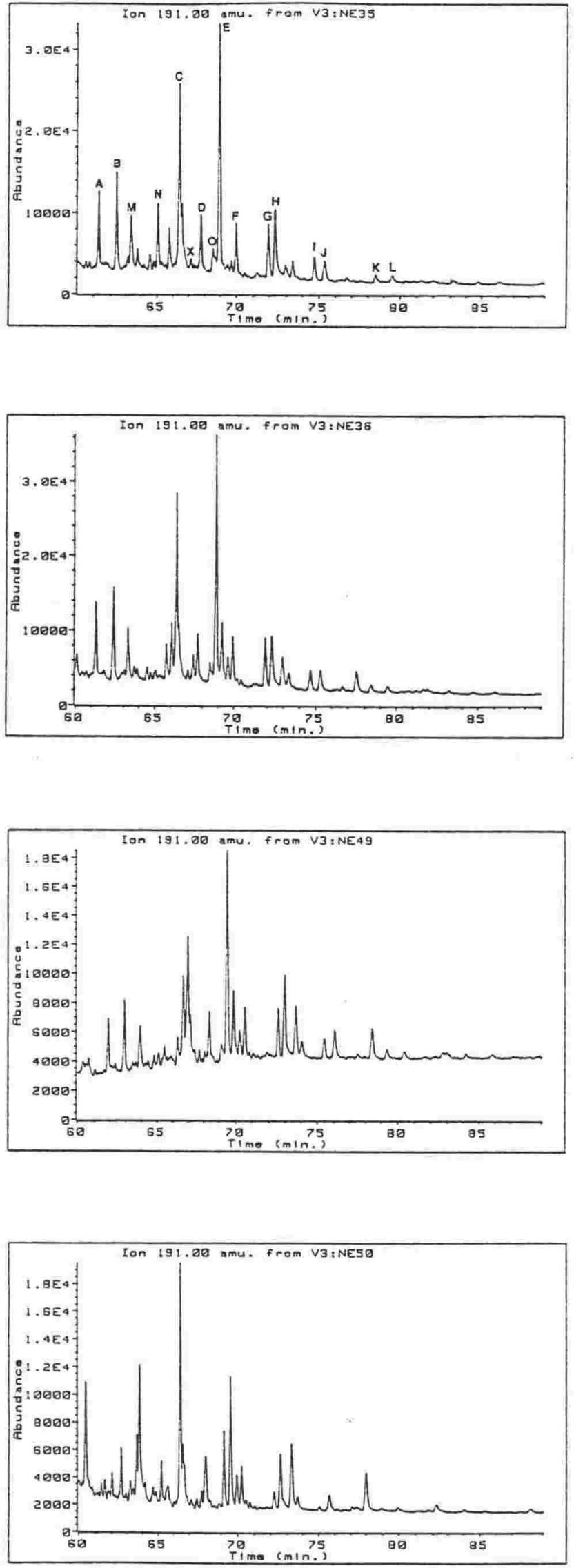
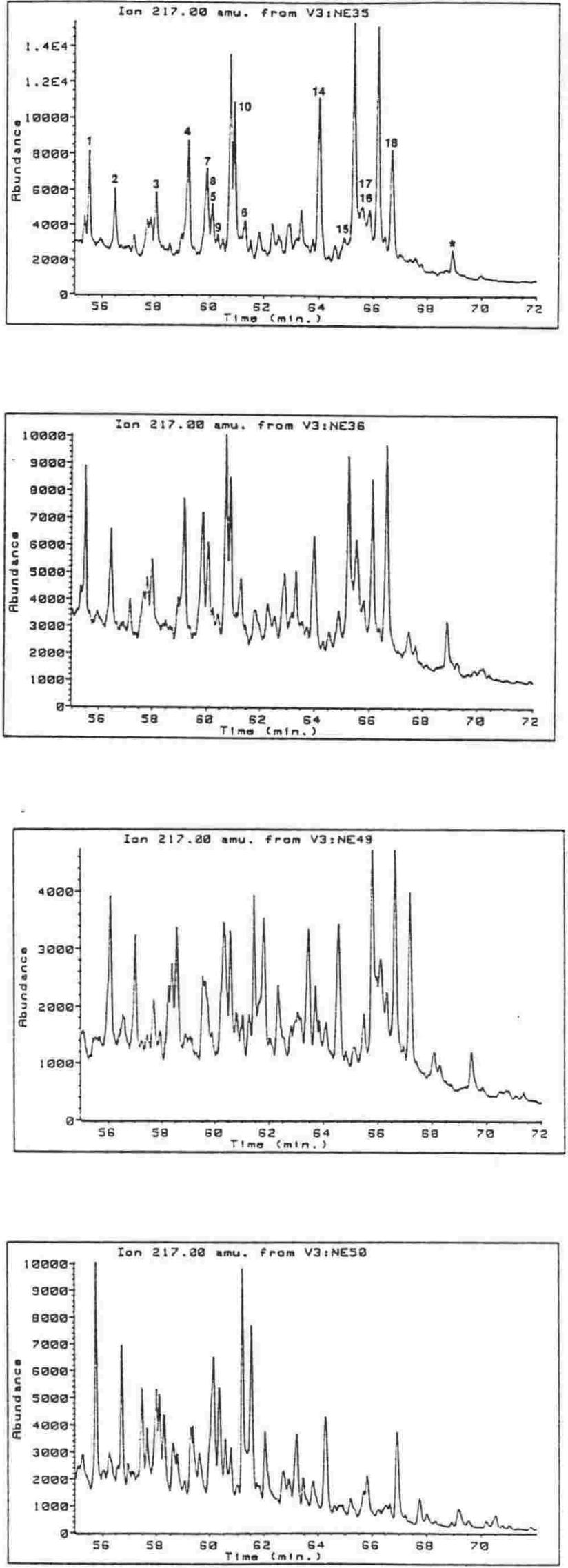


\section{Undifferentiated Whangai continued}
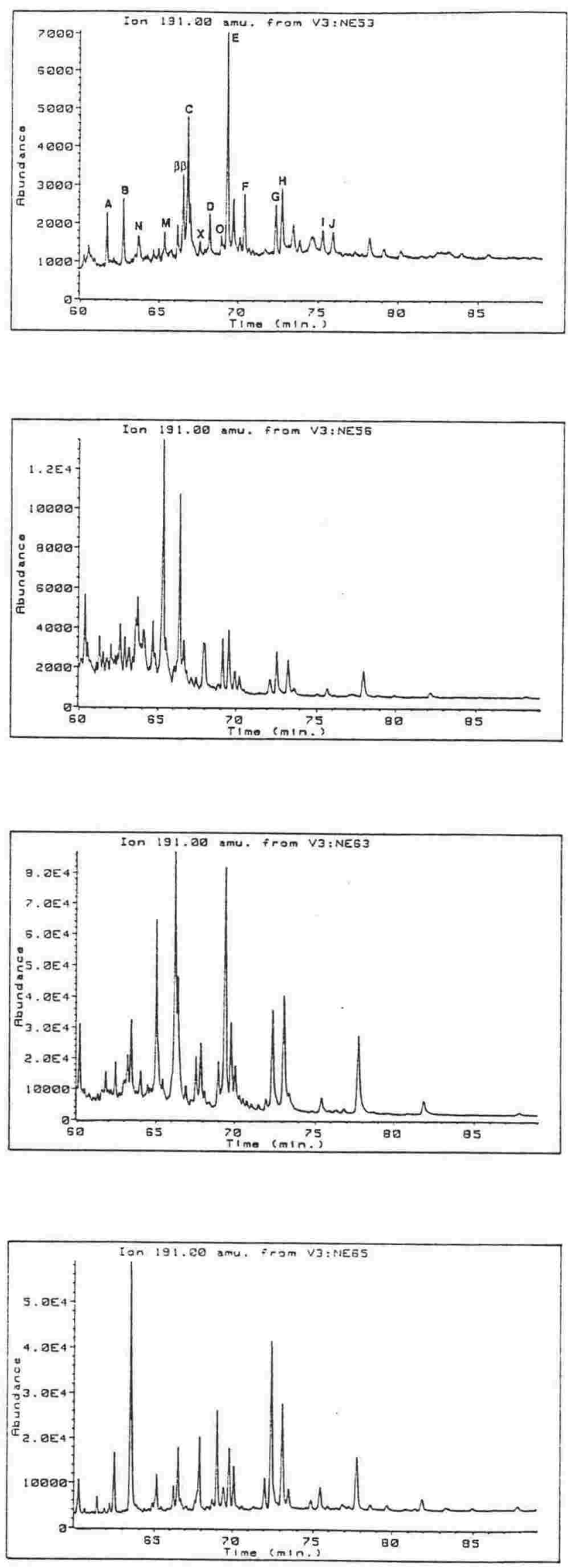
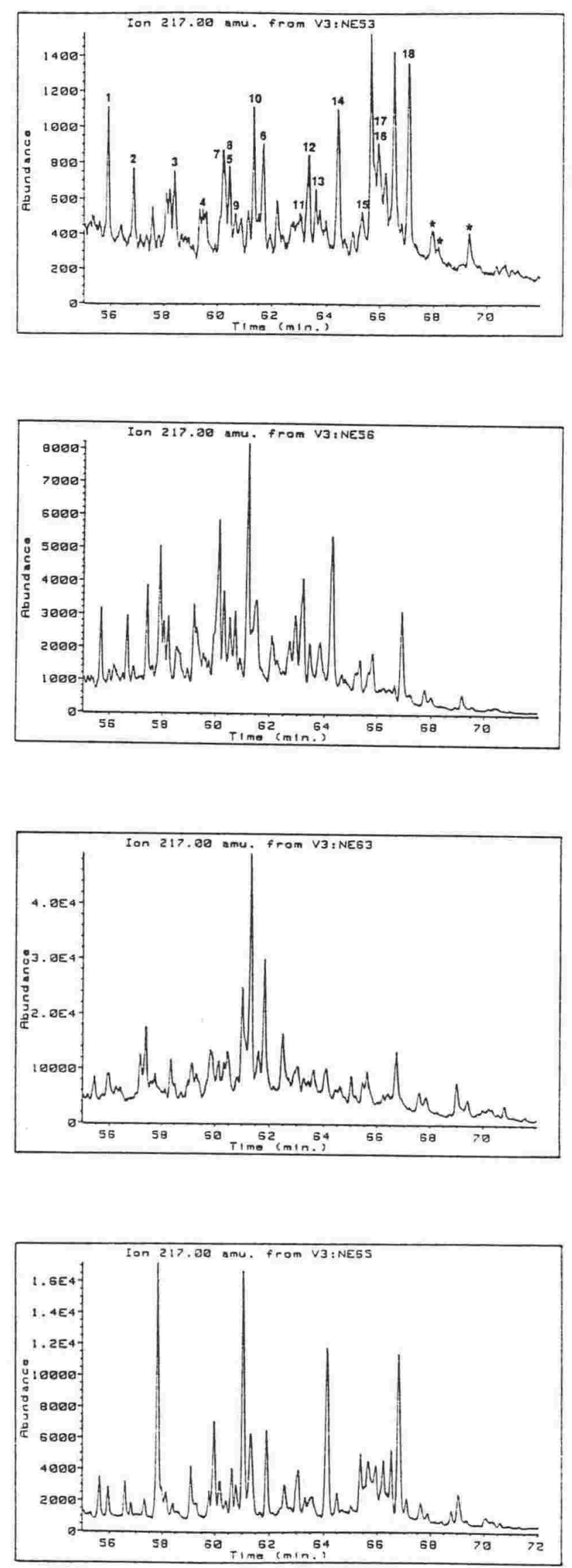


\section{Undifferentiated Whangai continued}
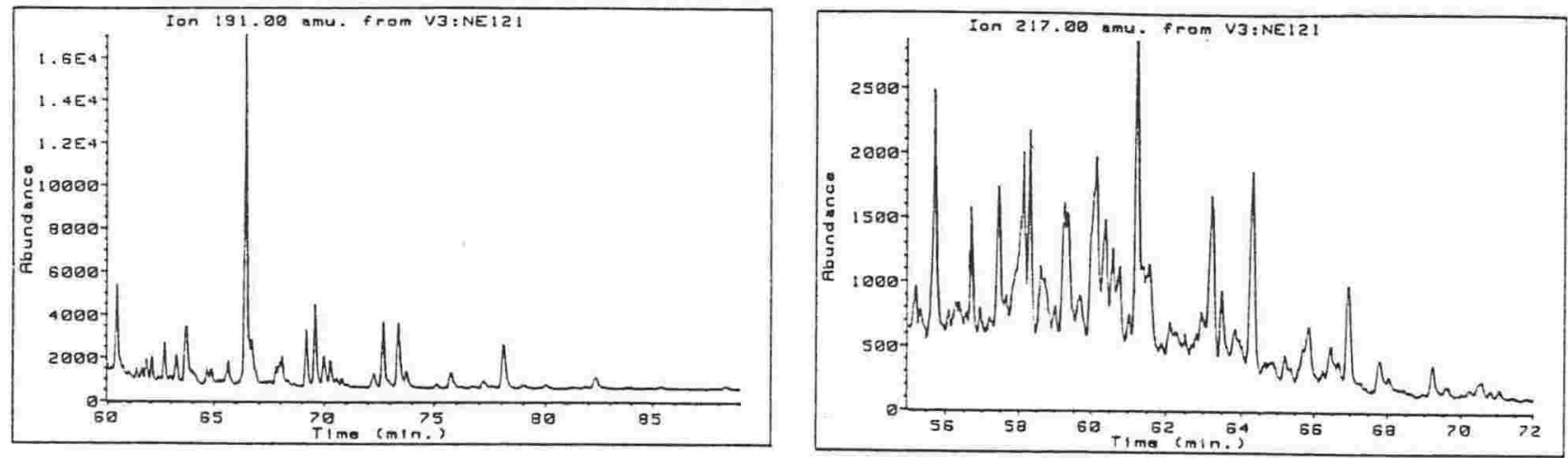

\section{Tangaruhe Formation}
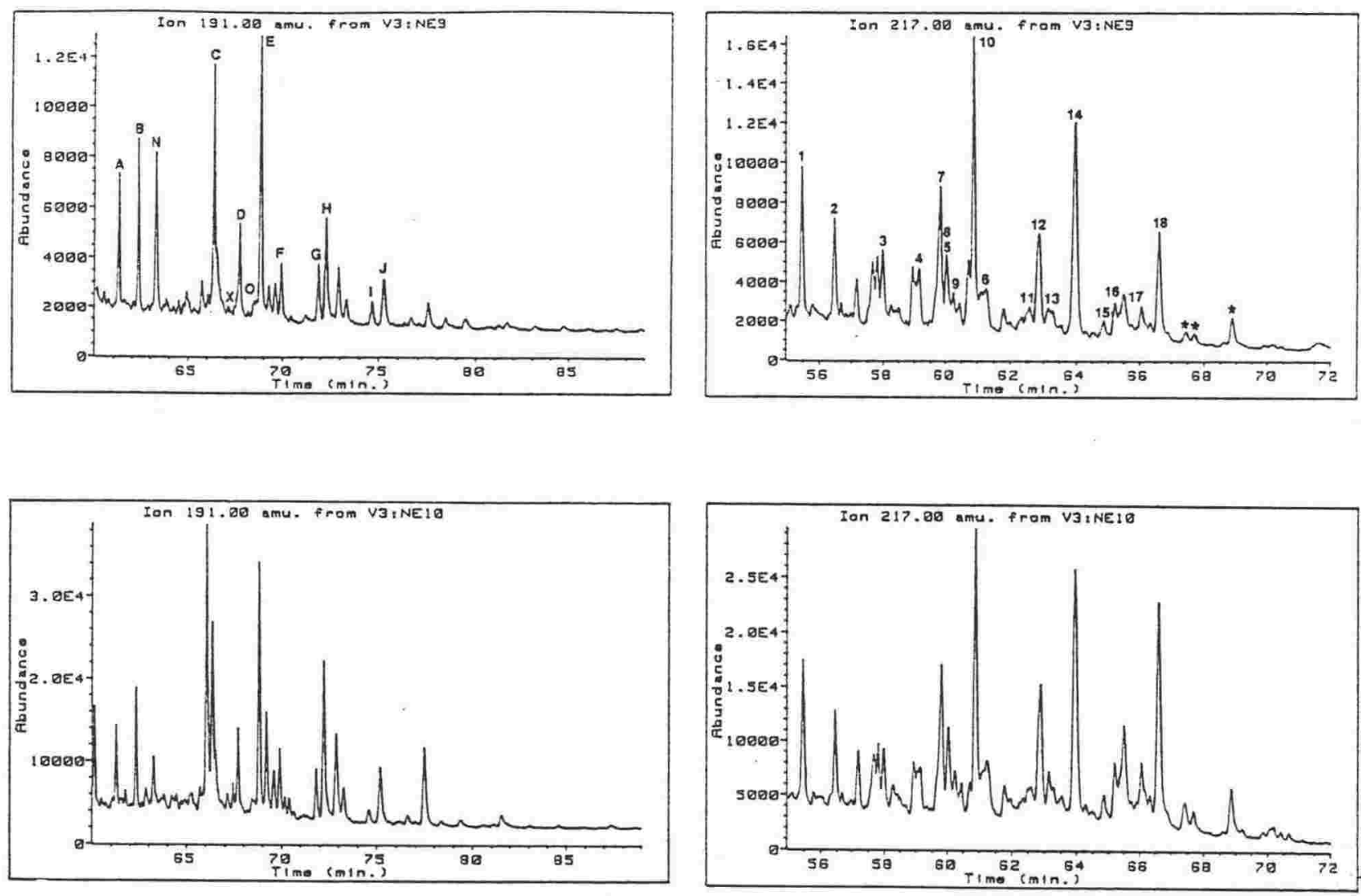

Te Mai Formation
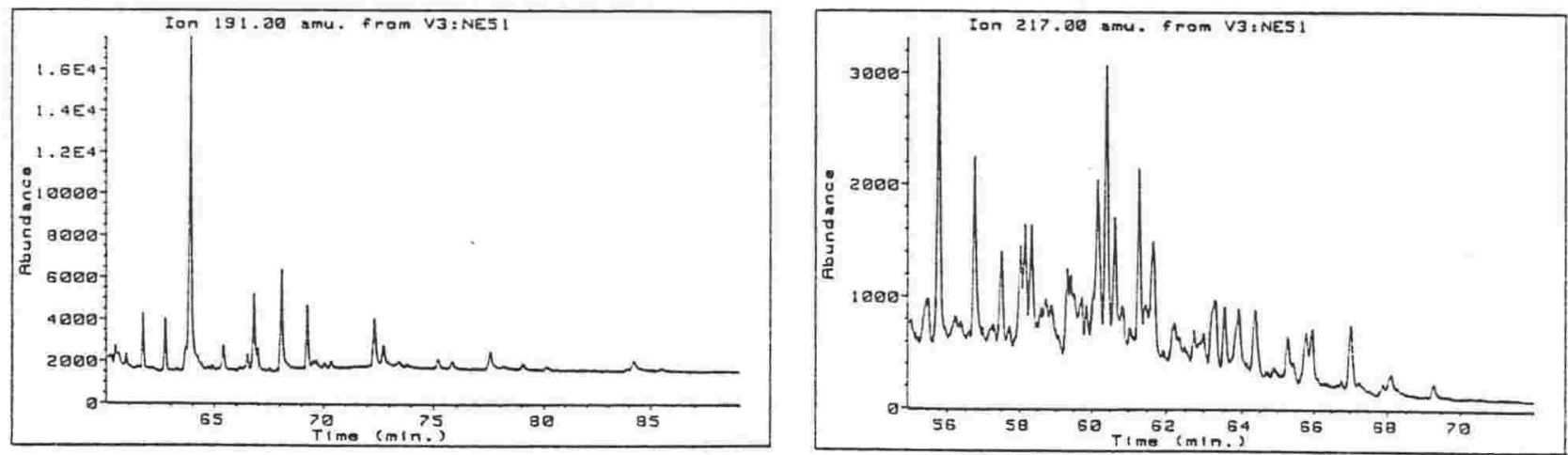


\section{Te Mai Formation continued}
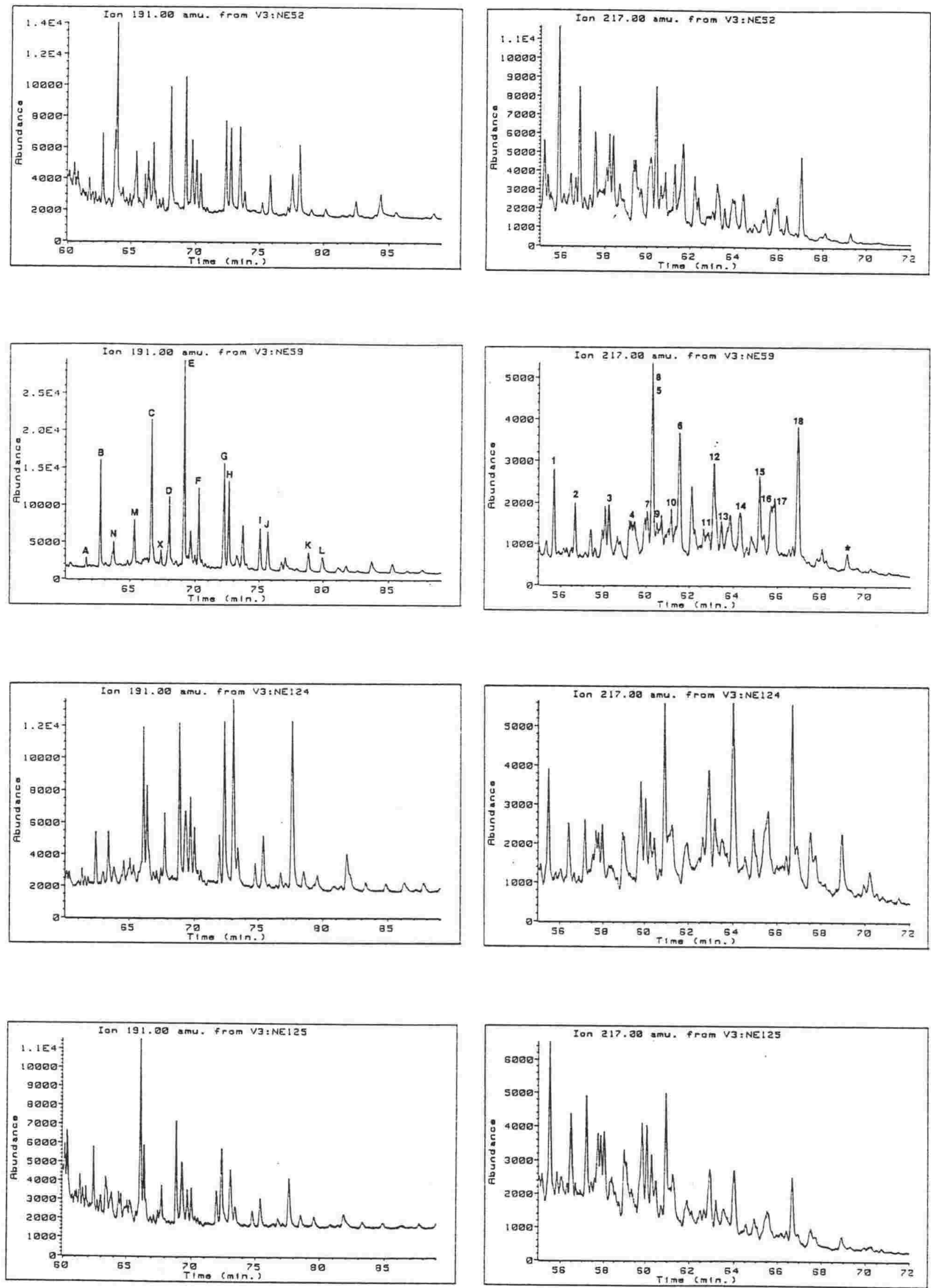


\section{Glenburn Formation}
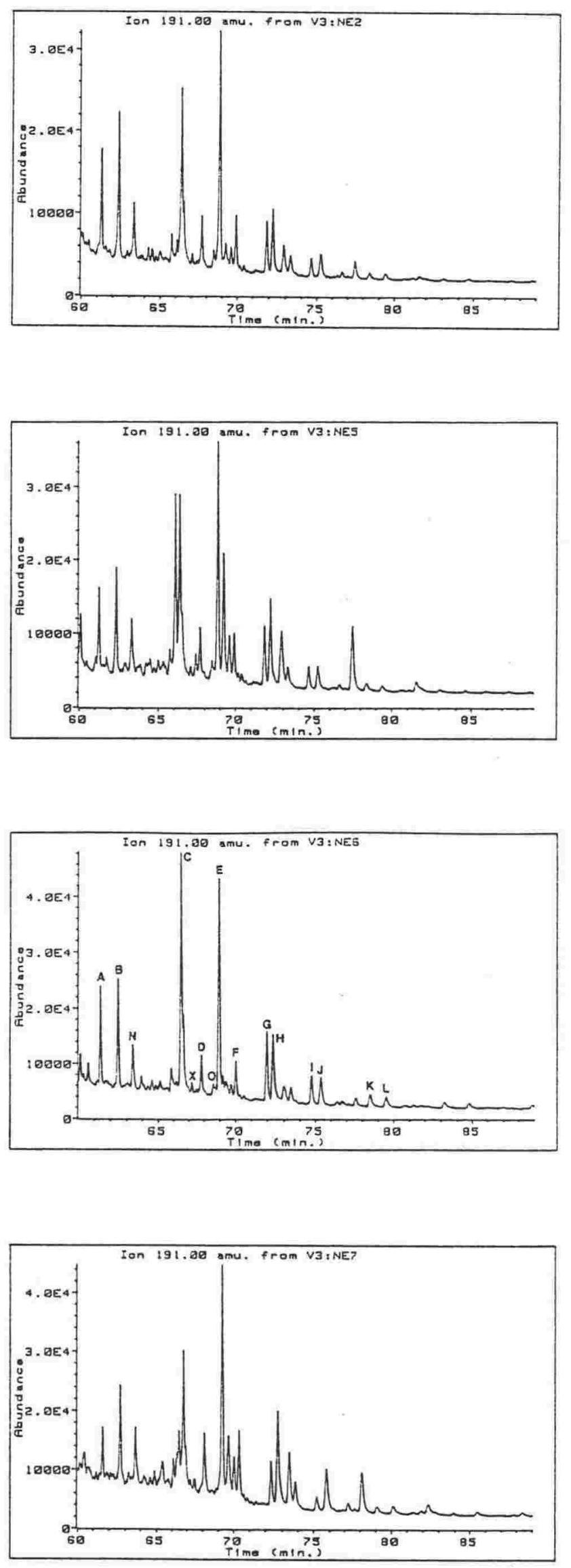
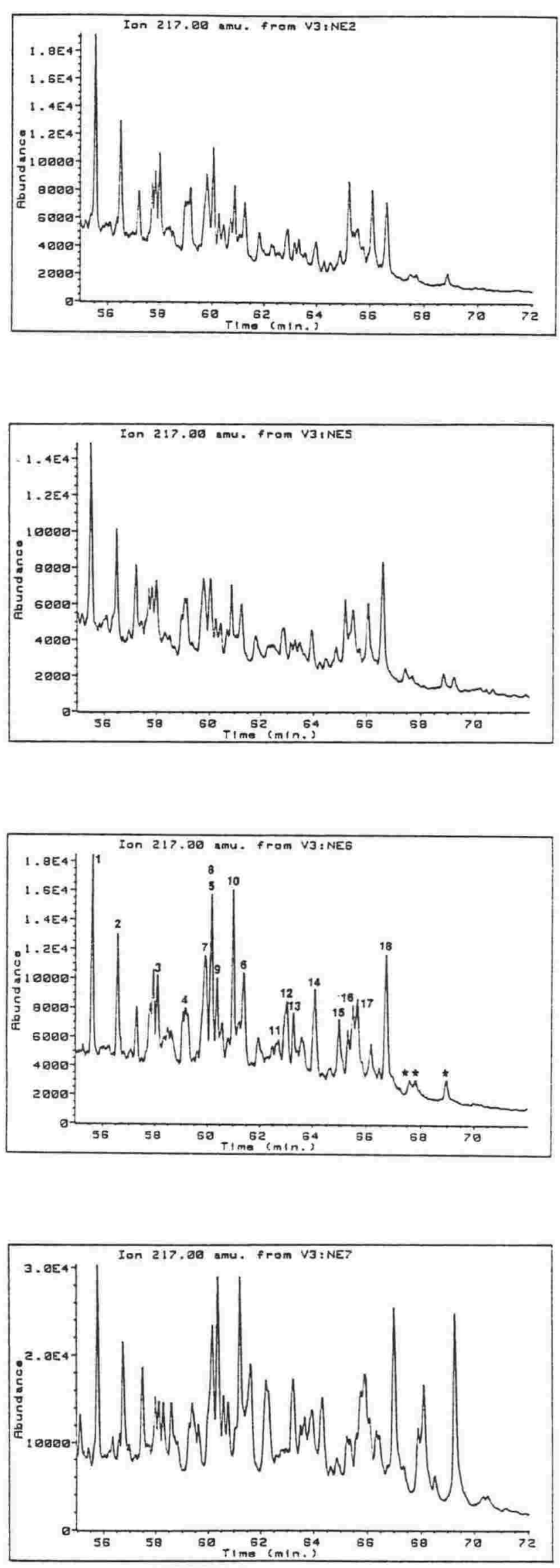


\section{Glenburn Formation continued}
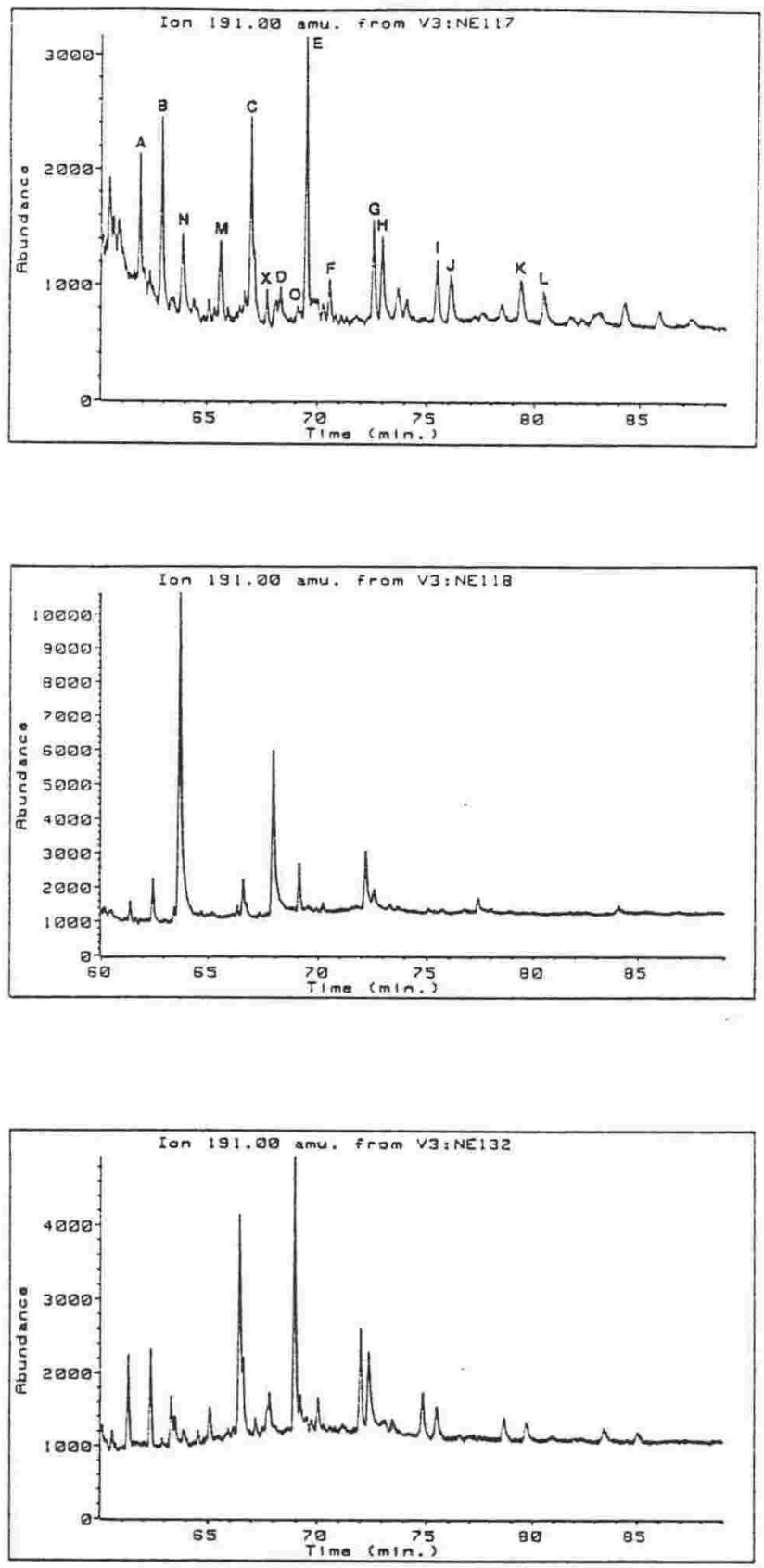

\section{Springhill Formation}

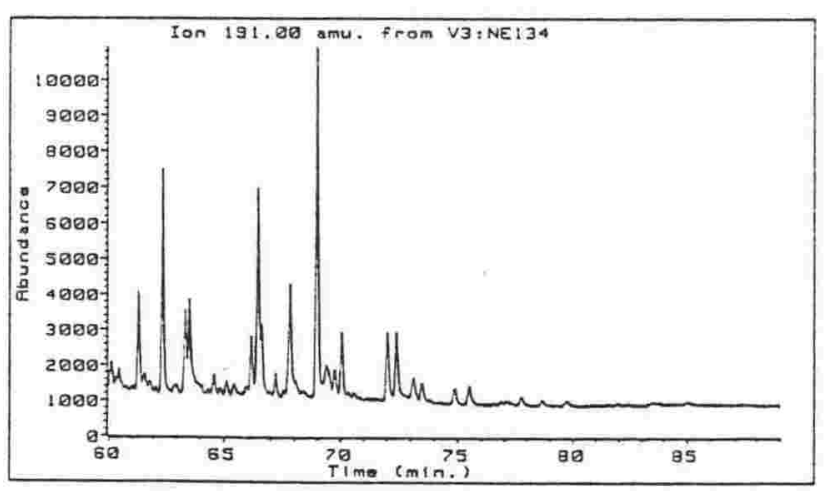

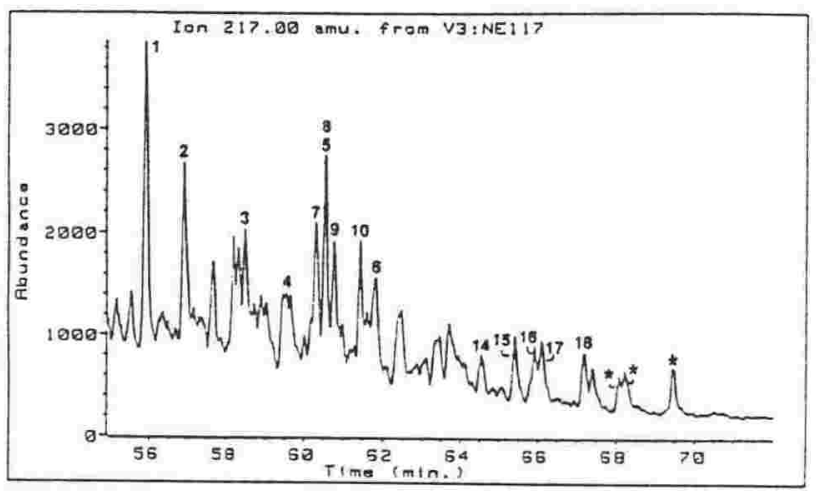
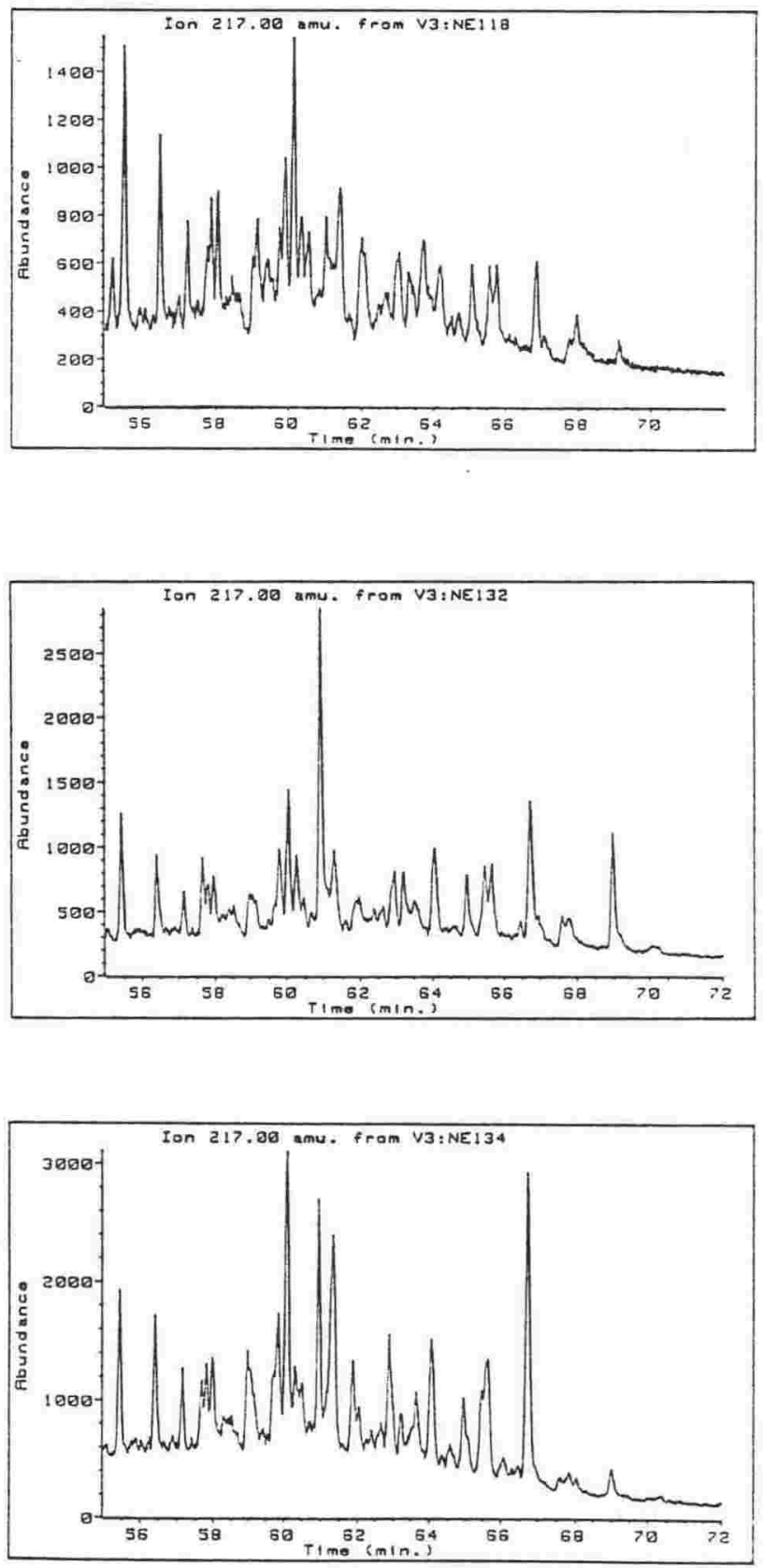


\section{Springhill Formation continued}

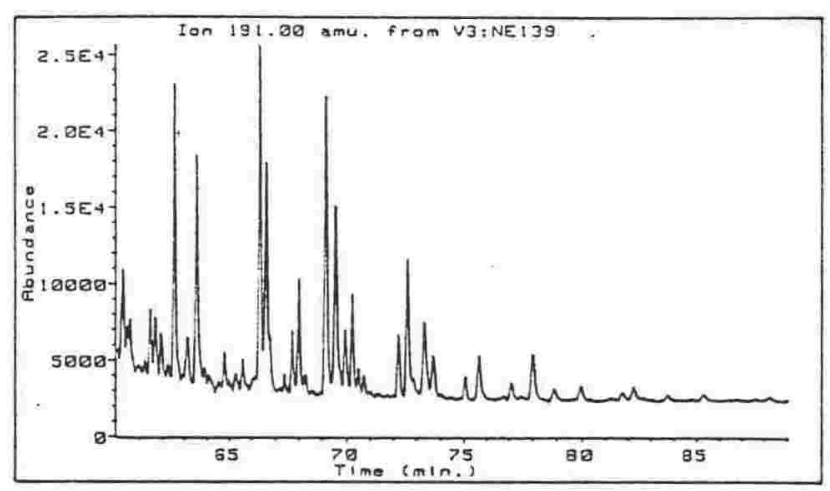

\section{Gentle Annie Formation}

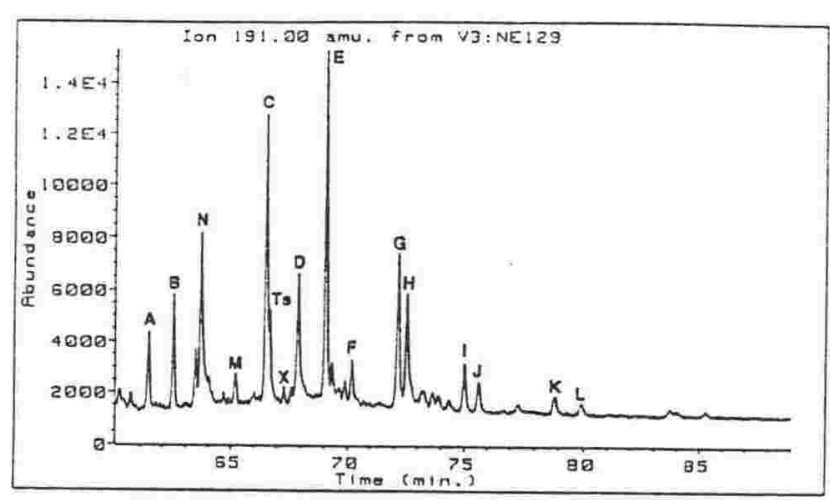

\section{Mangapokia Formation}
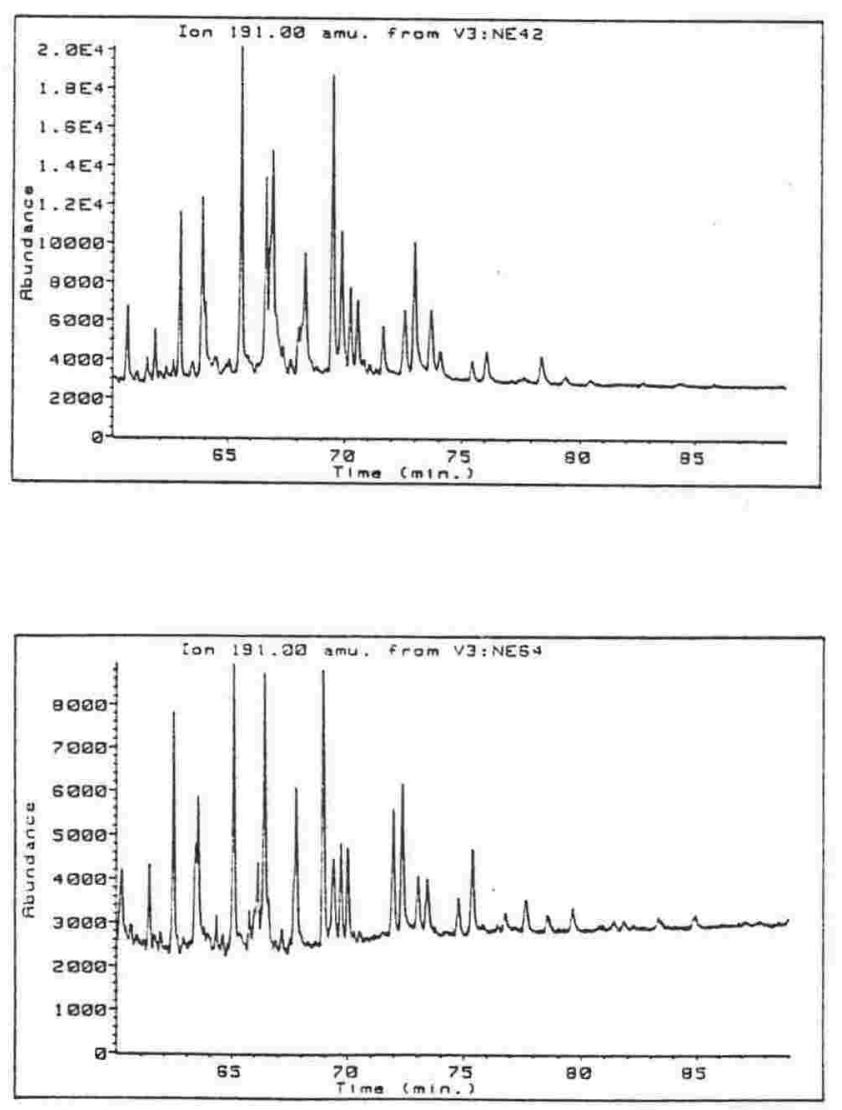
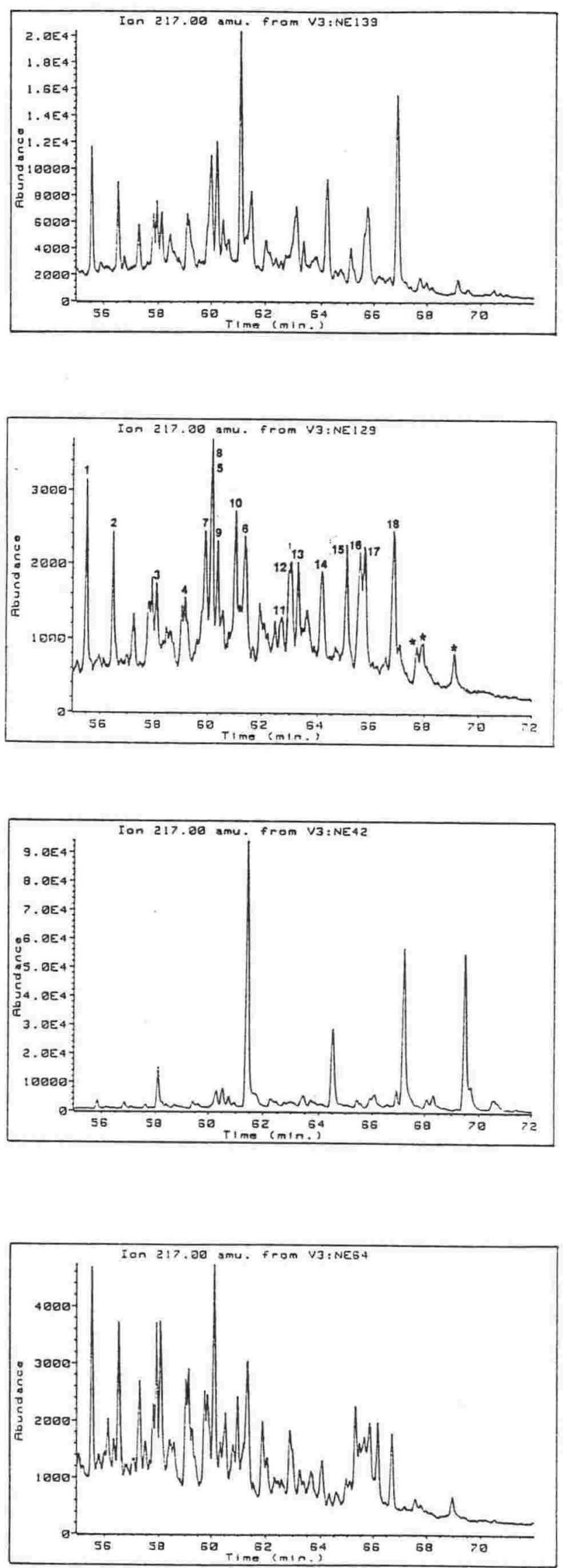


\section{Mangapokia Formation continued}
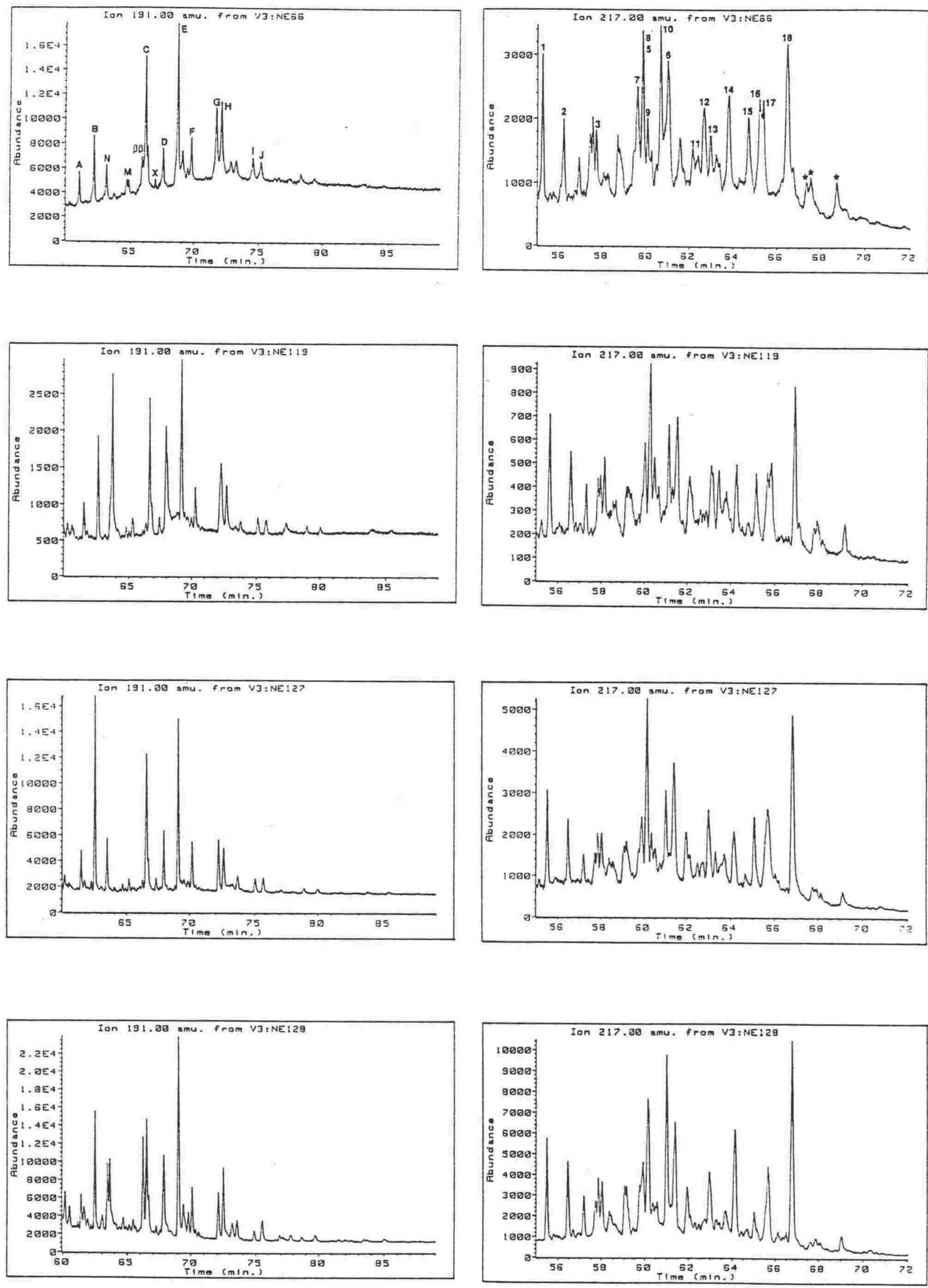


\section{Mangapokia Formation continued}
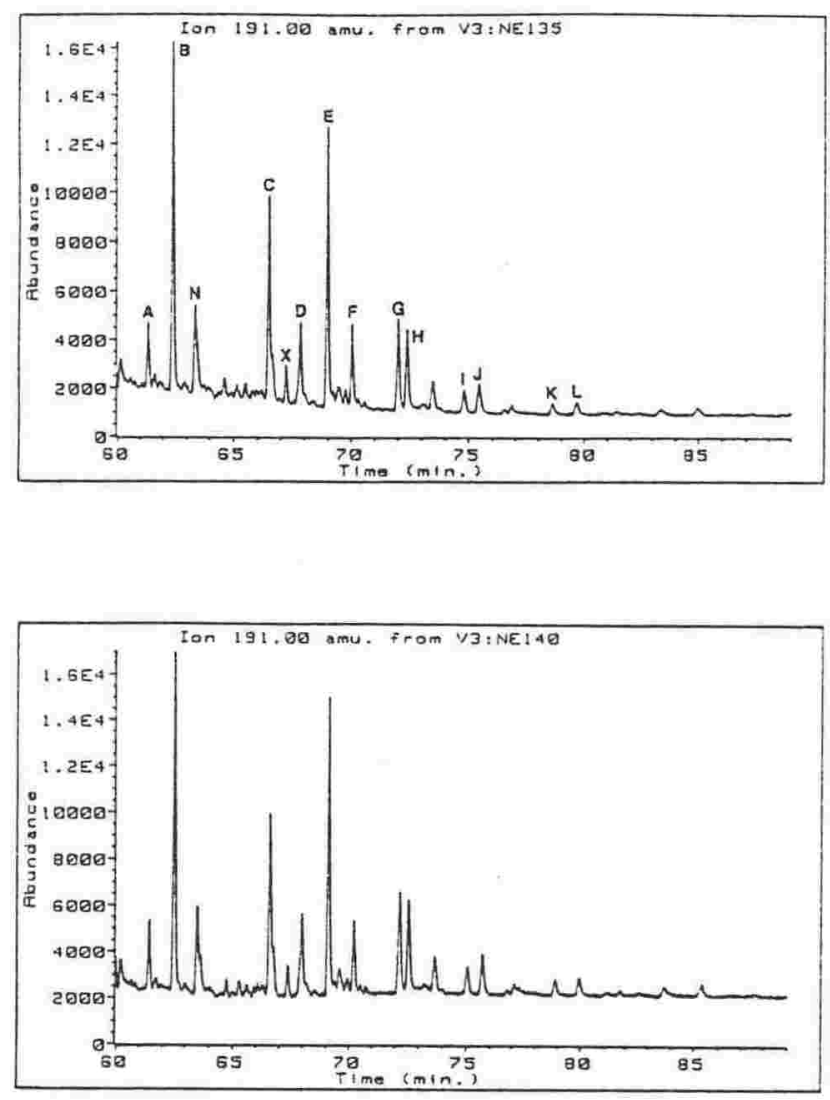

\section{Taipo Formation}

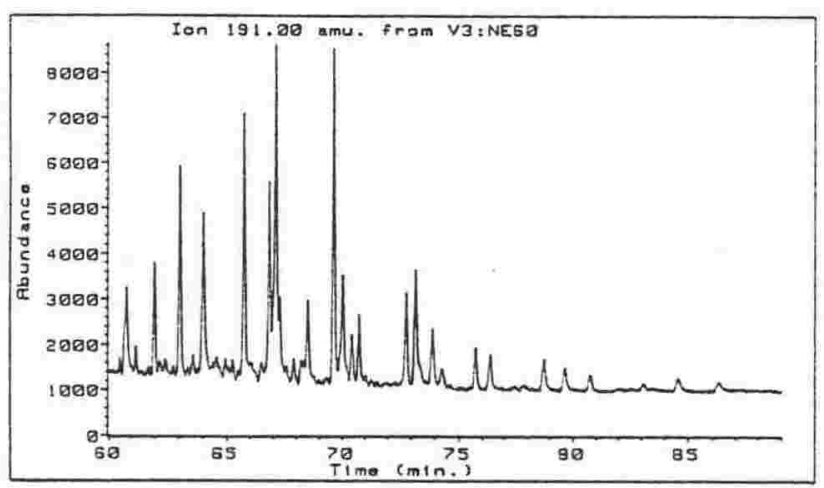

\section{Undifferentiated Pahaoa Group}

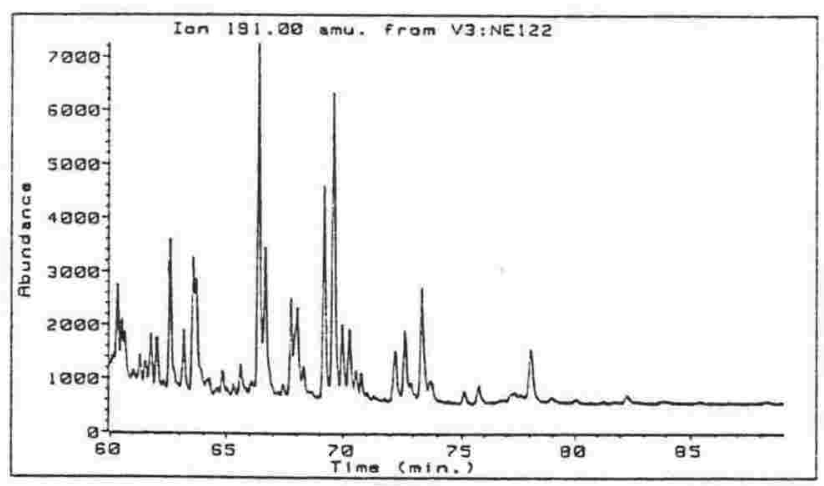

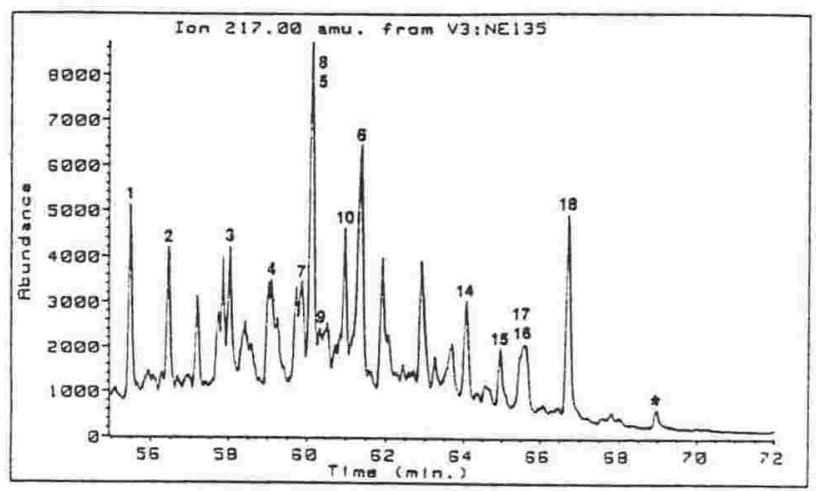
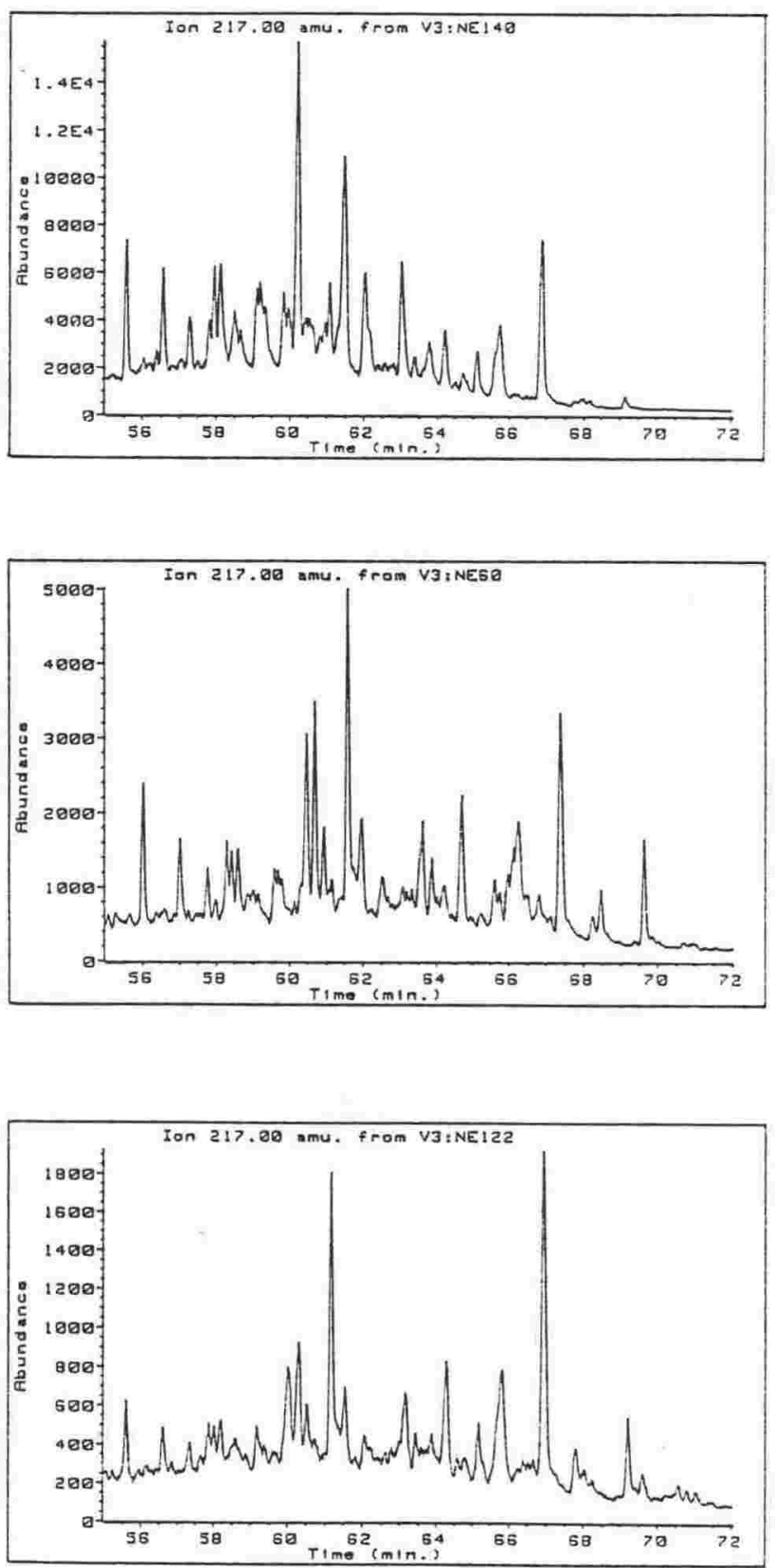


\section{Undifferentiated Pahaoa Group continued}
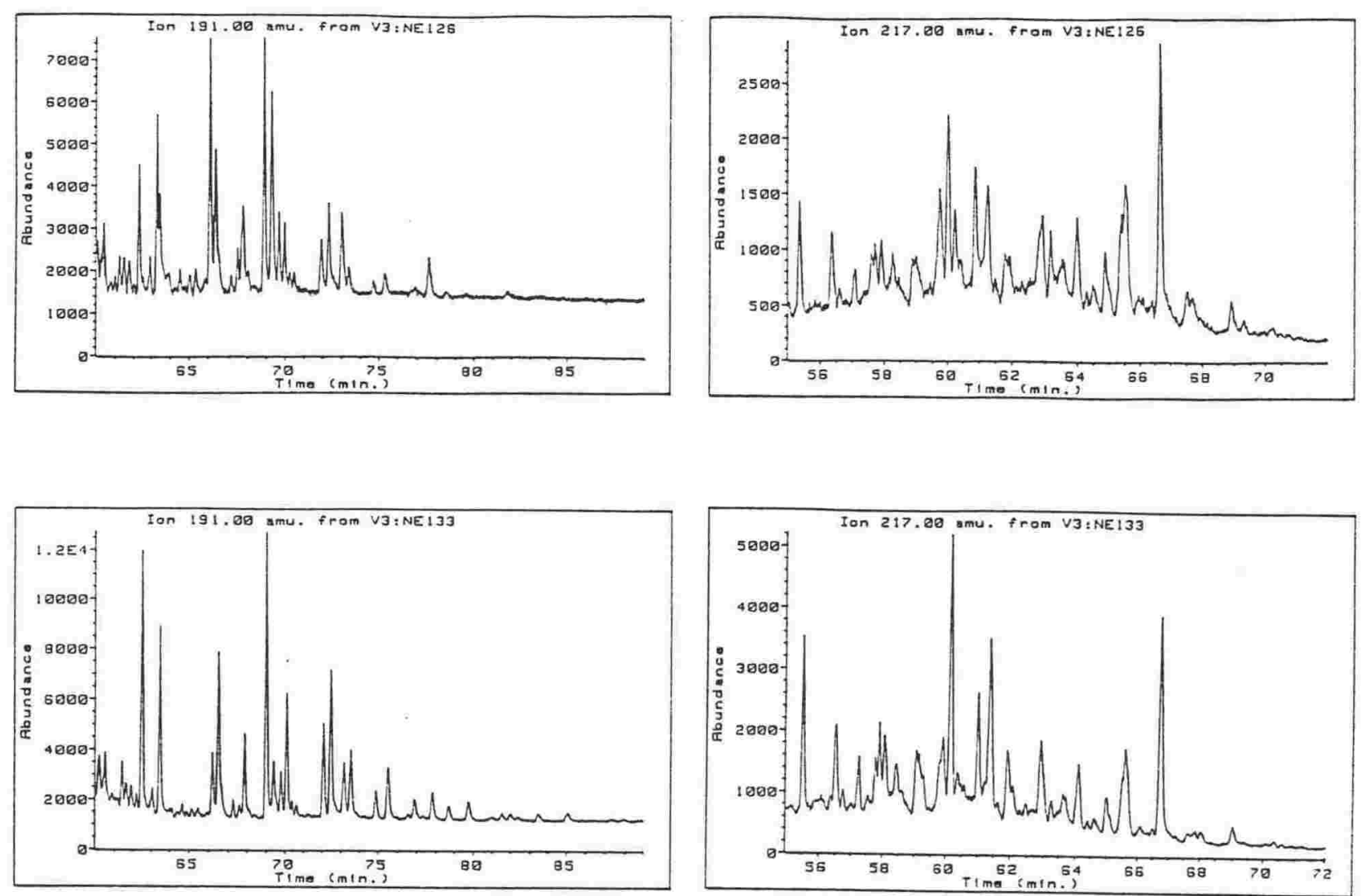

\section{Whatarangi Formation}
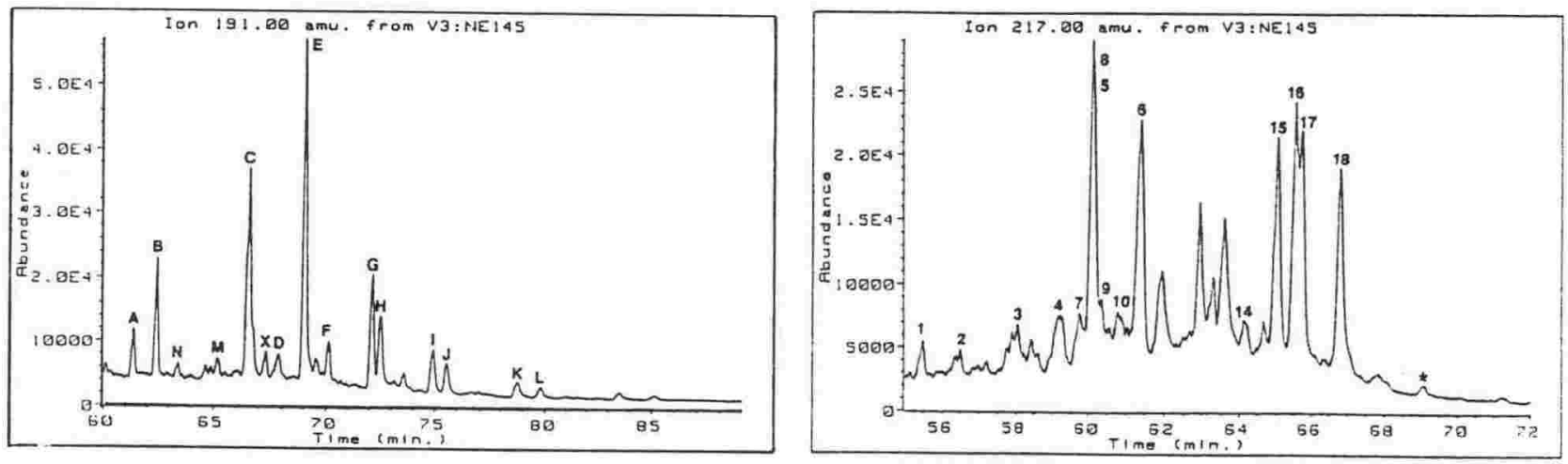

\section{Torlesse Supergroup}
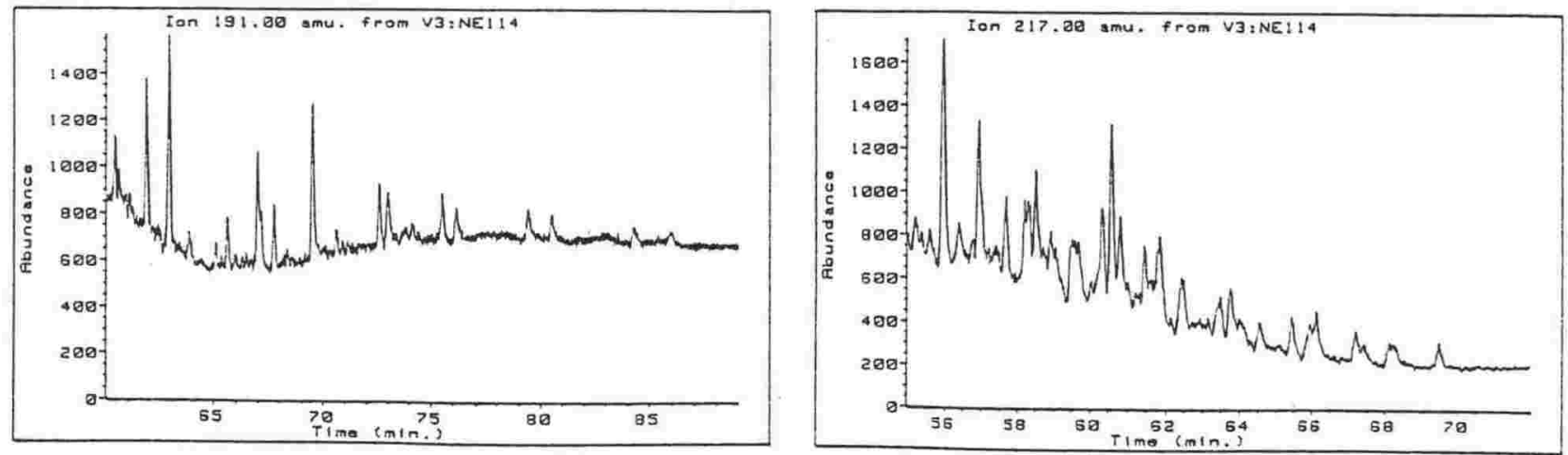


\section{South Island stratigraphy}

\section{Waima Siltstone}
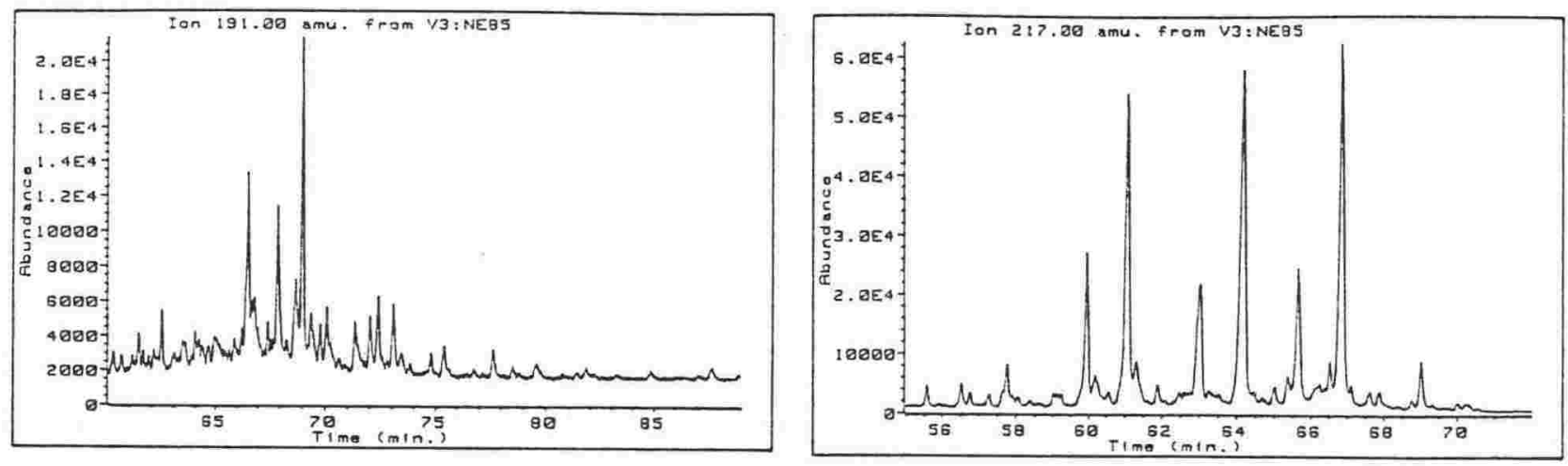

\section{Woodside Formation}
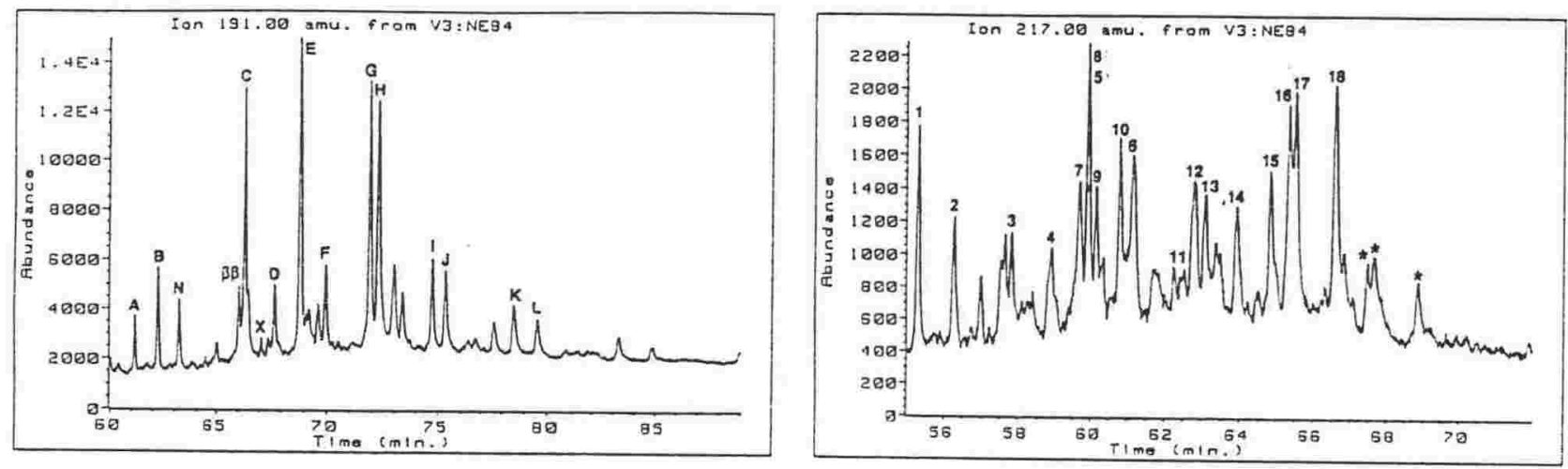

\section{Amuri Limestone}
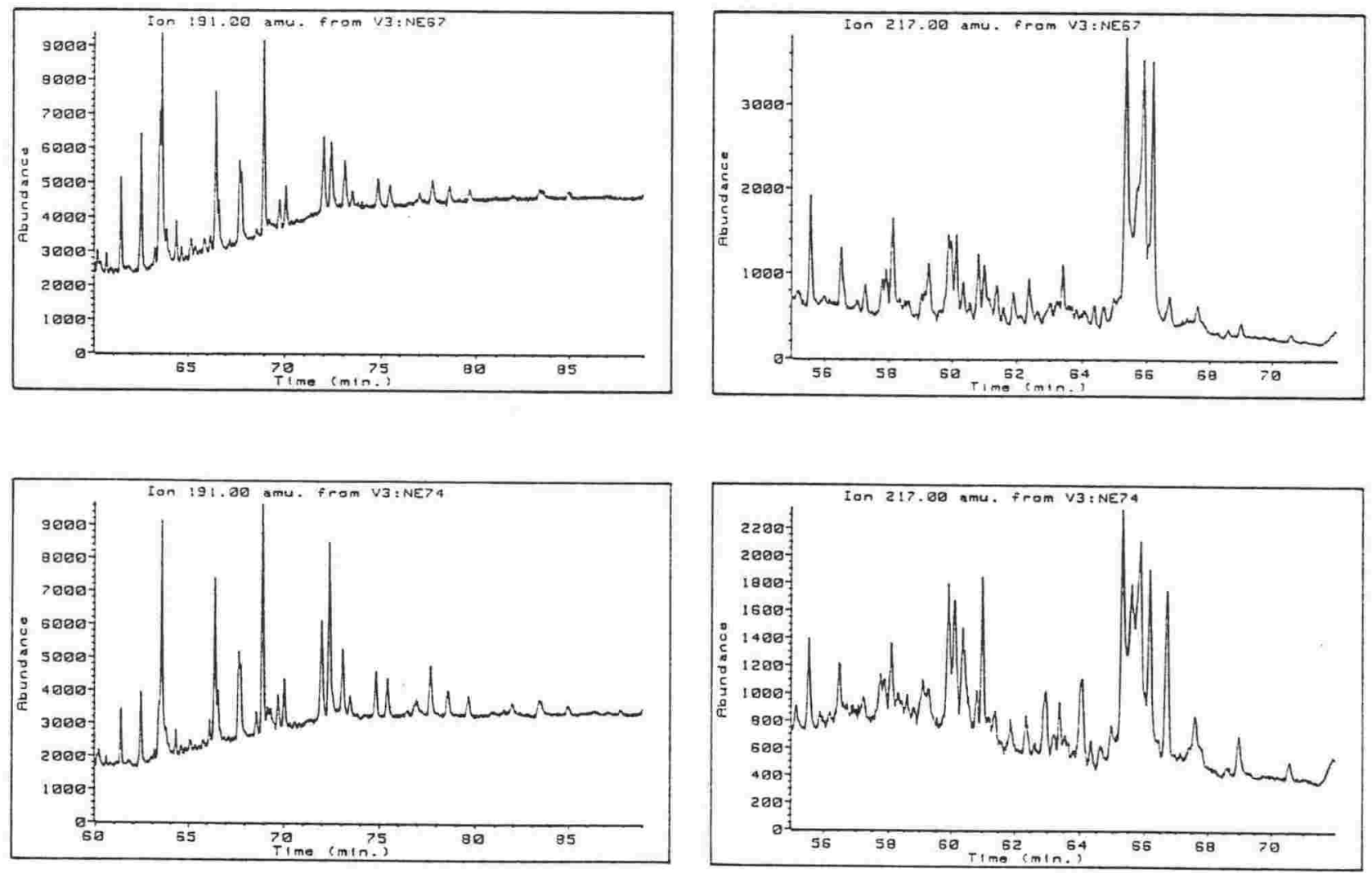


\section{Amuri Limestone continued}
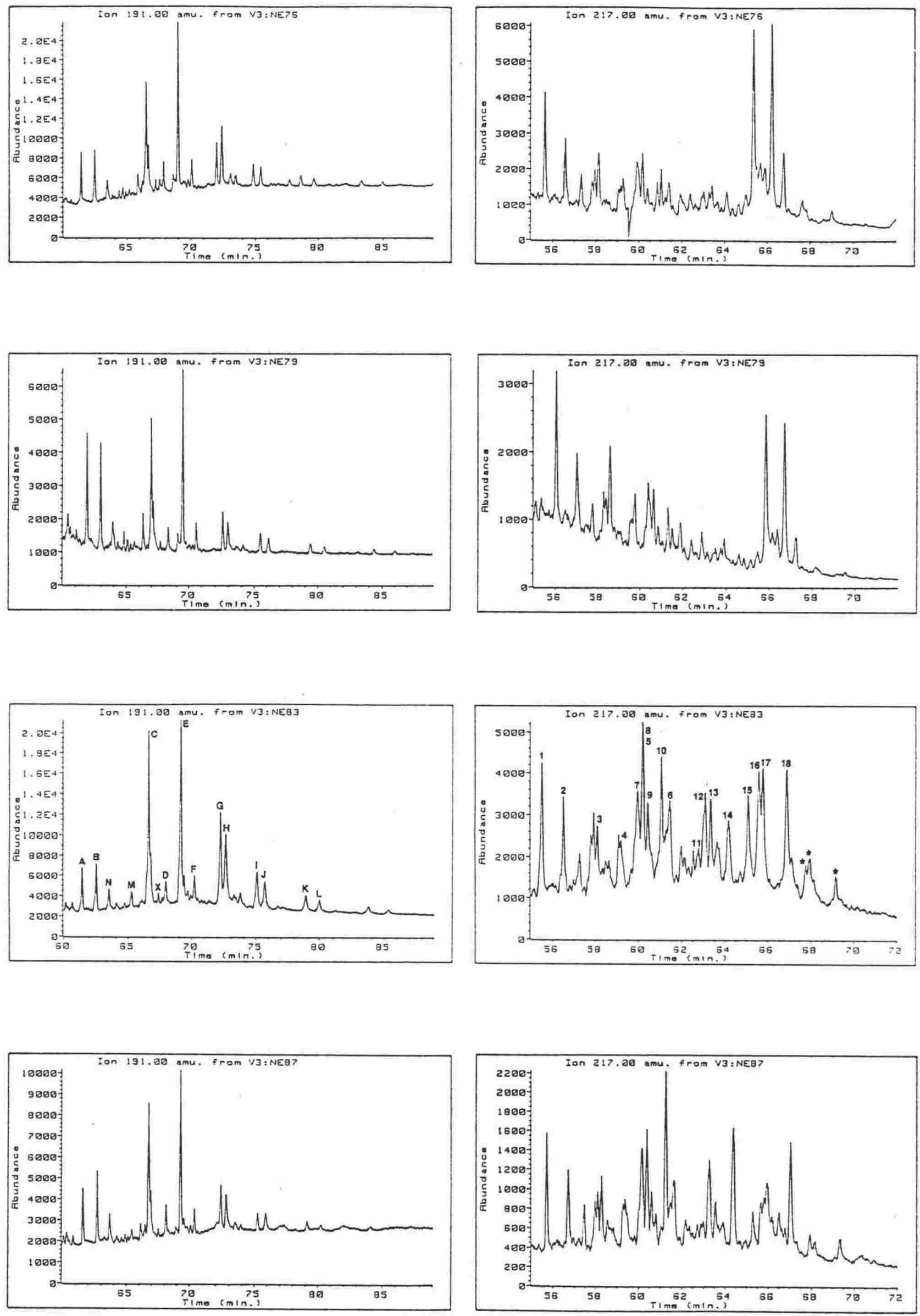


\section{Amuri Limestone continued}
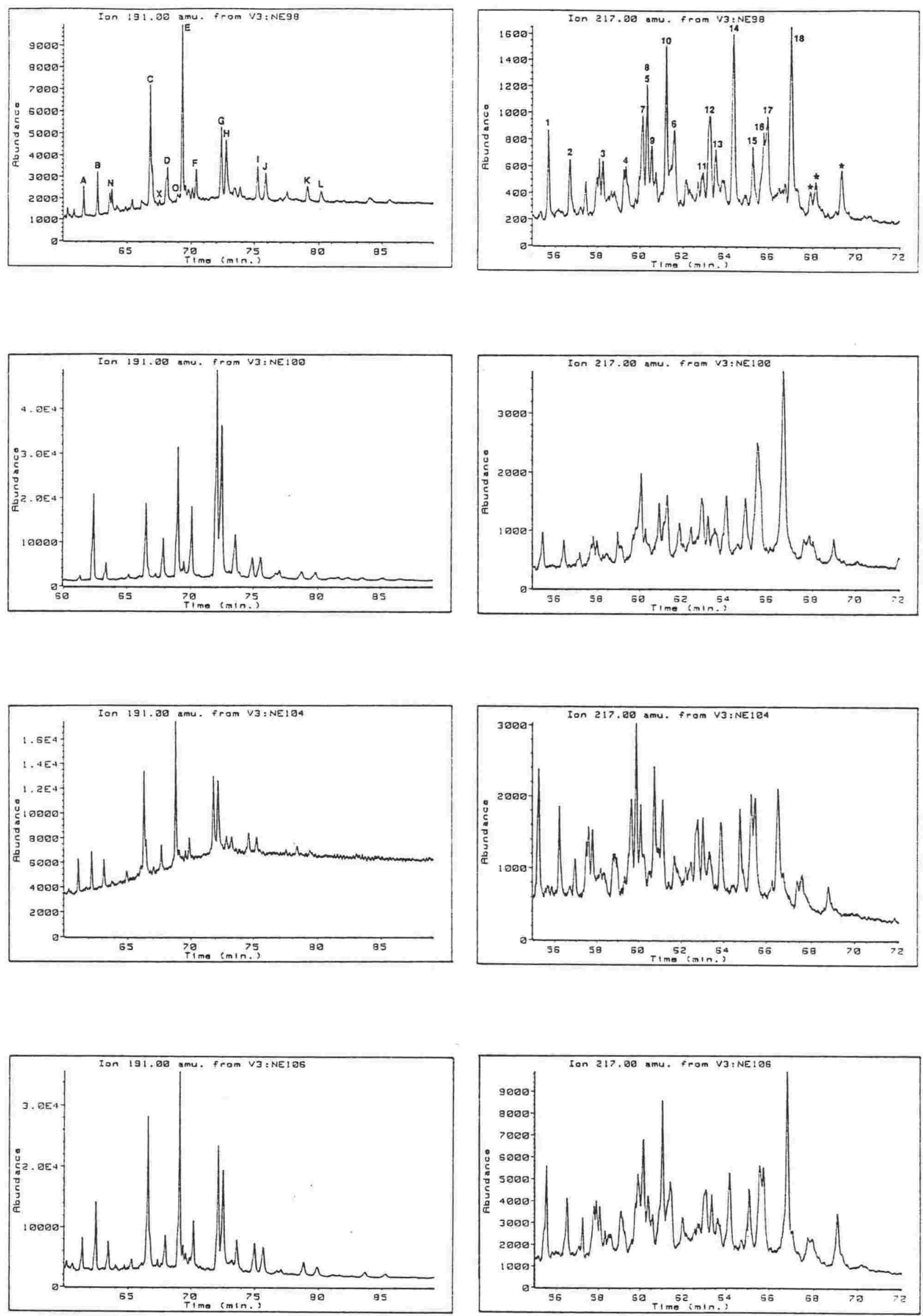


\section{Whangai Formation}
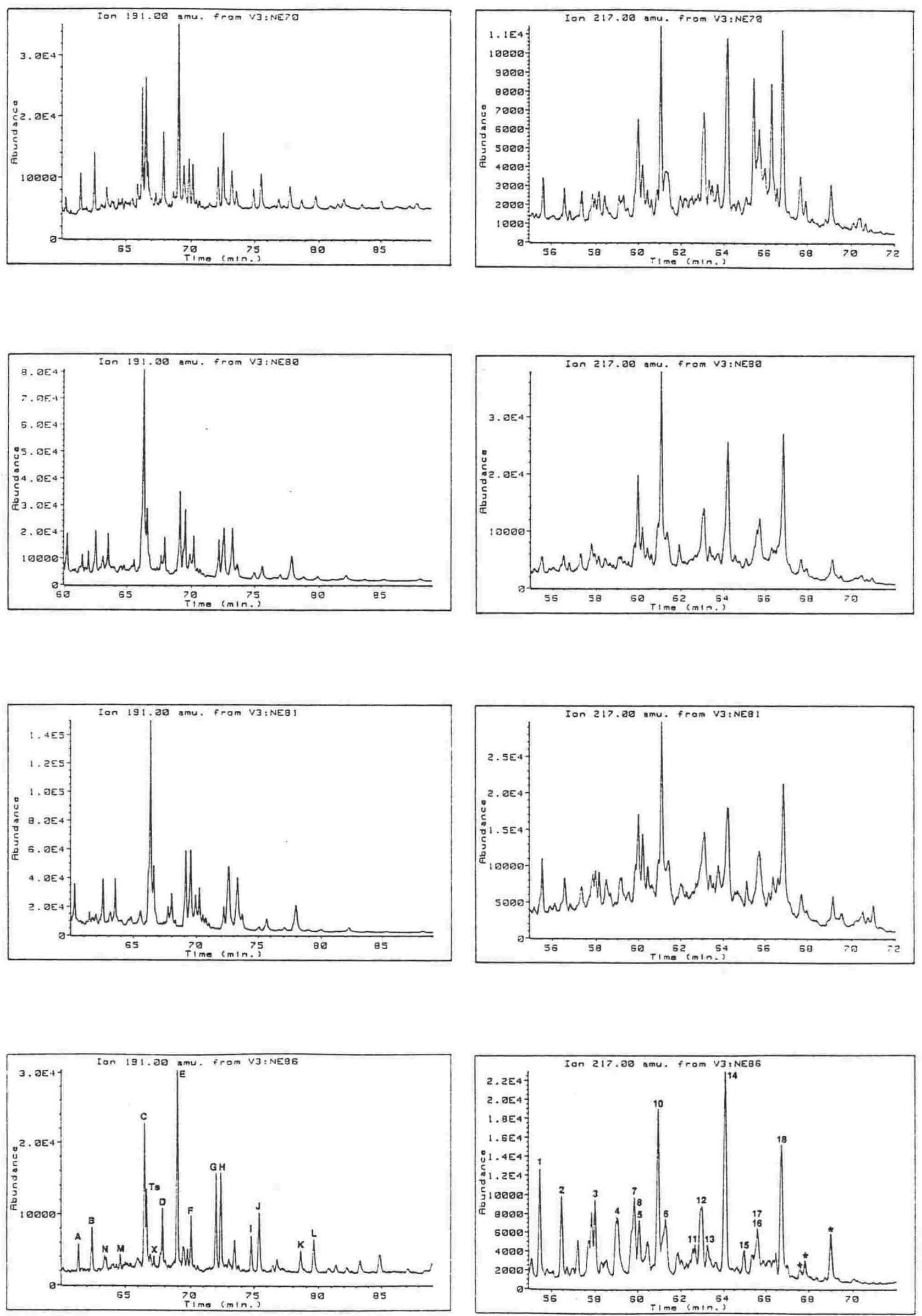


\section{Mata Series}
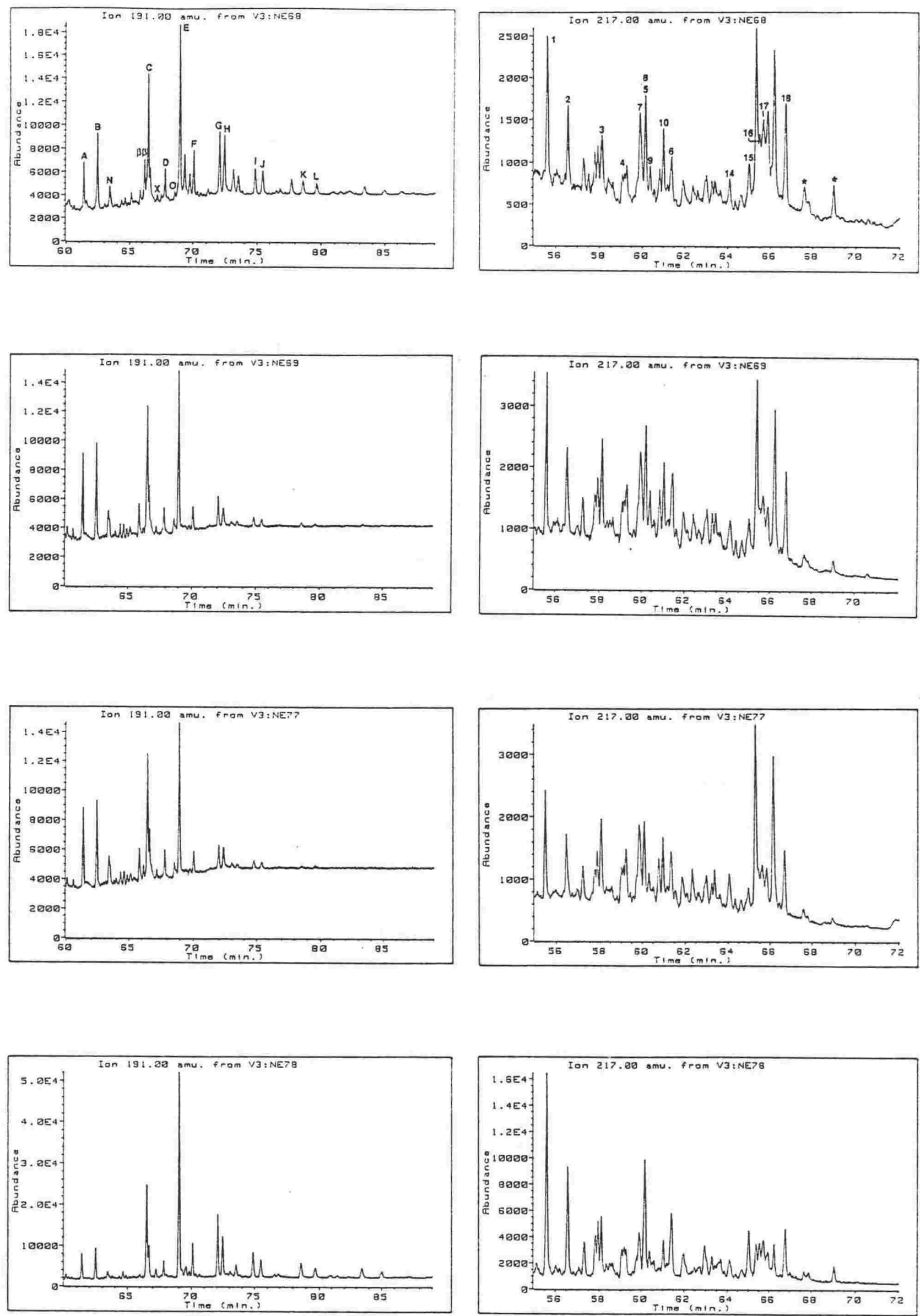


\section{Mata Series continued}
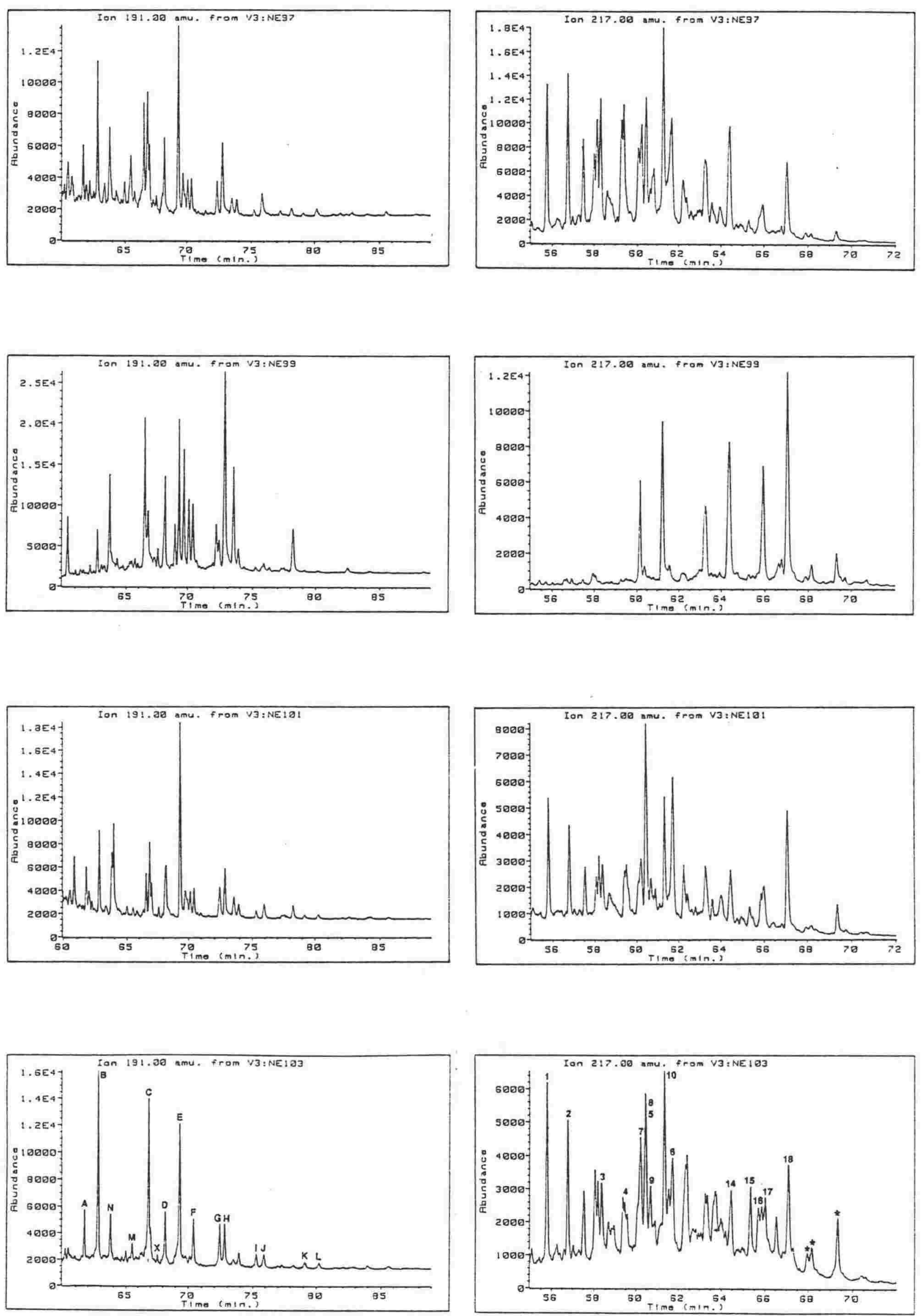


\section{Flags Formation}
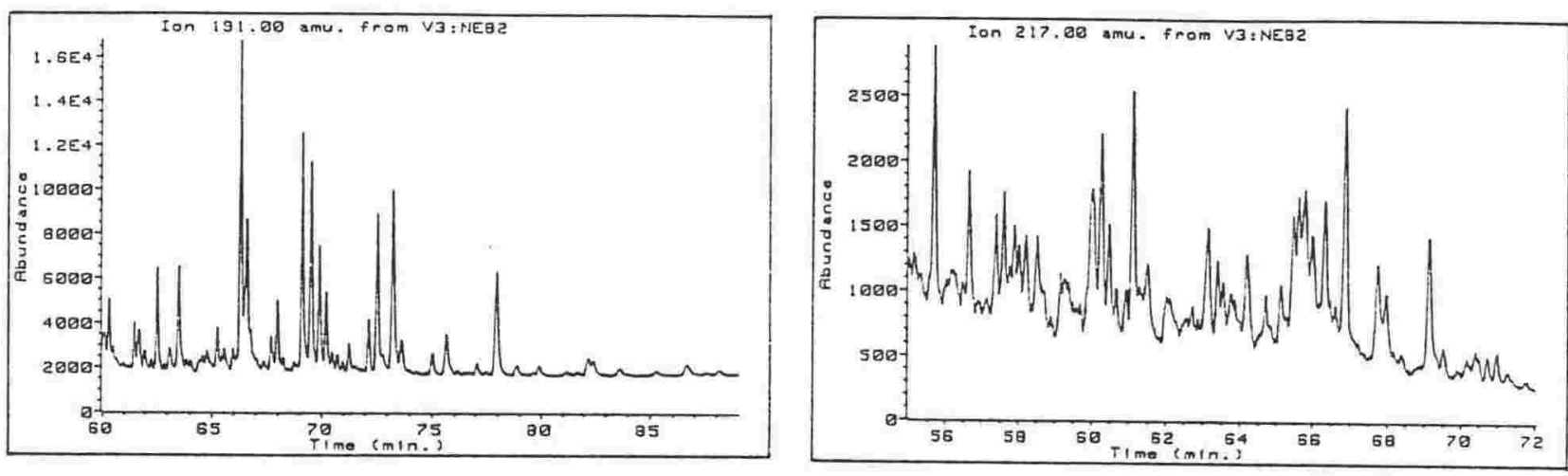

\section{Claverley Sandstone}
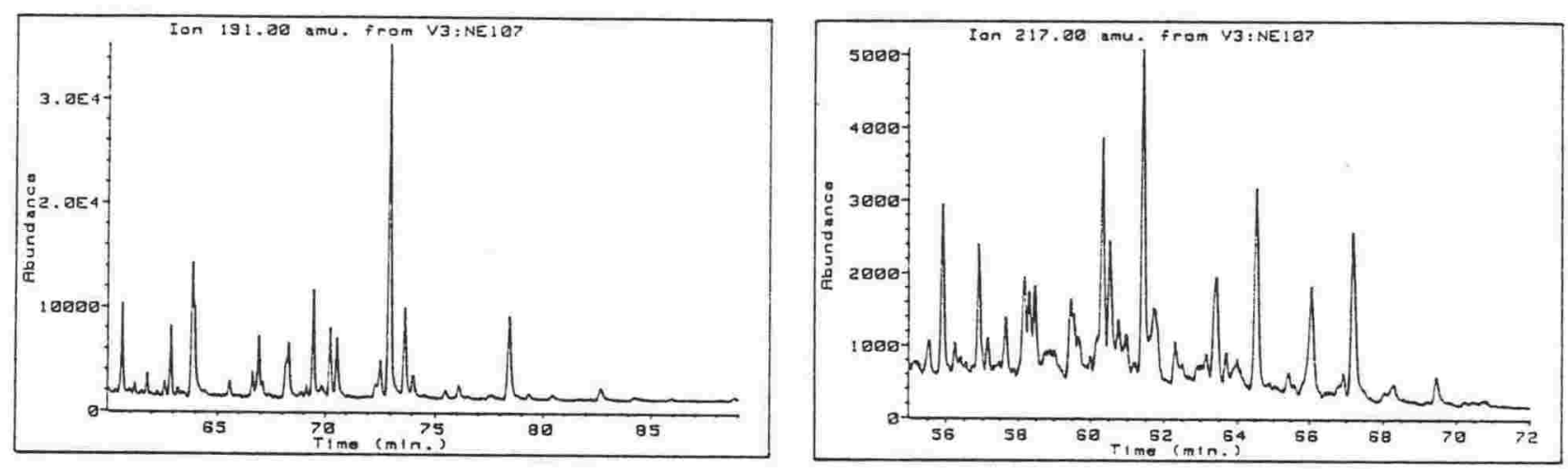

\section{Conway Siltstone}
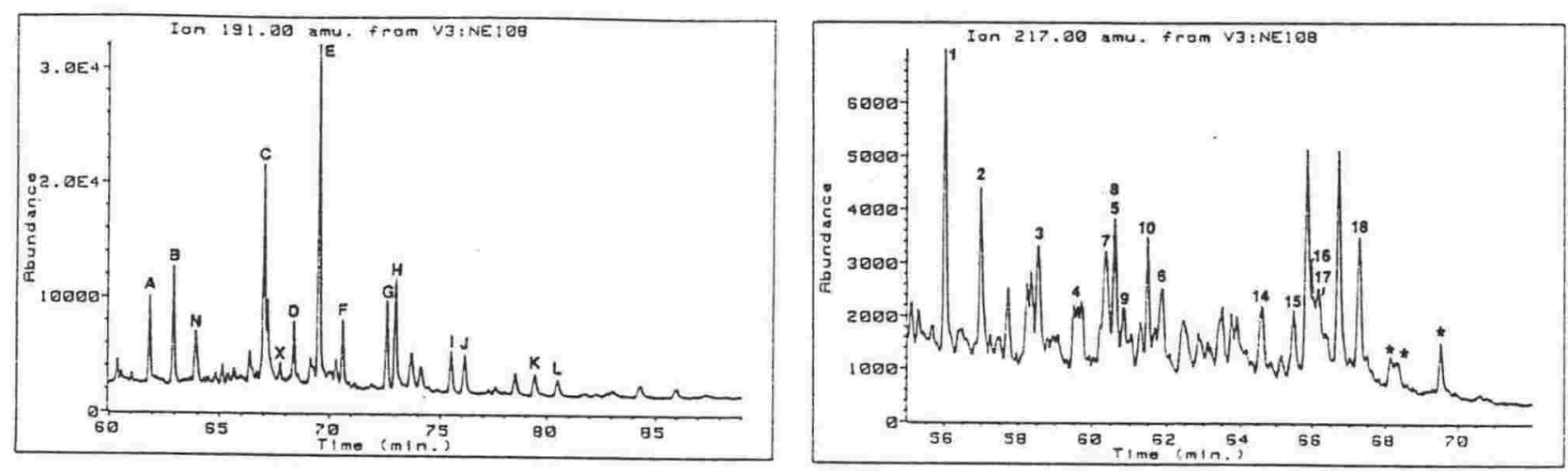

\section{Burnt Creek Formation}
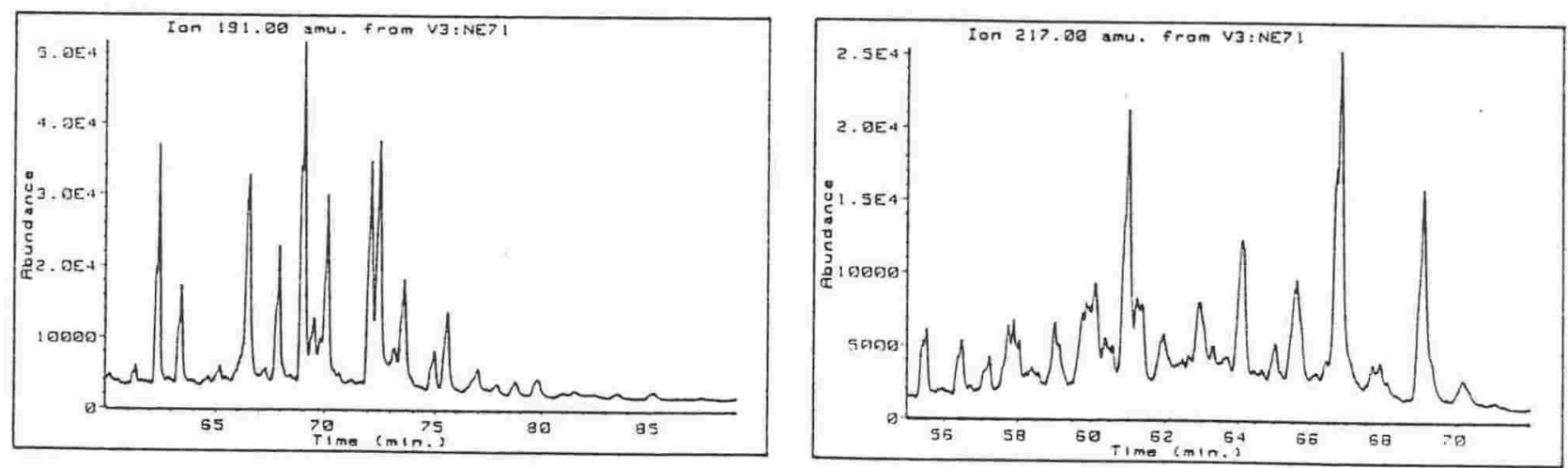


\section{Burnt Creek Formation continued}
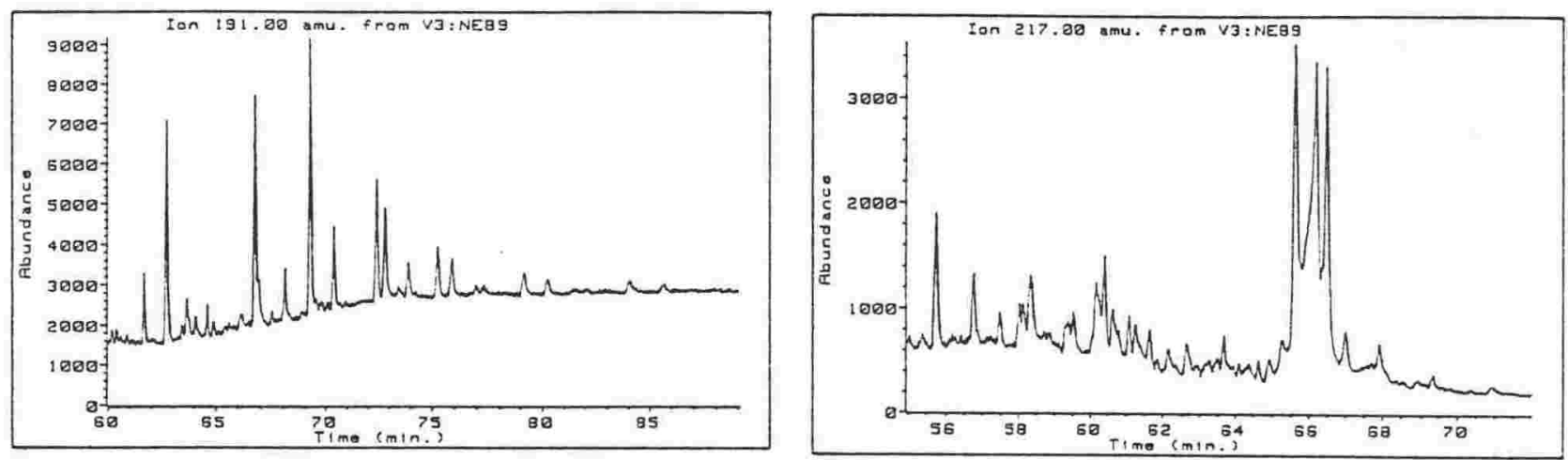

\section{Split Rock Formation}

Swale Siltstone Member
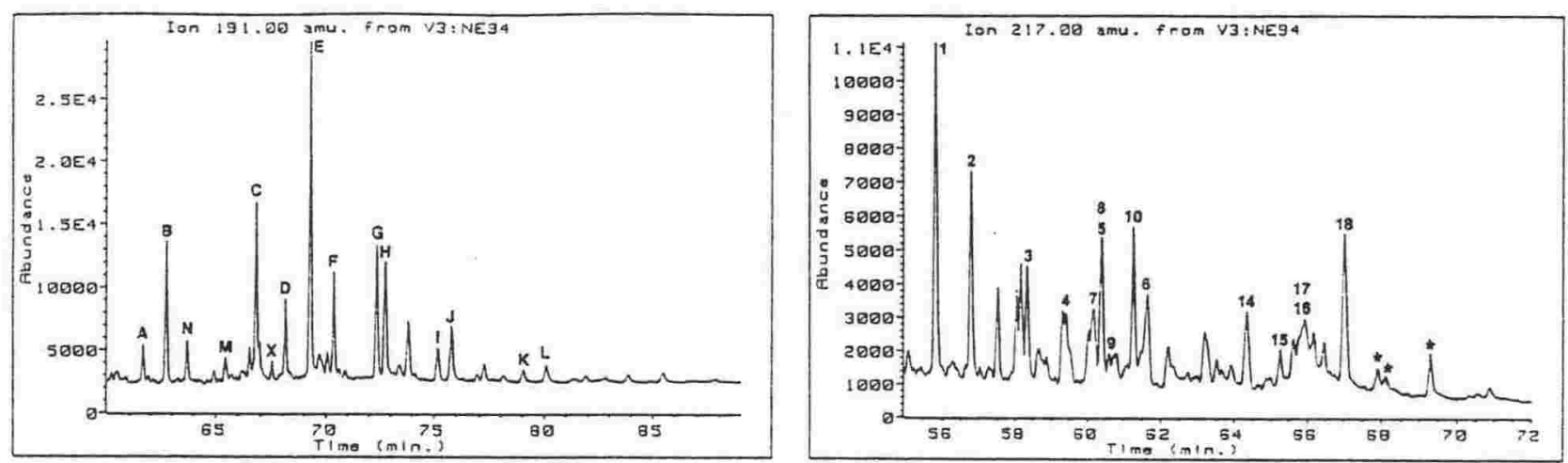

Wharfe Sandstone Member
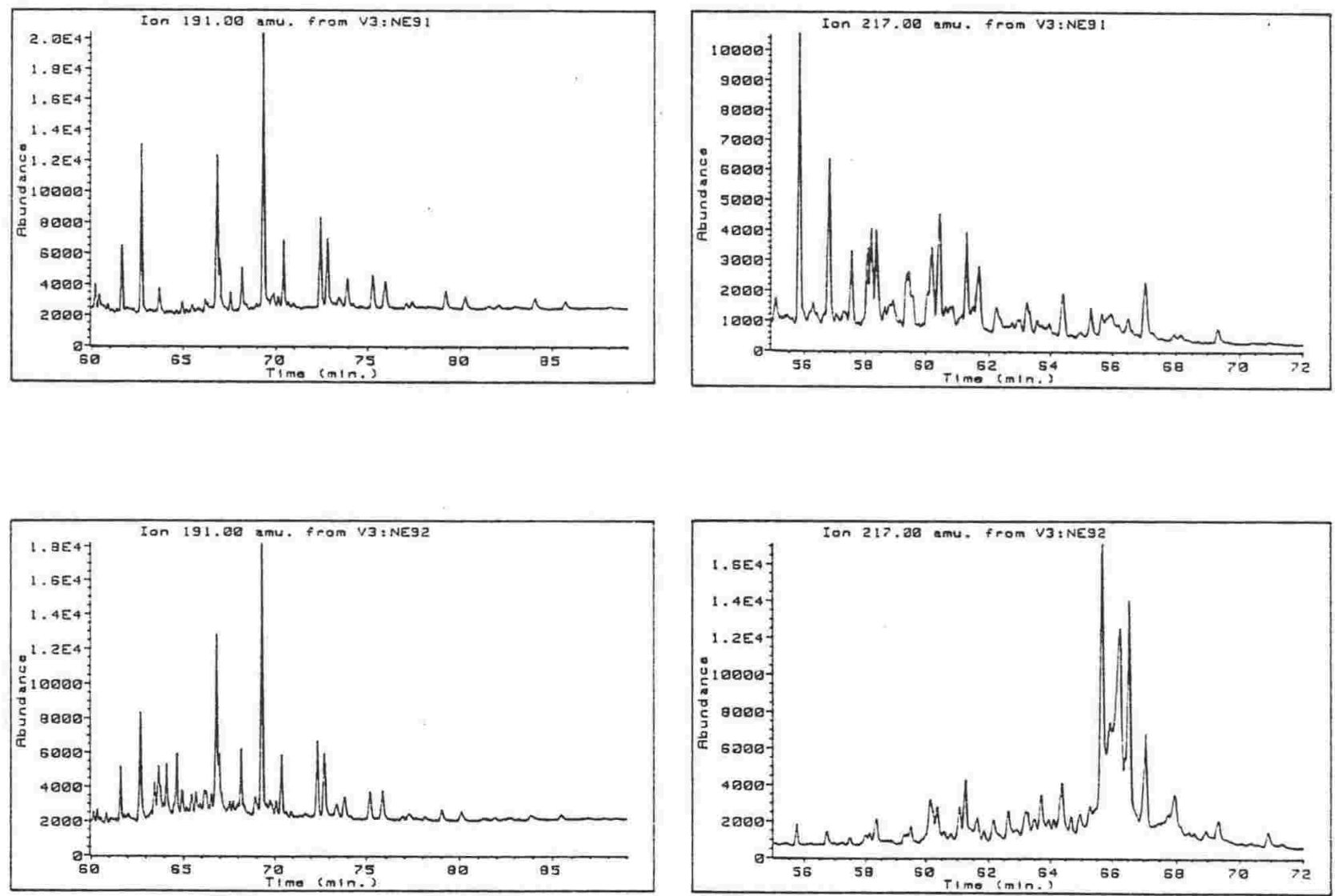


\section{Ouse Member}

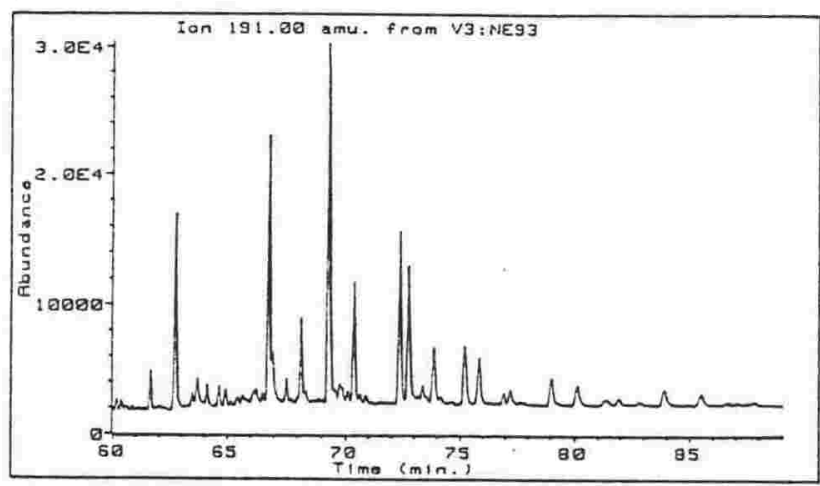

\section{Champagne Member}

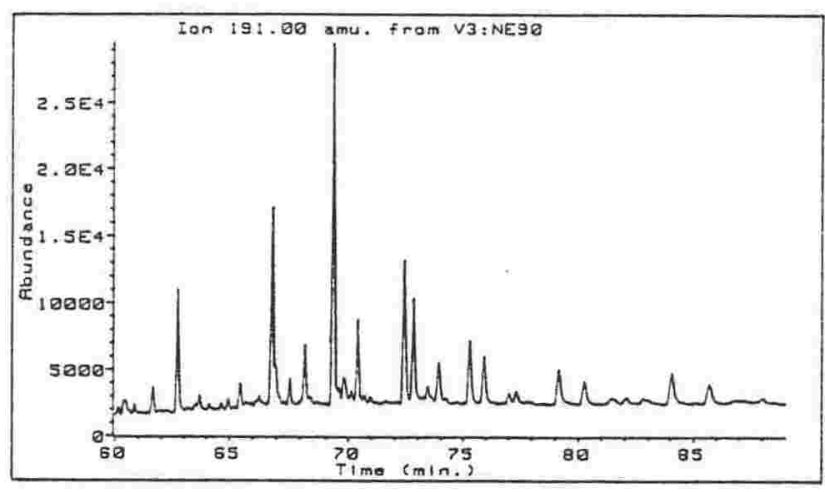

Torlesse Supergroup
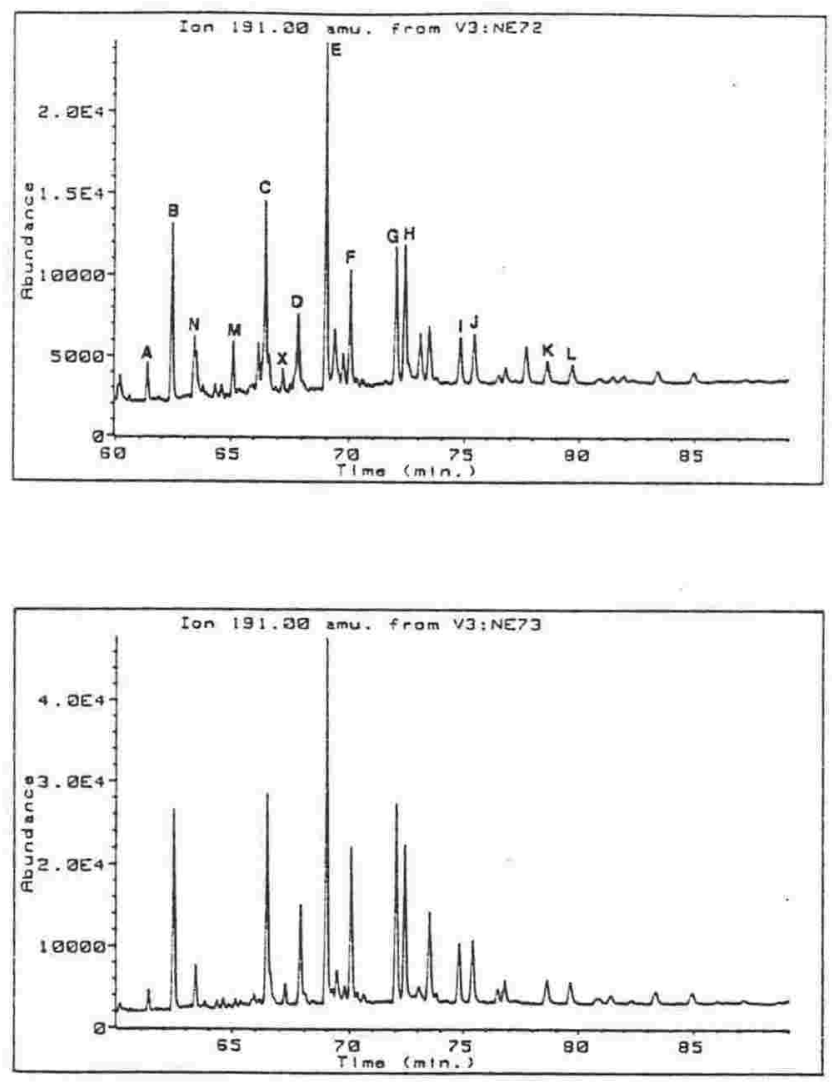
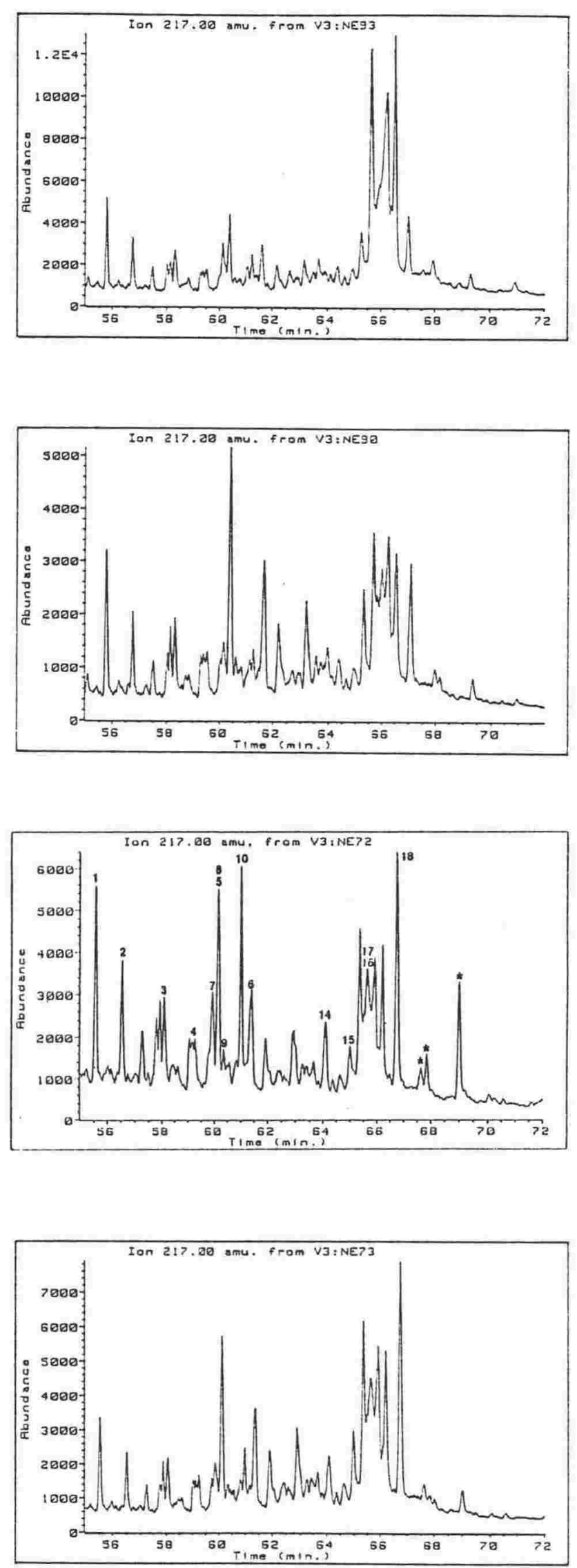


\section{Torlesse Supergroup continued}
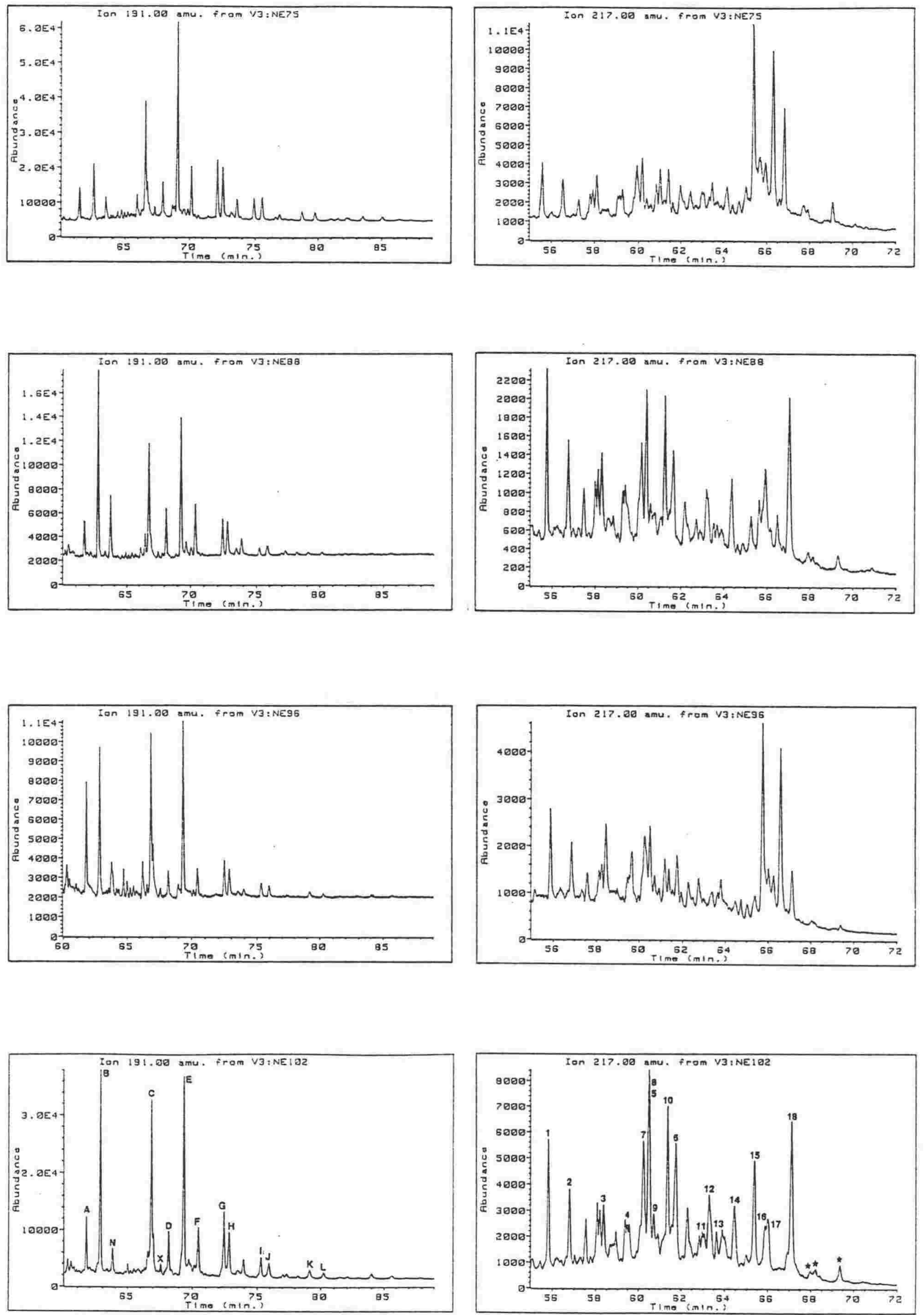


\section{Torlesse Supergroup continued}
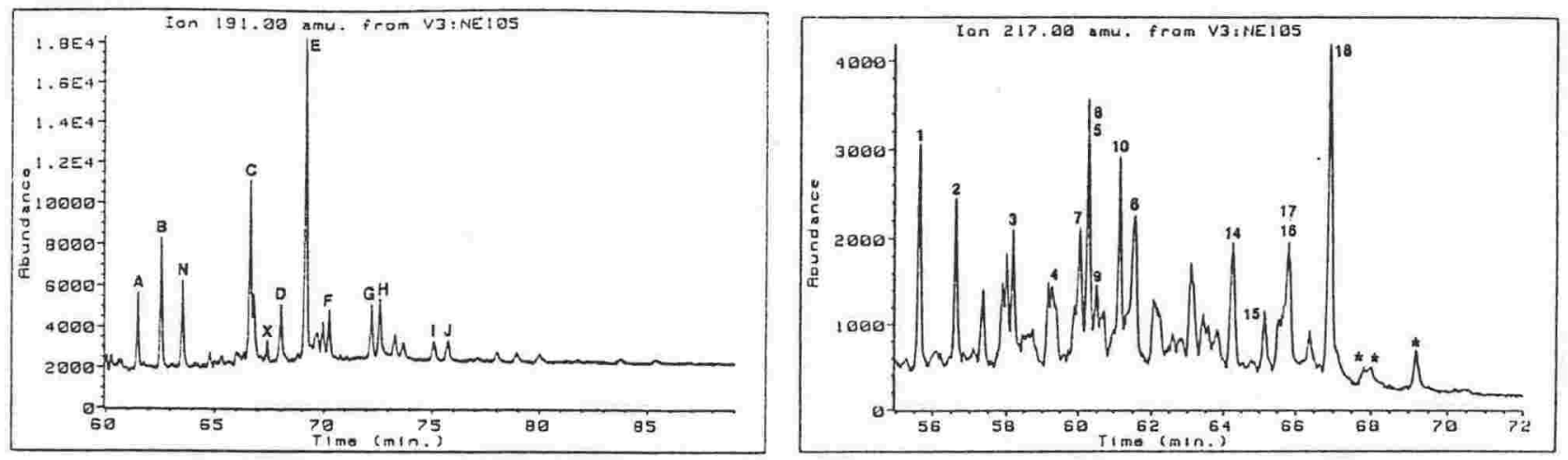


\begin{tabular}{|c|c|}
\hline Trite & panes \\
\hline A & $18 \alpha(\mathrm{H})-22,29,30$-Trisnorneohopane (Ts) \\
\hline B & $17 \alpha(\mathrm{H})-22,29,30$-Trisnorhopane $(\mathrm{Tm})$ \\
\hline C & $17 \alpha(\mathrm{H}), 21 \beta(\mathrm{H})-30$-Norhopane \\
\hline Ts & $18 \alpha(\mathrm{H})-30$-Norneohopane $\left(\mathrm{C}_{29} \mathrm{Ts}\right)$ \\
\hline D & $17 \beta(\mathrm{H}), 21 \alpha(\mathrm{H})-30$-Norhopane (Normortane) \\
\hline E & $17 \alpha(\mathrm{H}), 21 \beta(\mathrm{H})$-Hopane \\
\hline $\mathrm{F}$ & $17 \beta(\mathrm{H}), 21 \alpha(\mathrm{H})$-Moretane \\
\hline G,H & $17 \alpha(\mathrm{H}), 21 \beta(\mathrm{H})-30$-Homohopane $(22 \mathrm{~S}, 22 \mathrm{R})$ \\
\hline $\mathrm{I}, \mathrm{J}$ & $17 \alpha(\mathrm{H}), 21 \beta(\mathrm{H})-30,31$-Bishomohopane $(22 \mathrm{~S}, 22 \mathrm{R})$ \\
\hline $\mathrm{K}, \mathrm{L}$ & $17 \alpha(\mathrm{H}), 21 \beta(\mathrm{H})-30,31,32$-Tríshomohopane (22S,22R) \\
\hline M & 28,30-Bisnorhopane \\
\hline $\mathrm{N}$ & $17 \beta(\mathrm{H})-22,29,30$-Trisnorhopane \\
\hline $\mathrm{O}$ & Oleanane \\
\hline $\mathrm{X}$ & $17 \alpha(\mathrm{H})$-Diahopane (Compound X) \\
\hline$\beta \beta$ & $17 \beta(\mathrm{H}), 21 \beta(\mathrm{H})-30$-Norhopane \\
\hline Gam & Gammacerane \\
\hline Stera & \\
\hline 1 it: & $13 \beta(H), 17 \alpha(H)$-Diacholestane $(20 S)$ \\
\hline 2 & $13 \beta(\mathrm{H}), 17 \alpha(\mathrm{H})$-Diacholestane $(20 \mathrm{R})$ \\
\hline 3 & 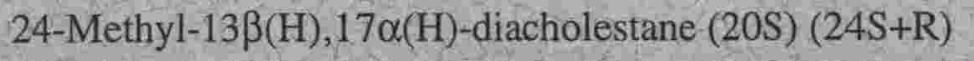 \\
\hline 4 & 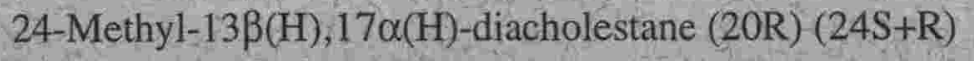 \\
\hline 5 & 24-Ethyl-13 $\beta(\mathrm{H}), 17 \alpha(\mathrm{H})$-diacholestane (20S) (coeluting) \\
\hline 6 & 24-Ethyl-13 $\beta(\mathrm{H}), 17 \alpha(\mathrm{H})$-diacholestane (20R) (coeluting) \\
\hline 7 & $5 \alpha(\mathrm{H}), 14 \alpha(\mathrm{H}), 17 \alpha(\mathrm{H})$-Cholestane $(20 \mathrm{~S})$ \\
\hline 8 & $5 \alpha(\mathrm{H}), 14 \beta(\mathrm{H}), 17 \beta(\mathrm{H})$-Cholestane (20R) \\
\hline 9 & $5 \alpha(\mathrm{H}), 14 \beta(\mathrm{H}), 17 \beta(\mathrm{H})$-Cholestane $(20 \mathrm{~S})$ \\
\hline 10 & $5 \alpha(\mathrm{H}), 14 \alpha(\mathrm{H}), 17 \alpha(\mathrm{H})$-Cholestane $(20 \mathrm{R})$ \\
\hline 11 & 24-Methyl-5 $\alpha(\mathrm{H}), 14 \alpha(\mathrm{H}), 17 \alpha(\mathrm{H})$-cholestane (20S) \\
\hline 12 & 24-Methyl-5 $\alpha(\mathrm{H}), 14 \beta(\mathrm{H}), 17 \beta(\mathrm{H})$-cholestane (20R) \\
\hline 13 & 24-Methyl-5 $\alpha(\mathrm{H}), 14 \beta(\mathrm{H}), 17 \beta(\mathrm{H})$-cholestane $(20 \mathrm{~S})$ \\
\hline 14 & 24-Methyl-5 $\alpha(\mathrm{H}), 14 \alpha(\mathrm{H}), 17 \alpha(\mathrm{H})$-cholestane (20R) \\
\hline 15 & 24-Ethyl-5 $\alpha(\mathrm{H}), 14 \alpha(\mathrm{H}), 17 \alpha(\mathrm{H})$-cholestane $(20 \mathrm{~S})$ \\
\hline 16 & 24-Ethyl- $5 \alpha(\mathrm{H}), 14 \beta(\mathrm{H}), 17 \beta(\mathrm{H})$-cholestane (20R) \\
\hline 17 & 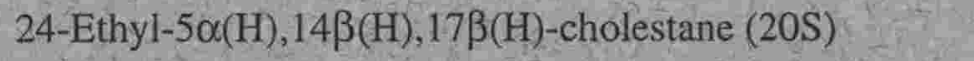 \\
\hline 18 & 24-Ethyl-5 $\alpha(\mathrm{H}), 14 \alpha(\mathrm{H}), 17 \alpha(\mathrm{H})$-cholestane (20R) \\
\hline 19 & 24-Ethyl-5 $\beta(\mathrm{H}), 14 \alpha(\mathrm{H}), 17 \alpha(\mathrm{H})$-cholestane (20R) \\
\hline * & $\mathrm{C}_{30}$ Steranes \\
\hline
\end{tabular}

Biomarker identification of triterpanes and steranes. 